\title{
LEXIKOS
}

3 


\section{Lexikos 3}

Redakteur

Editor

P. Harteveld

AFRILEX-REEKS 3:1993

AFRILEX SERIES 3:1993

BURO VAN DIE WAT

STELLENBOSCH 
Die publikasie van hierdie boek is moontlik gemaak deur 'n ruim subsidie van die L.W. Hiemstra-Trust.

The publication of this book has been made possible by a generous subsidy from the L.W. Hiemstra Trust.

\section{Uitgewer Publisher}

\section{BURO VAN DIE WAT \\ Universiteit van Stellenbosch \\ Privaatsak X5018 Private Bag. \\ 7599 STELLENBOSCH}

Kopiereg (C) 1993 deur die uitgewer

Alle regte streng voorbehou

Eerste uitgawe 1993

Tipografie en uitleg

deur Pieter Harteveld en

Hermien van der Westhuizen

Bandontwerp deur Piet Grobler

Geset in 10 op 12 pt Palatino

Gedruk en gebind deur Rotapress

Stewartstraat 59 Goodwood

ISBN 0958322236

Geen gedeelte van hierdie boek mag sonder skriftelike verlof van die uitgewer gereproduseer of in enige vorm of deur enige elektroniese of meganiese middel weergegee word nie, hetsy deur fotokopiëring plaat- of bandopname, vermikrofilming of enige ander stelsel van inligtingsbewaring 


\section{Inhoud / Contents}

Voorwoord

viii

Foreword

P. Harteoeld

\section{Artikels / Articles}

Aspekte van sintaktiese inligting in verklarende Afrikaanse woordeboeke

W.F. Botha

Lexicography in West Africa:

Preparing a Bilingual Kisi-English Dictionary

G.T. Childs

Afrikaans Learner's Dictionaries for

a Multilingual South Africa

R.H. Gouws

Normatiewe leiding in woordeboeke:

'n nuwe benadering

R.H. Gouws

General Lexicography in Europe

Reinhard Rudolf Karl Hartmann

Racist Language in Society and in Dictionaries:

A Pragmatic Perspective

D.C. Hauptfleisch

Etikette in sinchronies verklarende woordeboeke

F.J. Lombard

From Wordlist to Comparative Lexicography:

The Lexinotes

Tony Naden 
Grammatiese inligting ten opsigte van

adjektiewe in aanleerderwoordeboeke

Anna Nel Otto

Funksies van voorbeeldmateriaal in

eentalige woordeboeke

L. Rademeyer

Broadening the Perspectives of South African

English and Afrikaans Research (An Interview

with David L. Gold on his Work in these Fields)

Roy S. Rosenstein

Een gegevensbank van 14de-eeuwse

Middelnederlandse dialecten op computer

Pieter van Reenen en Maaike Mulder

Komponentontleding as

leksikografiese instrument

I.L. VoS

Resensie-artikels / Review Articles

Die nuwe $A W S$ in die praktyk:

'n gebruikersoorsig na twee jaar

J. du T. McLachlan

Die agtste deel van die

Woordeboek van die Afrikaanse Taal

Edith H. Raidt

\section{Resensies / Reviews}

Chambers Schoolbag Dictionary including

Southern African usage and pronunciation Elaine Ridge

G.R. Dent (Compiler) and C.L.S. Nyembezi (Ed.):

Compact Zulu Dictionary. Eng.-Zulu; Zulu-Eng.

A.C. Nkabinde

G.R. Dent and C.L.S. Nyembezi (Compilers):

Scholar's Zulu Dictionary. Eng.-Zulu; Zulu-Eng.

A.C. Nkabinde 
P.A. Joubert: Bilingual phrase dictionary/

Tweetalige frasewoordeboek $(E-A)$

David L. Gold

M.L.A. Kgasa: Thanodi ya Setswana ya Dikole

S.A. Swanepoel

Emst Kotzé en Patrick Wela (Opstellers):

Afrikaans/Zoeloe-Woordeboek met Engelse vertalings

A.C. Nkabinde

Sibusiso Nyembezi: Isichazimazwi Sanamuhla Nangomuso.

321

(Dictionary for today and the future). Zulu dictionary
A.C. Nkabinde

J. Smuts en 1.J. Smuts: Woordebock van Regs- en Handelsterme

Lourens M. du Plessis

J.W. Snyman (Ed./Red.), J.S. Shole and/en J.C. le Roux:

Setswana English Afrikaans Dictionary Woordeboek

S.A. Swanepoel

Publikasie-aankondigings / Publication Announcements 


\section{Voorwoord}

Die bydraes in hierdie derde uitgawe van Lexikos in die AFRILEX-reeks toon dat die Buro van die WAT daarin slaag om die leksikografiese gesprek oor 'n steeds wyer geografiese en tematologiese terrein te laat plaasvind. Dit is verblydend.

Daar is byvoorbeeld bydraes uit vyf lande buite Suid-Afrika, naamlik Engeland, Frankryk, Ghana, Nederland en die Verenigde State van Amerika.

Indien die tale van die geresenseerde woordeboeke in berekening gebring word, toon die bydraes selfs ' $n$ groter verskeidenheid as vantevore van tale wat as leksikografiese navorsingsonderwerpe dien. Benewens Afrikaans en Engels kom die Afrikatale Gur, Kisi, Tswana en Zoeloe asook die Europese taal Nederlands onder die loep.

Verder is daar tans bykans ' $n$ volkome balans tussen die aantal bydraes in Afrikaans en in Engels. Vir die eerste keer plaas ons 'n artikel in 'n ander taal, naamlik Nederlands.

Die onderwerpe van bespreking toon ook 'n groot verskeidenheid: van tradisionele leksikografie tot rekenaarleksikografie; van 'n onderhoud in die tradisie van die Sokratiese gesprek tot die hantering van rassismes in woordeboeke.

Ter wille van die vindbaarheid word die artikels en die resensie-artikels nou, anders as voorheen, onder aparte hoofde in die inhoudsopgawe gegee. Ook verskyn ons eerste rubriek vir die aankondiging van publikasies (boeke en rekenaarprogramme) in hierdie aflewering.

Al hierdie vernuwings sou nie moontlik gewees het sonder die goeie internasionale samewerking wat ons van outeurs, keurders, woordeboekinstellings en uitgewers geniet het nie. Ons is opreg dankbaar daarvoor.

Die Buro van die WAT streef na nog groter internasionale samewerking en nog wyer en beter dekking van leksikografiese temas. Daar word na sy mening veels te min aandag by kongresse en in vaktydskrifte gegee aan daardie baie belangrike onderwerpe wat aan die basis van enige leksikografiese projek moet staan, naamlik beplanning en bestuur. Bydraes hieroor word dringend gevra.

Met die verskeidenheid wat hy aanbied, is Lexikos nou 'n volwaardige vakjoemaal. Dit is ons voomeme om jaarliks aan die begin van September ' $n$ uitgawe te laat verskyn. 
Ek wil mnr. D.C. Hauptfleisch, afgetrede Hoofredakteur van die Woordeboek van die Afrikaanse Taal (WAT), bedank vir die deeglike werk wat hy as resensieredakteur van Lexikos verrig het.

Ten slotte, soos in die verlede, 'n opregte woord van dank aan Hanlie Meitzler en Hermien van der Westhuizen van die afdeling Redaksionele Steundienste in die Buro van die WAT vir hulle onmisbare en toegewyde hulp met die administrasie, redigering, elektroniese setwerk en proeflees van hierdie publikasie.

P. Harteveld

Buro van die Woordeboek van die Afrikaanse Taal. 


\section{Foreword}

The contributions in this, the third, issue of Lexikos in the AFRILEX Series show that the Bureau of the WAT is succeeding in its endeavour to further lexicographic discussion over an increasingly wider geographic and thematic terrain. This is gratifying.

For example, there are contributions from five countries outside South Africa, namely England, France, Ghana, the Netherlands and the United States of America.

If the languages of the reviewed dictionaries are taken into account, the contributions show an even larger variety than before of languages which serve as subjects of lexicographical research. In addition to Afrikaans and English, the African languages Gur, Kisi, Tswana and Zulu as well as the European language Dutch come under scrutiny.

Furthermore, currently there is a nearly total balance between the number of articles written in Afrikaans and English. For the first time we publish an article in another language, namely Dutch.

The subjects of discussion also show a large range: from traditional lexicography to computer lexicography; from an interview in the tradition of the Socratic discourse to the handling of racisms in dictionaries.

With a view to readily locating the articles and the review articles, they are now, unlike in the past, given under separate headings in the table of contents. Also, our first section for the announcement of publications (books and computer programs) appears in this number.

All of these innovations would not have been possible without the excellent international cooperation we have enjoyed from our authors, judges of articles, dictionary institutions and publishers. We are sincerely grateful for this.

The Bureau of the WAT is striving after still greater international cooperation and a still wider and better coverage of lexicographic themes. In our opinion still too little attention is given at conferences and in research journals to those very important subjects which should form the basis of any lexicographic project, namely planning and management. Contributions on these subjects are urgently requested.

With the variety it offers, Lexikos is now a fully-fledged research journal. The intention is to bring out one number annually at the beginning of September. 
I wish to thank Mr D.C. Hauptfleisch, former Editor-in-Chief of the Woordeboek van die Afrikaanse Taal (WAT), for the thorough work he has done as review editor of Lexikos.

In conclusion, as in the past, a special word of thanks to Hanlie Meitzler and Hermien van der Westhuizen of the division Editorial Support Services in the Bureau of the WAT for their indispensable and dedicated support regarding the administration, editing, electronic typesetting and proofreading of this publication.

P. Harteveld

Bureau of the Woordeboek van die Afrikaanse Taal 


\title{
Aspekte van sintaktiese inligting in verklarende Afrikaanse woordeboeke
}

\author{
W.F. Botha, Buro van die Woordeboek van die Afrikaanse Taal, \\ Stellenbosch, Suid-Afrika
}

\begin{abstract}
Aspects of syntactic information in descriptive Afrikaans dictionaries. Syntactic information is not presented in a consistent manner in the articles of lexical and multilexical lemmas in descriptive Afrikaans dictionaries. New terminology and information resulting from linglistic research are seldom portrayed. Three slots for syntactic information in the article of a lemma are suggested: a slot for a lexical item classification, a slot for information on the typical syntactic behaviour of a lemma and a third slot for usage examples in which explicit information on non-typical syntactic behaviour is provided. Ways are suggested for the presentation of syntactic information in the articles of multilexical lemmas. Practical proposals are made for the reflection of new termunology and information resulting from linguistic research.
\end{abstract}

Keywords: ADJUNCT, FIXED EXPRESSIONS, LEXICAL ITEM CLASSIFICATION, LOANWORD PHRASES, MULTILEXICAL LEMMAS, NON-TYPICAL SYNTACTIC BEHAVIOUR, PREPOSITIONAL PHRASES, SYNTACTIC INFORMATION, TYPICAL SYNTACTIC BEHAVIOUR

Opsomming: Sintaktiese inligting in verklarende Afrikaanse woordeboeke word nie op konsekwente wyse by leksikale en multileksikale lemmas aangebied nie en nuwe terminologie en inligting uit die teoretiese taalkunde word selde weerspieël. Drie gleuwe vir sintaktiese inligting in die artikel van 'n lemma word voorgestel: 'n gleuf vir 'n leksikale-itemklassifikasie, 'n gleuf vir inligting omtrent die tipiese sintaktiese optrede van 'n lemra en 'n derde gleuf vir voorbeeldmateriaal waarin ook eksplisiete inligting omtrent atipiese sintaktiese optrede verskaf word. Voorstelle word gemaak vir die aangawe van sintaktiese inligting in die artikels van multileksikale lemmas. Daar word ook gekyk na praktiese oplossings vir die weerspieëling van nuwe inligting en terminologie uit die teoretiese taalkunde.

Sleutelwoorde: ADJUNK, ATIPIESE SINTAKTIESE OPTREDE, GROEPSETSELS, LEENWOORDGROEPE, LEKSIKALE-ITEMKLASSIFIKASIE, MULTILEKSIKALE LEMMAS, SINTAKTIESE INLIGTING, TIPIESE SINTAKTIESE OPTREDE, UITDRUKKINGS 


\section{Inleidend}

Verklarende woordeboeke behoort die leksikon op só 'n wyse aan te bied dat al die verskillende inligtingstipes tot hul reg kom. Alhoewel die semantiese altyd die komponent sal wees waaraan die meeste aandag bestee word, behoort die sintaktiese komponent nou daarmee geïntegreer te wees. Zgusta (1971: 265) beklemtoon dat sintaktiese inligting ' $n$ wesenlike deel van ' $n$ woordeboek moet wees en nie hanteer moet word asof dit 'n soort nagedagte is nie.

Tussen die semantiese en die sintaktiese komponent bestaan daar 'n noue verband omdat leksikale items nie in isolasie funksioneer nie, maar in sinsverband. Die gebruiker moet derhalwe van voldoende sintaktiese inligting voorsien word om self die item in sinsverband te kan gebruik. Gouws (1989: 229) wys daarop dat tipiese asook problematiese aspekte van die lemma se optrede in sinsverband toegelig moet word.

In hierdie artikel word voorstelle gemaak rondom die eksplisiete en implisiete aanbieding van sintaktiese inligting by leksikale en multileksikale lemmas in verklarende Afrikaanse woordeboeke. Die artikel is gerig op 'n praktiese oplossing en is nie in die eerste plek op die teorie ingestel nie.

\section{Gleuwe vir verskillende tipes sintaktiese inligting}

Dit sou nadelig vir die gebruiksvriendelikheid van 'n woordeboekartikel wees indien verskillende tipes sintaktiese inligting gesamentlik in 'n bepaalde gleuf verskaf word. Anders as bv. morfologiese inligting is sintaktiese inligting van 'n geskakeerde aard en kan dit in die artikel versprei word. Hieronder volg 'n uiteensetting vir die aanbieding van sintaktiese inligting in drie verskillende gleuwe. In die eerste gleuf word 'n leksikale-iłemklassifikasie verskaf, bv. werkwoord, groepsetsel of uitdrukking. Die tweede gleuf bevat inligting omtrent die tipiese sintaktiese optrede van 'n lemma, bv. die vaste voorsetselverbinding van sekere werkwoorde (voorsien van). In die derde gleuf word voorbeeldmateriaal aangebied en met behulp van subgleuwe word ook bykomende inligting omtrent problematiese of atipiese sintaktiese optrede verskaf.

Omdat die gleuf vir 'n leksikale-itemklassifikasie die mees problematiese is, word veral dáárop gekonsentreer. Die gleuwe vir tipiese en atipiese sintaktiese inligting is relatief probleemloos en daarom word volstaan met enkele voorbeelde.

\section{$2.1 \quad$ Leksikale-itemklassifikasie}

Lemmas word in verklarende Afrikaanse woordeboeke tradisioneel van in woordsoortklassifikasie voorsien. Dit volg gewoonlik onmiddellik ná die lemmagleuf. Die vernaamste kritiek teen die heersende praktyk is dat slegs 
leksikale lemmas so 'n klassifikasie kan ontvang en dat van verouderde klassifikasieterme gebruik gemaak word (Gouws 1989: 213). Wat hier volg, is 'n poging om na aanleiding van hierdie en ander kritiek 'n beter leksikografiese praktyk rondom die klassifisering van leksikale items daar te stel.

\subsubsection{Leksikale lemmas}

Drie klassifikasieterme word vervolgens bespreek, nl. dié van werkwoord, byvoeglike naamwoord en bywoord.

\section{Die klassifikasie van werkwoorde}

Woordeboeke volstaan gewoonlik met 'n primêre klassifikasie van leksikale items as werkwoorde:

$$
\text { lyk ww. ... (Nasionale Woordeboek (hierna NW)) }
$$

Teoretici (Gouws 1989: 223, Otto 1989: 80 e.v.) is ten gunste van die verfyning van woordsoortaanduiding deur middel van 'n sekondêre klassifikasie. Ponelis (1979: 187) onderskei twee hoofklasse werkwoorde: hoofwerkwoorde en medewerkwoorde. Die hoofwerkwoorde sluit oorganklike, onoorganklike, koppel-, voorsetsel-, wederkerende en deeltjiewerkwoorde in. Medewerkwoorde word verdeel in die subkategorieë hulpwerkwoorde en skakelwerkwoorde.

Kom en laat soos gebruik in die verbindings kom kuier en laat hoor is voorbeelde van skakelwerkwoorde. NW en die Woordeboek van die Afrikaanse Taal (hierna WAT) maak wel in hul artikels van kom gebruik van 'n sekondêre klassifikasie. Beide gee 'n primêre klassifikasie as werkwoord en verstrek dan by ' $n$ bepaalde betekenisonderskeiding 'n sekondêre klassifisering:

kom. I w....

2. (as hulpw.) ... (WAT)

kom II ww....

8. as hulpww. van aspek ... (NW)

Deur kom as hulpwerkwoord te klassifiseer in 'n bepaalde betekenisonderskeiding, word te kenne gegee dat dit ook as 'n nieselfstandige werkwoord kan optree. Alhoewel die klassifisering nie aansluit by die heersende taalkundige terminologie nie, word die gebruiker wel van inligting voorsien omtrent die nieselfstandige optrede van kom.

NW maak geen werklike sekondêre klassifikasie in die geval van laat nie, maar volg tog 'n sekere prosedure ter aanduiding van 'n onderskeidende optrede van die woord in 'n sekere betekenisonderșeiding: 
laat. 1 ww....

6. veroorsaak, doen, maak dat iets gebeur. Iem. laat weet, haal, roep.

Opmerking: Daar is 'n algehele teenstelling tussen betekenis 6 en die voorafgaande betekenisse. (NW)

NW gaan hier op ' $n$ totaal inkonsekwente wyse te werk in die beskrywing van kom en laat, aangesien kom wel van 'n subklassifikasie voorsien word, maar daar net op 'n vae wyse d.m.v. 'n opmerking gewys word op die nieselfstandige optrede van laat. Soos vervolgens getoon sal word, kan die gebruik van 'n opmerking egter wel verhelderend wees.

Dit lyk nie asof die terme medewerkwoord, skakelwerkwoord of deeltjiewerkwoord al in so 'n mate tot die omgangstaal deurgedring het dat aanvaar kan word dat dit aan die meeste woordeboekgebruikers bekend is nie. Nie een van Suid-Afrika se onderwysdepartemente maak bv. voorsiening vir dié terme in hul Afrikaans-leerplanne nie.

Die woordeboekmaker is dus huiwerig om die nuwe terme te gebruik. Dit blyk opnuut uit die feit dat die 1993-uitgawe van die Verklarende Afrikaanse Woordeboek (hierna VAW) geen vernuwing t.o.v. woordsoortterminologie bevat nie. Dit is ' $n$ jammerte, want dit is by uitstek die handwoordeboeke wat die weg moet baan vir vernuwing. Handwoordeboeke word elke 5 tot 10 jaar hersien, wat 'n uitstekende geleentheid vir vernuwing in terminologie bied. 'n Omvattende woordeboek soos die WAT is nie in dieselfde posisie nie aangesien daar ter wille van kontinuiteit deurlopend van dieselfde terminologie gebruik gemaak moet word.

Die feit dat die 1991-uitgawe van die Afrikaanse Woordelys en Spelreëls die terme deeltjiewerkwoord, medewerkwoord en skakelwerkwoord in die lys van terme insluit wat in die toeligting verklaar word, kan lei tot 'n breër bekendstelling daarvan.

Dit lê nie op die weg van die leksikograaf om terminologie te skep of bestaande terminologie te beoordeel nie - hy moet hom egter van terminologie bedien wat die stand van die taalkunde weerspieël terwyl hy tegelykertyd ook die woordeboekgebruikers se bekendheid met die terminologie in ag moet neem. Dit is derhalwe te betwyfel of dit tans wys is om op blatante wyse in sekondêre klassifikasie volgens die jongste terminologie te verskaf. Die belange van die woordeboekgebruiker sal waarskynlik beter gedien word deur 'n primêre klassifikasie aangevul deur 'n opmerking waarin 'n sekondêre klassifikasie verstrek word:

3laat ww. ...

OPM. Laat behoort tot die hoofgroep werkwoorde bekend as medewerkwoorde. Medewerkwoorde word verdeel in die subkategorieë hulpwerkwoorde en skakelwerkwoorde. Laat is 'n skakelwerkwoord. 


\section{Die klassifikasie van byvoeglike naamwoorde}

Sommige woordeboeke (bv. NW) klassifiseer leksikale items wat as naamwoordelike sowel as bywoordelike bepalings optree as byvoeglike naamwoorde, bv. mooi, vinnig, skelm. Ander (WAT, HAT, VAW) klassifiseer hierdie items as byvoeglike naamwoorde én bywoorde:

krom. I b.n. en bw., krommer, kromste. (WAT)

mooi2, (b, bw), (-e); -er, -ste. (VAW)

vinnig, b.nw. en bw. (HAT)

Skerp kritiek is reeds uitgespreek teen die klassifikasie van leksikale items as "b.nw. en bw." (Redaksie, Buro van die WAT 1989: 43-44). Daar is geredeneer dat verwarring geskep word tussen woordsoortkategorieë en meerfunksionaliteit deurdat "b.nw. en bw." die indruk skep van twee woordsoortelike kategorieë, terwyl hier eintlik sprake is van meerfunksionaliteit.

In die geval van die WAT is die verwarring volkome deurdat die aanloop "byw. gebruik" verwys na die meerfunksionele optrede van 'n leksikale item. Voorbeelde hiervan kom in die artikel van die lemma KRING binne die selfstandigenaamwoordkategorie voor:

kring1. I s. ... 1. a. ... I/d iteratiefvorm, byw. gebruik: Die maan op die water is in tallose visskoffies van silwer verbreek, om langsaam kring-kring ' $n$ drywende boog te herbou.

b. i. ... I/d mv. sonder die voors. in, byw. gebruik: Die roofooël draai kringe oor die swart tentlatte van die kakebeenwa.

Hierbenewens word daar ook in die WAT aangedui dat 'n item slégs byvoeglik optree deur dit as "b.n." te klassifiseer:

kortwerkend. b.n. ... 'n Kortwerkende verdowingsmiddel.

'n Bepaalde lemma kan ook in sekere betekenisonderskeidings slegs as b.nw. en in ander slegs as bw. optree:

kortliks. I bw....

II b.n.

(WAT)

Dit wil dus voorkom asof daar tog ruimte bestaan vir ' $n$.klassifikasie ter aanduiding daarvan dat sommige byvoeglike naamwoorde as bywoordelike bepalings optree en ander nie. Die klassifikasie moet egter geen ruimte laat vir verwarring tussen woordsoortkategorie en meerfunksionaliteit nie.

Die term adjunk (Ponelis 1979: 289, e.v.) is baie wyd en verwys na een van die hoofkomponente in ' $n$ stuk of sin. Dit sluit o.a. byvoeglike naamwoorde 
(gradeerbare adjunk in 'n naamwoord- of werkwoordstuk), bywoorde (niegradeerbare adjunk in 'n werkwoordstuk) en groepvoorsetsels (adjunk in 'n naamwoordstuk) in. Dit is derhalwe te wyd om as term te gebruik vir die bywoordelike optrede van 'n byvoeglike naamwoord soos reeds voorgestel is (Redaksie, Buro van die WAT 1989: 43).

'n Moontlike oplossing sou wees om byvoeglike naamwoord te gebruik waar 'n item slegs as naamwoordelike bepaling optree asook waar ' $n$ item as naamwoordelike én bywoordelike bepaling optree. In laasgenoemde geval kan die bywoordelike optrede egter soos in alle gevalle van meerfunksionaliteit uitgelig word deur middel van 'n aanloop:

mooi b.nw.; mooier, mooiste.

1 Aangenaam vir die sintuie: Die mooi meisie laat die manne se koppe draai.

- Ook bywoordelik: Die virtuoos speel só mooi viool dat selfs die honde luister.

- Ook soms selfstandig: Die mooi van die lewe. Die goeie is beter as die mooie.

Die voorgestelde hantering stel die leksikograaf in staat om voorbeeldmateriaal volgens die funksionele optrede van die betrokke leksikale item te verdeel. Sodoende word waardevolle inligting omtrent die sintaktiese optrede van die lemma aan die gebruiker verskaf.

\section{Die klassifikasie van bywoorde}

Die kategorie bywoord word deur verklarende Afrikaanse woordeboeke gebruik ten opsigte van niegradeerbare bywoordelike bepalings:

$\begin{array}{ll}\text { amper bw.... } & \text { (NW) } \\ \text { dikwels bw.... } & \text { (NW) } \\ \text { liefs bw.... } & \text { (NW) } \\ \text { blindweg bw.... } & \text { (NW) }\end{array}$

Die VAW verskaf slegs 'n woordsoortaanduiding by homonieme wat ten opsigte van woordsoortelikheid verskil:

$$
\begin{aligned}
& \operatorname{nou}^{1},(s) \\
& \operatorname{nou}^{2},(b) \\
& \operatorname{nou}^{3},(b w)
\end{aligned}
$$

wat meebring dat bywoorde soos amper en dikwels geen woordsoortaanduiding ontvang nie en die gebruiker meestal in die duister gelaat word ten opsigte van die woordsoortelikheid van lemmas. 
Die hantering van die meerfunksionele optrede van bywoorde in verklarende Afrikaanse woordeboeke is nie altyd bevredigend nie (vgl. die behandeling in die HAT van amper en dikwels). Indien daar sprake is van meerfunksionaliteit sonder gepaardgaande betekenisverskil kan die hanteringswyse wat hierbo voorgestel is, gevolg word:

landinwaarts bw. In die land in of na die binneland toe: Hy sien dat duisende seevoëls landinwaarts vlieg. Kleiner skepe kan taamlik ver landinwaarts vaar op die rivier.

- Ook byvoeglik: In die landinwaartse distrikte het ander bouvorms vir plaashuise ontwikkel.

dikwels bw. ...

- Ook soms byvoeglik: Die dikwelse gebruik van vlooipoeier word aanbeveel.

Indien die meerfunksionaliteit van 'n leksikale item gepaard gaan met betekenisverskil behoort verskillende woordsoortkategorieë gemaak te word:

lekker I b.nw., lekkerder, lekkerste.

1 Wat genot verskaf: 'n Lekker naweek, partytjie, vakansie.

- Ook bywoordelik: Lekker eet, drink, ontspan.

2 ...

II bw. Baie erg of in 'n hoë mate: Jy's darem lekker laf! Lekker moeg, dors, siek, bang wees. Ek het lekker geskrik toe ek hom sien.

III tw. ...

Die bywoord-karakter van lekker in bet. Il blyk onder meer daaruit dat dit nie gradeerbaar is nie. In die bywoordelike gebruik van die byvoeglike naamwoord in bet. I is lekker egter wel gradeerbaar.

\subsubsection{Multileksikale lemmas}

Omdat multileksikale leksikonitems selde gelemmatiseer word en meestal as mikrostruktuurelemente opgeneem word, is daar nie eintlik sprake van 'n leksikale-itemklassifikasie nie. NW neem bv. die uitdrukkings met wortel en tak uitroei, van die hak op die tak spring, hoog in die takke wees en die takke insit onder die eerste betekenisonderskeiding van die leksikale lemma tak op. HAT en WAT neem uitdrukkings in 'n rubriek in die artikel van 'n leksikale lemma op.

Alle multileksikale leksikonitems behoort as multileksikale lemmas opgeneem te word en van 'n leksikale-itemklassifikasie voorsien te word in die gleuf wat daarvoor gereserveer word.

In die metaleksikografie is reeds wyses aangedui waarop meerwoordige leksikale items gelemmatiseer kan word (vgl. Gouws 1990 en Botha 1991). 'n 
Metode van gemerkte lemmatisering waarvolgens multileksikale lemmas volgens bepaalde kernkomponente (wat lidwoorde, voorsetsels en voornaamwoorde uitsluit) gealfabetiseer word, word deur hulle voorgestel. Die voorstel is ten opsigte van uitdrukkings gemaak maar dit sou ook na ander meerwoordige leksikale items uitgebrei kon word. 'n Kernkomponent word as soekwoord of trefwoord gekies. Die soekwoord, gevolg deur 'n dubbelpunt, word vooraan die meerwoordige item geplaas en die geheel as lemma opgeneem. Hiervolgens sou die groepsetsel met behulp van soos volg gelemmatiseer kon word:

\section{behulp: met behulp van}

Die toekenning van leksikale-itemklassifikasies aan drie tipes multileksikale lemmas, t.w. uitdrukkings, groepsetsels en leenwoordgroepe word vervolgens bespreek.

\section{Uitdrukkings}

Uitdrukkings kan nie in terme van die tradisionele woordsoortklassifikasies benoem word nie, omdat hulle nie oor die vereiste sintaktiese of morfologiese eienskappe beskik nie. Uitdrukkings sou bloot op grond van hul vorm as sintaktiese konstruksies benoem kon word. Ponelis (1979: 5 e.v.) gebruik terme soos naamwoordstuk, adjektiefstuk, setselgroep en sin wat ook op uitdrukkings van toepassing gemaak sou kon word:

lyf en goed naamwoorstuk

lam in die knieë adjektiefstuk tot oorlopens toe setselgroep

sy lampie is uit sin

'n Uitdrukking is 'n naamwoordstuk, adjektiefstuk, setselgroep of sin wat tot 'n betekeniseenheid ontwikkel het en dit is onderworpe aan sekere semantiese, morfologiese en sintaktiese beperkings. Dit is derhalwe geen gewone sin of stuk of groep nie en die gebruiker gaan waarskynlik meer nut daarvan hê as dit bloot as uitdrukking geklassifiseer word.

'n Sekondêre klassifikasie van uitdrukkings kan egter gemaak word. Daar is woordgroepvakterme soos laminêre vloei en figuratiewe kuns en ook woordgroepe met 'n mindere mate van vakkundige betekenis soos van die liug haal en dic feite van die lewe wat ook as uitdrukkings kan kwalifiseer. Ons sou hierdie uitdrukkings gespesialiseerde uitdrukkings kon noem en die ander uitdrukkings idiomatiese uitdrukkings:

lawaaiwa: op die lawaaiwa klim idiomatiese uitdr.

lol: iemand 'n lol aandraai idiomatiese uitdr. 
laminêre: laminêre vloei gespesialiseerde uitdr.

feite: die feite van die lewe gespesialiseerde uitdr.

\section{Groepsetsels}

'n Groepsetsel, ook 'n groepvoorsetsel genoem, het betekeniseenheid, tree as geheel as setsel op, vervul dieselfde funksie as 'n simplekse voorsetsel en is ook dikwels vervangbaar daardeur: ten tyde van (tydens), met behulp van (met).

Groepsetsels is nie ' $n$ homogene groep nie, aangesien sommige semanties volkome deursigtig is soos in antwoord op, in samewerking met en ander nie, soos ten spyte van, ten behoewe van. Die ondeursigtige groepsetsels sou ook as uitdrukkings geklassifiseer kon word en Ponelis (1989: 49) gebruik dan ook die term setseluitdrukkings.

Die term groepsetsel kan verwarrend wees dangesien sirkumposisiesetsels soos tot ... toe in tot nou toe, deur ... heen in deur die jare heen ook as groepsetsels beskryf sou kon word. Die term groepvoorsetsel (Ponelis 1979: 173) is minder bekend, maar ook minder verwarrend aangesien dit soos die ander setselbenamings verwys na die plasing daarvan t.o.v. die aanvulling: voorsetsel, agtersetsel en sirkumposisiesetsel. Beide terme is waarskynlik aan die gemiddelde woordeboekgebruiker onbekend, maar omdat die term voorsetsel geen bekendstelling nodig het nie behoort woordeboekgebruikers nie probleme te hê met groepvoorsetsel as leksikale-itemklassifikasie nie:

spyte: ten spyte van groepvoorsetsel

gevolg: as gevolg van groepvoorsetsel

\section{Leenwoordgroepe}

'n Leenwoordgroep is ' $n$ woordgroep wat aan ' $n$ vreemde taal ontleen is en as 'n betekeniseenheid optree soos bona fide, laissez faire, sotto voce. Aangesien leenwoordgroepe in so 'n mate vir die gebruiker 'n eenheid vorm dat hy nie in staat is tot woordsoort- of kernkomponentonderskeiding nie, behoort dit ongemerk alfabeties, volgens die beginwoord, gelemmatiseer te word. Leenwoord-. groepe word in verklarende Afrikaanse woordeboeke as multileksikale lemmas opgeneem, maar word selde van 'n leksikale-itemklassifikasie voorsien:

in camera. (L.) ...

comme ci comme ça $(F$.$) ...(WAT)$

Die NW het verskillende hanteringswyses t.o.v. leenwoordgroepe en in sommige gevalle word 'n woordsoortklassifikasie verskaf:

lingua franca It. s.nw.

bona fides L. s.nw. 
carte blanche F. s.nw.

conditio sine qua non $L$.:

de novo L.:

curator ad litem L.

In bogenoemde gevalle kan geredeneer word dat die sintaktiese optrede van die leenwoordgroepe telkens gelyk is aan dié van 'n leksikale lemma. Die eenheidskarakter van lingua franca word bv. ook daardeur geillustreer dat dit benewens die Latynse meervoud linguae francae ook 'n eiesoortige Afrikaanse meervoud het sonder die Latynse kongruensie van s.nw. en b.nw., nl. lingua francas. Die leenwoordgroep lingua franca se semantiese, morfologiese en sintaktiese optrede is dus dié van 'n eenheid en wel dié van 'n selfstandige naamwoord. Die hantering van lingua franca behoort in ooreenstemming met dié van ander selfstandige naamwoorde te wees:

lingua franca s.nw., lingua francas of soms linguae francae. (It.)

Alhoewel die Latynse leenwoordgroep bona fides 'n kongruente v roulike enkelvoudverbinding van b.nw. en s.nw. is, word dit in Afrikaans, waarskynlik na analogie van ander meervoudsuitgange op $-s$, as 'n meervoudsvorm gebruik met die betekenis van "goeie of opregte bedoelings". Sintakties, semanties en morfologies is dit ' $n$ eenheid wat optree soos ' $n$ selfstandige naamwoord.

Dit wil dus voorkom asof leenwoordgroepe 'n sterk woordkarakter het en in terme van die tradisionele woordsoortklassifikasies benoem kan word. Woordsoortaanduiding sal van groot nut wees omdat dit tesame met voorbeeldmateriaal die gebruiker in staat sal stel om die leenwoordgroep korrek te gebruik.

Verklarende Afrikaanse woordeboeke behoort hulle daarop toe te spits om op konsekwente wyse die gleuf vir leksikale-itemklassifikasie, bv. deur woordsoortaanduiding, in die artikels van leenwoordgroepe te vul.

\subsection{Tipiese sintaktiese optrede}

Inligting omtrent die tipiese sintaktiese optrede van 'n leksikale of multileksikale lemma kan in 'n tweede gleuf vir sintaktiese inligting verstrek word. Aangesien sintaktiese en morfologiese inligting die twee subtipes grammatiese inligting is, behoort dit opeenvolgend aangebied te word:

lus b.nw.; lusser, lusste. (slegs pred.)

lewensbelang s.nw. (gew. saam met van)

Inligting wat hier verstrek kan word, handel onder andere oor die tipiese voorsetselverbinding van sekere werkwoorde en selfstandige naamwoorde (voor- 
sien van, van lewensbelang), predikatiewe of attributiewe optrede van byvoeglike naamwoorde, die verbinding met 'n lidwoord (die meeste) en die passiewe of imperatiewe optrede van werkwoorde (gew. i.d. imperatief, gew. passief).

Inligting oor tipiese sintaktiese optrede kan ook by 'n spesifieke betekenisonderskeiding verskaf word:

lel s.nw., lelle; lelletjie ...

3 (gew. saam met lang) lemand wat ...: So 'n lang lel het dit ook maar moeilik om klere te kry wat pas.

lees ww., het gelees ...

2 (saam met soos) Die indruk wek van: Die reeks gebeurtenisse wat gelei het tot die ontdekking van die skatte lees soos ' $n$ speurverhaal.

3 (gew. in die imperatief) Vervang die voorafgaande deur: Die mense van Bavaria (lees: Beiere) is bekend vir hulle gemoedelikheid.

lekker b.nw.; lekkerder, lekkerste ...

3 (slegs i.d. negatief) Nie goed geluim of gesind nie: Haar kos was so smaaklik soos altyd, maar sy was nie lekker nie.

4 (slegs attributief) Joviaal en lief vir plesier: $H y$ is ' $n$ goeie tennisspeler en ' $n$ lekker kèrel in die kroeg.

\subsection{Atipiese sintaktiese optrede}

In die derde gleuf vir sintaktiese inligting word voorbeeldmateriaal aangebied. Dit is nie die doel om hier 'n uitvoerige bespreking te gee omtrent die keuse van en ander aspekte van voorbeeldmateriaal nie (vgl. in hierdie verband Lombard 1992: 148-162). Voorbeeldmateriaal word veral gesien as ' $n$ implisiete weergawe van sintaktiese inligting (Gouws 1989: 229). Hierdie inligting kan egter deur middel van subgleuwe vir die gebruiker ontsluit word.

Die voorbeeldmateriaal illustreer die sintaktiese inligting wat in die ander twee gleuwe vermeld is. Inligting omtrent die atipiese asook ander sintaktiese optredes van 'n lemma wat vir die gebruiker van belang kan wees, kan egter op eksplisiete wyse in subgleuwe verstrek word. Ook die meerfunksionele optrede van 'n lemma kan in hierdie gleuf op eksplisiete wyse geïllustreer word. In die artikel van die werkwoord lees kan die volgende eksplisiete inligting onder meer verstrek word:

- Ook selfst.: Die praat, lees en skryf van ' $n$ taal.

- Met 'n persoon, bv. 'n skrywer, as direkte voorwerp: Hy lees graag Shakespeare.

- Met dit wat gelees word as onderwerp: Chaucer lees moeilik. Die boek lees lekker en hanteer maklik. 
'n Term wat met vrug in hierdie gleuf gebruik kan word, is dié van nabepaling (Ponelis 1979: 119), bv. in die artikels van die b.nwe. lekker en leersaam:

- As nabepaling: Selfs die terugstap was iets lekkers. Daar is niks lekkerders in die wêreld as om jou eie baas te wees nie. Daar is vir Jannie niks lekkerder as hierdie koel vogtige grond om in te speel nie.

- As nabepaling: Die lugoffisier het iets leersaams om mee te deel.

\section{Slotwoord}

Daar bestaan leemtes in die aanbieding van sintaktiese inligting in verklarende Afrikaanse woordeboeke. Die leemtes bestaan veral t.o.v. 'n konsekwente aanbieding van sintaktiese inligting by leksikale én multileksikale lemmas en t.o.v. die gebruik van nuwe inligting uit die teoretiese taalkunde. Die hoop word uitgespreek dat die voorstelle in hierdie artikel die praktiserende leksikograaf tot nut mag wees in die uitskakeling van die bestaande leemtes.

\section{Verwysings}

\section{Woordeboeke}

De Villiers, M. e.a. 1987. Nasionale Woordeboek. Kaapstad: Nasou.

Labuschagne, F.J. en Eksteen, L.C. 19938. Verklarende Afrikaanse Woordeboek. Pretoria: Van Schaik. Odendal, F.F. 19792. Verklarende Handwoordeboek van die Afrikanse Taal. Doornfontein: Perskor.

Schoonees, P.C.F.J. Snijman/D.C. Hauptfleisch (Reds.). 1950-1991. Woordeboek van die Afrikaantse Taal. Pretoria: Staatsdrukker/Stellenbosch: Buro van die WAT.

\section{Ander bronne}

Botha, T.J.R. (Red.). 1989. Leksikografie en leksikologie. Pretoria: Serva.

Botha, W.F. 1991. Die lemmatisering van uitdrukkings in verklarende Afrikaanse woordeboeke. Lexikos. AFRILEX-reeks 1: 1991: 20-36.

Gouws, R.H. 1989. Leksikografie. Kaapstad: Academica.

Gouws, R.H. 1990. Vaste uitdrukkings as multileksikale lemmas in verklarende Afrikaanse woordeboeke. Tydskrif vir Geesteswetenskappe 30(4): 265-283.

Lombard, F.J. 1992. Voorbeeldmateriaal in woordeboeke. Lexikos 2. AFRILEX-reeks 2: 1992: 148-164.

Otto, A.N. 1989. Kriteria vir ' $n$ Afrikaanse aanleerderwoordeboek. Ongepubliseerde D.Litt.-verhandeling Universiteit van Stellenbosch.

Ponelis, F.A. 1979. Afrikaanse sintaksis. Pretoria: Van Schaik.

Ponelis, F.A. 1989. Leksikale elemente. Botha, T.J.R. (Red.). 1989: 48-54.

Redaksie, Buro van die WAT. 1989. Nofule van die groepsgesprek wat oan 27 tot 29 November 1989 op Stellenbosch plaesgevind het. Ongepubliseerde verslag. Stellenbosch: Buro van die WAT.

Zgusta, L. 1971. Manual of Lexicography. Den Haag: Mouton. 


\title{
Lexicography in West Africa: Preparing a Bilingual Kisi-English Dictionary
}

\section{G.T. Childs, Department of Linguistics, University of the Witwatersrand, Johannesburg, South Africa}

\begin{abstract}
This paper presents some of the issues involved in preparing a bilingual dictionary for Kisi, an underdocumented language spoken in West Africa. Because the language possesses little in the way of literacy materials, fundamental issues as to orthography, word division, etc., had to be considered. In addition, no grammar of the language (or its closest congeners) was available and thus basic grammatical analysis had to be performed simultaneously. 1 briefly consider some of these problems, discussing the use of the lexical data base programs known as LEXWARE. I then focus on the specific problems raised by the expressive word class known to Africanists as ideophones. The conclusion, in the form of advice to future lexicographers of such languages, is that before undertaking such an endeavour, one must seriously assess its feasibility.
\end{abstract}

Keywords: ATLANTIC LANGUAGES, BILINGUAL DICTIONARY, COMPUTER SOFTWARE, EXPRESSIVE LANGUAGE, IDEOPHONES, KISI, LANGUAGE VARIATION, LEXICOGRAPHY, PHONOLOCY, PRAGMATICS, SEMANTICS

\section{Opsomming: Leksikografie in Wes-Afrika: Die voorbereiding van 'n} tweetalige Kisi-Engels-woordeboek. In hierdie artikel word sommige van die kwessies in verband met die voorbereiding van 'n tweetalige woordeboek vir Kisi, 'n swak gedokumenteerde taal van Wes-Afrika, bespreek. Omdat Kisi oor min literêre materiaal beskik, moes fundamentele kwessies oor byvoorbeeld ortografie en woordskeiding in ag geneem word. Boonop was geen grammatika van die taal (of van 'n aanverwante taal) beskikbaar nie, en moes 'n basiese grammatikale analise terselfdertyd uitgevoer word. Ek beskou kortliks enkele van hierdie probleme en bespreek die gebruik van die leksikale databasisprogramme bekend as LEXWARE. Daarna konsentreer ek op die spesifieke probleme veroorsaak deur die ekspressiewe woordklas wat onder Afrikaniste as ideofone bekend staan. Die gevolgtrekking waartoe in die vorm van advies aan toekomstige leksikograwe van soortgelyke tale gekom word, is dat 'n deeglike lewensvatbaarheidsondersoek eers nodig is voor die aanpak van so ' $n$ woordeboekonderneming.

Sleutelwoorde: ATLANTIESE TALE, EKSPRESSIEWE TAAL, FONOLOGIE, IDEOFONE, KISI, LEKSIKOCRAFIE, PRAGMATIEK, REKENAARPROCAMMATUUR, SEMANTIEK, TAALVARIASIE, TWEETALIGE WOORDEBOEK 


\subsection{Introduction}

In West Africa many languages possess little in the way of lexicographic materials, in fact, little in the way of any written materials 1 . This is particularly true of the less widely spoken languages belonging to the Atlantic Group of NigerCongo, the latter being the phylum containing two-thirds of Africa's languages (Bendor-Samuel 1989). The position of Atlantic within Niger-Congo is shown in (1). Atlantic languages are only distantly related to the Bantu languages of southern Africa, all of which belong to Benue-Congo.

(1) Atlantic within Niger-Congo (Williamson 1989: 21)

Niger-Congo

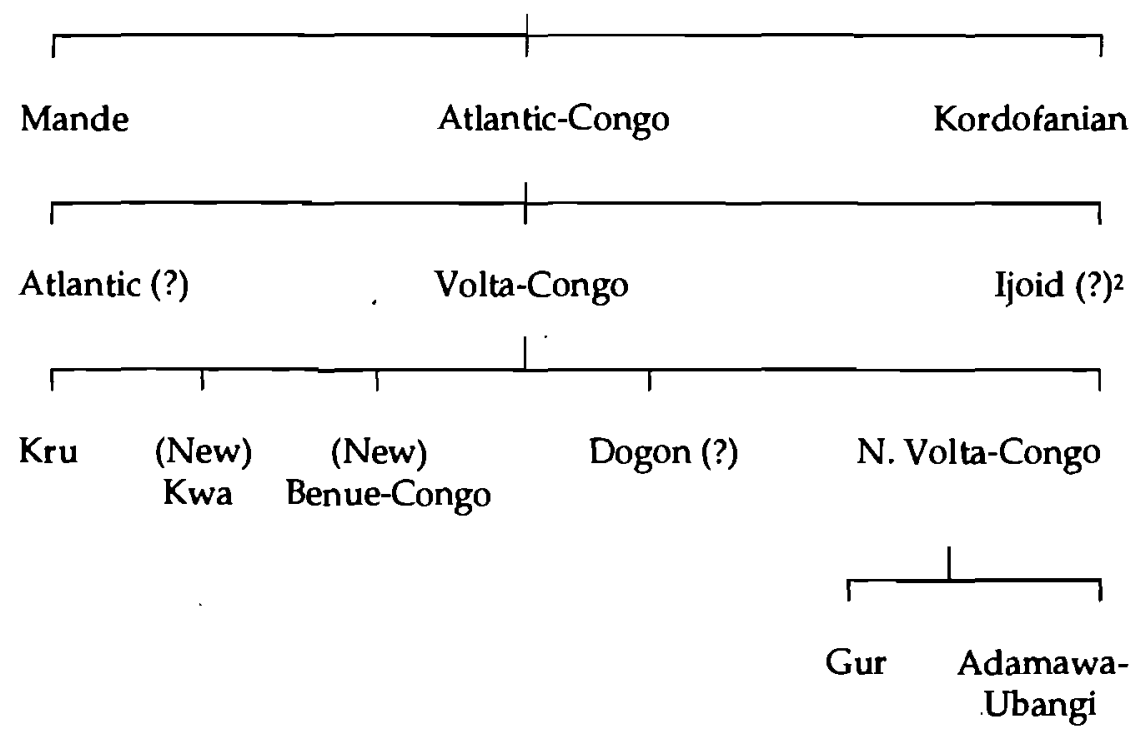

The Atlantic language on which I focus is Kisi, a member of Atlantic's Southern Branch, spoken primarily in the Republic of Guinea but also in Sierra Leone and Liberia. The display in (2) shows Kisi and its closest relatives.

(2) The position of Kisi within Atlantic.(Childs 1993b)

I. Northern Branch
A. Senegambian languages: Fula, Serer, Wolof
B. Cangin: Lehar, Safen, Non; Ndut, Falor
C. Bak: Diola, Manjaku, Mankanya, Papel, etc.
D. Eastern Senegal-Guinea: Tenda, Biafada, etc.
E. Nalu, Mbulungish, Baga Mboteni 
II. Bijago

III. Southem Branch

A. Mansoanka

B. Mel languages

1. Baga Binari, Landuma, Temne, etc.

2. Bulom: Mmani, Sherbro, Krim, Bom; Kisi

3. Gola C. Limba

Only a few Atlantic languages possess anything in the way of written materials. The exceptions are the more widely spoken languages such as Fula, Wolof, and Temne. For the less widely spoken varieties (some of which may be "dying" or already "dead", e.g., Krim of the Southern Branch (Heine 1970: 145)), written materials, if they exist, are rudimentary. They have been assembled by individuals with little linguistic much less lexicographic training, compiled primarily to assist nonnative speakers in learning a language or in translating religious works and educational materials ${ }^{3}$. This paper presents some of the problems involved in developing a dictionary for such a language.

The first point that needs to be made is that compiling a dictionary is a monumental task in terms of both time and resources. It should not be undertaken without some foreknowledge, even with all the new software and miniaturized hardware to assist in the task. Nonetheless, lexicography is a field well worth exploring, particularly in terms of probing a culture and discovering the mechanics of a language's operation. From a linguistic perspective one learns the centrality of the lexicon to a language and confronts the incredible variation that forms a part of all speakers' competences.

Crucial to any lexicographic undertaking is identifying the audience, for there are many forms a dictionary can take. Besides the monolingual vs. bilingual distinction, a dictionary can, for example, appeal strictly to the linguist. An example of such a irork is $A$ !Xód Dictionary, in which the entries are arranged phonologically because "the Dictionary was initially compiled as a resource for Khoisan phonologists and comparative linguists" (Traill 1993: 3). Entries are ordered by phonological classes rather than alphabetically: clicks precede non-click stops, which precede fricatives, etc. The sort of dictionary I set out to compile aimed at a English-speaking mostly non-Kisi audience, although literate Isis would certainly find the work of use.

Concomitantly with compiling a dictionary, any lexicographer must be involved with issues in language standardization (e.g., Fasold 1984), often more of a political than a linguistic activity (e.g., Eastman 1992). Other written materials exist, featuring more than three different orthographies (the form of which could at least be partially predicted on the basis of knowing who the colonizer was (cf. Awak 1992)5). However, none of these orthographies had been extensively supported (cf. Heine 1992 for a different report on the Kisi spoken in Guinea) and thus established conventions could be balanced against 
linguistic considerations. The dictionary was allowed to use a roughly phonemic orthography.

After a brief summary of the dictionary's history, I turn to some of the more technical aspects, concentrating in some detail on ideophones, an aspect that provides all Niger-Congo lexicographers with challenges and one that has not been satisfactorily resolved to date.

\subsection{Project background}

In 1979 I began to study Kisi as a linguistic object, having already learned to speak it in a sort of functional way some years before. Fieldwork began in 1983 when I studied the linguistic importance of Kisi for the pidgins used by Kisi people in the area where Guinea, Liberia, and Sierra Leone come together. An awareness of my ignorance of Kisi grammar recommended studying Kisi itself. Because of the difficulty in securing support for work on "minor" languages6, however, since then I have been able to work on the dictionary in only a desultory manner. More discouraging is that the grammar and dictionary need checking with native speakers, a project which can be carried out only with some change in the political situation for the past several years have seen the Kisi area of Liberia racked with civil war.

1 give this background information to inform the reader of the considerable persistence that is required to complete a project of this nature7. Such an undertaking should be begun only with a realistic assessment of the pragmatic aspects. The technical aspects of preparing a dictionary for a little known language, to which I now turn, also present a challenge, but one which is much more fulfilling and susceptible of resolution.

\subsection{Some technical issues}

Technical issues involve not only the choice of recording equipment, computer hardware and software, etc., but also purely linguistic, even theoretical, choices, e.g., the treatment of clitics, morphophonemic variants, etc. I give brief details of equipment choice and of linguistic decisions in this section, expatiating somewhat on the challenge ideophones pose to the conscientious lexicographer.

\subsection{Hardware and software}

I omit discussion of some of the more obvious and common concerns and turn first to several resources that proved valuable to determining the sort of software and hardware needed for lexicographic work. In the way of preamble, it 
should be noted that I started with the collection of data in a distant and somewhat inaccessible locale. This fact determined many of my choices. Works 1 found particularly helpful, aside from the standard lexicographic works, e.g., Zgusta 1971, Hartmann 1983, came from such missionary organizations as the Summer Institute of Linguistics (SIL) and the Lutheran Bible Translators (LBT), e.g., Hughes 1987, Bartholomew and Schoenhals 1983. Members of the latter organization had helped me even before I made my first trip back to West Africa (and have provided consultation since) ${ }^{8}$. The JAARS Center, a support organization for both SIL and LBT, also made available relevant reference materials and provided advice on the technical side of computer work in the field'.

In so far as the actual equipment one should use, a computer (or two) is absolutely indispensable. Portability is often crucial; fortunately, there are many exceilent laptops on the market at prices that continue to fall and with power that continues to increase ${ }^{10}$.

With regard to software, at the time I was preparing for fieldwork the most widely used software designed for linguists was the lexical database system LEXWARE (Hsu 1990). Its appeal was its linguistic orientation and the fact that it had already been used on ShiNzwani, a Bantu language closely related to Swahili and typologically similar to Kisi. LEXWARE is described as,

a package of programs designed to help linguists compile and manage files of lexical data. It is oriented toward compilation and exploitation of a lexical file as a RESOURCE for further investigation into aspects of a language and culture, e.g., phonology, lexicon, grammar, semantics, ethnog-1 raphy, etc. (Hsu 1990: 1).

LEXWARE is both useful and powerful. It performs all the tasks expected of such software, chief of these being sorting and organizing the data in a perspicuous fashion. It furthermore generates a reverse dictionary, albeit more of an index than a real dictionary. The relative simplicity of its programs allows for a great deal of customization.

One great virtue of LEXWARE, because of its wide use by linguists and extensive documentation, is that it forces the compiler into analysing the language in detail and provides ample guidelines for doing so. It also forces one into making early decisions as to grammatical categories and structures. A virtue of its versatile (and simple) architecture allows early (wrong) decisions to be changed with relative ease as one's analysis and knowledge of the language proceeds.

A weakness, however, that all lexicographers must consider, is that LEXWARE is not designed for publishing dictionaries, although the programs have been used for such purposes in many cases. It does not work on data with embedded word-processing codes but rather requires ASCIl-formatted text. As can be seen in Appendix A (and (4) below), for example, Kisi tones 
have been represented as post-vocalic slashes and mid vowels as upper case " $\mathrm{o}$ " and " $\mathrm{e}$ ". One can certainly enter the data using a word-processor but must make sure to feed it to the programs (performed in batch mode) only in DOS.

Additional details of the programs can be found in Kari 198911, which describes their application to Ahtna, an Athabaskan language of Alaska. SIL software such as IT, an interlinear text-processing program (Simons and Versaw 1992), and SHOEBOX, a data management program (Wimbish 1990), are other alternatives that should be considered. I now give a few details to illustrate the use of LEXWARE.

The lexical data base on which the LEXWARE programs operate is organized into what are called "bands" of information that are tied to a "headword" or sub-entry within that headword's entry. I give an (abbreviated) example of the sorts of information that can be encoded in (3) ${ }^{12}$. The band denoted by "der", for example, contains derivationally related words that would not be listed as sub-entries; "Ix" states whether the entry is a compound, a word, an affix, etc.

(3) Band name abbreviations and brief characterizations

$$
\begin{aligned}
& \quad=\text { headword } \\
& \text { ps }=\text { part of speech } \\
& \text { df }=\text { definition } \\
& \mathbf{w r}=\text { written sources } \\
& \mathrm{vp}=\text { phonetic and morphophonemic variants } \\
& \mathrm{vd}=\text { dialectal variants } \\
& \mathrm{der}=\text { derivationally related words } \\
& \mathrm{lx}=\text { lexical information, size of the unit } \\
& \text { my }=\text { morphological information } \\
& \text { syn }=\text { syntactic information } \\
& \text { sem }=\text { non-definitional semantic information } \\
& \text { bk }=\text { background information, encyclopedic } \\
& \mathrm{il}=\text { illustrations } \\
& \text { clc }=\text { collocational, idioms } \\
& \text { dsc }=\text { discourse properties } \\
& \text { usg }=\text { usage } \\
& \text { sl }=\text { sociolinguistic } \\
& \text { prg }=\text { pragmatic information } \\
& \text { ex }=\text { existential status } \\
& \text { ety }=\text { etymological } \\
& \text { sr }=\text { source } \\
& \text { nt }=\text { notes }
\end{aligned}
$$

In (4) I give a much-abbreviated sample entry to show how Kisi noun classes are represented. The stem here is sía - orange', and it can take three different 
noun class markers (suffixes) and mean 'orange tree', 'orange (the fruit); orange juice', and 'drop of orange juice'. The first line contains the headword, the second indicates its part of speech, here a noun belonging to the 0 class, the third line gives a definition, etc. The asterisks are markers for the reverse sort program "INVERT", and the non-alphabetic symbols illustrate the sorts of conventions that have to be adopted because the programs work on ASCII text only. The symbols " $\&$ ", "\%", and "I" indicate typographic directions. For example, "\%" indicates that the following string must be italicized. Note also how sub-entries are preceded by two periods; sub-listings may be extended down to any number of levels. Alternatives for an entry are denoted by numbers, as in "1df" and " $2 \mathrm{df}$ " below.

(4) Sample entry

\begin{tabular}{|c|c|}
\hline hw & $\& s i / a / u \backslash w o /$ \\
\hline ps & n \& \\
\hline df & ${ }^{*}$ orange tree $\left(\%^{*} x y\right.$ lopia aethiopica $\left.\mid\right)$ \\
\hline $\mathbf{w r}$ & TSL: siawo \\
\hline lx & word \\
\hline sr & TM \\
\hline ..pl & $\& s i / a / u \backslash w a / n g$ \\
\hline ps & n \&ma \\
\hline $1 \mathrm{df}$ & "fruit of the orange tree; *orange; ${ }^{*}$ orange juice \\
\hline $2 \mathrm{df}$ & *orange ${ }^{*}$ tree \\
\hline ..sg & \&si /a/u $\backslash l e / n g$ \\
\hline df & "fruit of the orange tree; ${ }^{*}$ orange; drop of *orange juice \\
\hline
\end{tabular}

Appendix A contains a sample page from a formatted version of the data base; Appendix $B$ has a page from the English index. The LEXWARE programs can also sort bands and produce statistics on the data base.

\section{$3.2 \quad$ Linguistic issues}

In this section I adumbrate the linguistic issues that I found most challenging in compiling a Kisi dictionary.

Lexicography and grammar. Certainly one has to begin lexicographic work with a thorough knowledge of the target language's grammar, yet this is hardly an attainable object in any reasonable period of time. This knowledge must reach a fairly intimate level. At the same time one has to be familiar with the analytic tools, the formal representations, and the typological possibilities for 
language in general. A trade-off exists between the two, embodied in what could be called, "The lexicographer's paradox", given in (5).

(5) The lexicographer's paradox: sophistication varies inversely as to intimacy

a. The more sophisticated one becomes in one's approach to language, the less likely it is that one will be intimately familiar with a language other than one's own.

b. The more intimately one knows a language, the less likely one is to be familiar with alternative approaches, theories of language and linguistic analysis.

Dictionary and encyclopedic knowledge. One also has to ponder the issue of what sort of information should be included and what excluded. One criterion for that selection is the dichotomy between what has been called denotation and connotation, sense and reference, and so on. Should one exclude encyclopedic knowledge in a dictionary entry? Where in fact is the boundary between dictionary and encyclopedic knowledge? It is generally agreed upon that the knowledge of the semantics of a language - properly codified in something like a dictionary - is distinct from that knowledge of the real world, which belongs in an encyclopedia alone (Haiman 1980: 331). For example, Bloomfield (1933, as discussed in Haiman 1980) sees no precise way of defining words such as 'love' and 'hate'. In other words, at least in this case, there is an equation between semantics and knowledge of the world. The easy answer to the lexicographer's dilemma is to exclude real-world knowledge, but often that knowledge is necessary, particularly when dealing with an "exotic" language and culture (cf. Busane 1990: 33-34). In the Kisi dictionary, l have chosen to include all cultural information that would not be of general knowledge to an "outsider". For example, details of upland rice cultivation procedures are included as are procedures of the Poro and Sande (secret initiation societies for men and women respectively).

Lumping and splitting. One antinomy basic to linguistic analysis is that between those who seek to maximally differentiate and those who look for similarities and seek to group exhaustively. This tension has played itself out dramatically, for example, in the controversy surrounding work on the classification of Amerindian languages, e.g., between Campbell (a splitter) and Greenberg (a lumper) (see Matisoff 1990 for discussion). This issue manifests itself in decisions when (grammatically) subclassifying lexical (as opposed to functional) items. For example, in most NigerCongo languages the noun-class or gender systems allow for an easy categorization of nouns on morphological grounds (see (4) above), but verbs present problems. One has to consider 
argument structure, allowable complements, etc., and identify when collocational restrictions are determined semantically rather than syntactically.

Ideophones ${ }^{13}$. Ideophones pose enormous problems to the lexicographer because of their monumental variation and semantic indeterminacy. The first problem, however, is their identity and coherence as a category. All words vary and likely form only prototype (as opposed to discrete and invariant) categories (e.g., Labov 1973), and ideophones form decidedly diffuse ones. Crosslinguistically ideophones may constitute one syntactic category, may be subcategorized in another, or may be found in multiple word categories. Yet in all of these cases, within a particular language, there is shading off into other word categories, or a "squishiness" (Ross, e.g., 1972) to the ideophone category identified.

Formally ideophones vary a great deal, which variation can be interpreted as neutralizing phonological contrasts operant elsewhere in the language. I give an example in (6) of a set of ideophones all of which have the same meaning.

\section{Lumping "word clusters" in Gbeya / Gbaya (Samarin 1991)}

\section{ham hem hal hEl pal pEl 'light (in weight)'}

This is much like, from a diachronic perspective, what Bolinger (e.g., 1940) calls "accretion", the gradual snowballing or clustering of meaning about a particular soundmeaning correspondence, forming a phonaesthetic partial often known as sound symbolism, a normal process in language change. What's worse with regard to the example in (6), some speakers will regard the minimally different forms as different words; others will see them as the same word.

The solution for a splitter is to regard each slight variation as a different word. This is the approach adopted in Doke et al.'s (1990) Zulu dictionary, e.g., gqamfu, gqashu, gqimfu, and gqunsu all have a gloss, 'of snapping'. The lexicographers proliferate entries even further by regarding doubling or reduplication as representing a separate form, e.g., both cwayi and cwayicwayi, separate entries, have glosses 'of blinking'. Reduplication is commonly associated with ideophones and with expressive language in general. That this approach is characteristic of the dictionary can also be seen in the decision to list both a derivational affix and at least some of the forms both with and without that affix.

Lumping, on the other hand, which approach the Kisi dictionary follows, seeks to recognize such clusters explicitly and provide them with a single (full) entry. The altemates cross-reference the head entry (there is a band "cr" not shown in (3)) and are listed as either sub-entries or phonological variants. 
What is additionally problematic to the lexicographer from a phonological perspective is ideophones' use of phonemes not constituting part of the phonological system of the matrix language. For example, some Zulu speakers reject ideophones with [r] as "not Zulu words". In addition, ideophones exploit prosodic resources, e.g., an expanded pitch register, breathy or creaky voice, not easily represented in familiar orthographies. Is it the lexicographer's task to faithfully record these features? If so, how?

Semantically, ideophones can do as little as simply underscore the meaning of the verb with which it has a close collocational association. Just as often they go to the other extreme and carry the entire semantic import of the predication. This occurs most transparently when they are introduced by a semantically bleached "dummy" verb such as thi 'say' in Zulu (e.g., Von Staden 1977: 214), the cognate $r i$ in Venda (Poulos 1990: 422), or go in English, 'Tucker ran lickety-split down the road.' The latter case is not so problematic, but what does one do when the ideophone seems to have no independent meaning?

Another problem is semantic variation. Sometimes the form will hold constant and the meanings will change slightly from speaker to speaker and from dialect to dialect (see "enchainment" or "abduction" in Haiman 1985). Admittedly these same processes are at work in other parts of the language, but within the ideophonic subsystem they are more extensive and more frequent.

Another issue arising in the inclusion of ideophones in a dictionary is their troublesome pragmatics. In the case of ideophones, it is often the case that meaning is determined situationally by speaker and hearer. This becomes most apparent in performance situations when a narrator publicly presents a story (Noss, e.g., 1988, Poulos 1990: 417). In much the same way as gestures (see below), ideophones are embedded in social interaction. Determining the meaning of ideophones can prove incredibly frustrating to the lexicographer since the meaning of an ideophone requires a context for interpretation much more than other words. In addition, ideophones require for their understanding an intensive knowledge of the language, a knowledge often inaccessible to an outsider (Samarin 1967).

The close functional relationship of ideophones to gestures demonstrates some further problems. Gestures are poorly understood at best and have not been considered part of language (as have not ideophones for some), yet often they form a necessary concomitant to an ideophone. Gestures are decidedly a part of language, as McNeill has convincingly demonstrated: "gestures are an integral part of language as much as are words, phrases, and sentences - gesture and language are one system" [author's italics] (McNeill 1992: 2). That gestures and ideophones are closely linked has been commented on by many, e.g., Alexandre 1966. In a study of Japanese "mimetics", roughly comparable to ideophones, Kita finds that mimetics exhibit close synchrony with the stroke portion (the essential part) of gestures $98 \%$ of the time (Kita 1992); Zulu 
ideophones exhibit the same sort of synchrony in a pilot study I have performed. How then must gestures be represented?

Because of these many problems, ideophones have often been ignored or omitted. The approach often taken is to ignore them, e.g., Munro and Gaye 1991, or consider them only peripherally (Institute for Swahili Research 1981). Such an approach (and it has also been followed in grammatical descriptions) is irresponsible, especially when ideophones constitute a significant portion of a language's lexicon $\left(5,000\right.$ in Gbeya (Samarin 1978) ${ }^{14}$ ), or constitute an open and productive class, e.g., Igbo (Maduka 1983-84).

\subsection{Conclusion}

What I have tried to do in this paper is give a personal and partial account of work on the lexicon (and grammar) of Kisi. I have exemplified several of the issues that arise in the process of compiling such a work, hinting that the theoretical or purely lexicographical issues admit to easier resolution than the purely pragmatic ones. This emphasis should be interpreted as a warning, but these caveats should not dampen anyone's enthusiasm. Numerous languages, particularly in Africa, have need for the attention of a dedicated lexicographer. Admittedly there is a high learning curve to the work, but the knowledge and output are both very satisfying. Another consolation is that once one has completed a dictionary, the next one is much, much easier.

\section{Endnotes}

1 Hartmann 1990 contains a sketchy and perhaps uneven assessment of lexicography in Africa. See Prinsloo 1991 for a review.

2 Note that the question marks represent uncertainty on Williamson's part.

3 Childs 1993 b contains a brief survey of Atlantic.

4 See Samuel Johnson's definition of a lexicographer as "a harmless drudge". These are not the only rewards; there is often a small but appreciative audience. There may be expressions of gratitude from the speakers of the target language and from expatriates, for example, Peace Corps volunteers and missionaries. In addition to the expected benefit to linguists of such work, one is able to contribute to such projects as the Useful Plants Project of the Royal Botanic Gardens at Kew (United Kingdom).

5 Although Sierra Leone was colonized by the English and Guinea by the French, one cannot really say that Liberia was colonized by the Americans. Nonetheless, American influence has been pervasive and certainly differs in its effect on the Kisi orthography used in Liberia. There are actually two different systems in Liberia, one developed by the Anglo-American Church of England missionaries in Bolahun, the other by the American Lutherans in the Foya area. 
As recent exchanges in linguistics journals indicate, e.g., Hale et al. 1992, and exchanges on the "Linguist" electronic bulletin board document, there is concern for documenting the less widely spoken languages (cf. Ladefoged 1992).

7 The reader might want to compare this account with Kari's (1989) project history of his work on Ahtna, an Athabaskan language of Alaska, a decidedly more stable area than Liberia.

8 I should also mention the not inconsiderable assistance provided me by Stanley Cushingham of the Center for Applied Research in African Languages (New Haven, CT (USA)).

9 Their particulars are, International Computer Services, JAARS Center, Box 248, Waxhaw, NC 28173 (USA); (704) 843-6000.

10 One wonders what Murray would have been able to accomplish had he had access to a computer in his compilation of the OED!

11 Kari's dictionary (the Ahtna-English portion) contains some 6000 lexical entries and over 9300 example derivations and sentences. The English-Ahtna side has 10500 entries.

12 Bands can be proliferated at will and not all entries will have all bands filled. One lexical data base using LEXWARE has over 300 bands (Hsu 1990: 23); Kisi now has forty-eight

13 I assume here some familiarity with ideophones. For an early survey of Bantu ideophones, see Samarin 1971. Childs 1993a contains a more recent and extensive discussion.

14 In a Gbeya (= Gbaya) French-English dictionary, ideophones constituted $24.6 \%$ of the lexicon (8 544 entries) (Noss 1985: 242).

\section{References}

Alexandre, Pierre. 1966. Préliminaire à une présentation des idéophones bulu. Neue Afrikanistische Studien: 9-28, ed. by Johannes Lukas. (Hamburger Beitrage zur Afrika-Kunde, 5.). Hamburg: Deutsches Institut für Afrika-Forschung.

Awak, Mario Kidda. 1990. Historical Background, with Special Reference to West Africa. Lexicography in Africa: 8-18. Exeter: Exeter University Press.

Bartholomew, Doris A. and Lou ise C. Schoenhals. 1983. Bilingual Dictioniaries for Indigenous Languages. Mexico, D.F.: Summer Institute of Linguistics.

Bendor-Samuel, John (Ed.) and Rhonda L. Hartell (Asst. Ed.). 1989. The Niger-Congo Languages. Lanham, MD/London: University Press of America.

Bolinger, Dwight L. 1940. Word Affinities. American Speech 15: 62-73. (Reprinted in Forms of English, 1965. Cambridge, MA: Harvard University Press.)

Busane, Masidake. 1990. Lexicography in Central Africa: The User Perspective, with Special Reference to Zaire. Lexicography in Africa: 19-35. (Ed. by R.R.K. Hartmann. Exeter: University of Exeter Press.)

Childs, G. Tucker. 1993a. African Ideophones. Hinton, L., J. Nichols and J. Ohala (Ed.). To appear. Studies in Sound Symbolism. Cambridge: Cambridge University Press.

Childs, G. Tucker. 1993b. The Atlantic Languages.' Moseley, Christopher and R.E. Asher (Ed.). To appear in May 1993. Atlas of the World's Languages. London: Routledge.

Doke, Clement M., D.M. Malcolm, J.M.A. Sikakha'na and B.W. Vilakazi. 1990. English-Zulu Zulu-English Dictionary (first combined edition). Johannesburg: Witwatersrand University Press. 
Eastman, Carol. 1992. Sociolinguistics in Africa: Language Planning. Language and Society in Africa: 95-114. Ed. by R.K. Herbert. Johnannesburg: Witwatersrand University Press.

Fasold, Ralph. 1984. The Sociolinguistics of Society. Oxford, England: Basil Blackwell.

Haiman, John. 1980. Dictionaries and Encyclopedias. Lingua 50: 329-57.

Haiman, Jahn. 1985. Nalural Symlax: Iconicity and Erosion. Cambridge: Cambridge University Press.

Hale, Kenneth, Michael Krauss, Lucille J. Watahomigie, Akira K. Yamamoto, Colette Craig Laverne Masayeves Jeanne and Nora C. England. 1992. Endangered Languages. Language 68: $1-42$.

Hartmann, R.R.K. 1983. Lexicography: Principles and Practice. London: Academic Press.

Hartmann, R.R.K. (Ed.). 1990. Lexicography in Africa. Exeter Linguistic Studies 15. Exeter: University of Exeter Press.

Heine, Bernd. 1970. Status and Use of African Lingua Francas. Afrika-Studien 49. Munich: Weltform.

Heine, Bernd. 1992. Language Policies in Africa. Language and Society in Africa: 23-36. (Ed. by R.K. Herbert.) Johannesburg; Witwatersrand University Press.

Hsu, Robert. 1990. LEXWARE Mantal. (Second edition.) Honolulu: Department of Linguistics, University of Hawai'i.

Hughes, John J. 1987. Bits, Bytes \& Biblical Studies. Grand Rapids, Ml: Zondervan Publishing House.

Institute for Swahili Rezearch. 1981. Kamusi ya Kiswahili Sanifu. University of Dar es Salaam.

Kari, Jamee. 1989. Notes on the Computerization of the Ahtna Dictionary. Society for the Sludy of the Indigenous Languages of the Americas Newsletter. (An abstracted version appears in the California Linguistic Newsletter 20, 1: 16. (1988).)

Kita, Sataro. 1992. Speaking Processes in Balanced and Unbalanced Japanese-English Bilinguals: Evidence from Spontaneous Gestures that Accompany Speech. M.S. University of Chicago: Departments of Psychology and Linguistics.

Labov, William. 1973. The Boundaries of Words and their Meaning. Bailey, C.-J.N. and Roger W. Shuy (Ed.). 1973. New Ways of Analyzing Variation in English: 340-73. Washington, DC: Georgetown University Press.

Ladefoged, Peter. 1992. Discussion Note: Another View of Endangered Languages. Language 68, 4: 809-811.

Maduka, Omen N. 1983-84. Igbo Ideophones and the Lexicon. Joumal of the Linguistic Assaciation of Nigeria 2: 23-29.

Matisoff, James A. 1990. On Megalocomparison. Language 66, 1: 106-120.

McNeilJ, David. 1992. Hand and Mind. Chicago: University of Chicago Press.

Munro, Pamela and Dieynaba Gaye. 1991. Ay Baati Wolof: A Wolof Dictionary (UCLA Occasional Papers in Linguistics 9). Los Angeles: Department of Linguistics, University of California.

Noss, Philip A. 1985. The Ideophone in Gbaya Syntax. Dimmendaal, G.]. (Ed.). Current Approaches to African Linguistics 3: 241-255. Dordrecht and Cinnaminson, NJ: Foris Publications.

Noss, Philip A. 1988. The Ideophone in Translation. Okonlawon, Tunde (Ed.). 1988. Comparative Literature and Foreign Languages in Africa Today. Port Harcourt: Transcontinental Publishers.

Poulos, George. 1990. A Linguistic Analysis of Venda. Pretoria: Via Afrika Limited. 
Prinsloo, D.J. 1991. Review: Lexicography in Africa, 1990, ed. by R.R.K. Hartmann. South African Joumal of African Languages 11, sup. 1: 74-77.

Ross, John Robert. 1972. Category Squish. Papers from the 8 ih Regional Meeting of the Chicago Linguistics Society: 316-28.

Samarin, William J. 1967. Determining the Meanings of Ideophones. Jourmal of West African Languages 4, 2: 35-41.

Samarin, William J. 1971. Survey of Bantu ldeophones. African Language Studies 12: 130-168.

Samarin, William J. 1978. Linguistic Adaptation to Speech Function. McCormack, William and Stephen A. Wurm (Ed.). 1978. Approaches to Language: Anthropological lssues: 559-614. The Hague: Mouton and Co.

Samarin, William J. 1991. Intersubjective and Intradialectal Variation in Gbeya Ideophones. lournal of Linguistic Anthropology 1, 1: 52-62.

Simons, Gary F. and Larry Versaw. 1992. How to Use IT (v. 1:2). Dallas, Texas: Summer Institute of Linguistics.

Traill, A. 1993. A IXóo Dictionary. To appear. Cologne: Köppe Verlag.

Von Staden, Paul M.S. 1977. Some Remarks on Ideophones in Zulu. African Studies 36, 2: 195-224.

Williamson, Kay. 1989. Niger-Congo Overview. Bendor-Samuel, John (Ed.). 1989. The NigerCongo Languages: 3-45. Lanham, MD/London, England: United Press of America,

Wimbish, John 5. 1990. SHOEBOX: A Dato Management Program for the Field Linguist. Ambon, Indonesia: Summer Institute of Linguistics and Pattimura University.

Zgusta, Ladislav. 1971. Manual of Lexicography (Janun Linguanum, Series Maior 39). Prague: Academia, Publishing House of the Czechoslovak Academy of Sciences, and The Hague, Paris: Mouton. 


\section{Appendix A: Page from lexical data base}
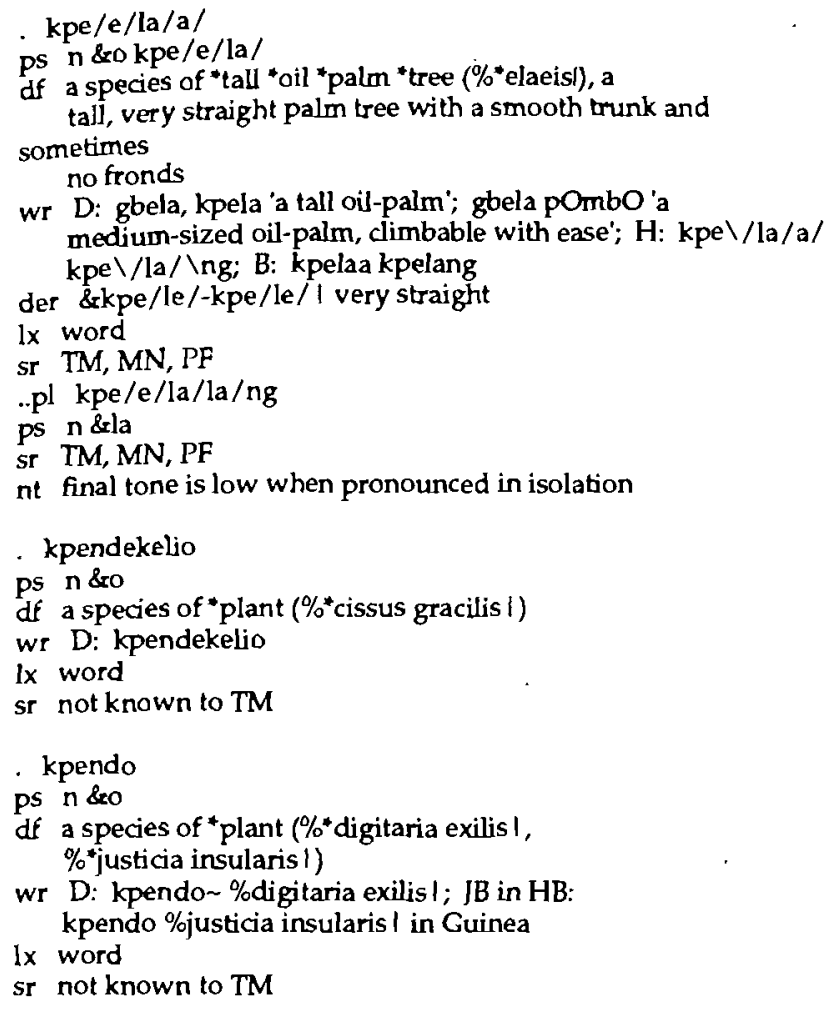

- $k p E \backslash i /$ yo/

ps $n$ \&o

df a species of *plant

lx word

st TM

. $k p E \backslash I E \backslash n g k p E \backslash I E \backslash n g n d o /$

ps $n$ \&o $k p E \backslash I E \backslash n g k p E \backslash l E \backslash n g$

df a species of *tree (\%*anthocleista l spp)

wr D: kpElE-kpElEndo, kpElE-kpEIEndo-lando

(\%anthocleista I), kpElE-kpEIEndo-piando (\%anthocleista

nobilis

and \%anthocleista vogelii l); TSL: kpEIE-kpEIEndo

$1 x$ word

my redup

sr TM

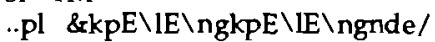

ps $n \& i$

, $\mathrm{kpE} / \mathrm{ndE} \backslash \mathrm{i} / \mathrm{le} / \mathrm{ng}$

ps n \&o $\mathrm{kpE} / \mathrm{ndE} \backslash \mathrm{i}$ / 


\title{
Appendix B: Sample page from English index
}

\author{
KISI FINDERLIST \\ oryza \\ a species of rice (\%oryza barthiil or \%oryza stapfil):: \\ oryza

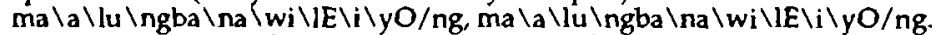 \\ generic name for rice (\%oryza sativa l), uncooked rice:: ma $\backslash a \backslash l o / n g$.
}

osbeckia

a species of plant (\%osbeckia tuboloa 1, \%dissotos paucistellata I)::

sandiyowo.

ottelia

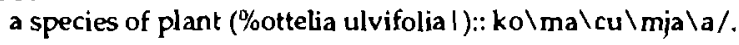

ouratea

a species of tree (\%ouratea flava 1):: do\ma/pu\a/a/to/o/ma/a/.

outside

outdoors area, outside, yard, a rea immediately outside or encircling one's house:: $b E / E \backslash l a / n g<b i / O \backslash O /$.

pail :: ba/a/wa/a/.

palisota

a species of plant (\%palisota hirsutal):: tulokpello, tundui.

palm

a species of palm kernel oil from the oil palm (\%elaeis):

ba $\backslash$ nya $\backslash$.ng.

a species of plant, palm nut, wild (\%Uvaria chamael):: koiyondue.

a species of tall oil palm tree (\%elaeis), a tall, very straight palm

tree with a smooth trunk and sometimes no fronds:: kpe/e/la/a/.

paim branch or leaf:: \&si $\backslash \mathrm{O} / \mathrm{le} / \mathrm{ng}$.

palm branch, thatch, thatching material (\%):: si $\backslash 0 / 0 /$.

palm fronds, especially those from a short palm tree, piassava paim::

$k E \backslash E / l e / n g$.

palm kernel or nut (kernel plus shell) of the oil-palm (\%elaeis)

fruit, shell quite hard and interior edible with a soapy taste::

$k E \backslash m b E \backslash i /$.

palm nuts, palm kemels: $b E \backslash / 110 / n g, b E \backslash / 110 / n g$.

palm oil residue, weak or watery liquid left over after palm oil has been scraped off the surface of the large pot of water in which the paim oil has been prepared: mbo $\backslash 0 \backslash y a / a /$.

palm wine derived from the piassava palm \%raphia vinefera l)::

lu\mbi $\backslash a / n g$.

raffia, palm thatch stripped from the leaves of a species of plant (\%raphia gracilis l):: $\mathrm{ki} / \mathrm{o} / \mathrm{o} /$.

panicum

a species of plant (\%panicum breviflorum I) and probably other similar grasses:: denoyeno.

a species of plant (\%paricum dinklagei 1):: yeno.

papaya

papaya (\%carica papaya I):: calekOngguluma.

papaya or pawpaw tree, pumpkin, anything of a gourd-like shape (\%carica papayal):: calle/ng. 


\title{
Afrikaans Learner's Dictionaries for a Multilingual South Africa
}

\author{
R.H. Gouws, Department of Afrikaans and Dutch, \\ University of Stellenbosch, South Africa
}

\begin{abstract}
Dictionaries have to be compiled in accordance with the specific needs and demands of a well-defined target user. Within the multilingual and multicultural South African society dictionaries should be aimed at the needs of the different groups of language learners. This article discusses aspects of Afrikaans learner's dictionaries. The emphasis is on the need and criteria for such dictionaries, the typical target user and on the nature of the macro- and microstructural information to be included. In a leamer's dictionary the information should be presented in such a way that it can be retrieved without problems. Attention is given to various access structures employed to enhance the retrievability of information. It is argued that a restricted and simplified microstructure leads to a decrease in the density of information but to an increase in the explicitness and retrievability. The article proposes a different approach to the inclusion of certain types of encyclopedic information in learner's dictionaries.
\end{abstract}

Keywords: ACCESS STRUCTURES, ADDRESSING, DENSITY OF INFORMATION, ENCYCLOPEDIC INFORMATION, EXPLICITNESS, ILLUSTRATIVE EXAMPLES, LEARNER'S DICTIONARY, MACROSTRUCTURE, METALEXICOGRAPHY, MICROSTRUCTURE, PICTORIAL ILLUSTRATIONS, RETRIEVABILITY, SIMPLICITY, TARGET USER, TRANSLATION EQUIVALENTS

Opsomming: Afrikaanse aanleerderwoordeboeke vir 'n meertalige SuidAfrika. Woordeboeke moet saamgestel word met inagneming van die behoeftes en eise van 'n spesifieke teikengebruiker. Binne die multikulturele en meertalige Suid-Afrika moet daar vir die behoeftes van verskillende groepe taalaanleerders voorsiening gemaak word. Hierdie artikel bespreek aspekte van Afrikaanse aanleerderwoordeboeke. Die klem is op die behoefte aan en kriteria vir sulke woordeboeke, op die teikengebruiker en ook op die makro- en mikrostrukturele inligting wat in so ' $n$ woordeboek opgeneem moet word. In 'n aanleerderwoordeboek moet inligting op so ' $n$ manier aangebied word dat dit probleemloos herwin kan word. Aandag word gegee aan toegangstrukture wat gebruik word om die herwinbaarheid van inligting te verhoog. Daar word aangevoer dat ' $n$ beperkte en vereenvoudigde mikrostruktuur tot ' $n$ verlaging in die inligtingsdigtheid lei maar tot ' $n$ verhoging in die eksplisietheid en herwinbaarheid. 'n Ander benadering word voorgestel vir die opname van sekere tipes ensiklopediese inligting in aanleerderwoordeboeke.

Sleutelwoorde: AANLEERDERWOORDEBOEK, ADRESSERING, EENVOUD, EKSPLISIETHEID, ENSIKLOPEDIESE INLIGTING, HERWINBAARHEID, ILLUSTRASIEPRENTE, INLIGTINGSDIGTHEID, MAKROSTRUKTUUR, METALEKSIKOGRAFIE, MIKROSTRUKTUUR, 
TEIKENGEBRUIKER, TOEGANGSTRUKTUUR, VERTAALEKWIVALENTE, VOORBEELDMATERIAAL

\section{Introduction}

Within the existing theoretical discussions of lexicographical issues much emphasis is placed on the so-called "user perspective". It is an accepted fact that every dictionary has to be compiled in accordance with the specific needs and demands of a well-defined target user. According to Diab (1990: 17) traditional lexicography concerned itself with the problems of the lexicographer instead of the needs of the dictionary user. It is important for any lexicographer to be needs-sensitive in the planning and compilation of a dictionary.

The latest versions of a general dictionary typology focus on the importance of learner's dictionaries and on their unique contribution in the teaching of a foreign language. The monolingual leamer's dictionary, which traditionally dominated this category, directs its pedagogical approaches at any nonnative learner of the target language. Herbst (1990: 1379) states that a learner's dictionary is a synchronic monolingual dictionary and Snell-Homby (1987: 159) refers to the absence of a bilingual dictionary designed to meet the specific needs of learners. Yet, the last decade witnessed the emergence of bilingual learner's dictionaries and an increased awareness of their functional value. However, much research is still needed to identify and formulate the theoretical principles to which these dictionaries should adhere and to determine their linguistic and pedagogical scope.

These changing perspectives of learner's dictionaries and the emphasis on the function of the bilingual learner's dictionary will have definite implications for the South African lexicographical endeavours, adding to the variety of exciting challenges that face both lexicographer and linguist in this multicultural and multilingual society.

\section{South African learner's dictionaries}

In spite of a well-established lexicographical tradition and a representative typological variety the South African dictionary collection lacks learner's dictionaries. This applies to both Afrikaans and the nine indigenous African languages used in South Africa. As far as English is concerned the existing British learner's dictionaries are used extensively. The general availability of these dictionaries and the comprehensive way in which they are employed in language teaching accentuate the need for learner's dictionaries for Afrikaans and the other indigenous languages. 


\section{Towards Afrikaans learner's dictionaries}

In a multilingual society learner's dictionaries are needed to grant members of the different speech communities access to the other languages. In the planning and compilation of South African dictionaries scant attention was given to the position, function and importance of leamer's dictionaries. This approach has changed. The lack of Afrikaans learner's dictionaries had been identified as a major void in the typology of dictionaries, cf. Alberts and Mtintsilana (1988) and Otto (1989), and suggestions were made to rectify the situation. These suggestions resulted in a comprehensive project aimed at the compilation of a series of Afrikaans learner's dictionaries with the compilation of an Afrikaans monolingual learner's dictionary as a first step. This dictionary, Basiswoordeboek van Afrikaans, has since then been completed and is due to be published later this year.

Basiswoordeboek van Afrikaans (henceforth abbreviated as BA) is aimed at the needs of non-native learners of Afrikaans but should also be of help to native speakers, especially at school level. BA has been compiled in such a way that it could form a basis for a wide-ranging selection of bilingual learner's dictionaries in which Afrikaans will feature alongside the nine indigenous languages. The macrostructural selection of BA endeavours to display the core vocabulary of Afrikaans, adhering to a criterion discussed by Kühn (1990: 1352) that it is sensible not to employ the full vocabulary of a language in teaching it as a foreign language, but rather to rely on a representative and functional selection of lexical items. The lemma selection of BA will form the macrostructural basis of the Afrikaans as source language component of the bilingual dictionaries.

The compilation of an Afrikaans-English learner's dictionary had not been envisaged as part of this project. The motivation for this decision lay in the extent and nature of the bilingual dictionaries presently available and the needs of the dictionary user. Since 1925 Afrikaans and English have been the two official languages of South Africa. This status of these two languages has led to the compilation of a variety of Afrikaans-English dictionaries. The intended target user of these dictionaries is the Afrikaans/English speaking bilingual South African. The fact that this target user lives in an environment where he is in daily contact with both languages has had an influence on both the macrostructure and the addressing in the dictionary articles. Bilingual Afrikaans/English dictionaries like Tweetalige Woordeboek/Bilingual Dictionary and Groot Woordeboek/Major Dictionary are actually aimed at a sophisticated user of both Afrikaans and English and they are not instruments in the hand of a learner. Yet, the availability, authority and comprehensiveness of these dictionaries made lexicographers and linguists less aware of the need for a bilingual Afrikaans-English learner's dictionary. Although these dictionaries may perhaps suffice the needs of a wide-ranging spectrum of language users they do not comply with the demands of the learner and therefore their existence 
should not prohibit the compilation of bilingual learner's dictionaries. Since the start of this learner's dictionary project and independent thereof, another publishing house has recently produced a bilingual Afrikaans-English learner's dictionary. This dictionary Tweetalige Aanleerderswoordeboek/Bilingual Learner's Dictionary (henceforth abbreviated as TAW) will play an important pedagogical role. In spite of the initial lack of interest in an Afrikaans/English learner's dictionary the publication of TAW stresses once again the validity of SnellHornby's belief (1987: 159) that the lack of bilingual learner's dictionaries results in the foreign learner falling back on traditional general-purpose concise or pocket dictionaries. These dictionaries, claims Snell-Hornby, are the type of reference book least suitable as an aid to language learning. This also applies to the situation in South Africa.

During the work on BA the project committee was approached by a publishing house to support the publication of an Afrikaans/Zulu bilingual learner's dictionary. The manuscript of this dictionary had already been completed and although it did not correspond with the editorial policy proposed for the dictionaries in this series, the need for an Afrikaans/Zulu dictionary prompted the committee to give its support to the publication of Afrikaans/Zoeloe Woordeboek met Engelse vertalings.

Following the completion of BA the rest of the project can continue with the compilation of bilingual dictionaries for Afrikaans and Northern Sotho, Southern Sotho and Tswana respectively as the following target publications.

\section{Criteria for a monolingual Afrikaans learner's dictionary}

Before the compilation of any dictionary the potential target user, his lexicographical needs and abilities have to be identified. Not only the macrostructural selection but also the microstructural treatment of lemmas and the addressing should be determined by the target user profile. As a monolingual Afrikaans learner's dictionary BA had to be compiled in such a way that it could be used in the compilation of a variety of bilingual learner's dictionaries involving Afrikaans and the indigenous African languages. Due to its unique assignment to function both as independent dictionary and as basis for a series of other dictionaries, the specific needs, demands and abilities of speakers from a broad linguistic and cultural spectrum had to be taken into account in the planning and compilation of this dictionary.

\section{The target user of a monolingual Afrikaans learner's dictionary}

According to Hansen (1990: 1) the selection and representation of information in a dictionary should be determined by the needs of users and the ordering of the information should be done in such a way that the user can find the 
answers to his questions in the quickest possible time. To achieve maximum retrievability the macrostructure of a learner's dictionary has to include access structures to overcome possible hedges in the search for a specific lemma, but retrievability also demands a microstructural display which is not only relevant to the linguistic and pragmatic needs of the user but also enhances an unbiased and neutral representation of cultural and ideological values. This point is especially applicable where the target users come from a multilinguistic and multicultural environment.

The potential users of Afrikaans learner's dictionaries represent a cultural and linguistic heterogeneous community. Besides native speakers of Afrikaans who might need to use the dictionary it will be used by speakers of various European languages, speakers of South African English and speakers from the nine indigenous African languages. The lexicographer cannot satisfy all these users on an equal basis and his decisions in the planning and structuring of the learner's dictionary have to be motivated by the sociolinguistic profile of the most typical target user.

The lexicographer of an Afrikaans learner's dictionary has to negotiate the reality of target users with opposing cultural and ideological views. The dictionary may not take a biased stand but the macrostructural selection as well as the treatment of the lemmas have to maintain a neutral attitude towards culture and ideology specific items. According to Carter (1983: 174) words contain and conceal ideology. The political history of South Africa had a far-reaching influence on language and especially on Afrikaans and its lexicon, and it has created a lexical stigmatization. This stigmatization has a varying occurrence because some words have acquired a general taboo in all the different ideological communities whereas other words have only been the target of a restricted taboo. The lexicographer has to be aware of the ideological and symbolic values and has to exercise the necessary sensitivity.

The policy of apartheid, that Afrikaans word included in almost every nonAfrikaans dictionary, was formulated by the National Party which used to be the political home of predominantly Afrikaans speaking white South Africans. As a result Afrikaans had for years been regarded as the language of the oppressor. Many Afrikaans words became stigmatized due to their occurrence in the apartheid terminology. Afrikaans dictionaries had not always been sensitive enough to the symbolic value of these items, and their lexicographical treatment has estranged many potential speakers from Afrikaans. Any Afrikaans dictionary compiled today, and especially a leamer's dictionary aimed at the promotion of Afrikaans amongst speakers of other South African languages, has to take linguistic affirmative action in order to rectify the old perception and to deideologize Afrikaans. Although dictionaries have to be regarded as sources of linguistic information, the scope of an Afrikaans learner's dictionary in South Africa exceeds the limits of linguistic lexicography by becoming also a cultural and a depoliticizing instrument. This additional 
function is a direct result of the sociolinguistic, cultural and political profile of the target users.

The decision of the project committee to use the lemma selection of BA as a basis for the bilingual dictionaries dealing with Afrikaans and the African languages is also influenced by the sociolinguistic profile of the target groups. Because the monolingual dictionary as well as the bilingual dictionaries are primarily aimed at users learning Afrikaans as a third or fourth language, the vocabulary needs are of a restricted nature and more or less the same vocabulary can be used throughout the series.

\section{The macrostructure of an Afrikaans learner's dictionary}

The compilation of a series of Afrikaans leamer's dictionaries will make Afrikaans more accessible to the whole South African community and will promote Afrikaans amongst non-Afrikaans speaking South Africans. The linguistic situation in South Africa compels the lexicographer to design an Afrikaans learner's dictionary for target users leaming Afrikaans as a second, third or even fourth language. As a pedagogical instrument the Afrikaans learner's dictionary has to employ a variety of methods to deal with the often conflicting demands of the teaching of a foreign language to such a diverse target group. This has definite implications for both the macro- and the microstructure and emphasizes the need for clarity and userfriendly access structures.

From a macrostructural perspective it is important that the lemma selection has to be restricted to a fairly simple level; even simpler than the level of those learner's dictionaries compiled for users learning a second language. Consequently BA's lemma selection could not have been done on a random basis but the lexicographers had to adhere to fixed selection criteria, with usage frequency as a dominating factor. Relying on frequency lists, transcriptions of oral interviews, general usage in papers, television programs, etc., a selection of core vocabulary items was made.

\section{The microstructure of an Afrikaans learner's dictionary}

One of the major aims of a learner's dictionary is to assist the user in achieving a certain degree of communicative competence. By creating a well-motivated macrostructure the lexicographer knows the user should be able to find the most typical words he is to encounter in the target language. However, communicative competence relies on much more than a sound lemma selection. The microstructural treatment of each lemma has to enable the user to cultivate the skills necessary for the actual usage of the word in real communication. Where the macrostructure offers the user access to a selected part of the vocab- 
ulary, the microstructure offers access to the linguistic characteristics of those items. This access should be given in an unambiguous way to provide the easiest possible transfer of information. According to Ayto (1984:50) a word should be defined using words simpler than itself. This belief of simplicity in the definition is widely respected. Ayto goes further by stating that the main motive behind adopting this notion of "greater simplicity" is to maximize the user's chances of understanding the definition.

A notion of greater simplicity should be a governing principle in learner's dictionaries and should not only apply to the definition but to every entry in the article. The learner's dictionary may not only differ in name from other dictionaries. According to Herbst (1990: 1379) the rationale behind a general learner's dictionary is the insight that the foreign users' demands on a dictionary differ fundamentally from those of a native speaker. Therefore the lexicographer's product intended for the foreign user has to differ fundamentally from the one intended for the native speaker.

Because the lexicographer may rely on neither the linguistic intuition nor any presumed dictionary skills of the target user, attempts to achieve the necessary simplicity have to depend on the structure and contents of the article. Communicative success in learner's dictionaries requires an interaction of the principle of simplicity and various pedagogical methods. One such method is the attempt to enhance the retrievability of the microstructural information by introducing a variety of clearly defined access structures in the article. This method coincides with an attempt at greater explicitness. Although macrostructural access can easily be ensured by a consistent ordering according to the alphabetical system, microstructural access demands the inclusion of additional entries specifically aimed at guiding the user to the given information. Following Hausmann and Wiegand (1989: 329) this type of access structure is known as the "inner access structure". A second pedagogical method to enhance the retrievability is the decreasing of the density of information in the article.

\section{Enhancing the retrievability of information}

\section{The utilization of access structures}

Dictionaries do not only convey information by way of language signs and codes but also by way of typographical conventions. These codes and typographical markers have to ensure an optimal transfer of information, but quite often they add to the complexity of the microstructure and impede the successful interpretation of the lexicographical text. The typical user of an Afrikaans learner's dictionary, and this can also apply to learner's dictionaries in general, is often unsophisticated in the skills of dictionary use, and he relies on the dictionary for instant assistance - without being obliged to follow cross- 
references to other parts of the dictionary; especially not coded crossreferences which he still has to decode to acquire the needed help. A learner's dictionary has to respond to the need for an instant retrieval of information by inventing and using the necessary access structures.

The utilization of access structures has to be employed in tandem with the principle of greater simplicity. This complementary combination should aim to decrease typographical markers and other entries that add to the complexity of the article and it should introduce innovative conventions aimed at an unambiguous guiding towards every information category in the article.

One type of inner access structure employed on a regular basis in BA, but not unique to BA, is the display of usage and semantic notes as part of the article of a lemma. These notes can either refer to the lemma or to a specific microstructural entry, and the position of these notes in the articles gives a clear indication of their scope. The usage or semantic notes are placed in a square frame and clearly distinguished from the other entries. This square frame is an access structure pointing unambiguously at a specified entry type. Afrikaans has a spectrum of varieties ranging from the formal and standard to the colloquial and dialectal. Although a learner's dictionary like BA focuses on the core vocabulary which consists largely of elements from the standard variety it also accommodates non-standard, informal and colloquial items. The way in which these items deviate from the neutral standard usage has to be marked: either by stylistic labelling or by usage notes. Both labels and clearly identifiable usage notes can be regarded as access structures aimed at the enhancement of the communicative and pedagogical function of a learner's dictionary. An example of one of these access structures in BA can be found in the article of the lemma aanhou ("continue"/"continuously"):

"Opmerking: Aanhou se gebruik as bywoord is beperk tot informele spreektaal" (Note: The use of aanhou as an adverb is restricted to informal oral usage.)

One of the major problems dictionary users experience with access structures and microstructural coding, is the complexity created by these entries. The first edition of the Longman Dictionary of Contemporary English (LDOCE) made extensive use of a system of grammatical coding. These codes are relevant and they convey important information by indicating the grammatical subsets to which a specific lemma belongs. The code letter $T$ indicates that a lemma is a transitive verb with one object, and $T 1$ indicates that such a transitive verb can be followed by one or more nouns or pronouns. Although these codes help with the retrieval of information, they convey it in an implicit way because the information identified by the code letter is not explicitly given in the article. The user has to turn to the back matter of the dictionary to get a key to the different codes. Inner access structures have to refer to information explicated in the article itself. To achieve communicative success a learner's dictionary 
should avoid unnecessary cross-references based on a system in which the interpretation of an article depends on information given elsewhere in the dictionary. Inner access structures are functional when they are anchored in the article and used to mark article internal information. They should point at the article itself and should not link the article with information given in other sections of the dictionary.

In TAW the lexicographers have opted for a limited number of access structures but they all have clearly identifiable internal referents. The limited use of access structures has increased the functionalism of the ones employed and it has improved the microstructural simplicity. Because TAW is a bilingual dictionary the focus of each article is on the translation equivalent(s) and the illustrative examples. TAW conveys this information in an uninterrupted way by deviating from the typical dictionary pattern to give information on word class, morphology and pronunciation immediately after the lemma. This microstructural representation establishes a new approach in learner's dictionaries. In any dictionary the lemma has to be seen as the head of the article. The microstructure can contain a variety of information types and in general monolingual and bilingual dictionaries, as well as in learner's dictionaries, the articles are characterized by a system of lemmatic-addressing because the microstructural information is typically directed at the lemma (cf. Hausmann and Wiegand 1989: 328).

Due to the hierarchical character of the microstructure the prominence of the first entries gives them a position of major focus while the last entries receive far less focus. This should influence the organization of information in the dictionary. Being familiar with the specific typological criteria a lexicographer knows what the priority of his dictionary is and which entry should receive the most emphasis. This should prompt him to position the entry of high priority in a focus slot of the article, i.e. as the first lemmatic-address and therefore in the highest position in the microstructural hierarchy. The lexicographers of TAW regard the translation equivalent(s), followed by the applicable illustrative examples as their entries of highest priority and consequently these entries are placed in the position of major focus:

"moeilik 1 difficult It's difficult to feed a baby that won't sit still. Dis moeilik om 'n baba te voer wat nie wil stilsit nie. 2 hard Tough meat is hard to chew. Dis moeilik om taai vleis te kou. 3 stiff The examination was so stiff that half the class failed. Die eksamen was so moeilik dat die helfte van die klas gesak het. ..."

Word class information is included but well down in the hierarchy. However, due to the traditional focus position of word class indication TAW does not give a neutral treatment of this entry but marks its occurrence with an access structure: a small rectangle preceding the word class entry. On a similar basis another information type, collocations and short expressions, are marked with 
a small diamond. If applied consistently these access structures can guide the user so that he can retrieve a specific information type as quickly and successfully as possible. The new Oxford Advanced Learner's Dictionary gives a fine display of the correct and functional use of this type of inner access structures. However, lexicographers should try to limit these access structures because if they employ too many it could easily become confusing. This could have similar disadvantages as a comprehensive system of grammatical coding where all the codes are explained in the front or back matter and the user has to turn to these sections to retrieve the information he is expecting to find in the alphabetical section of the dictionary.

\section{Greater explicitness}

As mentioned above the utilization of inner access structures coincides with an attempt at greater explicitness. One dominant feature of a leamer's dictionary should be the clear and explicit way in which it displays its information. This implies that accessibility is enhanced by entries which offer a direct information transfer. The application of this principle has to activate a reconsidering of the use of abbreviations as microstructural entries. Not only the coded transfer of grammatical information, as given in LDOCE1, should be reconsidered but also the use, in many leamer's dictionaries, of abbreviations for word classes. For the average user of an Afrikaans learner's dictionary abbreviations like $n w$. ("naamwoord", noun), ww. ("werkwoord", verb), nwsk. ("neweskikker", coordinator), etc. has much less value than their unabbreviated equivalents. In TAW this principle is applied and the word class is given as an unabbreviated entry.

Greater explicitness combined with a better chance of retrieving information can be acquired by abolishing the system of indicating morphological information, e.g. plurals, diminutives and past tense, by only listing the applicable suffix. Instead of the entries:

$$
\text { "domino ( } p l \text {-es)" }
$$

the lexicographer will do well to give an explicit presentation of the plural form:

$$
\text { "domino (pl dominoes)". }
$$

Such an approach enables the user to gain direct and instant access to the information he needs without the possibility of a wrong interpretation of the system followed in the dictionary. This principle of explicitness is already in use in the Collins COBUILD English Language Dictionary and adds to the userfriendliness of this dictionary. In BA the same principle is also applied and expanded. The lexicon of Afrikaans includes a wide variety of particle verbs. 
The mastering of these verbs confronts the foreign learner of Afrikaans with some real problems. Particle verbs have a diverse occurrence in Afrikaans. The verb aandring ("insist") can be used to explain the typical pattem of Afrikaans particle verbs.

Hy dring aan op ' $n$ verskoning. ("He insists on an apology")

Hy het aangedring op ' $n$ verskoning. ("He insisted on an apology")

Hy sal aandring op ' $n$ verskoning. ("He will insist on an apology")

Om aan te dring op ' $n$ verskoning. ("To insist on an apology")

In the treatment of particle verbs BA gives this type of information as clear as possible. The article of aandring gives evidence of this approach:

"aandring (dring aan, sal aandring, het aangedring, om aan te dring) ..."

Further on in the article examples are given to illustrate each one of these occurrences of the particle verb. By aiming at greater explicitness BA tries to provide the kind of information needed by typical foreign users of Afrikaans. This explicit way of treating some grammatical aspects of the particle verb enhances the chance of an instant retrieval of information, but it also prevents unnecessary mistakes in the communication process. This approach is adopted because BA will primarily be used as an instrument in the teaching of language.

\section{Decreasing the density of information}

Simplicity and explicitness can be regarded as two of the cornerstones of communicative and pedagogical success in a dictionary. Although both these ideals can be met by employing functional inner access structures, the lexicographer of a learner's dictionary will do well to utilize additional methods to achieve his purpose. One such method is to evaluate and decrease the density of information accommodated in the dictionary.

According to Hausmann (1989: 982) the density of information of a dictionary is the quantitive relation between the macro- and microstructure. An increase in the microstructure of a specific dictionary without changing the macrostructure implies an increase in the density of its information. A dictionary can be macro- or micro-orientated or it could maintain an equality in the macrostructural and microstructural richness.

Hansen (1990: 96) refers to the tendency in the present-day lexicographical practice to increase the density of information by making the articles more compact. Due to space restrictions lexicographical treatment often relies on an implicit transfer of information. An example of an implicit information transfer in a general bilingual dictionary can often be found in the listing of transla- 
tion equivalents. In the Afrikaans-English bilingual dictionary Groot Woordeboek/Major Dictionary the Afrikaans verb beslis gets the following translation equivalents:

"settle, determine, decide; award, adjudicate; conclude".

The implication of this presentation is that the lemma is a polysemous lexical item with three different polysemous senses. This can be deduced from the occurrence of the semi-colons in the list of translation equivalents. Commas are used to separate translation equivalents which are synonyms, and semi-colons separate translation equivalents representing different polysemous senses of the lemma. The relation of synonymy holding between award and adjudicate is not explicitly stated but it is implied by the system used in the dictionary. Implicit presentations increase the density of information; not only because it adds to the quantity of information categories accommodated in the dictionary but also because it impedes instant retrievability. In a dictionary with a high density of information one entry can of ten represent more than one information category (cf. Hansen 1990: 96). In the above-mentioned example the nonalphabetical ordering of the synonyms award and adjudicate implies that the first translation equivalent has a higher usage frequency than the second. Likewise the ordering of the equivalents representing the different polysemous senses of the lemma implies that "settle" is a more dominant sense of beslis than "award". One entry contains more than one type of information and this leads to an ever increasing density of information. Although a high density of information saves space it demands much more from the linguistic and lexicographical foreknowledge of the user. Hansen (1990: 96) states that a higher density of information decreases the explicitness of a dictionary.

The entries settle and determine in the article of beslis differ with regard to their addressing. Settle is given as a translation equivalent of the lemma and therefore it has a lemmatic address. Although determine is also presented as a translation equivalent of the lemma, it has an additional addressing because it is presented as a synonym of settle. In this function determine has a nonlemmatic address and represents a type of sub-addressing. The use of lemmatic and non-lemmatic addressing in one article creates topic switching because each non-lemmatic address is a new topic within the article (Hausmann and Wiegand 1989: 329). Topic switching inevitably increases the density of information as well as the complexity of a dictionary article.

\section{Bidirectional orientation}

In his discussion of the notion "density of information" and the relation between the macro- and microstructure of a dictionary Hausmann (1989: 982) argues that learner's dictionaries are characterized by their microstructural ori- 
entation. This means that their microstructure is richer than their macrostructure. This approach coincides with that of Jehle (1990: 11). According to Jehle the compilation of a monolingual dictionary for foreign users requires the application of scientific findings of modem linguistics to enable the user the optimal utilization of information regarding phonetics, syntax, semantics and pragmalinguistics. Jehle's perspective favours a microstructural orientation in a learner's dictionary. The application of both Hausmann's and Jehle's suggestions will not only enrich the microstructure but will inevitably lead to an increase in the density of information, a decrease in explicitness and a less friendly source of information for the foreign leamer. In a leamer's dictionary the lexicographer should endeavour to restrict the microstructure to such an extent that the retrieval of information is not impeded by a high degree of information density.

When deciding on the density of information of a specific dictionary, the lexicographer once again has to consider the needs and skills of his target user. Quite often in a leamer's dictionary it may be better not to maintain a rigid system but to treat each lemma according to the specific information need. Zgusta (1989: 7) argues that a modular dictionary with variable density of information could be the solution to a lot of these problems.

In an attempt to help the learner, the Afrikaans learner's dictionaries TAW and $\mathrm{BA}$ are not microstructural orientated but they try to maintain a definite balance between the macro- and microstructure by adopting a double or bidirectional orientation. The treatment of lemmas are aimed at the most typical information needs of the target users: a motivated vocabulary selection and a limited collection of microstructural elements. As a descriptive monolingual dictionary BA focuses on the meaning of the lemmas whereas the bilingual TAW puts its emphasis on the translation equivalents.

\section{A restricted and simplified microstructure}

In the multilingual South Africa the typical user of a monolingual Afrikaans learner's dictionary is primarily interested in the meaning of the lemma and in its actual use. BA's microstructure is directed at this need and ignores a variety of other information categories like pronunciation and etymology. It also eschews a too detailed analysis of the information categories which are included. In her comments on the Warlpiri dictionary project, Wierzbicka (1983: 135) argues that the Warlpiri dictionary, and the same criteria apply to an Afrikaans leamer's dictionary, should not contain definitions that give account of the full semantic spectrum of a word but they should rather be accessible, understandable and therefore functional for the largest possible variety of users. Instead of aiming the dictionary at "God's truth" it should rather be aimed at practical and useful approximations. If the semantic component of an article is restricted to a simplified definition, the lack of additional semantic information 
decreases the density of information but it improves the users' chances of better comprehension. Any aspect in a learner's dictionary, even something that is of great importance in other dictionaries, that is detrimental to the users' comprehension of the definition should be abolished.

In spite of its restricted microstructure BA will be an active or encoding learner's dictionary. Although it will not equip its users with all the information which distinguishes a native speaker from a foreign speaker, it is directed at a sound transfer of semantic and pragmatic guidance and this characteristic feature of BA will equip its users with encoding capabilities. Wolski (1991: 2842 ) argues that an active dictionary displays a higher degree of textual compression than its passive counterpart. BA will differ from typical active or encoding dictionaries because of its low density of information, its explicitness and the restricted textual compression. Yet, it presents its microstructural addressing in such a way that the user can apply it in an encoding function. The lower degree of textual compression in BA is motivated by its assignment as instrument in the teaching of Afrikaans as a foreign language. Because of the linguistic and cultural background of the users of BA their primary demand of an encoding dictionary is information on the meaning and correct use of Afrikaans lexical items. The dictionary has to be a functional tool and has to aid its users in the improvement of their communicative skills.

\section{Illustrative examples}

As part of its encoding function BA offers an extensive collection of illustrative examples. According to Wiegand (1988: 581) each example employed in the article of a polysemous lemma should represent only one polysemous sense. Following this idea BA allocates its examples to specific definitions and establishes a complementary relation between the example(s) and the definition. In a COBUILD-style BA's definitions are given as full sentences, strengthening the link between definition and example. In many articles a single polysemous sense gets more than one example. This is motivated by the need to illustrate different uses or stylistic levels in which the word can occur. The examples also help the user to distinguish between semantically related words and nearsynonyms, cf. Walter (1992: 129).

Hansen (1990: 19) regards examples as a formal lexicographical category. Examples can have a variety of functions in a dictionary, cf. Rademeyer (1992). The utilization of this lexicographical category can be aimed at any of these functions; also the pragmatic function. Examples play an important role, both in textreception and textproduction, to illuminate and distinguish different polysemous senses of a lemma, cf. Jehle (1990: 271). BA is not the only dictionary to emphasize the acute pragmatic need for examples in Afrikaans learner's dictionaries. In TAW examples are also awarded a focus position in the 
article. In the Afrikaans-English section each translation equivalent is followed by an English example and its Afrikaans translation:

"draaiz 1. turn [a] The harder you pedal, the faster the wheels turn. Hoe harder jy trap, hoe vinniger draai die wiele. [b] He turned the handle to check whether the door was locked. Hy het die handvatsel gedraai om te kyk of die deur gesluit was...."

Decreasing the density of information by introducing a bidirectional orientated dictionary, a restricted and simplified microstructure with emphasis on the definition/translation equivalent and the use of illustrative examples does not impede the encoding function of a learner's dictionary but rather substantiates its claims of being a most valuable instrument in the enhancement of communicative skills in a foreign language.

\section{Encyclopedic information in learner's dictionaries - a different ap- proach}

One of the traditional disputes in the descriptive lexicography involves the relation between linguistic and encyclopedic information. A strict structuralist approach favours a bias towards pure linguistic information. According to this approach the definition should only contain elements that represent the results of a semantic analysis of the lemma, cf. Gouws (1989: 185-199). A more lenient approach, as professed by cognitive semanticists, allows the definition to include a certain amount of information traditionally regarded as extra-linguistic. Cognitive semanticists argue that a lexical concept includes all the information associated with it, without a distinction between linguistic and encyclopedic information, cf. Geeraerts (1986: 187).

The discussion of the lexicographical representation of encyclopedic information has primarily been concerned with monolingual dictionaries and although a lot of attention has been given to this aspect, there has been no definite solution or a clearly definable distinction between encyclopedic and linguistic information. Zgusta (1971: 198-9) differentiates encyclopedic dictionaries from linguistic ones but he admits that this division is not necessarily an either-or matter because there are encyclopedic elements in almost every dictionary. He even says that some of these encyclopedic elements are unavoidable. Wiegand (1988b: 742-3) states it quite emphatically that it is wrong to differentiate between dictionaries and encyclopedias merely on the basis of a distinction between semantic and encyclopedic information in the lexicographical definition. Like Zgusta he does not regard this distinction as an either-or matter.

Questions about encyclopedic information have been relevant especially to general monolingual dictionaries of a more comprehensive nature. Neither 
the learner's dictionary nor the bilingual dictionary has received much attention as potential containers of this information type. In the relative short history of the learner's dictionary it has been accepted without argument that this typological category has to focus on the typical linguistic information needed by its target users and that this dictionary should contain little extralinguistic information. This approach has been motivated by the microstructural scope of learner's dictionaries. According to Herbst (1990: 1379) the encyclopedic elements of a monolingual dictionary may be of great importance to the native speaker, whereas the foreign learner will be looking for other types of information. This is a valid argument if the encyclopedic information is restricted to the definition. The definition in the learner's dictionary should primarily focus on the meaning of the lemma. However, to improve the pedagogical scope of the learner's dictionary, lexicographers should evaluate different types of microstructural entries in order to ascertain the most efficient ways of conveying information relevant to the learner's needs in his mastering of the foreign language. This might demand innovative approaches and changes in the existing perspectives, and may lead to a reappraisal of the desirability of encyclopedic information in learner's dictionaries and to an embarkation on a more encyclopedic-based approach.

As a potential microstructural category the notion "encyclopedic information" has so far been allocated a very limited scope. The discussion of this type of information in dictionaries has been directed at its occurrence in the definition, with some scant attention to the encyclopedic character of pictorial illustrations. Advocating in favour of encyclopedic information in learner's dictionaries does not necessarily imply a plea for the comprehensive inclusion of this information type in the dictionary definition. Encyclopedic information can be regarded as a separate microstructural category. The lexicographer has to decide how and where to accommodate it in the dictionary article. The acknowledgement of this category does not have to alter the status of encyclopedic features in the definition. As a semantic description the definition in a monolingual dictionary will almost always include some form of encyclopedicity. In this regard the lexicographer could adhere to the arguments of Zgusta (1971: 198-9) and Wiegand (1988b: 742-3) that the differentiation between encyclopedic and linguistic information is not absolute. Yet, the lexicographer has to be able to indicate the permissible extent of the encyclopedic infiltration in the definition. A dictionary definition is aimed at an unambiguous transfer of meaning. One of the most important functions of a learner's dictionary is to enable the potential user to acquire a certain degree of semantic and communicative fluency in the specific language. The amount of encyclopedic information needed to obtain this goal may be included as part of the semantic description, but it should be far less than the cognitive semanticists' idea of all the information associated with a specific lexical,concept.

Treating encyclopedic information as a separate microstructural category would neither impede nor extend the traditional occurrence of this information 
type, but will rather present a new opportunity to utilize encyclopedic features as an additional entry in the overall lexicographical treatment of a lexical item. One of the implications of working with the dictionary article as a text, cf. Wolski (1989), is that the different microstructural elements have to be employed in an interactive relation to one another. Without increasing the degree of textual compression in an article it can be expected from a lexicographer to construct an article in such a way that the different microstructural categories complement each other. This should also apply to the occurrence of an encyclopedic category.

The lack of encyclopedic information in learner's dictionaries gives evidence of inferior research regarding the needs of real language learners as well as the pedagogical assignment and function of a dictionary in the teaching of a foreign language. If the occurrence of encyclopedic information in learner's dictionaries received more attention and had it been at the focus of linguistic and pedagogical research, there would have been far greater recognition of its functional value as part of the overall educational process. Contrary to the belief of Herbst (1990: 1379) that encyclopedic information is not relevant to learners of a foreign language, and in spite of the fact that the inclusion of an encyclopedic component will increase the density of information, the accommodation of this microstructural category could enhance the learner's comprehension because of its explicitness and direct link with the real life experience.

This paper will neither endeavour to define the notion "encyclopedic category" nor discuss its potential nature and extent. Scant attention will be given to one type of entry often regarded as an unnecessary and encyclopedic part of the dictionary article, i.e. the use of pictorial illustrations. It has been mentioned above that Hansen (1990: 19) regards examples as a formal lexicographical category. Examples have, amongst others, a pragmatic function to illustrate the use of a lemma. This function is performed by verbal illustrations. As a formal lexicographical category examples also include a non-verbal component, i.e. pictorial illustrations. These examples are used to illustrate the object to which the lemma refers. Pictorial illustrations perform more than one microstructural function. They are part of at least two categories, i.e. the category of lexicographical examples as well as the encyclopedic category. The latter assignment of pictorial illustrations will be discussed briefly.

\section{The use of pictorial illustrations as part of the encyclopedic category}

Although they are employed quite frequently, pictorial illustrations are too often regarded as ornamental components of a dictionary article. This type of entry is primarily restricted to monolingual dictionaries with a comprehensive approach, where it is employed as a non-essential element which often duplicates the information given in the verbal definition. Dictionary critics have the full right to regard pictorial illustrations as redundant entries if they perform 
no distinctive function. However, the lexicographical validity of their employment is unquestionable when these entries enhance the comprehension of the target user. To achieve this goal in a monolingual dictionary the non-verbal illustrations should complement the verbal definition by giving additional information or by explicating some features which the definition cannot present clearly enough. The use of pictorial illustrations should not be limited to monolingual dictionaries. Examples and encyclopedic information are microstructural categories that should be included in monolingual and bilingual dictionaries. In both these functions pictorial illustrations have to be employed in bilingual dictionaries. In a bilingual dictionary a pictorial illustration can present an ostensive definition of a translation equivalent.

The use of pictorial illustrations display encyclopedic characteristics because of the emphasis on extralinguistic features. Yet they are not redundant entries because they support the pedagogical assignment of the dictionary article by endeavouring an optimal transfer of information relevant to the learner's needs and demands.

\section{Conclusion}

Learner's dictionaries are important instruments in the teaching of a foreign language. Their compilation has to rely on sound theoretical, pedagogical and linguistic principles. For the multilingual South African situation learner's dictionaries are needed to offer access to the different languages. These dictionaries can help to bridge cultural and linguistic gaps and can enhance the communicative competence of the speakers of different speech communities.

\section{References}

\section{Dictionaries}

Bosman, D.B. et al. $1984^{8}$. Tweetalige Woordeboek/Bilingual Dictionary. Cape Town: Tafelberg. Crowther, J. (Ed.). 1992. Oxford Advanced Learner's Dictionary. Oxford: Oxford University Press.

Du Plessis, M. 1993. Tweetalige Aanleerderswoordeboek/Bilingual Leamer's Dictionary. Cape Town: Tafelberg.

Gouws, R.H., F.A. Ponelis and A.E. Feinauer. 1993. Basiswoordeboek van Afrikaans. Pretoria: J.L. van Schaik.

Kotzé, E. and P. Wela. 1991. Afrikanns/Zoeloe Woordeboek met Engelse vertalings. Cape Town: Tafelberg.

Kritzinger, M.S.B. et al. 198613. Groot Woordeboek/Major Dictionary. Pretoria: J.L. van Schaik.

Procter, P. (Ed.). 1978. Longman Dictionary of Contemporary English. Harlow: Longman.

Sinclair, J. (Ed.). 1987. Collins COBUILD English Language Dictionary. London and Glasgow: Collins. 


\section{Other sources}

Alberts, M. and P. Mtintsilana. 1988. Leksikografiese ontleding van Afrikanse en Afrikatale-leksikons. Pretoria: Raad vir Geesteswetenskaplike Navorsing.

Austin, P. (Ed.). 1983. Papers in Australian Linguistics 15: Australian Aboriginal Lexicography. Pacific Linguistics, Series $A$, no 66.

Ayto, J. 1984. The Vocabulary of Definition. Goetz, D. and T. Herbst (Eds.). 1984: 50-62.

Carter, R. 1983. "You look nice and weedy these days!" Lexical Associations, Lexicography and the Foreign Language Leamer. Journal of Applied Language Study 1 (2): 172-189.

Cowie, A. (Ed.). 1987. The Dictionary and the Language Learnet. Tübingen: Max Niemeyer Verlag.

Diab, T. 1990. Pedagogical Lexicography. Tübingen: Max Niemeyer.

Geeraerts, D. 1986. Woordbetekenis. Leuven: Acco.

Goetz, D. and T. Herbst. (Eds.). 1984. Theoretische und praktische Probleme der Lexikographie. München: Max Hueber Verlag.

Gouws, R.H. 1989. Leksikografie. Cape Town: Academica.

Hansen, G.B. 1990. Artikelstruktur im zweisprachigen Wörterbuch. Tübingen: Max Niemeyer.

Hausmann, F.J. 1989. Das Definitionswörterbuch. Hausmann, F.J. et al. (Eds.). 1989-1991: 981-988.

Hausmann, F.J. and H.E. Wiegand. 1989. Component Parts and Structures of General Monolingual Dictionaries: A Survey. Hausmann, F.J. et al. (Eds.). 1989-1991: 328-360.

Hausmann, F.J., O. Reichmann, H.E. Wiegand and L. Zgusta. (Eds.). 1989-1991. Wörterbücher. Dictionaries. Dictionnaires. An Intemational Encyclopedia of Lexicography. Berlin: Walter de Gruyter.

Herbst, T. 1990. Dictionaries for Foreign Language Teaching: English. Hausmann, F.J. et al. (Eds.). 1989-1991: 1379-1385.

Jehle, G. 1990. Das englische und französische Lermerwörterbuch in det Rezension. Tübingen: Max Niemeyer.

Kühn, P. 1990. Das Grundwortschatzwörterbuch. Hausmann, F.J. et al. (Eds.). 1989-1991: 13531364.

Munske, H.H. et al. (Eds.). 1988. Deutscher Wortschatz. Berlin: Walter de Gruyter.

Otto, A.N. 1989. Kriteria vir 'n Afrikaanse Aanleetderwoordeboek. Unpublished D.Litt-thesis. University of Stellenbosch.

Rademeyer, L. 1992. Die funksies van verbale voorbeeldmateriaal in eentalige woordeboeke. Unpublished MA-thesis. University of Stellenbosch.

Snell-Hornby, M. 1987. Towards a Learner's Bilingual Dictionary. Cowie, A. (Ed.). 1987: 159170.

Tickoo, M.L. (Ed.). 1989. Learners' Dictionaries: State of the Art. SEAMEO Regional Language Centre: Singapore.

Tommola, H. et al. (Eds.). 1992. Euralex '92 Proceedings. Universitas Tampere: Tampere.

Walter, E. 1992. Semantic Set-defining: Benefits to the Lexicographer and the User. Tommola, H. et al. (Eds.). 1992: 129-136.

Wiegand, H.E. 1988. Shangai bei Nacht. Wiegand, H.E. 1988a: 521-626.

Wiegand, H.E. 1988a. Wiegand, H.E. Studien zur neuhochdettschen Lexikographie VI. 2. Teilband. Hildesheim: Georg Olms Verlag. 
Wiegand, H.E. 1988b. Was eigentlich ist Fachlexikographie? Munske, H.H. et al. (Eds.). 1988: $729-790$.

Wierzbicka, A. 1983. Semantics and Lexicography: Some Comments on the Warlpiri Dictionary Project. Austin, P. (Ed.). 1983: 135-164.

Wolski, W. 1989. Formen der Textverdichtung im allgemeinen einsprachigen Wörterbuch. Hausmann, F.J. et al. (Eds.). 1989-1991: 956-967.

Wolski, W. 1991. Formen der Textverdichtung im zweisprachigen Wörterbuch. Hausmann, F.J. et al. (Eds.). 1989-1991: 2837-2854.

Zgusta, L. 1971. Manual of Lexicography. The Hague: Mouton.

Zgusta, L. 1989. Idle Thoughts of an Idle Fellow; or, Vaticinations on the Learners' Dictionary. Tickoo, M.L. (Ed.). 1989: 1-9. 


\title{
Normatiewe leiding in woordeboeke: 'n nuwe benadering.
}

\author{
R.H. Gouws, Departement Afrikaans en Nederlands, \\ Universiteit van Stellenbosch, Suid-Afrika
}

\begin{abstract}
Normative Information in Dictionaries: An Innovative Approach. In a multilingual society linguistic contact leads to language influencing which effects different registers of the language. The standard variety of Afrikaans is largely subjected to language influence resulting from its continuous contact with English. In their treatment of the lexicon dictionaries should reflect the linguistic reality. The results of linguistic contact should also be included in a dictionary. Afrikaans monolingual and bilingual desk dictionaries as well as restricted normative dictionaries have traditionally adopted a strictly prescriptive approach, endeavouring to render the standard language as a puristic variety. This resulted in a restriction of the macrostructural scope of these dictionaries.

In this paper the traditional approach is discussed in order to contrast it with an innovative approach to the lexicographical treatment of language change. The normative Afrikaans dictionary Die korrekte woord is used to illustrate the new approach. This dictionary treats the Afrikaans Iexicon in a new way by including a substantial number of English loan words. While adhering to its normative assignment Die korrekte wourd gives an account of the dynamics of language change. This is done by responding to a new interpretation of the notion "Standard Afrikaans". The application of this approach leads to the inclusion of a lemma selection that represents the real standard variety of Afrikaans. The principles applied and the implications for normative lexicography in general are discussed.
\end{abstract}

Keywords: ANGLICISM, BILINGUAL DICTIONARY, DESK DICTIONARY, DICTIONARY, FUNCTIONAL BORROWING, LANGUAGE INFLUENCE, LANGUAGE STANDARDIZATION, LEXICAL BORROWING, LEXICOGRAPHY, LEXICON, LINGUISTIC CONTACT, LOAN TRANSLATION, NORMATIVE DICTIONARY, PRESCRIPTIVITY, PURISM

Opsomming: In 'n meertalige situasie lei taalkontak tot taalbeïnvloeding. Taalbeinvloeding raak verskillende registers van ' $n$ taal. Afrikaans se standaardvariëteit word grootliks beinvloed deur die voortdurende kontak met Engels. In hulle bewerking van die leksikon van 'n taal moet woordeboeke ' $n$ weersprieëling bied van die taalwerklikheid. Die gevolge van taalbeïnvloeding moet leksikografiese vergestalting kry. Verklarende en vertalende handwoordeboeke van Afrikaans asook beperkte normatiewe woordeboeke het tradisioneel 'n streng preskriptiewe benadering gevolg en gepoog om 'n puristiese weergawe van die standaardtaal aan te bied. Dit het gelei tot' $n$ verskraling van die bestek van hierdie woordeboeke.

Hierdie artikel is ' $n$ hersiene en uitgebreide weergawe van een onderafdeling van Gouws (1993). 
In hierdie artikeI word aandag gegee aan die tradisionele benadering as agtergrond vir 'n bespreking van ' $n$ innoverende leksikografiese behandeling van taalverandering. Die normatiewe woordeboek Die korrekte woord word gebruik ter illustrasie van die nuwe benadering. Hierdie woordeboek se vernuwende bydrae is veral ter sake in sy hantering van leenwoorde uit Engels. Sonder om sy normatiewe funksie te versaak, doen die woordeboek verslag van die geldende taaldinamika. Hierdie leksikografiese behandeling spruit uit 'n ruim interpretasie van die begrip "Standaardafrikaans". Die toepassing hiervan lei tot ' $n$ lemmakeuse wat verteenwoordigend is van die werklike standaardvariëteit van Afrikaans. Die beginsels waarvolgens die nuwe benadering werk, word bespreek asook die implikasies wat dit vir die normatiewe leksikografie het.

Sleutelwoorde: ANGLISISME, FUNKSIONELE ONTLENING, HANDWOORDEBOEK, LEENVERTALING, LEENWOORD, LEKSIKOGRAFIE, LEKSIKON, NORMATIEWE WOORDEBOEK, ONTLENING, PRESKRIPTIWITEIT, PURISME, TAALBEINVLOEDING, TAALKÓNTAK, TAALSTANDAARDISERING, VERTALENDE WOORDEBOEK, WOORDEBOEK

\section{Inleidend}

Linguistiese woordeboeke moet 'n weerspieëling bied van die taalwerklikheid. Vir die Suid-Afrikaanse leksikograaf bied hierdie opdrag ' $n$ omvattende uitdaging. Om verslag te doen van die Suid-Afrikaanse taalwerklikheid beteken dat daar eweneens verslag gedoen moet word van die multitalige en multikulturele plaaslike situasie. Taalkontak lei noodwendig tot ' $n$ onderlinge beïnvloeding van die verskillende tale. Geen Suid-Afrikaanse taal bestaan in isolasie nie en geen Suid-Afrikaanse taal spring dit vry om die teiken van taalbeïnvloeding te wees nie.

Algemene verklarende en vertalende woordeboeke is veral gerig op 'n bewerking van die standaardvariëteit van die betrokke taal of tale. Ook hierdie variëteit is onderhewig aan die invloed van taalkontak. Binne 'n meertalige opset sal pogings tot taalstandaardisering erkenning moet gee aan die gevolge van die kontaksituasie. Woordeboeke sal nie net 'n weergawe kan bied van 'n puristiese standaardvariëteit nie maar sal ag moet slaan op die dinamika van taalverandering en die gevolge wat dit vir die omvang en inhoud van spesifiek die standaardvariëteit van 'n taal het.

In hierdie artikel word daar gefokus op enkele aspekte van die leksikografiese hantering van die Suid-Afrikaanse taalkontaksituasie. Die klem is veral op die invloed wat dit op Afrikaans en op veranderinge in die tradisionele preskriptiewe perspektief van woordeboeke het. In hierdie verband word die bespreking gerig op die sewende uitgawe van die normatiewe woordeboek Die korrekte woord. Aandag word in 'n mindere mate ook gegee aan algemene verklarende Afrikaanse woordeboeke en vertalende Afrikaans-Engelse woordeboeke se benadering tot die preskriptiewe perspektief.

Weens die landswye geografiese verbreidheid van die gebruikers van Afrikaans en Engels skep die taalkontaksituasie 'n voortdurende interaksie tus- 
sen hierdie twee tale. Dit lei tot 'n wedersydse beïnvloeding wat nie tot leksikale veranderings beperk is nie maar wat ook geld op die vlak van byvoorbeeld die fonologie, morfologie, sintaksis en ortografie. Vanuit 'n leksikografiese perspektief is dit veral leksikale veranderings wat opvallend en ter sake is.

Die tussentalige wisselwerking in Suid-Afrika het 'n besliste uitwerking op die aard en omvang van voorskriftelike houdings oor puristiese taalgebruik. Dit geld veral die houding oor Afrikaans. Die ideaal om Afrikaans as ' $n$ onafhanklike taal naas die wêreldtaal Engels te laat ontwikkel, het 'n puristiese drang laat ontstaan wat gelei het tot talle pogings om die werklikheid van die taalkontaksituasie te ontken en om die invloed van Engels op Afrikaans te minimaliseer of te neutraliseer. Afrikaanse skoolgrammatikas het byvoorbeeld 'n baie sterk preskriptiewe houding weerspieël. Normatiewe woordeboeke is opgestel met die suiwering van Afrikaans as belangrike opdrag.

Gebeure van die laaste dekade of wat het egter ingrypende houdingsveranderinge meegebring. Dit het gelei tot 'n erkenning van die feit dat die SuidAfrikaanse tale saam moet bestaan, dat taalkontak 'n onontkombare werklikheid is en dat dit noodwendig tot taalverandering sal lei. Dit word ook aanvaar dat so ' $n$ verandering nie 'n verlaging in die gehalte van die betrokke taal impliseer nie. Hierdie houdingsverandering het 'n nuwe perspektief op die preskriptiewe en deskriptiewe funksies van woordeboeke tot gevolg gehad. Woordeboeke moet inligting oordra wat verteenwoordigend is van die linguistiese werklikheid en wat die dinamika van taalverandering erken.

\section{Afrikaanse woordeboeke en die tradisionele normatiewe benadering}

In Afrikaanse woordeboeke is standaardisering dikwels regstreeks verbind met preskriptiwiteit en normatiwiteit. In die ontwikkeling van Afrikaans naas Engels moes elke denkbare hulpmiddel tot uitbreiding en oorlewing benut word. Vertalende Afrikaans-Engelse woordeboeke het gevolglik die klem baie sterk op puristiese Afrikaans geplaas. 'n Soortgelyke nougesette en preskriptiewe benadering is ook in eentalige Afrikaanse woordboeke gevolg. Dit geld al die subtipologiese kategorieë, onder meer handwoordeboeke, skoolwoordeboeke en beperkte normatiewe woordeboeke.

\subsection{Die beïnvloeding van die informele register van Afrikaans}

Die invloed van Engels op Afrikaans is duidelik merkbaar op die vlak van tegniese en wetenskaplike taalgebruik. Tog is die sterkste en opvallendste invloed op die vlak van die informele register van Afrikaans, vgl. Van der Merwe en Ponelis (1991: 63). ' $n$ Mens kan die aard en omvang van die invloed van Engels op Afrikaans eers reg begryp wanneer jy vertroud is met die hoë mate van tweetaligheid van die sprekers van Afrikaans. As gevolg van die status van én 
Afrikaans én Engels as amptelike landstale beskik die gemiddelde lid van die Afrikaanse taalgemeenskap oor 'n gevorderde graad van tweetaligheid. $\mathrm{Hy}$ is nie net vlot in sy moedertaal Afrikaans nie maar die kragtige uitdrukkingsvermoë van Engels en veral die uitgebreide Engelse woordeskat staan voortdurend tot sy beskikking.

Die aktiewe taalkontak in die individuele lid van die Afrikaanse taalgemeenskap lei tot 'n produktiewe oordrag van woorde en uitdrukkings vanaf Engels na Afrikaans. Sommige van hierdie leksikale items word verafrikaans deurdat hulle byvoorbeeld by die Afrikaanse grammatiese, morfologiese, fonologiese of ortografiese stelsel aangepas word. 'n Groot aantal Engelse leksikale items word as deel van die Afrikaanse leksikon geïnternaliseer. Sommige van hierdie leenwoorde het 'n beperkte optrede en die leksikograaf hoef hulle nie vir opname in die woordeboek te oorweeg nie. Sodra 'n leenwoord egter 'n gevestigde gebruik in Afrikaans verwerf het, moet dit in woordeboeke aangedui word.

\subsection{Die Woordeboek van die Afrikaanse Taal}

Een woordeboek waarin die puristiese benadering nie so opvallend is nie, is die omvattende Woordeboek van die Afrikaanse Taal (voortaan afgekort as die WAT). Die mindere mate van preskriptiwiteit in die WAT spruit regstreeks voort uit die tipologiese kriteria wat die leksikograwe van hierdie woordeboek verplig om die leksikon van Afrikaans so omvattend as moontlik te weerspieël. Dit lei tot die insluiting van 'n groot klomp inskrywings met 'n beperkte, niestandaardoptrede, bv. die volgende lemmas wat in WAT VIII verskyn: kraalnetvlerkie, kree, kruiwasaaier en kwasmot. Die keuse van niestandaarditems is veral gerig op leksikale items met 'n beperking op grond van die dialektiese, kulturele, godsdienstige of tegniese veld waartoe hulle behoort. Die WAT bied 'n geldige verslag van 'n groot deel van die leksikon van Arikaans maar hierdie woordeboek moet ook beskou word as 'n waardevolle dokumentasie van die kultuurgeskiedenis van Afrikaans. Die WAT bevat kultuurspesifieke leksikale items as lemmas en gee 'n omvattende behandeling van hulle gebruik en betekenis asook 'n beskrywing van hulle historiese en kulturele waarde. Dit verhoog die WAT se waarde as 'n algemene naslaanbron. Die WAT is al dikwels in die verlede met reg gekritiseer vir sy oordrewe ensiklopediese benadering. Die behandeling van kultuurspesifieke items bevestig egter die belangrikheid van 'n omvattende en indringende leksikografiese behandeling waarin sowel die linguistiese as sekere buitelinguistiese kenmerke die aandag kry.

Ondanks die informatiewe benadering in die hantering van niestandaardgebruik word die WAT se stelsel steeds gestriem deur 'n puristiese vooroordeel wat vergelykbaar is met dié van vertalende Afrikaans-Engelse en ander eentalige Afrikaanse woordeboeke. As 'n woordeboek met 'n omvattende benadering 
het die WAT die volle spektrum van die leksikon van Afrikaans in sy bestek. Makrostrukturele omvattendheid impliseer die keuse van leksikale items wat verteenwoordigend is van alle style en registers, insluitende items uit die aansienlike versameling Engelse leenwoorde. Ongelukkig slaag die WAT nie daarin om die werklike omvang van die invloed van Engels op die Afrikaanse leksikon te reflekteer nie.

Getrou aan hulle normatiewe opdrag sal handwoordeboeke minder aandag gee aan die opname van leenwoorde aangesien hierdie woordeboektipe primêr gerig is op die weergawe van die standaardtaal. Daarenteen kan daar met reg van ' $n$ informatiewe woordeboek met 'n omvattende opdrag verwag word om 'n verteenwoordigende versameling van hierdie tipe leksikale items op te neem. Die opname van hierdie leenwoorde behoort gekomplementeer te word deur die aangawe van etikette ter aanduiding van hulle moontlike gebruiksbeperkinge. Deur 'n onvoldoende erkenning van die resultate van hierdie taalkontaksitusie boet die WAT se weergawe van die leksikon van Afrikaans in aan algemene geldigheid. Dit verminder die status van hierdie woordeboek as 'n omvattende bron van taalkundige inligting.

\subsection{Afrikaanse verklarende handwoordeboeke}

Ondanks die bogenoemde kritiek op die WAT se beleid ten opsigte van leenwoorde uit Engels is daar wel 'n hele aantal sulke lemmas in die WAT opgeneem; al is dit nie 'n verteenwoordigende versameling nie. Voorbeelde soos kothuis en krot is leenwoorde uit Engels wat verafrikaans is. Afrikaanse verklarende handwoordeboeke lewer 'n teleurstellende vertoning ten opsigte van die opname van leenwoorde uit Engels. Selfs met inagneming van die tipologiese kriteria wat die fokus in handwoordeboeke so sterk op die weergawe van standaardtaal plaas, kan die feitelike ignorering van hierdie komponent van die Afrikaanse leksikon nie verskoon word nie.

Woordeboeke soos die Verklarende Handwoordeboek van die Afrikaanse Taal (voortaan HAT) en die Nasionale Woordeboek (voortaan NW) moet hulle in hulle lemmakeuse aan die standaardtaal hou, maar die makrostrukturele keuse wat in hierdie woordeboeke geillustreer word, dui in baie gevalle op 'n verwronge siening van hulle tipologiese doelstelling. Hierdie probleem kan dikwels toegeskryf word aan 'n ongeldige interpretasie van die begrip "Standaardafrikaans". Deur vas te klou aan die tradisionele siening dat Afrikaans teen die invloed van Engels beskerm moet word, word hierdie begrip in puristiese terme verstaan, sonder inagneming van die sosiolinguistiese werklikheid en die prototipiese gebruik van Afrikaans. 'n Benadering wat teen die gebruik van leenwoorde uit Engels is, veroorsaak dat sulke woordeboeke dikwels 'n negatiewe normatiewe invloed het, vergelyk in hierdie verband Malkiel (1989: 64). 
Die puristiese vooroordeel in Afrikaanse verklarende handwoordeboeke voorkom nie net 'n geldige makrostrukturele keuse nie maar dit lei ook tot 'n oordrewe preskriptiewe en sterk normatiewe benadering. Selfs gevestigde leenwoorde, indien hulle wel opgeneem word, word dikwels op so 'n manier geëtiketteer dat woordeboekgebruikers dit as gestigmatiseerde items beskou wat in goeie taalgebruik vermy moet word. Vergelyk in hierdie verband die etikettering as Anglisisme van die lemmas geskeduleerd (-e) in NW en halfmas in HAT. In hierdie verband is die jongste uitgawe van die Verklarende Afrikaanse Woordebdek (voortaan VAW) 'n grootskaalse verbetering op die ander handwoordeboeke. Alhoewel VAW steeds onverteenwoordigend is wat sy leenwoordlemmas betref, neem hy tog heelwat meer Engelse leenwoorde op sonder om hulle per etiket te stigmatiseer. Daar word in hierdie publikasie ook baie minder voorskriftelike uitsprake gemaak.

Die preskriptiewe benadering in Afrikaanse verklarende woordeboeke is dikwels aangevul met en ondersteun deur die publikasie van normatiewe gebruikshandleidings. 'n Primêre doel van hierdie beperkte voorskriftelike woordeboeke was die bevordering van 'n suiwer variëteit van Afrikaans sonder tekens van Engelse invloed, vgl. Van der Merwe (1967) en Hiemstra (1980). Die hersiening van Van der Merwe (1967) Die korrekte woord deur Ponelis in 1982 en veral in 1991 was 'n belangrike leksikografiese deurbraak. Ponelis werk met ' $n$ ander siening van die funksie van 'n preskriptiewe woordeboek en sy benadering lui 'n era van Afrikaanse woordeboeke in wat erkenning gee aan die Suid-Afrikaanse sosiolinguistiese werklikheid en die gevolge daarvan vir die leksikon van Afrikaans.

\section{3. 'n Nuwe perspektief op die preskriptiewe funksie in die leksikografie}

\subsection{Die gevestigde benadering}

In die leksikografie het die preskriptiewe benadering 'n lang en eerbiedwaardige tradisie. Dit is veral gevestig deur die houding wat Samuel Johnson ingeneem het in die beplanning en uiteindelike publikasie van sy woordeboek (Johnson 1747 en 1755). Sedertdien is woordeboeke steeds as taalkundige gesagsbronne beskou waarna die gebruiker opgesien het vir leiding ten opsigte van korrekte taalgebruik.

Die preskriptiewe benadering is nie net in algemene verklarende woordeboeke gevolg nie maar dit het ook 'n tipiese funksie van beperkte normatiewe woordeboeke geword. Een van die kenmerkende eienskappe van Afrikaanse beperkte woordeboeke wat op normatiewe leiding gerig is, is hulle sterk Anglisistiese vooroordeel (vgl. Gouws 1990; 61). Hierdie benadering het gelei tot pogings om Afrikaans op grond van puristiese oorwegings te reglementeer. Hierdeur het die normatiewe woordeboeke dieselfde soort fout begaan as verklarende Afrikaanse en vertalende Afrikaans-Engelse woordeboeke deurdat 
die makrostruktuur asook die leksikografiese adressering (vgl. Hausmann en Wiegand 1989 vir 'n verklaring van dié begrip) verteenwoordigend is van die leksikon van 'n ideale spreker en nie dié van 'n tipiese gebruiker van Afrikaans nie. Volgens Hanks (1990: 32) is dit die taak van die leksikografie om dit wat konvensioneel in ' $n$ taal is te ontdek en in woorde vas te vang. Hierdie benadering beklemtoon weer eens die funksie van 'n woordeboek om nie net taalkundige inligting te weerspieël met betrekking tot byvoorbeeld die grammatika, betekenis, uitspraak en etimologie van 'n versameling leksikale items nie, maar ook om verslag te doen van die sosiolinguistiese werklikheid van die betrokke taalgemeenskap. Binne die Suid-Afrikaanse taalsituasie beteken dit dat die Afrikaanse leksikograaf aandag moet gee aan die werklikheid van taalkontak en dat hy die uitwerking daarvan in sy woordeboek moet aantoon.

Tydens die vroeë jare van sy ontwikkeling moes Afrikaans sukkel om naas Engels as 'n onafhanklike taal gevestig en erken te raak. Alhoewel hierdie "stryd" suksesvol afgehandel is, is dit vir nog baie jare deur sommige leksikograwe en taalpuriste voortgesit. Voortgaande pogings om Afrikaans se posisie te verseker en te beveilig, is in beginsel lofwaardig en behoort aangemoedig te word. Waar sodanige pogings egter die invloed van die Suid-Afrikaanse taalkontaksituasie en veral die natuurlike invloed van Engels op Afrikaans as tekens van taalverval beskou en dit met felle weerstand benader, kan dit nóg linguisties nóg leksikografies sonder meer aanvaar word. Ongelukkig het hierdie benadering sterk inslag gevind. As gevolg daarvan vertoon baie Afrikaanse woordeboeke nog steeds 'n makrostrukturele versameling wat verteenwoordigend is van dit wat die leksikograaf as korrekte taalgebruik beskou en nie wat deur die taalkundige en sosiolinguistiese werklikheid as sodanig bewys word nie. Afrikaanse beperkte woordeboeke met 'n normatiewe opdrag het grootliks tot hierdie wanopvatting help bydra. Die onhoudbaarheid van so 'n benadering is reeds tydens die reaksie. op die verskyning van die Webster's Third New International Dictionary of the English Language in 1961 aangetoon. Vergelyk in hierdie verband Sledd en Ebbitt 1962.

\subsection{Die innoverende benadering}

Die eerste uitgawes van Die korrekte woord (voortaan DKW) (Van der Merwe 1967) het getrou gebly aan die toe geldende benadering van sterk voorskriftelikheid. Met die uitgawe van 1982 en veral dié van 1991 wat deur Ponelis bewerk is (Van der Merwe en Ponelis 1982, 1991), breek Ponelis weg van die tradisionele benadering en stel hy 'n nuwe furiksie vir hierdie woordeboek aan die orde. Die eerste uitgawes van DKW het 'n uitgebreide versameling Afrikaanse taalkwessies behandel met die klem op die normatiewe behandeling van leksikale items met spelling-, semantiese, gebruiks- of ander taalkundige probleme of eienaardighede. Die leksikografiese adressering is gerig op in 
keuse van problematiese leksikale items en die mikrostruktuur het bestaan uit in bespreking van sommige van die opvallendste aspekte van die lemmas.

Ponelis keur die opname van makrostrukturele items ook volgens hierdie kriteria maar die vasstelling van leksikale items waarmee gebruikers probleme mag ondervind, word nie puristies gemotiveer nie maar volgens bewyse uit die sosiolinguistiese werklikheid. Gevolglik sluit hy 'n uitgebreide versameling Engelse leenwoorde in en in die behandeling van hierdie items illustreer Ponelis 'n liberale houding waarin die klem geplaas word op maniere waarvolgens Afrikaans baat kan vind en reeds gevind het by die taalkontaksituasie. 'n Deeglik gemotiveerde houding teenoor taalverandering geld nie net in die keuse en behandeling van leenwoorde en in hulle aanvaarding as deel van die leksikon van Afrikaans nie, maar Ponelis illustreer sy siening ook deur die behandeling van ' $n$ andersoortige lemmatipe in DKW. Hy verbreed die bestek en omvang van die lemmaversameling op ' $n$ innoverende manier deur seleksiekriteria in te voer wat voorsiening maak vir die opname van meer as net leksikale items wat pragmatiese probleme bied.

Ponelis gaan verder as die bestaande tipologiese kriteria van normatiewe woordeboeke deur sy woordeboek te gebruik vir die bespreking van taalkwessies wat van groot belang is in 'n taalkontaksituasie. Die opname en behandeling van lemmas soos normering, Engelse invloed, taalverandering en variasie gee ' $n$ ander statuur áan DKW. Die adressering in hierdie artikels weerspieël 'n gesonde en objektiewe daarstelling van die leksikograaf se siening van hierdie kwessies en beklemtoon die funksie van DKW as 'n nuttige hulpmiddel by die gebruik van Afrikaans. In die voorwoord van die 1991-uitgawe verwys Ponelis na die insluiting van hierdie lemmas. Daardeur lig hy nie net die gebruiker in oor die vernuwing in DKW se makrostrukturele aard nie maar stuur hy hom na hierdie artikels. Die manier waarop Ponelis hierdie aktuele aangeleenthede bespreek en die onbevange benadering tot uiters delikate kwessies vorm die basis van die algemene benadering wat hy inneem in die normatiewe behandeling van lemmas in DKW.

Beperkte normatiewe woordeboeke lewer per tipologiese opdrag kommentaar op die staandaardvariëteit van die teikentaal. Die benadering wat in DKW gevolg word, ekspliseer 'n herinterpretasie van Standaardafrikaans deurdat 'n omvattender bestekbepaling ingevoer word. Gevolglik kan DKW 'n andersoortige normeringsinvloed uitoefen waarby die vestiging en normering van die standaardvariëteit van Afrikaans grootliks kan baat. Volgens Zgusta (1989: 70) kan die leksikograaf se houding teenoor taalverandering as die "fundamentum divisionis" beskou word wanneer dit gaan oor "n woordeboek se invloed op die standaard taal. DKW se innoverende benadering bied 'n welkome alternatief op die tradisionele normatiewe inhoud en die kunsmatige begrensing van Standaardafrikaans. 


\section{Die amptelike bereëling van die Afrikaanse spelling en erkenning van leenwoorde}

Die Afrikaanse woordelys en spelreëls (voortaan AWS) bied die amptelike spellingreglementering vir Afrikaans maar gee ook leiding ten opsigte van die erkenning van leenwoorde. Alle lemmas wat in die AWS verskyn, kan beskou word as erkende items van die Afrikaanse leksikon. As normatiewe woordeboek uit eie reg, bied die AWS riglyne ter ondersteuning van die leksikografiese erkenning van die invloed van die Suid-Afrikaanse taaldinamika op Afrikaans. In sy amptelike bereëling van die Afrikaanse spelling en erkenning van leenwoorde hou die Taalkommissie rekening met en bevestig hy die invloed van taalverandering.

Alhoewel die Taalkommissie in die 1991-uitgawe van die AWS heelwat leenwoorde, en veral ook Engelse leenwoorde, opgeneem het en daardeur erkenning gegee het aan hulle status as volwaardige leksikonitems van Afrikaans, is die vroeëre werk van die Taalkommissie dikwels gekenmerk deur 'n ietwat konserwatiewer benadering. Daar is geskroom om amptelike erkenning aan te veel leenwoorde uit Engels te gee. Gevolglik kon die normatiewe AWS nie die volle omvang van die invloed van Engels op Afrikaans weerspieël nie. Die liberaler benadering wat in die 1991-uitgawe gevolg is, lei tot die opname van talle Engelse leenwoorde soos derby, folk, rock en shandy. Die leksikografiese en sosiolinguistiese waarde van die opname van hierdie lemmatipe mag nooit onderskat word nie. Op die mees amptelike leksikografiese vlak word erkenning gegee aan die taalkontaksitusie en word die omvang van die linguistiese en sosiolinguistiese wisselwerking geëkspliseer. Die opname van leenwoorde geskied nie net ter erkenning van hulle status in Afrikaans nie maar ook ter aanduuiding van 'n algemener beginsel. Dit dui naamlik vir die gebruikers van die AWS daarop dat die voortgesette groei en ontwikkeling van Afrikaans afhanklik is van sy wisselwerking met die ander Suid-Afrikaanse tale en veral die wisselwerking met Engels. Hierdie benadering bied rigtinggewende leiding aan leksikograwe om nie in 'n Anglisistiese vooroordeel te stagneer nie maar om die werklikheid van die Suid-Afrikaanse taalsituasie te weerspieèl.

\subsection{Afrikaanse woordeboeke en die AWS}

Omdat die AWS die amptelike spellinghandleiding van Afrikaans is, eerbiedig woordeboeke gewoonlik sy voorskrifte. Ook die mate van speling wat woordeboeke vertoon in hulle opname van Engelse leenwoorde is dikwels bepaal deur die benadering wat in die AWS gevolg is. Leksikograwe het die leenwoordkomponent van hulle woordeboeke se lemmaversameling so na as moontlik aan die AWS se geïmpliseerde grense gehou. Daardeur was hulle daarvan verseker dat hulle woordeboeke die amptelike erkende leksikon van 
Afrikaans bevat. Alhoewel dit vanuit 'n puristiese oogpunt 'n voorbeeldige benadering is, het dit ongelukkig daartoe gelei dat woordeboeke op makrostrukturele vlak te min nuwe inligting bevat het. Die AWS se riglyne is nagevolg maar woordeboeke het nie genoegsaam gepoog om 'n onafhanklike en innoverende rigting in te slaan nie. Dit kon byvoorbeeld gedoen gewees het deur die opname van 'n verteenwoordigende aantal leenwoorde ter illustrasie van die aktiewe groeikrag van Afrikaans en van die tipiese gebruik deur die meerderheid sprekers van Afrikaans.

In die 1991-uitgawe van die DKW volg Ponelis die meer liberale leiding van die nuwe AWS. Hierdeur gee DKW 'n objektiewer aanbieding van die sosiolinguistiese werklikheid van Afrikaans as enige ander beperkte normatiewe woordeboek. Maar DKW se leksikografiese erkenning van die taalkontaksituasie en sy invloed op Afrikaans oorskry die toeskietlikheid van die AWS. Ponelis verken en vertoon die werklike leksikale front van Afrikaans deur die opname van 'n wye versameling leenitems wat veral uit die informele register kom.

\section{DKW se weerspieëling van die taalkontaksituasie}

DKW bied ' $n$ verteenwoordigender behandeling van 'n belangrike onderafdeling van die Afrikaanse leksikon as enige ander beperkte, algemene verklarende of vertalende woordeboek deur die aandag te vestig op leksikale items uit die informele register en hulle te beskryf as deel van die algemene leksikon van Afrikaans.

Die omvang van DKW se leksikografiese bydrae ten opsigte van die invloed van taalkontak is nie beperk tot die insluiting en geimpliseerde erkenning van leenwoorde nie; selfs al is dít 'n belangrike funksie van hierdie woordeboek. Die mikrostrukturele adressering in die artikels van die leengoedlemmas verteenwoordig 'n ewe waardevolle aspek wat bewys lewer van 'n vernuwende houding jeens taalkontak en die status van leengoeditems.

In die verlede het die adressering van Engelse leenwoorde in Afrikaanse woordeboeke dikwels blyke gegee van 'n negatiewe houding aan die kant van die leksikograaf. Dit geld verklarende en vertalende woordeboeke. Vergelyk in hierdie verband die etikettering as Anglisisme van die lemma karavaan aan die Afrikaans-Engelse kant van Tweetalige Woordeboek. Engelse leksikale items wat veral die meer informele register van Afrikaans binnegedring het, is as Anglisismes geëtiketteer. In Afrikaanse woordeboeke het hierdie etiket 'n stigmatiseringsinvloed. In die stryd om die vestiging van Afrikaans as 'n onafhanklike taal is daar moeite gedoen om Anglisismes op te spoor en uit te wis: 'n vorm van "leksikale suiwering". Alhoewel daar sedertdien ingrypende houdingsveranderings was en die heksejag op Anglisismes grootliks gestaak is, het die term "Anglisisme" steeds 'n negatiewe konnotasie. Lemmas wat so geëti- 
ketteer word, word deur die gewone woordeboekgebruiker as ongewenste elemente beskou.

In DKW se artikel van die lemma Engelse invloed beweer Ponelis dat dit onsinnig sou wees om die invloed van Engels op Afrikaans ongehinderd sy gang te laat gaan. Dit sou die einde van Afrikaans kon beteken. Dit het, aldus Ponelis (Van der Merwe en Ponelis 1991: 64), ewe min sin "om Anglisismes fanaties uit te ruik en te probeer elimineer". So 'n optrede vervreem die taalgebruiker van sy taal. Dit hou eweneens rampspoedige gevolge vir Afrikaans in. Ponelis se siening is relevant vir alle Afrikaanse leksikografiese projekte. Woordeboeke behoort die invloed van Engels op Afrikaans op so 'n manier te behandel dat die leksikograaf se houding nie die lojale gebruiker van Afrikaans vervreem nie. ' $n$ Onsensitiewe behandeling van taalbeïnvloeding in woordeboeke kan ' $n$ ondermynende invloed hê op die houding van die taalgemeenskap vir wie die woordeboek saamgestel is. Zgusta (1989: 73) beweer dat daar sekere tipes diglossie bestaan waar die geskrewe standaardtaal, en selfs die gesproke standaardtaal in sy formeler registers, argaies is in vergelyking met die alledaagse omgangstaal. Woordeboeke moet erkenning gee aan die bestaan van verskillende registers binne die standaardvariëteit van Afrikaans. Dit beteken dat ook die omgangstaal geakkommodeer moet word en dat daar gevolglik 'n leksikografiese bewerking van onder meer leenwoorde moet wees. In hierdie verband tree DKW voorbeeldig op. Hierdie soort benadering werk die vervreemding van die tradisionele siening van Standaardafrikaans teë. Dit gee nie net erkenning aan 'n ruimer domein van hierdie variëteit van Afrikaans nie maar bevestig eweneens die aansprake van 'n groot deel van die Afrikaanse taalgemeenskap op die aanvaarbaarheid van hulle normale taalgebruik as deel van die erkende en aanvaarde variëteit.

\section{Leengoeditems in DKW}

\subsection{Leenwoorde}

Die houding wat in die artikel van die lemma Engelse invloed uiteengesit word, word konsekwent toegepas in DKW se behandeling van Engelse leenwoorde en ander fasette van taalbeinvloeding, byvoorbeeld in die opmerkings oor die plasing van aksent waar die uitspraak van 'n woord onder Engelse invloed tot aksentverskuiwing lei. Vergelyk in hierdie verband die opmerkings in die artikels van die lemmas kontak en konteks. Leenwoorde soos boobytrap, ladybird, lover, mechanic, O.K., rumpsteak, scrap en tissue is enkele van die Engelse leksikale items wat as lemmas opgeneem is. DKW erken nie net hulle optrede in Afrikaans nie maar die manier waarop Ponelis hulle behandel, bevestig hulle status as volwaardige Afrikaanse leksikale items. Dit blyk byvoorbeeld uit die behandeling van tissue: "Daar is 'n groot behoefte aan tissue (tiesjoe) om 'papiersakdoekie' aan te dui." Hierdie formule- 
ring is kenmerkend van die DKW-benadering wat gebaseer is op die beginsel van funksionele ontlening.

In sommige artikels motiveer Ponelis die behoefte aan 'n spesifieke leenwoord, byvoorbeeld in die artikel van die lemma jet-set waar hy sê dat dit nie maklik gaan om ekwivalente te kry vir jet-set en jet-setter nie. Die Afrikaanse stralerjakker(s) is onreëlmatig gevorm en behoort eintlik stralerjakkeraar(s) te wees. Op soortgelyke manier betoog hy ten gunste van die leenwoord cater en sy verafrikaanste spelling kyter. Ponelis stel dit onomwonde dat 'n Anglisismevrees daartoe gelei het dat hierdie woord vervang is deur spysenier. Hy verduidelik dan ook hoekom spysenier nie die mas opkom nie en hoe cater/kyter probleemloos by die Afrikaanse klanksisteem aangepas is en reeds algemeen gebruiklik is in die idiomatiese uitdrukking nie vir iemand se nonsens cater nie. Die gebruik van leenwoorde in die idioomskat van die ontvangertaal dui enersyds op die behoefte aan sodanige elemente en andersyds op die mate waarin hulle reeds ingeburger is in die gewone spreektaal.

Die onbevooroordeelde houding ten opsigte van Engelse leenwoorde word verder geëkspliseer in DKW se behandeling van leenwoorde wat algemeen gebruiklik is naas of in plaas van bestaande Afrikaanse woorde waar daardie leenwoord tog ' $n$ wins vir Afrikaans is. Ponelis sluit die lemma facelift in en die enigste behandeling wat hierdie lemma kry, is die Afrikaanse ekwivalent ontrimpeling. Die lemma jet lag kry die vertaalekwivalente lugroes en vlugtamheid. Hierdie soort behandeling impliseer dat sowel die leenwoorde as hulle Afrikaanse ekwivalente gangbare Afrikaans is. Woordeboeke behoort indringender aandag te gee aan hierdie fase van die taalbeïnvloedingsproses. Dit is ' $n$ manier waarop die leksikograaf verslag kan doen van die dinamika van taalverandering.

Die omvang van Engelse invloed word op verskillende maniere in DKW weergegee. Die eenvoudigste manier is die opname van leenwoorde soos die vermelde boobytrap, ladybird, O.K., ens. Leenwoorde is onderhewig aan aanpassings by die Afrikaanse taalpatroon en talle woorde het verafrikaansing ondergaan. DKW vertoon 'n verskeidenheid aanpassings waaronder spellingaanpassings, bv. orraait en oukei; deeltjiewerkwoorde met 'n Afrikaanse deeltjie en 'n Engelse werkwoordelike komponent, bv. uitfigure (gegee in die artikel van die lemma Engelse invloed) en rondshunt; 'n spellingaanpassing en 'n gedeeltelike vertaling, bv. opstêrs; multileksikale lemmas wat uit 'n Afrikaanse en 'n Engelse komponent bestaan, bv. finish en klaar en iemand sy pedigree vertel. Verskeie van hierdie leenitems, bv. opstêrs, rondshunt en iemand sy pedigree vertel vertoon opmerklike semantiese verskille tussen hulle optredes in Afrikaans, Suid-Afrikaanse Engels en Standaard Britse Engels.

DKW doen verslag van taaldinamika deur te wys hoe die aanpassing en uiteindelike assimilasie van Engelse woorde en uitdrukkings die leksikon van Afrikaans verryk. In hierdie proses beperk DKW sy bestek nie tot die formele en puristiese taalgebruik nie maar verleen ook erkenning aan die werklike taalgebruik en die informele register van Afrikaans. Die Engelse item show off het 
verskillende Afrikaanse vertaalekwivalente, bv. pronk en spog. In die informele register van Afrikaans het die leenwoord afshow 'n hoë gebruiksfrekwensie. Hierdie deeltjiewerkwoord bestaan uit die Afrikaanse deeltjie af en die Engelse werkwoordelike element show. Die Afrikaanse suffiks -erig is baie produktief in die vorming van bywoorde en adjektiewe. In die artikel van die lemma afshow wys Ponelis op die gebruik van hierdie suffiks in die vorming van die afleiding afshowerig. Ponelis sê dat afshow in die omgangstaal deeglik gevestig is maar nie in versorgde taal nie. Deur hierdie opmerking hou DKW hom aan sy normatiewe en pragmatiese opdrag.

Ondanks die insluiting en positiewe evaluering van 'n groot verskeidenheid leenwoorde vervul DKW steeds 'n preskriptiewe funksie deur in baie artikels aan te dui dat ' $n$ bepaalde leenwoord as 'n ongewenste Anglisisme beskou moet word. Die DKW-benadering verskil egter aansienlik van dié van ander woordeboeke op grond van die goed gebalanseerde en objektiewe evaluering en interpretasie van die eise, veranderinge in en werklikhede van die SuidAfrikaanse taalsituasie.

\subsection{Leenvertalings}

Een van die terreine waar die invloed van Engels op Afrikaans op sy produktiefste is, is by die vorming van leenvertalings. Waar twee tale as amptelike tale deur een gemeenskap gebruik word, is dit onvermydelik dat die konstante taalkontak nie net tot die oorname van leenwoorde sal lei nie maar ook tot die regstreekse vertaling van komplekse leksikale items soos samestellings en idiomatiese uitdrukkings. Afrikaans het baie leksikale items wat leenvertalings is en wat regstreeks na die Engelse vorme herlei kan word. Soos met ander aspekte van taalbeinvloeding in Suid-Afrika die geval is, is herdie tipe taalbeïnvloeding eweneens 'n tweerigtingproses wat Suid-Afrikaanse Engels ook grootliks beinvloed.

Die voorkoms van leenvertalings in Afrikaans en in Suid-Afrikaanse Engels en die manier waarop hierdie verskynsel in vertalende, verklarende en beperkte normatiewe woordeboeke hanteer word, is belangrike merkers van die verhouding tussen die heersende kulturele en linguistiese kontak. Oorspronklik was daar opvallende kulturele verskille tussen Afrikaans- en Engelssprekende Suid-Afrikaners. Voortgesette sosiale kontak tussen hierdie twee sprekersgroepe het gelei tot 'n wisselwerking tussen die twee tale en die twee kulture. Volgens Kromann e.a. (1991: 2712) moet woordeboeke kultuur interpreteer. As daar tussen twee tale 'n verhouding van sero-ekwivalensie vir 'n gegewe kultuurspesifieke item bestaan, moet die leksikograaf voorstelle doen om moontlike vertaalekwivalente te vestig. So 'n benadering het definitiewe implikasies vir die preskriptiewe/deskriptiewe funksie van woordeboeke. Vroeëre vertalende Afrikaans-Engelse woordeboeke het op 'n soortgelyke 
manier die taal- en kulturele invloed probeer verwerk deur vertaalekwivalente te probeer skep. Dit het dikwels tot uiters onnatuurlike produkte gelei.

Mettertyd kon die taalgrens tussen Afrikaans- en Engelssprekende SuidAfrikaners nie meer as 'n kulturele skeiding beskou word nie. Die saambestaan binne 'n enkele geografiese en sosiale gemeenskap het tot kulturele assimilasie gelei. Alhoewel klein kulturele verskille tussen die twee taalgroepe steeds binne sekere sosiale en geografiese groeperinge bestaan, kan Afrikaansen Engelssprekende Suid-Afrikaners as 'n enkele kulturele gemeenskap beskou word. Hierdie kulturele assimilasie en die status van Afrikaans en Engels as die twee amptelike landstale het verreikende implikasies gehad vir die invloed en bestek van taalkontak.

Tydens die vroeë dekades van hierdie eeu was daar by sommige mense 'n behoefte om Afrikaans en Engels met verskillende kulture te assosieer. Hierdie gevoel is onder meer bewerk deur vyandigheid tussen die twee taalgroepe in die jare van die Anglo-Boereoorlog. Die vyandiggesindheid tussen sommige sprekers van die twee taalgroepe en hulle begeerte om Afrikaans en Engels met verskillende kulture te vereenselwig, het gelei tot pogings deur Afrikaanse linguiste en leksikograwe om 'n veldtog van linguistiese suiwering op Afrikaans toe te spits. Een van die doelstellings van die puriste was om Afrikaanse ekwivalente vir elke Engelse woord en uitdrukking te skep en om die alleengebruik van die eg Afrikaanse items te bevorder. Woordeboeke moes behulpsaam wees in die bereiking van hierdie onrealistiese ideaal.

Die tweetalige Afrikaanssprekende se maklike toegang tot Engels en die omvattendheid van die Engelse leksikon het gelei tot die regstreekse vertaling van talle Engelse samestellings en uitdrukkings. Hierdie leenvertalings het 'n hoë gebruiksfrekwensie in Afrikaans. Puriste het die Afrikaanse leksikon noukeurig gefynkam op soek na en ter onderdrukking van sulke leenvertalings. Woordeboeke is gebruik om Afrikaanse ekwivalente te skep en hulle gebruik te bevorder ter vervanging van die leenvertalings. Hierdie pogings was gedoem tot mislukking want nóg 'n woordeboek nóg 'n preskriptiewe taalkundige kan die dinamika van taalverandering keer of van koers laat verander. Die leksikograaf se taak is nie om woorde te skep nie maar om die werklike en konvensionele taalgebruik te weerspieël.

Die evaluering van leenvertalings in Afrikaans mag nie kategories gedoen word nie maar moet op ' $n$ item-vir-item-basis geskied. Daar is talle ongewenste leenvertalings wat in kompetisie is met gevestigde Afrikaanse items. DKW sluit ' $n$ hele versameling sulke items in maar in hulle behandeling word dit uitdruklik gestel dat hierdie vorme as Anglisismes beskou moet word. Verwysings word telkens verstrek na die korrekte Afrikaanse vorm. Die volgende voorbeeld lewer daarvan bewys hoe DKW in hierdie opsig sy normatiewe funksie uitvoer. Die lemma aanvat word as Anglisisme gemerk met ' $n$ verwy sing na die aanvaarde Afrikaanse vorm aanspreek. Op 'n soortgelyke manier word die lemma en so aan gemerk en die Afrikaanse item en so meer/en dies meer word as korrektief daarop verstrek. Hierdie werkswyse word op 'n kon- 
sekwente manier in DKW gevolg. Maar 'n leenvertaling is dikwels ' $n$ waardevolle bydrae tot die leksikon van Afrikaans en waar leenvertalings so 'n funksionele rol vervul, moet woordeboeke op 'n sistematiese en objektiewe manier daarvan verslag doen. In sulke gevalle sou daar met vrug nog aandag gegee kon word aan subtiele betekenis- en gebruiksverskille wat wel tussen die woordpare mag bestaan.

Ongelukkig het ' $n$ bevooroordeelde beperking op die bestek en invloed van taalkontak in baie Afrikaanse woordeboeke gelei tot 'n minderwaardige behandeling van dié leksikale kategorie. Pogings van leksikograwe om Afrikaans van leenvertalings uit Engels te suiwer het gelei tot die leksikografiese vergestalting van onnatuurlike en onkonvensionele items wat geskep is in 'n kunsmatige poging om die Afrikaanse leksikon uit te brei sonder die insluiting van leenvertalings uit Engels. Afrikaanse woorde soos die volgende voorbeelde (almal uit Groot Woordeboek/Major Dictionary: voortaan GW), wat beswaarlik algemene gebruikstatus geniet het, is geskep om die gebruik van die leenvertalings wat tussen hakies gegee word, teë te werk: bruismelk/skuimmelk/roomysmelk (melkskommel), knormoer (selfaansitter), wisselwiel (spaarwiel) en ysterware (hardeware). Daarbenewens is daar in sommige gevalle op Nederlandismes teruggeval wat ewe onafrikaans is. Vergelyk in hierdie verband die GW-voorbeelde bestelkantoor (pakkettekantoor) en briewebesteller (posman). In sulke gevalle vervul die woordeboeke, volgens Zgusta (1989: 70), 'n argaisseringsfunksie deurdat hulle nie net die verandering in die standaardvariëteit wil voorkom nie maar verouderde en ongebruiklike vorme weer wil invoer en in die leksikon herbevestig.

DKW bied 'n nuwe perspektief op die status van leenvertalings in Afrikaans. Ondanks die kritiek op talle leenvertalings wat as Anglisismes gemerk word en wat van 'n gewenste Afrikaanse ekwivalent voorsien word, gee hierdie woordeboek erkenning aan die bestaansreg van 'n uitgebreide versameling van hierdie tipe leksikale items. Dit strook met die behoeftes en eise van die aktiewe taalgebruikers. Die DKW-gebruiker kry nou die versekering, dikwels met ' $n$ gepaardgaande taalkundige motivering, dat hy daarop geregtig is om leenvertalings soos die volgende te gebruik - in plaas van die puristiese vorm wat telkens tussen hakies gegee word: boekmerk (boeklêer/leeswyser), broodlyn (armoedslyn/bestaansminimum) en valstande (kunsgebit). Die lemma lokettreffer staan in skerp kontras met die onnatuurlike TW-inskrywings kasstuk, suksesstuk, kastreffer en kassukses. Dikwels verstrek DKW wel die puristiese Afrikaanse ekwivalente van bepaalde leenvertalings maar wys dan op hulle ongebruiklikheid, nie-Afrikaansheid of onnatuurlikheid.

Leenvertalings van idiome en vaste uitdrukkings word op 'n soortgelyke manier behandel. Waar 'n goeie en lewensvatbare Afrikaanse ekwivalent bestaan en gebruik word en waar die leenvertaling nie 'n werklike bydrae lewer nie, word die leenuitdrukking gemerk. Die uitdrukking Bloed is dikker as water word as Anglisisme gemerk en die Afrikaanse ekwivalente Waar bloed nie kan loop nie daar kruip dit/Die hemp is nader as die rok word ver- 
strek. Daarnaas word die leenvertaling 'n perd van 'n ander kleur as 'n gevestigde Engelse leenvorm aangedui. Eweneens word die uitdrukking op roep as 'n gevestigde leksikonitem behandel met die byvoeging dat hierdie leksikale item geen ekwivalent in Afrikaans het nie.

\section{3 'n Funksionele normatiewe benadering}

Die gevolge van taalkontak word in DKW so ver as moontlik op 'n objektiewe en onbevooroordeelde manier aangebied maar sonder dat dié woordeboek aan normatiewe krag inboet. Ponelis sluit 'n wye verskeidenheid Engelse en ander leenwoorde in en beoordeel elkeen telkens op sy eie meriete maar dan veral in terme van sy funksie en bydrae tot Afrikaans. Dit bring mee dat sowel gewenste as ongewenste onlenings lemmastatus kry, met die leksikografiese adressering wat die evaluatiewe verskille ekspliseer. Ongewenstheid word vasgestel op grond daarvan dat die betrokke leksikale item nie 'n funksionele optrede in Afrikaans het nie en daarom nie as deel van die Afrikaanse leksikon erken of bevestig moet word nie. Dit blyk byvoorbeeld uit Ponelis se behandeling van die lemmas malvalekker en zip. Die volledige bewerking van die eerste voorbeeld is: "Die Afrikaans vir marshmellow." en van die laasgenoemde lemma word onder meer gesê: "Ons het geen behoefte aan hierdie woord nie, want daar is die kort ekwivalent rits..." In sulke artikels beantwoord DKW steeds aan sy normatiewe opdrag maar die evaluering berus op die funksionele bydrae en waarde wat die spesifieke leksikale item vir Afrikaans het.

'n Belangrike deel van DKW se normatiewe leiding is om kritiese uitsprake te maak oor die motivering vir die gebruik van sekere Engelse leenwoorde waar die gebruik van hulle Afrikaanse ekwivalente verwag sou kon word. Die mikrostrukturele behandeling van die lemma leftovers is beperk tot die volgende stelling: "Dit is ' $n$ raaisel waarom hierdie leenwoord ons eie oorskiet/oorskietkos in die omgangstaal verdring." In sommige artikels gee Ponelis onwillig toe dat 'n spesifieke Engelse item uiteindelik erkenning sal moet kry omdat dit 'n hoër gebruiksfrekwensie as sy Afrikaanse vertaalekwivalent het. Die lemma idle word soos volg behandel: "As luier die pyp nie rook nie, sal idle maar teen wil en dank erken moet word." In ander artikels word leenwoorde verstrek maar dit word gestel dat die Afrikaanse ekwivalent besig is om veld te wen. Vergelyk die lemma masking tape se behandeling: "Die gebruik van maskeerband neem toe, maar masking tape is 'nog steeds baie lewenskragtig."

Hierdie benadering illustreer nogmaals die waarde van 'n woordeboek as ' $n$ instrument om die dinamika van taalverandering en linguistiese interaksie te weerspieël en te dokumenteer. 'n Mens sou wou sien dat dié beleid in volgende uitgawes nog uitgebrei moet word. 


\section{Ten slotte}

Die ontwikkeling in die Afrikaanse leksikografie het 'n punt bereik waar woordeboeke begin om verslag te doen van die linguistiese, sosiolinguistiese en kulturele werklikheid. Dit word onder meer bereik deur die insluiting en behandeling van leksikale items wat die voortdurende wisselwerking in 'n meertalige en multikulturele omgewing verteenwoordig. So 'n benadering verhoog die gehalte van woordeboeke en dra by tot hulle status as gesaghebbende bronne van inligting.

\section{Verwysings}

Bosman, D.B. e.a. (Reds.). 19848. Tweetalige Woordeboek/Bilingual Dictionary. Kaapstad: Tafelberg. De Villiers, Meyer e.a. 19877. Nasionale Woordeboek. Kaapstad: Nasou.

Gouws, Rufus H. 1990. Information Categories in Dictionaries, with Special Reference to Southern Africa. Hartmann, R.R.K. (Red.). 1990: 52-65.

Gouws, Rufus H. 1993 (ter perse). Dictionaries and the Dynamics of Language Change.

Gove, P.B. (Red.). 1961. Webster's Third New International Dictionary of the English Language. Springfield, Massachusetts:' Merriam Webster.

Hanks, Patrick. 1990. Evidence and Intuition in Lexicography. Tomaszczyk, J. en B. Lewandowska-Tomaszczyk (Reds.). 1990: 31-41.

Hartmann, R.R.K. (Red.). 1990. Lexicography in Africa. Exeter: University of Exeter Press.

Hausmann, F.J. en H.E. Wiegand. 1989. Component Parts and Structures of General Monolingual Dictionaries: A Survey. Hausmann, F.J. e.a. (Reds.). 1989-1991: 329-360.

Hausmann, F.J. e.a. (Reds.). 1989-1991. Wörterbücher. Dictionaries. Dictionnaires. An International Encyclopedia of Lexicography. Berlyn: Walter de Gruyter.

Hiemstra, L.W. 1980. Die juiste woord. Kaapstad: Tafelberg en Nasou.

Johnson, S. 1747. The Plan of a Dictionary of the English Langunge. Faksimilee-uitgawe 1970. Menston: The Scolar Press.

Johnson, S. 1755. A Dictionary of the English Language. Londen: J. \& P. Knapton, T. \& T. Longman e.a.

Kritzinger, M.S.B. e.a. 198613. Groot Woordeboek/Major Dictionary. Pretoria: J.L. van Schaik.

Kromann, H-P. e.a. 1991. Principles of Bilingual Lexicography. Hausmann, F.J. e.a. (Reds.). 1989-1991: 2711-2728.

Labuschagne, F.J. en L.C. Eksteen. 19938. Verklarende Afrikaanse Woordeboek. Pretoria: J.L. van Schaik.

Malkiel, Y. 1989. Wörterbuch und Normativität. Hausmann, F.J. e.a. (Reds.). 1989-1991: 63-70.

Odendal, F.F. 19792. Verklarende Handwoordeboek van die Afrikaanse Taal. Doomfontein: Perskor.

Sledd, J. en W.R. Ebbitt. (Reds.). 1962. Dictionaries and That Dictionary. Chicago: Scott, Foresman and Company.

Taalkommissie van die SA Akademie. 19918. Afrikaanse woordelys en spelreëls. Kaapstad: Tafelberg. 
Tomaszczyk, J. en B. Lewandowska-Tomaszczyk. (Reds.). 1990. Meaning and Lexicography. Amsterdam: John Berjamins.

Van der Merwe, H.J.J.M. 1967. Die korrekte unord. Pretoria: J.L. van Schaik.

Van der Merwe, H.J.J.M. en F.A. Ponel is. 19826. Die korrekle woord. Pretoria: J.L. van Schaik. Van der Merwe, H.J.J.M. en F.A. Ponelis. 19917. Die korrekte woord. Pretoria: J.L. van Schaik. Woordeboek van die Afrikaanse Taal. Pretoria: Staatsdrukker.

Zgusta, L. 1989. The Role of Dictionaries in the Genesis and Development of the Standard. Hausmann, F.J. e.a. (Reds.). 1989-1991: 70-79. 


\title{
General Lexicography in Europe
}

\author{
Reinhard Rudolf Karl Hartmann, Dictionary Research Centre, \\ University of Exeter, Great Britain
}

\begin{abstract}
On the basis of several surveys of experts, centres and projects in lexicography, and against the author's own experience of metalexicography, the paper traces the recent progress of academic lexicography, especially in Europe. Particular attention is paid to 'dictionary research' in four of its divisions. One special concern is the professionalisation of the discipline in terms of conferences, publications and training initiatives.
\end{abstract}

Keywords: DICTIONARY RESEARCH, EUROPE, LEXICOGRAPHY, SURVEY

Opsomming: Algemene leksikografie in Europa. In hierdie artikel word die onlangse ontwikkeling van die akademiese leksikografie, veral in Europa, nagespoor aan die hand van verskeie ondersoeke uitgevoer deur leksikografiese kundiges, sentrums en projekte, en teen die agtergrond van die outeur se eie ervaring van die metaleksikografie. In die besonder word aandag geskenk aan "woordeboeknavorsing" in vier geografiese gebiede. Een saak waarop die aandag spesifiek gevestig word, is die verlening van professionele status aan die dissipline deur konferensies, publikasies en opleidingsinisiatiewe.

Sleutelwoorde: EUROPA, LEKSIKOGRAFIE, ONDERSOEK, WOORDEBOEKNAVORSING

\section{Introduction}

State-of-the-art surveys are as quickly (out)dated as they are initially useful, but to attempt them on a continental scale seems like the ultimate folly. Nevertheless, I am going to risk some generalisations about the European dictionary front in the hope that shared information is better than (merely) filed information.

Against the background of a survey of linguistics in Europe which I was asked to undertake over 20 years ago (Hartmann 1972) and a number of other fact-finding ventures since then (EURALEX congresses, of. Hartmann 1984; Exeter D.R.C. bibliographical database and Who's Who directory; ERASMUS Consortium, cf. Hartmann 1992a), I sent out a questionnaire to all my main contacts to gather data for a lecture which I had originally intended for the 25th anniversary meeting of the Societas Linguistica Europaea (SLE) in 1991, but could not actually deliver until the inaugural conference of the European Society for the Study of English (ESSE) later that year. 
I asked such questions as "What would you estimate as the total number of dictionaries published since 1965", "What are the main dictionary types, in order of importance'?", and "Can you guess at the number of full-time lexicographers (in relation to the total population)?" (The questionnaire, completed by myself for the U.K., is reproduced in the Appendix. I gratefully acknowledge the help received by respondents). The replies I received were relatively incomplete, especially with respect to Eastern Europe where political changes have been momentous since 1991, but I relate them here in the context of other information 1 have in my files.

\section{Recent history}

Franz Josef Hausmann (1989) has remarked that "metalexicographical reflection is as old as lexicography itself" and cited the example of Paolo Beni and his critical review Anti-Crusca of 1612. Hausmann also has helpful things to say about the recent history of academic lexicography. For the period after World War II, he presents evidence for regarding the years between 1960 and 1970 as an important turning point, instanced by the pioneering conference at Bloomington, Indiana (1960) and the publication of Ladislav Zgusta's Manual of Lexicography (1971).

I find it intriguing that three other metalexicographers working in Europe have reached different conclusions about the start of contemporary lexicography, in their respective contributions to the International Encyclopedia of Lexicography, Wörterbücher/Dictionaries/Dictionnaires. Robert llson, in Article 199, calls 1968 a "momentous year" in British lexicography; Alain Rey, in Article 186, mentions several cases of a "reawakening" French lexicographic spirit in the period from 1950 to 1985; Herbert Emst Wiegand, in Article 206, states that for the post-war beginning of German lexicography, 1945 is "too early" and 1960 is "too late". What this suggests is that it would be unrealistic to assume a uniform rate of progress in European lexicography, at least in the post-war years to about 1970 .

Since the early 1970's it may be possible to stipulate a convergence of developments, due to a number of economic, sociological, educational and technological influences. There was economic prosperity, at least in Western Europe, which brought increased social mobility, more educational opportunities, better language teaching provision and more linguistic research at all levels, and the computer promised relief from mental drudgery. In lexicography, this produced new markets, new interests, new ideas, new investment. As we moved into the eighties, time seemed ripe for a boom.

If I was to highlight a single year, I would choose 1983, ten years ago, when a number of significant conferences were held at Newark (Delaware), Smolenice (Slovakia), Novi Sad (Yugoslavia), Augsburg and Aachen (Germany), and of course Exeter (U.K.) where the European Association for Lexi- 
cography (EURALEX) was founded, when the ambitious projects of the international encyclopedia Wörterbiucher/Dictionaries/Dictionnaires (3 volumes edited by Hausmann/Reichmann/Wiegand/Zgusta) and the double series of monographs (48 volumes published) and yearbooks ( 7 volumes published) under the general title Lexicographica were conceived, and when the European Science Foundation survey of lexicographical projects (Cignoni et al. 1983) was published.

\section{Lexicography in a European context}

I have already hinted at the difficulties of trying to build up a complete picture of the dictionary scene in Europe. One reason is that there have been few precedents for such surveys. The ESF survey mentioned above was limited to 114 scholarly dictionary projects in Western Europe, and Bernard Quemada's (1972) essay for the Current Trends in Linguistics series concentrated primarily on historical dictionaries, largely in Romance languages.

A second reason for the lack of information is the tension that still exists between academic lexicography and commercial dictionary production, with academics primarily interested in theoretical principles and dictionary publishers watching out tor market opportunities. In any case, most projects tend to operate within the confines of a particular dictionary tradition linked to the language, history and institutions of a country.

The third reason is that there are only a few centres, associations and periodicals through which projects and progress can be reported (the International Journal of Lexicography, which includes the EURALEX Newsletter, only started 5 years ago). Conferences have an important role to play in this respect, but as I have pointed out in one of my papers (Hartmann 1990a), we have a long way to go until the artificial barriers between universities, publishers and academies can be broken down.

For the purpose of presenting the data in this paper, I have divided them into four parts, (a) the three leading countries, (b) the rest of the European Community, (c) the countries outside the EC west of the former 'iron curtain', and $(d)$ the countries of Eastern Europe.

\section{"Les trois paysages"}

There are some good reasons for singling out the three largest countries of Europe in terms of population size (apart from Italy) for special treatment: Germany, France and the United Kingdom have long and distinguished lexicographical traditions, they are very productive both quantitatively and qualitatively, and many of the theoretical and practical innovations in recent years have come from them. That is why Hausmann (1985) speaks of "trois 
paysages", although he also characterises some of their differences: he praises the relatively well-developed "dictionary culture" in France, describes the British approach to "learners' dictionaries", and points out some inherent limitations of German lexicography.

There are established traditions and standards for the lexicography of the major languages, German, French and English, with 77,51 and 55 million native speakers respectively. The societies are effectively monoglot (admittedly with remarkable dialect differentiation), but there are also linguistic minorities of varying size and stability, e.g. Turkish and Sorbian in Germany, Arabic and Breton in France, and Urdu and Welsh in the United Kingdom.

We find comprehensive ranges of dictionary products, in terms of numbers and types. Wiegand has given the following estimates for Germany. in the period since about 1965:

\section{2,000 technical-terminological dictionaries, 100 dialect dictionaries, 80 spelling dictionaries \\ 70 general-explanatory dictionaries, \\ 30 dictionaries of foreign words, \\ 11 historical-etymological dictionaries.}

No figures are available for bilingual dictionaries, which I guess to be in the region of several hundred. Dictionary production in France and the United Kingdom appears to be more limited, and the distribution by types may be different, with (foreign) leamers' dictionaries forming an important genre in Britain (cf. Hartmann 1992b).

The three countries can boast strong publishing houses capable of delivering the goods, e.g. Duden and Langenscheidt in Germany, Le Robert and Larousse in France, Oxford and Collins in Britain. There are also sizeable bodies of working lexicographers, about 100 full-time in Germany and Britain and maybe fewer in France. Many of these have become members of EURALEX, and some regularly attend conferences in their own countries and elsewhere (some famous names from Germany: Drosdowski, Reichmann, Neubert; from France: Rey, Dubois, Gorcy; and from the U.K.: see Appendix).

There are periodicals and textbooks available, as follows: in Germany, Lexicographica (International Annual and Series Maior), Hausmann et al. (1989-91) and Schaeder (1987); in France, Lexique, Cahiers de Lexicologie, Quemada (1967) and Rey (1982); in Britain, the International Journal of Lexicography, McArthur (1986), Ilson (1986) and Sinclair (1987).

There are research centres, at least in embryo (particularly at Erlangen, Lille and Exeter), which may also exert a positive effect on the development of training (see below). Lexicography is occasionally linked to the study of the mother tongue (Institut für deutsche Sprache, Mannheim, Institut de la langue 
française, Nancy) or to Computational Linguistics (Bonn, Stuttgart, Birmingham).

Lest I give the impression that all is rosy in the European dictionary garden, I should frankly admit that there are a number of desiderata (cf. Hartmann 1986a) that have not yet been fulfilled even in the three leading countries:

- Complete, annotated lists of published dictionaries, by language, by information category, and by user group do not exist, and reliable production or sales statistics for the dictionary publishing industry are sadly lacking (for a bibliography of dictionary bibliographies, cf. Cop 1990), although according to one market report reference books now constitute over $15 \%$ of all books produced.

- Lists of ongoing dictionary projects, dictionary publishers and active lexicographers are not available, except for the rudimentary Who's Who directo ry database being assembled at Exeter.

- Job descriptions of required professional skills and accounts of on-thejob training schemes are hard to come by; one promising development is the elaboration of 'national vocational qualifications' for the (British) publishing industry, although not with the full backing of all dictionary publishers.

- A directory of relevant academic courses does not exist, although Wiegand (1989) gives a list of some of these involving aspects of dictionary research in German universities, and there are brochures about the European postgraduate Diploma in Lexicography (see below). It would be useful, too, to have a list of research topics treated at such centres as well as a catalogue of unpublished theses and dissertations.

[See also the relevant articles dealing with the monolingual and interlingual lexicography of German, French, English etc. in Hausmann et al. (1989-91).]

\section{The rest of the EC}

The remaining, currently 9, countries of the European Community include the three Benelux countries, Denmark, the Irish Republic, and the four southern countries Portugal, Spain, Italy and Greece, with two large language communities in terms of numbers of speakers ( 30 million for Italian and over $28 \mathrm{mil}$ lion for Spanish if non-standard dialects/languages like Lombardian, Sicilian, Catalan and Galician are counted separately), and the rest with fewer than 10 million each.

Dictionary production is much more limited in these countries (estimates for published dictionaries since 1965 include 500 for Italy, 200 for Denmark, 100 each for Spain and the Netherlands), as is the number of active lexicographers 
(one of the highest figures relative to population size, i.e. $50 / 5$ million, is claimed for Denmark, which has recently set up a professional association, Copenhagen having also hosted a series of 6 international Symposia since 1982).

Periodicals and other publications devoted to general lexicography are not so common in this group of countries (the Studi di lessicografia italiana are issued by the Accademia della Crusca in Florence; Marello 1989 is one of the few textbooks on bilingual lexicography; van Sterkenburg 1984 is a Dutch introduction to lexicography, Cabré and Lorente 1991 a bibliography of Catalan dictionaries, DANLEX Group 1987 a survey of computer applications to dictionary making).

Courses on aspects of lexicography are offered in Belgium (Universities of Liège and Gent, and at the M. Haps Terminology Institute at Brussels), Denmark (Arhus Business School has created a chair in Lexicography), and the Netherlands (INL at Leiden and Free University at Amsterdam). Some dictionary research is pursued at the above centres as well as in Ireland (Dublin), Italy (Pisa), Spain (Málaga, Barcelona, and Córdoba) and Greece (Thessaloniki). Because of the relative size and status of these languages vis-à-vis the 'big' European languages (German, French and English, e.g. as subjects taught in schools and universities, dictionaries for translation and other interlingual purposes are in greater demand here than in the relatively monoglot communities of Germany, France and the United Kingdom.

[See also the relevant articles dealing with the monolingual and interlingual lexicography of Danish, Dutch, Greek, Italian, Portuguese, Spanish etc. in Hausmann et al. (1989-91) and the EURALEX Congress proceedings (esp. Biblograf 1992).]

\section{Non-EC 'Western' Europe}

The next group, all except one in the European Free Trade Area and potential candidates for EC membership, include four Nordic and two Central European countries and one on the edge of the Middle East and Asia, a heterogeneous entity with little in common lexicographically, ranging from a prosperous island of 200,000 speakers of a single language to a relatively poor country with a population of over 50 million. I will venture only a few remarks about the lexicographic situation in these seven countries based on questionnaire returns.

In Norway, where the political and linguistic history was tied to that of Denmark for many centuries, the double standards of the literary bokmal and the colloquial Nynorsk have led to a high degree of language awareness, some deliberate language planning, and an active lexicographic community producing a wide range of bilingual-translation dictionaries, monolingual-spelling dictionaries, and normative-technical dictionaries. Courses are taught at Oslo 
University whose lexicographic centre under Dag Gundersen has also hosted the first conference of the new Nordic Lexicographic Association.

Iceland, the smallest country of Northern Europe, boasts a highly sophisticated literary tradition and good lexicographic output. Given the ratio of lexicographers per total population and the membership of its lexicographic society, Iceland outclasses the larger countries by a factor of 100 .

Sweden has a number of interesting dictionary projects linked to dialectology, computational linguistics and the teaching of Swedish to immigrants (e.g. at Göteborg and Lund), supported by the Swedish Academy. There is at least one textbook (Svensén 1987) used all over Scandinavia.

As in other countries of this group, bilingual dictionaries play an important role in Finland. However, relative to the number of Finnish native speakers (less than 5 million), lexicography is a lively activity, often in conjunction with language planning, translation and terminology work.

In the centre of Europe, the neutral countries Switzerland and Austria, with just under and over 7 million inhabitants, respectively, are concerned with documenting the various, mainly German, dialects (cf. Lurati and Stricker 1982); there is also some lexicographic interest at translator training and terminology centres (e.g. Infoterm in Vienna).

[See also the relevant articles dealing with the monolingual and interlingual lexicography of the Nordic Germanic languages, of Finnish, and Turkish (on which no other literature is available to me) etc. in Hausmann et al. (1989-91), and the ELRALEX Congress proceedings (esp. Snell-Hornby 1988 and Tommola et al. 1992).]

\section{Non-EC 'Eastern' Europe}

The last group in my survey are the countries of Eastern Europe, a region where we have seen many and rapid changes during the last few years. It is extremely difficult to keep up-to-date with developments, especially as far as the multiplying states of the former Soviet Union and Yugoslavia are concerned, since lexicographic information is rarely available and contacts are still limited.

Considering their relative population sizes (which range from over 150 million for Russia, through over 37 million for Poland and 20 million for Romania, to less than 3 million for Albania and under 2 million each for the Baltic States) and their weak economic superstructure, lexicographic research and production has a good record.

The Academies of Science (some of which are under review, or have been abolished recently) have promoted a long line of scholarly dictionary projects: historical dictionaries, etymological dictionaries; dialect dictionaries, idiom dictionaries and, just as important here as in the West, bilingual dictionaries for 
translation and foreign language learning. For Russia, one estimate for the number of dictionaries published since 1965 is 2,000.

From the wide range of anthologies, bibliographies and textbooks recently published (some may be difficult to obtain), I select the following: Dubichinskij et al. (1992, in Russian/Ukrainian), Kiefer et al. (1992, in English/French), Morkovkin and Trushinoj (1986, in Russian), Durco (1992, in Slovak/English), Filipec and Ćrmák (1985, in Czech), Miodunka (1989, in Polish).

[See also the relevant articles dealing with the monolingual and interlingual lexicography of the Slavonic languages (Russian, Polish, Czech, Bulgarian, Croatian etc.), Romanian, Hungarian, Estonian, Latvian, Lithuanian, Georgian, Albanian etc. in Hausmann et al. (1989-91), and the EURALEX Congress proceedings (esp. Magay and Zigány 1990 and Tommola et al. 1992).]

\section{Dictionary research in Europe today}

In this section 1 would like to widen the scope a little and discuss the status of lexicography in terms of dictionary making, dictionary research and professional training. There has indeed been a lively debate in the last ten years, especially in the context of EURALEX Congresses, as to whether lexicography has developed into a respectable field that deserves the title 'academic discipline', and what could or should be done to bridge the gulf between practical and theoretical lexicography.

The publication of Wörterbucher/Dictionaries/Dictionnaires. An International Encyclopedia of Lexicography (Hausmann et al. 1989-91) marks this move in the direction of a 'scientific activity'. To quote from Rufus Gouws's detailed review (1992: 290),

It is a prime example of the combination and interaction of a variety of methodological, didactic, linguistic and metalexicographic principles, and their practical application. It represents the state of the art of reference works by being encyclopedia, textbook, comprehensive bibliography and authoritative container of information.

1 usually distinguish four main aspects or branches of metalexicography or dictionary research: dictionary history, dictionary typology, dictionary criticism, and dictionary use, and I shall briefly illustrate them in the context of Europe.

As 1 have already mentioned, the lexicography of a country or language depends not only on the external history of that country or language, but also on the internal cultural traditions that evolve in successive generations of dictionary making. Thanks to such authorities as Gabriele Stein (1985) and Tom McArthur (1986), we now have an almost continuous account of the history of 
English lexicography. However, this is not a 'closed book': new knowledge comes to light all the time.

Thus, at a seminar on the subject of dictionary history (Hartmann 1986b), we heard Noel Osselton present evidence of a 16th-century dictionary compiler - Rawlinson - whose unpublished dictionary preceded and surpassed that of Robert Cawdrey who is normally regarded as the founder of the monolingual English dictionary. There had been other English dictionaries well before that, of course, as part of the interlingual Latinate tradition of Medieval and Renaissance Europe. At the same meeting, Nawal El-Badry speculated whether the fact that in bilingual lexicography (of English and Arabic) the passive or 'decoding' dictionary arrived before the active or 'encoding' dictionary can be generalised into a lexicographic universal.

Another fascinating branch of dictionary history revealed at the Exeter Seminar was called 'lexicographic archaeology' by Robert Ilson: showing connections between genealogically related dictionaries, e.g. tracing a recent British and a not so recent American dictionary via the Century Dictionary right back to the Imperial Dictionary, in tum a British adaptation of Noah Webster's American Dictionary. This is the kind of detective work that has led another contributor, Fredric Dolezal, to claim that the story of the English dictionary may actually be the story of a single edited and re-edited text!

Dictionary typology is concemed with the classification of the very different dictionary genres and profiles we find in various countries, periods, or cultures. The annual volumes which form one of the series of Lexicographica have attempted to highlight such dictionary types: the 'monolingual' dictionary in $1 / 1985$, the 'bilingual' dictionary in $2 / 1986$, the 'cultural' dictionary in $3 / 1987$, the 'computer-assisted' dictionary in $4 / 1988$, the 'LSP' dictionary in $5 / 1989$, and the 'etymological' dictionary in $7 / 1991$.

The type of dictionary in which I have myself taken some interest is the so-called leamer's dictionary. Most people specialising in English will be familiar with its prototypes, the Oxford Advanced Learner's Dictionary, the Longman Dictionary of Contemporary English, and the Collins COBUILD English Language Dictionary, and their minor imitators. There are comparable pedagogically oriented dictionaries for French on the market, but only one such monolingual dictionary has been designed for foreign learners of German; while lexicographers working on other languages have only just begun to experiment with this genre. Meanwhile, tensions have developed vis-à-vis the monolingual dictionary for native speakers, on the one hand, and the traditional bilingual dictionary for translators and foreign language learners, on the other. Combining features of both monolingual and interlingual lexicography, a compromise sub-type has emerged in, recent years, viz. the 'bilingualised learner's dictionary', in which translation equivalents are provided for each sense of each headword, an approach that has also yielded interesting results in other, e.g. onomasiological, dictionary types. 
Innovation may also come from another branch of dictionary research usually termed dictionary criticism, a relatively old field which has been bedevilled in the past by prejudice and arbitrary personal judgement. Several monographs in the Lexicographica Series Maior have not only shown, by detailed comparative text analysis, how idiosyncratic dictionary reviews can be, but also what might be done to work out more objective criteria for the evaluation and assessment of lexicographic output (cf. Hernández 1989 for Spanish, Ripfel 1989 for German, Jehle 1990 for English and French).

Dictionary use is the fourth branch of dictionary research or metalexicography. This allows us to find out by means of various empirical methods (interviews, tests, questionnaires, film and protocol analysis) what dictionary users actually do in the process of consulting the information presented in the dictionary.

The idea is not to guess what a particular reference work might be used for by its anonymous users, but to determine categorically for which tasks it has been found to be either beneficial or unsatisfactory. There have been quite a number of such interdisciplinary observational studies of different users of different dictionary types in different situational contexts, not just in Europe (cf. Hartmann 1989 for a review of the literature). Associated with the user perspective is the question of how dictionary users acquire the necessary reference skills, what these consist of, and how they can be taught deliberately. Some of the dictionary 'workbooks' now available for this purpose have been critically compared by a former M.A. student at Exeter (Stark 1990).

There are other topics apart from these four more widely publicised subjects of dictionary research. Some of these are covered in other volumes of the Lexicographica Series Maior and in articles contributed to the International Encyclopedia, notably interlingual lexicography, pedagogical lexicography, technical lexicography, and computational lexicography, all areas where there has been much progress in Europe. One particular area that does not yet appear to have an overall name, except perhaps for the concepts of 'macrostructure' and 'microstructure', covers the component structures of the dictionary, their interrelations, and the way they are put together in the successive stages of the lexicographic process. I can foresee, even predict, massive input and subsequent success in this specialised subject, but a lot will depend on the healthy interaction of theory and practice.

\section{Professional training}

Finally, a topic into which I have invested quite a lot of time during the last few years: how to raise standards by providing more and better training. We need to increase the public's awareness of lexicographic issues, and we need to teach dictionary users appropriate reference skills and how to improve them. Above all, we need to give the next generation of lexicographers a chance to do better, 
by looking at what has gone before (dictionary history), by appreciating the wide choice of genres available (dictionary typology), by elaborating criteria of assessing them (dictionary criticism), and by observing what goes on in the consultation process (dictionary use). At the same time, the practical side of dictionary making must not be ignored, in terms of field-work or recording (including text corpora), description or editing (including planning and resourcing), and presentation or publishing (including computer techniques).

For all these reasons I started in 1988 to negotiate with a number of representatives of dictionary research centres in various countries of Europe towards a training framework for lexicography, and with the help of an EC (ERASMUS) grant we managed to design a modular; interdisciplinary, multisite postgraduate programme at Diploma and Master's level which is now running at Exeter and at the same time at Lille III University in France and at the Free University Amsterdam in the Netherlands. The course at Exeter comprises the following components:

Principles and Practice of Dictionary Publishing,

Computing in Lexicography,

The Representation of Meaning in the Dictionary,

Typology and Component Structures of Dictionaries,

The User Perspective in Dictionary Research,

Bilingual Lexicography,

The Learner's Dictionary.

In addition, it includes a practical placement with a dictionary project and a dissertation as well as an optional ERASMUS exchange with students from Lille and Amsterdam. We are currently considering whether and how the course consortium could be extended to other centres in Europe.

\section{Conclusion}

My overall conclusion is that dictionary research is alive and well, and together with improved training facilities is likely to lead to further advances in dictionary making, although no single profile has yet emerged of the typical country, the typical dictionary, and the typical lexicographer in Europe. Quemada's statement (1972: 434) that "Lexicographic methodology has made great headway since the end of the last war" is even more valid today than two decades ago.

One caveat is perhaps in order as we reach the end of this continental conspectus. We should not be satisfied just with a knowledge about progress in Europe. A world perspective is now needed in lexicography just as in other spheres of human activity, and in this spirit $I$ join those who have attempted surveys of other scenes (Zgusta 1980, Algeo 1989, Hartmann 1990b, Hausmann 
et al. 1989-91, Delbridge 1992) in hoping for much widened lexicographic horizons.

\section{References}

Algeo, J. 1989. American Lexicography [Art. 200]. Hausmann, F.J. et al. (Eds.). 1990. Wörterbücher/Dictionaries/Dictionnaires. An International Encyclopedia of Lexicography (3 Volumes): 1987-2009. Berlin: W. de Gruyter.

Biblograf (Ed.). 1992. EURALEX '90 Proceedings. Actas del IV Congreso Internacional, Benalmádena (Málaga) 1990. Barcelona: Vox Biblograf.

Cabré, M.T. and M. Lorente. 1991. Els Diccionaris Catalans de 1940 a 1988 (Lexis 1). Bárcelona: Universitat de Barcelona.

Cignoni, L. et al. (Eds.). 1983. European Science Foundation Survey of Lexicographical Projects. Pisa: ILC.CNR.

Cop, M. 1990. Babel Unravelled. An Annotated World Bibliography of Dictionary Bibliographies, 16581988 (Lexicographica Series Maior 36). Tübingen: M. Niemeyer.

DANLEX Group. 1987. Descriptive Tools for Electronic Pracessing of Dictionary Data. Studies in Computational Lexicography (Lexicographica Series Maior 20). Tübingen: M. Niemeyer.

Delbridge, A. 1992. Lexicography in Australia. Lexikos 2: 63-72.

Dubich inskij, V.V. et al. (Eds.). 1992. Sovremennye problemy leksikografii. Sbormik nauchnykh trudov. Kharkov: KhLO.

Ďurčo, P. (Ed.). 1992. Bibliografia slovenskej idiomatiky, frazeológie a paremiolólgie. Bratislava: Komisia pre výskum frazeológie pri Slovenskom komitéte slavistov.

Filipec, J. and F. Cermák. 1985. Česká Lexikologie. Praha: Academia.

Gouws, R.H. 1992. Review of Hausmann et al. (Eds.). Wörterbücher/Dictionaries/Dictionnaires. Lexicographica International Annual 7/1991: 268-290.

Hartmann, R.R.K. 1972. The Organization of Linguistics in Western Europe. Sebeok, T.A. (Ed.). 1972. Current Trends in Linguistics. Vol. 9: 1795-1818. The Hague: Mouton.

Hartmann, R.R.K. (Ed.). 1984. LEXeter '83 Proceedings. Papers from the International Conference on Lexicography at Exeter 1983 (Lexicographica Series Maior 1). Tübingen: M. Niemeyer.

Hartmann, R.R.K. 1986a. The Training and Professional Development of Lexicographers in the UK. Ilson, R. (Ed.). 1986 Lexicography. An Emerging Internalional Profession: 82-92. Manchester: U.P.

Hartmann, R.R.K. (Ed.). 1986b. The History of Lexicography. Papers from the D.R.C Seminar at Exeter 1986 (Amsterdam Studies in the Theory and History of Linguistic Science 1ll.40). Amsterdam: J. Benjamins.

Hartmann, R.R.K. 1989. Sociology of the Dictionary User: Hypotheses and Empirical Studies [Art. 12]. Hausmann, F.J. et al. (Eds.). 1989. Wörterbücher/Dictionaries/Dictionnaires. An Intemational Encyclopedia of Lexicography (3 Volumes): 102-111. Berlin: W. de Gruyter.

Hartmann, R.R.K. 1990a. A Quarter of a Century's Lexicographical Conferences. Magay, T. and J. Zigány (Eds.). 1990. BudalEX '88 Proceedings. Pajers from the 3rd International EURALEX Congress, Budapest 1988: 569-575. Budapest: Akadémiai Kiadó. 
Hartmann, R.R.K. (Ed.). 1990b. Lexicography in Africa. Progress Reports from the D.R.C. Workshop at Exeter 1989. Exeter: U.P.

Hartmann, R.R.K. 1992a. Training in Lexicography - The Exeter ERASMUS Initiative. Biblograf (Ed.). 1992. EURALEX '90 Proceedings. Actas del IV Congreso Internacional, Benalmadene (Málaga) 1990: 527-532. Barcelona: Vox Biblograf.

Hartmann, R.R.K. 1992b. Lexicography, with Particular Reference to English Learners' Dictionaries. Language Teaching 25,3: 151-159.

Hausmann, F.J. 1985. Trois paysages dictionnairiques: La Grande-Bretagne, la France et l'Allemagne. Lexicographica: Intemational Annual for Lexicography 1: 24-50.

Hausmann, F.J. 1989. Kleine Weltgeschichte der Metalexikographie. Wiegand, H.E. (Ed.). Wörterbücher in der Diskussion (Lexicographica Series Maior 27). 1989. Tübingen: $M$. Niemeyer 75-109.

Hausmann, F.J. et al. (Eds.). 1989-91. Wörterbücher/Dictionaries/Dictionnaires. An International Encyclopedia of Lexicography (3 Volumes). Berlin: W. de Gruyter.

Hernández, H. 1989. Los diccionarios de orientación escolar. Contribución al estudio de la lexicografin monolingüe española (Lexicographica Series Maior 28). Tübingen: M. Niemeyer.

Ilson, R. (Ed.). 1986. Lexicography. An Emerging Intermational Profession. Manchester: U.P.

nson, R. 1990. Present-Day British Lexicography. Hausmann, F.J. et al. (Eds.). 1990. Wörterbücher/Dictionaries/Dictionnaires. An International Encyclopedia of Lexicography (3 Volumes): 1967-1983. Berlin: W. de Gruyter.

Jehle, G. 1990. Das englische und französische Lemerwörterbuch in der Rezension. Theorie und Praxis der Wönterbuchkritik (Lexicographica Series Maior 30). Tübingen: M. Niemeyer.

Kiefer, F. et al. (Eds.). 1992. Papers in Computational Lexicography (2nd COMPLEX Conference, Budapest 1992). Budapest: Linguistics Institute, Hungarian Academy of Sciences.

Lurati, O. and H. Stricker (Eds.). 1982. Die schweizerischen Wörterbücher. 4. Kolloquium der Schweiz. Geisteswissenschafliche Gesellschaft 1979. Fribourg: Editions Universitaires.

Magay, T. and J. Zigány (Eds.). 1990. BudaLEX '88 Proceedings. Papers from the 3rd International EURALEX Congress, Budapest 1988. Budapest: Akadémiai Kiad6.

Marello, C. 1989. Dizionari bilingui con schede sui dizionan italiani per francese, inglese, spagnolo, tedesco (Fenomeni Linguistici 6). Bologna: Zanichelli.

McArthur, T. 1986. Worlds of Reference. Lexicography, Learning and Language from the Clay Tablet to the Computer. Cambridge: U.P.

Miodunka, W. 1989. Podstawy leksykologii i leksykografii. Warszawa: PWN.

Morkovkin, V.V. and L.B. Trushinoj. 1986. Uchebniki i slovari $v$ sisteme sredstv obuchenija russkomu jazyku kak inost rannomu. Sbornik statej. Moscow: Russkij Jazyk.

Quemada, B. 1967. Les dictionnaires du français moderne (1535-1863). Etude sur leur histoire, leurs types et leurs méthodes. Paris: Didier.

Quemada, B. 1972. Lexicology and Lexicography. Sebeok, T.A. (Ed.). 1972. Current Trends in Linguistics 9: 395-475. The Hague: Mouton.

Rey, A. 1982. Diclionnaires et encyclopédies (Que sais.je? 200). Panis: P.U.F.

Rey, A. 1990. La lexicographie française depuis Littré. Hausmann, F.J. et al. (Eds.). 1990. Wönterbücher/Dictionaries/Dictionnaires. An Intemational Encyclopedia of Lexicography (3 Volumes): 1818-1843. Berlin: W. de Gruyter. 
Ripfel, M. 1989. Wörtertuchkritik. Eine empirische Analyse won Wörterbuchrezensionen (Lexicographica Series Maior 29). Tübingen: M. Niemeyer.

Schaeder, B. 1987. Germanistische Lexikggraphie (Lexicographica Series Maior 21). Tübingen: $M$. Niemeyer.

Sinclair, J.M. (Ed.). 1987. Looking Up. An Account of the COBUILD Project in Lexical Computing. London and Glasgow: Collins.

Snell-Hornby, M. (Ed.). 1988. ZüriLEX'86 Proceedings. Papers Read at the EURALEX Intemational Congress, Zürich 1986. Tübingen: A. Francke.

Stark, M. 1990. Dictioniary Workbooks. A Critical Evaluation of Dictionary Workbooks for the Foreign Language Learner (Exeter Linguistic Studies 16). Exeter: U.P.

Stein, G. 1985. The English Dictionary before Cawdrey (Lexicographica Series Maior 9). Tübingen: M. Niemeyer.

Svensén, B. 1987. Handbak i lexikografi. Pnnciper och metoder'i ordbaksarbetet. Stackholm: TNC.

Tommola, H. et al. (Eds.). 1992. EURALEX '92 Proceedings. Papers Submitted to the Sth EURALEX International Congress, Tampere 1992 (Studia Translatologia A.2, 2 volumes). Tampere: U.P.

Van Sterkenburg, P.G.J. 1984. Van woordenlijst tot woordenboek. Leiden: E.J. Brill.

Wiegand, H.E. 1989. Der gegenwärtige Status der Lexikographie [Art. 29]. Hausmann, F.]. et al. (Eds.). 1989. Wörterbücher/Dictionaries/Dictionnaires. An International Encyclopedia of Lexicography (3 Volumes): 246-280. Berlin: W. de Gruyter.

Wiegand, H.E. 1990. Die deutsche Lexikographie der Gegenwart. Hausmann, F.J. et al. (Eds.). 1990. Wörterbücher/Dictionaries/Dictionnaires. An International Encyclopedia of Lexicography (3 Volumes): 2100-2246. Berlin: W. de Gruyter.

Zgusta, L. 1971. Menual of Lexicography. The Hague: Mouton.

Zgust,, L. (Ed.). 1980. Theory and Method in Lexicography: Western and Non-Western Perspectives. Columbus SC: Hornheam Press. 


\section{Appendix}

\begin{tabular}{|c|c|c|}
\hline Lexicography in Europe 1991 & Return to: & $\begin{array}{l}\text { R. Harmann } \\
\text { Dictionary Research Cenire } \\
\text { University of Exeter } \\
\text { EX4 } 40 \mathrm{QH} \text { Great Britain }\end{array}$ \\
\hline
\end{tabular}

Country

U.K. Language(s) English, Welsh (etc.)

Informant R. Hartmann

\section{Background}

1. Mention one or two features that have influenced or dominated the lexicographic tradition in your country (e.g. bilingualism in Belgium, diglossia in Greece):

Largely monoglat society (English), with regional and social dialects. English as a foreign language taught widely. Minority languages (Welsh, Scots, Hindi) cannot compete with English, the medium of instruction at all levels of education.

2. Are there any traditional views of language that may have affected the development of native-speaker oriented dictionaries?

Usage not regulated by academies of any kind, but a 'purist' strand produced 'hard word' dictionaries (17th and 18th century).

3. Are you aware of any industrial, political or technological foundations that underpin current lexicographic production?

Scholarly lexicogmaphy (dictionaries of classical languages, dialect and historical dictionaries) underfunded in relation to commercial general-purpose dictionary-making. Computers beginning to have an impact, e.g. on text corpora.

\section{Professional data}

4. Can you make a guess at the number of full-time lexicographers (in relation to the total population)?

About 75 (56 million)

5. What would you estimate as the total number of dictionaries published since 1965 ?

About 1000

6. What are the main dictionary types, in order of importance?

(Give examples of prototypes)

historical-etymological dictionaries general-explanatory dictionaries technical-terminological dictionaries (foreign) leamer's dictionaries dialect dictionaries bilingual dictionaries other thesaurus idiom dictionaries
(Oxford English Dictionary) (Concise Oxford Dictionary) (Macmillan [various])

(Advanced learners' Dic.)

(Wright)

(Collins [various])

(Roget's)

(Manser) 


\section{Professional development}

7. Name some of the leading lexicographers in your country.

J. Aitken, R. Allen, S. Atkins, I. Ayto, A. Cowie, G. Fox, S. Greenbaum, P. Hanks, M. Hardcastle, R. llson, E. Kirkpatrick, M. Manser, T. McArthur, R. Moon, N. Osselton, P. Proctor, R. Quirk, A. Room, M. Rundell, J. Sager, I. Simpson, J. Sinclair, C.C. Smith, D. Summers, E. Weiner, J. Wells, J. Whitcut

8. Which are the main centres of dictionary research?

Exeter, London, Leeds, Oxford, Birmingham

9. Are there any academic courses in lexicography, apart from on-the-job vocational training offered by publishers?

Exeter University Annual International Lexicography Course (short-lerm)

Exeter University Dip./M.A. Course in Lexicography (one-year)

UMIST (Manchester)

Birmingham University

\section{Publications}

10. Are there any periodicals devoted to lexicography?

Intemational Joumal of Lexicography (Oxford)

11. Suggest one or two titles of basic textbooks published in your country recently.

R.R.K. Hartmann Lexicography, Principles and Practice London: Academic Press 1983

R. Ilson Lexicography, An Emerging Intema tional Profession Manchester UP 1986

M. Stork Dictionary Workbook Exeter UP 1990

12. Please provide bibliographical references of basic survey articles/reports.

A.I. Aitken (1990) "The Lexicography of Scots" (Ant. 199a) \&

R. Ison (1990) "Present Day British Lexicography" (Art. 199) in Hausmann et al.

Wörterbücher/Intermational Encyclopedia of Lexicography Berlin: W. de Gruyter pp. 1967-1983 


\title{
Racist Language in Society and in Dictionaries: A Pragmatic Perspective

\author{
D.C. Hauptfleisch, Stellenbosch, South Africa
}

\begin{abstract}
After a reference in the Introduction to action by pressure groups against derogatory language used by the speech community when referring to particular social groups or social convictions, mention is made of various unprotesting social groups. The whole of section 2 is devoted to a discussion of racist language in society. Seven different categories are illustrated with examples from various languages. The important question of how racist language should be handled in dictionaries is examined in section 3. Examples of protests by ethnic pressure groups are given, followed by a wide-ranging discussion of subjects such as the inclusion or exclusion of racist lexical items, definitions and usage labels of racist items, and the utilization of usage examples of racist items with definientia. Where applicable, suitable definitions and effectual usage labels are suggested.
\end{abstract}

Keywords: DEFINIENTIA, ETHNIC, EXAMPLES OF RACIST LANGUAGE, FAUNA AND FLORA, GEOGRAPHIC NAMES, INCLUSION OR EXCLUSION, INTERRACIAL, MULTICULTURAL AND POLYETHNIC SOCIETIES, PRAGMATIC PERSPECTIVE, PRESSURE GROUPS, RACE, RACIST, RACIST EXPRESSIONS, RACIST LANGUAGE, RACIST LANGUAGE IN DICTIONARIES, RACIST LANGUAGE IN SOCIETY, RACIST SECONDARY SENSES, SCHOOL DICTIONARIES, UNPROTESTING SOCIAL GROUPS, USAGE EXAMPLES, USAGE LABELS

Opsomming: Rassistiese taal in die gemeenskap en in woordeboeke: 'n pragmatiese perspektief. Na 'n verwysing in die inleiding na protesaksies deur drukgroepe teen neerhalende taalgebruik deur die spraakgemeenskap wanneer na bepaalde sosiale groepe of sosiale oortuigings verwys word, word melding gemaak van verskillende nieprotesterende sosiale groepe. Die hele afdeling 2 word gewy aan 'n bespreking van rassistiese taal in die gemeenskap. Sewe verskillende kategorieë word toegelig met voorbeelde uit verskillende tale. Die belangrike vraag van hoe rassistiese taal in woordeboeke gehanteer behoort te word, word in afdeling 3 ondersoek. VoorbeeIde van proteste deur etniese drukgroepe word gegee, gevolg deur ' $n$ omvattende bespreking van onderwerpe soos die insluiting of weglating van rassistiese leksikale items, definisies en gebruiksetikette van rassistiese items, en die aanwending van voorbeeldmateriaal van rassistiese items by definiense. Waar van toepassing, word geskikte definisies en doeltreffende gebruiksetikette aan die hand gedoen.

Sleutelwoorde: DEFINIENSE, DRUKGROEPE, ETNIES, FAUNA EN FLORA, GEBRUIKSETIKETTE, GEOGRAFIESE NAME, INSLUITING OF WEGLATING, INTERRASSIEEL, MULTTKULTURELE EN POLI-ETNIESE GEMEENSKAPPE, NIEPROTESTERENDE SOSIALE GROEPE, 
PRAGMATIESE PERSPEKTIEF, RAS, RASSISTIES, RASSISTIESE SEKONDêRE BETEKENISSE, RASSISTIESE TAAL, RASSISTIESE TAAL IN DIE GEMEENSKAP, RASSISTIESE TAAL IN WOORDEBOEKE, RASSISTIESE UITDRUKKINGS, SKOOLWOORDEBOEKE, VOORBEELDE VAN RASSISTIESE TAAL, VOORBEELDMATERIAALL

\section{Contents}

\section{Introduction}

1.1 Editorial problem areas

1.2 Action by pressure groups

1.3 Unprotesting social groups

2. Racist language in society

2.1 The origin of racist language

2.2 Definitions of terms relating to racist language

2.3 Examples of racist language

3. The treatment of racist language in dictionaries

3.1 Protests by ethnic pressure groups

3.2 Inclusion or exclusion of racist lexical items

3.3 Definitions and usage labels of racist lexical items

3.4 Usage examples of racist lexical items

4. Conclusion

\section{Introduction}

\subsection{Editorial problem areas}

In his Lexicography Today. An annotated bibliography of the theory of lexicography (1988) Zgusta included a 46-page index of topics treated by the authors listed in the bibliography. This wide-ranging index of subjects pertaining to metalexicography and lexicographical macrostructure and microstructure provides aspiring as well as experienced lexicographers with a salutary insight into the awesome, even daunting array of editorial problem areas they might encounter in the course of compiling their dictionaries.

Since a dictionary is generally intended and regarded as a practical reference book for users who are to a certain extent acquainted with its subjectmatter, the lexicographer may well expect critical comment from individual users or reviewers. Such mainly unconcerted comments should, however, not be unduly worrying, provided they are given the necessary thought with a view to adjusting the dictionary's editorial policy on valid critical points and thereby making the dictionary more informative and user-friendly. 


\subsection{Action by pressure groups}

A rather more serious threat to the acceptability of a dictionary (or perhaps even to the lexicographer's professional status and self-confidence) is posed by concerted criticism, sometimes backed by destructive action, from pressure groups in the community. Such criticism initially takes the form of protests against derogatory words, meanings and expressions used by the community at large when referring to particular social groups or social convictions. Eventually these protests are directed against the inclusion of such objectionable and offensive lexical items in dictionaries. These protests stem from the authority attributed to dictionaries by the general public, whereby such opprobrious usages are regarded as being wrongly enshrined in the lexicon as stereotypes.

The following are some examples of sensitive social areas involving group sensibilities, especially about the use of offensive or derogatory language with regard to such areas: obscenity, gays (male homosexuals, lesbians), religion, language and culture, political ideology, economy, physical and/or mental disability (cripples, the blind, the deaf, the dumb, the maimed, epilepsy, Down syndrome, idiocy, imbecility, insanity), sexism, racism.

While the more vociferous pressure groups often have recourse to the popular press or the electronic media for opportunities to state their case regarding the above-mentioned sensitive areas, such subjects are also treated in publications characterized by a more dispassionate and scientific approach. The following are but a few examples, specifically with reference to the handling in dictionaries of terminology relating to such sensitive areas: obscenity: Burchfield (1972); gays: Aman (1988-89), McCluskey (1989); religion: Burchfield (1974, 1980); political ideology: Strauß (1982), Esterhuyse (1987), Malige-Klappenbach (1989), Webb (1989); physical and/or mental disability: Jost and Crocker (1987); sexism: Whitcut (1984), McCluskey (1989), Hauptfleisch (1989), Beylefeld (1992). Publications on racist language will be cited where relevant further on in this paper.

\subsection{Unprotesting social groups}

In contrast to the mostly vigorous protests registered by the pressure groups discussed under 1.2 it is remarkable that there are also social groups that do not seem to feel a need to protest against being associated with names having a non-neutral character. Such names can be divided into three groups.

1.3.1 The inhabitants of particular areas are sometimes referred to by names which are supposed to show up some characteristic. South African examples are: Piesangboere, Banana Boys (Natalians), Vaalpense, Vaalies (Transvalers), Woltone (inhabitants of the Cape Province) and Blikore (Free Staters). Such 
names are mostly of jocular intent, used without malice or racist connotations. Some degree of non-racist disparagement is, however, sometimes present in references to certain towns, regions or countries, for example Putsonderwater, Pofadder, Timbuctoo, Sleepy Hollow (Stellenbosch), to be Stellenbosched, Karoo, Free State coal (dried cattle dung used as fuel), banana republic (small state in Central America), Bananaland, Piesangland (Natal), Cape Smoke (the earliest, rough Cape brandy), Durban Poison (a particularly potent type of dagga cultivated in Natal), Natal fever (languor and inactivity attributed to the hot climate of Natal), Natal sore (an eruption similar to a veld sore), Bananacity (Durban), Kaasland, Kaaskopland (the Netherlands), or the (in)famous Wet van Transvaal.

1.3.2 It is also significant, with respect to the question of personal and group sensibilities, that groups of individuals are quite happy to bear surnames which, due to their popular association with corresponding common names, could be regarded as seemingly not having a purely neutral character. Some examples, culled mostly from the Cape Peninsula Telephone Directory (1993-94), are:

$\begin{array}{lll}\text { Vice } & \text { Broodryk } & \text { Grootendorst } \\ \text { Savage } & \text { Februarie } & \text { Onrust } \\ \text { Fear } & \text { Varkevisser } & \text { Bierenbroodspot } \\ \text { Shout } & \text { Kleingeld } & \text { Borst } \\ \text { Rattle } & \text { Kleintjies } & \text { Borstrock } \\ \text { Coward } & \text { Oor } & \text { Taaibosch } \\ \text { Fox } & \text { Slinger } & \text { De Beer } \\ \text { Sardine } & \text { September } & \text { De Leew } \\ \text { Starling } & \text { Onkruid } & \text { La Fleur } \\ \text { Peacock } & \text { Buffel } & \text { Mouton } \\ \text { Ramsbottom } & \text { Snoek } & \text { Kaltwasser } \\ \text { Sweatman } & \text { Makriel } & \text { Donner } \\ \text { Peach } & \text { Malgas } & \text { Fledermaus } \\ \text { Peel } & \text { Kiewiet } & \text { Grosskopf } \\ \text { Pepper } & \text { Tarentaal } & \text { Hauptfleisch } \\ \text { Daddy } & \text { Olifant } & \text { Rindfleisch } \\ \text { Tickle } & \text { Pofadder } & \text { Rotkopf } \\ \text { Koekemoer } & \text { Steenbok } & \text { Puffpaff } \\ \text { Kaffer } & \text { Spaarwater } & \text { Fleischmann } \\ \end{array}$

1.3.3 The above-mentioned absence of personal objection is also evident in the case of personal names used metaphorically as common nouns in pejorative senses. Thus John could also refer to a policeman, a prostitute's client or a 
toilet, while Dick, Johnson and John Thomas are known as euphemisms for the penis. Compare, too, the use of Jim in Jim Crow, Jim Fish, and also Tom in the expressions Tom, Dick and Harry, peeping Tom and Uncle Tom. In Afrikaans a chamber-pot could be called a Koos, and expressions with negative connotations, such as Dom Jan, Jan Drel, Jan Pampoen, Kaatjie Kekkelbek, eers baas dan Klaas, Piet Verdriet and Van der Merwe jokes are well-known.

1.3.4 It would be interesting, from a psycho- and sociolinguistic point of view, to try to establish why the mildly pejorative but non-racist use of proper names, as illustrated above, hardly causes the individuals involved any distress, compared to the outcry by members of racial groups that consider themselves insulted by language forms which they regard as racist. However, such a study does not actually fall within the ambit of the lexicographer's assignment. His task is to formulate and apply a clear editorial policy for the lexicographical treatment of such proper names as common names, based on a responsible evaluation of all available oral and written evidence pertaining to the usage of these names.

\section{Racist language in society}

2.1 In his comedy Asinaria, 477, the early Latin author Plautus coined the dictum "Lupus est homo homini", man is a wolf to his fellow-man, i.e. his biggest enemy. Throughout past centuries this comment could be applied not only to physical violence between individuals of the same ethnic group or between different nations, but also to hostile, contemptuous, derisive or otherwise disparaging opinions expressed by one nation or ethnic group about another. An early instance of the latter is the utterance by Laocoon in Vergil's Aeneid:II, 49: "Timeo Danaos et dona ferentes", I fear the Greeks, even if they bring gifts, with reference to the Trojan Horse left behind by the Greeks. A more modern example is perfidious Albion, the English rendering of the French la.perfide Albion, described in A Supplement to the Oxford English Dictionary I (1972: 55) as: a rhetorical expression for "England", with reference to her alleged treacherous policy towards foreigners.

Racist language has occurred and still occurs in probably every society. Usually it originates from antagonistic interracial contact situations. As a result of disagreeable personal experiences in such situations, judgements and prejudices are formed and given expression through disparaging utterances which readily become stereotypes. Repeated use of such stereotypes fosters the perception that they are to be accepted as forming part of the lexicon of the language in question. 


\subsection{Definitions of terms relating to racist language}

The treatment of a sensitive subject such as racist language requires acceptable working definitions of certain key terms. For the purpose of this paper I suggest the following definitions of such terms:

racist: A pejorative adjective referring to an attitude of interracial superiority, prejudice, antagonism, discrimination or debasement, as manifested by word or deed in political, economic, social, cultural or ecclesiastical spheres of life.

interracial: Existing between or mutually affecting different races.

race: A social group of persons connected by common descent or origin; a tribe, nation or people regarded as of common stock; a group of several tribes or peoples forming a distinct ethnic stock.

ethnic: having a common national or cultural tradition; denoting origin by birth or descent rather than nationality; relating to race or culture. (This definition is based on the senses of ethnic appearing in The Concise Oxford Dictionary of Current English ${ }^{8}, 1990$.)

racist language: Any word, phrase, expression or sense characterised by a racist attitude, or considered to be so characterised.

\subsection{Examples of racist language}

The examples given in the lists below have been gathered mainly from dictionary sources, but also from articles about racist language, newspaper reports, letters to newspapers, fiction and introspective perceptions of which words and expressions are racially offensive and insulting. With regard to the acknowledgement of introspective perceptions and fiction as recognized sources of racist language Landau (1984: 188) sounds two notes of caution:

The advice (in dictionaries on whether a lexical item is offensive or not D.C.H.) is only about public behavior, since many reputable members of society routinely use terms of insult in private among like-minded people to whom these words are not in the least offensive.

Many citations for terms of insult in fiction do not at all support the judgement that they are offensive, since they are often used among intimates who share the same prejudices. 
Landau (1984: 188) does, however, point out that, in decisions on the indication of offensiveness, "the lexicographer is compelled to use his own experience, moderated of necessity by his own moral views, whether consciously or not".

The examples are divided into four main categories and given under the relevant language headings. (English includes British, American, Australian, Canadian, New Zealand and South African English.) The first two categories are also subdivided into subcategories.

\subsubsection{Common nouns and personal nouns as racist references to members of ethnic groups}

2.3.1.1 The first subcategory contains examples of the above-mentioned nouns in the use of which initially no derogatory connotation was intended to or felt by members of the particular ethnic group to whom they were referring. In passing, it should be noted that it is not always easy to determine whether at a particular stage the use of a term is racist or not. In his discussion of "criteria for finding some usages vulgarly offensive or contemptuous or abusive" and "the degree of offensiveness of specified terms under specified conditions" Landau (1984: 187) says inter alia:

The same term uttered with a laugh to a member of one's own group might be deeply offensive if uttered to a member of another group ... Even between members of two different groups, supposedly offensive words are not necessarily offensive if the two people know each other very well or if the situation is one where certain male ritualistic behavior is considered appropriate. Insult can be affectionate.

However, gradually such originally uncontroversial names assume a racist image which causes them to be substituted by more acceptable terms. As the substitutions in time also fall from grace new names have to be chosen or devised. A classic example of this process is the South African English and Afrikaans names Kaffir (kaffer) which in turn have become native (naturel), Bantu (Bantoe), African (Afrikaan, rare) and black (swarte), the latter being the terms favoured at present and also used by some dark-skinned race groups other that those of Negroid origin.

In the case of nigger varying degrees of usage acceptability are illustrated by its entries in different editions of American and English dictionaries. In the 1891 edition of Webster's International Dictionary of the English Language the entry is given as "A negro; - in vulgar derision or depreciation", whilst Webster's Third (1961) is less condemnatory in its indication of the word's usage register: "NEGRO - usu. taken to be offensive". A tum-of-the-century usage of nigger is indicated as follows in the 1900 edition of A Standard Dictionary of the English Language: 
nigger, n. 1. A negro: a word once in good use, and in England still utterable by a gentleman, but in America now vulgar and opprobrious; also used contemptuously of a swarthy, and even of a low, objectionable person.

The Standard's 1967 edition (International Edition) defines nigger with less usage tolerance as "A Negro or member of any dark-skinned people: an offensive and vulgar term of contempt".

The entry of Nigger in the 1933 edition of The Oxford English Dictionary, viz. "1. A negro. (Colloq. and usu. contemptuous.)" has been expanded in $A$ Supplement to the Oxford English Dictionary II (1976) by the addition of the following more forthright usage directions: "Except in Black English vernacular, where it remains common, now virtually restricted to contexts of deliberate and contemptuous ethnic abuse."

\section{Further examples of subcategory 23.1.1}

\section{(1) English}

Asiatic

boy (household servant) .

Bushman

Coloured

coolie

ethnic

European

girl (servant)

Hottentot

Jim

John

John Chinaman

(2) Afrikaans

aia

armblanke

Asiaat

bediende

Boesman

Boesnot

gammat

Hottentot

jong

Kaffers (kaffers) (adjective)

Kakie

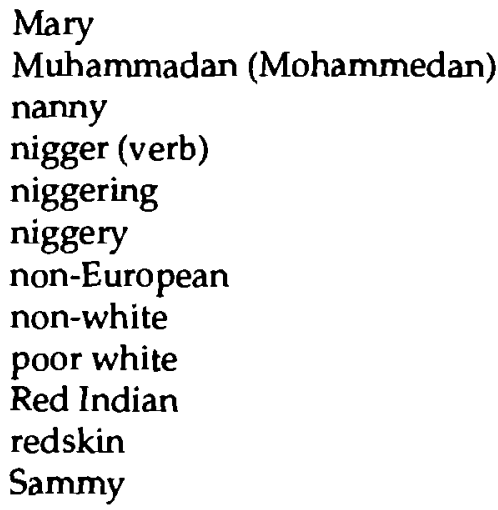

koelie

mak Kaffer

meid

Mohammedaan

nieblanke

outa

skepsel

Slamaier

Slams

volkies

volk (brown, black farm-hands) 
Kleurling klimmeid klong wit kaffer

witman

The racist element in witman is suggested by its meaning "high-minded person", which impliedly attributes ethnic superiority exclusively to whites compared to people of colour. Compare also the given meanings (translated) of the following entries in the Woordeboek van die Afrikaanse Taal V (1968) under kaffer 1 a: mak kaffer "a black who has adopted the ways of the whites", implying innate wildness, and wit kaffer "black of good character" which suggests that blacks characteristically lack the good character traits attributed to whites.

(3) Dutch: Hottentot, kaffer, kafferen (verb), koelie.

Resulting from the increasing usage sensitivity attaching to the racist appellations given in 2.3.1.1, a number of them have been replaced in use by more acceptable "affirmative" substitutions, particularly in South African English and Afrikaans. Examples are:

\section{(1) English}

\section{Asiatic $>$ Asian}

Bushman $>$ San

coolie $>$ Indian

ethnic $>$ black

European $>$ white

Hottentot $>$ Khoikhoi

maid $>$ housekeeper

Mary > Indian woman or girl

Muhammadan (Mohammedan) > Muslim (Moslem)

nanny > child minder

non-European (non-white) > brown, black person or a specific ethnic group denomination such as Indian, Ndebele, Sotho, Venda, Xhosa, Zulu, etc.

Red Indian $>$ American Indian

Sammy > Indian man

\section{(2) Afrikaans}

aia $>$ bruin, swart vrou

Asiaat $>$ Asiër

bediende $>$ huishulp

Boesman $>$ San

Hottentot $>$ Koikoi

Kleurling $>$ bruin mens

koelie > Indiër 
meid > bruin, swart vrou (meisie), Indiërvrou (-meisie)

Mohammedaan > Moslem (Moesliem)

nieblanke > bruin, swart mens (swarte) or a specific ethnic group denomination such as Indiër, Ndebele, Sotho, Venda, Xhosa, Zoeloe (Zulu), etc.

outa > bruin, swart man

skepsel $>$ bruin, swart mens

Slamaier (Slams) > Kaapse Maleier, Moslem (Moesliem)

volk, volkies > bruin, swart arbeiders

2.3.1.2 This subcategory includes names, or particular senses of such names, which seem to have been derogatory and racist from the start, with apparently no subsequent attempt at amelioration. The following are examples of such stereotypes:

\section{(1) English}

Abo (abo)
Canuck
charra
Chinaman
chink(ie)
coon
crunch(ie)
dago
Frog
goy
half-breed
hairyback
honky
Jap
Jim Crow
Jim Fish
jungle bunny
kike
Kraut
Limey

mick

nig-nog

ofay

Paki

Peruvian

Polack

pom (pommie, pommy)

redneck

rockspider

shiksa

slant-eye

spic

Uncle Tom

WASP (Wasp) (White Anglo-Saxon Protestant) wetback

white trash

Whitey

wog

wop

Yid

\section{(2) Afrikaans}

bitterbek

boesman

brandhoring

brandoor

draaihoring

gamsketel (kamsketel)

Kaaskop

kerriebek

kerrie-eter

kerrievreter

kieriekop

klipkop soutie

soutriem

soutvoet

swartasem

swarte tater

swartgoed 


geelbek
gifasem
goiingtot
gomtot
Hotnot (hotnot)
hottie
houtkop
Jooiens

klits
koffiepit
koffiestok
kombersdraer
kombersstem
kroeskop
peervoël
Rooinek

swartnasie swartnerf swartvel tjarra tottie vaalasem witvel zool

(3) Dutch: mof.

2.3.2 This category consists of compound words of which at least one component (see the lists of nouns under category 2.3.1.1 above) is considered to have a racist or otherwise negative connotation when used separately, whereby the compound as a whole is stigmatised as racist. Examples are divided into three subcategories.

2.3.2.1 This subcategory includes compounds which refer to a wide variety of dissimilar noun classes.

\section{(1) English}

Bantu administration
Bantu beer
Bantu culture
Bantu education
Bantu language
Bantu people
blanket native
Bushman painting
Coloured people
coloured tribe
Coolie Christmas
coolie hat
delivery boy
flat boy
garden boy
Hottentot apron
houseboy
housemaid
ironing girl

Kaffir beads
kaffir beer
Kaffir chief
Kaffir dictionary
Kaffir grammar
Kaffirland
Kaffir language
kaffir piano
kaffir pot
kaffir sheeting
Kaffir War
kaffir work
native beer
native boy
native cattle
native eating house
native girl
native law
native location

native man native reserve native woman nigger-ball nigger chaser nigger-driver. nigger-driving niggerhead nigger heaven nigger lover niggershooter niggers' knackers nigger-spit nigger stick nigger stock Paki-bashing school native servant-girl wash girl 


\section{(2) Afrikaans}

Bantoebier

Bantoehorde

Bantoe-impi

Bantoeonderwys

Bantoereg

Bantoestam

Bantoetaal

binnemeid

Boesmanboude

Boesmanmeid

boesmanskelm (adjective)

Boesmanstêre

Boesmantekening

Griekwahottentot

hanskakie

Hotnotsafrikaans (Hottentotsafrikaans)

hotnotsblymaak

hotnotshoender

hotnotshond

hotnotslaan (hotnotslaanspeletjie)

hotnotsklontjie (hottentotsklontjie)

Hotnotspraatjies (Hottentotspraatjies)

hotnotsriel (hottentotsriel)

Hottentotlokasie

Hottentotmeid

Hottentotrondloper

hottentotsvoorskoot

Kafferafrikaans

kafferbaai

kafferbees

kafferbier

kafferblits

Kafferboetie

kafferbrak

Kafferdans

Kafferdiensbode

kafferdom (adjective)

Kaffereethuis

Kaffergemors

kafferhond

Kafferkampong

Kafferklandisie

kafferklavier
Kleurlingafrikaans

Kleurlingarbeider

Kleurlingbaster

Kleurlingbediende

Kleurlingbevolkingsgroep

Kleurlingkieser

Kleurlingklong

Kleurlinglokasie

Kleurlingmeid

Kleurlingposjong

Kleurlingras

kleurlingskepsel

Kleurlingtaal

Kleurlingvolk

Kleurlingvolkies

Kleurlingvoorman

Kleurlingvraagstuk

Kleurlingwoonbuurt

Knopneuskaffer

Koelieafrikaans

Koeliearbeid

koeliebasaar

Koeliebuurt

koeliediamant

koeliegriep

koelieklere

Koeliekrismis (koeliekrismis)

Koeliemeid

Koelietaal

Koeliewerk

Koeliewinkel

komberskaffer

kombuisbediende

kombuiskaffer

kombuismeid

kombuisskepsel

kombuisvolk

Koranahottentot

Koranameid

Koranaskepsel

kraalkaffer

lokasiekaffer

meidepraatjies 


Kafferklong
kafferkombers
Kafferkonstabel
Kafferkraal
kafferkrul
kafferland
kafferlui (adjective)
kafferluis
kaffermaniere
Kaffermeid
Kafferoorlog
Kafferpeperkorrels
Kafferpolisie
kafferpot
kafferpraatjies
Kafferskepsel
kaffersleg (adjective)
Kafferstam
kaffervee
Kaffervolk
Kafferwerk
Kakieboer
Kakiekaffer
kindermeid

Kafferklong

kafferkombers

Kafferkraal

kafferkrul

kafferland

kafferluis

kaffermaniere

Kaffermeid

Kafferoorlog

Kafferpeperkorrels

Kafferpolisie

kafferpot

kafferpraatjies

Kafferskepsel

kaffersleg (adjective)

afferstam

kaffervee

Kaffervolk

Kafferwerk

Kakieboer

kindermeid meidewerk

mynkaffer

Namakwahottentot

naturellebevolking

naturellegebied

naturellekommissaris

naturelleonderwys

naturellereg

naturellereservaat

naturelletaal

naturellevraagstuk

naturellewetgewing

oumeidknoop

oumeid-onder-die-kombers

strykmeid

tuinjong

uitkaffer (verb)

volkshuis

volkswyn

wasmeid

witmansland

witmanstaal

Xhosakaffer

Zoeloekaffer

In the case of witmansland and witmanstaal the racist element is apparent in the racial exclusiveness implied by these terms, whereby the component witman could also acquire this negative connotation.

(3) Dutch: koeliewerk, uitkafferen (verb).

Unlike the increasingly racist connotations the primary (ethnic) senses of Hottentot, kaffir and coolie are acquiring in South African English and especially in Afrikaans, these connotations are not as yet present in the primary senses of their Dutch counterparts Hottentot, kaffer and koelie. In Dutch, however, these names do have a disparaging secondary (figurative) meaning, viz. "a rough, uncouth or stupid person". In Dutch compounds with Hottentot, knffer and koelie as components, these components are virtually all used in their primary, non-racist connotations, which consequently renders compounds like Hottentotschort, Hottentottentaal, kafferland, kafferpokken, kafferpolitiek, kafferstam, kafferwerk, Zoeloekaffer, koeliearbeid, koeliedienst, koelieloon, koeliewerving, koelieziekte non-racist. The only compound with possible racist overtones seems to be uitkafferen (call (someone) a blockhead; criticize abusively), which relates to the above-mentioned secondary sense of kaffer, a sense which could eventually 
cause kaffer, at present a neutral designation of a member of a particular ethric group, as well as compounds with kaffer to acquire a racist register.

The following sample illustrates the need for ameliorative action felt in cases such as those given under 2.3.2.1(1) and (2) above.

\section{(1) English}

Bantu beer, Kaffir beer, native beer $>$ sorghum beer, KB, mqombothi, tshwala Bantu culture $>$ black culture Bantu language $>$ African language

Bantu people $>$ black people, blacks

Bushman painting $>$ San painting

Coolie Christmas > Moharram, Divali

delivery boy $>$ delivery man

garden boy $>$ garden help

Hotten tot apron > pudendal apron, velamen vulvae

house boy $>$ house help

housemaid $>$ housekeeper

ironing girl $>$ ironing woman

Kaffir chief $>$ black chief

Kaffir dictionary > African language dictionary

Kaffir grammar $>$ African language grammar

Kaffir language $>$ African language

kaffir piano $>$ marimba

kaffir sheeting > bhayi, bhayi sheeting, K-sheeting, Bolton cloth, Bolton sheeting, Benson cloth

Kaffir War > Frontier War

native boy, eating house, girl, law, location, man, reserve, woman > black boy, eating house, girl, law, township, man, homeland, woman

niggerhead $>$ bollard

niggershooter $>$ slingshot, catapult

nigger stick $>$ officer's baton

wash girl > wash woman

\section{(2) Afrikaans}

Bantoebier, kafferbier > letieng, magou, sorghumbier, twala

Bantoehorde, -impi, -stam > swart horde, impi, stam

Bantoeonderwys, naturelleonderwys $>$ swart onderwys

Bantoereg, naturellereg $>$ inheemse reg, swart reg

Bantoetaal, naturelletaal > Afrikataal

Boesmanmeid > Sanvrou (-meisie)

Boesmantekening $>$ Santekening

Griekwahottentot $>$ Griekwa

Hottentotlokasie > Koikoiwoonbuurt 
Hottentotmeid > Koikoiv rou (-meisie)

Hottentotrondloper $>$ Koikoirondloper

hottentotsvoorskoot $>$ velamen vulvae

Kafferafrikaans $>$ Swart Afrikaans

Kafferboetie > negrofiel

Kafferdiensbode $>$ swart diensbode

Kafferkampong > swart kampong

Kafferklandisie > swart klandisie

kafferklavier $>$ marimba

Kafferklong $>$ swart seun

Kafferkonstabel > swart konstabel

Kafferland, naturellegebied > swart tuisland, swart nasionale staat

Kaffermeid > swart vrou (meisie)

Kafferoorlog > Grensoorlog

Kafferpolisie $>$ swart polisie

kafferpot $>$ driepootpot

Kafferskepsel > swart mens

Kaffervolk > swart volk

kindermeid > kinderoppasster

Kleurlingafrikaans $>$ Bruin Afrikaans

Kleurlingarbeider $>$ bruin arbeider

Kleurlingbediende $>$ bruin huishulp

Kleurlingbevolkingsgroep $>$ bruin bevolkingsgroep

Kleurlingkieser $>$ bruin kieser

Kleurlingklong $>$ bruin seun

Kleurlinglokasie $>$ bruin woonbuurt

Kleurlingmeid $>$ bruin vrou (meisie)

KJeurlingras $>$ bruin ras

Kleurlingskepsel > bruin mens

Kleurlingvolk, Kleurlingvolkies $>$ bruin arbeiders

Kleurlingvoorman $>$ bruin voorman

Kleurlingwoonbuurt $>$ bruin woonbuurt

Koelieafrikaans $>$ Indiërafrikaans

Koeliearbeid > Indiërarbeid

Koeliebuurt $>$ Indiërbuurt

koeliegriep > Oosterse griep

Koeliekrismis > Moeharram, Divali

Koeliemeid > Indiërvrou (-meisie)

Koelietaal > Indiese taal

Koeliewinkel > Indiërwinkel

kombuisbediende $>$ kombuishulp

kombuiskaffer $>$ manlike swart kombuishulp

kombuismeid $>$ vroulike bruin, swart kombuishulp

kombuisskepsel > bruin, swart kombuishulp 
Koranahottentot, Koranaskepsel $>$ Korana

Koranameid > Koranavrou (-meisie)

mynkaffer $>$ swart mynwerker

Namakwahottentot > Namakwa

naturellebevolking > swart bevolking

naturellegebied > swart gebied

naturellereservaat $>$ swart gebied

naturellewetgewing $>$ swart wetgewing

oumeid-onder-die-kombers $>$ ou-vrou-onder-die-kombers

strykmeid > v roulike bruin, swart strykhulp

tuinjong $>$ manlike bruin, swart tuinhulp

uitkaffer $>$ uitskel

volkshuis $>$ arbeidershuis

wasmeid $>$ vroulike bruin, swart washulp

Xhosakaffer $>$ Xhosa

Zoeloekaffer $>$ Zoeloe

2.3.2.2 This subcategory includes compound vernacular names of fauna and flora of which the first (determinant) component is currently regarded as racist. Examples, which have been selected mostly from The Oxford English Dictionary (1933), A Supplement to the OED (1972-1986), Webster's Third (1961), A Dictionary of South African English ${ }^{4}$ (1991), the Woordeboek van die Afrikaanse Taal I (1950), IV (1961), V (1968), Smith (1966) and the word collection of the Bureau of the WAT, are grouped under Fauna and Flora headings.

\section{Fauna}

(1) English

Bushman rice

Hottentot fish

Hottentot god

\section{(2) Afrikaans}

boesmanhaantjie

boesmanrys

hotnotgrysmol

hotnotkruipmol

hotnotsgot

hotnotsluis

hottentotgrysmol

hottentotkruipmol

hottentotsgot

hottentotsluis

hottentotsrys
Kaffir crane
Kaffir finch
niggerbug

niggerfish

niggergoose

niggerhead hottentotsvydopluis

kafferbokrooitjie

kafferboomblaarmyner

kafferboomblaartonnelaar

kafferboomboorder

kafferboomlootboorder

kafferboomruspe(r)

kafferboomsnuitkewer

kafferboontjiekalander

kafferbuffel

kafferhut kafferkoringaarwurm

kafferkoringmuggie

kafferkoringplantluis

kafferkraai

kafferkraanvoël

kafferkransvoël

kaffermossie

kaffermuishond

kafferpapegaai

kafferpruimboorder

kafferskaap 


\begin{tabular}{|c|c|c|}
\hline hottentotskaap & $\begin{array}{l}\text { kafferkoning } \\
\text { kafferkopervlerkie }\end{array}$ & $\begin{array}{l}\text { kaffervink } \\
\text { kafferweeluis }\end{array}$ \\
\hline
\end{tabular}

(3) Dutch: bosjesmannenrijst, hottentotsgodje, kafferbuffel, kaffervink.

\section{Flora}

\section{(1) English}

Bushman grass
Hottentot bean tree
Hottentot bread
Hottentot cabbage
Hottentot cherry
Hottentot fig
Hottentot's head
Hottentot tea
Kaffir bean
Kaffir boom
Kaffir bread
Kaffir-bread tree

\section{(2) Afrikaans}

boesmanamandel
boesmanboegoe
boesmandoring
boesmandruiwe
boesmangras
boesmankers
boesmangifbos
boesmanskweek
boesmansoog
boesmansrietjie
boesmanstee
boesmanuintjie
boesmanvingertjies
hotnotsboegoe
hotnotsboerboon
hotnotsbrood
hotnotsbroodboom
hotnotshaar
hotnotskersie
hotnotskooigoed
hotnotskool
hotnotskougoed

Kaffir bride
Kaffir cherry
Kaffir corn
Kaffir date
Kaffir grapes
Kaffir hut
Kaffir lily
Kaffir melon
Kaffir millet
Kaffir orange
Kaffir plum
Kaffir sorrel

hottentotstoontjie hottentotsvy kafferalmanak kafferakkasia kafferbal kafferbessiebos kafferblom kafferboegoe kafferboom kafferboontjie kafferbroodboom kafferbruid kafferdadel kafferdagga kafferdissel kafferdoring kafferdruiwe kafferdubbeltjie kaffergifboom kaffergrondboontjie kafferhut kafferkalmoes

\author{
Kaffir tea \\ Kaffir-thorn tree \\ Kaffir tree \\ Kaffir watermelon \\ nigger baby \\ nigger daisy \\ niggerhead \\ niggerhead cactus \\ nigger lice \\ nigger'pine \\ nigger toe \\ nigger weed
}

kafferskuil
kafferskuilpalmiet
kafferslaai
kafferslangwortel
kaffersuring
kaffertabak
kaffertabakboom
kaffertee
kaffertou
kaffertulp
kafferui
kafferwaatlemoen
kaffer-wag-'n-bietjie
kafferwortel
kafferysterhout
kakiebos
kakiegras
kakieklits
kakiekweek
kakiesydissel
koeliedruiwe
meideboom




hotnotsriem
hotnotstee
hotnotstoontjie
hotnotsvy
hottentotsamandel
hottentotsboegoe
hottentotsboerboon
hottentotsbrood
hottentotsbroodboom
hottentotsgifboom
hottentotsgifbos
hottentotshaar
hottentotskappie
hottentotskersie
hottentotskooigoed
hottentotskool
hottentotskougoed
hottentotsriem
hottentotstee

kafferkambro
kafferkanferfoelie
kafferkaroo
kafferkastaiing
kafferkersie
kafferklapper
kafferkop
kafferkoppampoen
kafferkoring
kafferlelie
kafferlemoen
kaffermanna
kaffermielie
kafferpatat
kafferpruim
kafferpyl
kafferrondeboontjie
kafferrosyntjie
kaffersering

meidebossie

meidederm

meidestert

meidjieblaar

meidjie-jan-willemse

meidjiewillemse

oumeidbos

oumeidboud

oumeidebos

oumeideknie

oumeid-op-die-werf

oumeid-se-derm

oumeid-se-knie

oumeid-se-koek

oumeid-se-onderrok

oumeid-se-snuif

oumeid-se-snuifdoos

oumeidsnuif

stinkafrikaner

Although there is no direct etymological connection between afrikaner in stinkafrikaner and the ethnic group name Afrikaner (cf. Boshoff and Nienaber 1967: 124), there is nevertheless a perception in spoken language that stinkafrikaner can be racially equated with Afrikaner, due to the absence of orthographic distinction by means of initial lower-case and capital letters, and through ignorance of the etymological difference.

(3) Dutch: hottentotsbrood, hottentottenvijg, kafferboom, kafferkoren.

About the possible semantic effect the above-mentioned initial components might have on the whole compound name, Smith (1966:5) states the following:

The casual student of the lists of Afrikaans vernacular names is struck by the prominence with which various nations and native tribes have become associated with the names of plants. It would be a very serious mistake to ascribe some implied quality of inferiority to every name in which the words "kaffer" or "hottentot" occur and they are by no means few.

In (1966: 7) Smith expands as follows on the meaning of "kaffer" in compound names:

When a list of vernacular names is examined with special reference to those names which include the adjective "kaffer", certain clear differentiation in the meaning attached to the word becomes evident ... In com- 
pound names the adjective "kaffer" came to mean "used by the Kaffirs" or "of the Kaffirs", but gradually deteriorated into the meaning conveying "inferior quality".

As a result of name components such as Bushman (boesman), Hottentot (hotnot, hottentot), Kaffir (kaffer), khaki (kakie), coolie (koelie); meid, nigger and oumeid having at present acquired an undeniably racist register, the question arises how fauna and flora names containing such components can best be substituted by generally acceptable vernacular names. Two methods come to mind, viz. the use of Latin taxonomic names as common names and the favouring of neutral synonymic vernacular names to the exclusion of racist designations. Examples are:

Fauna

Non-racist examples: Hippopotamus amphibius > hippopotamus; Equus zebra > zebra.

Racist examples: niggergoose > cormorant; kafferkraai, kafferpapegaai > boskraai; kafferkraanvoël, kafferkransvoël > mahem.

\section{Flora}

Kaffir corn > sorghum; kafferlelie > clivia (cf. Erica > erica and Protea > protea); Kaffir tree > coral tree; nigger daisy > blackeyed Susan.

The following are further examples of these two ameliorative mechanisms:

\section{Fauna}

(1) English

Hottentot god > praying mantis

Kaffir crane > crowned crane

Kaffir finch $>$ red bishop-bird

niggerbug $>$ negro bug

nigger fish > coney

niggerhead > scoter

\section{(2) Afrikaans}

boesmanhaantjie $>$ dagbrekertjie boesmanrys, hottentotsrys $>$ termietlarwes, miereiers

hotnotsgot, hottentotsgot > bidsprinkaan, roofsprinkaan

hottentotskaap > afrikanerskaap

hottentotsvis $>$ hangberg, hangberger

hottentotsvydopluis > suurvydopluis, vygiedopluis 
kafferboontjiekalander $>$ Chinese boontjiekalander

kafferkoning > flap, kolvink, mikstertbyevanger, mossiekoning, pypsteel, rookvoë]

kafferkoringaarwurm > Amerikaanse bolwurm, kopwurm, mieliebaardwurm, tamatiewurm

kafferkoringplantluis $>$ suikerrietplantluis

kaffermossie $>$ bergmossie

kaffermuishond > stinkmuishond

kafferskaap > steekhaarafrikanerskaap

kaffervink > flap, koningvink, langstertvink, rooivink, sakaboela

kafferweeluis > pampoenstinkbesie

(3) Dutch

bosjesmannenrijst > termieten

hottentotsgodje $>$ biddende mantis

kafferbuffel $>$ Afrikaanse buffel

kaffervink $>$ weduvogel

Flora

(1) English

Kaffir lily > clivia

niggerhead >negrohead beech, purple coneflower

niggerhead cactus $>$ bisnaga

niggerpine $>$ Jersey pine

nigger toe $>$ Brazil nut

nigger weed $>$ Joe-Pye weed

\section{(2) Afrikaans}

boesmanamandel $>$ bitteramandel

boesmandruiwe $>$ bobbejaandruiwe, bobbejaantou, wildedruiwe

boesmangras $>$ bosluisgras, twagras

boesmankers > griekwadoring, lemoendoring, skilpaddoring, ystervarkbos

boesmansgifbos, kaffergifboom > gifboom, naboom, noorsdoring, wolweboontjie

boesmanstee > dassiebos, jakobjong, spelonk(e)tee

homotsboerboon, hottentotsboerboon > huilboerboon, huilbos, Kaapse boerboon

hotnotsbrood, hottentotsbrood > olifantsvoet

homotsbroodboom, hottentotsbroodboom > broodboom

hotnotshaar, hottentotshaar > bitterbossie

hotnotskersie, hottentotskersie > aasvoëlbessie, swartbas, tolletjie, wilde koffie hotnotskooigoed, hottentotskooigoed > keibossie 
hotnotskool, hottentotskool > veldkool, wildeblomkool hotnotskougoed, hottentotskougoed > ganna, kougoed hotnotstee, hottentotstee $>$ vaaltee

hotnotsvy, hottentotsvy > ghoena, ghôkum, gladvy, perdevy, suurvy hottentotsamandel $>$ bitteramandel, wildeamandel hottentotsgifboom, hottentotsgifbos $>$ gifboom hottentotskappie > moederkappie kafferalmanak $>$ bloedblom kafferakkasia, kafferdoring, kaffer-wag-'n-bietjie > blinkblaarhaakdoring, blinkblaar-wag-'n-bietjie, katdoring, klein-wag-'n-bietjie, rank-wag-'n-bietjie kafferbal > brinjal, eiervrug kafferbessiebos > rosyntjiebos kafferblom > poinsettia kafferboom > koraalboom, koraalplant, kurkboom kafferbroodboom $>$ broodboom kafferdadel, kafferpruim > suurbessie, suurpruim, wildepruim kafferdagga > dagga, klipdagga, knopdagga, koppiesdagga, malkopdagga, perdedagga, rooipootjiedagga, stranddagga, velddagga, wildedagga

kafferdissel > Skotse dissel

kafferdruiwe > aarbossie, suikerbossie, teesuikerbossie, teesuikerkaroo, veldkaiings

kafferdubbeltjie > dubbeltjie, dubbeltjiedoring, perdedubbeltjie, rondomlelik, stranddubbeltjie, volstruisdubbeltjie

kaffergrondboontjie, kafferrondeboontjie > Angola-ertjie, bambaragrondboontie, grondertiie

kafferhut > eselskos, springbokkos, springboknoors, voetbalplant

kafferkalmoes $>$ katazo

kafferkambro > bergkambro, bobbejaankambro, bobbejaankos, dikvoet, don-

kiekambro, kragman, sterkman

kafferkanferfoelie $>$ handskoentjie

kafferkaroo > kousies-en-skoentjies

kafferkastaiing > wildeamandel, wildekastaiing

kafferkersie $>$ opgeitjies

kafferkop, kafferkoppampoen > hubbardskorsie, skorsie

kafferkoring > mabêla, sorghum

kafferlemoen > blouklapper, bobbejaanklapper, botterklapper, grootklapper,

klapper, klapperboom, swartklapper

kaffermanna > babala

kafferpatat > grondaartappel, kalahariaartappel, nabba, veldaartappel

kafferpyl > knapsakkerwel

kafferrosyntjie $>$ rosyntjiebos

kaffersering $>$ handskoentjie, trompetters, wildesering

kafferskuil, kafferkuilspalmiet $>$ palmiet

kafferslaai > misbredie 
kaffersuring $>$ kolsuring

kaffertabak $>$ wildetabak

kaffertee $>$ griekwatee

kafferui > gifbol, gifui, narsing, wilde-ui

kafferwortel > aambeiwortel, dawidjieswortel, dikvoet, donkiekambro, ghaai-

wortel, kragman, sterkman, wildedadel, wildewortel

kafferysterhout $>$ basterswartysterhout, fynblaarysterhout, oemsimbeet .

kakiebos > afrikanerbos, kleingousblom, knapsakkerwel

kakiegras > knapsekerwel, rolbos

kakieklits, kakiekweek > Australiese dubbeltjie, Engelse dubbeltjie

kakiesydissel $>$ knapsakkerwel

koeliedruiwe $>$ belhambra, bobbejaandruiwe, inkbessiebos

meideboom $>$ baakhout

meidestert $>$ bontbeeskloutjie, damarara, marara-uintjie

meidjie-jan-willemse, meidjiewillemse $>$ aambeibossie, bitterbossie, kalwerbossie

oumeidboud > kiepersol, nooiensboom, waaiboom, meiboom

oumeidebos $>$ stinkbos

oumeid-se-onderrok $>$ maanblom

oumeid-se-snuif, oumeid-se-snuifdoos, oumeidsnuif, oumeidsnuifdoos $>$ aapsnuif, apesnuif, bobbejaánsnuif, ouweltjie

stinkafrikaner $>$ afrikaner, jonkmansknoop

\section{(3)}

\section{Dutch}

hottentotsbrood, hottentottenbrood > olifantsvoet

kafferkoren > gierst, sorghum

Anticipated objections against vernacular names of fauna and flora which have Bushman (boesman), Hottentot (hotnot, hottentot), Kaffir (kaffer), khaki (kakie), coolie (koelie), meid, nigger and oumeid as components could be obviated through preemptive action by appointed committees composed of trained taxonomists in the fields of zoology and botany. These committees' terms of reference could be fourfold, viz. (a) to trace all racist names; (b) to declare such names to be objectionable in vernacular and scientific use; (c) to list existing neutral synonymic vemacular names which should be used in place of the racist names; and (d) to coin new names where no synonymic vernacular names exist. Examples of ad hoc coinings of such new names are found in, for example, the Butterfly List (1959), compiled by the Agricultural Terminology Committee of the South African Department of Agriculture, and in Smith and Jackson (1975). It is interesting to note how the authors of these two lists went about finding new names. In the Preface to the Butterfly List the following is stated:

Although many Afrikaans terms had to be coined, we have nevertheless succeeded in finding appropriate names for a large number of species, 
and the glossary should not be regarded as a mere translation of English names. The following are illustrative examples. The Charaxes have been named dubbelsterte in view of their distinctive double-tailed hind-wings; the commodores named blaarolerke because of the close resemblance between their wings and leaves. Numerous similar examples may be mentioned.

Many of these names are self-explanatory. A case in point is the Waaris-die-Witjie, a species which was formerly captured along the Natal Coast but which has now disappeared completely. The name is most appropriate since every butterfly collector is always on the look-out hoping to find a specimen for his collection.

Another striking example is the Uniekeswerwer, which appears only at two places in the Union, viz., Strandfontein at the coast and Giant's Castle 8,000 feet above sea level.

In Smith and Jackson (1975: 4) Smith makes the following specific recommendations with regard to the creation of new names for marine fishes:

Colourful, romantic, fanciful, metaphorical and otherwise distinctive and original names are especially appropriate. Many of these names add to the appeal of the fish: jumping bean, angelfish or cherub (engeltjie), prodigal son, jewelfish are attractive names to use.

Structural attributes, colour and colour pattern are desirable and are in common use in forming names. Sailfin, soapy, glassy, copper, tripletail are some in use. White, black, spotted and striped should be used only when absolutely necessary.

Ecological characteristics are useful in making good names. They too should be properly descriptive: sand, rock, weed, mountain, freshwater are frequently used.

Generic names may be employed outright (e.g. remora) or in modified form (e.g. scatty for Scatophagus) as common names. Once adopted, such names should be maintained even if the generic name is changed.

Both these lists (still) contain a minimum of racially objectionable names, viz.

Butterflies: kafferbokrooitjie (dusky acraea), kafferkopẹvlerkie (kaffir copper).

Marine fishes: blou•hottentot (blue hottentot), bruin hottentot (bronze bream). 
2.3.2.3 The last subcategory consists of Southern African compound geographic names containing racist determinant components. The following sources were consulted: Albertyn (1984), Official Place Names in the Republic of South Africa and in South-West Africa (1978), compiled by the National Place Names Committee, Raper $(1972,1989)$ and Rousseau (1975).

\section{(1) English}

Bushmans River

Bushmanland

Bushman's Hill

\section{(2) Afrikaans}

Boesmandrink

Boesmanfontein

Boesmanland

Boesmanpan

Boesmansberg

Boesmansfontein

Boesmanshoed

Boesmanshoek

Boesmanshoekpas

Boesmanshoekrivier

Boesmanskop

Boesmanskoppan

Boesmanskraal

Boesmansnek

Boesmanspoort

Boesmansputs

Boesmansrivier
Bushmansnek

Bushman's Rock

Hottentot Bay

Boesmansriviermond
Boesmansrivierstasie
Boesmanstad
Boesmanvlak
Boesmanvlei
Hotnotsbaai
Hottentotbaai
Hottentots-Holland
Hottentots-Hollandberge
Hottentotshuisiebaai
Hottentotskerk
Hottentotskloof
Kafferberg
Kafferboom
Kafferdraai
Kafferdrif
Kafferfontein

Kafferkuils River

Kaffir Drift

Kaffir River

In Official Place Names (1978: 13) one of the general principles governing the National Place Names Committee's rejection of names submitted to it for approval is stated as follows:

It does occasionally happen that the Committee has to deal with names that are phonetically unacceptable, or have something unaesthetic, obscene, derogatory or objectionable about them. Its policy in such cases is to point this out to the applicant and to suggest that he consider submitting a more acceptable name. Obviously the Committee's aim in all such instances is to be helpful and to give guidance, while at the same time bearing in mind the principles established from its initial terms of reference. 
Since place names with initial components Bushman (Boesman(s)-) Hottentot, Kaffir (Kaffer(s)-) en Meide- can be regarded as "derogatory or objectionable", it does seem strange that a total of 24 such names is included in the list. This could be due either to the NPNC's not regarding such names as derogatory or objectionable, or to the names not being new names submitted for approval but old, established ones. Be that as it may, these names should as soon as possible be reconsidered by the NPNC, together with inputs by local or other interested bodies. In any case, no new submissions of this kind should be accepted.

According to reports in the Weekend Argus (21 November 1992: 16) and Die Burger (26 November 1992: 19) the South African Deputy Minister of Land Affairs had announced that because of the abolishment of racial discrimination he had asked the Department of Land Affairs "to prepare legislation to enable the Registrar of Deeds to alter the name of immovable property in a registered deed, if the minister is satisfied that such a name is offensive because of any racial discrimination therein". According to the report in Die Burger the proposed legislation envisages the changing specifically of farm names if the owners request such change. The report also mentions that Dr Lucie. Möller of the Human Sciences Research Council in Pretoria said that "Kaffer" in place names had to a large extent already been changed. Her research showed that at present the names "Hottentot" and "Boesman" gave serious offence. However, the research team approached the issue with great circumspection and discretion, preparing questionnaires for a survey of who were affected by these names and how such respondents felt about them.

It seems clear that pressure for the elimination of South African racist place names is building up and that the problem should be given serious and speedy attention by well-appointed bodies such as the National Place Names Committee and the Human Sciences Research Council.

2.3.3 This category contains examples of racist secondary senses of language and ethnic group names which are primarily used in non-racist senses. Such names are encountered in original, derived or compound form, or in idiomatic and technical expressions. With a view to juxtapositional usage comparison, examples of these usage forms are grouped together under the relevant names.

\section{(1)}

\section{English}

Dutch (Afrikaans; Afrikaans-speakers - usually derogatory)

Dutchy (a familiar or contemptuous name for a Dutchman or a German)

Dutchman (Afrikaner - sometimes derogatory)

to do a Dutch act (to desert, escape, run away; to commit suicide)

Dutch bargain (a bargain concluded while drinking together)

Dutch comfort (cold comfort)

Dutch concert (a deafening noise and uproar)

Dutch courage (false courage gained from drink) 
Dutch curse (a troublesome, tall, leafy-stemmed perennial herb, Chrysanthemum leucanthemum; oxeye daisy, white daisy)

Dutch defence (a sham defence)

double Dutch (incomprehensible language, talk; gibberish)

Dutch elm disease (a fungous disease of elms, first discovered in Holland)

Dutch gleek (tippling)

to go Dutch (to share expensès equally for food, drink, etc.)

Dutch gold (imitation gold leaf)

his Dutch is up (he has flown into a sudden rage)

in Dutch (in trouble, out of favour, under suspicion)

Dutch nightingale (a frog)

to talk like a Dutch uncle (to rebuke, give advice firmly but kindly)

Dutch treat (a meal, entertainment, outing, etc. at which each person pays for himself or herself)

Dutchman's draught (a copious draught)

I'm a Dutchman if I do (a strong refusal)

French (bad language)

Frencher, Frency (a Frenchman)

to French someone (to engage in oral sex)

French disease (syphilis)

French kiss (a kiss with one partner's tongue inserted in the other's mouth)

French leave (absence without permission; a hasty or secret departure; leaving without paying one's debts)

French letter (a condom)

German cockroach (a small active winged cockroach, Blatella germanica; croton bug, water bug)

German measles (a contagious disease, resembling measles in a mild form; rubella)

Goth (a rude, uncivilized or ignorant person; a person lacking in culture, refinement or good taste)

Gothic, Gothish (barbarous, rude, uncouth; in bad taste; savage, ferocious)

Gothicism, Gothism (rudeness, barbarism; lack of taste or elegance)

Greek (a cunning or wily person; a hail-fellow-well-met and reveller)

all Greek to me, someone (quite unintelligible)

Greek gift (a treacherous gift)

to play the Greek (to indulge in one's cups)

Greek trust (no trust at all)

Hun (an uncultured devastator; a German, especially in military contexts, or Hungarian)

Jew (a person considered to be parsimonious or to drive a hard bargain in trading; a grasping or extortionate money-lender or usurer)

to jew (get a financial advantage over; to cheat by sharp business practice)

Jewey, Jewy (Jewish)

to jew down (to beat down in price; to drive a hard bargain) 
Jew-bail (insufficient bail; straw-bail)

Jew bird (any of several black cuckoos with arched bills; ani)

Punic (faithless, treacherous)

Punic faith (faithlessness, treachery)

Spanish fly (a bright green beetle, Lytta vesicatoria, dried and used as a supposed aphrodisiac)

Spanish influenza (pandemic influenza)

Spanish measles (a disease of grapevines in California; apoplexy, black measles)

tartar (a violent-tempered or intractable person; rough and violent; savage)

to catch a tartar (to catch a troublesome prisoner; to have dealings with a person who is more than a match for one)

Turk (a cruel, tyrannical, bad-tempered or unmanageable person)

to turn Turk (to tum renegade, to change very much for the worse)

young turk (a violent child or youth)

Vandal (a person who wilfully or maliciously destroys or damages property) vandalic, vandalistic (barbarously or ignorantly destructive; of, relating to, or perpetrating vandalism)

vandalism (wilful or malicious destruction of or damage to works of art or other property)

vandalize (to destroy or damage wilfully or maliciously; to treat in a vandalistic manner)

\section{(2) Afrikaans}

die Boere (the Afrikaners; the police; prison warders)

Duitse masels (German measles)

met iemand Duits praat (to have a straight talk with someone)

Engelsgesind, Hotnosgewind (said of someone of humble origin who, having achieved success, has become an Anglophile)

van die Engelse besies gesteek wees (talking English incessantly, inopportunely or unnecessarily)

Engels praat (to be drunk; to curse; to severely censure; to be putrid - said of meat)

Engelse siekte (rickets)

Engels vir iemand wees (to be incomprehensible)

Franse masels, Franse siekte (syphilis)

daar is geen woord Frans by nie (it is clear, unvarnished language)

Grieks praat (to speak unintelligibly)

Grieks en Katools praat (to talk rubbish)

Grieks wees vir iemand (to be unintelligible to him)

Hollands met iemand praat (to have a straight talk with someone; to put something very clearly to someone; to speak privately to someone)

Hun (an uncivilized devastator; a German)

Jood (stingy, a varicious person; cunning, sly businessman; usurer) 
jood (a lavatory)

om te jood (to cheat)

Joods (miserly, avaricious; cunning, sly)

Jodebasaar (a busy, disorderly, noisy place)

Jodelawaai (a big noise, fuss about nothing)

jodeluis (a low-growing scrub, Acanthospermum australe; sterklits)

Jodeskool (disorderly chatter; noise)

Jodestreek (a deceitful, fraudulent trick)

Jodeverneuker (someone who is very cunning in business)

jodevoël (hornbill; boskraai)

Jodewins (unlawful profit; profiteering)

aan die Jode oorgelewer wees (to be a victim of ruthless, merciless people)

agter iets wees soos 'n Jood agter 'n rou riem (to be very eager to acquire something)

so astrant soos ' $n$ Jood (obstinately persisting despite repeated rebuffs)

die Jood betaal (to defecate)

'n Jood met blou oë (a cunning rogue)

erger lieg as ' $n$ Jood (to be very mendacious)

die Jood kul, verneuk (to light two or more cigarettes, cigars or pipes with one match)

twee Jode weet wat ' $n$ bril' kos (crooks are well-acquainted with one another's tricks; one criminal can easily catch another one)

'n Jodekerk in die mond hê (to have bad breath)

Spaanse griep (a virulent, epidemic influenza)

spaansvlieg (the beetle Lytta vesicatoria, in dried form used as a supposed aphrodisiac)

vandaal (a person who commits destructive acts; a destroyer, damager of property)

\section{(3) Dutch}

Engelse ziekte (rickets)

Franschje (a jocular name for a person living in or coming from France)

Franse bediening (sexual services provided to the lady of the house by male staff)

Franse complimenten (fine words which mean nothing, which are insincere)

Franse eed (a frivolous promise one doesn't intend keeping)

de Franse kerk staat open (one's fly is open)

met de Franse slag (hurriedly, without the necessary care)

Franse verschoning (changing only to a clean collar)

Franse ziekte, fransoysche sieckt (17th c. Dutch) (syphilis)

fransoos (a contemptuous name for a Frenchman)

Griek (a surly, irritable, unfriendly person; a cheat, swindler)

Grieks voor iemand zijn (to be unintelligible, incomprehensible to someone)

Hun (a contemptuous name for a German) 
Jood (as a derogatory name and a term of abuse - a person who overcharges, makes usurious profit; a usurer, swindler, cheat)

Joden (to beat down (a price), not give someone in full what is due to him)

Jodenbed (an ungraceful, clumsy, inelegantly dressed woman)

Jodenfooi (a poor, trifling, paltry fee, or inadequate wages)

Jodengeld (money given in bribery; a traitor's reward)

Jodengoed (goods of poor quality)

jodenkind (a member of the Jewish people, often used with contempt or as a term of abuse)

Jodenlaken (cloth of poor quality)

Jodenlawaai (a great fuss about nothing)

Jodenlijm (saliva)

Jodenpost (very thin note-paper of poor quality)

Jodenstreek (a skilful, deceitful, treacherous trick)

jodentoer (a roguish trick)

Jodenvet (saliva)

Jodenwinst, Jodenwoeker (unlawful, excessive profit; usurious profit)

Jodenzweet (an insipid, watery drink)

aan de Joden overgeleverd zijn (to be a prey to evil, merciless people; to be in the hands of pitiless people)

zoo gierig als een Jood (not generous)

een joodje hebben (to be out of one's senses)

heb je een ouwe jood in je keel? (jocular question to someone who is very hoarse)

hij heeft een Jood gekist (said of a smelly person)

de helft zal wel van den Jood geweest zijn, daar is toch zeker van den Jood bij?

(one doesn't believe everything alleged or communicated by somebody else)

daar krijg je het joodje van (that will make you mad)

een jood over mijn graf (with reference to something terrible)

twee Joden weten (wel) wat een bril kost (cunning persons are equals in wiliness)

neger (a hateful person)

negeren (to bully, ill-treat; provoke)

negerzweet (black coffee)

zo swart als een neger (with a dark tan; very dirty)

Punische trouw (faithlessness)

Turk (a rough, unmannered, crusty, cruel, tyrannical person; something regarded as an example of ugliness)

turken (to rage, rant; to worry, provoke terribly)

turkenbaan (a job entailing dirty, grimy work)

aan de Turken overgeleverd zijn (to be treated badly, to be deceived, illtreated)

aangaan als een Turk (to rage, bluster; to storm at someone)

iemand plagen, mishandelen als een Turk (to severely worry, ill-treat someone) 
er uitzien als een Turk (to appear very dirty)

vandaal (someone who is guilty of destructiveness, vandalism)

\section{(4) German}

englische Krankheit (rickets)

englischer Schweiß (sweating sickness)

französischen Abschied nehmen (to take French leave)

Franzosenkrankheit, französische Krankheit (syphilis)

Jude (a usurer)

jüdeln (to bargain like a Jew; to cheat, defraud in selling)

jüdischer Wucher (Jewish usury, profiteering)

Judendeutsch (gibberish)

Judenseele (the soul of a usurious person)

Judenzins (usurious interest)

es geht hier zu wie in der Judenschule (it's hell broke loose)

ein Lärm wie in der Judenschule (a fearful row)

das ist spanisch für mich (I do not understand a (one) word of it)

es kommt mir spanisch vor (it is very strange; I don't know what to make of it)

Tartarennachricht (mendacious (war-)news; a false report)

eifersüchtig wie ein Türke (very jealous)

fluchen wie ein Türke (to swear like a trooper)

Vandale (a destroyer)

vandalisch (ferocious)

Vandalismus (vandalism)

\section{(5) French}

une querelle d'allemand (a groundless quarrel)

filer à l'anglaise (to slip away unnoticed; to take French leave)

parler français (to call a spade a spade)

parler français comme une vache espagnole (to murder the French language)

Goth (a barbarian)

Grec (a sharper, blackleg)

c'est du grec pour moi (that is Greek to me)

juif (a usurer, swindler, cheat)

juiverie (a fraudulent practice; a Jew's bargain, trick)

un nègre (somebody who does the donkey work; a drudge)

travailler comme un nègre (to work exceptionally hard)

\section{(6) Portuguese}

judeu (a bargainer)

judiaria (cruelty, ill-treatment; mockery, derision) 


\section{(7) Spanish}

judío (a usurer, miser; greedy)

\section{(8) Italian}

Giudèo (strictly according to the law; narrow-minded, stubborn)

In retrospect, it seems debatable whether Goth, Gothic, Gothish, Gothicism; Punic, Punic faith; and Vandal, vandalic, vandalistic, vandalism, vandalize (see under 2.3.3(1) above) should indeed be included in the lists as examples of racist usage. A decision on their inclusion or exclusion hinges on their being related to extinct or to existing ethnic groups. When related to particular historically existing ethnic groups, these usages could, from a historic point of view, probably be regarded as racist. If, however, a synchronic test of reference to an at present existing ethnic group as well as to apparent disparagement of that group is accepted and applied, it seems clear that the examples quoted above can be regarded as semantically pejorative, but not racially so.

The application of an acid test of the impossibility of objection from the grave as against concerted protest by the living may seem facetious, but not inevitably so if it is regarded as imperative that clear guidance on the racist or non-racist character of such usages should be given in dictionaries. Thus, in the Concise Oxford Dictionarys (1990) a sense of Hun, defined as "an uncivilized devastator; a vandal", needs no racist register label, since this sense does not relate to a living ethnic group. Conversely, the sense "a German (esp. in military contexts)" is rightly labelled offensive in deference to the particular existing ethnic group. So also should sense 2 of Tartar, $n$., namely "(tartar) a violenttempered or intractable person" be labelled, due to its association with the existing Tartar ethnic group. Such a label is lacking in $C O D^{8}$.

2.3.4 This final category of examples of racist language in society consists of idiomatic and technical expressions containing the names of ethnic groups as key-components which, in 2.3.1 and 2.3.2 above, were regarded as racist in all their applications.

\section{(1) English}

a white kaffir (a white person who associates with or is thought to favour black people; an uncultured, ill-bred, ill-mannered, unrefined white person) nigger luck (exceptionally good luck)

niggers in the snow (stewed prunes and rice) a white nigger (a term of contempt for a white person)

a nigger in the woodpile (a concealed motive or unknown factor affecting a situation in an adverse way)

to work like a nigger (to work exceptionally hard) 


\section{(2) Afrikaans}

'n Boesmantjie (Hotnotjie, Kaffertjie) doodslaan (vermoor) (to sleep badly; to have a drink; to be restless, in a hurray; to be dogged by misfortune)

almal se hotnot (someone who is given work by everybody)

'n los hotnot (someone without any work obligations, who is free to do, to come and go as he pleases; a widow(er) or grass widow(er))

niemand se hotnot wees nie (to be under no obligation to work for anybody; to be free to do what you like)

iemand die hottentotsriel laat dans (to give him a good hiding)

alle Kaffers het swart velle (blacks are untrustworthy)

'n Kaffer 'n Kaffer noem (to call a spade a spade)

'n Kaffer se nek omdraai (to open a bottle of drink)

onder die Kaffers grootgeword (to be ill-mannered)

'n wit kaffer (an uncultured, ill-bred, ill-mannered, unrefined white person)

jou verbeel jy is god van Kafferland (to have an overrated opinion of oneself)

stink soos 'n koelie wat knoffel geëet het (to give off a bad smell)

soos 'n koeliebasaar gaan (klink, lyk) (to be, appear noisy, rowdy and (or) in a state of disorder)

soos 'n Koeliekrismis lyk (to be dressed too conspicuously, flashily)

soos 'n Koeliemeid lyk (to be dressed conspicuously, flashily, in bad taste or slovenly, sloppily)

koelietaal wees (to be unintelligible)

'n meid, 'n ou meid (someone who lacks courage; a milksop, sissy)

2.3.5 The fairly extensive inventory of racist language in society, given in 2.3.1-2.3.4 above, points to the existence of a very real and problematic component of the lexicons of various languages. It is obvious, therefore, that the lexicographer should assume the task of enlightening the speech community on the usage sensitivity and constraints surrounding such racist language. In section 3 various aspects of the treatment of racist language in dictionaries will be discussed.

\section{The treatment of racist language in dictionaries}

3.1 In his article "Dictionaries and Ethnic Sensibilities" Burchfield (1980) gave vivid accounts of the outcries that followed the publication of the definitions of certain contested senses of Pakistan, Palestinian and Jew in the Concise Oxford Dictionary and the Pocket Oxford Dictionary. Confiscation of copies and sales boycotts threatened the $C O D$ until the offending definitions were amended. In the case of Jew an action was brought against the Clarendon Press by a Salford businessman who claimed that the secondary definitions of the word Jew were "derogatory, defamatory, and deplorable". He lost the case in the High Court in July 1973. The judge held that the plaintiff had no maintainable cause of ac- 
tion because he could not, as required by English law, show that the offending words in the dictionary entries "referred to him personally or were capable of being understood by others as referring to him".

As reported by Van der Spek (1987), a summary action was brought in 1970 against the compiler and the publisher of the Van Dale dictionary, with reference to negative expressions in which jood or joden appeared. The judgement was in favour of the publisher. Of interest, too, is the debate between Van der Spek (1987) and Cohen (1988), both in favour of the inclusion of the secondary senses of jood in Dutch dictionaries, and Stein (1987), chairman of the Stichting Bestrijding Antisemitisme (STIBA), who is of the uncompromising opinion that such denigrating secondary senses of jood should not be entered in dictionaries of Dutch or any other language.

In 1969 the WAT came under fire when representatives of the South African Jewish Board of Deputies complained about certain entries pertaining to Jood. During personal interviews and in protracted correspondence the matter was discussed in great depth by both parties. After a thorough re-examination of the offending definitions by the editors, it was found that some of the entries had been based on too flimsy evidence, or were explicitly offensive. Such entries were either deleted or amended in the list of corrections included in the next volume. Thereby the matter seems to have been settled amicably.

It should be noted that the Bureau of the WAT is safeguarded against litigation in terms of section 17 of the "Woordeboek van die Afrikaanse Taal" Act, 1973, which reads as follows:

17. Notwithstanding the provisions of any other law, no person shall be liable to any civil or criminal proceedings or to any damages by reason of anything published in the Dictionary, irrespective of whether such publication took place before or after the commencement of this Act.

Despite any existing legal protection, editors of dictionaries are not immune from protests in the media or from some other form of unfavourable reaction, for instance sales boycotts. Although such a situation will cause the editors to become increasingly conscious of the sensitivity surrounding certain controversial entries, and of the need to treat them with due caution, the editors should nevertheless not allow themselves to be buffeted beyond control by emotionally whipped up winds of change. What is needed are cool heads and a strict and dispassionate adherence to professional responsibilities and integrity in order to arrive at a clearly defined and consistently applicable editorial policy and editorial system for dealing with controversial, and especially racist material. The experienced editor will of course be aware; and constantly take account of current and changing semantic and social values, particularly in the way they affect linguistic relations between different ethnic and other groups. The examples given under 2.3.1.1(1)-(3) above point to an initially 
non-racist status which due to changing social awareness and values, are now labelled racist.

The three cardinal questions relevant to the preparation of dictionary entries in general are also applicable to the handling of racist lexical items in particular, namely:

(1) Should the item be included or excluded?

(2) How should the item be defined, including the choice and handling of usage labels?

(3) Should usage examples, i.e. editorial examples or illustrative quotations, be given with definitions and, if so, to what purpose and extent?

\subsection{Inclusion or exclusion of racist lexical items}

3.2.1 It is generally accepted that dictionaries, especially the larger, comprehensive dictionaries, should mirror all the manifold facets of the linguistic society and times in which they are compiled. The task of the lexicographer therefore involves the inclusion also of lexical items which can generally be classed as taboo, such as obscene, sexist, sacrilegious and racist terms, provided such inclusions áre well attested' by adequate recordings of use. Compare the pronouncement of Heestermans (1992: 41, translated) on the inclusion in the Van Dale Groot Woordenboek der Nederlandse Taal ${ }^{12}$ (1992) of words that are insulting to groups in society:

Such words should be included in a dictionary if they have been current for at least a few years ... If the dictionary indeed wants to be a mirror of society, it would be incorrect to block out and make invisible the unpleasant sides of society. But then the dictionary, as a mirror of society, should also reflect the judgement of society on these words. The contents of a dictionary is in fact co-determined by the visions and views which are alive in society.

In adhering to this principle the lexicographer would be carrying out his duty as language historiographer. It would also be in keeping with the definition of a dictionary and its aims presented by Berg (n.d.: 4) and quoted with approval by Zgusta (1971: 197):

A dictionary is a systematically arranged list of socialized linguistic forms compiled from the speech-habits of a given speech-community and commented on by the author in such a way that the qualified reader understands the meaning ... of each separate form, and is informed of the relevant facts concerning the function of that form in its community. 
Of "socialized" Berg says:

Linguistic forms are social facts in so far as they result from individual utterances being socialized, i.e. imitated time after time, under similar circumstances, by members of the community where they originated.

Instead of being swept under the carpet, racist language should indeed be included in the larger dictionaries, because by its inclusion the lexicographer can fulfil one of his most important functions, namely the giving of adequate guidance for the correct evaluation and usage of such language, which undeniably forms part of the lexicon he is describing.

3.2.2 It is illuminating to note what dictionaries themselves say about the inclusion or exclusion of racist terms. The following is but a small sample of such editorial policy statements, usually given in prefaces:

(1) The Funk \& Wagnalls New College Standard Dictionary (1956) states its case on page vi of the Plan of the dictionary:

Vulgarisms: A conscientious lexicographer may omit words or meanings of unquestionable vulgarity from a general dictionary; but, however greatly he may deplore the use of certain terms which are considered derogatory or offensive by individuals, or by persons of various races, nations, or religious beliefs, he cannot ignore them if they are widely encountered in reading or in speech. A thoughtful person, who would not intentionally injure the feelings of a neighbor or an employee, may do so in ignorance if unaware that the word he uses is offensive. Hence, particular attention has been given to such entries in this dictionary, and care has been taken to caution against the use of those that are especially likely to arouse ill feeling.

(2) On page vii of the Preface to volume II of $A$ supplement to the Oxford English Dictionary (1976) the three main conclusions on the topic of inclusion or exclusion are referred to, namely that

(i) offensiveness to a particular group, minority or otherwise, is unacceptable as the sole ground for the exclusion of any word or class of words from the O.E.D.; (ii) it is therefore desirable to enter new racial and religious terms however opprobrious they may seem to those to whom they are applied and often to those who have to use them, or however controversial the set of beliefs professed by the members of minority sects; (iii) it is also desirable, in order to avoid misunderstanding and consequent hostility, that the somewhat antiquated historical record of words like Jesuit, Jew, Negro, nigger, and others already 
treated in the O.E.D. should be brought up to date. These things we have done.

(3) On page ix of the Preface The Concise Oxford Dictionary of Current English ${ }^{8}$ (1990) sets out its policy on the inclusion and handling of offensive words and uses:

Far greater difficulty attends the treatment of vocabulary that is or can be offensive, either generally or to particular groups of people. All languages contain such words, and no dictionary that claims to treat the language in current use can exclude them. In this edition we have added the label offens. to words and uses that are offensive either directly because they offend the people they refer to or by indirect reference or association, often by historical stereotypes. Linguistic usage in such stereotypes is seldom concerned with historical truth but the use, once established, has to be explained, and I hope that by explaining them with appropriate historical comment and a clear indication of the offensiveness involved, a better awareness of their inherent distastefulness may be generated.

(4) In 1992 the Board of Control of the Woordeboek van die Afrikaanse Taal decided, at the instance of the editors, that racist lexical items and sense aspects should only be included if they qualify for inclusion in terms of the WAT"s editorial policy regarding inclusions. This policy follows the internationally accepted practice that inclusions should be based on sufficiently conclusive written or oral evidence of the well-established existence and use of such items or senses in the lexicon described in a particular dictionary.

(5) The picture of editorial policies regarding the inclusion or exclusion of racist items would not be complete without at least one example of an exclusionist standpoint. In the foreword to Webster's. New World Dictionary of the American Language (Second College Edition, 1972), p. viii, the editor, David B. Guralnik, defends his policy of excluding "a handful of old, well-known vulgate terms for sexual and excretory organs and functions" on the practical grounds "that there is still objection in many quarters to the appearance of these terms in print". In a similar vein, it was decided in the selection process "that this dictionary could easily dispense with those true obscenities, the terms of racial or ethnic opprobrium, that are, in any case, encountered with diminishing frequency these days" (from the quotation in Burchfield 1980: 21-22).

3.2.3 The ideal editorial situation of having a free hand in the inclusion of racist language in dictionaries, as indicated in 3.2.1-3.2.2 above, could be chal- 
lenged by in-house commercial considerations related to the target user market. Fearing a possible ban by education authorities and a resulting financial loss, the editor as well as the publisher of a school dictionary, or of a general adult dictionary that may be used lucratively in schools, would rather exercise the prudent editorial option of exclusion. Such a decision is given his blessing by Burchfield (1980: 22), a staunch and consistent defender of free lexicography, when, with reference to the inclusion of vulgar words and terms of racial abuse in larger dictionaries, he says: "In smaller dictionaries, and in school dictionaries, the absence of such vocabulary needs no defense."

The sensitivity surrounding racist terms in school dictionaries is highlighted especially in multicultural and polyethnic societies like South Africa, where under the present restructuring of white schools, classes increasingly consist of pupils from black, brown and white cultural and ethnic groups. Lombard (1990: 44, translated) gives this situation a caveat perspective:

In the South African society the presentation in a school dictionary is even more problematic than in other societies which culturally and linguistically are not as varied. If the compiler of an Afrikaans school dictionary wants it to be suitable for all pupils who are interested in Afrikaans or who are studying Afrikaans as a school subject, he will have to consider his presentation very carefully. This applies in particular to definientia and editorial usage illustrations which can be regarded as offensive (even if they are in fact a true reflection of linguistic reality). A lemma which could be offensive or unacceptable to specific cultural groups should not be included. Editorial illustrations in any dictionary which is considered for extensive use in South African schools should be neutral and applicable across cultural barriers, otherwise the dictionary will not succeed.

Destructive reaction by brown pupils who regarded some lemmas and definitions in M.S.B. Kritzinger's Beknopte Verklarende Woordeboek ${ }^{4}(1972)$ as offensive, insulting and derogatory occurred in 1980 at two Cape schools in the Somerset West area. According to reports in The Argus (27 Aug. 1980: 1) and Die Burger (28 Aug. 1980: 4) the pupils vented their anger about the inclusion of racist entries such as baas, Hotnot, korrelkop, meid, skepsel, witman, witmens by tearing up, trampling on and burning copies of the dictionary.

In view of the very sensitive present and future race relations situation in South Africa the South African lexicographer will need all the vigilance, discernment and editorial diplomacy he can muster. This has relevance also to other types of wordbook, such as spelling and word lists. A case in point is the exclusion from the eighth edition of the Afrikaanse Woordelys en Spelreëls (1991) of the following racist entries included in the seventh (1964) edition: 


$\begin{array}{ll}\text { aia } & \text { kaffer-wag-'n-bietjie-boom } \\ \text { Ampie } & \text { kleinjong } \\ \text { Boesman } & \text { kleinmeid } \\ \text { Boesmans } & \text { Kleurling } \\ \text { Boesmanssprekend } & \text { kleurling } \\ \text { Boesmantaal } & \text { klimmeid } \\ \text { Boesmantjie } & \text { Knopneuskaffer } \\ \text { Boesnot } & \text { Koelie } \\ \text { Engelse siekte } & \text { krulkopklonkie } \\ \text { gammat } & \text { meid } \\ \text { Gamsgeslag } & \text { meidepraatjies } \\ \text { Hotnot } & \text { Mohammedaan } \\ \text { hotnotsgot } & \text { Mohammedanisme } \\ \text { hotnotsriel } & \text { Rooikaffer } \\ \text { Hottentot } & \text { oumeid-onder-die-kombers } \\ \text { Hottentots } & \text { ousie } \\ \text { hottentotsgot } & \text { outa } \\ \text { hottentotsriel } & \text { skepsel } \\ \text { jong } & \text { Slamaier } \\ \text { Kaffer } & \text { Slams } \\ \text { kafferkoring } & \text { tater } \\ \text { Kaffertaal } & \end{array}$

Faced with a catch-22 situation in which the deletion of these items would deprive the $A W S^{8}$ user of orthographic and morphological guidance, while retaining them might invite negative racial comment, the compilers, namely the Taalkommissie of the Suid-Afrikaanse Akademie vir Wetenskap en Kuns, decided that racial discretion is the better part of instructional valour. Thereby adverse racial reactions which might lead to boycotts could be averted. In any case, a decision in favour of exclusion could also be firmly based on the circumstance that in a word list such as the AWS a fully explanatory usage and register perspective of these racist items can hardly be expected.

Oddly enough the following racist terms in the seventh edition have been retained in the eighth:

armblanke

Asiaat

Asiaties

bediende bediendekamer

boesmangras

boesmansgras

Boesmantekening
Kakie

klong

klonkie

Mohammedaans 


\subsection{Definitions and usage labels of racist lexical items}

3.3.1 Having decided to include racist language in his dictionary, the editor should have a clear and consistently applicable vision of how such items should be treated. Underlying this vision should be the taking into account of constantly changing social and racial values and attitudes, particularly insofar as relations between different ethnic groups are affected by such values and attitudes. Above all, the lexicographer, as biographer of the lexicon, should at all times maintain the strictest objectivity and impartiality when defining sensitive and controversial lexical items such as racist language.

How should such items be defined? Obviously definitions should be based on well-established principles of lexicographic practice, while consideration should also be given to theories and recommendations contained in publications on the nature and presentation of lexicographic definitions, such as, for example, those of Zgusta (1971: 252-259), Landau (1984: 120-173) and Lombard (1991) from three different decades. It is also evident that different categories of lemma would need definientia tailored to the specific requirements of an informative explanation and indication of the sense and usage aspects of a particular lemma. Thus racist language lemmas would require unequivocal indications, such as usage status labels, warning users of their racist nature. In formulations of the definientia of such lemmas the reaction perspective of the potential hearer/reader should also be taken into account.

3.3.2 After the general statement above of the various definition obligations the lexicographer should assume, we can now turn to practical examples of such definitions. As it can be expected that some of the categories of racist language given under 2.3.1-2.3.4 will require case-specific definientia, discussion by category is indicated. However, before discussing the form and content of the definientia, we should first take a look at an accessory closely linked to the definiens, viz. the usage label.

The usage label is regarded as an accessory because it functions as an indication of the usage status of the lemma, whereby the dictionary user is provided with information on the usage suitability of the lemma in a particular communication situation. Such usage guidance is especially indicated where reference is made to particular social groups or social values, such as those mentioned under 1.2 above. In these cases the usage-restrictive function of the label is of prime importance. This is borne out by Murphy (1991: 56) when she mentions two sources of a demand for usage labels:

Because it is demanded ... that dictionaries indicate whether a term is likely to offend, this demand for usage labels in ethnonym entries has two sources. First, the named populations want terms offensive to them to be clearly marked as derogatory ... Second, dictionary users from outside the 
named group expect that less acceptable terms will be marked, in keeping with their perceptions of dictionaries as prescribers of proper usage.

As if anticipating the above-mentioned expectations, Jess Stein, Editor in Chief of The Random House Dictionary of the English Language (1967), indicated his views on usage strictures and reader guidance as follows in the Preface, p. vi:

Since language is a social institution, the lexicographer must give the user an adequate indication of the attitudes of society toward particular words or expressions, whether he regards those attitudes as linguistically sound or not. The lexicographer who does not recognize the existence of longestablished strictures in usage has not discharged his full responsibility. He has not been objective and factual; he has reported selectively, omitting references to a social attitude relevant to many words and expressions. He does not need to report approval or disapproval of a disputed usage, but he does need to report the milieu of words as well as their meanings. In this dictionary ... we have used labels to guide the reader to effective and appropriate use of words.

Before discussing the application of sociolinguistic labels with reference to racist language, let us look' at an inventory of such labels. The following list has been compiled mainly from dictionary sources:

abuse; racial abuse; colloquial and usually contemptuous; in contempt; used chiefly in contempt; a term of contempt; a usually hostile term of contempt; a term of mild contempt; term of contempt or derision; a term of contempt and hostility; contemptuous; now chiefly contemptuous; deliberate and contemptuous ethnic abuse; a contemptuous term; often a contemptuous term; sometimes a contemptuous term; often used contemptuously; controversial; denigrating term; depreciatory; term of derision; in vulgar derision or depreciation; derisive; derogatory; often derogatory; regarded by Negroes as derogatory; usually derogatory; a derogatory term; disparagement; disparaging; often disparaging; disparaging and offensive; often disparaging and offensive; sometimes a disparaging term; often used disparagingly; often used familiarly, now chiefly contemptuously; figurative; hostile; viciously hostile; a hostile and offensive term; a term of hostility and contempt; insult; insulting; metaphorical; negative; not preferred; not the preferred term; objectionable; offensive; deeply offensive; often offensive; racially offensive; offensive slang; usually offensive; sometimes taken to be offensive; usually taken to be offensive; very offensive; a very offensive term of contempt; vulgarly offensive; an offensive and vulgar term of contempt; opprobrious; patronizing; usually considered patronizing or mildly offensive; pejorative; racist; reprehensible; in transferred sense; vulgar; a vulgar and offensive usage; a vulgar term of hostility and contempt. 
The above list of 70 labels suggests a closer look at the following aspects:

3.3.2.1 The appropriateness of the temporal adverbs often, sometimes and $u$ sually as qualifiers of the main label epithets, e.g. contemptuous, derogatory, offensive, etc., is doubtful. The dictionary user may well ask the question "When is it (not) the case as stated?" when trying to get an unambiguous interpretation of the terms often, sometimes and usually. The answer will obviously lie in the listing of various communication contexts in which terms generally regarded as racist would not be viewed as racist. In identifying such contexts it should be established "who is using the-term with whom and with what intentions?" (Aman 1988-89: 127). Compare also the opinions expressed by Landau (1984: 187):

There are few studies that shed any light on the degree of offensiveness of specified terms under specified conditions. Such studies would have to take into consideration these vitally important questions: Did speaker and listener belong to the same or different groups? The same term uttered with a laugh to a member of one's own group might be deeply offensive if uttered to a member of another group. The intonation patterns (patterns of rising and falling pitch) and loudness will be quite different in the two utterances, as will paralinguistic features (gesture, non-meaningful sounds accompanying speech, facial expression).

As dictionaries could hardly be expected to include such studies in their definientia, the quoted adverbs with their inexplicit applications should be deleted from usage labels.

3.3.2.2 The 70 examples of labels given above contain 27 keyterms, such as contemptuous, derogatory, disparaging, offensive, opprobrious, racist, etc. (The terms figurative, metaphorical and transferred are not included as they will be discussed under 3.3.3.5.2 below.) In the dictionaries in which they appear the $27 \mathrm{key}$ terms all refer to examples of racist language. McCluskey (1989) has shown that in different dictionaries the same lemma is either not labelled or labelled differently, despite the fact that the lemma can in all cases be considered to have the same racist character.

If it is accepted that all 27 keyterms point to a common result, namely that racist lemmas give offence to the ethnic groups concerned, the question arises whether the number of 27 keyterms should not be replaced by one well defined label. Four candidates come to mind, viz. derogatory, insulting, offensive and racist. The usage label derogatory is indicated in the Concise Oxford Dictionary ${ }^{8}$ (1990: xxxii) as denoting "uses that are intentionally disparaging", while offensive denotes "uses that cause offence, whether intentionally or not". The labels insulting and racist could both be classed under derogatory as well as under offensive as indicated above. If intention (always difficult to prove) is disre- 
garded, offensive would be a good general label to indicate racist language that refers to ethnic groups. However, since offensive as a general label could also be used when referring to other sensitive but non-racist usage areas, such as obscenity, religion, political ideology and sexism, it seems that racist would be the best single cautionary label for racist lemmas. Its exact usage significance should of course be clearly set out in the guide to the use of the dictionary. Racist could be indicated as denoting "racially offensive".

In view of the increasingly sensitive relations between the different ethnic and cultural groups in South Africa, in particular between black, brown and white, South African dictionaries should be meticulously correct in their treatment of racist language items, including the choice of a suitable label. Du Toit (1989: 62, translated) focuses the attention on this aspect:

For South Africa, and particularly for Afrikaans dictionaries, this matter (i.e. the labelling of insulting language - D.C.H.) is at present very topical. The Afrikaans lexicographer has in this regard a big responsibility towards the dictionary user. Through the labelling of racist, religious, sexist or politically offending items, a value judgement is expressed that acts as a norm for the dictionary user. By means of a label the lexicographer can take a stand against racial prejudice for example.

\section{A Dictionary of South African English4 (1991: xvi) states:}

Racially offensive items have been marked as such, but we have not for this edition adopted the marker $\mathrm{R}$ ('racially offensive') used in some Oxford dictionaries, partly because we prefer in the present circumstances plain English to a symbol which the casual reader may misinterpret or simply miss.

The South African Pocket Oxford Dictionary (1987) is one of the Oxford dictionaries in which "R (=racially offensive) indicates a use that is regarded as offensive by members of a particular ethnic or religious group" (p. xx). Following the same line the Bureau of the WAT will in future label all racist lemmas and senses as (rassisties).

3.3.2.3 A last aspect relating to the labelling of racist lexical items is the label's position in the entry. Should it be placed before or after the definiens, or should it form part of the definiens? For example:

nigger $n$. offens. 1 a Black person. 2 a dark-skinned person. (COD 81990$)$ gringo a white foreigner in Spain or Latin America esp. when of English or American origin - often used disparagingly. (Webster's Third, 1961)

hotnot $n$. An offensive mode of address or reference to a coloured person. (Dictionary of SA English', 1991) 
Gouws (1988: 48-49) points out that the way in which a label is entered in a dictionary is not arbitrary but has been fixed by convention in order to give an immediate indication of the marked entries. As a result, labels are mostly presented in italics and in brackets. Due to its normal manner of entry (i.e. before and not as part of the definiens) a label appears in a focal position. Thanks to this focus the Iabel's function, viz. to ensure an immediate provision of information, is maintained. A departure from the conventional manner of entry leads to an abandonment of the lexicographical focal position and a resultant fading of the label's usage indication value. Du Toit (1989: 112) is of the same opinion when she states that information provision will be much more effective if the label contemptuous (minagtend) or derogatory (neerhalend) catches the attention of the user by being placed directly after the entry word instead of appearing further on as part of the definition.

\subsubsection{How should racist lexical items be defined?}

As envisaged under 3.3.2 the different categories of racist language given under 2.3.1-2.3.4 can best be discussed separately where such a procedure is indicated.

3.3.3.1 Defining the items given under 2.3.1.1 and 2.3.1.2 seems to be unproblematic. All are racist names used in referring to members of specific ethnic groups who are conventionally referred to in non-racist terms. Although it is a commendable practice to add all known synonyms of a lemma to its definiens, this should not, as a matter of lexicographical prudence, be done in the case of racist lexical items. Examples of such definitions are:

\section{(1) English}

nigger (racist) A Black American.

Red Indian (racist) An American Indian.

Sammy (racist) An Indian man.

Frog (racist) A Frenchman.

poor white (racist) A member of a socially inferior group of white people. rockspider (racist) An Afrikaner.

\section{(2) Afrikaans (translated)}

kaffer (racist) A black person; a black.

koelie (racist) An Indian.

meid (racist) A black or brown woman or girl

Kaaskop (racist) A Dutchman.

soutie (racist) An Englishman.

witvel (racist) A white person. 
3.3.3.2 General compounds, with one or two racist components (see under 2.3.2.1) should either be given a definition in non-racist terms or be referred for definition to a non-racist synonym where other non-racist synonyms could be added. For example:

\section{(1) English}

Bantu beer (racist) Sorghum beer. (add synonyms: mqombothi, tshwala) garden boy (racist) A garden help.

ironing girl (racist) An ironing woman.

Kaffir language (racist) An African language.

kaffir sheeting (racist) Bhayi. (add synonyms: bhayi sheeting, Benson cloth, Bolton cloth, Bolton sheeting, heavy sheeting)

native location (racist) A black township.

$$
\text { Afrikaans (translated) }
$$

Boesmanmeid (racist) A San woman or girl.

Hottentotlokasie (racist) Khoikhoi township.

Kafferboetie (racist) A white sympathiser with black people or their causes.

Kleurlingskepsel (racist) A brown person.

Koeliewinkel (racist) An Indian shop.

tuinjong (racist) Male black or brown garden help.

As Gouws (1986: 77) points out, "it is an accepted lexicographical practice to define a compound in terms of its components". If, however, the above-mentioned "definition in non-racist terms" is to be adhered to, the racist component should be replaced by an unstigmatised synonym or a paraphrase in such a way that the syntactic and semantic relations between the components are still clearly explicated. Definition in non-racist terms also implies that no literal relation between the components of the compound should be assumed and stated when the compound's figurative sense is defined. Let us look at the following example from WAT V (1968, translated):

Kafferhond. 1. Dog belonging to a Kaffir. 2. kafferhond. a. Inferior, nopedigree dog, such as is found among Kaffirs; Kaffir mongrel. b. (obsolete) Name for a cockroach.

In sense 1. "Kaffir" should be replaced by "black" and in 2.a. the phrase "such as is found among Kaffirs" as well as the synonym "Kaffir mongrel" should be deleted. The lemma should also be indicated as (racist).

It is important in this case that the lexicographer should be very sensitive to components of compounds which could become stigmatized in the future. When defining, the lexicographer should put himself in the position of both the hearer/reader of his time and the hearer/reader of the future. The component 
inboorling (native) of the Afrikaans compound inboorlingtaal (native language) would perhaps not give offence at present, but might well do so in the future. The lexicographer should therefore preferably choose an undoubtedly neutral term or phrase for the component inboorling in a definition of inboorlingtaal, for example: "Taal van enigeen van oorspronklik inheemse bevolkingsgroepe" (Language of any one of originally indigenous population groups).

3.3.3.3 Compound vemacular names of fauna and flora containing racist first components can be defined either by referring the lemma to a non-racist synonym for definition or, where such a synonym is non-existent, by defining the racist name where it appears as an entry word. The following are examples of these two altematives:

\section{(1) Fauna \\ (a) English}

Hottentot god (racist) Praying mantis. (definition at mantis)

Kaffir crane (racist) Crowned crane. (definition at crane) niggergoose (racist) Cormorant.

Bushman rice (racist) The larvae of termites.

Hottentot fish (racist) Any of several brownish-coloured fish species of the genus Pachymetopon, tamily Sparidae, e.g. P. blochii, P. aeneum and P. grande.

\section{(b) Afrikaans (translated)}

boesmanhaantjie (racist) Dagbrekertjie. (add synonyms: japjappie, klapklappie, sekelvlerkspekvreter)

hottentotsvydopluis (racist) Suurvydopluis. (add synonym: vygiedopluis)

kaffermossie (racist) Bergmossie. (add synonyms: blesmossie, grasvink, kaneelmossie, koringvoël, wildevoël)

hottentotsluis (racist) A darker form of the well-known human lice species.

kafferbokrooitjie (racist) Medium-sized yellow or reddish-brown butterfly, Acraea esebria of the family Nymphalidae.

kafferpruimboorder (racist) A large, bark-coloured snout-beetle, Mecocorynus loripes of the family Curculionidae.

\section{(2) Flora}

\section{(a) English}

Hottentot bread (racist) Elephant's foot. (definition under elephant)

Kaffir tree (racist) Coral tree. (definition under coral)

nigger daisy (racist) Black-eyed Susan. (definition under Susan)

Hottentot cabbage (racist) Any of several Anthericum species of the family Liliaceae, of which the developing inflorescences can be used as vegetables, e.g. A. ciliatum, A. hispidum, A. revolutum. 
Kaffir bride (racist) A fairly large shrub, Pavetta corymbosa of the family Rubi. aceae, bearing white, tube-shaped flowers.

Kaffir grapes (racist) A small shrub, Pollichia campestris of the family Caryophyllaceae, with fruit-bearing twigs resembling bunches of grapes.

\section{(b) Afrikaans (translated)}

boesmanamandel (racist) Bitteramandel. (add synonym: wildeamandel)

hottentotsvy (racist) Ghoena. (add synonyms: elandsvy, ghoenavy, ghôkum, ghoukom, gladvy, perdevy, suurvy)

kafferpruim (racist) Suurpruim. (add synonyms: suurbessie, wildepruim)

koeliedruiwe (racist) 1 Belhambra. 2 Inkbessiebos. (add synonym to 2: bobbejaandruiwe)

meidestert (racist) Damarara. (add synonyms: bontbeeskloutjie, marara-uintjie)

boesmanboegoe (racist) A small, aromatic subshrub, Ocimum fruticulosum of the family Labiatae, bearing two-lipped flowers.

hottentotstoontjie (racist) The stem succulents Duvalia polita and Stapelia gigantia, both of the family Asclepiadaceae.

kafferboontjie (racist) Annual summer legume, Vigna sinensis of the family Leguminosae, cultivated for fodder and soil-improvement.

3.3.3.4 Customarily place names are not entered as lemmas in non-encyclopaedic dictionaries. The exceptions are those place names which are also used as common names or in idiomatic expressions, for example:

Sodom $n$. a wicked or depraved place. $\left(C O D^{8}, 1990\right)$

Timbuctoo $n$. any distant or remote place. $\left(C O D^{8}, 1990\right)$

Yorkshire 2. Used allusively, esp. in reference to the tboorishness, cunning, sharpness, or trickery attributed to Yorkshire people. To come (or put) Yorkshire on one, to cheat, dupe, overreach him. Yorkshire bite, a sharp overreaching action or person. tAlso in prov. phr. a pair of Yorkshire sleeves in a goldsinith's shop, said of anything worthless. (OED, 1933)

Stellenbosch $v b$. trms. and name 1. $v b$. Anglo-Boer War term: to relegate an incompetent or foolhardy officer to a post where he is unable to do harm, usu. as pass: to be $\sim e d$ : fig. to put a difficult or controversial person in a position on the shelf. cf. Fr. Limoger to relegate to Limoges. [fr. name of town, then a military post] 2. The site of a prehistoric Stone Age culture. [fr. place name] (Dictionary of SA English4, 1991)

AKEN. Aken en Keulen, ... in transferred sense, the total number of various things taken together; everything combined; and, with further extension of the notion, a whole lot, a large number of all kinds of things together, quite a lot. Aken en Keulen zijn niet op één dag gebouwd, big undertakings are not completed in a short time; a big job requires time and patience; an admonition 
not to be overhasty in a matter of great extent, or, not to wish for too much all at once. (WNT II, 1898, translated)

As far as could be ascertained only Kafferland in the list of geographic names with racist components given under 2.3.2.3 is also used in idiomatic expressions, which are explicated as follows in WAT V (1968, translated):

Kafferland. Familie wees so ver soos (as) van hier na Kafferland, distantly related. Hy dink (verbeel hom) hy is god van Kafferland, he has a high opinion of himself.

Incidentally, the lemma Kafferland in the WAT should be labeled (racist), and in the definition (translated), viz. "Territory inhabited by Kaffirs", "black people" should be substituted for "Kaffirs".

The 58 English and Afrikaans geographic names with Bushman (Boesman(s)-), Hottentot (Hottentot(s)-), Kaffir (Kaffir(s)-) and Meide- will not be entered in non-encyclopaedic dictionaries.

3.3.3.5 Under 2.3.3. fairly extensive lists are given of examples in various languages of racist secondary senses of language and ethnic group names which in their primary senses are used with non-racist connotations. These names are encountered in original, derived or compound form, or in idiomatic and technical expressions. As the examples of such names are accompanied by denotations of their secondary senses, they can be regarded as rough-and-ready dictionary entries. Thus we need only discuss two major aspects which relate to the editorial refinement of the definientia of these entries.

3.3.3.5.1 Should the lexicological connection between the primary and secondary senses of the above-mentioned lexical items be referred to in the formulation of the secondary senses? It seems that diachronic dictionaries regard such a reference as required. Let us look at the treatment by three diachronic dictionaries of secondary senses of Jew.

(1) In the OED V (1933) sense 2 of Jew $s b$. read as follows:

transf. As a name of opprobrium or reprobation; spec. applied to a grasping or extortionate money-lender or usurer, or a trader who drives hard bargains or deals craftily. (1llustrative examples 16061844.)

This definition was replaced in the OED Supplement II (1976) by the following one:

transf. and offensive. As a name of opprobrium: spec. applied to a grasping or extortionate person (whether Jewish or not) who drives hard bargains. (Illustrative examples 1846-1964.) 
The following lexicological note was also added:

In medieval England, Jews, though engaged in many pursuits, were particularly familiar as money-lenders, their activities being publicly regulated for them by the Crown, whose protégés they were. In private, Christians also practised money-lending, though forbidden to do so by Canon Law. Thus the name of Jew came to be associated in the popular mind with usury and any extortionate practices that might be supposed to accompany it, and gained an opprobrious sense.

(2) In the WNT VII (1926) the following senses of JOOD are elucidated by lexicological comments (translated):

4) The Israelites rejected Jesus and crucified him; as a result their name became synonymous with despiser, scomer, enemy of the Christians of Christianity; for this reason they suffered, and in some countries are still suffering, all kinds of oppression and persecution.

5) Due to various peculiarities of personal appearance, manners, customs and character, the Israelites are exposed to derision, insults, contempt; hence Jew. as a contumelious name and - frequently intensified by an adj. with an unfavourable meaning - as a term of abuse.

6) The Israelites, especially the less esteemed among them, often eam their livelihood by various kinds of commerce and street trade; they are buyers of and dealers in second-hand goods, money-changers, moneylenders, etc. (These sense 6 comments apparently serve as pointers to the development of sense $7-$ D.C.H.)

7) In an unfavourable conception, metaphorical. Someone who overcharges, who takes usurious profit; usurer; swindler; cheat.

(3) The following (translated) appears under sense 3 of JUDE in the Deutsches Wörterbuch IV (1877):

3) of their bad qualities, particularly their uncleanliness, as well as their profitseeking and their taste for usury are emphasized in diverse phrases. dirty as an old Jew; he thinks like a Jew; linked therewith to taste like a Jew, repulsive, and accentuated to taste like a dead Jew ... to profiteer, cheat, lend, borrow like a Jew. 
Sense 4 of Dutch A. adj. is formulated as follows in OED Ill (1933):

Characteristic of or attributed to the Dutch; often with an opprobrious or derisive application, largely due to the rivalry and enmity between the English and Dutch in the 17th $\mathrm{c}$.

Often with allusion to the drinking habits ascribed to the 'Dutch'; also to the broad heavy figures attributed to the Netherlanders, or to their flat-bottomed vessels. Sometimes little more than = foreign, un-English.

Dutch auction, bargain, concert, courage, gleek, nightingale, uncle: see AUCTION, BARGAIN, etc. Dutch comfort, consolation, defence, feast, palate, reckoning, widow: see quots.

This presents another example of bridging the lexicological gap between the primary and secondary senses of èthnic group names and their derivatives.

Although this bridging action may be regarded as faithful adherence to a respected diachronic lexicographic principle, it could synchronically also be argued that this procedure entrenches and perpetuates the racist character ascribed to such secondary senses. This aspect of the treatment of racist language in dictionaries will be taken further in 3.3.3.5.2.

3.3.3.5.2 If it is decided that the above-mentioned lexicological data should not be attached to the definientia of the secondary senses of ethnic group names in synchronic dictionaries, the question remains whether such secondary senses should be regarded as reflecting on the group name, and if so, what label should be used to indicate such a reflection.

In the case of lexical items noted under 2.3.1-2.3.2 there seems to be no problem in regarding and labelling them as racist. With regard to the secondary senses illustrated under 2.3.3, however, the lexicographer finds himself in a Scylla and Charybdis situation. On the one hand he might argue, in support of his decision to include such senses, that these senses are used metaphorically and therefore in a non-racist application. In such a case the usage could merely be indicated as (metaph.), (fig.) or (transf.), thus causing any direct references to the particular ethnic groups to be eliminated. If, on the other hand, the lexicographer should decide to safeguard himself against a possible critical onslaught, he might decide to use various clear-cut labels such as (derog.), (offens.) or (racist) to mark the acknowledged racist nature of the secondary senses. As obviously cautionary labels they might succeed in giving the desired usage direction as well as smoothing the ruffed feathers of the more hostile critics.

Deciding which one of the above two mechanisms should be employed, could be a difficult matter for the lexicographer. His choice would to a large extent depend on the target market envisaged for his dictionary, and also on 
his willingness to take into account well-established lexicographical principles as well as sound practical perspectives.

3.3.3.6 The examples of racist expressions presented under 2.3.4 differ from those given under 2.3.3 insofar as the former category contains the names of ethnic groups as key-components which are regarded as racist in all their applications, for example knffir, nigger, hotnot, koelie, meid.

Here, too, the lexicographer is confronted with the two problems stated in 3.3.3.5.1 and 3.3.3.5.2, namely whether to incorporate in the definiens an explication of the lexicological connection between the key-components and the senses of the expressions, and which type of label to employ that will function as an indication of usage caution.

It seems that dictionaries in general do not offer lexicological explanations of derogatory expressions containing the above-mentioned key-components. For instance, neither the OED Supplement Il (1976) nor Webster's Third (1961) gives any indication of the origin of the expression a nigger in the woodpile (a concealed motive or unknown factor affecting a situation in an adverse way). Compare also an interesting example in the WAT VI (1976). The expression koelietanl wees vir iemand is defined (translated) as "to be unintelligible to someone". The definition of koelietaal (sense 2), viz. "(transf.) Strange, unfamiliar, unintelligible, jabbering language" is however complemented by the addition of "that sounds like Koelietaal (sense 1)". (This sense is defined as "In general, language spoken by Koelies as their mother tongue; especially, any one of the Indian languages spoken by Koelies in South Africa".) It seems therefore that dictionaries do not consider it necessary to include explanations of lexicological origin in their definientia of expressions, whether racist or not.

The same problem of the choice of usage labels discussed in 3.3.3.5.2 is encountered in respect of the handling in dictionaries of the type of expression referred to above. In this case, too, the lexicographer will have to decide on either a semantically indicative label, such as (fig.), (metaph.), (transf.), or an unambiguous cautionary usage label like (derog.), (offens.) or (racist). Identical decisional considerations previously stated apply in this case.

\subsection{Usage examples of racist lexical items}

3.4.1 Usage examples can consist of quotations (also called "citations"), editorially constructed sentences or phrases, and collocations. (For a discussion of the important role played by collocations in monolingual explanatory dictionaries, see the instructive paper by Van Niekerk 1992.)

In his referentially well-documented paper on usage examples in dictionaries Lombard (1992: 149) points out that usage examples have a semantic, syntactic and pragmatic function. The following quotation from Landau (1984: 
166) gives an indication in a nutshell of the functional applications of usage examples:

The illustrative quotations or invented phrases that exemplify meaning are a critical part of the dictionary definition and should not be regarded as mere appurtenances. Illustrative quotations can convey a great deal of information about collocation, variety of usage (degree of formality, humorous or sedate context), connotation (affective implications), grammatical context (if a verb, does it take an indirect object?), and, of course designative meaning. Often there is no better way to provide this information than by an illustrative quotation. Short, invented phrases are frequently essential to tell the reader how the definition is actually used in ordinary contexts.

3.4.2 An important question to be decided about usage examples of racist lexical items is whether or not such examples should be included in entries of the racist items. In 1992 the editors of the WAT decided that (provisionally?) no usage examples of a racist nature would in future be included in the WAT. This exclusion also refers to the use in non-racist entries of examples (mostly quotations) that contain racist elements. Such examples should be judiciously edited to free them from racist features which are not regarded as necessary for a full understanding of the relevant sense as defined. What was said in the last paragraph of 3.3.3.2 also applies in this instance. It is tantamount to the sensitive and thoughtful lexicographer donning the prophet's mantle which would put him in the position of the hearer/reader of today and tomorrow. Also that which could give offence in the future should in advance be excluded from the dictionary entry. The following are Afrikaans examples of such editing:

kryttekening ... Allerhande klomp kryttekeninge deur die kleurlingkinders. (Delete "kleurling" (= coloured) and substitute "... ")

losmaak ... Die osse word al losgemaak en veld toe aangejaag; 'n kaffer stap hul agterna. (Delete "'n kaffer stap hul agterna" (= a Kaffir is following them).)

tamboer ... Ver op die westewind gedra, hoor sy die ritmiese doef-doef van tamboere - tamboere van Kaffers wat op roof en moord uit is" (Delete " tamboere van Kaffers wat op roof en moord uit is" (= - drums of Kaffirs who are intent on plunder and murder).)

uitstalkas ... Die ronde tafeltjie is haar uitstalkas. Alles kan jy daar kry, kompleet 'n Koeliebasaar. (Delete "kompleet 'n Koeliebasaar." (= just like a coolie bazaar).)

It can be questioned why the WAT chose to omit, on the one hand, usage examples of racist lemmas but, on the other hand, not usage examples of other categories of offensive language, for example obscene or sexist lexical items. 
The answer may lie in the sensitive colour and political relations prevailing at present in South Africa. Accordingly, South African lexicographers would be reluctant not only to include racist items in their dictionaries, but in particular to illustrate such entries by means of locally offensive usage examples. Their British and European counterparts, however, do not seem to have any such compunction:- If racist usage examples were available, the diachronic $O E D$, WNT and the Deutsches Wörterbuch included them. Although the synchronic Webster's Third does provide usage examples, including quotations, it sheers away from giving them at racist lemmas or senses, such as Jew and nigger.

\subsubsection{Lombard (1992: 162) comes to the following conclusion (translated):}

Since language is learned mainly in a particular context, attention should be focused in explanatory dictionaries on explicit usage examples that can aid the user to employ a particular lemma with grater proficiency in his own language usage as well as to comprehend it all the more clearly.

Let us now look at some functional aspects of usage examples attached to definientia of racist lexical items, with a view to better comprehension and greater usage proficiency. The lists given under 2.3.1-2.3.4 can be regarded as providing a fairly comprehensive perspective of the various categories of racist lexical items whose definientia could profit by usage examples.

3.4.3.1 To.start with, it is obvious that usage examples can be regarded as convincing evidence of the existence and incidence of the lemma. Coupled to this, the dating of the examples gives an indication of the age and therefore of the degree of establishment in the lexicon of the lemma and its sense(s) as defined. This is clearly illustrated by the 84 quotations of Kaffir, 2 and its derivations and compounds, ranging from 1792 to 1973, in the OED and Supplement. Compare also the 253 quotations of nigger (nigga, niggah) and its derivations, compounds and expressions, ranging from 1633 to 1975 , in the same dictionaries.

3.4.3.2 Reliable quotations can act as proof of the correctness of the sense(s) and racist register of the lemma as stated. Compare the following usage examples of Kaffir:

OED Supplement II (1976): When we ... were young people the word 'kaffir' meant nothing more than to indicate a Black man ... It has deteriorated to such an extent that it offends people with a dark coloured skin and ... we try to avoid it (Deb. Senate S. Afr. 17 May 1973, 2777).

Dictionary of SA English (1991): The Supreme Court ruled yesterday that the word 'Kaffir'. was an insult and awarded an .African damages of R150 (E.P. 
Herald 4.6.76). The Supreme Court ... granted an interdict restraining a white Zonnebloem flat tenant from assaulting ... his black neighbour or calling him a 'kaffir' (C. Times 6.4.91).

Quotations in the OED Supplement II (1976) are also illuminative of the sense and register of nigger, for example:

I hate the bloody niggers. Mustn't call 'em that you know (G. GREENE Heart of matter I. i. 179, 1948). I remember that in conversation, some boys occasionally used 'nigger' in reference to black people. I never dreamt that it was a racial name and generally used with contempt; I just reckoned it was a harmless slang word for a black man (D. ONYEAMA Nigger at Eton iii, 83, 1972).

In view of the usage sensitivity attaching to lexical racist items, it is doubtful whether editorially devised usage examples ought to be given to prove the acceptability of the labels and definientia of such items. It could be argued that the credibility of editorial examples might be suspect due to imaginable bias on the part of the editor. This could especially be the case when the label or definiens is not also substantiated by quotations. The following is a sample of such editorial examples in the WAT (translated):

aia. 2. Term of abuse, indicating a weak-kneed person: Sis, you old aia! Whenever Hennie dares to play with you, you start crying.

Hotnot. I s. 2. Abusive name referring to a Coloured person: Blooming Hotnot, why do you mess up one's stuff like that?

hotnotsdronk. (regional) Very drunk; blind drunk: Everyone could see that he was drunk; he staggered and smelled - simply hotnotsdronk.

Joods I b.n. 2. Miserly, avaricious; cunning, crooked, shrewd: Don't come and try your Joodse tricks here.

Kafferagtig, b.n. en bw. 2. Also kafferagtig. Like (that of) an uncultured Kaffir; uncivilized, ill-mannered: $A$ white man who behaves kafferagtig. Don't be so kafferagtig; dress yourself decently. You should rid yourself of those kafferagtige manners.

3.4.3.3 With one possible exception, it seems that collocations are not used with racist'entries. Can to jew down be regarded as a collocation with jew (verb)? When the difference in meaning between to jew (to get a financial advantage over; to cheat by sharp business practice) and to jew down (to beat down in price; to drive a hard bargain) is taken into account, it is more likely that to jew down should be regarded as a stereotyped expression which should be defined. Compare the following view (translated) of a collocation by Gouws (1989: 227): 
A collocation is a combination of words which are often used together, but which is not a stereotyped expression, because the lexical meaning of the individual words is constantly maintained and the combination does not operate as a lexicalized unit of meaning. A collocation is therefore not a lexical item, but a combination of lexical items. Consequently it is not entered as a lemma.

3.4.4 A last aspect to be considered regarding usage examples of racist lexical items is the question of how many quotations should be given with each entry. Primarily their number may be determined by the functions they can fulfil in the entry. Landau (1984: 166) gives the following view on this point:

Whenever actual citations can be used, especially in larger dictionaries, they should. Actual usage has the weight of authority behind it. It provides documentation for the definition, which is really only an interpretive claim made by the lexicographer. He says the definition means thusand-so based on the citations available, of which the one or two quoted are presumably exemplary. The reader is free to form his own conclusions as to whether the citations are apposite and justify the definition. But the illustrative quotation does more than support the definition; it can indicate its range of application and show whether it is used metaphorically as well as literally.

In line with their historical approach, of which the dating of senses forms an important informative part, diachronic dictionaries would probable use more quotations than synchronic ones. This would probably also be the case with racist lemmas and their senses. (See the figures for quotations of Kaffir and nigger given in 3.4.3.1.) In general it can be stated that the number of quotations used with racist lemmas in synchronic dictionaries would depend on the availability of such quotations as well as on their semantic and pragmatic applicability to the individual lemmas and their definientia.

\section{Conclusion}

The theme of this paper belongs to the comprehensive lexicographical category which is generally described as taboo or offensive lexical items. Ifts aim was, firstly, to survey the types and prevalence of racist language in society, and, secondly, to examine and comment on ways and means by which such language is and could be handled in dictionaries.

The survey showed an extensive range of racist language of which seven distinct categories could be identified. The fairly large number of examples pointed to the existence of a very real and problematic component of the lexicons of various languages. The lexicographer is therefore faced with the heavy 
responsibility of enlightening the speech community on the usage sensitivity and constraints linked to such racist language.

In the section on the treatment of racist language in dictionaries it was argued that racist items should be included in the larger dictionaries but excluded from the smaller ones, such as school dictionaries. As a cautionary usage label, (racist) was suggested, and sample definitions were given. It was also indicated that the lexicological connection between the primary and secondary senses of certain racist lexical items should not be included in synchronic dictionaries. A case was made out for the inclusion of quotations with racist lemmas, but not of editorially constructed usage examples, due to possible bias by the editor. The opinion was also expressed that a smaller number of quotations would be needed with racist lemmas in synchronic dictionaries than in diachronic ones.

Finally, if this study is judged, from a pragmatic perspective, to have contributed to an increased realization of the need for a cautious and cautionary approach to the treatment of racist language in dictionaries, its aims will have been achieved.

\section{References}

A Dictionary of South African English. 1991. Fourth edition. Cape Town: Oxford University Press. Afrikanse Woordelys en Spelreëls. 1991. Eighth, revised edition. Second printing. Cape Town: Tafelberg.

Albertyn, A.P.J. 1984. Die ensiklopedie van name in Suidwes-Afrika. Somerset West: A.P.J. Albertyn.

Aman, R. 1988-89. Offensive Words in Dictionaries. IV. Ethric, Racial, Religious, and Sexual Slurs in an American and an Australian Dictionary. Maledicta 10: 126-135.

A Standard Dictionary of the English Language. Volumes 1-II. 1900. New York and London: Funk \& Wagnalls Company.

A Supplement to the Oxford English Dictionary. Volumes I-IV. 1972-1986. Oxford: Oxford University Press.

Beknopte Verklarende Woardeboek. 1972. Fourth edition. Pretoria: Van Schaik.

Berg C.C. n,d. Report of the Need for Publishing Dictionaries which do not to date exist, prepared by the International Academic Union. n.p.: Conseil International de la Philosophie et des Sciences Humaines.

Beylefeld, A.A. 1992. ' $n$ Ondersoek na taalseksisme as ' $n$ vorm van eensydige leksikografie in enkele Afrikaanse woordeboeke. Unpublished MA thesis. University of the Orange Free State.

Boshoff, S.P.E. and G.S. Nienaber. 1967. Afrikanse etimologieë. Pretoria: Die Suid-Afrikaanse Akademie vir Wetenskap en Kuns.

Burch field, R.W. 1972. Four-Letter Words and the O.E.D. Times Literary Supplement, 13 October 1972: 1233.

Burchfield, R.W. 1974. The Treatment of Controversial Vocabulary in The Oxford English Dictionary. Transactions of the Philological Society, 1973: 1-28. 
Burchfield, R.W. 1980. Dictionaries and Ethnic Sensibilities. Michaels, L. and C. Ricks (Eds.). 1980. The State of the Language: 15-23. Berkeley, Los Angeles, London: University of California Press.

Butteffy List. 1959. Pretoria: The Government Printer.

Cape Peninsula Telephone Directory. 1993-94. Cape Town: Telkom SA Ltd.

Cohen, H. 1988. De Ieek en het verboden woord. Onze Taal 57(5): 76-77.

Deutsches Wörterbuch. Bände I-XXXII. 1854-1961. Leipzig: Verlag von S. Hirzel.

Du Toit, E.L. 1989. Sosiolinguistiese gegewens in handwoordeboeke oan Afrikaans. Unpublished MA thesis. University of Stellenbosch.

Esterhuyse, J. 1987. Die politieke taal van 'n Afrikaanse woordeboek. Du Plessis, H. and T. du Plessis (Eds.). 1987. Afrikaans en taalpolitiek: 123-130. Pretoria: HAUM.

Funk \& Wagnalls New College Standard Dictionary. 1956. New York: Funk \& Wagnalls Company.

Funk \& Wagnalls Standard Dictionary of the English Language. Intemational Edition. 1967. New York: Funk \& Wagnalls Company.

Gouws, R.H. 1986. Afrikaans Lexicography. Hartmann, R.R.K. (Ed.). 1986. The History of Lexicography: 75-83. Amsterdam, Philadelphia: John Benjamins Publishing Company.

Gouws, R.H. 1988. Die gebruik van etikette as leksikografiese hulpmiddel. South African Journal of Linguistics. Occasional Papers 6, April 1988.

Gouws, R.H. 1989. Leksikografie. Pretoria: Academica.

Hauptfleisch, D.C. 1989. Taalseksisme en die woordeboek. Botha, T.J.R. (Ed.). 1989. Leksikografie en Leksikologie: 121-128. Menlopark: Serva-Uitgewers.

Heestermans, H. 1992. Toespraak bij de officiële presentatie van de twaalfde editie van die Grote Van Dale op 31 augustus 1992. Nieuw Letterkundig Magazijn X(2): 40-42.

Jost, D.A. and A.C. Crocker. 1987. The Handling of Down Syndrome and Related Terms in Modem Dictionaries. Dictionaries. Journal of the Dictionary Society of North America 9: 97-109.

Landau, S.I. 1984. Dictionaries. The Art and Craft of Lexicography. New York: The Scribner Press.

Lombard, F.J. 1990. 'n Metaleksikografiese fundering van Afrikaanse skoolwoordeboeke. Unpublished D.Litt. thesis. University of Stellenbosch.

Lombard, F.J. 1991. Die aard en aanbieding van die leksikografiese definisie. Lexikos. AFRILEX series 1: 1991: 158-182.

Lombard, F.J. 1992. Voorbeeldmateriaal in woordeboeke. Lexikos 2: 148-164.

Malige-Klappenbach, H. 1989. Sprache und Ideologie, insbesondere bei der Wörterbucharbeit. Muttersprache 99(2): 153-159.

McCluskey, J. 1989. Dictionaries and Labeling of Words Offensive to Groups, with Particular Attention to the Second Edition of the OED. Dictionaries. Journal of the Dictionary Society of North America 11: 111-123.

Murphy, M.L. 1991. Defining Racial Labels: Problems and Promise in American Dictionaries. Dictionaries. Journal of the Dictionary Society of North America 13: 43-64.

Official Place Names in the Republic of South Africa and in South-West Africa. 1978. Pretoria: The Government Printer.

Raper, P.E. 1972. Streekname in Suid-Afrika en Suidwes. Cape Town: Tafelberg.

Raper, P.E. 1989. Dictionary of South African Place Names. Second edition. Johannesburg: Jonathan Ball Publishers. 
Rousseau, W.L. 1975. Suid-Afrikaanse Pleknaam-Leksikon. Cape Town and Pretoria: Kennis-Uitgewers.

Smith, C.A. 1966. Common Names of South African Plants. Pretoria: The Government Printer.

Smith, M.M. and P.B.N. Jackson. 1975. Common and Scientific Names of the Fishes of Southern Africa. Grahamstown: Rhodes University.

Stein, R.A. 1987. Woordenboeken discrimineren. Onze Taal 56 (7/8): 102-103.

Strau B, G. 1982. Aspekte des Sprachausschnitts 'Politik' im einsprachigen Wörterbuch: Politischideologische Ismen - Lexicographisch betrachtet. Mentrup, W. (Ed.). 1982. Konzepte zur Lexikographie: Studien zur Bedeutungserklärung in einsprachigen Wörterbüchern: 34-64. Tübingen: Max Niemeyer Verlag.

The Concise Oxford Dictionary of Current English. 1990. Eighth edition. Oxford: Clarendon Press.

The Oxford English Dictionary. Volumes I-XII and Supplement. 1933. Oxford: Oxford University Press.

The Random House Dictionary of the English Language. The Unabridged Edition. 1967. New York: Random House.

The South African Pocket Oxford Dictionary. 1987. Cape Town: Oxford University Press.

Van Dale Groot Woordenboek der Nederlandse Taal. 1984. Eleventh edition. Utrecht, Antwerpen: Van Dale Lexicografie.

Van der Spek, E.J. 1987. Discrimineren woordenboeken? Onze Taal 56(4): 46-47.

Van Niekerk, A.E. 1992. Kollokasies: 'n leksikografiese perspektief. Lexikos 2: 254-264.

Webb, V.N. 1989. Enkele gepolitiseerde woorde in Afrikaans, HAT en die sosiolinguistiek. Botha, T.J.R. (Ed.). 1989. Leksikografie en leksikologie: 129-142. Menlopark: Serva-Uitgewers.

Webster's International Dictionary of the English Language. 1891. London: George Bell \& Sons. Springfield: G. \& C. Merriam \& Co.

Webster's Third New International Dictionary of the English Language. Unabridged. 1961. London: G. Bell \& Sons, Ltd. Springfield: G. \& C. Merriam Co.

Whitcut, J. 1984. Sexism in Dictionaries. Hartmann, R.R.K. (Ed.). 1984. LEXeter '83 Proceedings: 141-144. Tübingen: Max Niemeyer Verlag.

Woordeboek van die Afrikaanse Taal. Volumes I-VIII. 1950-1991. Pretoria: The Government Printer. Stellenbosch: Bureau of the WAT.

Woordenboek der Nederlandse Taal. Volumes I-. 1882-. 's-Gravenhage: SDU Uitgeverij.

Zgusta, L. 1971. Manual of Lexicography. Prague: Academia. The Hague, Paris: Mouton.

Zgusta, L. 1988. Lexicography Today: An Annotated Bibliography of the Theory of Lexicography. Tübingen: Max Niemeyer Verlag. 


\title{
Etikette in sinchronies verklarende woordeboeke*
}

\author{
F.J. Lombard, Buro van die Woordeboek van die Afrikaanse Taal, \\ Stellenbosch, Suid-Afrika
}

\begin{abstract}
Labels in Synchronic Descriptive Dictionaries. It is the lexicographer's duty to point out limitations concerning the use of certain lexical items to his target users, for example limitations as far as stilistic application is concerned. This is mainly achieved by using labels. Labels often depend more on the judgement of the lexicographer than on a scientific basis and are often presented haphazardly in dictionaries. Yet the lexicographer can give linguistic as well as pragmatic guidance by using labels correctly. In standard dictionaries various labels should be used judiciously and uniformly for the greatest possible benefit of the user.
\end{abstract}

Keywords: FREQUENCY, GEOGRAPHIC, LABELS, LINGUISTIC, PRAGMATIC, PRESCRIPTIVENESS, SPHERE OF USE, STANDARD DICTIONARY, STILISTIC, SYNCHRONIC, TEMPORAL

Opsomming: 'n Leksikograaf behoort beperkinge op die gebruik van leksikale items, byvoorbeeld ten opsigte van styl, vir die teikengebruikers van sy woordeboek aan te dui. Dit word veral met behulp van etikette gedoen. Etikette berus dikwels op die leksikograaf se oordeel eerder as op wetenskaplikheid en word nie altyd uniform en gebalanseerd in woordeboeke aangebied nie. Tog kan taalkundige en pragmatiese leiding deur middel van korrek aangebode etikette gebied word. In handwoordeboeke behoort 'n verskeidenheid etikette oordeelkundig en uniform aangebied te word sodat die gebruiker maksimaal daarby kan baat.

Sleutelwoorde: ETIKET, GEBRUIKLIKHEID, GEBRUIKSFEER, GEOGRAFIES, HANDWOORDEBOEK, PRAGMATIES, PRESKRIPTIWITEIT, SINCHRONIES, STILISTIES, TAALKUNDIG, TEMPOREEL

\section{Inleidend}

Die opsteller van 'n verklarende woordeboek het dikwels dié dilemma dat hy sekere leksikale items in sy woordeboek moet opneem waarvan die gebruik in bepaalde omstandighede nie wenslik is nie. Omdat sulke woordeskatelemente dikwels ook deel van die gemeenskaplike wete van die taalgebruikers is, is dit

Hierdie artikel is 'n verkorte en aangepaste hoofstuk uit 'n D.Litt.-verhandeling, ' $n$ Metaleksikografiese fundering van Afrikaanse skoolwoordeboeke, wat in Desember 1990 deur die Univerșiteit van Stellenbosch aqnvaar is. 
die verantwoordelikheid van die deskriptiewe leksikograaf om hulle op te neem, selfs al is daar sekere gebruiksbeperkinge.

Die opsteller kan egter nie so 'n woordeskatelement net aanbied en dan glo dat hy sy plig volledig nagekom het nie. 'n Groot deel van enige leksikograaf se werk is om aan sy teikengebruikers gebruiksleiding te gee. Woordeboekgebruikers moet immers baie deeglik op hoogte gehou word van woorde wat byvoorbeeld nie sonder meer in sekere gespreksituasies gebruik kan word nie. Gebruiksleiding wat beperkings van die lemma aandui, of dit nou sosiale, temporele of ander beperkings is, word dikwels met behulp van etikette aangebied. In die hedendaagse leksikografie behoort etikette een van 'n woordeboek se belangrikste middele tot taalbeskrywing te wees.

\section{Die aanwending van etikette}

Etikette word nie net in 'n sensurerende hoedanigheid gebruik nie. Volgens Alberts en Mtintsilana (1988: 8) verwys die term etiket na daardie inskrywing in 'n woordeboekartikel wat as merker optree om die lemma of 'n ander inskrywing se beperkinge ten opsigte van byvoorbeeld stylaard, gebruiksfeer en geografiese voorkoms aan te dui. 'n Etiket help dus om die gebruik van 'n sekere woord binne 'n sekere gebied van die taalgebruik te plaas, en Gouws (1988: 14) beweer daarom tereg dat 'n etiket 'n verband tussen 'n woord en sy gebruik lê.

Daar is 'n hele aantal woordeskatelemente wat geëtiketteer kan word. Terme uit wetenskaplike en tegniese taalgebruik, en woorde wat uit sekere taalkringe kom, van plat tot verhewe woorde, behoort etikette te kry. Indien woorde wat uit verskillende geografiese gebiede kom in 'n woordeboek opgeneem word, moet dit vir die gebruiker deur middel van etikette aangedui word. Ook woorde wat aan vreemde tale ontleen is en wat nog nie ingeburger is nie, behoort geëtiketteer te word (Eksteen, 1965: 79).

Otto (1989: 331-340) en Du Toit (1989: 37-91) onderskei 'n hele aantal etikette, onder andere stilistiese, geografiese, temporele en vaktaaletikette. Die vernaamste gebruik van stilistiese etikette is om bepaalde sosiolinguistiese waardes van lemmas te illustreer en die gebruik van sulke lemmas in gespreksituasies te toon (Gouws, 1988: 32). Lemmas wat nie standaardtaalstatus het nie, word met stilistiese etikette gemerk. Dié merkproses moet 'n aanduiding gee of die lemma 'bo' of 'onder' die standaardtaal lê.

Vanweë beperkte ruimte, neem handwoordeboeke nie baie lemmas op wat geografies gemerk hoef te word nie. Dialektiese variasie moet in 'n omvattende woordeboek tereg kom, maar in 'n handwoordeboek is daar nie genoeg ruimte beskikbaar nie.

Temporele etikette word gebruik om lemmas te merk wat chronolekties van die standaardtaal afwyk (Gouws, 1988: 15). Woorde verouder gedurig of is aan die verouder. Sommige van dié woorde word in boeke teruggevind, of word nog soms in gesprekke gebruik. Dit kan dus gebeur dat die leksikograaf 
van 'n handwoordeboek hulle wil/moet reflekteer. Indien sulke woorde as lemmas in 'n woordeboek opgeneem word, moet hulle temporeel gemerk word. Dit is belangrik dat die leksikograaf sal onderskei tussen woorde wat verouderd is en woorde wat verouderde maar steeds bekende sake aandui. Slegs die eersgenoemde tipe moet (temporeel) gemerk word.

Vaktaaletikette word gebruik om 'n lemma se gebruiksfeer in 'n bepaalde vakgebied of spesialiteitsrigting aan te dui. Otto (1989: 337) wys daa rop dat dié tipe etiket veral gebruik moet word waar 'n polisemiese lemma 'n algemene en 'n gespesialiseerde verklaring het. Kwantumsprong kan hier gebruik word om dit toe te lig. Die een betekenisonderskeiding, naamlik ' $n$ groot sprong, is algemeen van aard, en hoef nie gemerk te word nie. Die ander betekenisonderskeiding is egter gespesialiseerd en moet met 'n vaktaaletiket gemerk word om aan te dui dat dit tot die terrein van die fisika behoort. Du Toit (1989:169) wys tereg daarop dat die etikettering van vakterme op die nie-kenner van die betrokke vakgebied gerig moet word.

\section{Etikette en preskriptiwiteit}

Die meeste woordeboekopstellers probeer om deskriptief te werk te gaan met die materiaal tot hul beskikking. Dit is ' $n$ vraag of dit moontlik is om ook ten opsigte van etikette deskriptief te werk te gaan. Dit is ook 'n vraag of die opsteller van ' $n$ woordeboek ten opsigte van etikettering preskriptief te werk gaan as hy net die norm, wat soms wel 'n sekere sensuurwaarde het, dokumenteer. Daar is uiteenlopende standpunte hieroor.

Volgens Eksteen (1965: 209) moet etikettering dokumenterend en nie preskriptief wees nie. Alberts en Mtintsilana (1988: 9) noem dat daar in deskriptiewe woordeboeke etikette gebruik word wat op semantiese neutraliteit wys terwyl etikette in preskriptiewe woordeboeke 'n sekere sensuurwaarde het. Hierdie-stellings kan bevraagteken word omdat deskriptiewe woordeboeke ook van etikette gebruik maak wat sensuurwaarde het en wat daarom normatief en nie semanties neutraal is nie. Gouws (1988: 6) wys tereg daarop dat etikette vandag nog preskriptief vanuit 'n objektiewe evaluering kan optree.

Die leksikograaf is nie 'n sedemeester wat die taalgebruik normatief probeer beheer nie, maar ' $n$ woordeboek is ' $n$ spieël van die samelewing en die leksikograaf moet dit wat in die samelewing gebeur, opteken. Dit is die deskriptiewe norm van woordeboekmaak. Die leksikograaf kan egter nie die sosiale norm verontagsaam nie, want dan sal hy die gebruiker in die steek laat (Heestermans, 1988: 24, 25). Stein, aangehaal in Odendal (1978: 71), sluit in die volgende woorde by Heestermans aan: "The lexicographer who does not recognize the existence of long-established strictures in usage has not discharged his full responsibility. He has not been objective and factual: he has reported selectively, omitting references to a social attitude relevant to many words and expressions". 
Die opsteller van 'n woordeboek moet daarom deskriptief wees in die aanbieding van stof uit die samelewing, maar hy moet ook normatief wees in die kwalifisering van sommige woorde, anders versuim hy een van sy sentrale take: die aanbied van gebruiksleiding. Soos Heestermans en Stein tereg beweer het, moet die opsteller van 'n woordeboek die sosiale norm weerspieël deur sommige woorde met behulp van etikette te kwalifiseer. Dit is waarskynlik 'n preskriptiewe funksie van die leksikograaf wat in die hantering van etikette uitdrukking sal vind.

\section{Probleme rondom die aanwending van etikette}

Die verkeerde aanwending van etikette of die gebrek daaraan kan belangrike implikasies vir 'n woordeboek hê. Die leksikograaf moet toesien dat sy aanbieding van etikette uniform en gebalanseerd is. Cowie (1980: 205), en Monson (1973: 209) beweer tereg dat daar nog dikwels arbitrêre en inkonsekwente besluite ten opsigte van etikettering geneem word. Die leksikograaf moet sorg dra dat etikette nie op sy subjektiewe oordeel berus nie.

Die grootste problematiek met betrekking tot etiketaanduiding het juis te doen met 'n gebrek aan wetenskaplikheid. Bailey (1980: 310) is dus heeltemal reg as hy beweer dat die leksikograaf se artistieke gevoel eerder as 'n suiwer wetenskaplike begronding tot dusver die grootste rol gespeel het by die toekenning van etikette. Dié probleem kom voor omdat sommige leksikograwe nog steeds die bedenklike praktyk volg deur 'n woordeboek sonder 'n databasis saam te stel. In so 'n geval werk die leksikograaf nooit met konteks nie, maar slegs met gevoel. Die resultaat gee aanleiding tot die etiketteringspraktyk wat Cowie en Monson hierbo kritiseer.

Onwetenskaplike etikettering kan grotendeels ondervang word deur van 'n databasis, veral 'n elektronies-geindekseerde databasis, gebruik te maak. Hoe groter so 'n databasis, des te wetenskapliker kan die leksikograaf met etikette omgaan omdat hy met werklike taalmateriaal werk. Die leksikograaf hoef hom dus nie tot raaiwerk of sy subjektiewe taalgevoel te wend nie. 'n Tweede faktor wat waarskynlik tot meer geloofwaardige etikettering sal bydra, is die standaardisering van etikette. Dit is hoog tyd dat daar in die Afrikaanse leksikografie werk gemaak word hiervan.

Normaalweg word die standaard taal ongemerk in handwoordeboeke aangebied. Dit kan dus aanvaar word dat lemmas wat ongemerk in woordeboeke voorkom, die standaardtaal verteenwoordig. Lemmas moet daarom so gemerk word dat afwykings van die standaardtaal gereflekteer word. In dié opsig is dit voorbeeldige leksikografie as Verklarende Handwoordeboek van die Afrikaanse Taal (HAT) die bywoord dikwerf as (verh.) merk, maar twyfelagtige leksikografie as dikkop in die betekenisonderskeiding van domkop, onnosel persoon nie gemerk word nie. 
Die opstellers van Nasionale Woordeboek (voortaan NW) maak hulle soms ook skuldig aan inkonsekwente en gebrekkige etikettering. Hidroponika, hipallage, hiperbaton, hipotaksis, hipsometer en histologie word nie in NW geëtiketteer nie. Hierdie lemmas het standaardtaalstatus, maar dit is te bevraagteken of hierdie gespesialiseerde lemmas omgangstaalstatus het. Die gebruiker moet in sulke gevalle tegemoet gekom word. Dit is ook inkonsekwente aanbieding as hiposentrum gemerk word (met die vaktaaletiket geol.) maar die bogenoemde lemmas nie. Die leksikograaf kan meer doen om die gebruiker tegemoet te kom deur stelselmatig en konsekwent te etiketteer.

Sommige etikette wat toegeken word, is ook nie akkuraat nie. In NW word kruiwa, 2 geëtiketteer met (skerts.). Die betekenis van kruizwa, 2 is "voorspraak by die verkryging van 'n betrekking". Die etiket skerts. is in dié geval nie akkuraat genoeg nie. Skertsend het net 'n positiewe waarde, maar kruiwa word in die betekenisonderskeiding hierbo dikwels sarkasties of spottend gebruik. 'n Goeie databasis sou dit in die geval uitgewys het.

Dit is nie net handwoordeboeke wat leemtes ten opsigte van etikettering vertoon nie. Volgens Monson (1973: 209) moes die Redaksie van.Webster's Third New International Dictionary of the English Language (voortaan W3) baie kritiek verduur omdat hulle minder etikette gebruik het terwyl daar meer van illustratiewe aanhalings gebruik gemaak is om kontekstuele leidrade te verskaf. Ook Odendal (1978: 71) wys daarop dat Gove (die Hoofredakteur), in 'n mate skuld gehad het aan die fel kritiek wat teen W3 uitgespreek is omdat etikette nie genoeg aandag gekry het nie, en in Odendal se woorde, nie "geraffineer" genoeg was nie.

\section{Die funksie van etikette}

Etikette geniet prominensie ten opsigte van hulle plasing en die informasie wat hulle deurgee. Omdat etikette normaalweg in 'n fokusposisie in die artikel staan, is hulle verantwoordelik vir 'n onmiddellike inligtingsoordrag met die eerste deurlees van 'n woordeboekartikel. Dit is daarom belangrik dat etikette maklik verstaanbaar moet wees. Dit is verder belangrik dat teikengebruikers tegemoet gekom word deur konsekwente etikettering.

As etikette reg hanteer word, kan dit 'n belangrike beskrywingsapparaat in 'n woordeboek wees. Gouws (1988: 4, 5) beklemtoon dié feit. Volgens Gouws $(1988: 6,7)$ is etikette die inskrywingstipe waarin taalkundige én pragmatiese leiding aan die gebruiker verskaf kan word. Taalkundige leiding wat verskaf kan word, is byvoorbeeld die wat rondom die verandering wat in taal kan plaasvind, voorkom. Dit is die leksikograaf se plig om sy teikengebruikers op hoogte te hou daarvan. Een van die maniere waarop dit gedoen kan word, is deur intelligente, gebalanseerde gebruiksinligting en in dié opsig kan etikette van groot waarde wees. 
Etikette speel nie net 'n inligtinggewende rol rondom gebruik nie; dit kan ook by die aanbieding van betekenis 'n belangrike funksie verrig deur die gebruiker onmiddellik te plaas ten opsigte van die definiendum. 'n Etiket kan nie alleen die gedifferensieerde aard van die woordeskat wat in woordeboeke tuisgebring word, weergee nie, maar dit kan ook ' $n$ faktor by die betekenisomskrywing van sekere woorde wees (Eksteen, 1965: 210). Die (gebruik)sfeeretikette landm. (landmeetkunde), sweiswerk, drukk. (drukkuns) en kartogr. (kartografie) kan byvoorbeeld help om die terme kontoerplan, kontoersimbool, kontoerplaat en kontoertekening vir die gebruiker te plaas. Omdat etikette lemmas in bepaalde semantiese velde plaas, het dit 'n bepaalde dekoderende funksie.

Pragmatiese inligting wat deur etikette aangebied kan word, is onder meer waar die gepastheid of nie van 'n.woord vir 'n sekere gespreksituasie aangedui word. Op dié wyse dra goeie etikettering by tot suksesvolle kommunikasie. In hierdie opsig vervul etikette dikwels 'n tipe deiktiese funksie deurdat dit die verband tussen 'n woord en die gebruik daarvan lê (Gouws, 1988: 14, Alberts en Mtintsilana, 1988: 9, Kirkpatrick, 1985: 12). Dit is byvoorbeeld die funksie van stilistiese etikette om sosiolinguistiese beperkings van lemmas en die gebruik daarvan in gespreksituasieverband aan te toon (Gouws, 1988: 32).

Etikette kan die leksikograaf ook help om tussen verskillende tipes taalkundige inligting te onderskei - tot voordeel van die gebruiker. Gouws (1988: 39) wys daarop dat leksikografiese benoeming wat per etiket aangedui word, die leksikograaf in dié verband kan help. Die meeste woordeboeke maak van etikette gebruik om bepaalde taalkundige inligtingstipes oor te dra. Metaforiese of figuurlike taalgebruik en gevalle wat na die Engels is, word byvoorbeeld deur middel van etikette in Afrikaanse handwoordeboeke aangedui. Preston (1977: 79) glo dat etikette in algemene woordeboeke eerder sosiale as linguistiese markeerders moet wees, maar etikette se funksie kan wyer strek, ook in algemene woordeboeke.

Een van die voordele van etikette kom voor waar die definiendum nie volgens die tipiese patroon van genus en differentia verklaar kan word nie en waar die klas of kategorie waartoe die lemma behoort, dus nie eksplisiet genoem kan word nie. In so 'n geval vervul die etiket dieselfde rol as wat die genus normaalweg vervul, naamlik om die gebruiker dadelik ten opsigte van die betrokke lemma te plaas. Die etiket skaak plaas byvoorbeeld die gebruiker dadelik in die prentjie ten opsigte van die lemma koningperd.

Die belangrikheid van etikette blyk daaruit dat woordeboeke beoordeel word volgens die etikette wat daarin aangebied word sowel as die gebruiksleiding ten opsigte daarvan wat voor in die toeligting gegee word (Amold, 1980: 76). Wells (1973: 108) vat die belang van etikette goed raak as hy die volgende beweer: "Certainly a general dictionary is often consulted for the connotative value of a word, or to determine whether a word is appropriate to a certain situation. To present 'every word mysteriouly labeled for its best contextual appearance' is to fix limits to language; but to find knowledgeable commentary on the sets of relationships which exist between words and the general 
situational characteristic of their use is not to ask too much of a general dictionary".

\section{Die aanwending van etikette in Afrikaanse handwoordeboeke}

\subsection{Inleidend}

Etikette, veral dié wat aandui dat sekere woorde formeel of informeel, sleng of taboe is en die wat die definiendum van 'n gespesialiseerde of tegniese lemma presies vir die gebruiker plaas, is vir die gebruikers van 'n woordeboek belangrik. Dit is ook belangrik vir gebruikers wat nog hul moedertaal leer ken, en daarom het die opstellers van handwoordeboeke wat dikwels in skoolverband gebruik word, 'n wesenlike plig in hierdie verband.

Die soort woordeboek wat geskryf word, bepaal die etikette wat aangebied word na hoeveelheid en tipe. Aangesien handwoordeboeke tot 'n groot hoogte slegs die standaardtaal reflekteer, word etikette wat gebruik word om afwykings van die standaardtaal aan te dui, nie so algemeen daarin gebruik as in omvattender woordeboeke nie. Woorde en woordbetekenisse wat nie in stilistiese opsig gelykwaardig is nie, moet egter gereflekteer word. In 'n handwoordeboek kan daar egter nie so baie stilistiese onderskeidings soos in groter woordeboeke gemaak word nie; .minder stilistiese etikette kom gevolglik daarin voor.

Alhoewel 'n handwoordeboek minder woorde opneem wat byvoorbeeld ongewoon, weinig gebruiklik, verhewe of plat is (teenoor 'n omvattende woordeboek), moet gevalle wat wel opgeneem word, gemerk word sodat die deiktiese funksie waarvan Gouws praat, vervul kan word. Op dié wyse kry die gebruiker waardevolle gebruiksinligting. Indien die lemma mynersyds byvoorbeeld opgeneem word, moet die gebruiker daarop gewys word dat dit verhewe taalgebruik, en nie deel van die alledaagse gebruikswoordeskat is nie. Aan die ander kant moet 'n kragterm soos bliksem as 'n vloek gemerk word. Indien die handwoordeboekopsteller nie lemmas merk wat 'bo' en 'onder' die standaardtaal is nie, laat hy sy teikengebruikers in die steek. Van 6.2 tot 6.6 (wat hierop volg) word voorstelle ten opsigte van etikette en etikettering gemaak vir moontlike gebruik in sinchronies verklarende Afrikaanse woordeboeke.

\subsection{Stilistiese etikette}

Daar is reeds vermeld dat 'n handwoordeboek nie te veel stilistiese etikette behoort aan te wend nie. Dit kan die gebruiker verwar en die leksikograaf se taak vertraag en bemoeilik. Dit is veral noodsaaklik vir gebruikers om te weet of 'n woord standaardtaalstatus het of nie, en indien nie, of die woord substandaard of superstandaard is. Omdat daar oorvleueling tussen sosiolektiese en 
stilistiese etikette is, kan daar na dié etikette as sosiostilistiese etikette verwys word. Vanweë die subjektiewe aard van baie van hierdie etikette, is dit moeilik om vaste riglyne neer te lê wat almal tevrede sal stel.

Die etiket verhewe kan gebruik word om alle leksikale items wat bo die neutrale vlak van die standaardtaal lê, dit wil sê leksikale items wat tot formele, superformele of superstandaardtaal behoort, te merk. Voorbeelde van dié tipe leksikale items is jongkragtig, ween, ontslaap, poog, ensovoorts.

Daar is 'n hele paar etikette wat gebruik kan word om leksikale items te merk wat wissel van geselstaal wat informeel is tot woorde wat meer gestigmatiseer is, byvoorbeeld taboewoorde en -uitdrukkings. Die spektrum van leksikale items wat onder die standaardtaal lê, wissel van items soos gô, poegaai, makietie, ensovoorts, tot items soos kak, moer en poep.

Die etiket geselstaal kan gebruik word vir die markering van leksikale items wat net effens onder die neutrale vlak van die standaardtaal lê, byvoorbeeld $g \hat{0}$, gorrel (as werkwoord), poegaai, makietie, bakgat, ensovoorts. Leksikale items wat sonder sterk sarkasme of neerhalendheid gebruik word ter wille van die verkryging van 'n humoristiese effek, byvoorbeeld boetebessie, kranswagter, kripvreter, ensovoorts, kan met die etiket skertsend gemerk word.

Vir name van plante, diere, kwale, ensovoorts, wat nie-wetenskaplik is en wat in die volksmond ontstaan het, kan die etiket volksnaam gebruik word. 'n Voorbeeld van dié tipe is 'n geval soos kuikendief. Die probleem wat dikwels in rierdie besondere geval voorkom, is dat leksikale items wat in die volksmond leef, dikwels so algemeen word dat dit nie meer geëtiketteer hoef te word nie. Dit is byvoorbecld nie nodig om kelkiewyn (vir 'n patrys), klem-in-die-kaak en pampoentjies te etiketteer nie.

Leksikale items wat 'n neerbuigende of geringskattende houding van 'n spreker verraai, dit wil sê items wat dikwels in neerhalende of minagtende verband gebruik word en wat deel uitmaak van beledigende taalgebruik, kan met die etiket neerhalend gemerk word. Leksikale items wat met dié etikette gemerk word, kan nog nie as taboewoorde getipeer word nie. Die leksikograaf het veral met dié tipe 'n taak om die gebruiker te waarsku dat sekere woorde of uitdrukkings beledigend of neerhalend kan wees. Deur rassistiese, seksistiese of ander kwetsende items te etiketteer, lê die leksikograaf 'n norm neer vir die gebruiker. Voorbeelde van dié tipe is boer, hond (vir die polisie), hotnot, wyf, ensovoorts.

Leksikale items wat 'n spreker/skrywer se oordeel verraai, en kragwoordstatus benader, kan met die etiket skeltaal gemerk word. Die onderskeid tussen skeltaal, plat taal en vloektaal is nie altyd duidelik nie. In dié verband kan Feinauer (1981: 7) se bevindings die leksikograaf help. Sy onderskei skeltaal van plat taal deur die semantiese kenmerke [+menslik] [+karaktertekenend] aan skeltaal toe te ken. Voorbeelde van dié tipe is esel, buffel, pampoen, swernoot, ensovoorts.

Leksikale items wat 'n taboewaarde het en wat gebruik word om 'n saak te benoem waarvan 'n sagter ekwivalent gewoonlik bestaan, kan met die etiket 
plat gemerk word. Volgens Feinauer het die tipe leksikale items 'n hoër taboewaarde as skeltaal. Aan die ander kant het vloeke en vulgêre leksikale items volgens haar 'n hoër taboewaarde as plat taal. Voorbeelde van leksikale items wat met die etiket plat gemerk kan word, is kaalstert, pram, snot. Leksikale items wat kragwoorde en uitroepe verteenwoordig wat dikwels ter verkryging van 'n bepaalde effek gebruik word, byvoorbeeld met die opset om te skok, en wat dikwels met die weer en buitekonteksgebruikte godsdienswoorde te doen het, kan met die etiket vloektaal gemerk word. Voorbeelde is bliksem, gotta, donder, ensovoorts.

Die leksikale items wat die hoogste taboewaarde het, is dié wat veral verwys na die onaanvaarbare sosiale gebruik van die laer liggaamsdele, en hulle funksies en produkte. Feinauer (1981: 16) wys daarop dat sulke woorde 'n baie sterk sosiale stigma het. Die etiket vulgêr kan gebruik word vir leksikale items soos poep, skyt, stront, ensovoorts.

Alhoewel Feinaeur se taboehiërargie baie waardevol vir enige leksikograaf kan wees, moet dit in gedagte gehou word dat van haar kategorieë kan oorvleuel. Die lemma stront kan gebruik word om dit te illustreer:

stront (vulgêr) I s.nw. 1 Uitwerpsel: Ek het in 'n bol stront getrap. 2 (skeltaal) Onaangename persoon: $H y$ is ' $n$ regte ou stront. II tw. (vloektaal) Uitroep waarmee ontevredenheid of frustrasie te kenne gegee word: "Stront!" roep hy uit toe hy sy duim raakslaan.

In betekenisonderskeiding 2 word die lemma stront gebruik om mee te skel, maar dit bly vulgêre skeltaal. In II het 'n mens te make met vloektaal en wel met vulgêre vloektaal. Die bogenoemde hantering is myns insiens 'n akkurater refleksie van die leksikale item stront se status as om dit net oorkoepelend met vulgêr te merk.

\subsection{Geografiese etikette}

'n Handwoordeboek het nie ruimte om te veel lemmas op te neem wat geografies geëtiketteer moet word nie. Waar dit egter wel gebeur dat gebiedsgebonde lemmas om bepaalde redes opgeneem word, lyk dit sinvol om Du Toit (1989: 167) se raad te volg deur 'n geografiese etiket te kies wat presies dui op die gebied of plek waar ' $n$ bepaalde vorm algemeen voorkom.

\subsection{Gebruiklikheidsetikette}

Dit is wenslik dat die gebruiklikheid van woorde vir die handwoordeboekgebruiker aangedui word. Geen aanduiding word benodig indien lemmas standaardtaalstatus en 'n normale gebruiksfrekwensie het nie, maar woorde wat minder algemeen of gebruiklik is, moet as sodanig gemerk word. Die etiket 
ongewoon, wat maklik verstaanbaar is, kan in so 'n geval vir laars, kurieus, blaak, gemelik, ensovoorts, gebruik word. Gevalle wat nie ongewoon is nie, maar wat wel skaarser as ander (wisselvorm- of sinoniem)gevalle is, kan met die etiket minder gebruiklik gemerk word. Die voornaamwoord hul (vir hulle) is byvoorbeeld nie ongewoon nie, maar net minder gebruiklik as hulle.

\subsection{Temporele etikette}

Temporele etikettering moet ook in 'n handwoordeboek beperk aangebied word. Woorde wat verouderd of verouderend is, behoort alleen met groot omsigtigheid as makrostruktuurelemente tereg te kom. Dit kan egter voorkom dat sommige van hierdie woorde, byvoorbeeld argaïsmes, wel opgeneem word. In so 'n geval moet hulle temporeel gemerk word. Ook ten opsigte van temporele etikette moet die leksikograaf nie te 'n wye net span nie. Dit lyk asof twee tipes in die temporele kategorie onderskei kan word, naamlik leksikale items wat na 'n saak verwys wat nie meer vir die hede relevant is nie, en leksikale items waarvan die saak in onbruik, maar nog steeds relevant vir die hede is. Leksikale items waarvan die Iekseem nog bekend is in die standaardtaal, maar waarvan die saak verouderd geraak het, moet nie geëtiketteer word nie. Dit is byvoorbeeld nie nodig om kakebeenwa of laer te etiketteer nie.

Leksikale items wat verouderd is en waarvan daar 'n meer bekende en gebruiklike sinoniem bestaan, moet met die etiket verouderd gemerk word. In dié geval word daar streng linguisties geëtiketteer omdat die lekseem en nie noodwendig die saak nie, verouderd is. Voorbeelde van dié tipe is snaphaan, jongeliede, meug, muid(jie), ensovoorts.

'n Leksikale item waarvan die lekseem én die saak verouderd geraak het, kan met die etiket histories gemerk word. Sulke woorde het 'n lae gebruiksfrekwensie en hulle sal nie sonder meer in 'n handwoordeboek opgeneem word nie. Indien Ieksikale items soos landauer, kwispedoor, ensovoorts, opgeneem word, behoort hulle egter gemerk te word.

\subsection{Gebruiksfeeretikette}

Aangesien ons in 'n tegnologies snel ontwikkelende wêreld leef, kom daar waarskynlik meer tegniese en gespesialiseerde woorde in handwoordeboeke voor as wat algemeen vermoed word. Terme van dié aard wat 'n redelike lae gebruiksfrekwensie het, behoort deur middel van vaktaaletikette gemerk te word. Vaktaaletikette slaag meermale daarin om die gebruiker deur die onmiddellike inligtingsoordrag ten opsigte van die lemma te plaas. Sulke etikette het dus dikwels 'n dekoderende waarde. Voorbeelde van dié tipe etikette is landmeetkunde, sweiswerk, houtwerk, ensovoorts. 


\subsection{Slotsom}

'n Handwoordeboekopsteller moet seker maak dat alle lemmas wat nie tot die standaardtaal behoort nie, gemerk word. Die etikette wat gebruik word, moet verder volledig in die toeligting van die woordeboek verklaar word. Die toeligting van die meeste handwoordeboeke in Afrikaans is in dié verband ontoereikend.

Etikette mag nie lukraak of inkonsekwent toegeken word nie. Dit kom meermale in handwoordeboeke voor dat leksikale items wat op dieselfde wyse gemerk moet word omdat hulle aan dieselfde beperkings onderhewig is, verskillend hanteer word. Dit is nodig dat daar met die aanbieding van etikette, soos met die aanbieding van ander inligtingstipes, 'n uniformiteit en konsekwentheid van aanbieding moet wees. Die etikette wat aangewend word, moet ook maklik begrypbaar wees; daarom moet vreemde of onbekende woorde nie as etikette gebruik word nie. Etikette wat in 'n handwoordeboek gebruik word, moet myns insiens ook nie afgekort word nie omdat dit die onmiddellike inligtingsoordrag waarvoor etikette verantwoordelik is, in die gedrang kan bring.

Die behoeftes van die teikengebruikers van 'n woordeboek is bepalend by die keuse van etikette. Omdat etikette die taalgebruiker met intelligente, gebalanseerde en ingeligte gebruiksleiding kan help, is leidinggewende etikettering belangrik. Nie alleen kan etikette 'n sensurerende waarde hê nie, maar die onkundige gebruiker kan ook deur middel van veral vaktaal- en gebruiksetikettering dadelik ten opsigte van 'n lemma geplaas word.

Ter afsluiting kan Du Toit (1989: 171) oor etikette en hulle belangrikheid aangehaal word: "... Gebruiksleiding in handwoordeboeke (is) nie slegs 'n bykomende hulp nie, maar 'n noodsaaklikheid. 'n Woordeboek is waarskynlik die enigste bron waar die gewone taalgebruiker leiding sal kry oor sekere aspekte van temporele of geografiese beperktheid, of die gebruiksfeer, stylaard, gebruiksfrekwensie, en status van leksikale items. Dit behoort die redaksionele beleid van álle woordeboeke, omvattendes sowel as handwoordeboeke, te wees om op die basis van ekstensiewe navorsing en oorleg, gebruiksleiding deur etikette te verskaf".

\section{Verwysings}

\section{Woordeboeke}

De Villiers, M. e.a. 19856. Nasionale Woordeboek. Kaapstad: Nasou.

Gove, P.B. 1961. Webster's Third New International Dictionary of the English Language. Springfield, Massachusetts: Merriam-Webster.

Odendal, F.F. e.a. 19792. VerkJarende Handwoordeboek van die Afrikaanse Taal. Doomfontein: Perskor. 


\section{Ander bronne}

Alberts, M. en P. Mtintsilana. 1988. Leksikografiese ontleding van Afrikaanse en Afrikatale-leksikon. RGN-verslag LEXI-2. Pretoria: RGN.

Arnold, D.I. 1980. College-Level Dictionaries and Freshman Composition. Dictionaries 2-3, 198081: 69-79.

Bailey, R. 1980. Bespreking oor Ekbo se Reflections on Some Kind of Information Given in Historical Dictionaries. Pijnenburg, W. en F. de Tollenaere (Reds.). 1980: 310.

Cowie, A.P. 1980. Lexicography and its Pedagogic Applications. Applied Linguistics II(3): 203-206.

Du Toit, E.L. 1989. Sosiolinguistiese gegewens in woordeboeke. Ongepubliseerde M.A.-verhandeling. Universiteit van Stel]enbosch.

Feinauer, A.E. 1981. Die taalkundige gedrag van vloekwoorde in Afrikaans. Ongepubliseerde M.A.verhandeling. Universiteit van Stellenbosch.

Eksteen, L.C. 1965. Die leksikale definisie. 'n Leksikografiese ondersaek. Ongepubliseerde D.Litt.proefskrif. Universiteit van Pretoria.

Gouws, R.H. 1988. Die gebruik van etikette as leksikografiese hulpmiddel. S.A. Tydsknif oir Taalkunde. Geleentheidsuitgawe 6: 1-56.

Heestermans, H. 1988. Woordenboek: wetboek of archief? Nieuw letterkundig magazijn, Des. 1988: 24-25.

Hobar, D. (Red.). 1982. Papers of the Dictionary Society of North America 1977. Terre Haute, Indiana: The Dictionary Society of North America, Indiana State University.

Ilson, R. (Red.). 1985. Dictionaries, Lexicography and Language Learning. Oxford: Pergamon Press.

Kirkpatrick, B. 1985. A Lexicographical Dilemma: Monolingual Dictionaries for the Native Speaker and for the Learner. Ilson, R. (Red.). 1985: 7-13.

McDavid, R.I. Jr. en A.R. Duckert (Reds.). 1973. Lexicognaphy in English. Annals of the New York Academy of Sciences 211. New York: The New York Academy of Sciences.

Monson, S.C. 1973. Restrictive Labels - Descriptive or Prescriptive? McDavid, R.l. Jr. en A.R. Duckert (Reds.). 1973: 208-212.

Odendal, F.F. 1978. Die gesag van die woordeboek. Snyman, H. (Red). 1978: 65-77.

Otto, A.N. 1989. Kriteria vir 'n Afrikanse aanleerderwoordeboek. Ongepubliseerde D. Litt.-verhandeling. Universiteit van Stellenbosch.

Pijnenburg, W. en F. de Tollenaere (Reds.). 1980. Proceedings of the Second Intermational Round Table Conference on Historical Lexicography. Dordrecht: Foris Publications.

Preston, D.R. 1977. Distinctive Feature Labeling in Dictionaries. Hobar, D. 1982: 78-93.

Snyman, H. (Red.). 1978. Uit vier windstreke. Kaapstad: Nasou.

Wells, R.A. 1973. Dictionaries and the Authoritarian Tradition. Den Haag: Mouton. 


\title{
Die nuwe $A W S$ in die praktyk: 'n gebruikersoorsig na twee jaari
}

\author{
J. du T. McLachlan, Taalpraktisyn, Pretoria, Suid-Afrika
}

\begin{abstract}
The Afrikaanse Woordelys en Spelreëls in Practice: A User's View after Two Years of Use. A language practitioner takes a critical look at the eighth improved edition of the Afrikaanse Woordelys en Spelreels, the authoritative Afrikaans spelling list and spelling rules, after using it intensively for two years. The first impression contains many confusing typographical errors, but these have for the most part been corrected in the second. In many respects the Eighth Edition is an improvement on its predecessor; the rules are explained more comprehensively and the spelling list and abbreviations list are greatly expanded. The spelling list contains more information for the user, for example more diminutives, degrees of comparison, attributive past participles and certain compounds the styling of which often presents problems for writers of Afrikaans. However, some of these rules create problems: they complicate established usage unnecessarily, are formulated inadequately and are difficult to apply in practice, and the examples are too simplistic. The list also contains many apparent inconsistencies the ordinary user may find incomprehensible and confusing. The conclusion is that, while the publication is in many respects more user-friendly than its predecessor, it lacks the necessary consistency and cohesion. Many shortcomings could have been eliminated if the complete draft had been submitted to language practitioners to use and evaluate in practice.
\end{abstract}

Keywords: ABBREVIATIONS, COMPREHENSIVE EXPLANATIONS, DEGREES OF COMPARISON, DIMINUTIVES, EDITING, EXPANSIONS, INCONSISTENCIES, INDEX, LANGUAGE DESIGNATIONS, LINK PHONEMES, NEW RULES, NEW WORDS, NUMERALS, OVERALL IMPRESSION, PAST PARTICIPLES, PROPER-NAME RULE, SEPARATED COMPOUNDS, SPELLING LIST, SPELLING RULES, TERMS, VULGAR FRACTIONS

Opsomming: Die agste, verbeterde uitgawe van die Afrikaanse Woordelys en Spelreëls word na twee jaar se intensiewe gebruik in die taalpraktyk krities beskou. Hoewel die eerste druk heelwat verwarrende setfoute het, is dit in die tweede druk grotendeels reggestel. Die $A W^{8}{ }^{8}$ het heelwat verbeteringe vergeleke met sy voorganger, soos omvattender omskrewe reëls en 'n grootliks uitgebreide woordelys en afkortinglys. Die woordelys bevat meer inligting, soos meer verkleiningsvorme, trappe van vergelyking, adjektiwies gebruikte voltooide deelwoorde en samestellings waarvan die skryfwyse problematies kan wees. Terselfdertyd lewer van die reëls probleme op omdat hulle onnodig kompliserend is, ontoereikend geformuleer is, eensoortig geillustreer is of prakties moeilik toegepas word. Daar is ook heelwat oënskynlike inkonsekwenthede in die woordelys wat vir die gewone gebruiker onbegryplik en verwarrend is. Die gevolgtrekking is dat hoewel die $A W^{8}{ }^{8}$ in sommige opsigte gebruikersvriendeliker as sy voorganger is, daar by die opstel daarvan skynbaar te seksioneel te werk gegaan is en dat hegter koördinering nodig was. Baie tekortko- 
minge sou uitgeskakel gewees het as die konseppublikasie eers aan taalpraktisyns voorgelê is om in die praktyk te toets.

Sleutelwoorde: AFKORTINGS, AFSTANDSAMESTELLINGS, BREUKNAME, EIENAAMREëL, EIETYDSE WOORDE, GEHEELINDRUK, INDEKS, INKONSEKWENTHEDE, NUWE REËLS, OMVATTENDER OMSKRYWINGS, SPELREëLS, TAALNAME, TEKSVERSORGING, TELWOORDE, TERME, TRAPPE VAN VERGELYKING, UITBREIDINGS, VERKLEINWOORDE, VOEGSELS, VOLTOOIDE DEELWOORDE, WOORDELYS

\section{Inleidend}

\subsection{Kritiese beskouing}

Die nuwe Afrikaanse Woordelys en Spelreëls ${ }^{2}$ (hierna $A W^{8}$ ) het nagenoeg twee jaar gelede verskyn. Ten tyde van die vrystelling is daar heelwat gesê oor veral die groter vryheid wat dit vir gebruikers van Afrikaans sou bring en die groter gebruikersvriendelikheid daarvan. Na twee jaar van intensiewe gebruik van die $A W S^{s}$ kan uitsprake soos dié, maar ook die publikasie as geheel, seker weer krities beskou word.

\subsection{Praktyk as uitgangspunt}

Die bespreking wat volg, is die mening van 'n taalpraktisyn wat daagliks die reëls van die $A W S^{8}$ moet toepas en daagliks vrae oor Afrikaanse taalgebruik (dikwels met spesifieke verwysing na die. $A W S^{8}$ ) moet beantwoord, en wil dus nie voorgee om 'n suiwer taalwetenskaplike of leksikografiese analise te wees nie. Die menings is my eie (hoewel ek die insigte wat verskeie kollegas met my gedeel het, met dank erken) en die kritiek wat uitgespreek word, is nie puntenerigheid of foutsoekerigheid nie, maar spruit sonder uitsondering voort uit probleme en navrae wat uit die harde werklikheid van die praktyk gekom het.

\section{Verbeteringe}

\subsection{Gebruikersvriendelikheid}

Die $A W S^{8}$ is inderdaad in sommige opsigte gebruikersvriendeliker as sy voorganger, maar dan moet ' $n$ mens die boek in sy geheel deeglik leer ken. Dit is terselfdertyd egter ook 'n punt van kritiek, want diegene wat dit nie doen of die nodigheid daarvar. insien nie, kan maklik onder ' $n$ wanindruk kom as hy die AWS ${ }^{8}$ bloot selektief of lukraak as vinnige naslaanbron gebruik. Dit is hoofsaaklik die gevolg van die feit dat sekere alternatiewe wat in die spelreël- 
gedeelte gegee word, nie in die woordelysgedeelte gereflekteer word nie. Die Taalkommissie (TK) meld hierdie feit wel duidelik op verskeie plekke (o.a. op pp. 6 en 7), maar 'n mens moet nogal kophou om te onthou watter alternatiewe nié in die woordelys gegee word nie (vgl. byvoorbeeld p. $13 \# 33^{3} 3.1$ en p. 24 \# 3.4(1), teenoor p. 24 \# 3.1). Die TK sou die AWS \&baie meer gebruikersvriendelik gemaak het as hy by die talle inskrywings in die woordelys ten opsigte waarvan daar keuses in die spelreëls gelaat word, 'n kommentaarsimbool aangebring het om die gebruiker se aandag daarop te vestig dat hy 'n keuse het.

\subsection{Omvattender omskrywings}

Die $A W S^{8}$ is heelwat lywiger as die vorige uitgawe: die woordelys is langer met meer "probleem"-samestellings en die afkortinglys is ' $n$ reuseverbetering op die vorige.

Die spelreëls is eweneens omvattender omskryf en geillustreer, en is in sommige opsigte ook toegankliker. Nietemin is die "wetenskaplike" inslag daarvan - wat 'n sekere taalkundekennis, en minstens vertroudheid met die terme in die termlys, veronderstel - blykens talle navrae wat ek al ontvang het, soms 'n probleem. So byvoorbeeld moet die gewone gebruiker direk die verskil tussen afleidings en samestellings ken om die deelteken $x$ koppeltekenreël op p. 32 \# 1.1.2(1) - die verskil tussen geëien en toe eien - te kan toepas.

Daarenteen word die beginsel agter die skryfwyse van ekonomieseklaspassasier e.d. nóg op p. 36 nóg op p. 72 of elders verklaar. 'n Eenvoudige verduideliking van die verskil tussen konstruksies soos warm waterbottel en warmwaterbottel en 'n saaklike reëlformulering daarby sou al baie help. Eweneens word die stelsel van meervoudsvorming by sekere tipes koppelinge (p. $28 \# 4$ ) byvoorbeeld glad nie verklaar nie. Hier moet m.i. gesê word hoekom dit luitenantgeneraals maar direkteurs-generaal is.

\subsection{Eietydse woorde}

Die woordelys bevat ook heelwat eietydse woorde en verbindings wat nou deur die TK as Standaardafrikaans gesanksioneer is, of wat so gedurig verkeerd gespel of geskryf word. Die lys sluit woorde in wat in die pers opsien gebaar het, soos steak en tjopper, maar ook talle ander, soos -

affair, berese $\mathrm{x}$ bereisde, blosser, braaivleis (die kos én die geleentheid), country (musiek), drein -e of -s, drom ('n - petrol), dwelm -s, faks (ww. en s.nw.), fooi (professionele vergoeding), impak, implementeer, integrale naas integrerende deel, luuks (b.nw.), monitor (ww.) x moniteer, ombudsman, pormofilm, spitsuur, stres, subpoena (ww. en s.nw.), trippel (drie maal), tussenpose -s, uitstaande 
('n - prestasie), vanilla (naas vanielje), vertoring (naas vertoorn!), vigilante, vigs, Zimbabwiër (nie *Zimbabweër nie).

\subsubsection{Gebruiklikheidsheidsaanduidings}

Hoewel op p. 5 beklemtoon word dat die $A W S^{8}$ nie 'n woordeboek is nie en 'n mens dus nie woordeboekinligting daarin moet verwag nie, sou dit tog gerade wees om soms gebruiklikheidsaanduidings te gee by woorde soos tjopper, hendikep, kys, laitie, propper(s), spot (vrae -) e.d. Die TK gee immers toe (p. 2 \# 4) dat opname in die $A W S$ die status van Standaardafrikaans aan woorde verleen.

\subsubsection{Norme}

'n Mens wonder soms ook onwillekeurig volgens watter norme dié status verleen word. Hoekom sou steak, tjopper en boks(e) aanvaarbaar wees, maar jeans, belt en tjips nie? En as vertoring nou aanvaarbaar is, is dit so vergesog om te dink dat "Sy toring het ontvlam" ook gaan volg? Bylaag word naas bylae erken en demoon naas demon, maar nie byvoorbeeld aflas naas afgelas of ampuul naas ampule/ampul of ikoon naas ikon nie - almal, het die ondervinding geleer, ewe veel voorkomende vorme.

\section{$2.4 \quad$ Nuttige uitbreidings}

Die heelwat groter getalle verkleinwoorde wat gegee word, is ook 'n verbetering, en miskien nog nuttiger is die tientalle byvoeglik gebruikte voltooide deelwoorde (dikwels onder ge-ingeskryf) - daardie ewige probleem van -de of -te. Laasgenoemde probleem word ook redelik uitvoerig bespreek op pp. 2325 , en die reëling dat werkwoorde wat op $f, g$ of $s$ uitgaan, nou maar 'n -te of 'n -de kan kry (p. 24 \# 3.4), sal dit vir talle makliker maak.

Hoewel die kwessie van woordgroepe waarvan ' $n$ afleiding gevorm word en wat dan vas geskryf word, in die spelreëls bespreek word (bv. p. 71 \# 2.3), is daar talle voorbeelde van sulke gróepe en die gepaardgaande afleidings in die lys. Hopelik sal die gewone taalgebruiker hierby baat vind. Dieselfde kan gesê word van die herbereëling van aksenttekengebruik (hfst. 8, pp. 30-31).

\subsection{Trappe van vergelyking}

By die oorgrote meerderheid van die byvoeglike naamwoorde word daar nou ook trappe van vergelyking gegee - ook baie nuttig. Hoewel die meeste steeds slegs die -er/-ste kry, is dit opvallend hoe dikwels meer/mees nou ook 
aanvaarbaar is. Die beginsel waarvolgens albei vorme toegelaat word, is onduidelik. Dit wil voorkom asof daar enigsins arbitrêr te werk gegaan is, asof gebruiksfrekwensie soos die TK dit sien, die maatstaf was.

\subsection{Voegsels}

Dit is ook van harte te verwelkom dat die AWS's op pp. 15-16, \# 3.6, die mite dat voegsels ("soms verkeerdelik 'n verbindingsklank genoem" - p. 10) vermy moet word, die nek inslaan. Nie dat al die probleme daarrondom nou opgelos is nie, maar daar is nuttige riglyne. 'n Welkome paragraaf is ook Die koppelteken as weglatingsteken (p. 43 \# 4). Hierin word o.a. die kwessie van staats- en provinsiale hospitale $x{ }^{*}$ provinsiale - en staatshospitale bespreek, asook die ou geskilpunt van mans- en dameskoene $x^{*}$ man-en dameskoene (wat op p. 15, \# 3.6.1, gemotiveer word).

\subsection{Afkortings}

Die afkortingslys is eweneens grootliks uitgebrei en gemodemiseer. Die afkortingsreëls word ook uitvoeriger uiteengesit, met duidelike standpunte oor die gebruik van punte en, nuut, die gebruik van koppeltekens in afkortings. Wat laasgenoemde betref, val koppeltekens in afkortings weg, bv. lt.genl. i.p.v. lt.genl., hoewel dit nie beteken dat verbindings met afkortings nou ook sonder koppeltekens moet wees nie (p. 331 \# 6) - 'n misverstand wat al opgeduik het. Die TK skryf nou voor dat afkortings van graadname punte móét hê (p. 330 \# 4.1).

Hoewel dit duister is waarom punte by graadafkortings verpligtend is terwyl dit by talle ander vergelykbare soorte afkortings minstens opsioneel is, is dit seker gerieflik om 'n vaste reël te hê waar 'n mens nie aan 'n bepaalde universiteit se stelsel gebonde is nie. Die omvattendheid van die lys graadafkortings maak dit egter 'n baie nuttige naslaanbron.

\subsection{Terme en indeks}

Nuut in die $A W S^{s}$ is ook 'n lys termverklarings (pp. 8-10), wat noodsaaklik is vir die gebruiker wat nie met taalkundige terme bekend is nie, of wat terme soos skeibare werkwoorde, lettergrepe en verbindingsklanke ken en "soms nog verkeerdelik" gebruik. Hier word diesulkes daarop gewys dat onderskeidelik deeltjiewerkwoorde, sillabes en voegsels eintlik die korrekte terme is.

Daar is ook agter in die boek 'n indeks (pp. 385-393), wat nuttig kan wees mits die gebruiker die terme en die uiteensetting van die indeks ken. 


\section{Teksversorging}

\subsection{Setfoute}

Die eerste druk het heelwat setfoute. Die meeste daarvan (39) is in 'n erratalys agter in die boek vervat, maar daar is ook 'n klompie ander, waarvan sommige nogal verwarrend is. Dit is jammer, want duisende mense gebruik natuurlik nog hierdie eerste druk. Verreweg die meeste van die foute is egter in die tweede druk reggestel, met inbegrip van alfabetiese verskuiwings waar nodig. Die oorblywendes is seker nie van kritieke belang nie.

\subsection{Kommentaar}

Van die regstellings en oorblywende foute verdien egter kommentaar:

(a) Die skryfwyse ouest-onderwyser-vereniging is verander tot ouet-onderwysers-vereniging.

Eersgenoemde skryfwyse kom ooreen met die reël op p. 36, \# 3.1, terwyl laasgenoemde skryfwyse in stryd is met die beginsel op p. 36, \# 2.2.1(2), as die $s$ 'n voegsel is. As dit 'n meervouds-s is, klink dit soos ' $n$ vereniging van onderwysers en 'n ouer, wat onsinnig is. Die $s$ word seker amper uitsonderingloos uitgespreek, maar is dit nodig om 'n gevestigde skryfwyse te verander om in die keurslyf van die soms twyfelagtige reël en voorbeelde op pp. 36 en 37 in te dwing?

(b) Die verandering van volvet (- kaas) tot volvetkaas vestig noodwendig die aandag op soortgelyke kombinasies oral in die woordelys, byvoorbeeld:

$\begin{array}{ll}\text { volvetkaas } & \text { keurgraad botter } \\ \text { eerstegraadperske } & \text { oorgewig bagasie } \\ \text { oopplankombuis } & \text { kaalvoet seun }\end{array}$

Die verskil lê vermoedelik daarin dat, na iemand se oordeel, die bepalers van sulke kombinasies soms predikatief gebruik kan word en soms nie. Dié soort kombinasie word egter nêrens verduidelik of bereël nie, en skep, het die praktyk geleer, baie verwarring by sowel "gewone" as meer ingeligte gebruikers.

(c) Die eerste druk het op p. 43 in \# 4 (Opm.) die voorbeeld wol-en poliësterbaadjies $\times$ wol-en-polièster-baadjies gebruik, wat natuurlik, volgens die nuwe reël op p. 35, \#2.1.4.1, wol-en poli-esterbaadjies en wol-en-poliester-baadjies moes gewees het. In die tweede druk is poliëster deur katoen 
vervang. Dit stel wel die setfout reg en illustreer die betrokke reël goed genoeg, maar los nog nie die eintlike probleem op nie. 'n Mens kry immers nog steeds baadjies van wol en poli-ester, en hier en in tientalle ander kombinasies sit ' $n$ mens nog steeds met onaanvaarbare skrifbeelde.

Terloops, dié reël kan baie nuttig wees, maar is, behoudens enkele gevestigde gevalle, in die praktyk morsdood. Bowendien, die argument agter die skryfwyse wol-en-katoen-baadjie word ontoepasbaar wanneer drie of meer bepalerelemente aanwesig is maar dieselfde beginsel bly geld, bv. in ' $n$ wol-, katoen- en bokhaarbaadjie of 'n oor-, neus- en keelspesialis.

(d) Op p. 52 staan Menlopark en Koue Bokkeveld i.p.v. Menlo Park en Koue-Bokkeveld, soos in die Amptelike Pleknamelys, terwyl die TK op p. 2, \# 10, spesifiek sê dat hy die Pleknamekomitee se spellings aanvaar en erken. Vergelyk Koue Bokkeveld bowendien met p. 41, \# 3.10.1, wat sê dat 'n koppelteken in sulke gevalle gebruik word, bv, Klein-Karoo en Verre-Ooste.

\section{Nuwe reëls}

Soos reeds gesê, is daar van die nuwe reëls wat te verwelkom is. (Met "nuwe reëls" word ook dié bedoel wat nie in die vorige uitgawe verskyn het nie, maar wel vroeër bekendgemaak is.) Hier word egter net enkeles genoem wat, soos die ondervinding geleer het, probleme oplewer.

\subsection{Die poli-ester-tipe}

Die reël (p. 35 \# 2.1.4.1, gelees met 2.1.4.2) dat koppeltekens in verbindings gebruik moet word waar 'n opeenvolging van vokaalletters verkeerd gelees kan word en waar die eerste lid twee- of meersillabig en van Griekse of Latynse herkoms is, is om verskeie redes kortsigtig. Dit is wel so dat gebruikers soms nie kan onderskei tussen bv. foto- as woord en as woorddeel in foto-omslag en foto-osmose nie, maar dit kom so selde voor dat dit amper nie saak maak nie.

Dit is ook so dat daar in baie gevalle wel ' $n$ weerstand was teen gevalle soos sosioëkonomies. Daarenteen is die honderde gevalle van die poliëster-tipe reeds in so 'n mate aanvaar in die wetenskaplike en tegnologiese wêreld dat daar nou weerstand teen poli-ester ens. ondervind word.

Bowendien word hier nou van die "nietaalkundige" gebruiker allerhande taalkundige vaardighede vereis, soos om een- en meersillabigheid te kan onderskei en om soms 'n heel deeglike kerinis van die etimologie te hê. Wat byvoorbeeld gemaak met ensoöties? Hy moet die samestelling van die woord kan onderskei van dié van hidroëlektries, hy moet kan erken dat enso- nie 'n 
tweesillabige voorvoegsel is nie, selfs dat soö- nie dieselfde as koö- in koöperatief $x$ ko-operatief is nie. Selfs al sou hy 'n woordeboek soos die groot Webster's gebruik, sou dié se en + zo + otic of zo + ology hom verwar as hy nie sy etimologie goed ken nie.

Dit is vir die niechemikus of nie-etimoloog dikwels haas onmoontlik om te onderskei tussen ' $n$ meersillabige voorvoegsel en 'n kombinasie van voorvoegsels, bv. bufadiênolied, pièso-elektries e.d.

Gevalle soos die -eder-tipe is ook 'n probleem. In hidroêlektries sal die gewone gebruiker nog elektries in 'n woordeboek kry en sy afleidings op grond daarvan kan maak, maar hy sal vergeefs soek na eder in gevalle soos holoëder of tetartoëder. En om van byvoorbeeld die geoloog te verwag om gespesialiseerde taalkunde soos semantiese merkers en dies meer te ken voordat hy reg kan skryf, is onrealisties.

Bowendien skep die koppelteken soms skrifbeelde wat net nie aanvaarbaar is nie. Dit is asof die koppelteken betekeniseenhede onnodig skommel en misleidende betekenisgroeperinge skep; kyk maar na mikro-elementinhoud, heksakisokta-eder (vgl. okta-eder p. 226) e.d. Dis asof 'n mens soms gedwing word om nóg ' $n$ koppelteken in te sit, wat onaanneemlik is.

\subsubsection{Woordeboeke}

Op p. 2, \#6, sê die TK dat talle terme soos bogenoemdes uit die $A W^{8}{ }^{8}$ weggelaat is omdat dit "tans maklik in tegniese woordeboeke nageslaan kan word". Die ironie is dat selfs die jongste (selfs soms 1991-) uitgawes van sodanige en ander woordeboeke meteens verouderd is.

'n Veel sinvoller reëling sou gewees het om nie die onderskeid tussen eenen meersillabige woorde te maak nie en om by albei tipes die keuse van koppelteken of deelteken te laat. Dan sou baie van bg. probleme uitgeskakel gewees het en sou die woordeboeke minstens ook reg gewees het.

\subsection{Die mond-tot-mond-asemhaling-tipe}

Die reël gestel op p. 39, \# 3.5.3, is m.i. ontoepasbaar. (Dit is bevestig op die bekendstellingseminaar van die $A W^{8}{ }^{8}$, toe TK-lede skerp van mekaar verskil het oor die toepassing daarvan.) Die verskil tussen mond-tot-mond-asemhaling en kop aan kop botsing is blykbaar daarin geleë dat die adjektiwiese groep in eersgenoemde nie predikatief gebruik kan word nie, maar dié in laasgenoemde wel. Dit, meen ek, is dikwels ' $n$ kwessie van opinie en omstandighede.

'n Gewone gebruiker verstaan miskien die begrippe attributief en predikatief en wil nou daarvolgens toets of hy vas of los moet skryf. Dan sou die volgende seker nie onredelik wees nie: Op 'n vraag deur die dokter aan die ambulansman oor noodbehandeling, sê laasgenoemde: 
"Die asemhaling was mond tot mond, dokter - die resussiteerder was stukkend." Of iemand vra: "Wat moet ek aantrek vanaand?", en kry die antwoord: "Trek informeel aan, man, die onthaal is kaas en wyn, nie formeel nie."

Hoekom dan nie ook mond tot mond asemhaling en kaas en wyn onthal nie? Bowendien gebruik die TK self op pp. 25 en 26, \# 4 en 6, die skryfwyse een-toteen-verhouding in sinne wat sonder twyfel ewe goed kon gelui het: "... maar die verhouding is nie een tot een nie." Hoekom dan die koppeltekens as dit by stap vir stap ontleding nie daar moet wees nie?

Om van die gewone gebruiker te verwag om allerhande tegniese afleidings en ontledings te maak om sinne soos die omstellings hierbo te onderskei van die $A W S^{8}$ se voorbeelde en te bepaal waarom dit nie geldig is nie, is futiel.

Op p. 158 word gesê dis ' $n$ heen en weer diens, maar dis tog nie die diens wat "heen en weer" is nie - wel dit wat "diens" by implikasie benoem. Hierdie inskrywing het my ook heeltemal in die war gebring toe ek wou kontroleer hoe die $A W S^{8}$ "heen- en terugreis" sou skryf. Dit is seker nie ondenkbaar dat 'n gebruiker op grond van dié inskrywing kan aflei dat hy "die heen en terug reis" moet skryf nie. En met heenreis en terugreis afsonderlik en \# 3.5.2 en 3.5.3 op p. 39 sowel as \# 4 Opm. op p. 43 in gedagte, wat is dit nou: heen-en terugreis of heen-en-terug-reis?

\subsection{Die eienaamreël}

Die losskryf van eienaamverbindings (p. 68 \# 2.1) kan baie nuttig wees, veral by baie komplekse kombinasies, maar meestal kom dit diegene tegemoet wat in ieder geval nooit geweet het dat bv. Hatfield apteek eintlik as 'n samestelling geskryf moet gewees het nie. Vir die redigeerder wat moet besluit of die teks voor hom korrek is al dan nie, of wat 'n konsekwente styl moet probeer handhaaf, lewer die reël baie probleme op omdat dit so vaag en onvolledig geformuleer is en die voorbeelde so eensoortig is.

Minstens die volgende vrae moes ook aandag gekry het:

\subsubsection{Saamgestelde eiename}

Wat van "saamgestelde eiename" wat verder verbind? As Curriebeker en Lesotho-hoogland ook Currie Beker en Lesotho Hoogland kan wees, is Currie Beker krieketwedstryd en Lesotho Hoogland waterprojek ook korrek, of slegs Currie Bekerkrieketwedstryd en Lesotho Hooglandwaterprojek?

Daar is 'n mediese fonds genaamd die MICWU- Mediese Fonds (wat ook sonder die koppelteken korrek sou wees volgens die afstandsamestellingreël, p. 40 
\# 3.6) en 'n nywerheidsooreenkoms in verband daarmee. Is MICWU(-) Mediese Fonds Ooreenkoms ook korrek, of slegs MICWL(-)Mediesefondsooreenkoms?

\subsubsection{Voegsels}

Wat van gevalle met voegsels? "Boer" kan 'n eienaam wees (p. 48 \# 2.4.1); "Arbeider" (p. 49 \# 2.6.2) vermoedelik ook en "Hoffmann" beslis. Dus ook Boere Oorlog, Arbeiders Party en, argumentshalwe, Hoffmanns Druppels?

Vergelyk hier ook die vereiste van 'n koppelteken by samestellings met voegsels (p. 40 \# 3.6 Opm. en p. 36 \# 2.2.1(2)).

\subsubsection{Eienaam $x$ soortnaam}

Wat van die wisseling eienaam x soortnaam? As Andes gebergte reg is, is Rots gebergte (die vertaling vir "The Rockies" of "Rocky Mountains") ook reg? En as Benjamin Moodie setlaars reg is, is 1820 setlaars ook reg?

\subsubsection{Plant- en diemame}

Die volgende reeks uitsprake/reëls skep in samehang ook probleme:

p. 45 \# 2: "Die algemene reël geld dat eiename met 'n hoofletter begin."

p. 49 \# 3: "Sekere tipes dier- en plantname is eiename ..."

p. 56 \# 17: "Die name van kultivars, dier- en plantvariëteite ... word met of sonder 'n hoofletter geskryf." Voorbeelde sluit jerseykoei en rambouilletskaap in.

p. 69 \# 2.1.2: Onder die opskrif Soortnaam- plus eienaamelement staan dan ook die voorbeeld volbloed Bonsmara, volbloed-Bonsmara.

As dit nog gelees word met p. 55, \# 15.2 ("As die samestelling 'n soortnaam is, word dit normaalweg met ' $n$ kleinletter geskryf, selfs wanneer een of meer van die dele daarvan met die vorming van die samestelling ' $n$ eienaam of 'n gewysigde eienaam was"), word dit bitter moeilik om te weet wat die skryfwyseverskille en -moontlikhede is ten opsigte van byvoorbeeld -

volbloed Bonsmara (p. 69)

jerseykoei (p. 172)

Knysnaloerie (p. 184)

namakwaduif (p. 220)

Oom Sarelperske (p. 231)

smirnavy (p. 274) 


\subsubsection{Taalname}

Taalname staan uiteraard in noue verband met eiename. Die gewone gebruiker, wat moet weet dat samestellings met eiename anders behandel kan word as samestellings met ander selfstandige naamwoorde, moet verder ook nog weet dat taalname nie soos ander samestellings met eiename behandel word nie. Hy moet dus weet dat hy Oxfordengels móét skryf (p. 70 \# 2.2.1.1), maar dat hy Oxford woordeboek kan skryf, en dat dit Wit-Rusland (p. 52 \# 6(1)) en dus vermoedelik die "Wit-Russiese landskap" is, maar dat die Wit-Russe Wit Russies (p. 71 \# 2.2.3) praat en dus vermoedelik "Wit Russiese letterkunde" lees.

Boonop is dit Pseudolatyn (p. 252 - vergelyk dit met p. 71 \# 2.2.2.2), maar Proto-Semities (p. 252) en Pidgin-Engels (p. 243). Dan is daar nog Rugbyafrikaans en Standaardafrikaans, maar Griekwa-Afrikaans (p. 70). (Terloops, is "die koeël is deur die kerk" 'n Standaardafrikaanse of 'n standaard-Afrikaanse uitdrukking?)

Hierdie soort onderskeid is hoogstens 'n akademiese oefening; in die praktyk is dit gedoem om geïgnoreer te word.

\subsubsection{Praktiese omskrywing en voorbeelde}

Baie van bogenoemde probleme sou in groot mate opgelos kon word as die $A W S^{8}$ ' $n$ benutbare omskrywing van "eienaam" of minstens meer verteenwoordigende en illustratiewe voorbeelde bevat het. Die gebrek daaraan is m.i. 'n ernstige tekortkoming.

\subsection{Telwoorde en breukname}

Telwoorde en breukname word op p. 77 behandel. \# 2.9.1 bespreek die skryfwyses van hooftelwoorde en laat omtrent elke denkbare moontlikheid toe. Van die reëls t.o.v. rangtelwoorde en breukname is egter onverklaarbaar: $v y f-$ en-veertig sowel as vyf en veertig word toegelaat, en so ook die rangtelwoorde vyf-en-veertigste en vyf en veertigste. Hoewel driehonderd $\mathrm{x}$ drie honderd, tienduisend $\mathrm{x}$ tien duisend ens. ook telkens toegelaat word, geld die ooreenstemmende vorme nie by rangtelwoorde nie - slegs driehonderdste, tienduisendste, ens. is toelaatbaar. Hoekom? By breukname kan 'n mens skielik weer óf ' $n$ driehonderdste of ' $n$ drie honderdste skryf.

Hierdie verskille is op sigself al moeilik genoeg verstaanbaar, maar as 'n mens dit verder sien teen die agtergrond van die reëls in \# 2.3 en 2.4 op pp. 71 en 72 (by breukname word immers s.nwe. gevorm m.b.v. agtervoegsels), word dit nog onverklaarbaarder. Voorts word naas twee derdes en sewe agstes ook twee-derdes en sewe-agstes toegelaat, maar, soos uit die formulering van die paragraaf afgelei kan word, dié moontlikheid geld nie by bv. sewentien driehonderdstes nie. 
Dit is hierdie ongemotiveerde verskille wat nie "groter vryheid" bring nie - dit maak die lewe vir die skrywer van Afrikaans net moeiliker.

\section{5 \\ Afstandsamestellings}

Die $A W^{8}$ bevat ook nou die reël dat die afstandskoppelteken in gevalle soos adjunk-besturende direkteur weggelaat kan word (p. 40 \#3.6), hoewel dié besluit reeds in 1978 geneem en bekendgemaak is. Die 1978-voorbeelde het mede besturende direkteur ingesluit, maar nie een met 'n voegsel aan die eerste lid (groeps-finansiële sekretaris) nie. Die $A W S^{8}$ gee weer nie eersgenoemde nie, maar wel laasgenoemde en bepaal dat die afstandskoppelteken in voegselgevalle verpligtend is.

Is dit omdat iets soos groeps- onselfstandig is? Moet mens nou maar aflei dat dit ook geld vir mede-, wat in hierdie betekenis deur al die woordeboeke as onselfstandig ("mede-") ingeskryf word? So 'n afleiding is m.i. te veel gevra van die gewone gebruiker - die $A W S^{8}$ se uitgangspunt hier is immers voegsels en nie onselfstandigheid nie. Geld 1978 se mede besturende direkteur nog? Indien wel, sou dit ook geld vir voorvoegsels soos $k o$ in bv. ko artistieke produksie? Die reëlformulering en voorbeelde is dus gebrekkig.

\subsection{Nie-, non- en oud-}

Op p. 41 \# 3.9, word bepaal dat, behoudens sekere dwingende redes, nie-, nonen oud-sonder koppelteken vas geskryf word. Hoekom daar, veral wat die niebetref, aan 'n ou gevestigde en haas probleemlose skryfwyse getorring is, is onduidelik. Dit gebeur selde of nooit, het die ondervinding geleer, dat iemand natuurlikerwys of per ongeluk nie-sonder koppelteken vas skryf nie - los wel. Bowendien versluier nie- vas dikwels die kernwoord en maak 'n herlees nodig. In die praktyk kom sulke woorde dikwels amper alleenstaande voor, bv. in lyste, op vorms, ens.: op 'n vorm oor versekeringspolisse staan bo die kolom byvoorbeeld Nielewens.

Die TK voeg 'n opmerking by dat die koppelteken weggelaat kan word "waar dit gebruiklik geword het". Die ironie is dat - met uitsondering van nietemin, nieteenstaande e.d., wat in ieder geval 'n heel ander saak is - dit áltyd gebruiklik was om die koppelteken te gebruik.

\section{Klein jakkalsies}

Weens beperkte ruimte kan daar nog net hier en daar lukraak iets genoem word. 


\subsection{Ondermyning}

Op talle plekke word 'n reël gestel en dan direk ongedaan gemaak deur opmerkings deurspek met stellings soos "maar in gevalle soos", "as die gebruiker oordeel", "waar dit gebruiklik geword het" en dergelike. (Vgl. byvoorbeeld p. 30 \# 9; p. 35 \# 2.1.3; p. 41 \# 3.9(1); p. 54 \# 12(Opm.); p. $55 \# 15.3$ (Opm.), ens.) Sommige kan dit beskou as groter vryheid wat gegee word, vir ander șkep dit eindelose probleme.

\subsection{Wisselvorme en verwante sake}

ln ag genome dat die $A W S$ nie 'n woordeboek is nie en dat allerhande kruisverwysings nie moontlik is nie, is daar vir die gebruiker tog sekere probleme rondom wisselvorme, doeblette en sinonieme.

Hoewel dit taalteoreties seker nie so is nie, ervaar die gewone mens iets soos balpuntpen, bolpuntpen en rolpuntpen prakties as wisselvorme. Is beeldhoueres nie 'n wisselvorm van beeldhouster $x$ beeldhoudster (p. 97) nie? En hoe verskil die ewige strydpunt organigram in betekenis van organogram? Daar is geen verbandswoord nie en dit word ook nie as wisselvorme aangegee nie.

Regtig en rêrig wörd nie as wisselvorme aangegee nie, oppervlak $\times$ oppervlakte en tabak x twak wel. Op p. 6 sê die $A W S^{8}$ dat wisselvorme "na betekenis en gebruik as gelykwaardig beskou en erken word", terwyl doeblette baie van mekaar verskil "in betekenis, gevoelswaarde, maatskaplike waardering e.d." (p. 7). Volgens hierdie uitsprake is regtig en rêrig eerder wisselvorme en twak en tabak doeblette, en veral op min of meer tegniese terrein is daar eenvoudig ' $n$ verskil tussen oppervlak (boonste vlak) en opperolakte (maat).

En óral, selfs by ag(t)daegeneesbossie, word ag x agt as wisselvorme gegee, behalwe by agtien. Hoekom?

\subsection{Oënskynlike inkonsekwenthede}

(a) Dit is moeilik om te begryp hoe die reël in die tweede paragraaf van \# 1.2.3 op p. 67 en die voorbeelde daar, en dan die inskrywings linksaf, links af loop, linksom en links om ry op p. 204 asook die ooreenstemmende inskrywings by regsaf en regsom op p. 258 by mekaar uitgebring word.

(b) 'n Mens wonder wat die gewone gebruiker gaan maak met aaneenflans en aaneenryg teenoor aan een skryf en aan mekaar skryf, in ag genome al die betekenisse by laasgenoemde twee gegee (p. 83). So ook met agter aan ('n lap [hang] - - die wa) (p. 86), boaan (die naam staan - die lys) (p. 105) en onderaan (die woord staan - die bladsy) (p. 227). 
(c) Kleuradjektiewe word los geskryf, bv. appelkoos serp en olyf hemp (p. 72 \# 2.5(3)). So ook sweetvos perd (p. 285) - hoekom dan vosperd op p. 315?

\subsection{Woordgroepkoppelings}

Die reël dat daar 'n koppelteken moet.kom tussen ál die lede van samestellings soos ondergenoemdes (p. 39 \# 3.5.2 en 3.5.3) lyk ook 'n bietjie kortsigtig. Die reëlformulering, gelees met die voorbeelde, is onvoldoende. Die voorbeelde in die $A W S^{8}$ kan seker nog s 6 werk, maar wat van verdere verbindings? Moet dit dan ook bek-en-klou-seer-virus, hand-om-die-nek-hek-slot, wins-en-verlies-rekeningkantoor en so meer wees? Dit word absurd vanweë die rits koppeltekens. Indien tog korrek, wat van gevalle met voegsels: tref-en-trap-ongelukstoneel, mond-tot-mond-asemhalingsprosedure. Die alternatief lewer weer skrifbeelde wat onaanvaarbaar (of erger as tevore) is: - bek-en-klou-seervirus, wins-en-verliesrekeningkantoor.

\section{Slotopmerkings}

\subsection{Esoteries}

Gee die $A W^{8}{ }^{8}$ inderdaad groter vryheid vir die gebruiker van Afrikaans? Ja, wel, vir diegene wat in elk geval skryf sonder om hulle aan spelreëls te steur hulle "foute" van jare word geakkommodeer. Daarteenoor word van diegene vir wie dit erns is om hul taal korrek te probeer skryf, verwag om dikwels nogal gevorderde taalkundige kennis te hê - "esoteries" sou seker nie 'n onvanpaste woord wees nie - ten einde sommige van die reëls te begryp en toe te pas.

\subsection{Arbitrêr}

Die noukeurige leser-gebruiker word telkens gekonfronteer met wat as arbitrêre besluite gesien moet word. Hoekom anders word byvoorbeeld slegs ten spyte van en ten slotte erken, terwyl terwille van en tenminste naas ter wille van en ten minste erken word? Die beginsel word ondermyn, en 'n mens het geen ander keuse as om maar gedurig die $A W S^{8}$ te raadpleeg nie.

\subsection{Geheelindruk}

$\mathrm{Na}$ uitvoerige gebruik bly die algemene indruk dat daar by die opstel van die $A W S^{8}$ te seksioneel te werk gegaan is, so asof verskillende dele van veral die 
spelreëls nie behoorlik by mekaar invoeg nie. Die $A W S^{8}$ het m.i. 'n enkele eindredakteur nodig gehad wat met 'n onbevange oog kon kyk en groter en hegter koördinering kon bewerkstellig.

'n Mens kry ook die indruk dat van die reëls op grond van te eenvoudige en te beperkte voorbeelde geformuleer is en dat nie al die implikasies besef is nie. Ek is daarvan oortuig dat as die TK die konsep van die AWS ${ }^{8}$ as geheel aan ('n beperkte aantal) taalpraktisyns beskikbaar gestel het om dit in die praktyk te toets, baie van die probleme wat hierbo genoem is - ten minste baie van die formuleringsprobleme, asook swak, onvoldoende, eenvoudige en eensydige voorbeelde en die setfoute - uitgeskakel sou gewees het.

\section{Aantekeninge}

1 in Soortgelyke resensie het oorspronklik in Bulletin 4/91 van die Suid-Afrikaanse Vertalersinstituut verskyn. Dit is hier, met SAVI se verlof, aangepas om voorsiening te maak vir die tweede druk en 'n langer gebruikstydperk.

2 Taalkommissie van die SA Akademie vir Wetenskap en Kuns. 1991. Agste, verbeterde uitgawe. Eerste en tweede druk. Kaapstad. Tafelberg.

3 Met \# word hier die paragraafnommer in AWS ${ }^{8}$ aangedui. 


\title{
From Wordlist to Comparative Lexicography: The Lexinotes ${ }^{1}$
}

Tony Naden, Ghana Institute of Linguistics, Literacy and Bible Translation, Walewale, N.R., Ghana

\begin{abstract}
This paper sketches the history of the study of the languages of West Africa, particularly of their lexical resources, offered as a typical example of similar developments elsewhere in the world. The collection of wordlists from the languages and their use to establish genetic relationships is considered, with some practical observations on the improvement of this methodology. The final section reports on an ongoing project for a comparative dictionary in northern Ghana, particularly the use of simple semantic network studies both within and across languages. An appendix presents one of the preliminary papers circulated in connection with this project.
\end{abstract}

Keywords: COLONIALISM, COMPARISON, DICTIONARY, EXPLORATION, GUR, HISTORY, LANGUAGES, LEXICOGRAPHY, LEXICOLOGY, LINGUISTICS, SEMANTICS, VOCABULARY, WEST AFRICA, WORDLIST

\begin{abstract}
Abstrait: De la liste-de-mots au lexique comparatif - les lexinotes. Cétte étude présente d'abord une esquisse de l'histoire de l'étude, surtout sur le plan du lexique, des langues de l'Afrique occidentale, comme échantillon type des tels développements dans les autres régions pareilles. La fonctionnalité de la collectionnement et comparaison des listes de mots est abordé, avec des conseils pratiques pour l'usage des listes. Enfin on offre deux aspects des recherches en Ghana du nord envers un dictionnaire comparative: une appendice présente une des études préliminaires du projet.
\end{abstract}

Mots Clef: AfRIQUE OCCIDENTALE, COLONLALISME, COMPARATISME, DICTIONNAIRE, EXPLORATION, HISTOIRE, LANGAGES, LEXICOGRAPHIE, LEXICOLOGIE, LINGUISTIQUE, LISTE-DE-MOTS, SEMANTIQUE, VOCABULAIRE, VOLTAIQUE

\section{Introduction}

While several major civilizations in the history of the world have developed written traditions and some form of lexicography, it is post-Renaissance Western - or as one might have said a decade or so ago 'modern' - culture which has shown interest in the languages and lexicon of groups which are in some sense alien to it and accounted minor either in importance or number of speakers. The Greeks' attitude to the 'bleating' of foreigners ${ }^{2}$ was largely echoed in the attitude to non-Chinese or non-Arabic tongues by these respective civilizations ${ }^{3}$. 
Be that as it may, in spite of the inadequacies of lexicographical resources for contemporary African (for instance) societies - as regretted in Busane, 1990 , amongst other commentators - there is available in the world a considerable amount of published and archived material on the vocabulary of languages of smaller populations and those spoken in politically non-prominent areas. I want to develop here a sketch of the history lying behind these lexicographic resources, exemplifying - in a necessarily simplified, not to say simplistic, sketch - from the area with which I am most familiar, West Africa. For practical purposes the history of this region is typical of many parts of the world which were controlled or dominated by European powers in the colonial period, and now mostly constitute the 'third' or 'developing' world of 'the South'. From this base 1 then consider some ways forward to a more sophisticated understanding of: lexical systems, both within and across language boundariès.

\section{History: Early Fragments}

In most cases, the earliest information we have on the languages of West Africa and similar regions is in the form of unsystematic notes from early European explorers, traders or missionaries. Journals and travel tales of such persons may sometimes attempt to add local colour by quoting a phrase which the natives' "shouted", or "kept repeating", or whatever, at the particular point in the proceedings. These are usually explained as being their 'word" for "Welcome" or some other formulaic utterance - with no guarantee, of course, that we are being given what linguistic analysis would consider a word, rather than a phrase or a sentence. As Christian missionary work necessitates some kind of communication of more complex ideas, and Christians have in general been oriented towards written texts of Scripture, liturgy, and doctrinal definition, the Church sources may have more extended texts of such materials translated into local languages;

For this region a number of studies have been made of this early material by P.E.H. Hair (e.g. 1965, 1966, 1968). There are considerable problems because of the generally low view which the European recorders held of the African peoples and languages which they recorded, and both transcriptions and identifications are of ten difficult to interpret and relate to present-day languages and peoples. The whole question of the interaction of linguistic history and the history of peoples and migrations is still hazy, as explored in Naden (1988) for one region of West Africa. There is still plenty of untapped material in these early sources, particularly in archives of commercial and governmental sponsors of exploration/colonization in Europe. 


\section{History: Colonial Collections}

There followed a phase of more settled and organised penetration of West Africa by Europeans - what may be roughly described as the Colonial period. The exact political situation, and the effectiveness and manner of operation of colonial régimes, protectorates, and so on, were of course, multifarious in their realisations. A particular point to note for the West Coast is that the endemic diseases which made it 'The White Man's Grave' precluded settlement by outsiders such as was found in parts of East and Southern Africa, South Asia and so on. Traders, administrators and missionaries were basically expatriates, visiting for longer or shorter tours of duty, and the long-term involvement in the area of individuals was of ten curtailed by ill-health or death.

In this period, roughly from just before the middle of the nineteenth century to just after the middle of the twentieth, there was also the development in the Western academic world of ethnographic and linguistic studies alongside the existing fields of classical literature, history and philology. This is often seen as largely a result of the colonial experience in the broadest sense - including the expansion of the United States at the expense of Native America, with similar movements in Canada, and of Russia into northern Asia. The development of phonetics, and later of phonemic and structural syntactic analyses, moved forward under a considerable impetus from those attempting to give an account of the languages of Africa, the Americas, South and Southeast Asia, the Caucasus and Siberia. And conversely scholars looked to these areas for field studies of languages and cultures on which they could wield and refine their new analytical tools (some relevant thoughts are found in Goldsmith 1992), particularly the comment:

"it can hardly escape even the casual observer of the current phonological scene that it stands in profound debt to work on African languages" (149)

West Africa presented some particular restrictions in this period. There was a lack of large centralized states in much of the hinterland, and unsettled conditions consequent upon the break-up of earlier states which was partly the result and partly the cause, or at least the opportunity, of the growth of influence/interference by the European powers. The power and then the decline of slave-raiding; mostly done by local agents for trade to both coastal European and Saharan Arab/Tuareg/Berber traders, added to confusion and lawlessness - summed up in the folk-history of northern Ghana as "the days of Samori and Babatu" - two famed and feared land pirates who raided and plundered with private armies around the turn of the century (Naden 1988). These conditions, along with the 'White Man's Grave' effect, made it difficult to even determine the names and locations of peoples and languages. 
Symptomatic of this situation is the fact that the most important of the early collections, Koelle's 'Polyglotta' (1854), represents data gathered without visiting the areas where the languages were spoken at all. Koelle's informants were slaves freed by the British from traders and settled in Freetown, Sierra Leone. In some cases they had not spoken their mother tongues for many years, and information on the location where the language was spoken is in the form of memories of how many days' journey the slave caravan took to reach various landmarks between the informant's place of capture and the sea-port. Furthermore, the name of the language is often buried behind many layers of foreigners' pronunciations, epithets and designations in a variety of trade languages. In the face of these problems Koelle's data seem to be remarkably good, and his work is another major quarry for information on earlier states of the languages of the area (e.g. Köhler 1964, Prost 1966, Delord 1968).

The spirit of this period placed a value on the number of languages from which samples were collected (e.g. Christaller 1889, Delafosse 1904, Groh 1911, titles). I always mentally associate this with the collections of butterflies assembled by contemporary entomologists, or lovingly-assembled patterns of diatoms on slides prepared by microscopists. However, the factors which are mentioned above as deterring European settlement would also have had an effect: when a scholar was able to assemble the funding, personnel and equipment to mount an expedition to these areas which were so difficult to access, he wanted to come 'out' with as much material as possible, for who knew when the area could be studied again? Because of the uncertainty over names and locations it is necessary to consult records of explorers, such as Binger (1892), as well as those explicitly studying language and culture.

The major aim of this activity was the establishment of genetic relationships by comparison of languages. The great success story of Indo-European comparative-historical work in the nineteenth century was both an inspiration and a challenge to those working in other parts of the world. A further reason for the collection of a large number of language samples was the establishment of an adequate data base for comparison. However it is noteworthy that the initial advances in this approach for Africa came in Bantu studies in the eastern and southern areas of the continent (all through the nineteenth century, but note particularly Meinhof 1906), partly because of the substantial group of obviously-related Bantu languages, but surely also because in the areas where there were European settlers there was the opportunity to study some major languages in greater depth. These results then fed into our area with studies like Westermann (1935).

\section{History: Consolidation}

The period roughly from the end of the first World War to the time of the independence of the West African nations from colonial rule formed a time of 
consolidation, though because of various economic and political problems results continue to be refined and published. It is true that 'new' languages may still be identified (e.g. Naden 1986a), and new collections of data appear, as in Dakubu $(1977,1980)$ or the work of the late, indefatigable, Fr. Prost (from a long list, especially important here is the series of articles on 'Atakora' languages culminating in the 1975 wordlists). However, improved accessibility, education of speakers of the languages, and the cumulative results of the earlier studies, have resulted in a fairly reliable picture of the names, locations and nature of most languages in the area. One concrete manifestation of this is the publication of maps and inventories for particular countries or areas (e.g. Brasseur and le Moal 1963, Hansford et al. 1976, and for our area Hall 1983).

Cumulative research results can be seen in areal summaries like Lavergne de Tressan (1953), leading into the Handbook of African Languages of Westermann and Bryan (1961), and the Africa-wide rethinking in Greenberg $(1966 / 70)$. A key development for the Gur languages, was the study of Swadesh et al. (1966). These findings are taken up by Bendor-Samuel (1971), summarized by Fivaz and Scott (1977) and revised by Bennett and Sterk (1977). Meanwhile, Manessy was publishing results of studies in Gur from the viewpoint of the francophone countries, notably (for our focus here) Manessy (1975, 1979); and Mukarovsky $(1977,1976)$ offered comparative material from his own research. A new synthesis is presented in Bendor-Samuel (1989), containing Naden (1989) for Gur.

At the same time studies of individual languages continue to be made. In our area there is still a shortage of full-scale reference or academic grammars, but pedagogic grammars are made for practical purposes (e.g. Riccitelli 1955, Wilson 1972). Similar practical studies are also made in the lexical domain (e.g. Durand 1953, Melançon and Prost 1972), and there are also dictionaries published for the development of literacy and practical use of the languages (Blass 1975, Langdon and Breeze s.a.) and as part of a research project (cf. Spratt and Spratt s.a., Arana and Swadesh 1967, Kröger 1992). Particularly noteworthy is the project at Saarbrücken University where African scholars are enabled to pursue masters' level studies while contributing to a series of dictionaries of their languages (cf. Lebizaka 1979, Badjona 1983, Derman 1983, Katia 1983).

\section{Wordlists: Techniques}

It has been a basic assumption above that much of the early sampling of languages was in the form of the collection of wordlists. In a brief visit to the area where a language is spoken, or within the limited time spent with an informant, perhaps even with no common language of communication, or working through an imperfectly-understood lingua franca or chain of interpreters, it is certainly easier to elicit names of common objects, or actions, than to get a a reliable record of morphological paradigms or syntactic structures. While there 
are numerous limitations and pitfalls in wordlist-collection, this can still be a useful tool among many in the toolbag of the student of these languages from the point of view of establishing names, distribution, usage and relationships.

This methodology was superseded by Swadesh (1950) with his lexicostatistic theory, which crucially bases comparative study on a specific wordlist (Swadesh 1953) of 200 items, claimed to be universally applicable as a core of basic vocabulary not only resistant to innovation but also undergoing change at a fixed rate. The glottochronology corollary claimed that this would make it possible to go beyond the grouping of languages by closeness of genetic relationship to establishing the length of real time elapsed since any pair of languages separated. We may seriously doubt the absolute percentages and centuries claimed by the proponents of the method, but it seems unnecessary to deny that within a given family or subfamily the relative distances are usefully mapped by this method. Some attempts have been made to refine the approach with further statistical analyses, as in Bennett and Sterk (1977), though the results have been queried (cf. Schadeberg 1986). My own reservation concerns not so much the method as the basic data on which it operates - a set of complete and accurate wordlists would probably yield better results under both the Swadesh and Benett/Sterk kind of analyses.

In practical terms the use of Swadesh lists has a few problems which can be minimised by careful use. The claim that the 'Swadesh-200' list is universal, has to be treated with caution. For example, it makes a wry point about everyone having lice (item $\# 22$ in the list 4 ), while not everyone has houses. In applying this list, one encounters the following typical problems of basic wordlists:

a) Unknown referent: in tropical Africa (with no high mountains) "ice", "snow" and "freeze" (\#148-150) are non-existent, and, therefore, not lexicalized.

b) Lexical distinction not made: "green" and "yellow" (\#88, 89) may not be lexicalized (low saturations are 'white' (\#90), high 'black' (\#91) and 'red" (\#87) respectively (cf. Berlin and Kay 1969 and the vast literature spawned thereby). "Wife" (\#146) may be "woman" (\#16), possessed.

c) Wordclass: the Englishs stimulus term belongs to a particular wordclass; merely glossing it with a target word of a different class is misleading Mampruli zibi-does not mean "dark" (\#152) but "be dark". There is also wordclass ambiguity e.g., "sleep" (\#60) and "fear" (\#191) can be a noun or a verb.

d) Ambiguous word: the stimulus item may be patently ambiguous "fly" may be an insect or the action of a bird, though at (\#64) the neigh- 
bouring verbs dictate the latter interpretation. But.is "burn" (\#84) "the fire is burning", "burn the grass!", "I burned my finger", or "I burned the dinner" ...?

e) More distinctions in target: in some cases we may feel that the stimulus is unambiguous in the English semantic system, but more fine-grained distinctions are made in the target language/culture. Is the "louse" (\#22) a fowl-louse, a dog-louse, or a human louse? To "wash" (\#123) may be different if the object is oneself, a baby, or clothes.

f) Grammatical frame: languages differ as to what form of the verb is best for citation: imperative, third person past, or first person singular. And the best form for exemplification may not be the best for elicitation. It may be useful to get several morphological 'principal parts' - in NigerCongo with its historical noun-class system it is very desirable to have singular and plural forms of all nominals. Prepositions ("with, in, at" $\# 139-141)$ are both fuzzy in reference and need a grammatical frame to show their usage. Other items needing grammatical context are "if" (\#142), pronouns (\#1, 2, 3, 102, 103), deictics (\#4, 5, 107, 108), interrogatives $(\# 6,7,104-106)$ and "not" (\#8).

In most cases the solution is to make clear the exact sense and grammatical class of the item given. The items needing context should be elicited in a set context:

1. I will not ${ }^{6}$ sleep. $\mathbf{N}$ ku gbisi.

...

60. I will not sleep. $\mathrm{N}$ ku gbisi.

...

140. The stone is in the pot. Kugri be la dukku ni.

I would always advise adding to the standard list rather than revising it and removing difficult items. The value of the standardized list is that it is standard. If any sample is available for a little-known language it is likely to be a Swadesh 'first 100 '. One can specify which sort of louse, either after collecting the term or in advance. Someone familiar with the sort of lexicalization patterns operative in a geographical or linguistic area can modify the list by specifying sense-discriminations, contextual frames, and additional locally-important vocabulary ("cow", "house", "Chief", "pot" and so on). The modified list can be used consistently by its compiler, at least, and if possible by colleagues, students, or as wide a circle of cooperating researchers as can be recruited. 


\section{Ways Forward: Thesaurus}

Items on wordlists like those of Swadesh, or the larger 550-word list of Greenberg, are usually subgrouped by meaning: body parts, verbs of posture, colour terms, and so on. This has been noted above as sometimes helping to disambiguate the English word (if "fly" was next to "louse" it would be the insect; between "swim" and "walk" it is the verb). This may also help informants in what is already a strange and arbitrary task, and is an improvement on presentation in alphabetical order which has sometimes been advocated, as long as one is working with a single wordlist. When published dictionaries, nonstandard wordlists, or several different standard lists are consulted, the virtues of alphabetical order for location become apparent - I had to spend some time compiling an alphabetical index of items in Swadesh and Greenberg lists, and data lists published by Mukarovsky (1977, 1976), Dakubu (1977, 1980) and Manessy (1975 and 1979). Computerized data processing cuts this knot, items can be grouped semantically so that the user can 'browse' among a set of related meanings, while a specific item can be located by the machine without the user being concerned with the search method used.

As part of the researches of GILLBT in languages of Ghana, we have developed an etic thesaurus of English stimulus-words grouped according to general West African cultural patterns, e.g., items sold in the same section of a market, tools and action verbs used in discussing cereal farming, and so on. A numerical code makes it possible to search for semantically-related items, while the hard-copy version has a full alphabetical index. Researchers are encouraged to use the etic list as a beginning, and then try to develop ways of reshaping the material in accordance with the emic judgements of speakers of each language. This is valuable for the study of individual languages, but it also feeds into the comparative enterprise, because one problem of wordlistbased comparison is semantic slippage - Language B may have a cognate of a given Language $A$ word but the meaning has changed so that it will not be given in response to the same stimulus item. With semantic indices from the thesaurus system, a computer can locate possible cognates which have undergone this slippage, and inversely, examples of slippage across related languages are additional evidence for co-membership of an emic semantic class.

\section{Ways Forward: Comparative Dictionary}

From the comparative-historical viewpoint, the ultimate aim of this research is the production of a dictionary of the Westem Oti/Volta (W.O/V) languages. In one sense this is merely a superior version of the wordlist-comparisons like those of Swadesh et al. (1966), with a larger inventory of items, and based in many cases on ongoing research, even published dictionaries, in the individual languages. The sort of detailed sense-discriminations, usage notes, exemplifi- 
catory citations, and so on, offered by the dictionary of a single language, or even a bilingual dictionary for a pair of languages, cannot be usefully utilized for a group of some sixteen to twenty languages or named dialects. On the other hand, the thesaurus research does make it possible to group items in a more rigorous semantic network. The approach makes it possible to deal with a specific problem of wordlist work, the subcase of the target-language distinctions problem which is focussed on by Sankoff:

"In reality, although for some meanings it may be easy to find unique lexical representations, for others it may be difficult to choose between two, three or more words." (1970:565)

Take, for example, 'the word' given in W.O/V wordlists for "river". On the basis of the data available, one could distinguish three sub-groups of the languages, with "river" as something like "KUL-GA, "MOG-RI and *BUL-GA respectively. However, working at greater depth in one specific language I found that all three terms existed (in the same language group), kuliga (in Mampruli (MP)) being the place you go to for water - river, well or waterhole; mo'ari is a large body of water which does not dry up even in the dry season, and is, therefore, a big river, natural lake or artificial reservoir; and buliga is a well or spring where water seeps or springs or flows. Further research in to other languages of the group showed that most, if not all, have all three words with comparable, if not identical, distinctions.

As a result I set about presenting more detailed discussions of problematic semantic fields, with the data available to me so far laid out in wordlists for individual glosses, and circulating these "Lexinotes" to researchers working on, or interested in, these languages. Those who. received the notes were (or are, the series is still being issued intermittently) requested to return corrections or additions to the data and interpretations given. Thus one of some twenty-five topics proposed is "Water", including not only the three 'river' words above but also the word for "water" itself (which may, in fact, be a major shared-innovation defining the $W . O / V$ group) and also referents like "pothole, puddle", "swamp", the verb "to flow", and so on. Other areas discussed are colour terms, or words for "sun" and "God", which are obviously related although the present-day cultures show no sign of sunworship. As an example of these Lexinotes, I append the partially revised text of one of the earlier notes, on verbs of motion (cf. Appendix).

At present I envisagse a publishable comparative dictionary to contain entries like the individual wordlists ("ARRIVE", etc.) in the Lexinote arranged according to semantic fields in an overall thesaurus-style framework. Where there is a problem in specifying W.O/V discriminations with English words, the field will be presented in a simplified Lexinote-style discussion. Detailed alphabetical indices in English and French, the two international languages of the area, will facilitate the location of a specific item: one can either look up a 
word of particular interest in itself, or look for something in the semantic area required, as an entrée to the whole field.

\section{Conclusion}

The use of wordlist collection as a sampling technique and a basis for comparing languages has a considerable history in West Africa and comparable areas of the world. While we may today be aware of various limitations and problems of the method it is not to be wholly discarded. With thoughtful use it can still yield useful data, and in addition it can feed into more sophisticated studies of genetic relationships and comparative lexicology. This, in turn, will lead to better comparative lexicography.

\section{Notes}

1 My apologies to Clarence Bamhart who used the term 'Lexinote' before me. I graciously accept the (as yet un-offered) apologies of Reinhard Hartmann who started using the word after me. It is obviously a term whose time has come.

Detailed acknowledgements for data take up a whole page: blanket thanks to colleagues in GILLBT and the University of Ghana, officers of Governmental and non-governmental agencies in the various locations, chiefs, elders and many individuals in the language communities. Also to Clara Rosingh for keyboarding assistance.

2 One proposed etymology of "barbarian".

3 The only important exception known to me is that of the Mesopotamian cultures which developed some wordlists comparing the Sumerian, Akkadian and Westem Semitic (e.g. Ugaritic) languages. Further details on various linguistic traditions are now appearing in Lepschy's 'Storia' (Lepschy (Ed.) 1990).

4 Item numbers in the 'Swadesh-200' list are henceforth merely indicated by a preceding \#.

5 "English" stands here for whatever language is used to present the stimulus item - English, French, Portuguese, Afrikaans, Arabic, Swahili, Hausa or a local lingua franca.

6 In Mampruli the future negative is the most easily elicited unmarked verb form of a verb.

\section{References}

* marks references in the Appendix

Arana, Evangelina and Mauricio Swadesh. 1967. Diccionario analitico del mampruli. Mexico D.F.: Museo de las Culturas.

1

Badjona, M. 1983. Nawdem-Deutsch Wörterbuch (Dialekt von Siou). Saarbrücken: Universität des Saarlandes. 
Bendor-Samuel, John T. 1971. Niger-Congo, Gur. Berry, Jack and Joseph H. Greenberg (Eds.). 1971: 141-178.

Bendor-Samuel, John T. 1989. The Niger-Congo Languages. Lanham, MD: University Press of America.

Bennett, Patrick R. and Jan P. Sterk. 1977. South Central Niger-Congo: a Reclassification. Studies in African Linguistics 8(3): 241-273.

Berlin, Brent and Paul Kay. 1969. Basic Color Terms: their Universality and Evolution. Berkeley: University of California Press.

Berry, Jack and Joseph H. Greenberg. (Eds.). 1971. Linguistics in Sub-Saharan Africa (Current Trends in Linguistics VIl). The Hague / Paris: Mouton.

Binger, L.G. (Capt.). 1892. Du Niger au Golfe de Guinée (2 Vols.). Paris: Hachette.

Blass, Regina. 1975. Sisala-English / English-Sisaala Dictionary. Tamale, N.R.: Ghana Institute of Linguistics (now GILLBT).

Brasseur, Georges and Guy le Moal. 1963. Cartes ethnodémographiques de l'Afrique occidentale, feuilles $3 / 4$ nord. Dakar: IFAN.

Busane, Masidake. 1990. Lexicography in Central Africa: the User Perspective. Hartmann, R.R.K. (Ed.). 1990: 19-35.

Christaller, J.G. 1875. A Grammar of the Asante and Fante Language Called Tshi (Chwee, Twi). Basel: Basel Evangelical Missionary Society.

Christaller, J.G. 1889. Sprachproben aus dem Sudan von 40 bis 60 Sprachen und Mundarten hinter der Gold- und Sklavenküste. Z.A.S. 3: 133-154.

Dakubu, Mary Esther Kropp (Ed.). 1977. West African Language Data Sheets I. no place: WALS.

Dakubu, Mary Esther Kropp (Ed.). 1980. West African Language Data Sheets 11. Leiden: WALS / African Studies Center.

Delafosse, Maurice. 1904. Vocabulaires comparatifs de plus de 60 langues et dialectes parlés à la Côte d'Izoire et dans les régions limitrophes. Paris: Leroux.

Delord, J. 1968. Le kaure de la Polyglotta Africana et le kabré d'aujourd'hui. African Language Review 7: 114-139.

Derman, Tankar. 1983. Dictionnaire tem-frangais-allemand / Tem-Französisch-Deutsch Wörterbuch. Saarbrücken: Universität des Saarlandes.

Durand, J.B. (Fr.). 1953. Dagaari-English Dictionary. Jirapa: Catholic Mission.

Fivaz, Derek and Patricia F. Scott. 1977. African Languages: a Genetic and Decimalized Classification for Bibliographies and General Reference. Boston, Mass.: G.K. Hall.

Fortes, Meyer. 1949. The Web of Kinship among the Tallensi. London: OUP.

Goldsmith, John. 1992. A Note on the Genealogy of Research Traditions in Modern Phonology. Journal of Linguisties 28(1): 149-163.

Greenberg, Joseph H. 1966/70. The Languages of Africa. Bloomington, Indiana: Indiana University. (IJAL 29(1) 11. The Hague: Mouton.)

Groh, B. 1911. Sprachproben aus zwölf Sprachen des Togo-Hinterlands. MSOS 14: 227-239.

Hair, P.E.H. 1965. Temne and African Language Classification before 1864. Journal of African Languages 4: 46-56.

Hair, P.E.H. 1966. Collections of Vocabularies of Western Africa before the Polyglotta. Journal of African Languages 5: 208-217. 
Hair, P.E.H. 1968. An Ethnolinguistic Inventory of the Lower Guinea Coast before 1700. African Language Review 7: 47-73.

Hall, Edward. 1983. Ghanaian Language: with Fold-out Map. Accra: Asempa.

*Hall, John F. S.a. (1948). Dictionary and Practical Notes, Mossi-English Languages. Ouagadougou: Mission des Assemblées de Dieu.

Hansford, Keir, John T. Bendor-Samuel and Ron Stanford. 1976. Index of Nigerian Languages. Ghana: S.I.L.

Hartmann, R.R.K. (Ed.). 1990. Lexicography in Africa. Exeter Linguistic Studies 15. Exeter: University of Exeter Press.

Huttar, George and Kenneth Gregerson (Eds.). 1986. Pragmatics in Non-Western Perspective. Dallas: S.l.L./University of Texas at Arlington.

Katia Camara, C. 1983. Tagbana-Deutsch Wörterbuch. Saarbrücken: Universität des Saarlandes.

Koelle, Sigismund W. 1854. Polyglotta Africana. London: CMS.

Köhler, Oswin. 1964. Gur Languages in the Polyglotta Africana. African Language Review 3: 65-73.

Kröger, Franz. 1992. Buli-English Dictionary. Münster/Hamburg: Lit.

Langdon, Margaret A. and Mary J. Breeze. s.a. (1981). Konkomba-English/Likaln-Likpakpaln Dictionary. Tamale, N.R.: Ghana Institute of Linguistics (now GILLBT).

Lavergne de Tressan, M. de. 1953. Inventaire linguistique de l'Afrique Occidentale Française, et du Togo. MIFAN No. 30. Dakar: MIFAN.

Lebizaka, Koyenzi Kézié. 1979. Kabiye-Deutsch Wörterbuch. Saarbrücken: Universität des Saarlandes.

Lepschy, G. (Ed.). 1990. Storia della Linguistica I. Bologna: il Mulino.

Manessy, Gabriel. 1975. Les langues OtiNolta. Paris: SELAF.

*Manessy, Gabriel. 1979. Contribution à la classification généalogique des langues voltaïques: - le proto-central. Paris: SELAF.

Meinhof, Carl. 1906. Grundzüge einer vergleichenden Grammatik der Bantusprachen. Berlin: D. Reimer.

Melançon, Lucien and André Prost (R.PP.). 1972. Dictionnaire buli-français. Dakar: Univ. de Dakar.

Mukarovsky, Hans. 1976. A Study of Western Nigritic 11. Wien: Institut für Ägyptologie und Afrikanistik der Universität Wien.

Mukarovsky, Hans. 1977. A Study of Western Nigritic I. Wien: Insthtut für Ägyptologie und Afrikanistik der Universität Wien.

Naden, Tony. 1986a. Première note sur le konni. JWAL XVI(2): 76-112.

Naden, Tony. 1986b. Social Context and Mampruli Greetings. Huttar and Gregerson (Eds.). 1986: 161-199.

Naden, Tony. 1988. Language, History and Legend in Northern Ghana. Sprache und Geschichte in Afrika 9: 205-246.

Naden, Tony. 1989. Gur. J.T.Bendor-Samuel (Ed.). 1989: 141-168.

Prost, André (R.P.). 1966. La langue gurma dans le Polyglotta. Africana. African Language Review 5: 134-138.

Prost, André (R.P.). 1975. Vocabulaires comparés des langues de l'Atakora. BIFAN 37, B (2): 412448.

*Rattray, R.S. (Capt.). 1932. Tribes of the Ashanti Hinterland. (2 Vols.). Oxford: O.U.P. 
Riccitelli, J.M.R. 1955. Pedagogic Grammar - Red Bobo, Ouarkoye Dialect. No place.

Sankoff, David. 1970. On the Rate of Replacement of Word-meaning Relationships. Language 46(3): 564.

Schadeberg, Thilo C. 1986. The Lexicostatistic Base of Bennett \& Sterk's Reclassification of NigerCongo with Particular Reference to the Cohesion of Bantu. SAL 17(1): 67-83.

Spratt, David and Nancy Spratt. s.a. (1975). A Kusaal-English Dictionary. Tamale, N.R.: Ghana Institute of Linguistics (now GILLBT).

Swadesh, Morris. 1950. Salish Internal Relationships. IJAL 16: 157-167.

Swadesh, Morris. 1953. The Languages of the Archaeologic Huastecs. Camegie Institution of Washington, Dept. of Archaeology, Notes on Middle American Archaeology and Ethnology 114: 223227.

Swadesh, Mauricio, Evangelina Arana, John T. Bendor-Samuel and W.A.A. Wilson. 1966. A Preliminary Glottochronology of Gur Languages. Journal of West African Languages III(1): 2765.

Westermann, Diederich. 1935. Nominalklassen in Westafrikanischen Klassensprachen und in Bantusprachen. MSOS 38(3): 1-53.

Westermann, Diederich and Margaret A. Bryan. 1961. Languages of West Africa. Handbook of African Languages. London: OUP for I.A.I.

"Wilson, W.A.A. 1972. Dagbani, an Introductory Course. (2 Vols.). Tamale, N.R.: Ghana Institute of Linguistics (now GILLBT). 
Table: "Come" and "Go"

FORM

"TI

"TA (cf.

"REACH",

"SEND"(iii)

*WE

"YE

*GA (cf.

"PASS")

*KEN
"GO"

MP/SF ti

BL ta (?tua?)

$\mathrm{HG}^{\mathrm{A}} / \mathrm{KR}(\mathrm{N})$ we

$\mathrm{KR}$ (Hunt) waya

$$
\begin{aligned}
& \mathrm{HG}^{\mathrm{B}} \text { gaa/gaari } \\
& \text { KR(P) gaate! } \\
& \text { KR(P,N) gaariya } \\
& \text { DR(K) ga/gere } \\
& \text { DR(E.Hall) gaa } \\
& \text { WL gaa/gara } \\
& \text { BL ga; KM ga/ } \\
& \text { gara/gama!/gana }
\end{aligned}
$$

DB chap/chema/chendi

MP kyappi/kyema!/

$\mathrm{KR}(\mathrm{N}) \mathrm{c} \varepsilon \mathrm{ma}$ !

\section{KLA ken/kenne \\ KLT(N) kiq,cin \\ NB kep/kem!/keenya \\ TL ken,kyapi/ \\ kyema!/kyenya}

FR kip(e)/kene/kena!/kene

NK(N) sena/seni

MR(J,P) kyene

$\mathrm{MR}(\mathrm{H}, \mathrm{N})$ kende

$\mathrm{MR}(\mathrm{O})$ kêng/kênda

DR(J) ci p; DG kye

LB(R) cep/ceri

NR(J) cen; BR(J) cen

SF(J) cini

BL (ga)/kyeena/chep
"COME"

KLT tin...na

HG ta/tani

$\mathrm{NB}^{\mathrm{A}} / \mathrm{KR} / \mathrm{TL}\left(\mathrm{N}^{\mathrm{A}}\right)$ ta...na

$F^{A}$ wa'an...na,

wa'ana/wa'ane...na

MR wa/watwaoongo

$\mathrm{DR} / \mathrm{BR} / \mathrm{LB} / \mathrm{NR} / \mathrm{SF}$ wa

WL wa/waana; NT waare

FR $^{\mathrm{B}}$ ye'a...na/ye...na

DB ka/kani/kama!/kandi,...na

MP kye/kyem/kyenni,...na

HG chena ("be coming")

KLA kep...na

KL(R) kyem

$\mathrm{NB}^{\mathrm{B}}$ ki...na,(R) kyim

TL(J) kyep...na

TL(R) kyim

TL(A) kam...na

TL $\left(N^{B}\right)$ kyem...na

$\mathrm{FR}^{\mathrm{C}}$ kena...na
BL(P)ja/jam!/jaya

BL(Gray) chee...na

KM ken...ge

keenini/kenye 
"WALK"
"BE GOING"

MP ti

FR/MP/WL ta

HG/KR(N) wara

MP wa/wara

KLA wa'e/wa'ana

KLT We'e

FR ye'/ye'a

NB ye'e

TL yeaa/yaa

DR gere

*GA

$\mathrm{KR}(\mathrm{P})$ gaate

WL gara(la)

'TI

*TA

*WE

*YE

$\mathrm{DB} / \mathrm{HG} / \mathrm{KR} / \mathrm{MP} \mathbf{t}$
FORM

$\mathrm{DB}$ as "go"

MP as "go"

HG chapoi/

chapina

KL as "go"

NB(N) keo

NB(R) kim

\author{
FR as "go" \\ MR as "go" \\ NT cangi/cangto \\ DR cep/cene/cepe \\ LB cene \\ WL chep/chene \\ BR cin; SF cio \\ BL cep,cep \\ KM chup/chuma/ \\ cumma!
}


Appendix. Western Oti-Volta Lexinote No. 3.

\section{Coming and Going.}

In English idiom, complete confusion is in the state of one who 'doesn't know whether he is coming or going'. We might well imagine that a similar fate might overtake one who held the Rattray (1932) theory that the languages of Northern Ghana, or at least 'Mole-Dagbane', are interchangeable dialects of a single language.

1. A quick glance at survey-type samples of vocabulary from the major or more-accessible languages of the group might suggest to the person envisaged above the simple generalization that all the languages have a verb which one might summarize as ${ }^{*} \mathrm{KE}(\mathrm{N})$, where the first consonant ranges from [k] via [ky] and $[\mathrm{t}]]$ to $\left[\mathrm{t}^{\mathrm{h}}\right]$, and the vowel from [æ] through $[\varepsilon]$ to $[1]$, and which means "go, walk" and, with the addition of a final na, "come". Thus we have ka in DB ${ }^{1}$ (kana "came") ken in KLA, kyenni MP ("walking", kyena "came"), cen in $\mathrm{NR} / \mathrm{BR}(\mathrm{J})$, tin in KLT, and ta in HG.

The above is fine until you ask, e.g. in MP, for:

and get:

$$
\text { "where are you'going?" - "I am going to market." }
$$

Ya ni ka i wa? - N wa la daa.

(where to that you going - I going (assert.) market)

(alongside Kyema! - "Go!" and Kyem na! - "Come!"). It transpires that in a number of these languages "going" in the present ("continuous' or 'progressive') must be realized by a different root from that used in the past, future, imperative and infinitive (in some other $\mathrm{O} / \mathrm{V}$ languages, for instance Kokomba and Nawdm, the same occurs with "come", thus giving four distinct roots "go", "be going", "come", "be coming"). The basic verb means both "go" and "walk" but in the present it is unambiguously "walking" - cf. MP U kyenni ni. "He is walking." (usually heard in reference to a child's stage of development - i.e. habitual imperfective rather than progressive), while perfective U kyappiya. can mean "He went." or "He walked." (to emphasise the latter, add "(his) feet." - Lexinote \#12 forthcoming).

Then after some years in Mampruli I heard $\mathrm{N}$ ti la ... for "I went to ..." and I ti la ya ni? "Where did you go/are you going?", showing that in at least one language the *TI root is used alongside the *KEN, proving them to be distinct. Several languages also have $t i$ and/or ta as a particle or auxiliary indicating purpose/intention/achievement and/or change of scene between verbs in a series (cf. Wilson 1972 II. Ch. 50).

Further research in the group throws up at least three other roots *TA, " $G A$ and "WE; this last one would expect to be the origin of both the MP wa 
above and the FR ye' by the semivowel-harmonizing tendency noted in Lexinote \#3, ("sun" "WEN $\rightarrow$ wun, yen), but FR has both ye' "going" and wa'(an(na)) for "come" so for the moment we will keep wV and yV separate. These various roots mix ' $n$ ' match in a complex way in the various languages; the vocabulary for "come" and "go" (cf. Table) attempts to set this out in two dimensions.

2. There are also a number of verbs of motion with more specific content "go in", etc. - which I usually gloss with a single word ("enter","exit") where possible to avoid congestion in the "go" section of the dictionary. We may define these verbs of motion as those which take the complement of destination (or, for "exit", of origin - etc.) without an intervening "go" verb, in contrast with verbs of manner of locomotion such as "run" — you can say "entered (into) the room" but not "ran to the room" which would have to be "ran, went to the room": this distinction is clearly set out in Wilson (1972 II, Ch. 21). The "hither" particle of the "come" verb (not in HG or the North-western group) can also be used with these words to contrast "come in" with "go in" (within "enter"), and so on. This is obligatory if the motion is towards the speaker, so that if you are speaking of someone falling from a tree, for instance, you have to say "He fell hither." - i.e. coming to the ground where the speaker is located. In fact the verb need not be one of motion: one can speak of "buying something hither" meaning to go somewhere and buy it and bring it here. A common way of saying "Bring it!" or "Hand it over!" is (as is just possible in English) 'Have it here!' - in MP Mari ka na!, FR Tare ka na!.

As in many languages the axis by which the 'hither' is determined is the speaker's present location, or his location at the time (past or future) of the motion concerned, or his normal or expected location; the scope of 'location' depends on the distance of travel - someone from outside the village "comes" to Gbeduuri (any part thereof), while someone from the village only "comes" to my house (or where I am, or was, or will be...). If anything, the use of na is even broader than Eng. "come"; in a narrative it is often used if the next event takes place where the motion arrived at.

A further dimension is added by the possibility of making a causative derivative: "go in" $\rightarrow$ "put in": in MP, at least, this is almost certainly a productive process, suffix -si. The same is found sporadically (possibly universally, the sporadic nature belonging to our sources of data) in most of these languages - forms marked * in the lists below.

Note: In these languages there is a variation $\mathrm{s} / \mathrm{h}$ with various conditions. In DB $h$ is obligatory following a short vowel, in MP before a consonant; in FR and its neighbours * $s$ before a front vowel is $h$. In most of the languages any non-initial $s$ can come out as $h$ in fast or informal speech. It should also be noted that $h$ often nasalizes adjacent vowels - the effect is particular clear in DB \& FR. 
"ASCEND"1, 2 DB du, duhi*; HG du/duura; MP du/duuri, duusi*; KLA du/dut; KLT dos; NB(R) do; TL(R) do, (A) du; $\mathrm{FR}^{\wedge}$ doe/doora; $\mathrm{MR}^{\wedge}(\mathrm{R}) \mathrm{du},(\mathrm{H})$ dou; $\mathrm{DR}^{\wedge} \mathrm{du}$, do/duoro; $\mathrm{LB}(\mathrm{R})^{A}$ do; WL do/duoro, duoho*; $\mathrm{FR}^{\mathrm{B}}$ zom/zona; $\mathrm{MR}^{\mathrm{B}}(\mathrm{R})$ zom; $\mathrm{DR}^{\mathrm{B}}(\mathrm{R}) \mathrm{zom}$; $\mathrm{LB}(\mathrm{R})^{\mathrm{B}}$ zom; $B L(P)$ gyeule, (R) dyur, (Kröger) jue; KM juali (in the Northwestern group the * $\mathrm{ZOM}$ items are probably the preferred equivalent for "ascend")

"DESCEND" DB sigi, sigsi*; HG sigi/sigira; MP sigi/sigri, sigsi*;

$\mathrm{KR}$-/sigsiri/sigsiy a*; KL sig, sie*, sigis*;

$N B(R)$ sige; TL(F) sig, (R) sige, (A) sik;

FR sige/sigire, sigera, sigehe, sirehe sigi, siki*;

DR sigi; LB sige; WL sigi, sigihi*;

$B L(R)$ sig, (P) sini; KM sup

"ENTER" DB kpe, kpehi*; HG kpe/kpeera; MP kpe/kpeeri, kpeesi*;

KLA kpen', kpen'es*; TL/NB(R) kpen; TL (A,F) kpe;

FR ken'/ken'enra, ken'enhe*; NK(R) kye; LB kpe;

MR kẽ, kẽẽs*, (R) kye, (H) ke, kese*;

DR kye(n), kpe(n); NT kwen/kwiyento/kwenys;

WL kpe/kpiera; $B L(R)$ dyo, (P) gyo; KM dzu

"EXIT" DB yi, yihi*; HG yi/yiira; KR yi; MP yi/yiiri, yiisi* ("take out, choose"); KL yi, yiis*; NB(R) yim (?imperat.?);

TL yi; FR ye, yehe/yehera, -/yehere*;

MR yi(i)/yit(a), yiimi, (R) yi, (H) woude, yi, yiis *;

NT yi/yito/yirs; DR yi/yie; LB(R) yi;

HG nyisi ("choose"); BL nyin; KM nyin/nyimma!/nyinna

3. All the languages have a verb for "to go home". This is common, amongst other usages, as a farewell spoken by a parting guest: 'I have gone home.' (proleptic perfective - "I am just about to go home."). It, and/or its causative, may be used for "to marry", especially with the woman as subject (the man often 'eats' his wife) and /or "give in marriage".

"GO HOME" DB kuli, kulsi*; HG'kuli/kunna, kulisi ("marry"); KR kuli; MP kuli/kunni/kulima!, kulsi* (and "marry"); KL kul; TL kuli, kulh*3; FR kule/kula; NK(N) kuli; MR kouli, kwili, kuili, kuilis* (also "marry"); DR kule; KM kuli/kulimi/kuliya; BL kuli 
4. The separate lexeme glossed "return" then means to go back somewhere other than home (or in the collocation 'return, go-home' - "to go back home"), or to go backwards (specifically 'return his (etc.) back'), or to do (something) again. The causative, besides "take/send back", often also means "to answer" a question.

"RETURN"

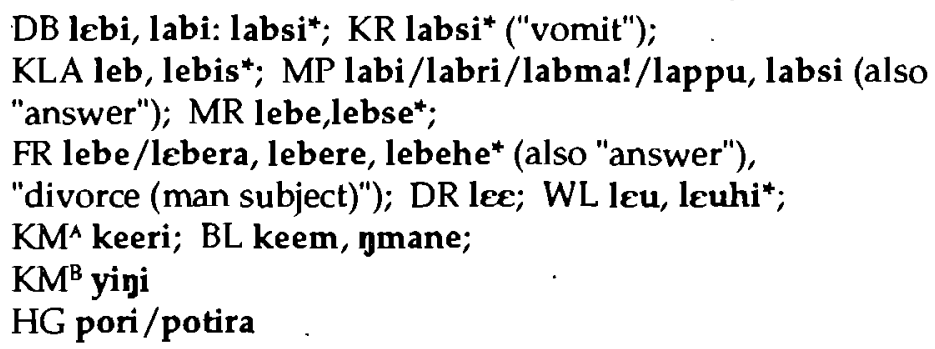

5. We have noted above that some verbs, 'means of locomotion' like "run", "jump", need one of the 'verbs of motion' discussed in this note to indicate the goal or origin of motion ("jumped in" = "jumped, entered"; "ran to town" = 'ran, went town'). Even the verbs of motion, however, do not assert the attainment of the goal. There is yet another lexeme which signifies arrival, and to show that the runner actually reached town one may need to say 'ran, went, reached town'. This verb, glossed "reach, arrive" is in most of these languages something like the MP paai (MR and DR alone, not here supported by .FR or KL, have a reflex of the *TA which Manessy (1979) sets up as a 'common central Voltaic' proto-form - V.C.1; see also the "TA forms in the Table). This is the

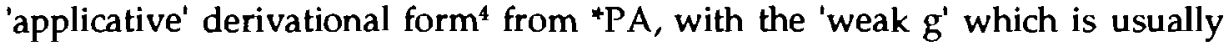
lost in the vowel, but may surface - especially in DB (Wilson, 1972 II, 6.2) before a vowel-initial pronoun (DB paag'o "reach him" from paai). MP has the base verb pa - "to be immediately on top, to be an immediate successor (e.g. specifically come second in a race, or be the 'next-born' in a family)", derivative paai which not only means "to arrive at the goal of motion" but also "to arrive" of a particular time and "to reach, be enough" in quantity, and further the causative paasi both for the first sense of paai - farewell greeting Naawunni paasi ya.! - "God will cause you to arrive (sc. safely)!" - and in the last sense - "cause to reach/be sufficient", this being the normal term for "add"; this m-paasi (serial infinitive 'to add') is often found after other verbs in a series with the quasi-adverbial meaning of "additionally". Whether paali "fill" and paam "plait" a re also derived from the same base is less decidable.

\footnotetext{
"REACH, arrive" DB paai (paag')/paama/paabu, pahi*; HG paa (paag');

KR paa;

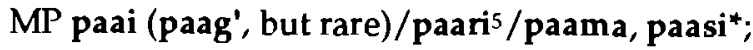

KLT paa; KLA paae/paad, paas*; NB(R) pa;

TL paa, pa'a (N), paa (F, R); FR pae/paare;
} 
MR ta, tall, tase*; DR ta; $L B(R)$ ta;

[WL pa(g-) "meet"]; BL pae (R)/paare/paaya (P);

KM tugi

6. "To cross" is less commonly represented in the sources, and the vocabulary below may represent several distinct lexemes: the *YAK items, for instance, may be specifically to cross over the top of (cf. the common MP collocation yikki n-yakki - "jump/fly over"), while "LO(N) may perhaps be "pass through" (? cf. MP longu "throat" which is also "interior cavity").

"CROSS" DB yagi; MPA yakki; FR yake/yakere; (HGA yagi "come of") $\mathrm{HG}^{\mathrm{B}}$ loo; $\mathrm{MP}^{\mathrm{B}}$ looi, lokki, longi; KL lo'on; DB looi; MR^ $\operatorname{loog}($ "go past");

$F^{B}$ doe (cf. "ascent"); $M^{B}$ doage; DB duui (duli*); $M^{c}$ piouge, piuug; MR budga; $B L$ tam; H' ${ }^{c}$ pulli

7. Most of the languages have a verb, or perhaps two verbs, "to surround" and "go round". "Surround" may be positional ("we are surrounded by the enemy") or motional ("send a task force to surround that town"), while "go round" may imply a circumnavigation ("he went right round the house and came back to us at the gateway") or a detour ("there was a puddle on the path so I went round it"). The sources are not usually clear enough to attribute these various senses to the respective items. In MP n-gyili is "to go round" (including "to wander around aimlessly" - see 9 below) and n-gyiligi "to surround" (Na Gyerimja built a wall n-gyiligi Nalerigu "around Nalerigu (town)").

"ROUND"(go -, be -) DB, WL gili; MP gyili/gyinni, gyilgi;

HG jili, giligi; KL gilig; FR ${ }^{A}$ gilige /giligera;

MR` gilige; DR gol;

BL kia, kiage; $M R^{B}$ kae/kaara;

$M R^{c}$ saaga, gubig, gubga (+adv. gilli)

Wordlists more often have adjective or adverb "round" which is "GIL (/GBIL/KPIL/KIL...) in DR, BL, HG, FR, KL, KR, KM, MP, MR, NB, SF, TL.

8. Our next verb is "to pass", which may mean to go past a fixed spot, or to overtake someone travelling on the same route as oneself. It is also used, in MP at least, for "Come/Go on!" - urging a child or companion not to dawdle, or someone not to hang about but to continue on their journey. This verb also (? from the "overtake" sense ?) means "to surpass" and is used in comparisons; the most obvious form is where it follows a descriptive verb: 
U veela n-gaari i. "She is prettier than you."

(he/she is pretty to-pass thee)

"PASS"

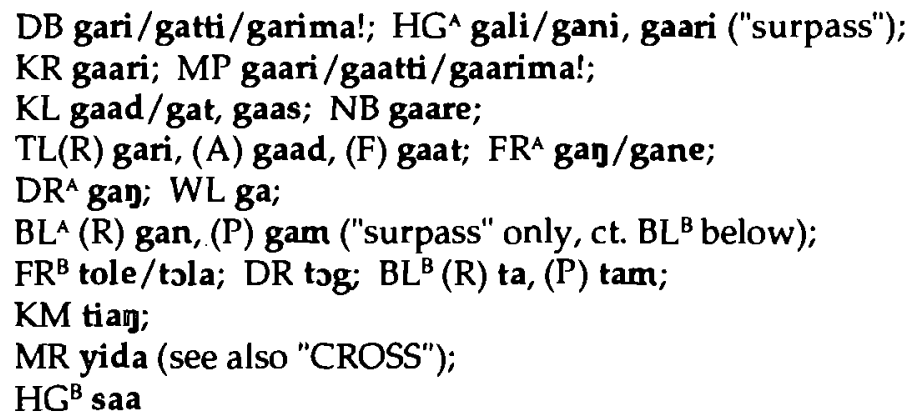

Note: The majority of forms are derived by various thematic consonants (l, $n, r,-$ all frequent in this function) from a base ${ }^{*} G A$ which we may reasonably identify with the item in the Table. Do BL, ?KM, ??FR, DR derive similarly from *TA therein? The KR forms in the table imply gaar- for "go" there.

9. These languages also have a verb meaning "to travel, journey, roam, wander". As this gloss suggests, this can be used for just "going for a walk" ("I don't have any business, I'm just roaming." - cf. on MP "go round", 7 above). It can also mean to take a specific journey: the MP welcome is $\mathrm{Ni}$ i goorim ! "with your travelling" (Naden 1986b). The verb can also indicate travelling in general, the same MP greeting being appropriate to greet someone passing (e.g. on a bicycle) whose start and end points and destination are unknown. A welcome may include a greeting for the goorim-dima - "the people you met on your travels".

"TRAVEL" DB go/gori/goya, (n.) gorim; HG go/goora; KR go; $\mathrm{MP}$ go/goori/goya, (n.) goorim; KLA^ guann/goon;

TL goma (F, ? impat.?); $\mathrm{MR}^{A}$ go,gõ(od);

$\mathrm{KLA}^{\mathrm{B}}$ eed; FR eere/cera; $\mathrm{MR}^{\mathrm{B}}$ yeebe; $\mathrm{KM}$ (n.) diisi;

BL $(G, P)$ nyeem,(N.,D) cerim

10. In section 1., on basic "go, come", we did not discuss causative derivatives. In fact morphological derivatives of these bases do not seem to be found except for the link with "pass" (note to vocabulary in 8 above, "GA, TA) and with "send" (below "SEND" iii, "TA). There are separate lexemes for "send"; in fact local English has a number of different 'send's:

a) Two of these are "to send, or 'message"', the contrast between the two being that although in both cases the Agent, the sender, entrusts an errand or mes- 
sage to the person sent, in one case he is "sending" someone who otherwise would have no reason to go, while in the other he entrusts his errand to someone who is going anyway on his own business:

i) "SEND (on an errand)" DB tim; HG tumi/tumina; KL tum; BL tom; MP tum/tumni / tumma! / tumpu; FR tom /tone; MR toum, tum ${ }^{6}$

ii) "SEND (message with sb.)" HG tolimi; MP tolim; MR tole; KLA tolisi;

b) In local Eng. "send" is also used for the situation where the Agent actually transports or travels with the person 'sent': "I had to go to Nalerigu in my lorry to send the Chief to Hospital." The only sure examples I have of this are derivatives of the *TA base of "go".

iii) "'SEND' (take sb. to..)" DB tahi; HG/MP taasi; TL ta'ah; MR tall; (? BL ta);

c) There are two further verbs involving two people travelling together. One is usually translated "follow", but basically means rather 'to accompany in a subordinate or secondary position'. Thus we have the local English "If you are going to Tamale in your lorry, may I follow you?" meaning "Will you give me a lift?" not "May I drive along behind?". This is therefore rather "be a follower of"; to get the usual meaning of the Eng. "follow sb." you have to say "follow sb.'s back'. There are also collocations of "follow" with a path or placename in the sense of "go via ...". The other sort of 'accompanying' implies that the 'follower' is the more important - "lead" is sometimes used in local Eng. - and it is particularly used in "Take me to your leader!" Type situations: the subject of the verb "escorts" someone to show him the way, introduce him to the person to be visited, or just to provide a guard of honour to add dignity to his progress.

i) "ACCOMPANY, 'follow'" DB doli/dola/dola!; MP doli/dola/dola!;

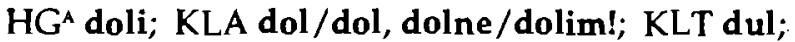

TLA (F) doli; FR^ dole/dsla; TL ${ }^{B}$ duh (vocab. 3, note);

FR $^{B}$ doohe;

$M R^{A}$ toun,tũn, tuu,tule; $\mathrm{MR}^{\mathrm{B}}$ pogele,pugla;

DR beere (cf./ct. ii) below);

BL sape; $K M^{A}$ supun; $K M^{B 2}$ dii/diiya;

$H G^{B}$ pa...zu (normal way of expressing this sense; cf. "REACH")

(zu is "head, on") 
ii)

"ESCORT,'lead" " DB bicli; HG beeli/beena; KLAA biel;

MP beeli/beenni/beelima!; FR beele; DR biel, beele;

TL^ beeh; BL bane;

$\mathrm{MP}^{\mathrm{B}} \mathrm{kJ}$ 'ali ("give a lift on bike, horse");

$\mathrm{TL}^{\mathrm{B}}(\mathrm{F})$ kogal;

$\mathrm{KLA}^{B}$ pi'e; MR nyage; KM supun (see i) above, q.v.

11. Our final verb of motion is "to be near" which itself or in a derivative may also be "to get near, approach". In MP there is a syntactic distinction between the predication types, the process ("come near") has the possibility of occurring in the imperfective with the verb-assertive particle ni: U potti ni. - "He is approaching." - or in the absolutive (verb is final in the clause) perfect with ya: U poriya. - "He has approached." (these are the normal active verb frames). The stative frame appropriate to "be near" allows the verb stem followed by both the perfective and the assertive markers (this is impossible for action verbs): U poriya ni - "He is near."

"NEAR" (be -, get -) ( is "get near, approach")

$\mathrm{DB}(\mathrm{R})$ miri, (Okraku Dict.) mire, (N) muri, (O) miri /mirti

$\mathrm{MP}^{\wedge}$ miri/mitti (rare);

$\mathrm{MP}^{\mathrm{B}}$ pori/potti/porima! ( ${ }^{*}$ also); KLA ${ }^{\mathrm{A}}$ ponri;

$\mathrm{NB}(\mathrm{R})$ pore; $\mathrm{TL}(\mathrm{N})$ pori, $(\mathrm{F}, \mathrm{A})$ poriga (?*); $\mathrm{FR}^{\wedge}$ ponre;

$\mathrm{NK}(\mathrm{R})^{\wedge}$ pore; $\mathrm{MR}^{\wedge}$ peya; SF peel; $\mathrm{WL}^{\wedge}$ pieli;

$\mathrm{NK}(\mathrm{R})^{\mathrm{B}} / \mathrm{MR}^{\mathrm{B}}$ kolege; KLA ${ }^{B} \mathrm{kpi}^{\mathrm{i} e} / \mathrm{kpi}^{\prime} \mathrm{ene} ; \mathrm{DR}{ }^{*} \mathrm{kpiele}$;

$\mathrm{BL} *$ kpaje;

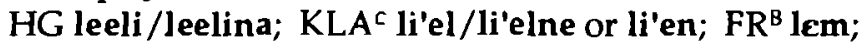

$\mathrm{BL}^{\mathrm{A}}$ gela; KM gbagi;

$\mathrm{BL}^{\mathrm{B}}$ mosta (caus. mostte "bring sth. near");

WL ${ }^{B}$ tohi

The inverse "be far" does not, to my knowledge, have a "go far, s'éloigner" sense in any of these languages". "Be far" is usually a descriptive verb "be long, tall, far", basic form *WOG, with various adjectival and adverbial derivatives.

\section{Notes to Appendix}

1 The Western (and other) Oti/Volta languages are referred to here by the standard two-letter codes (Swadesh et al. 1966, Naden 1989):

$\begin{array}{lll}\text { BL } & - & \text { Buli (O/V Buli) } \\ \text { BR } & - & \text { Birifor } \\ \text { DB } & - & \text { Dagbani } \\ \text { DG } & - & \text { Dagara (B. Faso) } \\ \text { DR } & - & \text { Dagaari }\end{array}$

$\begin{array}{lll}\text { KM } & - \text { Konni (O/V Buli) } \\ \text { KR } & - \text { KaMara } \\ \text { LB } & - & \text { Lobiri' }\left(R^{2}\right) \\ M P & - & \text { Mampruli } \\ \text { MR } & - & \text { Moore }\end{array}$




\begin{tabular}{|c|c|c|c|c|}
\hline FR & Frafra & NB & - & Nabit \\
\hline GN & - Gurenne $\left(J^{2}\right)$ & NR & 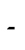 & Nura \\
\hline HG & Hanga & NT & - & Nootre \\
\hline KL & Kusaal & $\mathrm{SF}$ & & Safalaba \\
\hline KLA & Kusaal Agole (West) & $\pi$ & & Talni \\
\hline KLT & Kusaal Toonde (East) & WL & - & Wali \\
\hline
\end{tabular}

2 Other abbreviations:

/ - separates paradigrn co-forms singular/plural (Noun), neutral/imperfective/ imperative/verbal noun (Verb)

A,B - (partial) synonyms or different sources for the same language

(A) - written data from Abraham Manga (TL)

(F) - data from J. Hall (1948) (MR)

(H) - data from Fortes (1949 and other writings) (TL)

(J) - data from JWAL article - Swadesh et al. 1966

(K) - data from J. Kennedy (DR)

(N) - data from Tony Naden field research

(O) - orthographic form from published material

(P) - data from Prost (various publications, N.B. Melançon and Prost 1972 (BL))

(R) - data from Rattray (1932)

$3 \pi$ distinguishes reflexes of *-Sl and *-FU as a final -h with spread and rounded lips respectively

4 cf. MP te "spread (self)" - teaai "straighten, stretch out sth."

zE "blow (wind)" - zeaai "blow something (away)"

This structural type of derivative may also be inversive in sense:

ye "put on (shirt, etc.)" - yeaai "take off (...)"

yo "open" - yoaai "close"

and singulative:

gba "catch" - gbaai "catch (one only)"

5 Far-west dialect imperfective paagri.

$6 \pi(\mathrm{F})$ tumh (" causative, see note in 2 above) "follow through kinship links".

7 MR does have zara "être loin" vs. zaage "éloigner" (move something to a distance); cf. FR zaam "be deep". 


\title{
Grammatiese inligting ten opsigte van adjektiewe in aanleerderwoordeboeke*
}

\author{
Anna Nel Otto, Departement Afrikaans, Universiteit Vista, \\ Port Elizabeth, Suid-Afrika
}

\begin{abstract}
Grammatical Information with Regard to Adjectives in Leamer's Dictionaries. Because a learner's dictionary is used for both decoding and encoding, it should contain far more grammatical information (explicitly indicated) than standard dictionaries. Therefore, with regard to adjectives for example, attention should be given to the following: the possibility or not of inflection; the comparative and superlative forms; a complete identification of the different types of adjectives, an indication whether an adjective can only be used attributively or predicatively; the different ways in which so and sulke are used; the fact that not all "past participles" can be derived from the passive forms of wees; the provision of a spelling list with the names of people, countries, places, nations, tribes, languages, as well as derivations thereof; cross-references between nouns/verbs and their adjectival correlates if there are striking differences between them, and an indication of adjective complements. The value of valency theory by determining adjective complements is examined in this article and the importance of a distinction between obligatory and peripheral complements for both learners and teachers is stressed. The linguistic categories which can function as adjective complements in Afrikaans are provisionally indicated, but it is stated that further research in this regard is necessary.
\end{abstract}

Keywords: ADJECTIVE, ADJECTIVE COMPLEMENTS, GRAMMATICAL INFORMATION, LEARNER'S DICTIONARY, LINGUISTIC CATEGORIES, MICRO-STRUCTURE, MINI GRAMMAR, OBLIGATORY COMPLEMENTS, OPTIONAL COMPLEMENTS, PERIPHERAL COMPLEMENTS, VALENCY

Opsomming: Aangesien in aanleerderwoordeboek vir sowel dekodering as enkodering gebruik word, moet dit baie meer grammatiese inligting (eksplisiet aangedui) as standaardwoordeboeke bevat. Gevolglik moet daar byvoorbeeld ten opsigte van adjektiewe aandag geskenk word aan: ' $n$ aanduiding of adjektiewe verbuig moet word of nie, trappe van vergelyking, ' $n$ volledige identifikasie van adjektiewe, 'n aanduiding of adjektiewe net attributief of net predikatief kan optree, die verskillende wyses waarop so en sulke gebruik word, die feit dat nie alle "voltooide deelwoorde" uit lydende vorme met wees gevorm kan word nie, die voorsiening van 'n spellys met die name van mense, lande, plekke, volkere, stamme, tale, asook afleidings daarvan, kruisverwysings tussen selfstandige naamwoorde/werkwoorde en hul adjektiwiese korrelate indien daar

Hierdie artikel is 'n verkorte en aangepaste hoofstuk uit 'n D.Litt-verhandeling, Kriteria vir 'n Afrikaanse aanleerderwoordeboek, wat in 1989 deur die Universiteit van Stellenbosch aanvaar is. 
groot verskille tussen hulle is, en die aandui van adjektiefkomplemente. Die waarde van valensieteorie by die bepaling van adjektiefkomplemente word ondersoek en daar word gewys op die belangrikheid van ' $n$ onderskeid tussen verpligte en perifere komplemente vir sowel aanleerders as onderwysers. Die linguistiese kategorieë wat in Afrikaans as adjektiefkomplemente kan optree, word voorlopig aangedui, maar daar word op gewys dat verdere navorsing oor hierdie aspek nodig is.

Sleutelwoorde: AANLEERDEERWOORDEBOEK, ADJEKTIEFKOMPLEMENTE, ADJEKTIEWE, GRAMMATIESE INLIGTING, LINGUISTIESE KATEGORIEë, MIKROSTRUKTUUR, MINICRAMMATIKA, OPSIONELE KOMPLEMENTE, PERIFERE ELEMENTE, VALENSIE, VERPLIGTE KOMPLEMENTE

\section{Inleidend}

Grammatiese inligting in woordeboeke sluit sowel sintaktiese as morfologiese inligting in. Dié inligting kan enersyds in die mikrostruktuur 'n neerslag vind as eksplisiete gegewens oor bepaalde lemmas. Andersyds kan dit in die minigrammatika los van die woordeboek se alfabetiese deel aangebied word (Gouws 1986: 27).

Die inkorporering van.grammatiese inligting in 'n aanleerderwoordeboek behoort so volledig as moontlik aangebied te word ten einde die aanleerder in staat te stel om op grond van die leiding wat hy ontvang, selfstandig korrekte, natuurlike sinne te genereer.

Aangesien grammatiese inligting voorkom as inskrywings in ' $n$ woordeboekartikel maak dit deel uit van 'n woordeboek se mikrostruktuur. Hierdie soort inligting val in twee hoofkategorieë uiteen, naamlik eksplisiete inligting en implisiete inligting. Die mate waarin aandag geskenk word aan hierdie twee tipes inligting word bepaal deur die betrokke woordeboeksoort.

Eksplisiete inligting word in die meeste woordeboeke voor die definiens geplaas. Volgens Jackson (1985: 54) is daar vier tipes inligting wat van woordeboekartikels verlang kan word. Die eerste drie tipes verteenwoordig eksplisiete inligting. Eerstens is daar inligting oor die wyse waarop 'n leksikale item verbuig kan word, veral wanneer dit nie afleibaar is uit die algemene reëls van die grammatika nie. Tweedens is daar woordsoortaanduiding. Derdens kan meer spesifieke eksplisiete sintaktiese inligting gegee word, byvoorbeeld werkwoorde wat geklassifiseer word as oorganklik of onoorganklik. Volgens Jackson (1985: 54) is lg. tipe inligting van besonder groot belang vir die tweedetaalgebruiker.

Die vierde tipe hou verband met implisiete grammatiese inligting wat onregstreeks met behulp van goed gekose voorbeeldsinne en kollokasies aangebied word. Dit word gewoonlik ná die definiens geplaas.

Die woordeboekgebruiker moet nie slegs in staat gestel word om effektief te kan kommunikeer nie, maar die leksikograaf moet self ook effektief kommu- 
nikeer met die woordeboekgebruiker sodat woordeboekartikels sinvol ontsluit kan word.

Die inligting wat in die toeligtende aantekeninge van 'n woordeboek weergegee word, is tweeledig van aard. 'n Deel van dié inligting het die sinvolle ontsluiting van die woordeboekartikels ten doel. Die ander deel van die inligting kom voor as 'n minigrammatika, dit wil sê 'n betroubare samevatting van die taal se grammatika (Gouws 1986: 29).

Die minigrammatika kan op verskillende wyses aangebièd word. Dit kan byvoorbeeld op so 'n wyse by die grammatiese mikrostruktuurinligting geïntegreer word dat die woordeboekartikels 'n reeks kodes bevat wat in die minigrammatika geëkspliseer word. Gouws (1986: 30) noem die volgende tipes inligting wat vir Afrikaans deur bogenoemde wyse van kodering en kruisverwysing gegee kan word: woordsoortaanduiding en talle onderafdelings wat daarmee verband hou, byvoorbeeld die attributiewe of predikatiewe gebruik van adjektiewe, adjektiwiese verbuigings, trappe van vergelyking, substantiwiese gebruik van adjektiewe, oorganklikheid en onoorganklikheid van werkwoorde, moontlikheid om werkwoorde in die lydende vorm te gebruik, te of -de as uitgange by voltooide deelwoorde, deelwoordvorming as sodanig, optrede van 'n voegsel waar die lemma in kompositumverband optree, ensovoorts.

Die minigrammatika kan ook die vorm aanneem van 'n beknopte beskrywing van bepaalde grammatiese aspekte van die taal. So 'n minigrammatika moet veral konsentreer op morfologiese en sintaktiese reëlmatighede (Gouws 1986: 30).

Volgens Gouws (1986: 30) is die ideaal dat woordeboekgebruikers met behulp van die woordeboekartikel by dié minigrammatika moet kan uitkom. Die gebruik van direkte kruisverwysing kan verseker dat die twee grammatiese inligtingskategorieë in 'n interaktiewe verhouding benut word. In dié verband kan woordeboekgebruikers baie baat vind by onderrig in woordeboekontsluitingsvaardighede.

\section{Kriteria ten opsigte van die aanduiding van adjektiewe}

Afrikaanse woordeboeke en Bosman e.a. se Tweetalige Woordeboek/Bilingual Dictionary dui adjektiewe as sodanig aan, maar genoegsame inligting word nie aan aanleerders verskaf om hulle in staat te stel om adjektiewe korrek (d.w.s. vir enkodering) te gebruik nie. Om voorsiening te maak vir die aanleerder se behoefte aan meer gedetailleerde inligting, moet adjektiewe op 'n andersoortige wyse in aanleerderwoordeboeke behandel word.

Die inligting wat noodsaaklik is om adjektiewe korrek te kan gebruik, word vervolgens bespreek. 


\subsection{Algemene kriteria}

'n Aanduiding of die adjektief die attributiewe verbuigingselement - $e$ moet neem of nie is noodsaaklik en dit behoort eksplisiet aangedui te word. Indien dit moontlik is dat 'n bepaalde adjektief met of sonder die - e gebruik kan word, behoort ook dít eksplisiet aangedui te word. In lg. gevalle verbind die adjektiewe met $-e$ dikwels met 'n vaste naamwoord(e) en verkry ' $n$ figuurlike of idiomatiese betekenis wat uit die voorbeeldsinne moet blyk. In sodanige gevalle behoort nagegaan te word of hulle as lemmas opgeneem moet word of nie. Vergelyk diepe waters.

- Die trappe van vergelyking van die betrokke adjektief behoort aangedui te word. Daar behoort op 'n duidelike wyse onderskei te word tussen adjektiewe waarvan die vergelyking deur -er en -ste (d.w.s. morfologies) gevorm word en adjektiewe wat meer en mees neem (d.w.s. leksikale gradering - vergelyk Carstens 1991: 78, 79). Indien die trappe van vergelyking op beide morfologiese en leksikale wyses gevorm kan word, behoort dit ook so aangedui te word. Hierdie kriterium verteenwoordig 'n ideaal wat nagestreef behoort te word. Op die oomblik is die vergrotende en oortreffende trappe van adjektiewe in Afrikaans onvas as gevolg van Engelse invloed.

Onreëlmatige vorme behoort ook aandag te geniet. In Afrikaans sal daar dan in hierdie verband aandag geskenk moet word aan die adjektiewe baie, goed, graag, naby en weinig wat suppletiewe (morfologies onverwante) graadtrappe het:

$\begin{array}{lll}\text { (1) baie } & \text { meer } & \text { meeste } \\ \text { goed } & \text { beter } & \text { beste } \\ \text { graag } & \text { liewer } & \text { graagste/liefste } \\ \text { naby } & \text { nader } & \text { naaste } \\ \text { weinig } & \text { minder } & \text { minste }\end{array}$

(Vergelyk Ponelis 1979: 279).

Asimmetriese trappe soos die onderstaande verdien ook aandag:

(2) afgeleë bek-af ideaal pootuit

$\begin{array}{ll}\text { meer afgeleë } & \text { afgeleënste } \\ \text { meer bek-af } & \text { bek-afste } \\ \text { meer ideaal } & \text { ideaalste } \\ \text { meer pootuit } & \text { pootuitste }\end{array}$

(Vergelyk Ponelis 1979: 279). 
Beide die Nasionale Woordeboek (voortaan NW) en Handwoordeboek van die Afrikaanse Taal (voortaan HAT) dui nie die asimmetriese trappe van bogenoemde woorde aan nie. Die feit dat die betrokke woordeboeke nie die trappe van vergelyking van hierdie adjektiewe aandui nie, impliseer dat hulle nie so gebruik kan word nie.

- Adjektiewe (wat wel gradeerbaar is), moet onderskei word van die adjektiewe wat nie gradeerbaar is nie, soos byvoorbeeld aaneenskakelend. 'n ldentifikasie van adjektiewe is noodsaaklik, met ander woorde 'n aanduiding of die adjektief selfstandig, oorganklik, 'n voorsetseladjektief of ' $n$ adjektief gevolg deur ' $n$ infinitiefsin is. Voorbeelde hiervan is:

(3) (a) Selfstandige adjektief,

- Die seun is ongelukkig.

(b) Oorganklike adjektief

- Hy is Xhosa magtig.

(c) Voorsetseladjektief

- Sy is vertroud met die reëls.

(d) Adjektief en infinitiefsin

- Ek is nie lus om nou te gaan swem nie.

Hierdie inligting kan deur middel van kodes aangedui word. In die toeligtingsgedeelte kan hierdie kodes en die verskillende soorte adjektiewe dan verduidelik word.

Sommige adjektiewe kan sowel attributief as predikatief optree. Sulke adjektiewe hoef nie vir dié optredes gemerk te word nie, maar daar is ook ander adjektiewe wat beperk is in hul optrede deurdat hulle of net attributief óf net predikatief gebruik kan word. Dit is 'n gemerkte waarde wat aangetoon moet word (Gouws 1989: 225). Adjektiewe wat net attributief of net predikatief optree, kan deur middel van kodes as sodanig geïdentifiseer word.

Adjektiewe wat net predikatief kan optree, is onder meer begaan, bestund, gedagtig, gewoond, kwaad, vatbaar, gesteld. (De Villiers 1983: 58).

"Onder die adjektiewe wat net attributief voorkom, is ' $n$ baie belangrike groep naamwoordelik van aard, byvoorbeeld provinsiale, regterlike, ministeriële, botaniese, mediese, chemiese, stedelike, ens." (De Villiers 1983: 58).

Aanleerders moet gewys word op die onderskeid tussen so en sulke. Die aanwysende PRO-adjektief so verskyn net in onbepaalde naamwoordstukke, byvoorbeeld so 'n seun. Voor enkelvoudige soortnaamwoorde het dit die vorm so, maar voor massanaamwoorde en meervoudige soortraamwoorde tree sulke op: sulke seuns, sulke onsin (vergelyk Ponelis 1979: 152). Sommige aanleerders gebruik sulke voor enkelvoudige soortnaamwoorde. Dit is dus belangrik dat aan hulle eksplisiet voorgehou word hoe om so en sulke korrek te gebruik. Dié inligting kan deur 
middel van 'n gebruiksnota oorgedra word en voorbeelde kan ter illustrasie gebruik word.

- Nie alle "voltooide deelwoorde" kan uit lydende vorme met wees gevorm word nie. Vergelyk:

(4) gesingde versie

gegooide klip

gesiende plek

Hierdie beperkings behoort onder die aandag van die gebruiker gebring te word. Indien daar byvoorbeeld in die woordeboek deurgaans (teenwoordige en voltooide) deelwoorde by die lemma aangedui word, sal die weglating impliseer dat die deelwoorde nie moontlik is nie. ' $n$ Alternatief is om ' $n$ volledige lys stamme en deelwoorde voor of agter in die woordeboek aan te bring. Woorde wat nie in hierdie lys voorkom nie, kan dan nie as deelwoorde gebruik word nie.

- Dit is verder ook noodsaaklik dat 'n spellys met die name van mense, lande, plekke, volkere, stamme, tale, asook afleidings daarvan, voorsien behoort te word, aangesien die spelling van die basisvorm en afleiding dikwels baie verskil. Vergelyk:
(5) Genève
-
Geneefse
Algerië
Algerynse
Kreta
Kretensiese

- By Germaanse teenoor Romaanse sinonimie is daar dikwels 'n groot verskil tussen naamwoordstamme en hul adjektiwiese korrelate, gevolglik behoort daar kruisverwysings van die naamwoord na die adjektief en omgekeerd te wees. ' $n$ Altematief is om gebruiksnotas te gebruik. Vergelyk:

\section{Samestelling}

(6) eindstaat

buite-oor

oogsenuwee

taalverskynsels

\author{
Adjektief + naamwoord \\ finale staat \\ eksterne oor \\ optiese senuwee \\ linguistiese verskynsels
}

(Vergelyk Ponelis 1979: 147).

- Daar behoort ook kruisverwysings tussen werkwoorde en hul adjektiwiese korrelate te wees indien daar groot verskille is. Vergelyk: 


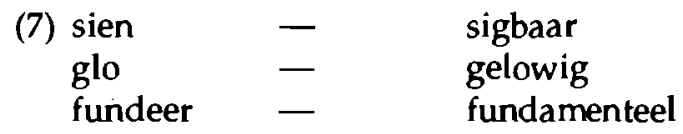

\subsection{Kriteria met betrekking tot adjektiefkomplemente}

Adjektiefkomplemente behoort aangedui te word.

Reeds in 1899 het Henry Sweet in sy,Practical Study of Languages die volgende vereiste aan woordeboeke vir nie-moedertaalsprekers gestel:

"A thoroughly useful dictionary ... ought to give full information about those grammatical constructions which characterize individual words and cannot be deduced with certainty and ease from a simple grammatical rule. They thus ought to give full information about the prepositions by which verbs are connected with the words they govern ..."

Wat werkwoorde betref, is Sweet se vereiste intussen waarskynlik deur woordeboeke soos Oxford Advanced Learner's Dictionary of Current English (voortaan OALDCE) met sy 25 basiese werkwoordpatrone en Longman Dictionary of Contemporary English (voortaan LDOCE) met sy patrone gebaseer op die Grammar of Contemporary English (Quirk et al. 1972) nagekom. Alhoewel albei woordeboeke inligting oor die komplementeringsmoontlikhede van adjektiewe bevat, verskaf hulle nie genoeg detail om die aanleerder in staat te stel om uit te vind "whether valency theory is 'useful for' or 'not available to him', (...) whether it may be 'important for him to find' and/or 'important that he should find" such information in a dictionary" (Herbst 1984: 1). Dit is nie duidelik op grond waarvan die samestellers besluit het om die komplementeringsmoontlikhede van ' $n$ adjektief wel te spesifiseer of dit nie te spesifiseer nie. Herbst (1984: 1 ) is van mening dat die toepassing van die valensieteorie op Engelse adjektiewe kriteria kan voorsien op grond waarvan 'n besluit met betrekking tot moontlike komplementering geneem kan word.

Vanuit 'n linguistiese oogpunt kan die konsep valensie volgens Herbst (1984: 1) omvattender beskou word as wat die geval is met die meer tradisionele konsepte van oorganklikheid en reksie ("government"). 'n Werkwoord wat byvoorbeeld tradisioneel as 'n oorganklike werkwoord beskryf 'word, kan ook beskou word as ' $n$ werkwoord wat 'n valensie van twee het en 'n direkte voorwerp regeer. Die werkwoord vang het byvoorbeeld twee sintaktiese gleuwe wat gevul moet word. Vergelyk die volgende voorbeeld:

(8) Jannie vang die bal.

Die valensieteorie word onder andere deur Lyons 1977, Leech $1981^{2}$ en Matthews 1981 bespreek. 
Valensie omvat meer as net die getal uitdrukkings waarmee 'n werkwoord mag of moet verbind. Valensie beteken dat daar ook rekenskap gegee moet word van die verskille in lidmaatskap van die stelle uitdrukkings wat met verskillende werkwoorde kan kombineer. Die werkwoorde give en put (in hul algemeenste gebruike) het albei 'n valensie van drie, maar hulle verskil ten opsigte van die drie uitdrukkings wat hulle regeer: give regeer 'n onderwerp, 'n direkte voorwerp en 'n indirekte voorwerp, terwyl put 'n onderwerp, 'n direkte voorwerp en 'n rigtinggewende lokatief regeer. 'n Mens kan dus sê dat hulle ten opsigte van valensie verskil: hulle word geassosieer met twee verskillende valensiestelle (Lyons 1977: 486-487).

Leech (19812: 198) definieer valensie as "the potential that a word possesses for combining with other words both syntactically and semantically." Die valensie van ' $n$ werkwoord is die getal en tipe sintaktiese gleuwe wat gevul moet word om die betekenis van die werkwoord te voltooi. Vergelyk:

$\begin{array}{lll}\text { (9) } 1 \text { valensie } & 2 \text { valensies } & 3 \text { valensies } \\ a \text { speak } & a \text { say } b & \text { a remind } b \text { of } c\end{array}$

Die volgende belangrike punte met betrekking tot valensie moet in gedagte gehou word:

- Werkwoorde kan net soos ander tipes woordsoorte dubbelsinnig wees. Hierdie dubbelsinnigheid kan toegeskryf word aan die feit dat dieselfde werkwoord verskillende getalle valensies kan hê. In een betekenisonderskeiding kan sowel say as speak byvoorbeeld bivalent wees: The actor spoke his lines en The actor said his lines.

-. Valensies kan elemente bevat wat opsioneel gerealiseer word, byvoorbeeld die opsionele direkte voorwerp in Jill was writing/Jill was writing a letter.

- Adjektiewe het ook valensies. 'n Adjektief soos happy is monovalent (a be happy) maar ' $n$ adjektief soos glad is bivalent ( $a$ is glad at/about $b$ ). Laasgenoemde voorbeeld illustreer dat bivalensie nie net funksioneel (onderwerp $\times$ voorwerp) of kategoriaal (infinitiefsin $\times$ NS) gemotiveer word nie, maar ook leksikaal, dit wil sê ten opsigte van twee woorde wat dieselfde funksie en woordsoort het. Glad verbind met 'n setsel, maar verskillende leksikale elemente wat tot dié kategorie behoort (at en about) kan met glad verbind.

Die leksikografies belangrike vraag oor hoe konstruksies wat individuele woorde karakteriseer, geskei kan word van daardie konstruksies wat nie individuele woorde karakteriseer nie, word in die valensieteorie gereflekteer deur die onderskeid tussen komplemente (Fr. 'actants, D. Ergänzungen) en perifere elemente (circonstants, Angaben). Die komplemente, wat in verpligte en opsionele komplemente verdeel kan word, vul die valensieposisies van die regeren- 
de element, terwyl die voorkoms van perifere elemente geensins bepaal word deur of tipies is van 'n regerende element nie. Perifere elemente maak nie deel uit van valensie nie en dit is slegs die komplemente wat in die woordeboek in die regerende lemma se artikel opgeneem behoort te word. Volgens Herbst (1984: 1) kan daar dus gesê word, dat indien die valensieteorie 'n bydrae tot leksikografie wil lewer, dit in staat moet wees om betroubare kriteria te verskaf vir die onderskeid tussen komplemente en perifere elemente.

Die vraag is hoe verpligte en perifere komplemente van mekaar geskei kan word. Die eerste of verpligte tipe komplement kan deur middel van ' $n$ eenvoudige weglatingstoets gedefinieer word (Herbst 1984: 1).

Vergelyk die onderstaande voorbeeld waarin aan mense geklassifiseer kan word as 'n verpligte komplement van gewoond:

(10) (a) Hy is gewoond aan mense omdat

(b) Hy is gewoond

ongrammatikaal is.

By hierdie kriterium speel nie slegs sintaktiese faktore 'n rol nie, maar ook semantiese faktore.

Gevolglik is $n a+$ NS in ' $n$ sin soos

(a) Jan is gek na lekkers

'n verpligte komplement, want die betekenis van gek in 11(a) verskil (op grond van die setsel $n a$ ) aansienlik van gek in 11(b).

(b) Jan is gek

Wat verpligte komplemente betref, mag hulle nie weggelaat word nie, terwyl die teendeel vir opsionele komplemente geld. Ter illustrasie:

\section{(c) Jan is gek omdat hy die snaaksste dinge doen}

Weglaatbaarheid kan dus as kriterium dien om verpligte elemente te isoleer. Hierdie kriterium kan nietemin nie sonder meer gebruik word om tussen opsionele en perifere elemente te onderskei nie, soos blyk uit

(d) Jan is gek in die namiddag

aangesien perifere elemente weglaatbaar is. As gevolg van die feit dat perifere elemente onafhanklik van die valensie van ander woorde in 'n sin voorkom, kan daar geargumenteer word dat hulle nie net weglaatbaar is nie, maar ook vryelik bygevoeg kan word. Dit geld nie vir opsionele komplemente wat nie 
so vryelik aan ander sinne gevoeg kan word nie aangesien hulle optrede afhanklik is van die valensie van die regerende woord.

In die voorafgaande bespreking is daarop gewys dat perifere elemente onafhanklik van enige vereistes. weggelaat of bygevoeg kan word. Matthews (1981: 127) wys nogtans daarop dat die byvoeging van perifere elemente "free of any restriction but the need to make sense" is.

Semantiese oorwegings speel dus wel 'n rol by die byvoeging van perifere elemente. Hoewel rondom sy lessenaar as perifere element aan 10(a) gevoeg kan word soos in die volgende sin:

(c) Hy is gewoond aan mense rondom sy lessenaar

is dit leksikografies irrelevant vir gewoond.

Gegee die woordeboek se primêre gerigtheid op die leksikale semantiek, sal valensie-inligting nie verder as die eerste kombinasievlak hoef te strek nie. Gewoond, as lemma, se kombinasie met aan + NS moet dus gegee word. Vrye toevoeging is nie ter sake nie.

Hoewel die riglyn van vrye toevoeging mag help om in sommige gevalle komplemente van perifere elemente te skei, is dit nie op sigself voldoende om die onderskeid te bepaal nie.

Dit blyk ook waar te wees van die ander kriteria wat in hierdie verband bespreek is, veral met betrekking tot verbale valensie. Emons (1978: 18-21), wat die valensiebenadering op Engelse werkwoorde toegepas het, beweer dat mens grootliks op verligte intuisie moet staatmaak ten einde tussen opsionele en perifere elemente te onderskei. Matthews (1981: 136) wat vyf kriteria gebruik om tussen komplemente en perifere elemente te onderskei, kom eweneens tot die gevolgtrekking "that we are left with a mass of boundary cases, subtle ambiguities, and gradience generally".

Alhoewel die onderskeid tussen verpligte komplemente, opsionele komplemente en perifere elemente nie altyd duidelik is nie, mag so 'n differensiëring nie uit linguistiese beskrywing weggelaat word nie. Aangesien hierdie onderskeid as arbitrêr beskou kan word, is dit belangrik om dit op duidelik gedefinieerde kriteria te baseer. So 'n onderskeid kan dan vrugbaar in die leksikografie toegepas word.

Herbst (1984: 6) beklemtoon die belangrikheid van die onderskeid tussen verpligte en opsionele komplemente en tussen komplemente en perifere elemente: "... it is of great importance for the foreign learner to be able to distinguish whether the constructions given for a word in the dictionary are merely possible uses of that word or whether the word must be used with a certain construction (at least in a certain meaning)."

In ' $n$ aanleerderwoordeboek is die volgende inligting byvoorbeeld noodșaaklik: 
(12)
(a) Hy is ryk.
(b) Hy word ryk uit goud.
(c) Siberië is ryk aan olie en minerale.
(d) Hy is ryk aan ervaring.

Daar moet aangetoon word dat uit goud in (b) perifere elemente is, terwyl aan + aanvulling in (c) en (d) verpligtend is in die besondere betekenis.

Hy is ryk

beteken dat hy baie geld en goed besit, terwyl

Hy is ryk aan $X$

beteken dat hy ruim voorsien is van $X$.

Sodra aan by ryk gevoeg word, verander die betekenis dus. Vergelyk ook:

(13) Sy is erg vatbaar vir verkoue.

(14) Hy is vatbaar vir goeie indrukke.

In albei sinne is vir + aanvulling verpligtend. Vergelyk:

(15) Sy is erg vatbaar.

(16) Hy is vatbaar.

In Afrikaanse woordeboeke word hierdie onderskeid glad nie aangedui nie.

\subsection{Linguistiese kategorieë wat as adjektiefkomplemente kan optree}

Die volgende aspek met betrekking tot adjektiefkomplemente wat bespreek word, is die verskillende linguistiese kategorieë wat as adjektiefkomplemente kan optree. Die volgende elemente kan as adjektiefkomplemente in Engels voorkom:

a prepositional phrases (Alcoholic drinks are not available to people under eighteen)

b infinitive clauses (He is willing to be honest)

c ing-clauses (It is handy living on campus)

d that-, if-en wh-clauses (It is nice that/would be nice if you could come; Judith was not certain whether/where/when she had met Dennis) (Herbst 1984: 5). 
In Afrikaans sou a, b en $\mathrm{d}$ moontlik kon geld op basis van die vraagkriterium soos voorgestel deur Herbst (1984: 5). Daarvolgens neem opsionele komplemente vraagvorme wat wie of wat bevat, terwyl perifere elemente nie hierdie vrae toelaat nie.

Vergelyk die volgende voorbeelde:

(a) dit was goed, om eerlik te wees,

(b) Dit was goed om eerlik te wees.

Slegs in (b) kan die vraag: Wat was goed? gestel word. Voorbeèld (b) bevat dus die opsionele komplement om eerlik te wees, terwyl dieselfde element in (a) 'n perifere element is.

Daar sal egter deeglike navorsing gedoen moet word om vas te stel watter kriteria vir Afrikaans geld. Binne die raamwerk van die valensieteorie kan 'n onderskeid dan getref word tussen komplemente en perifere elemente by adjektiewe en op grond daarvan kan die konstruksies wat in 'n aanleerderwoordeboek opgeneem moet word, en die vorm waarin dit opgeneem moet word, bepaal word.

Herbst (1984: 6) sê dat daar geargumenteer kan word dat woordeboeke vir die aanleerder nie noodwendig daarop gerig moet wees om 'n omvattende beskrywing van die komplementeringsmoontlikhede te gee nie, aangesien sommige patrone nie algemeen voorkom nie of beperk is tot sekere stylvlakke. Indien dit nie die geval is nie, kan hulle insluiting meer misleidend as bruikbaar vir die aanleerder wees. Aan die ander kant moet daar onthou word dat woordeboeke soos OALDCE en LDOCE nie slegs bruikbare instrumente vir die aanleerder vir enkodering is nie, maar dat hulle ook van groot belang is vir die onderwyser van die vreemde taal wat die woordeboek sal raadpleeg om vas te stel of 'n konstruksie (soos gebruik deur 'n aanleerder) aanvaarbaar is al dan nie. Herbst (1984: 6) kom dan tot die gevolgtrekking dat woordeboeke soos OALDCE en LDOCE wel na omvattendheid moet streef. Dit is tog wenslik dat patrone wat nie algemeen voorkom nie, ooreenkomstig die beperking gemerk moet word, byvoorbeeld deur etikette soos seldsaam, informeel, ensovoorts.

'n Gebrek aan ruimte kan as 'n verdere argument aangevoer word vir die nie-opname van patrooninligting. Herbst (1984: 6) wys nietemin daarop dat patrooninligting nie baie ruimte in beslag hoef te neem nie. Verder kan inligting oor komplemente aansienlik verbeter word indien die onderskeid tussen komplemente en perifere elemente by die saamstel van voorbeeldsinne in ag geneem word.

In die geval van die adjektief available, gee LDOCE byvoorbeeld slegs voorbeelde wat perifere elemente bevat: There is water available at the hut; I' $m$ sorry, sir, these shoes are not available in your size. Indien hierdie sinne vervang sou word deur sinne met komplemente soos Alcohol is not available to children en There is no space available for parking your car there sal die betekenis van die 
adjektief ewe goed geillustreer word. Terselfdertyd word relevante sintaktiese inligting gegee sonder dat meer ruimte benodig word (Herbst 1984: 6).

\section{Slotwoord}

Om reg te laat geskied aan sy funksie as aanleerhulpmiddel, behoort ' $n$ aanleerderwoordeboek baie meer grammatiese inligting as standaardwoordeboeke te bevat. Inligting moet ook meestal eksplisiet aangedui word om verwarring by aanleerders te voorkom. Ten opsigte van adjektiewe moet die volgende grammatiese inligting in aanleerderwoordeboeke aandag geniet: 'n aanduiding of adjektiewe verbuig moet word of nie, trappe van vergelyking, ' $n$ volledige identifikasie van adjektiewe, ' $n$ aanduiding of adjektiewe net attributief of net predikatief kan optree, die verskillende wyses waarop so en sulke gebruik word, die feit dat nie alle "voltooide deelwoorde" uit lydende vorme met wees gevorm kan word nie, die voorsiening van 'n spellys met die name van mense, lande, plekke, volkere, stamme, tale, asook afleidings daarvan, kruisverwysings tussen selfstandige naamwoorde/werkwoorde en hul adjektiwiese korrelate indien daar groot verskille tusen hulle is, en die aandui van adjektiefkomplemente. Meer gedetailleerde grammatiese inligting, soos hierbo uiteengesit, kan daartoe lei dat aanleerderwoordeboeke effektiewe aanleerhulpmiddels word, wat aanleerders kan help om selfstandig nuwe, natuurlike sinne in Afrikaans te skep.

\section{Verwysings}

\section{Woordeboeke}

Bosman, D.B., I.W. van der Merwe en L.W. Hiemstra. 19848. Tweetalige Woordeboek/Bilingual Dictionary. Kaapstad: Tafelberg.

De Villiers, M. e.a. 19856. Nasionale Woordeboek. Kaapstad: Nasou.

Hornby, A.S. e.a. 1974. Oxford Advanced Leamer's Dictionary of Current English. Oxford: Oxford University Press.

Odendal, F.F. e.a. 19792. Verklarende Handwoordeboek van die Afrikaanse Taal. Doomfontein: Perskor.

Proctor, P. e.a. 1978. Longman Dictionary of Contemporary English (LDOCE). Londen, Harlow: Longman.

\section{Ander bronne}

Carstens, W.A.M. 1991. Nomie vir Afrikaans: Enkele riglyne by die gebruik van Afrikans. P'retoria: Academica. 
De Vill iers, M. 1983. Afrikaanse grammatika vir volwassenes. Goodwood: Nasou.

Emons, R. 1978. Valenzgrammalik für das Englische. Tübingen: Niemeyer.

Gouws, R.H. 1986. Die taalkundige grondslae van die teoretiese leksikografie en die praktiese neerslag van taalkundige inliging in woordeboeke. RCN-verslag.

Herbst, T. 1984. Adjective Complementation: A Valency Approach to Making EFL Dictionaries. Applied Linguistics 5(1): 1-11.

Ilson, R. (Red.). 19855. Dictionaries, Lexicography and Language Leaming. Oxford: Pergamon Press.

Jackson, H. 1985. Grammar in the Dictionary. Uson, R. (Red.). 19855: 53-59.

Leech, G.N. 19812. Semantics. Harmondsworth: Penguin.

Lyons, J. 1977. Semantics. Volume 1 \& 2 . Cambridge: Cambridge University Press.

Matthews, P. 1981. Syntax. Cambridge: Cambridge University Press.

Ponelis, F.A. 1979. Afrikanse sintaksis. Pretoria: Van Schaik.

Quirk, R. e.a. 1972. A Grammer of Contemporary English. Londen: Longman.

Sweet, H. (1899/1964). The Practical Study of Languages. Londen: Dent (heruitgawe Londen: Oxford University Press). 


\title{
Funksies van voorbeeldmateriaal in eentalige woordeboeke*
}

\author{
L. Rademeyer, Buro van die Woordeboek van die Afrikaanse Taal, \\ Stellenbosch, Suid-Afrika
}

\begin{abstract}
Functions of Illustrative Material in Monolingual Dictionaries. Illustrative material is a microstructural element which in most dictionaries is not used to its full potential. Interaction between examples and other microstructural elements is imperative. Correlation between the definiens and illustrative material in the dictionary article aids the user of the dictionary with his encoding skills. Without illustrative material supporting it the information conveyed by the definiens is not as significant as it could be. However, illustrative material should not be viewed as an only means of conveying semantic information. Correlation between usage labels and examples is especially important. An example which contradicts a label, or vice versa, confuses the user. If either label or illustrative material is absent, the user can easily be misled. Illustrative material should also support the grammatical information given in the dictionary article. It has an implicit function because it complements and illustrates the explicit information. A correlation between these two microstructural elements of the dictionary article will result in a dictionary which is more user-friendly. Both citations and constructed examples can be applied successfully to assist the user in the comprehension and generation of utterances. Furthermore examples shows that each lexical item is related to others semantically as well as syntactically. Certain semantic resemblances and differences between related lexical items are reflected by illustrative material. Illustrative material should not be viewed as an optional element of the dictionary article, but as an essential component thereof.
\end{abstract}

Keywords: CITATIONS, CONSTRUCTED EXAMPLES, CONTEXT, DEFINIENS, DICTIONARY ARTICLE, DICTIONARY USER, EVIDENCE OF USAGE, EXAMPLES, GRAMMATICAL INFORMATION, ILLUSTRATIVE MATERIAL, INTERACTION, LEMMA, LEXICAL ITEM, PRAGMATIC, REGISTER, SEMANTIC, SEMANTIC RELATIONS, SYNTACTIC USAGE

Opsomming: Voorbeeldmateriaal is 'n mikrostrukturele element van die woordeboekartikel wat in die meeste woordeboeke nie tot sy volle reg kom nie. Interaksie tussen voorbeelde en ander mikrostrukturele elemente is noodsaaklik. Korrelasie tussen die definiens en voorbeeldmateriaal in die woordeboekartikel help die woordeboekgebruiker met sy enkoderingsvaardighede. As 'n definiens nie deur voorbeeldmateriaal ondersteun word nie, is die inligting wat daarin vervat is, nie so betekenisvol as wat dit kan wees nie. Voorbeeldmateriaal behoort egter nooit as enigste definiëringsmeganisme op te tree nie. Korrelasie tussen gebruiksetikette eri voorbeelde is veral

Hierdie artikel is 'n verkorte en aangepaste hoofstuk wit 'n M.A.-tesis, Die funksies van verbale voorbeeldmateriaal in eentalige woordeboeke, wat in Januarie 1992 deur die Universiteit van Stellenbosch anvaar is. 
belangrik. 'n Voorbeeld wat 'n etiket weerspreek, of omgekeerd, verwar die gebruiker. Indien óf etiket of sitaat ontbreek, kan die woordeboekgebruiker maklik mislei word. Voorbeelde behoort ook die grammatiese inligting in die woordeboekartikel te ondersteun. Dit het 'n implisiete funksie in hierdie geval, aangesien dit die eksplisiete inligting aanvul en illustreer. 'n Woordeboek warin hierdie twee mikrostrukturele elemente korteleer, is gebruikersvriendelik. Sowel sitate as poëme kan suksesvol gebruik word om die gebruiker te help met die verstaan en voortbring van taaluitings. Verder toon voorbeeldmateriaal ook aan dat elke leksikale item op semantiese sowel as sintaktiese vlak verwant is an ander leksikale items. Dit weerspieël ook bepaalde semantiese ooreenkomste en verskille tussen verwante leksikale items. Voorbeeldmateriaal behoort nie as ' $n$ bykomende element van die woordeboekartikel beskou te word nie, maar as in noodsaaklike komponent daarvan.

Sleutelwoorde: BETEKENISBETREKKINGE, BEWYS VAN GEBRUIK, DEFINIENS, GRAMMATIESE INLIGTING, INTERAKSIE, KONTEKS, LEMMA, LEKSIKALE ITEM, POËME, PRAGMATIES, REGISTER, SEMANTIES, SINTAKTIESE GEBRUIK, SITATE, VOORBEELDE, VOORBEELDMATERIAAL, WOORDEBOEKARTIKEL, WOORDEBOEKGEBRUIKER

\section{Inleiding}

Voorbeeldmateriaal kan verbaal of nie-verbaal wees. Verbale voorbeeldmateriaal sluit eenwoordsitate, kollokasies en voorbeeldsinne in. Nie-verbale voorbeeldmateriaal verwys na illustrasieprente, grafieke en soortgelyke hulpmiddels. In die bespreking wat volg, word slegs die funksies wat verbale voorbeeldmateriaal as mikrostruktuurelement van die woordeboekartikel verrig, gedek. Wanneer daar dus na voorbeeldmateriaal verwys word, gaan dit om verbale voorbeeldmateriaal.

Volgens Wiegand (1988: 52) is die woordeboekartikel 'n geordende versameling leksíkografiese tekssegmente en/of teksboustene waarby die lemma die verpligte teksbousteen is. Indien die woordeboekartikel so beskou word, vorm die voorbeeldmateriaal een van die tekssegmente waaruit dit opgebou is. Elke stuk inligting wat 'n inskrywing in die woordeboekartikel vorm, vorm ook 'n tekssegment of -bousteen daarvan. Dit is noodsaaklik dat hierdie tekssegmente mekaar aanvul en dat daar ' $n$ eenheidskarakter tussen hulle bestaan. Voorbeeldmateriaal speel ' $n$ belangrike rol in die bewerkstelliging van hierdie eenheidskarakter. Die voorbeeldmateriaal in 'n woordeboekartikel sê iets meer oor die lemma as element van die woordeskat. Hierdie inligting is van groot belang. Hoewel dit implisiete inligting is, kan die weglating daarvan die woordeboekgebruiker van belangrike inligting ontmeem.

In hierdie artikel word onder andere gepoog om aan te toon dat voorbeeldmateriaal die eksplisiete inligting wat in die woordeboekartikel gegee word, op verskillende vlakke ondersteun. 


\section{Wisselwerking tussen voorbeeldmateriaal en definiens}

Voorbeeldmateriaal en definiens is twee tekssegmente wat nie onafhanklik van mekaar kan optree nie. 'n Woordeboekartikel is onvolledig indien daar nie voorbeeldmateriaal is wat die inligting wat in die definiens gegee word, aanvul en illustreer nie. Dit moet beklemtoon word dat voorbeeldmateriaal nie daar is om leemtes in die definiens te ondervang nie. Dit dien as ondersteunende element by ' $n$ volledig gedefinieerde lemma of betekenisonderskeiding daarvan.

\subsection{Alleenstaande definiens}

Wanneer ' $n$ definiens verskaf word wat nie met voorbeeldmateriaal aangevul word nie, is die inligtingsoordrag onvolledig. Indien die woordeboekgebruiker van óf 'n sinoniemdefinisie óf 'n betekenisomskrywing voorsien word, en dit nie aangevul word met 'n praktiese illustrasie van die gebruik van die lemma nie, is die definiens van minder waarde. Die afwesigheid van ' $n$ wisselwerking tussen definiens en voorbeeldmateriaal veroorsaak ' $n$ verskraling van die inligting wat die gebruiker uit die woordeboekartikel kan ontsluit. Vergelyk in hierdie verband Lombard (1992: 161) se uitspraak dat die enkoderende funksie van voorbeeldmateriaal nie geringgeskat moet word nie.

Die definiens wat by betekenisonderskeiding 1 van moeilik in Nasionale Woordeboek (voortaan NW) voorkom, is wat inspanning vereis. Aangesien dit nie deur voorbeeldmateriaal aangevul word nie, is dit nie duidelik ten opsigte van watter tipe(s) naamwoord(e) die woord moeilik in hierdie betekenis gebruik kan word nie. 'n Kort, deursigtige voorbeeld soos ' $n$ moeilike som sou hier van waarde wees om 'n tipiese attributiewe gebruik van moeilik saam met 'n selfstandige naamwoord te illustreer. Vergelyk ook die werk was baie moelik ("dit het groot inspanning vereis") as voorbeeld van 'n predikatiewe gebruik van moeilik.

Vergelyk ook die volgende definiens wat by die vierde betekenisonderskeiding van plak II in NW gegee word: jou vestig. Aangesien hier geen voorbeeldmateriaal of etikettering is nie, kan die woordeboekgebruiker die aanname maak dat plak in hierdie betekenis in enige konteks gepas sou wees. $\mathrm{Na}$ analogie van die inligting wat verskaf is, kan ' $n$ sin soos die volgende verkeerdelik gevorm word: Piet plak in Kaapstad vandat hy daar werk. 'n Vollediger definiens en duidelike illustrasievoorbeelde sou hier help om 'n wisselwerking tussen definiens en voorbeeld te bewerkstellig. As definiens kan byvoorbeeld ' $n$ omskrywing soos die volgende gegee word: jou onwettig of. sonder die toestemming van ander inwoners of eienaars in 'n gebied vestig. 'n Voorbeeld soos die volgende sou hier nuttig gewees het: Die hawelose mense het sommer op die vlakte begin plak, en nou is daar ' $n$ plakkersdorpie. 


\subsection{Voorbeeldmateriaal sonder definiens}

Voorbeeldmateriaal moet nooit as enigste definiëringsmeganisme aangewend word nie. Dit behoort gebruik te illustreer, ter aanvulling van 'n definiens wat betekenisleiding verskaf.

In die negende uitgawe van Samuel Johnson se woordeboek $A$ Dictionary of the English Language word voorbeeldmateriaal in die vorm van sitate soms as enigste definiëringsmeganisme aangewend. Dit kom volop voor, byvoorbeeld by die volgende lemmas: abdomen, cartilage, macaw-tree, marrow en stablestand. In sommige gevalle het sulke sitate ortografies die vorm van 'n definiens. Tog word dit van inligting soos die naam van die outeur voorsien. Dit gaan hier om 'n vermenging van betekenis- en gebruiksleiding. Hierdie ontsporing van inligtingsaanbieding kan die woordeboekgebruiker grootliks verwar.

Die implikasie van hierdie werkswyse is dat dit aan die woordeboekgebruiker oorgelaat word om sowel betekenis- as gebruiksinligting uit die sitate te haal en hierdie twee inligtingstipes van mekaar te skei. Daar word hoë eise aan die woordeboekgebruiker gestel, aangesien hy nou self die leksikograaf se siftingstaak moet uitvoer terwyl eersgenoemde voorsiening moes gemaak het vir duidelik'omlynde definiense en voorbeelde. 'n Bondige definiens, met die noodsaaklikste inligting, aangevul deur 'n voorbeeld waarin die lemma se gebruik in die taal geillustreer word, sou beter leiding verskaf.

\subsection{Gebrekkige definiens plus voorbeeld}

Indien die leksikograaf streef na 'n volkome wisselwerking tussen voorbeeld en definiens, behoort hy altyd te poog om eers volledige betekenisleiding te verskaf. Daar kan nie vir gebrekkige definiëring vergoed word deur die verskaffing van uitgebreide voorbeeldmateriaal nie. Dit behoort nie vir die woordeboekgebruiker nodig te wees om betekenisinligting in die voorbeeldmateriaal te gaan soek nie. Elkeen van hierdie mikrostruktuurelemente behoort hul eie funksie en plek in die artikel te beklee.

\section{Wisselwerking tussen die aanduiding van styl- of registervlak en voorbeeldmateriaal}

Waar 'n lemma geëtiketteer is en dus in die een of ander opsig afwyk van die standaardtaal, behoort daar voorbeeldmateriaal te wees ter ondersteuning van die inligting wat per etiket verskaf is. Indien óf voorbeeld óf etiket ontbreek, kan hierdie twee mikrostruktuurelemente mekaar nie aanvul nie.

Dit is ook noodsaaklik dat voorbeeldmateriaal en etiket met mekaar korreleer. Vergelyk die artikel van blotto in die Longman's Dictionary of Contempora- 
ry English (voortaan LDOCE): Old John was really blotto last night. Die etiket wat gegee word, is BrEng $\mathrm{sl}$. Die voorbeeldsin illustreer die inligting wat eksplisiet deur die etiket daargestel is op 'n praktiese wyse. Hier is dus wel 'n wisselwerking tussen etiket en voorbeeldsin. Die twee mikro-inskrywings korreleer met mekaar en verskaf nuttige leiding aan die woordeboekgebruiker.

Dit behoort ook nie vir die woordeboekgebruiker nodig te wees om uit die voorbeeldmateriaal af te lei dat die lemma geëtiketteer moes gewees het nie. Indien dit nodig sou wees, is onvolledige leiding verskaf. By die lemma gawk in LDOCE word die volgende voorbeeld gegee: Don't gawk at it, do something! 'n Moedertaalspreker van Engels sou waarskynlik kon aflei dat 'n etiket soos infml (d.i. informal) hier nodig is. Dat die etiket ontbreek, is egter 'n tekortkoming.

In 'n aanleerderwoordeboek is etikettering van die allergrootste belang, aangesien die gemiddelde gebruiker van so 'n woordeboek nie oor moedertaalsprekerintuïsie ten opsigte van die taal wat hy aanleer, beskik nie. Daar kan dus nie van die woordeboekgebruiker verwag word om aannames te maak met betrekking tot gebruik of enige ander aspek van die taal nie: die inligting moet eksplisiet gegee word.

\section{Wisselwerking tussen eksplisiete en implisiete grammatiese inligting}

Dit is noodsaaklik dat daar in elke woordeboekartikel grammatiese inligting verskaf sal word. Hierdie inligting word eksplisiet as afsonderlike mikrostrukturele inskrywings aangebied. Voorbeeldmateriaal verskaf implisiete grammatiese inligting, met ander woorde dit ondersteun en illustreer die eksplisiete grammatiese inligting wat per opmerking of etiket gegee is. Gouws (1989:230) noem dat voorbeeldsinne 'n illustrasie van tipiese grammatiese patrone moet bied.

'n Voorbeeld van eksplisiete grammatiese inligting wat by werkwoordelike lemmas verskaf behoort te word, is die plasing van die verledetydsmorfeem ge- om die verledetydsvorm van die werkwoord te vorm. By deeltjiewerkwoorde moet byvoorbeeld aangetoon word dat die verledetydsmorfeem getussen die werkwoordelike deel en die deeltjie geplaas moet word. Indien 'n voorbeeldsin of -frase hierdie inligting prakties illustreer, korreleer die eksplisiete en implisiete inligting met mekaar. Die woordeboekgebruiker word terselfdertyd ook van 'n praktiese illustrasie van die eksplisiete inligting voorsien.

In NW word die eksplisiete grammatiese inligting, naamlik die aandui van die plasing van ge- by deeltjiewerkwoorde dikwels nie aangevul met voorbeeldmateriaal nie. Vergelyk die lemmas hokslaan, stokkiesdraai, visvang, voetslaan en weglaat. Sulke woordeboekartikels is onvolledig. Ter wille van sintaktiese leiding is dit veral noodsaaklik om volsinne by sulke lemmas as voorbeelde te gee. 


\section{Sitate as bewysmateriaal}

Sitate, dit wil sê voorbeelde van aangehaalde taalgebruik, dien eerstens as bewys dat ' $n$ woord wel in ' $n$ taal bestaan en optree. By omvattende woordeboeke stel die samestellers daarvan hulle dit ten doel om diẹ volle inventaris van die taal se woordeskat in hulle woordeboeke weer te gee. In sulke woordeboeke verskyn daar dikwels leksikale items wat vir die gemiddelde woordeboekgebruiker heeltemal onbekend is. Hier dien sitate as bewysmateriaal van die bestaan van hierdie leksikale items. Dit geld veral gevalle waar ' $n$ woord die maaksel van 'n digter of skrywer is. Geeraerts en Janssens (1982: 18-19) noem dat voorbeelde bewys lewer daarvan dat ' $n$ bepaalde betekenis nie ' $n$ versinsel van die leksikograaf is nie.

Indien die woordeboekgebruiker 'n woord wat vir hom onbekend is met 'n sitaat daamaas in die woordeboek aantref, is hy nie net verseker van die feit dat die woord wel in die taal voorkom nie, maar ook in watter styl- en registervlakke dit tipies optree. Voorbeeldmateriaal is hier veral nuttig waar 'n woord 'n beperkte gebruikspektrum het.

Voorbeeldmateriaal dien ook op 'n tweede vlak as bewysmateriaal. Anderson, Goebel en Reichmann (1983: 29) wys daarop dat voorbeeldmateriaal alles wat dit in die woordeboekartikel voorafgaan, bewysbaar maak. Dit illustreer dus die gegewe sintaktiese, morfologiese, semantiese en grammatiese inligting. Hierdie funksie sluit dus aan by die daarstel van 'n wisselwerking tussen die verskillende tekssegmente om 'n eenheidskarakter in die woordeboekartikel te skep.

\section{Voorbeeldmateriaal het genererende krag}

Zgusta (1971: 264) noem dat 'n leksikograaf nooit volledig kan werk nie, en slegs enkele voorbeelde kan gee wat vir die woordeboekgebruiker as aansporing moet dien om ander uitings te vorm na analogie van die gegewe voorbeelde. Voorbeeldmateriaal help die woordeboekgebruiker om patroonmatigheid raak te sien en soortgelyke grammaties korrekte uitings te vorm. Dit help hom dus met enkodering. Voorbeelde moet dus met groot sorg gekies word om die woordeboekgebruiker te help by die vorming van nuwe uitings.

Voorbeeldmateriaal moet op verskeie vlakke verteenwoordigend wees van dit wat tipies in die taal optree. Hierdie funksie is veral by eentalige aanleerderwoordeboeke baie belangrik. Die niemoedertaalspreker kry al die inligting in die woordeboekartikel in die vreemde taal. Hy het dus nie die voordeel van 'n vertaling of omskrywing van die inligting in sy moedertaal nie.

In sy keuse van voorbeeldmateriaal moet die leksikograaf daarteen waak om te veel voorbeelde van afwykende, abnormale of atipiese taalgebruik te gee. Sulke voorbeelde kan die woordeboekgebruiker mislei en verwar. Dit is 
ook nie vir hom van veel waarde wanneer hy dit raadpleeg vir enkoderingsdoeleindes nie. Dit geld ook woordeboeke vir moedertaalsprekers.

Vergelyk die volgende voorbeeld wat by afoor in die Verklarende Handwoordeboek van die Afrikaanse Taal (voortaan HAT) optree: Van Gogh was afoor teen die einde van sy lewe. Hierdie voorbeeld dui eerder 'n moontlike as 'n tipiese gebruik van afoor aan. Die feit dat die sin lagwekkend is terwyl dit nie veronderstel is om dié effek op die leser te hê nie, is ' $n$ aanduiding daarvan dat dit as voorbeeldsin misluk. 'n Alombekende tipiese kombinasie soos ' $n$ afoor koppie sou hier 'n beter keuse wees, aangesien dit genererende krag sal hê. Die woordeboekgebruiker kan byvoorbeeld na analogie daarvan die naamwoordstuk 'n afoor beker vorm en suksesvol gebruik.

\section{Voorbeeldmateriaal illustreer sintaktiese verbindingsmoontlikhede van lemmas asook die beperkinge daarop}

Die optrede van sommige leksikale items is beperk tot bepaalde sinstipes. Hierdie inligting word met behulp van voorbeeldmateriaal geillustreer. By lemmas waarby daar ' $n$ beperking is op die sintaktiese omgewing waarin die woord kan optree, kan hierdie inligting as eksplisiete grammatiese inligting verskaf word. By kleiner woordeboeke, waar sulke inligting weens gebrek aan spasie nie eksplisiet aangebied kan word nie, vervul voorbeeldmateriaal ' $n$ baie belangrike funksie.

Hierdie funksie van voorbeeldmateriaal geld byvoorbeeld sekere adjunkte. Die woord allesbehalwe tree slegs in positiewe stelsinne op. In HAT word wel ' $n$ voorbeeldsin by allesbehalwe gegee, naamlik Hulle het my allesbehalwe goed ontwang. Die sin illustreer die korrekte optrede van hierdie adjunk. Dit is goeie leiding. Ter aanvulling van hierdie leiding sou eksplisiete inligting ook aan die gebruiker gegee kon word in die vorm van 'n etiket, naamlik slegs in positiewe stelsinne.

Nog 'n groep leksikale items waarvan die sintaktiese optrede beperk is, is neweskikkers. By sekere korrelatiewe neweskikkers kan slegs woorde as konjunkte optree; by ander woorddele, woorde en sinne. Hierdie inligting moet in die voorbeeldmateriaal weerspieël word. Vergelyk byvoorbeeld die korrelatiewe paar nóg...nóg. Hier kan twee tipes konjunkte optree, naamlik woorde en woorddele. Die volle gebruikspektrum van die lemma moet weerspieël word. By nog II in NW is daar twee voorbeelde, naamlik $H y$ het nóg kind nóg kraai en Nóg die een, nóg die ander. Dit is goeie leiding, aangesien dit toon dat 'n naamwoordstuk met slegs 'n enkele naamwoord asook ' $n$ uitgebreider naamwoordstuk as konjunkte kan optree. Hier moes egter nog 'n voorbeeld opgetree het, wat sou aandui dat woorddele ook as konjunkte van hierdie korrelatiewe neweskikkingspaar kan optree, byvoorbeeld Hy eet nóg vis-nóg herderspastei. 


\section{Voorbeeldmateriaal illustreer die lemma se gebondenheid aan 'n kon- teks}

Hierdie funksie van voorbeeldmateriaal kan geklasssifiseer word as 'n pragmatiese funksie. Dit is ' $n$ funksie wat beperk is tot sitate uit die geskrewe en optekeninge uit die gesproke taal. Fox (1987: 141) toon aan dat dit belangrik is dat voorbeelde deel vorm van 'n samehangende stuk teks, aangesien taal nie bestaan uit ' $n$ reeks geïsoleerde sinne nie. 'n Nadeel van poëme is dat hulle dikwels veels te netjies afgeronde klein gehele is. In werklike taalgebruik kom daar egter sekere elemente voor wat verraai dat 'n sitaat deel vorm van 'n groter geheel. ' $n$ Voorbeeld hiervan is teksbindmiddels. Woorde soos en, daarna en toe verbind ' $\mathrm{n}$ stuk teks aan dit wat dit voorafgaan of dit wat daarop volg. Tydsadjunkte soos toe en daarop verbind ook stukke teks met mekaar om 'n groter geheel te vorm.

In omvattende woordeboeke word grootliks van sitate gebruik gemaak om werklike taalgebruik weer te gee. 'n Woordeboek soos die Woordeboek van die Afrikaanse Taal bevat talle gesiteerde voorbeelde wat illustreer dat hierdie stukke teks oorspronklik deel gevorm het van 'n groter geheel. Vergelyk byvoorbeeld die volgende sitaat by $\mathbf{k l i t s}^{2}$, betekenisonderskeiding 1: Daarna kom die louwarm water, en 'n bietjie klits maak alles mooi deurmekaar. Die woordeboekgebruiker wat hierdie sitaat lees, kan duidelik sien dat hierdie sin nie 'n geïsoleerde sin is nie, maar uit ' $n$ groter stuk teks geneem is.

\section{Voorbeeldmateriaal onderskei die lemma van ander semanties ver- wante lemmas}

Indien die leksikon van ' $n$. taal beskou word as 'n netwerk van betekenisbetrekkinge, moet daar aanvaar word dat geen leksikale item los staan van alle ander leksikale items nie. In die definiens word dikwels van leksikale betrekkinge soos sinonimie, antonimie en hiponimie gebruik gemaak om 'n lemma te definieer. Voorbeeldsinne verrig 'n soortgelyke funksie. Leksikale items wat aan 'n lemma verwant is, tree dikwels in voorbeeldșinne onder daardie lemma op. In sulke voorbeeldsinne word daar aan die woordeboekgebruiker riglyne gegee ten opsigte van die korrekte gebruik van meer as een leksikale item. Hierdie tipe voorbeeld verskaf nie net nuttige sintaktiese leiding nie, maar is boonop ekonomies.

Hierdie funksie van voorbeeldsinne help om die sintaktiese optrede van 'n lemma te laat aansluit by dié van ander lemmas deurdat die leksikon van 'n taal beskou word as deel van 'n netwerk van betekenisbetrekkinge. Vir verdere inligting oor die struktuur van die leksikon, vergelyk De Stadler (1989: 52).

By kuns in NW kom die volgende voorbeeld onder die eerste betekenisonderskeiding voor: Fotografie kan ook kuns wees. In hierdie sin is fotografie 'n 
hiponiem van die superordinaat kuns. Die twee leksikale items val in dieselfde semantiese veld, naamlik dié van kunsvorme.

By gelowige in HAT kom 'n soortgelyke voorbeeld voor: ' $n$ Mens is of ' $n$ gelowige of ' $n$ ongelowige. In hierdie sin is daar 'n semantiese verhouding van opposisie tussen gelowige en ongelowige. Dit gaan hier oor 'n komplementêre paar.

\section{Slotwoord}

Voorbeeldmateriaal kan 'n belangrike bydrae lewer tot die geslaagdheid van 'n woordeboekartikel mits dit op doeltreffende wyse gebruik word om onderlinge samehang te bewerkstellig tussen die verskillende mikrostrukturele inligtingstipes in die artikel. Dit is noodsaaklik dat elke leksikograaf ingestel sal wees op die behoeftes van woordeboekgebruikers om sy woordeboek gebruikersvriendeliker te maak. In sy hantering van voorbeeldmateriaal moet die leksikograaf altyd in gedagte hou dat voorbeeldmateriaal 'n verteenwoordigende monster van werklike taalgebruik moet wees. Sowel die gesproke as die geskrewe taal moet in sy voorbeeldmateriaal verteenwoordig word. Sitate en poëme kan met groot sukses vir hierdie doel aangewend word.

\section{Verwysings}

Anderson, R.R., U. Goebel en O. Reichmann. 1983. Probeartikel zum frühneuhochdeutschen Wörterbuch. Wiegand, H.E. (Red.). 1983: 11-52.

De Stadler, L.G. 1989. Afrikaanse semantiek. Johannesburg: Southern.

De Villiers, M. e.a. 19877. Nasionale Woordeboek. Kaapstad: Nasou.

Fox, G. 1987. The Case for Examples. Sinclair, J.M. (Red.). 1987: 137-149.

Geeraerts, D. en J. Janssens. 1982. Wegwijs in woordenboeken. Assen: Van Gorcum.

Gouws, R.H. 1989. Leksikografie. Kaapstad: Academica.

Hyldgaard-Jensen, K. en A. Zettersten (Reds.). 1988. Symposium on Lexicography III. Tübingen: Max Niemeyer.

Johnson, S. 18069. A Dictionary of the English Language. Londen: Luke Hansard.

Lombard, F.J. 1992. Voorbeeldmateriaal in woordeboeke. Lexikos 2: 148-164.

Odendal, F.F. 19792. Verklarende Handuoordeboek van die Afrikaanse Taal. Doomfontein: Perskor.

Procter, P. (Red.). 19842. Longman Dictionary of Contemporary English. Essex: Longman.

Sinclair, J.M. (Red.). 1987. Looking Up. Londen: Collins.

Wiegand, H.E. (Red.). 1983. Germanistische Linguistik 1-4/82. Hildesheim: Georg Olms Verlag.

Wiegand, H.E. 1988. Überlegungen zu einer Theorie der lexikographischen Sprachbeschreibung. Hyldgaard-Jensen en Zettersten (Reds.). 1988: 35-72.

Zgusta, L. 1971. Manual of Lexicography. Den Haag: Mouton. 


\section{Geraadpleegde werke}

Abraham, W. 1974. Terminologie zur neueren Linguistik. Tübingen: Max Niemeyer.

Gouws, R.H. 1982. Die sknapping van ident ieke stukke in Afrikeanse meweskikkingstontruksies. Ongepubliseerde D.Litt.-proefskrif. Universiteit van Stelenbosch.

Hartmann, R.R.K. (Red.). 1983. Lexicography: Principles and Practice. Londen: Academic Press.

Landau, S.I. 1984. Dictionaries: The Art and Craft of Lexicography. New York: The Scribner Press.

Lemmens, M. en H. Wekker. 1986. Grammar in English Leamers' Dictionaries. Tübingen: Max Niemeyer.

Levinson, S.C. 1983. Pragmatics. Cambridge: Cambridge University Press.

Ponelis, F.A. 1979. Afrikanse sintaksis. Pretoria: J.L. Van Schaik.

Wolski, W. Partikellexikographie. 1986. Tübingen: Max Niemeyer. 


\title{
Die agtste deel van die Woordeboek van die Afrikaanse Taal
}

\author{
Edith H. Raidt, Universiteit van die Witwatersrand, \\ Johannesburg, Suid-Afrika
}

\begin{abstract}
Volume VIIl of the Woordeboek van die Afrikaanse Taal ("Dictionary of the Afrikaans Language"). Since its inception in 1926 as a government funded project, the Woordeboek van die Afrikanse Taal has undergone repeated editorial changes which caused extensive delays in the publication of volumes I-VIII (1951-1991) and, quite understandably, elicited serious criticism. With the publication of Volume VIII the letter $K$ is at long last completed. It has taken three decades to compile the words starting with $\mathrm{K}$. Such a delay is totally unacceptable and one can only hope that the future volumes will appear in reasonably quick succession. Volume VIII seems to be a volume in transition concerning editorial policy. Great progress has been made in avoiding the much criticised encyclopedic approach of preceding volumes, the articles are better structured, semantic definitions are on the whole succinct, but the quotations are still too numerous and without any clear sequence. The main points of criticism expressed in this article concern (1) the random choice and ordering of quotations; (2) the lack of consistent etymological references, (3) the lack of historical principles.

However, Volume VIII contains many signs of promising developments which seem to indicate that the future volumes will be the fruit of clearly defined editorial policies, resulting in speedy, yet thorough publications.
\end{abstract}

Keywords: AFRIKAANS, ANGLICISM, CITATION, COMPOSITUM, DEFINITION, DERIVATION, DICTIONARY, EDITORIAL POLICY, ENGLISH, ETYMOLOGY, HISTORICAL PRINCIPLES, IDIOM, (VERBAL) ILLUSTRATION, LEMMA, LEXICOGRAPHY, LOANWORD, NEOLOGISM, REGIOLECT, SOCIOLECT, STANDARD LANGUAGE, TERMINOLOGY, VARIANT

Opsomming: Vanaf sy begin in 1926 het die Woordeboek van die Afrikaanse Taal baie ingrypende redaksionele wysigings ondergaan. Dit het veroorsaak dat die publikasie van dele 1 tot VIll (1951-1991) met onaanvaarbaar lang vertragings gepaard gegaan het. Met WAT VIIl is die letter K - na drie dekades - uiteindelik klaar. Hierdie deel is klaarblyklik die produk van 'n oorgangsfase in die redaksionele beleid. Dit is veel strakker in die aanbod, die artikels is beter gestruktureer, die betekenisdefinisies is op min uitsonderings na nie meer ensiklopedies van aard nie. Daar is egter nog steeds onnodig baie en sleg geordende voorbeeldmateriaal wat nie op historiese beginsels gebaseer is nie hoewel daar indirek waardevolle historiese inligting verskaf word. Die hoofkritiek wat in hierdie artikel geopper word, het betrekking op (1) die lukraak keuse van aanhalings; (2) die wegskram van etimologieë; (3) die afwesigheid van historiese beginsels. 
WAT VIII toon egter in baie opsigte ' $n$ belowende vooruitgang. Dit laat 'n mens uitsien na 'n beter omlynde redaksionele beleid wat hopelik sal lei tot 'n deeglike en spoedige voortsetting van die Woordeboek van die Afrikaanse Taal.

Sleutelwoorde: AFLEIDING, AFRIKAANS, ANGLISISME, DEFINISIE, ENGELS, ETIMO LOGIEë, HISTORIESE BEGINSELS, IDIOME, LEENWOORDE, LEKSIKOGRAFIE, LEMMA, NEOLOGISMES, POËME, REDAKSIONELE BELEID, REGIOLEK, SAMESTELLING, SITAAT, SOSIOLEK, STANDAARDTAAL, TEGNIESE TERME, TERMINOLOGIE, VARIANT, WOORDEBOEK

\section{Inleiding}

As "n mens van 'n "leksikografiese generasie" kan praat dan is dit van toepassing op die optekening van die letter $\mathrm{K}$ in die Woordeboek van die Afrikaanse Taal (voortaan WAT), want dit het die leksikograwe van die Woordeboek-redaksie dertig jaar geneem om die letter $K$ te behandel en af te rond. $K$ is wel op een na die langste letter in ' $n$ Afrikaanse woordeboek, nogtans bly dit 'n onaanvaarbare slakkepas; mens kan net hoop dat so 'n vertraging in die toekoms nie meer gebeur nie. Met die verskyning van die Agtste Deel van die WAT (KOSKYWIEHOUER), wat 584 bladsye beslaan en van 'n uitgebreide inleiding (12 paginas) voorsien is, het die taalgebruiker egter ' $n$ belangrike toevoeging tot sy broodnodige naslaanwerke gekry. $\mathrm{Al}$ is ons nou nog nie eens halfpad deur die alfabet nie, is 'n mens tog dankbaar vir hierdie vooruitgang wat bowendien selfs belowend lyk.

Die WAT het ' $n$ uiters trae begin gehad. Reeds in 1926 is die projek onder leiding van prof. J.J. Smith van stapel gestuur met die verondersteling dat dit teen 1936 voltooi sou wees. Die bedoeling was om 'n deskriptiewe woordeboek van die standaardtaal op te stel, 'n soort Afrikaanse Van Dale (Gouws en Ponelis 1992: 21-23). Maar van die begin af het sake anders verloop want prof. J.J. Smith se beleid was veel meer omvattend. Soos uit die materiaalversameling van die vroeë jare blyk, het hy 'n groot aantal nie-standaardvorme opgeteken. Die gebrek aan 'n duidellke en haalbare redaksionele beleid het die publikasie met dekades vertraag. Volgens Gouws en Ponelis (1922: 22) het dit gelei

... to a divergence between this dictionary and the main stream research in Afrikaans linguistics. This divergence resulted in the linguistic isolation of the WAT, but in addition it diminished the potential influence on the development of Afrikaans of the most expensive and comprehensive lexicographical and linguistic project within that language community.

Ten tye van J.J. Smith se aftrede was daar nog geen persklaar manuskrip gereed nie. Nadat P.C. Schoonees die hoofredakteur geword het, verskyn in 1950 deel I (A-C), vyf jaar later deel II (D-F), deel III (G) volg in 1957 en deel IV 
$(H-I)$ in 1961. Van toe af sloer die saak egter weer. Eers sewe jaar later verskyn deel $\mathrm{V}(\mathrm{J}-\mathrm{KJ})$ en word daar met die letter $\mathrm{K}$ begin wat na ' $\mathrm{n}$ pouse van 8 jaar in 1976 uiteindelik voortgesit word in deel VI (KLA-KOL). Na nog 'n pouse van agt jaar verskyn deel VII wat die letter $\mathrm{K}$ vanaf $\mathrm{KOM}$ tot by $\mathrm{KOR}$ - behandel. Maar toe is $\mathrm{K}$ nog steeds ver van klaar. Die hoofredakteurs vir die dele V en VI was F.J. Snijman, vir VII en VIII D.C. Hauptfleisch. Onder die hoofredakteurskap van dr. Snijman het die WAT al hoe meer ensiklopedies van aard geword wat nie tot voordeel van dle Woordeboek was nie. Dit het dan ook duidelik in die kwaai maar regverdige kritiek wat veral deel VI uitgelok het, tot uiting gekom (vgl. Combrink 1979 en Odendal 1979).

Dit is tog vreemd dat 'n ander belangrike en rigtinggewende naslaanwerk in dieselfde tydperk ook besonder lank gesloer het, $\mathrm{nl}$. die sewende uitgawe van die Afrikaanse Woordelys en Spelreëls (1991, voortaan AWS); wat 'n volle 27 jaar na die vorige uitgawe gepubliseer is. Wat het in die afgelope drie dekades, wat andersins gekenmerk was deur vooruitgang en vinnige ontwikkeling op amper alle lewensterreine, gebeur om dergelike vertragings toe te laat? Gebrek aan taalkundige leiding en inisiatief? Verwaarlosing van die leksikografie as 'n taalkundige dissipline? Of diepgaande herbesinning en heroriëntering t.o.v. die beskrywing van die Afrikaanse leksikon? Die jongste AWS getuig beslis van 'n nuwe benadering, veral teenoor leenwoorde en neologismes en is in die opsig die WAT vooruit.

\section{Tradisie én vooruitgang}

Hoewel deel VIII nog duidelik in die tot dusver gebruiklike tradisie van die WAT I-VII staan, is daar tog opvallende verbeterings. Die ensiklopediese aanbod is nog nie heeltemal uitgeskakel nie maar dis aansienlik besnoei. Daar is tekens van 'n strakker aanbod van die leksikale items; die artikels is beter gestruktureer; die oordadige aanbod van aanhalings word oor die algemeen besnoei hoewel dit tog plek-plek nog kop uitsteek. Die "Toeligting by die gebruik van die Woordeboek" (pp. viii-xix) getuig van 'n nuwe benadering, en veral van 'n beter verantwoording en sistematisering a.g.v. 'n strakker redaksionele beleid. In teenstelling met vorige dele word daar pertinent op terminologieverklaring, rangskikking en vorm van artikels, samestellings en afleidings, verwysingsmetodes by wisselvorme, variante, sinonieme en antonieme en ander aspekte ingegaan wat getuig van die redaksie se meer sistematiese benadering en meer doeltreffende beskrywing van leksikale items en die verwerking van die data. Oor die algemeen is daar 'n groot vooruitgang in die betekenisdefinisies van woorde. In teenstelling met die omslagtigheid van bv. WAT VI, word betekenisse nou meestal in kort sinne met tersaaklike inligting verskaf. 'n Mens verwelkom die goed verantwoorde betekenisonderskeiding, betekenistoepassing en betekenisindeling soos vermeld in die Toeligting pp. viii, xi, en die aandag wat aan homonieme gegee word. Lg. word omskryf as 
Leksikale item met dieselfde vorm (spelling) as 'n ander, maar waarvan die betekenis sodanig verskil dat die leksikale items tans as onverwant aan mekaar beskou word, ongeag of hulle 'n gemeenskaplike of verskillende herkoms het (p. viii).

Hoewel die term polisemie nie in die "Terminologieverklaring" opgeneem is nie, word die verskil tussen homonimie en polisemie tog gehandhaaf en op grond van sinchroniese oorwegings gemaak. Soos Gouws (1989: 126) opmerk, verg "die korrekte leksikografiese hantering van polisemiese gevalle ... deeglike taalkundige insig". Hier toon die leksikograwe van WAT VIII goeie oordeel en knap hantering van homonieme en poliseme.

Nie alle artikels. volg dieselfde patroon nie. Sommige is hegter saamgestel as ander, soms is daar nog steeds onnodige aanhalings; soms is die verklarings tog nog aan die ensiklopediese kant (bv. by kriterium, kropmelk, kroton e.a.); en wat die keuse van opname en behandeling in die vorm van artikels betref, wil dit voorkom of daar nog nie 'n duidelik omlynde strategie bestaan nie. Gevolglik kry 'n mens die indruk dat hierdie deel 'n soort oorgangsfase daarstel en dat die redaksie besig is om 'n nuwe beleid t.o.v. die volgende dele van die Woordeboek te ontwikkel: Dit sou beslis 'n wenslike ontwikkeling wees wat deur die woordeboek-gebruiker verwelkom sal word.

\section{Bronne}

Die leksikale items van deel VIII is op 'n indrukwekkende en redelike verteenwoordigende databasis uit meer as 3000 bronne gebaseer. Eintlik sou 'n mens meer bronne oor regionale Afrikaans daarby wou gehad het, bv. die studies van Tony Links, So praat ons Namakwalanders (1989), Van der Waal-Braaksma en Ferreira, Die Noordweste (1986), Hans du Plessis, Suidwesafrikaans (1985), om slegs enkeles te noem. Maar hierdie beperking tot "Standaardafrikaans" kan dalk as 'n terugkeer tot die oorspronklike opset van die WAT beskou word, want die WAT was aanvanklik bedoel om 'n standaard-deskriptiewe woordeboek te wees.

Hier lê vir my 'n byna tragiese mistasting waardeur gulde geleenthede verpas is. In die dertiger- en veertigerjare het daar juis 'n enorme behoefte bestaan aan 'n standaard-woordeboek wat sou kon bygedra het tot die standaardisering van Afrikaans. Hierdie standaardisering het hom voltrek sonder die hulp en die rigtinggewende leiding van die WAT. Na die Soweto-opstande in 1976 en dan veral in die tagtiger- en vróeë neëntigerjare het die verset teen 'n plek-plek eksklusiewe en onsensitiewe ștandaardtaal egter tot uiting gekom in die aandrang op 'n "alternatiewe Afrikaans" wat ook die regiolekte en sosiolekte van die hele Afrikaanssprekende bevolking sou verteenwoordig. Ook hierdie ontwikkeling voltrek hom blykbaar sonder die hulp van die WAT, en weer 
eens wil dit voorkom of die Woordeboek uit die pas raak met die ontwikkelings in die spraakgemeenskap.

\section{Neologismes, leenwoorde en leenvertalings}

Heelwat bronne dateer uit die tagtigerjare en weerspieël dus iets van die meer resente taalgebruik soos uit onderstaande voorbeelde blyk.

Nuwe woorde van die afgelope drie dekades verraai dikwels Engelse invloed, bv. kovert (Eng. covert), kothuis (volksetimologies vir Eng. cottage), kwad (Eng. quad). Dit geld ook vir leenvertalings soos kousbroekie en broekieskouse (Eng. pantihose), kweekhuistoestand, kweekhuiseffek (Eng. greenhouse effect), kropskêr (Eng. crop shears); woorde soos kruisneef, kruisniggie is leenvertalings uit swart tale.

Sommige woorde het gekom en gegaan soms sonder dat hulle vermelding kry: krimpelien (sintetiese materiaal uit die sewentigerjare) is byvoorbeeld nie opgeneem nie, terwyl krinolien ("stywe weefstof van perdehaar of katoen") uit die ou dae wel vermeld en selfs in drie artikels, mét aanhalings bespreek word. Die meeste neologismes illustreer Afrikaans se byna eindelose vermoë om samestellings en afleidings te maak, bv. kykaand, kykbaar wat die nuwe tydperk van TV weerspieël, krotbuurte, kreukelvry, krimptraag, krimpbaar, kruisbaar, krummelbaar, kuierkoop en die nogal onsuksesvolle kroostrooster, almal uit die jare sestig, sewentig en daarna.

Dit is opvallend dat die AWS dikwels meer resente woordvormings en uitspraakvariante bevat en daardeur meer progressief voorkom as die WAT VIII. Die AWS het bv. (uiteindelik!) die totaal verouderde kosthuis weggelaat, terwyl dit in WAT VIII nog steeds as wisselvorm van koshuis verskyn. Die AWS het die (Anglisistiese) variante kousjer naas kosjer, kreip naas crêpe, in heerlike nuutskepping soos kyk-in-die-pot (Eng. potluck) en 'n resente "vakterm" KwaZulu wat in die WAT VIII ontbreek. Die AWS openbaar 'n innoverende rigting wat nie in dieselfde mate in die WAT voorkom nie. Die weglating in WAT VIII van veel gebruikte Anglisismes wat bv. in Van der Merwe en Ponelis, Die korrekte woord (1991) wel opgeneem is, skep die indruk van 'n normatiewe optrede waardeur dergelike leenwoorde nog nie in die "standaardwoordeboek" aanvaarbaar is nie.

\section{Lemmas}

Uit die Toeligting blyk dat die redaksie hulle behoorlik rekenskap gegee het van wat hulle as ' $n$ lemma beskou. Hulle definisie is handig en insiggewend:

lemma. Elk van die leksikale items wat verklaard in die Woordeboek opgeneem, in vet druk gegee en alfabeties gerangskik word. Onverklaar- 
de samestellings en afleidings van sò 'n lemma word binne die stelsel van die Woordeboek nie as lemmas beskou nie maar word afsonderlik gealfabetiseer en as laaste inskrywing onder die betrokke lemma saamgegroepeer. (p. ix)

Verreweg die meeste van die nagenoeg 11000 leksikale items word as aparte lemmas behandel, meer as 7000 van hulle met verklarings in aparte artikels, en ongeveer 4000 daarsonder. Dit het sy voor- en nadele. Aan die een kant word die naslaanwerk daardeur vergemaklik, aan die ander kant kan dit tot onnodige, met aanhalings geillustreerde lemmas lei, wat kosbare ruimte in beslag neem. 'n Mens verwelkom die aparte inskrywings van iteratiewe. Op enkele uitsonderings na (bv. kreupel-kreupel, kroes-kroes, krom-krom) word hulle as aparte lemmas behandel en met aanhalings geillustreer, maar dit sou wenslik wees om hier 'n vaste beleid te volg.

By wisselvorme word soms onnodige artikels gemaak; bv. word die variante kruisement, kruisemint, kruisemunt, kruistemint, kruistemunt met aanhalings in 5 lemmas vermeld, krokkedel, krokodel en krokodil in 3 lemmas, en kwaaivriende, kwaaivrinde en kwaaivrinne, ook in 3 lemmas, en almal mét aanhalings. Hier skemer die ou redaksionele onduidelikheid deur, en nog steeds die gebrek aan 'n vaste redaksionele beleid t.o.v. die opname al dan nie van regionale variante.

Seldsame of idiosinkratiese woordvormimgs soos koster-skoolmeester, of Adam Tas se spottend bedoelde krankebedroewer en die uiters ongewone kultuureners is mi. nie 'n aparte inskrywing werd nie. Hier behoort die redaksie meer selektief te wees. As ' $n$ woord slegs een keer of by een bepaalde skrywer voorkom, is dit nie noodwendig deel van die Afrikaanse leksikon nie. Dan sou 'n mens beslis veel meer gewestelike variante en lekker sêgoed, bv. uit Namakwalandse Afrikaans, Griekwa-Afrikaans ens. moet opneem. In dié verband waardeer 'n mens 'n regionale woord soos kos-my-niks (volksetimologies uit Eng. cosmetics) wat soortgelyk is aan oliekolonie (volksetimologies uit Frans eau de Cologne).

Verskeje Khoi-woorde word in aparte artikels behandel, soms met etimologiese verwysings soos in kousa en kousang < Hott. \#kou, "smeer" en sa, "boegoe"), kouroe <!kouroe = "klipgat", soms is daar slegs die opmerking <Hott., bv. by koubee. In teenstelling met ander artikels val dit op dat by Khoi-woorde bitter min aanhalings verskaf word, wel word daar melding gemaak van die plek waar die woorde opgeteken is.

Dit is vir my nie duidelik of en wanneer 'n leksikale item 'n aparte inskrywing "verdien" nie. Hoekom word samestellings soos kroonslagaaromleiding, kroonslagaarsiekte, kroonslagaartrombose, kroonslagaarverstopping in aparte artikels behandel terwyl kroonslagaaraandoening, -behandeling, -bloedstroom, -operasie e.a. slegs as onverklaarde samestellings aangedui word? Waarom word 'n hoogs gespesialiseerde mediese vakterm soos Krim-Kongokoors mét verskeie aanhalings opgeneem en in 'n airtikel beskryf met daarby 
nog twee verdere samestellings as onverklaarde samestellings? Ons kry lemmas vir krom-Hollands, krom-Nederlands en krom-Portugees terwyl kromAfrikaans en krom-Engels nie eens vermeld word nie. Hier behoort 'n strakker beleid ontwikkél te word om dergelike ongerymdhede uit te skakel.

Een van die swakste aspekte van die artikel-inskrywings is die gebruik en ordening van voorbeeldmateriaal. Dit wil voorkom of die voorbeeldsinne met bronneverwysing en datum - lukraak gerangskik is. Ek kan nóg 'n chronologiese nóg 'n semantiese ordening ontdek. Die aantal voorbeeldsinne is in verdere probleem soos later bespreek sal word.

\section{Samestellings en afleidings}

'n Interessante aspek wat 'n mens by die deurlees van deel VIll opval, is die aard en die groot hoeveelheid samestellings en afleidings wat vermeld word. Ek volstaan met 'n paar voorbeelde. Daar is 358 samestellings met kultuur-, almal as aparte lemmas, afgesien van nog verdere lektiese items met dieselfde stam. Daar is letterlik honderde samestellings en afleidings met die stamme krag-, kruis- en kuns-. Die selfstandige naamwoord kryg mag "tans verouderend" wees, maar die meeste samestellings en afleidings is beslis nog baie gebruiklik, soos blyk uit die 153 lemmas met die stam kryg-, bv. krygsgevangene, krygsmakker, krygswet, krygslustig. Natuurlik figureer ook die tegnosamestellings en -afleidings taamlik sterk met talle lemmas i.v.m. kosmo-, krio-, kwadraat-, kwantum- ens.

Soms sit in die samestellings interessante brokkies taalgeskiedenis. Die kompositum kreefkerrie kom bv. reeds in Peter Kolb se Beschreibung voor, "Zy ... smaken best, als men kreeft kerria, dat is een zoort van goede, gezonde en lekkere spys, daar uit gemaakt heeft". (Deel I, 1727: 239a) WAT Vlll vermeld ook die bekende uitdrukking in ouer Afrikaans "Ek laat nie kreefkerrie van my maak nie" (Scholtz 1965: 171). Uit hierdie voorbeeld blyk dat die WAT soms wel aanhalings uit ou bronne verskaf al is dit op 'n lukraak manier.

\section{Vaktale}

Dit is nie duidelik watter beleid by die vermelding van vakterme uit bepaalde vakrigtings en sosiolekte toegepas word nie. Heelwat mediese en veral tegnologiese terme, landbou- en wetenskapsterme is in deel VIIl opgeneem, en sommige is vir die leek baie gespesialiseerd. Maar 'n vaste beleid ontbreek.

As voorbeeld van 'n goed gedokumenteerde vaktaal of sosiolek kan hier verwys word na die Rooms-Katolieke terme wat amper volledig verteenwoordig is in deel VIII, bv. kromstaf, kruieseëning, kruin, kruinskering, kurie (curia), kwatertemperdag (verouderd), kruisaanbidding, kruisverering, kruisverheffing, kruisweg(stasie), Kyrie, kyriaal. Slegs enkele woorde en 
vaste uitdrukkings soos Kosbare Bloed (van Christus), kruisstaf in die betekenis van kromstaf, "biskoplike herderstaf" (Eng. crozier) ontbreek. Dit wil voor. kom of hier hoofsaaklik vanaf die ongepubliseerde $P h D$ verhandeling van D.J. Gomes (1962) gewerk is en nie so seer aan die hand van die meer gesaghebbende tweetalige Church Dictionary / Kerkwoordeboek (1970), wat gedeeltelik die werk van Karel Schoeman was nie. In watter mate ook woorde uit ander godsdienstale en sosiolekte - bv. Kaapse Moesliemafrikaans (vgl. Davids 1992) voorkom, is hier nie nagegaan nie.

\section{Voorbeeldmateriaal}

'n Kenmerk van die WAT was nog altyd die aanhalings (vgl. Toeligting p. xii, par. 2.9). Sover vasgestel kon word, kom daar geen poëme voor nie. Die voorbeeldmateriaal bestaan deurgaans uit sitate met bronvermelding (outeur en datum) en illustreer die semantiese, sintaktiese en pragmatiese funksie van 'n bepaalde leksikale item. Hier behoort egter die "bondigheidsbeginsel" (Lombard 1992: 153) toegepas te word. Die sitate is informatief as ' $n$ mens ' $n$ beeld van die Afrikaanse taalgebruik oor die afgelope honderd jaar wil kry, maar die oordadige en skynbaar willekeurige vermelding van sitate kan ook 'n irriterende effek hê op die woordeboekgebruiker. Oor die algemeen is die sitate goed gekies; die probleem lê in die hoeveelheid en in die rangskikking. Die leksikograwe van die WAT beskik oor so ' $n$ magdom van voorbeeldmateriaal dat die seleksie klaarblyklik problematies word.

Hoewel die Woordeboek nie op 'n historiese grondslag gebou is nie, kan 'n mens dikwels die ouderdom en die register van 'n woord aan die hand van die gebruikte aanhalings nagaan. Hier ontbreek egter 'n vaste redaksionele beleid: soms word die aanhalings histories gerangskik, heel sporadies word daar van vroeë, argivale bronne en gepubliseerde Kaapse tekste gebruik gemaak (bv. kuier uit 1766, kwas (1) uit 1850, kropslaai - by Van Riebeeck, kros vir karos - by Tregardt 1838, Teenstra 1830, Mansvelt 1884), maar dit is sonder enige stelselmatigheid. Soms is daar lang reekse van sitate sonder dat hulle semantiese, regionale of registerverskille illustreer. Van kroonkandelaar word daar bv. 7 aanhalings van dieselfde tipe en betekenis verskaf. Dit maak die Woordeboek wel informatief en onderhoudend om te lees, maar dit affekteer die struktuur en die funksie van die woordeboek. By lang artikels soos krag (34 kolomme), kruis (16 kolomme), kritiek (15 kolomme), kroon (13 kolomme), kos ( 9 kolomme), kraak ( 9 kolomme), kring ( 8 kolomme), kultuur (7 kolomme), krisis ( 5 kolomme), om maar 'n paar te noem, word m.i. gans te veel aanhalings gegee. Hier sou 'n drastiese besnoeiing die effektiwiteit van die Woordeboek beslis verhoog. Soos Lombard (1992: 148-164) beklemtoon, moet die "bondigheidsbeginsel" nie net ten opsigte van definiense toegepas 
word nie, maar ook by die keuse van sitate. Ook in 'n verklarende woordeboek soos die WAT behoort daar na kort en informatiewe voorbeeldmateriaal gestreef te word (Mostert 1988: 156).

\section{Spreekwoorde en gesegdes}

Dit sou 'n studie op sy eie verg om al die gesegdes, spreekwoorde en ander idiomatiese uitdrukkings te beskryf wat hier so volledig vermeld word. By die deurlees van WAT VIII word 'n mens opnuut getref deur die sterk idiomatiese inslag van Afrikaans, die rykdom aan spreekwoorde en die lekker, aardse sêgoed. Die woordeboekgebruiker is beslis dankbaar vir hierdie taamlik volledige vermelding van idiome. Soos in die Toeligting op p. xii vermeld, word 'n uitdrukking gewoonlik onder die "eerste vaste komponent" opgeneem en verklaar; dié kan egter die eerste selfstandige naamwoord of byvoeglike naamwoord of werkwoord of bywoord of voorsetsel of ander woordsoort wees! Al word die verwysingsmetode pertinent uitgespel, moet die gebruiker eers die redaksionele sisteem goed bestudeer; anders raak hy/sy totaal verward of gefrustreerd. Hoewel daar bv. meer as 100 gesegdes by die werkwoord kry voorkom, word hulle onder kry slegs vermeld, maar onder die soekwoord dan verklaar, bv. "'n bloutjie kry", "iets/iemand kan my kry", "'n blou skeen kry", "kry waarna jy soek". Daarmee word dubbele inligting verskaf, een oor die uitdrukking self, die ander oor die rol van bepaalde werkwoorde. Kry is klaarblyklik besonder frekwent; dikwels het dit in soortgelyke Nederlandse gesegdes 'n ander werkwoord vervang. Vanuit 'n historiese oogpunt is daar dus 'n massa indirekte maar hoogs relevante gegewens ten opsigte van die verskille tussen Afrikaans en Nederlands, en die funksionele lading van die werkwoord kry.

Ook by die uitdrukkings word daar heelwat sitate aangehaal, soms op historiese grondslag, maar in die meeste gevalle is dit suiwer toevallig as 'n ou bron vermeld word. In die artikel kwas kom 'n mens toevallig op die vroegste opgetekende voorbeelde van die gesegdes "iets aan jou kwas hê" (1850), "met dieselfde kwas geteer wees" (1861) af. Dit is uiters waardevolle inligting, jammer dat dit so versteek is in 'n massa ander gegewens. Sou dit nie moontlik wees om hier 'n historiese/chronologiese rangskikking te verskaf nie? In ander artikels soek 'n mens egter verniet na die vroegste gevalle van sekere uitdrukkings. Onder die lemma kous byvoorbeeld word die vroegste gevalle van die uitdrukkings "met die kous op die kop" (1863), "met die kous op sy klapperdop" (1863) en "(kouse) oor hulle koppe laat trek" (1868) .(vgl. Raidt 1992: 252-253) nie vermeld nie. Slegs een van die drie gesegdes word uit 'n bron van 1876 aangehaal. Hierdie onsistematiese dataversameling en bronneverwerking maak die WAT onbetroubaar vir historiese gebruik. 


\section{Etimologieë}

Een van die tekortkominge van die WAT is die feit dat die redaksie doelbewus wegskram van die aangee van etimologieë (vgl. Toeligting p. xi). Etimologiese verwysings word slegs "oorweeg" o.a. by "leenwoorde, leenvertalings, en basterwoorde uit nie-Afrikaanse tale", verder by wetenskaplike terme en 'n paar ander kategorieë. Dit kom weer eens neer op nog 'n lukraak keuse, hierdie keer t.o.v. die etimologie van woorde. Hoekom word die herkoms verklaar van woorde soos "kraal (via Oos-Ind. Ndl. <Port. curral)", "krabbetjie, kraw[w]eltjie, krawwe[r]tjie (<Mal. k(e)raboe, waarsk. <Port. cravo-)", lg. selfs met 'n argivale verwysing: "In 'n argiefstuk van 1709-1724 ...", verder "krediettranche (<Fr. tranche)", "krok (<Eng. crock)", "kroep (via Ndl. <Fr. croup)", "krupsie (<dial. Ndl. vir corruptie)", "kwad (<E. quad)", "kwêlafluit (<X, Z khwela)", en selfs Adam Tas se onnosele krankebedroewer "(hist.) Verafr. v/d skertsend-satiriese benaming vir 'n sieketrooster deur Adam Tas in sy dagboek gebruik ...", terwyl talle ander belangrike etimologieë (bv. kurang, kwansuis, kwas=lemoensap) met opset onverklaar bly? Hier word 'n mens pynlik bewus van die hibridiese opset van die WAT as 'n verklarende woordeboek wat slegs nou en dan etimologies, en slegs nou en dan histories te werk gaan. Dit weerspieël natuurlik ook die leemtes wat in die leksikografie van Afrikaans bestaan: ons besit.nog geen historiese woordeboek van Afrikaans nie, en die etimologieë van woorde is maar net gedeeltelik beskryf. Maar daar is beslis reeds baie navorsing gedoen en talle etimologieë is goed nagevors; bestaande studies soos die van Boshoff en Nienaber (1967), Scholtz $(1965,1972,1980,1985)$ e.a. behoort deeglik benut te word.

In hierdie verband lewer die nuwe Dictionary of South African English on Historical Principles (DSAE) wat nog onder bewerking is, die bewys dat etimologiese verwysings in ' $n$ hoë mate moontlik is en verskaf kan word. Die beknopte formule wat deur die DSAE-redaksie gebruik word (vgl. Dictionary of South African English ... Project description 1991), kan ook vir die WAT aanbeveel word. Skakeling met die DSAE-kantoor in Grahamstad sou seker vrugbaar kon wees.

\section{Ten slotte}

Die Woordeboek van die Afrikaanse Taal is nog nie eens halfpad deur die alfabet nie, daarom is dit seker nie te laat en ook nie onvanpas om nou nog aanbevelings vir die volgende dele van die WAT te maak nie, veral aangesien daar tog op die oomblik 'n fase van redaksionele besinning en heroriëntering aan die gang skyn te wees. Die WAT beteken vir Afrikaans wat die Woordenboek der Nederlandsche Taal vir Nederlands en die Oxford English Dictionary vir Engels en alle betrokke taalgebruikers van daardie tale beteken. As die WAT eers klaar is, sal dit die mees omvattende beskrywing van die Afrikaanse leksikon in die 
ruimste sin van die woord wees. Juis daarom sou 'n mens graag 'n stelselmatige uitbreiding wou sien van die historiese en etimologiese dimensies van woordbeskrywing, verder 'n ruimer gebruikmaking van regionale variante van Afrikaanse woorde om ook aan die verskillende variëteite van die Afrikaanse taal reg te laat geskied. Die Woordeboek van die Afrikaanse Taal wat by uitstek "gebruikervriendelik" is, sou beslis daarby baat.

\section{Aantekening}

- Hauptfleisch, D.C. (Hoofred.). 1991. Woordeboek van die Afrikaanse Taal, Agtste deel, KOS-KYW-. xxii +584 bladsye, 1 plaat en 1 volbladafteelding.

Die Buro van die WAT, Privaatsak X5018, Universiteit van Stellenbosch, 7600 Stellenbosch. Prys: leerband R142.50, plastiekband R71 (posgeld ingesluit).

\section{Verwysings}

Afrikaanse woordelys en spelreëls. 1991. Agste, verbeterde uitgawe. Kaapstad: Tafelberg.

Boshoff, S.P.E. en G.S. Nien aber. 1967. Afrikaanse etimologieë. Die Suid-Afrikaanse Akademie vir Wetenskap en Kuns.

Church Dictionary / Kerkwoordeboek. 1970. Onder redaksie van die Taalkomitee B.S.A.K.B. Pretoria: K.A.S. (Katolieke Afrikanersentrum).

Combrink, J. 1979. Die sesde deel van die W.A.T. Standpunte 140, 32(2): 49-64

Davids, Achmat. 1992. Some Lexical Aspects of Cape Muslim Afrikaans. Lexikos 2: 39-62.

Dictionary of South African English on Historical Principles, Project Description. 1991. Rhodes University, Grahamstown.

Du Plessis, H. 1985. Suidwesafrikaans. Suid-Afrikanse Tydskrif vir Taalkunde. Geleentheidsuitgawe.

Gomes, D.J. 1962. 'n Ondersoek na die wenslikheid en noodsaaklikheid van 'n Katolieke woordeskat in Afrikaans. Ongepubliseerde Ph.D.-proefskrif. Universiteit van die Witwatersrand, Johannesburg.

Gouws, R.H. 1989. Leksikografie. Pretoria / Kaapstad: Academica.

Gouws, R.H. en F.A. Ponelis. 1992. Issues in the Development of Afrikaans Lexicography. SuidAfrikaanse Tydskrif vir Taalkunde. Supplement 12, April 1992.

Links, Tony. 1989. So Praat ons Namakwalanders. Kaapstad: Tafelberg.

Lombard, F.J. 1992. Voorbeeldmateriaal in woordeboeke. Lexikos 2: 148-164.

Mostert, N. 1988. Die funksie van poëme en sitate in die verklarende leksikografie. Tydskrif vir Geesleswetenskappe 28(2): 150-160.

Odendal, F.F. 1979. Plus positief en plus negatief: gedagtes na aanleiding van WAT VI (KLA-KLO). Tydskrif vir Geesteswetenskappe 19(1): 24-41.

Raidt, E.H. 1992. Taalvariasie in negentiende-eeuse Afrikaans. Tydskrif vir Geesteswetenskappe 32(4): 240-256.

Scholtz, J. du P. 1965. Afrikaans uit die vroeë tyd. Kaapstad: Nasou. 
Scholtz, J. du P. 1972. Afrikanns-Hollands in die agtiende eeu. Kaapstad: Nasou.

Scholtz, J. du P. 1980. Wording en ontwikkeling van Afrikans. Kaapstad: Tafelberg.

Scholtz, J. du P. 1985. Afrikaanse woorde en uitdrukkinge - eiegoed of erfgoed? Tydskrif vir Ceesteswetenskappe 25(4): 235-290.

Van der Merwe, H.J.J.M. en F.A. Ponelis. 1991. Die korrekte woord. Pretoria: J.L. van Schaik.

Van der Waal-Braaksma, G. en O.J.O. Ferreira. 1986. Die Noordweste. Johannesburg: Genootskap vir Afrikaanse Volkskunde. 


\title{
Broadening the Perspectives of South African English and Afrikaans Research (An Interview with David L. Gold
on his Work in these Fields)
}

\author{
Roy S. Rosenstein, American University of Paris, France
}

\begin{abstract}
David L. Gold is a student of South African English and Afrikaans who looks at these two languages in the context of several other Germanic languages, as well as other Indo-European and certain non-Indo-European languages. He suggests that the traditional comparison of Afrikaans only with European Dutch be supplemented by comparing it with New Netherland Dutch, which, like Afrikaans, began as a non-European variety of Dutch in the seventeenth century. A comparison of Afrikaans and New Netherland Dutch sheds light not only on those two languages but on earlier European Dutch too.

Gold suggests that the etymology of Afrikaans lexemes not be limited to their form but be extended to their meanings as well. If effect is given to that suggestion, we see that South African English has had greater influence on Afrikaans vocabulary than hitherto believed, i.e., the meanings of many Afrikaans lexemes are of English origin, although the lexemes themselves are not of that origin.

David L. Gold is also a student of Jewish aspects of South African English and Afrikaans. Most Jews who have settled in South Africa have been native speakers of Yiddish and it is only natural that traces of their native language can be found in their English or Afrikaans. A number of those vestiges are found in the speech of their descendents too (even if they do not know Yiddish) and a small number of them have been adopted by non-Jewish South Africans as well. Investigation of the influence of Yiddish on South African English and Afrikaans requires a good knowledge of the varieties of Yiddish brought to South Africa (in the early days: Western Yiddish; beginning in the late nineteenth century: Northeastern Yiddish), varieties of Jewish English spoken in other countries (for comparison with Jewish South African English), and Jewish Dutch (for comparison with Jewish Afrikaans).

Another Jewish aspect of South African English and Afrikaans which David L. Gold has looked into is non-Jewish usages of Jewish interest, like words meaning 'Jew' and idioms referring to Jews. All of this material of Jewish interest needs to be recorded and compared with similar material in other languages.
\end{abstract}

Keywords: AFRIKAANS, AMERICAN ENGLISH, ARABIC, ARMENIAN, BULGARIAN, CAPE-COLORED ENGLISH, CARIBBEAN DUTCH, COUNTING-OUT RIMES, DIGLOSSIA, DUTCH, ENGLISH, ETHNOLECTS, ETYMOLOGY, FAMILY NAMES, FRENCH, GERMAN, 
JEWISH AFRIKAANS, JEWISH AMERICAN ENGLISH, JEWISH BRITISH ENGLISH, JEWISH ENGLISH, JEWISH IRISH ENGLISH; JEWISH JAMAICAN ENGLISH, JEWISH SOUTH AFRICAN ENGLISH, LANGUAGE PLANNING, LANGUAGES IN CONTACT, LEXICOCRA. PHY, LEXICOLOGY, MARATHI, NEOSEMANTICISMS, NEW NETHERLAND DUTCH, PLACE NAMES, PORTUGUESE, SERBOCROATIAN, SOUTH AFRICAN ENGLISH, TURKISH, YD. DISH, ZEELAND DUTCH

\section{Opsomming: 'n Verruiming van die navorsingsperspektiewe op Suid-Afri-} kaanse Engels en Afrikaans ('n onderhoud met David L. Gold oor sy werk op hierdie gebiede). David L. Gold is 'n navorser van Suid-Afrikaanse Engels en Afrikaans wat hierdie twee tale teen die agtergrond van sowel verskeie ander Germaanse tale as ander IndoEuropese en sekere nie-Indo-Europese tale bestudeer. Hy doen aan die hand dat die tradisionele vergelyking van Afrikaans slegs met Europese Nederlands aangevul word met 'n vergelyking van Afrikaans met Nieu-Nederlandse Nederlands wat net soos Afrikaans as ' $n$ nie-Europese variëteit van Nederlands in die sewentiende eeu ontstaan het. 'n Vergelyking van Afrikaans met NieuNederlandse Nederlands werp lig nie slegs op hierdie twee tale nie, maar ook op vroeëre Europese Nederlands.

Gold stel voor dat die etimologie van Afrikaanse lekseme nie tot hulle vorm beperk word nie maar ook tot hulle betekenisse uitgebrei word. Indien hierdie voorstel toegepas word; sal dit blyk dat Suid-Afrikaanse Ėngels 'n groter invloed op die Afrikaanse woordeskat gehad het as wat tot dusver geglo is, d.w.s. die betekenisse van baie Afrikaanse lekseme is van Engelse oorsprong, alhoewel die lekseme self nie van Engelse oorsprong is nie.

David L. Gold is ook 'n student van die Joodse aspekte van Suid-Afrikaanse Engels en Afrikaans. Die meeste Jode wat hulle in Suid-Afrika gevestig het, was moedertaalsprekers van Jiddisj, en dit is bloot natuurlik dat spore van hulle moedertaal nog in hulle Engels en Afrikaans voorkom. 'n Aantal van hierdie oorblyfsels kan ook gevind word in die taal van hulle afstammelinge (selfs al ken hulle nie self Jiddish nie), en enkele gevalle word ook gebruik deur nie-Joodse Suid-Afrikaners. 'n Ondersoek na die invloed van Jiddisj op Suid-Afrikaanse Engels en Afrikaans verg ' $n$ deeglike kennis van die vorme van Jiddisj wat na Suid-Afrika gebring is (in die vroeë jare: Westerse Jiddisj; sedert die laat neëntiende eeu: Noordoostelike Jiddisj), variasies van Joodse Engels gepraat in ander lande (ter vergelyking met Joodse Suid-Afrikaanse Engels) en Joodse Nederlands (ter vergelyking met Joodse Afrikaans).

Nog 'n Joodse aspek van Suid-Afikaanse Engels en Afrikaans waaraan David L. Gold aandag geskenk het, is die nie-Joodse gebruike van woorde wat van Joodse belang is, soos woorde wat "Jood" beteken en idiome wat na Jode verwys. Al hierdie materiaal wat van Joodse belang is, behoort opgeteken en met soortgelyke materiaal in ander tale vergelyk te word.

Sleutelwoorde: AFRIKAANS, AMERIKAANSE ENGELS, ARABIES, ARMEENS, BULGAARS, DIGLOSSIE, DUITS, ENGELS, ETIMOLOGIE, ETNOLEKTE, FRANS, JIDDISI, JOODSAMERIKAANSE ENGELS, JOODS-BRITSE ENGELS, JOODSE AFRIKAANS, JOODSE ENGELS, JOODS-IERSE ENGELS, JOODS-JAMAIKAANSE ENGELS, JOODS-SUID-AFRIKAANSE ENGELS, KAAPSE KLEUIRLING-ENGELS, KARIBIESE NEDERLANDS, LEKSIKOGRAFIE, LEKSIKOLOCIE, MARATHI, NEDERLANDS, NEOSEMANTISISMES, NIEU-NEDERLANDSE NEDERLANDS, PLEKNAME, PORTUGEES, SEEUSE NEDERLANDS, SERWO-KROATIES, 
SUID-AFRIKAANSE ENGELS, TAALBEPLANNING, TALE IN KONTAK MET MEKAAR, TURKS, UITTELRYMPIES, VANNE

Q.

How did you become interested in Afrikaans and South African English?

I grew up speaking Yiddish and English. With those two languages, it was fairly easy to teach myself to read German. Then, with those three languages, Dutch. And finally, with those four languages, it's easy to learn to read Afrikaans. As a linguist with an interest in Jewish languages, English, etymology, lexicography, family names, and some other topics, I've been able to put my reading knowledge of Afrikaans to good use.

Strange as it may seem, South African English and Afrikaans are useful in studying Dutch influence on New York City English, a subject which attracts me for a personal reason. Being a native of New York City (which until 1664 was called New Amsterdam and was part of New Netherland, a Dutch colony), 1 became interested in New York City English, specifically in how its vocabulary differs from the English spoken in other parts of the United States. One of the reasons New York City English is different is that it's been influenced by Dutch more than most other varieties of American English have. Today, that influence is hardly to be discerned, but as you go back in time, you find that the number of Dutch-origin usages increases.

Many of these Dutch-origin usages in New York City English and, more broadly, in American English had been identified before I became interested in the subject, but a number of them had not been. In American Speech and Leuvense Bijdragen, l published three articles on the word sliding pon/sliding pond, which was once commonly used in New York City to designate a children's slide (as in a playground). Growing up, 1 knew only sliding pond. It wasn't until my early thirties that I learned that outside Greater New York City the word (in either of its forms) was not used. It's based on Dutch glijbaan or some synonymous word ending in -baan. Until my articles on this word were published, it had been recorded only seldom and its etymology was unknown.

Since the three articles on sliding pon/sliding pond were published, l've gathered new material on the word and now plan to publish a more comprehensive treatment. After that, I'll go on to report on more vestiges of Dutch in New York City English in particular and American English in general.

\section{Q. But how do South African English and Afrikaans enter the picture?}

If you suspect that a certain usage in New York City or American English is from Dutch, your hunch is strengthened (but not proven) if three conditions are met: [1] you can find the same usage in South African English, [2] you're 
certain that in South African English the usage is of Afrikaans origin, and [3] you can't find the usage in any other variety of English. In such cases, you conclude that the New York City or American usage is probably of Dutch origin. That is, both of the English usages - in the United States and in South Africa - presumably go back to the same non-immediate source: European Dutch. South African English can thus serve as the basis for drawing up a checklist of usages in New York City or American English that may be of Dutch origin.

An important word here is checklist. The possibility of chance resemblance (convergence) always exists. That is, the researcher must constantly be on the lookout for the following situation: a certain usage in South African English may indeed be from Afrikaans (and in Afrikaans it is from Dutch), but that same usage in New York City or American English happens not to be from Dutch. Hence the checklist is merely an inventory of usages to be examined. Some may in fact tum out to be of Dutch origin and some may turn out not to be.

Students of American English can thus benefit from an examination of South African English. It also follows that students of South African English can profit from a look at New York City and American English, which may serve as the bases for drawing up checklists of usages in South African English that could be of Afrikaans origin.

Q. Can you give me an example of how students of South African English and American English can be of service to one another?

In South African English, the word forget means, inter alia, 'to leave [somethingl behind unintentionally'. For example, "I forgot my book on the table." That use of the word has been attributed to Afrikaans (cf. vergeet in the same sense). In the English of New York City (if not of the entire United States), we find exactly the same usage. Here, for instance, is a quotation from The New York Times of 6 May 1992: "As Mrs. Lipstein spoke, she noticed that a stranger had forgotten her sunglasses on the counter" (p. B3). Since the South African English usage is said to be of Afrikaans origin, we naturally ask whether the New York City English one is of New Netherland Dutch origin. If it is, we should be able to take both the New York City and South African English usages back to a common source, European Dutch.

However, if it tums out that forget in this sense in New York City English is not of New Netherland Dutch origin (let's assume, for argument's sake, that research showed the usage to go back to older British English), we might question attribution of the South African English usage to Afrikaans. If the American English usage could, for example, be of older British origin, so too could the South African English one (or, at least, of both Afrikaans and British English origin). 
Although I once entertained the possibility that forget in this sense might be of Afrikaans origin in South African English (others have indeed said it is) and of New Netherland Dutch origin in American English (in which case, the usage could probably be taken back further, to European Dutch), it's clear that this is a universal and standard English usage: at forget, the second edition of the Oxford English Dictionary has 'to omit to take, leave behind inadvertently' (with no condemnation or any kind of restrictive label), giving non-SouthAfrican citations from before 1300, 1535, 1596, 1766, and 1860. Therefore, at most, Afrikaans reinforces this usage in South African English. One should not condemn it as substandard, as at least two South African observers of South African English have.

We must now ask whether Afrikaans vergeet in this sense is due to English influence (or, at least, reinforced by English forget). Since one of the meanings of Dutch vergeten is 'uit onoplettenheid [iets] ergens achterlaten' (= sense III.7 in the Woordenboek der Nederlandsche Taal), as in "Ik moet terug naar de bibliotheek, want ik vergat mijn boek bij de balie" or "Ik moet terug naar het hotel, want ik vergat mijn paraplu bij de receptie," it's virtually certain that the Afrikaans usage is of Dutch origin. All three languages thus converge, so that the most that has happened is that Afrikaans and South African English reinforce each other in this respect. It would thus not be correct to speak of outright Afrikaans influence on South African English or vice versa as far as the use of these verbs is concerned.

New York City English (or, more broadly, American English) and South African English are thus suited for comparison with each other because both have been in contact with varieties of the same language (Dutch) or with languages that are closely related to each other (Dutch and Afrikaans): New Netherland Dutch in the case of American English, and South African Dutch and Afrikaans in the case of South African English. The periods of contact and the extent of the contact, however, are different. New Netherland existed for only a short time: in 1609, Henry Hudson, in the service of the Dutch West India Company, explored the river later named for him; by 1613, the Dutch had built four houses on Manhattan Island; in 1621, New Netherland was founded, but the first permanent colonists did not arrive until the spring of 1623; in 1664 , Great Britain seized the colony; for part of 1673 and 1674, it was again in Dutch hands, but in 1674 the Netherlands officially ceded New Netherland to Great Britain (Leisler's Rebellion, in 1691, aimed at restoring Dutch control, failed). Even after Dutch rule over New Netherland ended, the Dutch language continued to lead a vigorous existence in New York and New Jersey (as the British had renamed New Netherland) until the American Revolution. Then it began to decline, although even as late as the 1830 s Dutch could still be heard on the streets of New York City. In the Hudson Valley and parts of New Jersey, the language survived into the early years of the twentieth century and even today at least two men are alive who learned New Netherland Dutch from their parents as their first language (Charles Gehring tells me that one of 
them is L.G. van Loon and that the other one wishes to remain anonymous). New Netherland Dutch thus began going out of use in the late eighteenth century, whereas Afrikaans has led a vigorous existence ever since Dutch was brought to southem Africa.

Q. If I may inject a word, Charles T. Gehring, who wrote his doctoral dissertation at the University of Indiana on New Netherland Dutch, is director of the New Netherland Project, whose principle aim is to translate into English and publish the approximately 12,000 pages of records of the Dutch West India Company which relate to New Netherland, and the organizer of the Rensselaerswyck Seminar, an annual conference of people engaged in research on New Netherland.

Yes, quite so. To go on: also, as a result of outmarriage and cultural assimilation, the New Netherland Dutch have disappeared as an ethnic group in the United States. Many Americans know that they're of partial New Netherland ancestry and many of those people who are well-to-do belong to the Holland Society, a fraternal organization with headquarters in New York City. Periodically, "Dutch festivals" are held in Albany (which is built on the site of Fort Orange, a Dutch outpost). Charles Gehring tells me that some elderly people remember some isolated words and phrases in New Netherland Dutch from their childhood and that many recall the nursery rime Trip a Trop a Trontie. The Dutch language, culture, and society of New Netherland are thus for all practical purposes like the Cheshire cat: the cat has disappeared, leaving only its smile. In contrast, Afrikaans, Afrikaans culture, and Afrikaner society are alive.

Those differences between New Netherland Dutch and Afrikaans are reflected in American and South African English: New Netherland Dutch has been a minor influence on New York City (or American) English, whereas Afrikaans has been the major non-English influence on South African English. Dutch and English are no longer in contact in the United States or South Africa, whereas Afrikaans and South African English continue to be in contact and influence each other. Much more material is available for the study of Afrikaans than for New Netherland Dutch, but as a student of several obsolescent and supposedly obsolete lects, I'm often surprized at what does tum up if one looks hard enough: it's probable that not all Dutch texts written in New Netherland (and, later, New York and New Jersey) have been uncovered, whether they are now in public or private hands, and it's possible that elderly people can be pumped for still more vestiges of the spoken language. Those looking for spoken vestiges in the twentieth century have interviewed mostly Whites, but Blacks too used New Netherland Dutch, likewise down to the twentieth century, although little has been recorded of their speech. I suspect that Black New Netherland Dutch may still be partly recoverable from elderly people. 
When a language ceases to influence another language, as is the case of Dutch and American English, what happens to the borrowings is unpredictable. Certain ones may continue to be used. Others may come to be used less. Still others may go out of use altogether. Here are some examples from American English. The word coleslaw, of New Netherland Dutch origin, is now universal in American English and all indications are that it is here to stay. The closure of American English to Dutch influence has thus had no effect on the secure position of coleslaw in American English. The word sliding pon/sliding pond, on the other hand, is obsolescing. A smaller percentage of New Yorkers know the word today than when I was a child. The closure of American English to Dutch influence thus had an adverse effect on the word: without the support of Dutch, it began going out of use. American English kill 'stream, channel', likewise from New Netherland Dutch (kil), hasn't fared well either: it now survives only in place names (Arthur Kill, Catskill, Fishkill, Fresh Kills, Great Kills, Kill Van Kull, Outer Kill, Peekskill, Schuylkill River, Val-Kill, Varkenskill, Whorekill, and a few others; cf. Dutch Kills, the now forgotten name of a town incorporated into Long Island City, New York, in 1870), but the average English-speaker has no idea what kill means in these names and doesn't use the word as a common noun. And some Dutch-origin usages have probably disappeared completely, like blummie 'flower'.

\section{Q. Isn't Whorekill an unusual place name?}

I don't know how it came about. The southernmost Dutch settlement in what is now the United States was on a cape which the Dutch called Henlopen. This settlement, in what is now Delaware, was first called Zwannendael, later Whorekill, and is now called Lewes. Perhaps Whorekill was a facetious name given by English-speakers or perhaps this name does not contain English whore at all.

To get back to the discussion: thus, as Dutch receded into the background in New York and New Jersey, the number of Dutch-origin usages in American English fell (but some have remained as part of the core vocabulary and others are marginal). It's not only the disappearance of the New Netherland Dutch language which led to a decrease in the number of such English usages, but also the disappearance of the New Netherland Dutch people into the American woodwork. The people simply assimilated, eventually losing almost all of their Dutchness, retaining at most a family name and/or, more rarely, a given name (like Cornelius). One normally expects religious institutions to be conservative, but even the Dutch Reformed Church in America eliminated the word Dutch from its name (in 1867) as jts members became more and more American and less and less Dutch. Today, most of its members are not of New Netherland Dutch origin, though the church still uses few Dutch-origin religious. 
In South Africa, Dutch has disappeared as far as the English-speaking population is concerned. Hence South African English is now closed to Dutch influence. The number of Dutch-origin usages in South African English may remain the same or decrease, but it won't rise. Afrikaans, on the other hand continues to influence South African English. Hence the number of Afrikaansorigin usages will in all likelihood go up. If any usages of Afrikaans-origin in South African English obsolesce, that will probably be only because people no longer need them, not because Afrikaans is absent as a reinforcement. Because of the disappearance of New Netherland Dutch in contrast to the continuing presence of Afrikaans, today's average speaker of American English does not know that lexemes like coleslaw, cookie, cruller, play hooky, poppycock, Santa Claus, sliding pon/sliding pond, spook, stoop (in front of a building), waffle (food), and waffle iron, to name just a few of the borrowings from New Netherland Dutch, are of non-English origin, whereas today's average speaker of South African English is quite aware of the Afrikaans origin of words like kas, katel, and katkop.

Even the spelling of these lexemes plays a role: in the case of American English, the spelling blinds us to their Dutch origin, whereas and in the case of South African English, it reminds us of their Dutch or Afrikaans origin. Thus, American English lexemes of New Netherland Dutch origin tend to be respelled following rules of English spelling, whereas South African English items of Afrikaans (or Dutch) origin tend to be spelled as in Afrikaans (or Dutch), that difference being due to the disappearance of written Dutch in the United States vs. the continuing presence of written Dutch and written Afrikaans in South Africa, hence their continuing influence as a reinforcement of the traditional spellings. A good example of the difference is American English stoop vs. South African English stoep. There's nothing un-English about the spelling of stoop, but stoep has oe, which is unusual for English, hence a reminder that the word is of non-English origin. Likewise with respect to wordinitial $k$, which is generally a sign in English that the word is a borrowing from some other language, usually German, Dutch, Afrikaans, or Yiddish.

Whereas the spelling of American English non-proper lexemes of New Netherland Dutch origin has been fully anglicized in most if not all cases, American place names of that same origin may be classified along a continuum: between the two extremes of full retention of Dutch spelling and of full anglicization, we find various intermediate stages. For example, Spuyten Duyvil ( $=$ full retention of Dutch spelling), Harlem (= fully anglicized respelling of Haarlem, but with the net result being only a slight change), the Bowery (= fully anglicized respelling of die Bouwerij 'the Farm', with moderate changes), Hempstead ( = fully anglicized respelling of Heemstede [with $p$ due to the influence of Hampstead, near London, England, and now part of it]), Brooklyn (= fully anglicized respelling of Breuckelen 'Broken Land', with the result that a name which was meaningful to Dutch-speakers is meaningless to English-speakers), Tenafly (= fully anglicized respelling of Tiene Vly 'Ten Swamps', with the same 
result as in the previous example), Staten Island (= retention [with a slight simplification of spelling identical to the one seen in Haarlem $\rightarrow$ Harlem] of the first part of Staaten Eylandt [which name the Dutch gave to the island in honor of the States-General of the Dutch Republic] and translation of the second part), Midwood (= translation of at least the second morpheme of Midwout; since both Dutch and English have mid, the first morpheme of Midwood shows both retention and translation), Coney Island (= full translation of Konynen Eyland, in contrast to Staaten Eylandt $\rightarrow$ Staten Island, in which the first part has not been translated, with the result that Staaten, which was meaningful to Dutch-speakers, has become Staten, which is meaningless to English-speakers), North River (= full translation of Nordrivier), Broadway (= full translation of Breed Wegh), and hook 'curving cape; curving headland', as in Corlear's Hook, Jeffrey's Hook, Red Hook, and Sandy Hook (= translation of Dutch hoek, as in Hoek van Holland). Full replacement of the Dutch name (like Rustdorp changed to Jamaica [now in Queens, NY]) illustrate even more radical anglicization.

Some of the changes are unusual in other ways. According to some, die Helle-Gat means 'the Beautiful Passage' and was the name which the Dutch gave to the East River (in what is now New York City). English-speakers, they say, folk-etymologized this name as Hell Gate, i.e., as if it meant 'the Gate to Hell', and, because of this ominous reference, applied Hell Gate only to the dangerous whirlpools caused by reefs in the narrow channel of the East River between the southwest side of Ward's Island and the northwest side of what is now Queens (the whirlpools were eliminated in 1876 when the Army Corps of Engineers blasted the reefs, thus making the channel easily navigable). According to others, die Helle-Gat originally meant 'the Hell Strait' and was always applied (whether in this Dutch form or its anglicized form, Hell Gate) to that dangerous channel. According to still others, die Helle-Gat originally meant 'the Narrow Passage' and was always applied to that channel. In any case, Hell Gate (which is now taken to mean 'the Gate to Hell') is an anglicization based on the written, not spoken, form of Dutch Gat, for if had been based on the spoken form, the end result would not have been be Gate. The name now survives mostly in Hell Gate Bridge, the name of a bridge spanning Ward's Island, Randall's Island, and Queens. Another noteworthy change concerns Schuylkil or Schuilkil, the name (literally 'Hidden Channel') which the Dutch gave to a river now in Pennsylvania. English-speakers adopted it as Schuylkill (doubling the $l$, as in all place names containing Dutch kil), but, not understanding the name, they added the generic word river, so that the full English name of the waterway is Schuylkill River, which is tautologous if you interpret it literally.

Several English place names reflect or may reflect folk-etymologized Dutch names. The Arthur Kill (the name of a waterway straddling the border between New York and New Jersey) honors no person bearing the given or family name Arthur. Rather, Arthur is a folk-etymology of Dutch achter (the Dutch called this waterway die Achter Kil 'the Back Channel'). The first element in the name Gramercy Park is an English-speaker's reinterpretation of Dutch 
Krom Moerasje 'Crooked Little Swamp', which is what the Dutch called a swamp where the park is now located. According to some, Turtle Bay was so named because of the turtles in the area. According to others, it was so named because this small bay was shaped like a turtle's back. And according to still others, Turtle is an English-speaker's reinterpretation of Dutch deutal 'unevenly curved sword', the bay having been so named by the Dutch because of its shape (supporters of the third explanation call attention to a nearby farm called Deutal Bay Farm). I rather think that the last explanation is the correct one, as shown by the name of the farm.

The borough of New York City officially called Bronx and informally known as the Bronx is said to have been named in honor of Jonas Bronck, an early settler there, but the story is a bit more complicated. Jonas Bronck was a Dane who settled in that part of New Netherland (it is sometimes though that the population of New Netherland was exclusively Dutch, but it was actually heterogeneous). People who visiting or intending to visit Bronck and his family would say "I'm going to the Broncks" and in time "the Broncks" was reinterpreted as the name of the area where he and his family lived. The Bronx is thus an English respelling of the Broncks, hence the areas was not named in his honor, but results merely from a folk etymology.

A problematic English place name is Flushing, which now designates part of Queens, NY. Some have written that it is English for 'flowing water' (in allusion to a meandering river there now called the Flushing River). Some have written that a group of people fleeing religious persecution in England settled in the seaport of the southwestern Netherlands known as Vlissingen in Dutch and Flushing in English; later they set sail for Massachusetts and, in 1654, left that English colony (again because of religious persecution), making their way to New Netherland, where they founded a village, which they named Flushing in honor of the Netherlands seaport which had given them refuge. And some have written that the Dutch founded the village in 1628, named it Vlissingen in honor of the Netherlands seaport, and the English-speakers in New Netherland consequently called it Flushing. I do not know which of the three explanations in correct.

The contrast between the tendency of non-proper lexemes to have anglicized spelling (let us generically call it "modern spelling") and of place names to retain (to various degrees) their spelling (generically "archaic spelling") is not limited to American English items of New Netherland Dutch origin. It was only some time after the French pronunciation of Liége changed from /ljež/to $/$ ljez / that the spelling was modified accordingly (to Liège). In Mexican Spanish, the now archaic spelling México is still used (and exclusively so), whereas in other varieties of the language Méjico is the norm. Certain Spanish given names and family names are now spelled in two ways: archaically (Xavier, Ximénez, Yglesias) and as modern spelling requires (Javier, Jiménez, Iglesias), yet the common noun from which the third name is derived (iglesias 'churches') is now spelled only in its modern form. Similarly in English, the common noun 
is now solely smith, whereas the family name is now Smith, Smithe, or Smythe. Similarly in South Africa: even after Afrikaans became official in 1925, Dutch place names in that country were not, as far as I know, replaced by Afrikaans ones. And even after Dutch spelling was modified in 1947, Dutch place names in South Africa were not changed to accord with the new rules. A South African place name which serves as an example of both kinds of conservatism is Stellenbosch. It should be *Stellenbos according to the spelling rules both of Afrikaans and of post-1947 Dutch, yet a non-Afrikaans, pre-1948 Dutch spelling has been retained to this day.

To get back to the three conditions, condition [3] can't always be met completely, but no matter. Take, for example, English cookie. The word is found only in American English, South African English, and Scots English (with not exactly the same meaning in all three varieties). Were condition [3] to be applied strictly, we'd have to discard this word from our checklist because it's found in a variety of English outside the United States and South Africa, but we include it anyway because it's clear that it shows the identical influence of New Netherland Dutch on American English and of South African Dutch and Afrikaans on South African English (the Scots English word is a borrowing from European Dutch).

Another reason for my interest in South African English is that linguists looking at a language from the outside - as observers rather than as participants - can often discem things which natives, that is participants, can't (that's in fact how I came to know that sliding pon/sliding pond is restricted to Greater New York City: someone from California once remarked on "this strange word" I'd used). As a non-speaker of South African English, I can often pick out usages which are typical of that variety of English more easily than speakers themselves. You can't tell what's different until you've made comparisons - and outsiders often make those comparisons more quickly and more accurately because they're looking at the fishbowl with a certain perspective rather than swimming around inside it. Since most students of South African English have been South Africans, I'm at a special advantage.

I might add that to my knowledge no one has ever compared Afrikaans and New Netherland Dutch, although it's a subject crying out for attention, especially since the two share two major features: they both derive from varieties of Dutch which were brought from the Netherlands within twenty-five years of each other, hence they are about the same age (New Netherland was founded in 1624 and Jan van Riebeeck landed in 1652), and both have a marked Southem Dutch character. The corpus of New Netherland Dutch is small enough that the topic could be treated in a dissertation or a monograph. Here are two of the many gems probably waiting to be unearthed: Branford 1991 lists sit up and opsit 'to court a girl by "sitting up" with her after the family have gone to bed' and derives them from Afrikaans opsit 'to court, woo', which it says is from Dutch opzitten 'to sit up'. That etymology implies that 'to court, woo' is an Afrikaans innovation, that is, such a meaning is, presumably, absent in Dutch 
opzitten. Yet / /pset / 'courting' was recorded in the English of one of the last speakers of New Netherland Dutch (Shetter 1958: 251). That is clearly not the English word upset with a new meaning, but an anglicization of the underlying New Netherland Dutch verb. Several questions with respect to this meaning thus need to be asked: [1] did New Netherland Dutch influence Afrikaans? [2] did Afrikaans influence New Netherland Dutch? [3] was the meaning present in seventeenth-century European Dutch, but simply failed to get recorded in that variety (though surviving in New Netherland Dutch and Afrikaans)? [4] do we have here merely a chance convergence, i.e., independent innovation in New Netherland Dutch and in Afrikaans? The answer to one of those questions must be yes. We may safely reply "no" to the first two questions, since New Netherland Dutch and Afrikaans were not in significant contact. The answer to the third question might be "yes" (what can students of seventeenthcentury European Dutch tell us?), but, if "no," then we must answer "yes" to the last question. My hunch is that the third possibility is the correct one. I would therefore first look for evidence in Southern Dutch (of Europe) for opzitten *to court, woo' and then in Northern Dutch (of Europe). If no evidence could be found, we would conclude either that [a] the New Netherland Dutch and Afrikaans usages are circumstantial evidence for such a usage in the seventeenth-century (Southern?) Dutch of Europe, although no direct evidence is available, or [b] that this is an instance of independent innovation.

Here is the second gem. European Dutch vallei, as far as I know, means only 'valley'. Yet South African English vlei and Afrikaans vlei mean 'a large shallow lake or swampy piece of ground'. The South African English word is clearly derived from the Afrikaans one, hence the question is whether the meaning 'a large shallow lake or swampy piece of ground' is an Afrikaans innovation or reflects an older European Dutch usage. However, as in the case of 'to court, woo', we find that New Netherland Dutch and Afrikaans usages are identical. Carpenter 1908: 62 listed American English vly/fly/vley/vlei/vlaie'a swamp, marsh, shallow pond'. The phonological and semantic identity between the Afrikaans and New Netherland Dutch words is striking. Again, Afrikaans influence on New Netherland Dutch is unlikely, as is New Netherland Dutch influence on Afrikaans. Independent innovation is possible (we should never forget that no language is static, hence Dutch in both New Netherland and southern Africa changed in certain, not necessarily identical, ways, as did European Dutch in ways in which extra-European Dutch may not have - all the more so if we use English to recover New Netherland Dutch or early Afrikaans: since English reflexes of New Netherland Dutch or Afrikaans items may be innovative, we must be certain not to attribute those innovations to the source language). 
The trick is to determine precisely where the innovation occurred. Q. Can you give me an example of one which is certain to have occurred in the reflex rather than in the etymon?

Greater New York City English has both sliding pon and sliding pond for 'slide'. Both forms go back to one or more New Netherland Dutch compound nouns ending in -baan (cf., for example, European Dutch glijbaan), but none of those European Dutch nouns is attested with /d/ (for New Netherland Dutch, no compound whatsoever has been recorded, though we may assume at least one on the basis of the English forms). Because sliding pon first designated a slippery area on a frozen pond that was suitable for sliding (before the word came to designate a slide in a playground for children), it's virtually certain that sliding pond is an English folk etymology of sliding pon that was induced by English pond. The innovation thus occurred in the English reflex rather than in the Dutch etymon.

To get back to the matter of analogs. However, the more analogs in Afrikaans and New Netherland Dutch which we record, the less probable it becomes that we have instances of independent innovation (how could there be so many chance similarities between the two?) and the more likely it becomes that Afrikaans and New Netherland Dutch are two tips of the SAME iceberg, whose submerged part is seventeenth-century spoken European Dutch basilect and mesolect, that is, Afrikaans and New Netherland Dutch may turn out to preserve features of European Dutch which are not known to us directly from European Dutch. You will not fail to notice, by the way, that in this example it is not only the meanings which are the same but the form as well: the Afrikaans and New Netherland Dutch words lack a vowel between the / $/$ and the $/ 1 /$.

Shetter does refers to Afrikaans a few times (but not in connection with opzitten or vallei), so it is clear that I am not the first to see the value of comparing Afrikaans and New Netherland Dutch. The more points of comparison we have (European Dutch, New Netherland Dutch, Afrikaans, South African English, and American English), the better able we are to understand each of these languages. And the more analogs we find between New Netherland Dutch and Afrikaans, the less the likelihood that they are due to chance, hence the more valuable these two languages will be in reconstructing older spoken European Dutch. Thus, whereas researchers have often compared (a) Afrikaans and European Dutch OR (b) New Netherland Dutch and European Dutch, we actually need a THREE-WAY comparison or, even better, a SIX-WAY comparison (including British English, American English, and South African English). Again the word checklist is important, for the possibility of chance resemblance (convergence) between Afrikaans and New Netherland Dutch always exists (especially since both began with essentially the same raw material - seventeenth-century spoken Dutch of Europe), as does the 
possibility of chance resemblance between South African English and American English.

An example of the latter possibility is South African English the taal/the Taal/die taal 'Afrikaans' and now obsolete American English the Tawl 'Dutch'. The South African English usage is derived from Afrikaans die taal the language', which is derived from Dutch die taal 'the language'. The American English usage reflects the New Netherland Dutch pronunciation of Dutch die taal 'the language'. It's clear that semantic narrowing occurred somewhere along the line ('the language' $\rightarrow$ 'Afrikaans' and 'Dutch'). Here, in contrast to opzitten and vallei, I do not think that the semantic innovation occurred in European Dutch. Rather, it must have been in American English and in South African English - and it must have been independent in each language. That is, identical conditions led to identical results: English-speakers designated "the other language" (New Netherland Dutch and Afrikaans) simply by the words for 'the language' in that "other language." We therefore have nothing more than a coincidence in this instance.

Q. You say that "in South Africa, Dutch has disappeared as far as the English-speaking population is concemed." Hasn't it disappeared with respect to the Afrikaans-speaking population too? That is, aside from the study of Dutch in schools and the many Dutch place names, the language plays no role here.

l suspect that Dutch has continued to play a minor role in the development of Afrikaans, although an ever diminishing role, even after the de-officialization of Dutch in 1925. Take, for example, the Afrikaans words for 'zipper', rits and ritssluiter. The Dutch word is ritssluiting. Now it could be that the Afrikaans and Dutch words resemble one another only by chance, but I think that even after 1925 certain Afrikaans-speakers have looked to Dutch as the possible model for Afrikaans neologisms. I'm not implying that Dutch has been followed slavishly, only that certain Afrikaans-speakers may have gotten the idea for this or that coinage from Dutch. Remember that the zipper is a fairly new device. It was invented in the 1890 s but did not become popular until the 1930s. Indeed, J.B. Berns, head of the Dialectology Section at the P.J. Meertens Institute of the Royal Dutch Academy of Sciences, tells me that his earliest citation for ritssluiting is only from 1937. Although it could be sheer coincidence that the Afrikaans words resemble the Dutch one, I wouldn't be surprized if rits were a shortening of ritssluiter and the latter had been inspired by ritssluiting. If my analysis is correct, Dutch influence did not end in 1925.

Another example Afrikaans oordruk 'offprint', which is clearly based on Dutch overdruk 'offprint'. We may be certain that early Dutch-speaking settlers 
in southern Africa had no idea what an offprint was (if one may judge by English offprint, which is not attested to the 1880 s, we may say that the phenomenon, hence the concept, was not known until the mid-nineteenth century at the earliest). Therefore, unlike, say, "Dutch over $\rightarrow$ Afrikaans oor" (where the arrow indicates a phonological change that took place as the word was passed from generation to generation), in "Dutch overdruk $\rightarrow$ Afrikaans oordruk" we have a (twentieth-century?) literal translation (rather than a phonological change).

The vestiges of Dutch in South Africa and in the United States are thus similar in their lexical distribution: they tend to be place names and family names, that is, proper names, which is the segment of the vocabulary that is often most conservative. The remaining vestiges are non-proper lexemes in local languages. In the United States, that local language is mostly English, though New Netherland Dutch presumably influenced certain Native American languages too. In South Africa, that local language is English (could there be vestiges of Dutch in African languages of South Africa too?). Possibly the only major difference between the two countries concerns the post-1925 influence of Dutch on Afrikaans neology: as far as I can tell, that influence has no American analog. That is, after New Netherland came under British rule, European Dutch ceased to influence New Netherland Dutch. Shetter writes: "The Dutch of seventeenth-century New Netherland seems only in the last dozen years or so to have become finally a matter of the past. After the forty-odd years of Dutch sovereignty came to an end in 1664 the Dutch-speaking settlements flourished and spread, but they were for all practical purposes cut off from the mother country. The language, which from now on lived and developed independently of the Dutch of the Netherlands, survived a remarkably long time, but by the end of the nineteenth century it was in active use only around Albany, New York, and in the northernmost part of New Jersey. The latter settlements seem to have preserved best their identity as speech islands, and even the tide of Dutch immigration in the 1840s appears to have done little or no mingling with this isolated group no longer felt by the Dutch to be compatriots" (p. 243). Since the corpus of New Netherland Dutch is now almost closed (though, as I've said, we should still expect to uncover more written monuments and I wouldn't be surprized if more spoken vestiges were ferreted out from elderly people), the time has come for a comprehensive work on New Netherland Dutch, which would reprint and comment on all known primary and secondary sources, adding whatever newly recorded oral material could be gleaned. Such a work should contain material on New Netherland Dutch influence on other languages too (including place names) and once a book like that were available, students of Afrikaans would have as large a fund of information as possible for purposes of comparison with Afrikaans. An aspect of that comparison which should not be overlooked is place names, as l've suggested in Gold 1992: 98. 


\section{Q. Have you done any research in South Africa?}

I've never been to South Africa. That's been a benefit, for, as I say, it allows me to view the fishbowl from the outside. On the other hand, the number of aspects of South African English which I can study is limited. Sociolinguistic topics, for example, are excluded because you have to be on the spot to see how language functions in society. Most subjects in phonology too are beyond my ken. But vocabulary is easily studied. With a mass of printed material in English and access to speakers of South African English outside South Africa, it's relatively easy to go through a text or listen to a speaker and pick out the usages which are absent in American English (hard to find, however, are Jews who are native speakers of Afrikaans).

However, one mustn't think that something present in South African English and absent in American English is necessarily a usage which arose in South Africa or which is limited to South Africa. To determine which usages are South-Africanisms (by birth or by residence), one must also be acquainted with British English. Thus, a speaker of American English will be struck by the South African English verb post, as in "to post a letter," because we say mail in the United States. That, however, isn't a South African English innovation or a usage restricted to South Africa, for post is so used in British English too (which in this case is the source of the usage).

Although the number of topics I can investigate is indeed limited, the few which do lend themselves to research from afar are so broad that $I$ have work galore. And, anyway, I have more research interests which keep me busy.

Q. And how does Afrikaans help in the study of Dutch influence on American English?

It goes without saying that you need to know Afrikaans if you want to use South African English in making a checklist of New York City or American English usages that are possibly from New Netherland Dutch. Assume this hypothetical situation: a certain usage is found in New York City (or American) English and in South African English. The researcher doesn't know Afrikaans or Dutch. The researcher thus doesn't know to what that usage common to both varieties of English should be ascribed: the influence of British English? The influence of New Netherland Dutch in the United States and South African Dutch and/or Afrikaans in South Africa? The influence of some other language or languages? South African English influence on the English of New York City or of the United States? New York City or American English influence on South African English? Convergence? Afrikaans is therefore essential to my study of Dutch influence on American English. Otherwise it would be an unknown factor, lurking in the background but never brought to the fore. 
Needless to say, you have to know Afrikaans to study South African English vocabulary too. For example, anyone approaching South African English from the outside will be struck by the use of slim in the sense of 'clever'. If you don't know Afrikaans, you might think that this is a specialized use of the English word slim (are thin people in South Africa, you might ask, for some reason considered clever?). However, if you know Afrikaans, you realize that this slim is not English slim 'slender' but a borrowing from Afrikaans, where the word is from Dutch slim (which happens to be the etymon of English slim 'slender', but that's another story). Being an outsider is therefore beneficial in identifying specifically South African English usages, but you have to observe more than English if you want to explain how they arose.

A major problem in the study of Afrikaans and South African English is deciding, with respect to any given usage, in which direction influence has gone, if any (as we've just seen with forget and vergeet). English influence on Afrikaans? Afrikaans influence on English? The influence of a third language (which is a kind of convergence) on both? Influence of English on Afrikaans (or vice versa), with subsequent mutual reinforcement of the usage (i.e., English reinforces the usage in Afrikaans and Afrikaans reinforces it in English)?

Having used the word checklist several times, I should say that any language can serve as the basis for compiling a checklist of investigable usages in another language. An example from Afrikaans, Yiddish, English, and Dutch will illustrate. Dutch distinguishes wij 'we' and ons 'us', but Afrikaans has neutralized that distinction, that is, Afrikaans ons means both 'we' and 'us' and Afrikaans has no reflex of wij. In Central Yiddish as spoken in Congress Poland and western Galicia, the same thing has happened: the distinction between mir 'we' and undz 'us' has been neutralized, with the latter word meaning both 'we' and 'us'. So too in English: the second edition of the Oxford English Dictionary has citations for us 'we' from 1607, 1699, 1737, before 1775, 1846, and 1880 (labeling it "now dialectal"), with citations from c. 1489, 1814, 1840, 1853 , and 1889 for $u s$ 'we' in apposition to a noun or an adjectival numeral (like "Us guys have to..." and "Us two have to..."). So too in the Dutch of Zeeland (].B. Berns tells me that ons 'we' has been recorded at twenty-three points in that province). It's interesting that in all four cases the neutralization has favored the form which originally meant only 'us'. Is that an instance of convergence ( $=$ independent development in three Germanic languages) or, rather, can abandonment of the 'we' word be traced to a single source? It's probably safe to say that the Afrikaans usage is likely to be of Zeeland Dutch origin, but whether further links can be found is unclear. At least, however, the parallels have now been noted.

American English coleslaw, Santa Claus, and the Tawl suggest another.way in which Afrikaans and New Netherland Dutch are similar and another way in which they may be studied. Research on New Netherland Dutch and early Afrikaans has been hampered by the fact that their users had no desire to forge a language different from European Dutch. Their standard, at least in writing, 
was European Dutch. It is thus only by chance that we may glean the specificities of New Netherland Dutch and of early Afrikaans, that is, only when writers of Dutch in what are today New York, New Jersey, and South Africa happen to have deviated, whether consciously or unconsciously, from the European Dutch norm.

However, since both Afrikaans and New Netherland Dutch have influenced other languages (chiefly English, but also native languages of what are now the United States and South Africa), another way of recovering those specificities is by looking at those other languages. Although coleslaw, Santa Claus, and the Tawl clearly go back to European Dutch koolsla, Sinterklaas, and die taal, we may assume from the spellings $a w$ and $a u$ in these American English words that Dutch aa was pronounced /o:/ in New Netherland Dutch (which was once a feature of European Dutch south of Amsterdam). That feature is not, to my knowledge, found in written New Netherland Dutch, but we may assume its presence in the spoken language on the basis of allolingual evidence - which is to say that we also assume these English borrowings to have been made orally rather than from written Dutch texts (an entirely natural and justified assumption since New Netherland Dutch was preeminently a spoken language). Relevant here too is American English crawl 'pen for pigs or any kind of livestock; enclosure in shallow water on the seacoast for containing fish, turtles, etc.' (as in crab crawl, pig crawl, or unmodified crawl), a word which is used chiefly in the South Atlantic states and which is first recorded for the mid-seventeenth century. It is derived from Caribbean Dutch kraal 'idem', which is derived from Spanish corral '(animal) pen, fold; fish trap'. The aw of crawl is thus evidence that aa was rendered in Caribbean Dutch (at least to the mid-seventeenth century) as it was in New-Netherland Dutch. Caribbean Dutch kraal is a cognate (not a reflex) of Afrikaans kraal, which is a reflex of Portuguese curral (which is a cognate of Spanish corral).

Afrikaans-origin borrowings in South African English and other languages of Africa,might likewise shed light on earlier Afrikaans phonology. Since Dutch was official in South Africa until 1925, Afrikaans-speakers for a long time made an effort to write Dutch as best they could, even though that was not what they were speaking. It was a typical case of diglossia - people spoke $x$ language but wrote (or tried to write) $y$ language. Even though Afrikaans often shows through in written South African Dutch, Afrikaansisms interspersed in Dutch texts are not enough for an adequate investigation of Early Afrikaans. What the linguist would like to have is an abundance of early texts in pure Afrikaans. Since that is lacking, one must make due with what one has. The reconstruction of Early Afrikaans therefore proceeds along three lines: [1] present-day Afrikaans serves as the starting point for diachronic linguists who work back in time by the standard methods of internal reconstruction and comparative linguistics; [2] South African Dutch texts are gleaned for whatever non-European Dutch features they may contain; and, as illustrated 
with Tawl and coleslaw, [3] borrowings in other languages are examined to see whether they contain non-European Dutch innovations.

Those borrowings should be sought not only in speech but in written monuments too, like diaries and travel literature. Travelers often pick up bits and pieces of local languages from speech rather than from writing, especially as we go back in time, when much more was spoken than written. Naturally, the linguist must be on guard, for it is not always easy to interpret what travelers and other non-linguists were trying to record. Sometimes they do record written and not spoken forms (for example, Heinrich Lichtenstein's Travels in Southern Africa has "the Predikstoel," which is from predikstoel and not Afrikaans preekstoel [cited in Branford 1991: 251]). Sometimes their spellings are misleading or now uninterpretable. Sometimes the spelling conventions of the allolanguage do not permit them to record accurately what they have accurately heard (how, for example, would speakers of non-Scots English who do not have an $/ x /$ in their phonology record this Afrikaans phoneme?). And, even if written monuments are interpretable, they may reflect not Afrikaans or New Netherland Dutch pronunciation but the writers' reinterpretation of what they have heard. The distinction between, say, an Afrikaans word and an English word of Afrikaans origin is thus important, for once a word enters another language, it is usually subject to the phonology of that language. For various reasons, therefore, allolingual written monuments not infrequently contain altered forms, but even with those problems, earlier English and other allolingual texts as sources of New Netherland Dutch and of Early Afrikaans should not be neglected. The compilers of the Woordeboek van die Afrikaanse Taal do search nonAfrikaans sources and I hope that compilers of South African English dictionaries look at allolingual material too.

A comparison of Afrikaans and New Netherland Dutch could extend to more than just language. Say we have the Dutch or Afrikaans lyrics of a song but it's not known whether they were written. If at least similar lyrics were sung in New Netherland, chances are they were composed in Europe. Architecture, dances, dress, folk beliefs, folk remedies, games, recipes, stories, tunes, and other aspects of material and non-material culture can thus be compared too. The feasibility of comparative research depends on the availability of data, although, as I've said, much more is known about southern Africa than New Netherland.

And perhaps not only New Netherland could be brought into the picture: the Dutch had other colonies and trading posts in Africa at various times beginning in the late sixteenth century (Axim, Bereku, Cape Coast Castle, Crèvecoeur, Dixcove, Elmina, Gorce, Lüdzaamheid, Mouree, Nassau, Orange, Secondi, Sierra Leone, St. Sebastian, Vredenburg, and Whydah), South America (what are now Suriname, Guyana, and parts of Brazil), the Caribbean (Tobago and what are now the Netherlands Antilles), Asia (Bimpipatam, Cannanore, Calicut, Cochin, Colombo, Cranganore, Deshima, Firando, Fort Zelandia, Jafnapatam, Martaban, Negapatam, Negumbo, Pegu, Pointe de Galle, Pulicat, 
Quilon, Tenasserin, Trincomali, and various parts of what are now Malaysia and Indonesia), and Oceania (Cape Leeuwins, Dirk Hartog Island, Eendrachtsland, and Tasmanland), as well as on Amsterdam Island, Mauritius, and St. Helena. Although it would be naive to expect that Dutch material and nonmaterial culture left any substantial imprint in any but a few of those places, we can often never predict what stray datum might turn up that could shed light on Afrikaans or Afrikaans-medium culture. Deshima (also spelled Dejima) is especially interesting. The Dutch opened a trading post on this island in the harbor of Nagasaki in 1641 and operated it until 1854, when Japan was opened to Western trade. It was from Deshima that the Dutch introduced Western medicine and mapmaking into Japan and it was through this contact that Dutch came to influence Japanese, especially its medical terminology.

\section{Q. Tell me about your work on Jewish aspects of South African English and of Afrikaans?}

That subject consists of two parts. First, we know from sociolinguistics in general and from the study of Jewish languages in particular that wherever people are different - however they may be different - differences in language will be discernible. These differences can be major, as when group $x$ uses language $x$ and group $y$ uses language $y$, or they can be less than major, as when group $x$ uses language $x$ in certain ways and group $y$ uses language $x$ in different ways.

Most Jews settling in South Africa have been native speakers of Yiddish, although the language hasn't been long-lived in the country. Like many immigrants in all parts of the world, the older the Yiddish-speaking immigrants are at the time of their arrival, the better they know their Old-Country language and the less they learn a New-Country language. The younger the immigrants are, the more quickly they forget their Old-Country language and the faster and better they learn a New-Country language. The native-born children of immigrants have some knowledge of the Old-Country language (usually just rudiments of the spoken language), but they know less than their parents, their best language being a New-Country one. At most, the second native-born generation knows only bits and scraps of the Old-Country language, being, for all practical purposes, monolingual in a New-Country language (except those of the second native-born generation who are in close contact with an immigrant grandparent, in which case an elementary speaking knowledge of the OldWorld language is often passed on from grandparent to grandchild; however, after the grandparent dies, the grandchild often begins to forget the Old-World language - if there is no longer any occasion to use it - and may in fact forget it completely). The next generation knows next to nothing or absolutely nothing of the Old-Country language. 
If immigration is continuous, one may gain the impression that use of the old-Country language in the New Country has likewise been continuous, but that may be an illusion. Thus, one can say that Yiddish has been spoken in South Africa ever since the first Jews came to southern Africa, but that doesn't mean that the language has been transmitted from generation to generation, from parent to child, for any significant number of generations. Usually, in fact, it's transmitted for only one generation: from immigrant parents to their children. By the second native-born generation, Yiddish and Yiddish-medium culture are extinct. Actually, the only languages brought from Europe which have taken root in South Africa are English and Dutch (in Namibia, German too).

Since the end of the 1940s no significant numbers of Jews have been settling in South Africa. Hence the Yiddish-speaking immigrant generations are now either dead or elderly. Yiddish has been receding into the background, as the percentage of native-born Jews rises and as the native-born, with every new generation, become more South-Africanized - indeed, to a large extent, less and less Jewish. The number of Yiddishisms in the English or Afrikaans of South African Jews has, consequently, been decreasing, but some remain. Also, some specifically Jewish usages (not necessarily from Yiddish) are being added (from Israeli Hebrew), so that the English and Afrikaans of Jews in South Africa are still a bit different from those of non-Jews, but not by much.

Study of Jewish South African English and Jewish Afrikaans requires a knowledge of three additional languages: Yiddish (in two varieties: Western Yiddish and Northeastern Yiddish), Israeli Hebrew, and other varieties of Jewish English.

Q. Why are those two varieties of Yiddish, rather than any other, pertinent to South Africa?

The Jewish community of South Africa in former times consisted mostly of Western Ashkenazim, that is, Jews who trace their immediate ancestry to what in Jewish geography is called Western Ashkenaz (an area whose eastern boundary is more or less the 1939 boundary between Germany and Poland and its imaginary southward extension and whose westernmost reaches include the Netherlands, Alsace, and Switzerland). In contrast, the present-day Jewish community of South Africa is of the following makeup: most Jews trace their immediate ancestry to northern Lithuania; a smaller number to Latvia, Belarus, and the former Russian provinces of Lomza and Suvalki; and an even smaller number to other places. In Jewish geographical terms, we would say that most of contemporary South African Jewry is of Northeastern Ashkenazic descent (Northeastern Ashkenaz corresponds to present-day Lithuania, Latvia, Estonia, Belarus, and adjacent parts of Poland and Ukraine). Study of the kinds of Yiddish used in South Africa and of its vestiges in South African English and 
Afrikaans thus requires a knowledge of both Western Yiddish (for the earlier period) and Northeastern Yiddish.(for the later one). Indeed, all Yiddish-origin usages in Jewish South African English can be traced either to Western Yiddish or to Northeastern Yiddish, though sometimes it's hard to tell which of the two is relevant (and perhaps both are in certain instances). Jewish South African English vover 'six pence', for example, could just as easily be from Western as from Northeastern Yiddish. The third variety of Yiddish, Southern Yiddish, is the source of no usages and for good reason: relatively few speakers of Southern Yiddish have settled in South Africa.

Q. You're implying that vover was brought to South Africa. Could it not be a Jewish South African English coinage?

Possibly. The Yiddish names of the letters of the Hebrew alphabet have numerical values. Thus, alef is 'one', beys is 'two', giml is 'three' and so on down to the last letter of the alphabet (the eleventh letter stands for 'twenty'; the twelfth for 'thirty'; the twentieth letter 'two hundred'; etc. - it's more systematic than the Roman system because all of the Hebrew letters have numerical values and the values follow the alphabetical order of the letters). With the Yiddish names of the letters, you can form coin names by adding the suffix -er. Thus, beyser is the name of any coin worth two of something. And so on with heyer, vover, yuder, khof-heyer, and memer 'coin worth five, six, ten, twenty-five, forty....', respectively.

The model according to which the word was coined thus goes back to European Yiddish, but where and when vover was coined remain to be seen. If no other country where Yiddish-speakers have lived had minted a coin worth six of something, we would have to conclude that vover was minted (no pun intended!) in South Africa (by a speaker of Western or Northeastern Yiddish). However, Russia once minted a six-kopeck coin (called a zekser in Yiddish), Poland once minted a six-grosz coin (also called a zekser in Yiddish), Austria once minted a six-kreuzer coin (called a zekserl in Yiddish), and the United Kingdom once minted a half-shilling (six-pence) coin (whose Yiddish name or names I do not know). Any of those coins could easily have been called a vover. If so, the word was probably brought to South Africa rather than minted there. Thus, the pattern for the word is definitely pre-South-African and the word itself may be too (I have no evidence, however, that vover was ever used in Europe). Because the United States has never minted six-cent coins, the word has understandably been absent in (at least) post-independence American English (if such a coin was in circulation before the American Revolution, the few Ashkenazic Jews in the Thirteen Colonies could conceivably have used such a word). 


\section{Q. Jewish English, then, is not uniform the world over.}

Precisely. The differences are sometimes attributable to local general conditions (having nothing to do specifically with Jews), as in the case of vover: the existence of a six-pence coin in South Africa triggered use of the word vover (whether the word was coined in South Africa or brought from Europe being another matter), though it did not have to be used (Jews could have simply used whatever words non-Jews were using to designate the coin). Jewish American English, on the other hand, has no word meaning 'six-cent coin' because the United States has never minted a coin of that value.

Sometimes, however, local general conditions are irrelevant to spatial variation in Jewish English. That is, Jewish English has a certain dynamics of its own, independently of what local non-Jewish usage or conditions might be. Again, an example involving South Africa comes to mind. Certain varieties of Jewish English and Western Yiddish have a wish used before any fast. In the British Isles and South Africa, Jews wish one another Well over the fast! or Have an easy fast! (at least in the British Isles, the former is the older usage and the latter is the newer one). In Jamaica, Jews say Have a nice fast!. At least in Franconian Yiddish (but probably in many other varieties of Western Yiddish too), the wish is fast gut! 'fast well!' (Lowenstein 1975: 37). In Ashkenazic Berlin German, the wish is Gutes Fasten! (which is probably based on the Western Yiddish wish). In the United States, it seems that nothing is said, at least not today, (rather, here one asks solicitously AFTER a fast Did you have an easy fast?). The prejejunial wishes used by English-speaking Jews are not borrowed from non-Jewish English (for non-Jews have nothing comparable), but they could be non-literal translations of the Western Yiddish wish. The postjejunial question used in the United States is a translation of Eastern Yiddish d'host gehat a laykhtn tones? /ets hot gehat a laykhtn tones? /ir't gehat a laykhtn tones? We thus have several Jewish English usages in different parts of the world, all of them responding to a certain element of Jewish life, none of them being of non-Jewish English origin (except for the individual words making them up), at least one of them being a literal translation of an Eastern Yiddish usage, and the others probably being based on a Western Yiddish usage.

The specifically Jewish features of Jewish English therefore have a geography of their own, sometimes as a result of non-Jewish factors and sometimes as a result of Jewish factors. Yet one usually can't predict what the linguistic results of those Jewish and non-Jewish factors will be: Jews in South Africa did not have to use vover to designate a six-pence coin (but they did use it) nor do Jews anywhere have to have a special pre-fast wish (as they indeed do not have in the United States, whereas in the British Isles, South Africa, and Jamaica they do). Jewish English, like all other Jewish languages, thus results from what Max Weinreich called vertical (= Jewish) and horizontal (= non-Jewish) factors. The results of the interplay of those factors are to a large extent unpredictable. Jewish English is a subtle blend - those who think it's nothing more than 
"English with an admixture of Hebrew" (or Yiddish) are unacquainted with it, just as those who think it differs from non-Jewish English only in vocabulary overlook often subtle, often not so subtle Jewish specificities of pronunciation, morphology, semantics, syntax, style, and paralinguistics like gestures, facial expressions, and other body movements.

Study of Jewish South African English thus goes hand in hand with study of Jewish English elsewhere. Naturally, Jewish South African English and Jewish Afrikaans can't be investigated separately, just as South African English and Afrikaans in general must be taken together. To see even a small part of the picture you have to look at its entire sweep.

\section{Q. And the second part of your research on Jewish aspects of South African English and Afrikaans?}

The second part of my investigation of Jewish aspects of South African English and Afrikaans deals with how these two languages mirror the attitudes of nonJewish South Africans toward Jews. It is probably a universal of human history that outsiders (however they are defined) are regarded negatively. Probably all languages therefore have contemptuous words for such people (think, for example, of the derogatory words in South African English meaning 'Afrikaner').

I'm thus interested, for example, in how non-Jewish speakers of South African English and Afrikaans designate Jews and what other words and expressions they have which are of Jewish interest.

\section{Q. Even if words or expressions of Jewish interest are contemptuous?}

Yes. The linguist, as well as the lexicographer, is like a photographer who photographs people as they are, warts and all; like the botanist, who studies ugly as well as beautiful flowers; or like the zoologist, who studies clumsy as well as graceful animals. On the other hand, studying these usages dispassionately does not imply condoning them.

In trying to see how non-Jews in South Africa view Jews, we must also look at the situation elsewhere. Let's take as an example three entries from volume 5 of the Woordeboek van die Afrikaanse Taal:

[a] Jodebasaar 'woelige, deurmekaar plek waar baie geraas word' (as in "Dit gaan, lyk soos 'n Jodebasaar").

[b] Jodekerk 'gesê van 'n onordelike, rumoerige plek of byeenkoms, waar almal gelyk praat of deurmekaar skree' (as in 'Dit gaan soos [in], lyk soos, is 'n Jodekerk [hier]"). 
[c] Jodeskool 'verwarde gebabbel; die deurmekaar klink van stemme en geluide; lawaai' (as in "Die Jodeskool in die kinderkamer maak 'n mens dol") and 'wanordelike plek (kamer of huis) waar so 'n lawaai aangaan' (as in "Dis 'n regte Jodeskool daar").

Did Afrikaans-speakers themselves perceive Jews to be noisy and therefore innovate those usages? Or, rather, are they merely inherited from Dutch? Or are those usages borrowed from German? If the answer to the second or third question is yes, the Afrikaans usages are almost like dead metaphors, telling us little about how Afrikaans-speakers have perceived Jews. I say "little," because at least they show that Afrikaans-speakers haven't been loathe to using words which cast Jews in a bad light.

To examine these words in perspective, one must look at linguistic material from outside South Africa. Without going into the question in depth, I'll merely note that Bulgarian has evreiska xavra! 'what a noisy place!' (literally 'Jewish synagog!'). Turkish has çıfit çarsısı 'a noisy place' (literally 'sheeny market, sheeny bazaar', with a contemptuous word meaning 'Jew'). SerboCroatian ${ }^{1}$ has civutlija 'noisy game' (the word is derived from a contemptuous word meaning 'Jew'). Dutch has het lijkt wel een jodenkerk! 'what noise!' (literally 'it looks like a synagog!'). German has hier geht's zu wie in einer Judenschule! 'what a madhouse!' (literally 'this place is like a synagog!'). One of the meanings of Portuguese sinagoga (literally 'synagog') is 'noise, uproar, clamor; disorder, tumult'. Greek has an expression meaning 'disorderly place' which translates literally as 'Jewish synagog'. And it's been suggested that French brouhaha and English charivari go back to non-Jewish perceptions of Jewish prayer services as being particularly noisy (some take those suggestions to be proven, but to my mind the etymology of those two words needs more study).

More data from other languages could probably be cited, but the point is clear by now that in studying Afrikaans usages of Jewish interest, one must look at a range of languages - not only Dutch and South African English - in order to put matters into perspective. We see the value of that approach not only with respect to the Afrikaans expressions themselves but also with regard to the correct interpretation of jodeskool. If you consider the usages l've just mentioned; only Afrikaans jodeskool and German Judenschule seem to be different in that they appear to mean 'Jewish school' (cf. Afrikaans skool and German Schule 'school'), whereas the others refer to a synagog. Yet the original meaning of both jodeskool and Judenschule (or, in the case of the Afrikaans word, at least the original meaning of its Dutch etymon, jodenschool) was 'synagog' and not 'Jewish school', hence we have in these usages perfect semantic unity. To understand how jodeskool and Judenschule originally meant 'synagog', we have to look at Yiddish, where shul means both.'synagog' and 'school' (the pairing of those two meanings in the same word is found in several other Jewish languages as well; it came about as a result of the fact that Jewish schools were often housed in synagogs and because the synagog has always been what is 
called a bet-midrash, literally 'house of study', in Hebrew). Thus, if Yiddish shul has both meanings and if German Schule 'school' and Dutch school 'school' are cognate with Yiddish shul, the German and Dutch words, by analogy, can come to mean 'synagog' as well (= an instance of emulated polysemy). In the case of Dutch jodenschool, we may also suppose the semantic influence of German Judenschule (but only after the latter word came to mean 'synagog' too). Dutch jodenschool is the etymon of Afrikaans jodeskool, hence the assumption that the latter word once meant 'synagog'. Nowadays, however, in German, Dutch, and Afrikaans (but not in Yiddish and other Jewish languages), the meaning 'synagog' has been forgotten in these words and people interpret them to mean only 'Jewish school'.

In studying Jewish aspects of South African English and Afrikaans, one should observe more than just White English and White Afrikaans. For example, many English-speaking Cape Coloreds use Black Fast 'Day of Atonement (= the chief Jewish fast)'. This is a non-Jewish South African English coinage, no such word or analogous word being found in Jewish English, any other Jewish language, or any non-South-African variety of English that I know of. It appears that Black Fast was coined in Cape-Colored English and continues to be used only in this variety of English. Which brings me to another point.

Researchers are now paying more attention to spatial, ethnic, social, and chronological variation in South African English. Students of Afrikaans, I hope, are now paying more attention to ethnic and social variation (they have never neglected the diachrony of Afrikaans, for how the language emerged and developed has been a major topic on the agenda of Afrikaans research for many years; spatial variation in Afrikaans has also received attention).

Black Fast is an example of ethnic variation in non-Jewish South African English. Since, therefore, non-Jewish South African English and non-Jewish Afrikaans vary spatially, ethnically, socially, and chronologically, I wonder to what extent Jewish South African English and Jewish Afrikaans vary too (with respect to their specifically Jewish features). To take a hypothetical example, when six-pence coins were still used, might South African Jews in certain parts of the country have used vover whereas others did not? That question must be posed, not only because we know that non-Jewish South African English and Afrikaans vary (hence we must allow for the possibility of variation in Jewish varieties of these languages too), but also because we know from outside South Africa that Jewish English may vary spatially even within a single country. For example, in northern Eastern Ashkenazic British English ( = the English of Eastern Ashkenazim in Scotland and northern England) and in Ashkenazic Irish English, the word for 'skullcap' is traditionally yarmlke, whereas in southern Eastern Ashkenazic British English (= the English of Eastern Ashkenazim in southern England and in Wales), the word for 'skullcap' is traditionally kapl. That difference reflects a migration difference: many of the Eastern Ashkenazim in northern England, Scotland, and Ireland are of Northeastern Ashkenazic ancestry, whereas many of those in southern England and Wales are of 
Southern Ashkenazic ancestry. In Northeastern Yiddish (= the Yiddish of Northeastern Ashkenaz), the usual word for 'skullcap' is yarmlke and in Southem Yiddish (= the Yiddish of Southern Ashkenaz), a frequent word is kapl. Thus, spatial variation in Yiddish has been carried over into Eastern Ashkenazic British English.

Because Ashkenazim from many parts of Europe have settled in many parts of the British Isles, Ashkenazic British English is, expectedly, not uniform spatially. That is, because many varieties of Yiddish were brought to the British Isles and not all in the same measure everywhere, certain varieties of Ashkenazic British English have been more influenced by $x$ variety of Yiddish whereas other varieties of Ashkenazic British English have been more influenced by $y$ variety of Yiddish. And since non-Jewish British English varies from place to place, the non-Jewish features of Ashkenazic British English vary too. Thus, for instance, Ashkenazic Glasgow English is a function of non-Jewish Glasgow English and of whatever varieties of Yiddish happen to have influenced it (= horizontal and vertical factors, respectively).

In contrast to the situation in the British Isles, most Jews now living in South Africa trace their ancestry to a relatively small area: Lithuania and Latvia. The Yiddish of both of these countries is relatively uniform. The Ashkenazic community of contemporary South Africa is thus much more homogeneous linguistically and in other ways than that of the British Isles. It's therefore doubtful - but not impossible - that the specifically Jewish features of today's Jewish South African English or Jewish Afrikaans vary spatially. So far I haven't come across any spatial differences, but the matter needs to be investigated further.

\section{Q. We've spoken about South African English, Jewish South African En- glish, Jewish aspects of South African English, and Jewish aspects of non-Jewish Afrikaans, but not about Jewish Afrikaans.}

Perhaps intentionally so, for the study of Jewish Afrikaans has not yet begun. I remarked earlier that different groups of people use either different languages or different varieties of the same language. In the nineteenth and early twentieth centuries, many Jews coming to South Africa settled in Afrikaans-speaking areas, where they made their living usually as small shopkeepers or peddlers (Afrikaans smouse, English smouses). Afrikaans was thus either the first language which they acquired after coming to South Africa or, 'if they eventually learned English too, the stronger of the two languages. If they spoke Afrikaans to their children, these youngsters were native to the language. Solly Rechtman (to whom I owe all of this information on Afrikaans-speaking Jews) tells me that many such people, both foreign- and native-born, could be found earlier in this century, perhaps even into the 1920s. It stands to reason that at least in some respects the Afrikaans of these Jews has differed from that of non- 
Jews, though 1 have no examples at the moment. In the 1920s these Afrikaans. speaking Jewish communities began to disappear, as its members left for large cities, where they joined the local English-speaking Jewish communities. suppose one can still find elderly Jews who speak Afrikaans natively or at least once spoke it better than English. They have to be interviewed as soon as possible.

\section{Q. You've also done work on family names and genealogy. Does it have a South African angle?}

Only a Jewish South African angle. What little has been written till now about Jewish family names in South Africa does not merit consideration. l've brought discipline into the field by treating these names scientifically. Nadine Gordimer, by the way, recently told me the origin of the name Gordimer and 1 hope to look into its history soon.

Some of my work in Jewish genealogy should be of interest especially to South African Jews - Northeastern Ashkenazim as most of them are. Because my father was a Northeastern Ashkenazi, my genealogical files are particularly rich for his area of Northeastem Ashkenaz, namely the towns of Anykšciai and Ukmergé, whose respective Yiddish names are aniksht and valkemir.

\section{Q. What may we expect from your pen in the future?}

I plan to continue reviewing monolingual and bilingual dictionaries published in South Africa, review work on family names in South Africa, and continue to study Jewish aspects of South African English and Afrikaans. The title of one of my planned articles will give you an idea of how wide the study of these two languages must often range: "From Egyptian mes/mesu 'child; son' - By Way of Hebrew, Yiddish, Dutch, Afrikaans, and British English - to South African English smous/smouse 'to peddle goods'." I also want to look into the English of Southern Rhodesia/Rhodesia/Zimbabwe. It has been said that at one time about half of the White population of Southern Rhodesia was Jewish (mostly Ashkenazic). Might such a large percentage of Jews not have left some linguistic traces of their presence?

I want to show the need for looking not only at form but also at meaning in Afrikaans etymology. For example, Afrikaans span 'team' is said to be from Dutch span 'team' and the etymology ends there. That's correct with respect to form, but when you look at meaning, something has to be added. The Dutch word refers to a team of animals and that was the original meaning (and still one of the meanings) of the Afrikaans word. However, when Afrikaans-speakers needed a word for 'team' in the sen'se of 'group of people constituting one side in a contest or competition' (a need which arose only in the nineteenth 
century), they took English as their model: if span = team in reference to a pair of animals, and if team also means 'group of people constituting one side in a contest or competition', then, by analogy, span came to be used in the latter sense as well. Call it literal translation, emulated polysemy, or whatever, Afrikaans is full of such items, few of which have been noted in the research literature. Another example is beperk in the names of companies and corporations, which translates English limited. And a third example may be borg in the sense of 'sponsor' (thus, the Nedbank is the "amptelike borg van die SuidAfrikaanse Olimpiese Span"/"the official sponsor of the South African Olympic Team"). As far as 1 can tell, neither Dutch beperkt nor borg are used in this way.

\section{Q. Can you summarize your work on South African English and Afrikaans?}

Speaking generally, I hope I've made two contributions: emphasizing the need to broaden perspectives and stressing the need to raise standards in etymology and in lexicography.

Till now, it seems that when students of South African English or of Afrikaans have considered languages outside southern Africa, they have looked chiefly at British English or European Dutch respectively. Occasionally they glance at Malay, Portuguese, German, languages of India, and perhaps French. All of that couldn't be more correct, but other languages shouldn't be neglected. American English is useful, as l've explained, in studying Afrikaans influence on South African English. Tristan da Cunha English shouldn't be overlooked either, for it and South African English share some features possibly absent in all other varieties of English. Without consideration of Western Yiddish and Northeastern Yiddish, one can't study Jewish South African English or Jewish Afrikaans properly. To investigate Jewish South African English, one must also look at Ashkenazic British English.

In general, I would like to show that Afrikaans can be better understood if it is compared with more languages than just European Dutch. For example, Gold 1990 shows that in children's counting-out rimes in languages ranging from American English across many languages of Europe to languages of Asia like Turkish, Armenian, Arabic and Marathi one can often discern a pattern in the first words of these rimes: the second word is an increment of a first one, that is, the second one consists of a preposed phoneme and the first word (thus, in American English, for example, eena meena), these two words usually being bisyllabic, in which case each of them is usually penultimately stressed; and the third word often, and the fourth word sometimes, have that same preposed phoneme as their first element (eena meena mina mo).

At least three Afrikaans children's counting-out rimes meet those requirements: ina dina daina das/skolle wina waina was/ink stink, die muskadel/ druif's gepluk - jy's uitgetel has three segments answering to the description 
I've just given (ina dina daina das... wina waina was... ink stink), as do Afrikaans rimes beginning ana drana... and olke bolke.... Which of the segments is of Dutch origin remains to be seen. So far, I've found olke bolke in a Dutch rime (olke bolke ribisolke/olke bolke knol), but not any of the other four. They might be of Dutch origin, but they could also be Afrikaans innovations. If they are innovations, we would conclude that Afrikaans-speaking children have inherited not only counting-out rimes from Dutch but also a pattern, which they have unconsciously used to create new rimes. The important point is thus that had we not looked at Afrikaans children's counting-out rimes in the broadest perspective possible the pattern in question might not have leaped to the eye so quickly and might not have been noticed at all.

Comparing the history of Afrikaans and of Yiddish helps to broaden one's perspective - or at least gives one the consolation of knowing that one's plight is not unique - because in looking at the two languages we see that their supporters have had to struggle to achieve an identity for them - and more or less in the same circumstances: Afrikaans has stood in the shadow of its "big brother," Dutch, and Yiddish has stood in the shadow of its "big brother," German. In both cases, linguistically naive detractors have used the same specious arguments against them ("Afrikaans is nothing more than corrupt Dutch" = "Yiddish is merely corrupted German") and the same pseudo-scientific, atomistic, reductionist tactic of trying to disprove the existence of these languages by pulling them apart, as if with tweezers, to show, supposedly, that this or that element "really isn't Afrikaans" or "really isn't Yiddish," but "actually" something else.

A case in point is ons in the sense of 'we'. A detractor of Afrikaans might argue along these lines: "since ons in the sense of 'we' is found in Dutch, it's not really Afrikaans." That approach, however, does not recognize the distinction which structural linguistics makes between etic and emic units or its requirement that linguistic systems be viewed as wholes. Of course ons 'we' in Afrikaans and ons 'we' in Zeeland Dutch are in an absolute (i.e., etic) sense identical, just as a yellow shirt in the United States, for example, and that same yellow shirt in Thailand are identical. Emically, however, Afrikaans ons and Dutch ons are not the same. In Afrikaans, ons 'we' is standard, universal, and competes with no variants: It is thus unmarked - the normal way of saying 'we'. In Dutch, on the other hand, this usage is limited (at least in recent years) to Zeeland (and even there it is not universal). In Dutch, it is regional and nonstandard, competing with standard and more widespread wij. Ons in the sense of 'we' is thus marked in Dutch. Similarly with yellow shirts. In the United States, yellow is just another color. In Thailand, however, yellow is a color reserved for the royal family. For someone not belonging to the royal family to wear yellow in Thailand would be a gross breach of etiquette. Therefore, a yellow shirt is a yellow shirt is a yellow shirt (etically identical the world over), but its emic status in Thailand is different from its emic status elsewhere. 
The detractors of Afrikaans and Yiddish thus look only at etic identities and not at emic differences. With a reductionist approach, you can deny the existence of practically anything (you and I don't exist - we're "merely" accumulations of atoms). If, however, we look at these two languages at close range, intimately, and not as the linguistically naive and uninformed armchair or cocktail-party pontificators do, we see that Afrikaans and Yiddish are in countless ways different from their supposed "big brothers."

As for the need to look at entire systems, when we look at Afrikaans or Yiddish in toto, it immediately becomes clear that neither of these two languages (or any variety of them) is identical with, respectively, Dutch or German (or any variety of them). Each is a unique finished product.

\section{Q. And with respect to raising standards?}

In recent years, the study of dictionaries has intensified in several countries. Lexicographical methods are being refined and today we require much greater rigor of people setting out to compile dictionaries than years ago. What Yakov Malkiel once said of etymology is no less true of lexicography and other branches of linguistics: "... a rehabilitation of etymology, through vigorous rejuvenation of its presuppositions and techniques, cannot be achieved by assiduous, painstaking accumulation of data alone. It requires the periodic cleansing and, if necessary, the bold replacement of antiquated tools, so as to enable etymologists to engage in a dialogue with other scholars on a high level of generality" (Malkiel 1976: vii).

\section{Note}

1 D.L.G. comments: "The usual spelling in English is Serbo-Croatian, but Morton Benson and other students of the language use SerboCroatian in order to emphasize that this is a single language, with two major varieties, the eastern one being the standard in Serbia and the western one the standard in Croatia (see Benson's SerboCroatian-English Dictionary, third edition, Belgrade, Prosveta, 1988). The solid spelling stresses the unity of the language and the internal capital letter stresses the fact that both varieties are equally acceptable (hence CroatoSerbian is also used). Although an internal capital is not frequent in English, it is not absent: we find it in Irish and Scottish family names (those with the prefix $M c$ are regularly written solid and with an internal capital, like McGrath, and those with Mac may be written solid, in which case an internal capital is used, as in MacGorman), in the names of some products (like WordPerfect), and in certain prefixed African-origin English words (like amaBunu, eBhayi, eGoli, eRawutini, eThekwini, iJuba, iJuvi, isiBhulu, isiNiu; isiZulu, kwaZulu, and Mayibuye iAfrika, all of which are in Branford 1991). It may also be noted that in 1959 the Royal Spanish Academy decided that certain compounds should be spelled solid unless they expressed a contrast or opposition, in which case they were to be hyphenated. For example, la guerra anglo-boer 'the Anglo-Boer War' vs. una persona de ascendencia angloboer 'a person of Anglo-Boer descent: 
Precedents can thus be found for the spelling Serbocroatian, which is a linguist's minuscule yet important protest at the madness now prevalent in the Balkans, where speakers of SerboCroatian, who once constituted a single people, have been riven into three by religious differences.

Afrikaans has a distinct advantage over English in that it has an excellent spelling system, in which the fit between phoneme and grapheme could probably not be better. The chaos of English spelling and the orderliness of Afrikaans spelling could thus not be in starker contrast. Afrikaans has that good fortune thanks to its having a commission which sets the official spelling for everyone writing the language. Since in a well-ordered society a certain degree of discipline is expected of all its members, I accept the spelling rules of the Afrikaans Language Commission of the South African Academy of Arts and Sciences, which allow only for Serwo-Kroaties (cf. the Afrikaans keywords of this interview), even though that spelling is not consistent with SerboCroatian. On the other hand, innovations which enhance understanding only enhance the very goal of language itself. Perhaps, then, the language commission will consider accepting SerwoKroaties (at least as an alternate spelling) and thus, like Engish-writing linguists who prefer Serbocraatian, make its tiny but important contribution to peace."

\section{References}

Branford, Jean with William-Branford. 1991. A Dictionary of South African English. 1991. Cape Town: Oxford University Press [rev. Gold 1992].

Carpenter, William H. 1908. "Dutch Contributions to the Vocabulary of English in America: Dutch Remainders in New York State." Modern Philology Vl: 53-68.

Gold, David L. 1981. "Three New-York-Cityisms: sliding pond, potsy, and akey." American Speech 56: 17-32.

Gold, David L. 1984. "More on a Dutch-Origin Word in New York City English: sliding pon(d)." Leuvense Bijdragen 73: 171-175.

Gold, David L. 1986. "Still More on the Origin of New York City English sliding pon(d)." Leuvense Bijdragen 75: 335-357.

Gold, David L. 1990. "Some Yiddish, Judezmo, and Hebrew Children's Counting-Out Rimes in Their European Context and Evidence Against the Suggestion That the First Line of the English Children's Counting-Out Rime eena meena mina mo May Be of São Tomense Origin." Jewish Linguistic Studies 2: 84-104.

Gold, David L. 1992. "On the Fourth Edition of A Dictionary of South African English." Lexikos 2: 85-136.

Gold, David L. In prep. "From Egyptian mes/mesu 'child; son' - By Way of Hebrew, Yiddish, Dutch, Afrikaans, and British English - to South African English smous/smouse to peddle goods."

Lowenstein, Steven. 1975. "Remnants of Franconian Yiddish (Part 3)." Yidishe Shprakh XXXIV: 37. 43.

Malkiel, Yakov. 1976. Etymological Dictionaries: A Tentative Typology. Chicago and London: The University of Chicago Press.

Shetter, William Z. 1958. "A Final Word on Jersey Dutch." American Speech 33: 243-251. 


\title{
Een gegevensbank van 14de-eeuwse Middelnederlandse dialecten op computer
}

\author{
Pieter van Reenen en Maaike Mulder, Vakgroep Taalkunde, \\ Vrije Universiteit, Amsterdam, Nederland
}

Abstract: A Database of 14th Century Middle Dutch Dialects on Computer. This study describes the organization of a database, created at the Free University Amsterdam, consisting of about 2,500 charters in Middle Dutch, about 750,000 tokens. The charters were written in the Netherlands and Flanders between 1300 and 1400. Only original texts were chosen, which are dated and located. Most of them have not been published before and are to be found in the archives of The Hague, Leiden, Zwolle, Antwerp, Brussels, etc. It is shown how a charter is treated on its way from the archives to its computer format, how the data are structured and how new information - morphological coding - is added. Special attention has been paid to the way how information has been stored which is not easy to be handled on computer directly. The enriched text may be used for different purposes, not only lexicographical but even dialectal. The second part of the study serves to illustrate how the data can be exploited in view of dialect research. As an example, the verb "zullen" has been chosen. It is shown that the vowels of this verb are not the same in the different Dutch speaking areas. The results are represented on dialect maps.

Keywords: CHARTERS, COMPUTER FORMATS, COMPUTERIZATTON, DUTCH, ELECTRONIC LANGUAGE DATA BASE, ETYMOLOGY, GRAMMATICAL ANALYSIS, LEXICOGRAPHY, MANUSCRIPTS, MIDDLE DUTCH DIALECTS, PRONUNCIATION, SEMI-AUTOMATIC CODING OF TEXT

Samenvatting: Deze stude beschrijft de organisatie van een databank, aangelegd aan de Vrije Universiteit Amsterdam, van ongeveer 2.500 Middelnederlandse oorkonden, bij elkaar zo 'n 750.000 tokens. De oorkonden zijn geschreven in Nederland en Vlaanderen tussen 1300 en 1400. Alleen originele teksten zijn gekozen, die gedateerd zijn en waarvan de plaats van herkomst bekend is. De meeste zijn nooit eerder gepubliceerd, en zijn afkomstig uit de archieven van Den Haag, Leiden, Zwolle, Antwerpen, Brussel, etc. Getoond wordt hoe een oorkonde wordt behandeld van archief tot computerformaat, hoe de gegevens gestructureerd zijn en hoe nieuwe informatie - morfologische codering - wordt toegevoegd. Speciale aandacht wordt besteed aan de manier waarop informatie is opgeslagen die niet makkelijk direct door de computer kan worden verwerkt. De verrijkte tekst kan voor verschillende doeleinden worden gebruikt, niet alleen leksikografisch maar ook dialectaal. Het tweede deel van de studie laat zien hoe de gegevens kunnen worden aangewend voor dialectonderzoek. Bij wijze van voorbeeld is het werkwoord "zullen" 
gekozen. Getoond wordt dat de klinkers van dit werkwoord niet hetzelfde zijn in de verschillende Nederlands sprekende gebieden. De resultaten worden weergegeven op dialectkaarten.

Sleutelwoorden: COMPUTER FORMATEN, COMPUTERISERING, ELECTRONISCHE TAALGEGEVENSBANK, ETYMOLOGIE, GRAMMATIKALE ANALYSE, LEKSIKOGRAFIE, MIDDELNEDERLANDSE DIALECTEN, NEDERLANDS, OORKONDEN, SEMI-AUTOMA. TISCHE CODERING VAN TEKST, TEKSTEN, UITSPRAAK

\section{Inleiding}

Wie de oudste fase van de dialecten in het hele Nederlandse taalgebied toegankelijk wil maken voor onderzoek kan niet verder teruggaan dan de 14de eeuw. ${ }^{1}$ Pas in die eeuw zijn van Groningen tot Zuid-Limburg en West-Vlaanderen voldoende teksten voor dat onderzoek bewaard gebleven: originele oorkonden waarvan de datum en plaats van redactie bekend is. Figuur 1 laat zo in oorkonde zien. ${ }^{2}$

De oorkonden zijn in groten getale te vinden in de Nederlandse en Belgische archieven. Wij sporen ze daar op, maken een selectie en fotograferen ze. Op het ogenblik (eind maart 1993) hebben we ruim 2.500 oorkonden bij elkaar, ongeveer 750.000 tokens.

Deze teksten lenen zich uitstekend voor taalkundig en leksikografisch onderzoek. Vanuit het oogpunt van de computer maakt het in wezen niet uit om welk type onderzoek het gaat, al zijn er wel graduele verschillen.

De processen en methoden die hieronder worden beschreven hebben dus niet alleen zuiver linguistische toepassingen maar ook leksikografische. In de taalkunde kan daarbij worden gedacht aan etymologisch onderzoek, in de leksikografie aan het ontwerpen van woordenboeken voor oudere taalfasen.

Wij willen aan dat corpus veelvuldig en systematisch taalkundige informatie onttrekken met het oog op een onderzoek naar uitspraakverschillen tussen de dialecten binnen een precies in de tijd afgebakende periode. Om dat te bereiken hebben wij het corpus op computer gebracht, van extra informatie voorzien, en in verband met de bevraging en verrijking van het corpus pro-

1 Het onderzoek maakt deel uit van het onderzoeksprogramma Corpusgebaseerde Woordanalyse Vulet $88 / 9$. Het corpus is mede tot stand gekomen dankzij NWO/ST 300 166-011. Jan Berns, Ton Goeman en Henk Meijering zijn wij dankbaar voor suggesties ter verbetering van deze studie.

2 In de 13de eeuw vinden we ook al heel wat oorkonden, maar die zijn voomamelijk uit Vlaanderen afkomstig, zie Gysseling (1977). V́erder zijn uit de 13de en 14de eeuw literaire teksten bewaard gebleven, maar die vermelden - in tegenstelling tot oorkonden - meestal hun plaats en datum van ontstaan niet. Bovendien zijn het vrijwel nooit originelen, en weten we niet hoe letterlijk ze zijn gecopieerd. Daarom kunnen ze, in tegenstelling tot originele oorkonden, niet dienen als primaire getuigen voor het dialectonderzoek. 
grammatuur ontwikkeld. Alle oorkonden zijn nu op computer beschikbaar. Dat is veel werk geweest, ook veel extra denkwerk over bits en bytes, maar een andere keus hadden we niet. Zonder computer zou ons onderzoek niet haalbaar zijn. Hadden we volstaan met alleen maar transcriberen en collationeren van de oorkonden, dan zouden ze alle 2.500 nog steeds zo goed als onbruikbaar zijn geweest voor dialect- en diachroon onderzoek. We hadden een onderzoeksinspanning moeten leveren die het menselijk vermogen eenvoudig te boven gaat. Daarom is het onderzoek dat wij beogen nooit eerder van de grond gekomen. En wat wij nu tot stand brengen moet ook voor het nageslacht zorgvuldig bewaard blijven als uitgangsbasis voor uitbreiding en verder onderzoek op het gebied van de taalkunde en de leksikografie. Bij de aanleg van het corpus op computer en de ontwikkeling van de programmatuur is daar zoveel mogelijk rekening mee gehouden.

Ten eerste worden zoveel mogelijk algemene normen gehanteerd. Al zijn die er nog steeds niet veel, waar mogelijk wordt bij de aanleg van het corpus en de ontwikkeling van de programmatuur gewerkt volgens richtlijnen van het Text Encoding Initiative (TEI) en de Stichting Tekstcorpora en Databestanden in de Humaniora (STDH). Standaardizering van procedures werkt op termijn drempelverlagend en werkbesparend voor de onderzoekers.

Een tweede uitgangspunt is dat alles wat de linguist aan informatie uit de oorkonden wil bewaren in een of andere vorm ook op de computer terecht komt. Het komt nog steeds veel voor - tot schade van het onderzoek - dat gegevens worden opgeofferd, omdat dat makkelijker werken op de computer zou zijn. Veel zogenaamde data-base benaderingen lijden aan dit euvel. Zij hebben veel weg van het beruchte bed van Procrustus. Bij de opslag op computer hoeft helemaal geen informatie verloren te gaan. Onze teksten worden daarom in hun geheel opgeslagen.

Ten derde is de ontwikkelde programmatuur modulair: taalgebonden componenten (bijvoorbeeld de Franse of Latijnse component) kunnen worden vervangen door andere taalgebonden componenten (de Nederlandse component) zonder dat de programmatuur op andere punten hoeft te worden aangepast. Op het ogenblik werkt de programmatuur met Middelnederlands, Oudfrans, Modern Frans, Arabisch, Latijn of Middelnederduits. Ook de opslag en verwerking der gegevens op computer is modulair. Een zoekcomponent kan onafhankelijk van een opslagcomponent worden aangepast of vervangen. Bovendien is de programmatuur zo veel mogelijk machine-onafhankelijk. Zo kan het overzetten van corpus en van programmatuur naar andere computersystemen met een minimum aan problemen tot stand komen.

Tenslotte moet de aanleg en verrijking van het corpus, gezien het vele handwerk, zo efficiënt mogelijk verlopen. Door alle handelingen zo eenvoudig mogelijk te houden kunnen we tijd en moeite sparen danwel onze productie verhogen. Met het oog hierop hebben wij een algemeen tekstformaat gedefinieerd: het invoerformaat. Het aanleveren van teksten in invoerformaat geeft de linguist of leksikoloog het minste werk, maar maakt dit formaat daarmee 
nog niet geschikt voor ondervraging van het corpus met computerprogrammatuur. Daartoe moet het corpus eerst worden omgezet in het computerformaat. Invoer- en computerformaat bevatten nog niet alle informatie die de linguist of leksikoloog in de tekst zou willen aantreffen. Wij zouden onze teksten op zijn minst morfologisch gekodeerd willen zien, te zijnertijd ook syntactisch. De morfologische kodering wordt in ons corpus semi-automatisch tot stand gebracht. Het resultaat noemen we een tekst in onderzoeksformaat. Pas dan kan het onderzoek naar middeleeuwse dialecten goed beginnen.

In het vervolg zullen wij in sectie 2 nader aandacht schenken aan de opbouw van ons corpus: wat is precies de informatie die wordt toegevoegd en hoe wordt het ene formaat in het andere omgezet. Voor een technischer en uitvoeriger behandeling van dit aspect wordt verwezen naar Huber (1989). Alle inspanningen hebben tot doel te komen tot resultaten die we anders niet hadden kunnen bereiken. Het is in dit stadium al duidelijk dat een van de resultaten die al heel eenvoudig verkregen kunnen worden een woordenlijst is die, met verwijzing naar kontekst, een mooie aanzet vormt voor het maken of aanvullen van een Middelnederlands woordenboek. Maar er kan veel meer. In sectie 3 laten wij zien met welk gemak dialectgegevens kunnen worden aangemaakt, mede dankzij het kaartontwerp van E. Wattel, zie Wattel (1990). Bij wijze van voorbeeld geven wij een paar kaarten van de klinkers van het werkwoord zullen. Ze zijn tot stand gekomen met behulp van frekwentietabellen, die (vrijwel) automatisch uit het corpus kunnen worden gedestilleerd. Een paar samenvattende tabellen staan ook in de tekst. Bij wijze van contrast bezien we onze resultaten kort in het licht van eerdere publikaties.

2. Het oorkondenbestand op computer: van archiefstuk tot onderzoeksformaat

Zoals een rups een pop wordt, en een pop een vlinder, zo verandert ook een oorkonde van vorm. Van archiefstuk tot object van taalkundig of leksikografisch onderzoek op computer onderscheiden we vijf stadia:

Archiefstuk $>$ transcriptie $>$ invoerformaat $>$ computerformaat $>$ onderzoeksformaat

Tot en met invoerformaat gaat het om puur handwerk. Het wordt besproken in 2.1. Het omzetten van invoerformaat in computerformaat gaat volautomatisch. Hoe wordt besproken in 2.2. Het onderzoeksformaat komt interactief tot stand, dat wil zeggen semi-automatisch, zie 2.3. In deze sectie zal ook de disambiguering van homografen worden behandeld. 


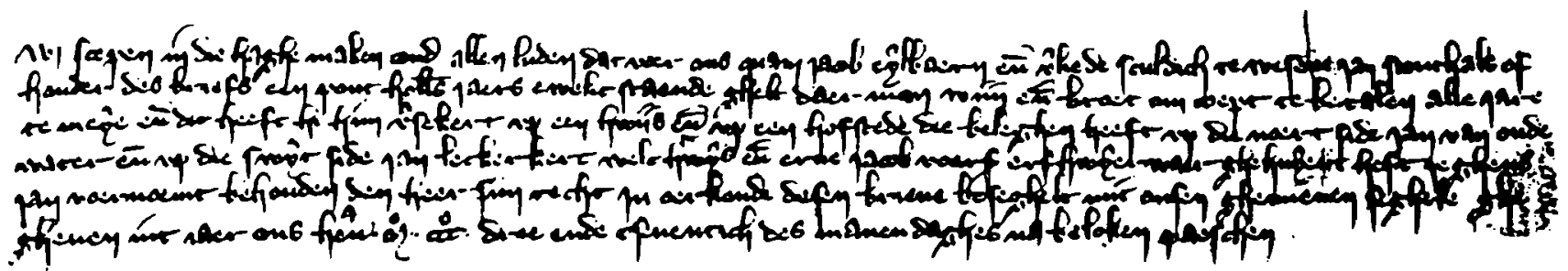

[1] Wj scepen in die haghe maken cond allen luden dat voer ons quam jacob eylbaern en(de) v(er)liede sculdich te wesene jan stouthals of

[2] houder des briefs een pont holl(an)s jaers ewelic staende ghelt daer men wiin en(de) broet om coept te betalen alle jare

[3] te meye en(de) dit heeft hi hem versekert vp een hwijs en(de) vp een hofstede die beleghen heeft $v p$ die noert side jan van oude+

[4] water en(de) vp die swyt side jan leckerkerc welc hwys en(de) erue jacob voerseit erfhuyerwaer ghehuyert heft jeghens

[5] jan voernoemt behouden den heer siin recht jn oerkonde desen brieue beseghelt mit onsen ghemienen seghele ghe+

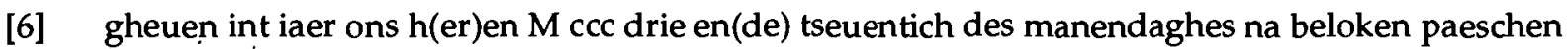

Figuur 1: Een oorkonde met transciptie uit Den Haag van 1373.

Archief: Tafel van de Heilige Geest. Inv. 590. 


\subsection{Van archiefstuk tot invoerformaat}

De weg van archiefstuk tot oorkonde in invoerformaat moet zo snel mogelijk worden afgelegd. Het is veel handwerk dat niet kan worden geautomatiseerd. Wij bespreken kort hoe de selectie, transcriptie en verrijking van de oorkonden in dit stadium tot stand komt.

\subsubsection{Selectie van archiefstukken}

De grote meerderheid van onze 14de-eeuwse oorkonden is niet uitgegeven en moet van (foto's van) de perkamenten originelen in de archieven worden overgeschreven en gecollationeerd (papieren dokumenten zijn nog heel zeldzaam). In de archieven kiezen wij zo mogelijk zo 'n 100 oorkonden per plaats, gelijkelijk over de eeuw verdeeld. Wij selecteren bij voorkeur goed leesbare teksten, wat in de tweede helft van de eeuw meestal geen probleem geeft: er is overvloed aan keuze. We streven geen volledigheid na, zoals Gysseling (1977) heeft gedaan voor de 13de eeuw, daarvoor is er te veel materiaal en te weinig tijd beschikbaar (we zijn al 10 jaar bezig!). Soms kunnen we gebruik maken van bestaande tekstuitgaven, bijvoorbeeld Erens (1950, 1952), Moors (1952), Vangassen (1964). We kiezen alleen teksten die plaatselijk of regionaal taalgebruik bevatten, dat wil zeggen ze moeten zelf vermelden uit welke plaats of streek zij afkomstig zijn. Alleen in Drente hebben we geen plaatselijke oorkonden kunnen vinden en hebben we ons tevreden gesteld met streekgebonden oorkonden, en de onderscheiden streken zijn vrij groot. Ook elders - bijvoorbeeld in Noord-Brabant - onderscheiden wij naast plaatsen wel regio's, maar die zijn dan vaak beperkt in omvang.

\subsubsection{Transcriptie van de oorkonden}

Wij slaan de documenten niet als foto's op computer op, maar wij transcriberen ze diplomatiek: $u$ blijft $u$ (bijvoorbeeld in ghegheuen), $v$ blijft $v$ (bijvoorbeeld in $v s$ ), hoofdletters en kleine letters uit het origineel blijven gehandhaafd, leestekens eveneens, aaneengeschreven woorden blijven aaneengeschreven (vanden is heel frekwent). Enzovoort. Wij laten codicologische en paleografische aspecten buiten beschouwing en doen ook geen onderzoek naar zegels of handen. Wel kiezen wij zo veel mogelijk verschillende handen, voorzover daarvoor in een archief voldoende materiaal beschikbaar is. Na transcriptie van het perkament, kan een oorkonde eruit zien als in figuur 2. 


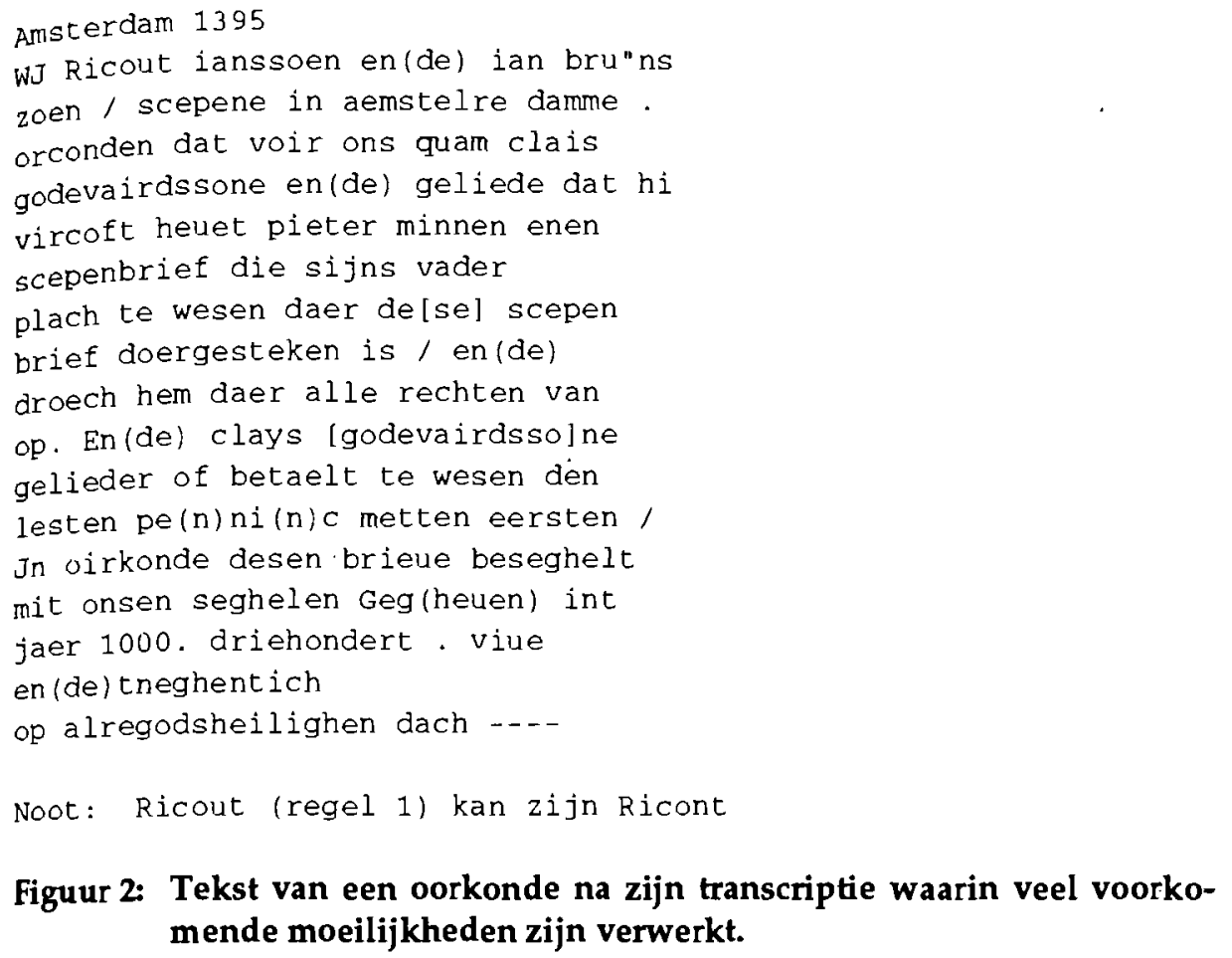

Noot: Ricout (regel 1) kan zijn Ricont

Figuur 2: Tekst van een oorkonde na zijn transcriptie waarin veel voorkomende moeilijkheden zijn verwerkt.

\subsubsection{Identificatie van teksten}

De Middeleeuwse teksten moeten stuk voor stuk makkelijk zijn te herkennen en terug te vinden. In de meesten archieven zijn ze dat ook, maar voor ons taalkundig of leksikografisch onderzoek hebben we een andere klassifikatie nodig, waarin in elk geval plaats van herkomst en tijd van redactie zijn verwerkt. Wij hebben dat uniform voor alle dokumenten opgelost door middel van een letter-cijfercombinatie, bijvoorbeeld_o:E109`39509, zie figuur 3. Die zit als volgt in elkaar.

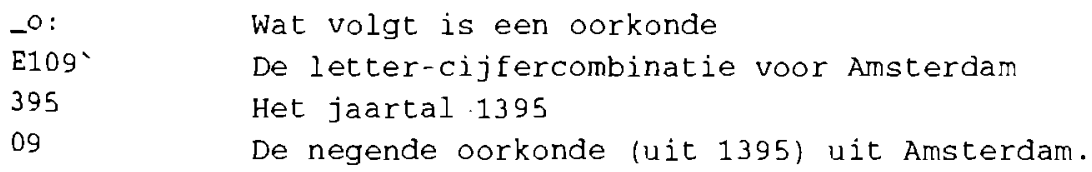

De plaats-tijdcode hoeft maar eenmaal boven de oorkonde vermeld te worden en geldt tot de volgende oorkonde, die weer met_o: begint.

Later kan op elk gewenst moment de _o:code automatisch aan alle woorden van de betrokken oorkonde gekoppeld worden. Hoe, daar gaan wij hier nu niet verder op in. 
Letter-cijfercombinaties als E109 geven aan om welk dialect het gaat volgens de klassifikatie van Kloeke. Zo kunnen de middeleeuwse gegevens op dialectkaarten worden geplot en is vergelijking mogelijk met dialectgegevens van andere herkomst, bijvoorbeeld uit het hedendaagse Nederlands. ${ }^{3}$ Een voorbeeld hiervan wordt in sectie 2 gegeven.

Tussen het Kloekenummer en het jaartal staat een " ", een dummy. Er had ook een $a$, een $b$ etc. kunnen staan, want het Kloekenummer heeft wel eens een extensie (het gaat dan om een later aan de lijst toegevoegde plaats). Zelf hebben wij vaak een $r$ toegevoegd ter aanduiding van regio. De regio krijgt het nummer van de centrale plaats binnen de regio, waarbij wij het Kloekenummer met 500 hebben verhoogd. Dat geeft nooit problemen met het aantal cijfers dat blijft altijd drie -, want het Kloeknummer is altijd lager dan 500. E109 is een plaats (Amsterdam), E609 is diezelfde plaats gelegen in de regio (regio Amsterdam). De dummy "' zorgt ervoor dat alle nummers even lang zijn, ook als er geen extensie nodig is: 10 karakters. Die uniformiteit is heel belangrijk voor latere computerbewerkingen.

Met letter-cijfercombinaties als E109`39506 identificeren wij ieder dokument ondubbelzinnig. Bovendien geven wij tegelijk plaats of regio van herkomst en het jaar binnen het millennium (van 1000 tot 1999) aan.

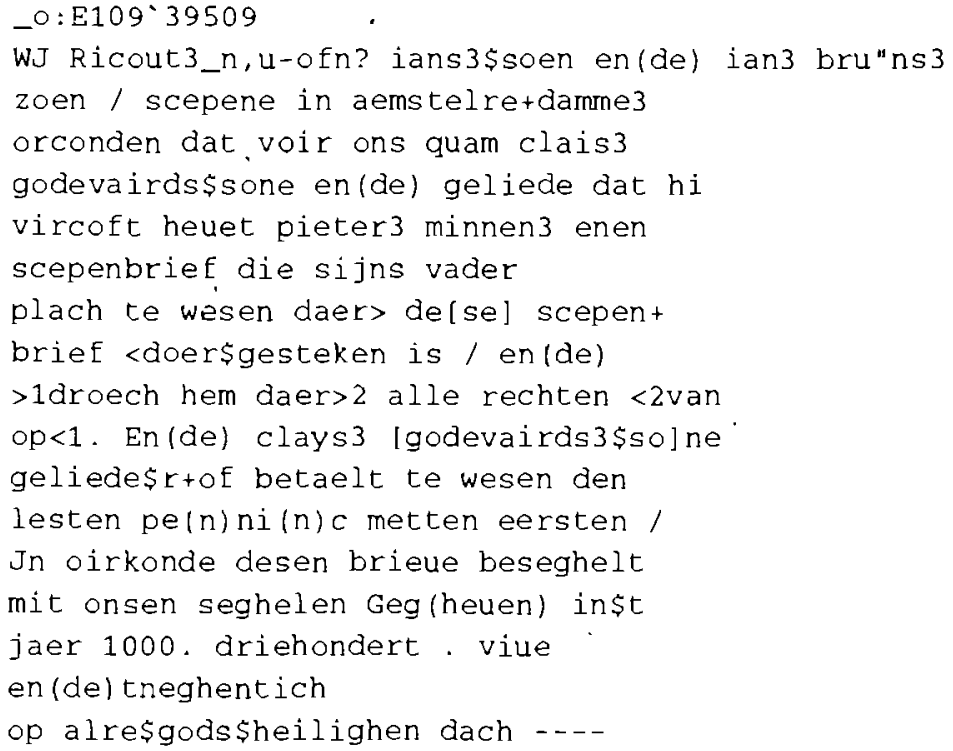

Figuur 3: De oorkonde uit figuur 2 in invoerformaat

3 Dit corpus is eveneens beschikbaar aan de Vrije Universiteit, die voor dit project samenwerkt met het P.-J. Meertens-Instituut. 


\subsubsection{Speciale tekens}

In de oorkonden komen speciale, typisch middeleeuwse tekens voor. De "/" bijvoorbeeld is een zogenaamde Duitse komma. De Umlaut in Bru" $n s$ staat in het origineel op de klinker, wij zetten hem erachter. Er zijn meer van zulke superscripten, zoals " $\wedge$ ", dat (toevallig) staat voor een hoog geschreven " 0 ". Andere symbolen van deze aard kunnen zonodig vrijelijk worden toegevoegd. Een lijst van zulke conventies moet per project worden bijgehouden. Uitsluitend standaard ASCII wordt gebruikt.

\subsubsection{Aanvullingen op de transcripties: afkortingen en verminkte passages}

Afgekorte passages die zijn aangevuld of verminkte tekst die is hersteld staat tussen [ ] of ( ). De ( ) worden gebruikt om aan te geven dat er een afkorting in het middeleeuwse handschrift stond die door de moderne uitgever is opgelost. De [ ] omgeven passages uit het origineel die niet leesbaar zijn, maar waarvan kon worden gereconstrueerd wat er gestaan moet hebben.

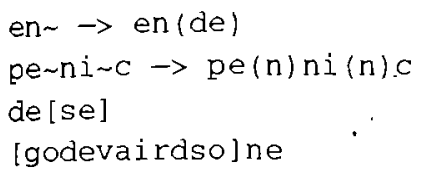

Zulke gereconstrueerde passages en opgeloste afkortingen hebben een aparte status. Ze lijken middeleeuws maar zijn het niet. Is de middeleeuwse vorm van de woorden onderwerp van onderzoek, dan kunnen we ze dus niet gebruiken. Maar we kunnen ze ook niet weglaten. Complete woordvormen en volledige zinnen zijn wel heel belangrijk bij syntactische analyse, waar de woordvorm er als zodanig niet toe doet. (Ze maken de tekst ook makkelijker begrijpelijk voor de onderzoeker.) En ze maken het semi-automatisch coderen van het tekstmateriaal, zie 2.3, niet ingewikkelder dan nodig. Daarom verwaarlozen wij zulke tekst niet, maar geven het met behulp van de haken een speciale status.

\subsubsection{Aanvullingen op de transcripties: scheiden en samenvoegen}

Heel vaak zijn in middeleeuwse teksten woorden gescheiden of aaneengeschreven, waar wij dat niet zouden doen. Toch respecteren wij de middeleeuwse schrijfwijze. Tegelijk willen we kunnen beschikken over het moderne equivalent. Dat is makkelijker, want uniformer en bekender, en voorkomt verwarring. We slaan de brug tussen de twee systemen met koppel- en ontkoppeltekens. De $\$$ in doer $\$ g e s t e k e n$ (="door gestoken") is zo 'n ontkoppelteken, 
waar het origineel doergesteken heeft. Als koppelteken gebruiken we een " + ": daarmee wordt aemstelre+damme tot een enkele eigennaam.

Bij telwoorden wordt "\%" ingevoegd als ze gescheiden in het dokument staan, als ze dat niet zijn een "\#". Wij kunnen op die manier het telwoord en zijn samenstellende delen zo gewenst apart onderzoeken. Romeinse cijfers in de middeleeuwse tekst worden in de computer ingevoerd gevolgd door $g$ ("getal"). Anders kan men verkeerde dingen lezen. In figuur 2 staan geen voorbeelden, maar $l v i=$ ongelijk "lui" en wordt lvi_g. Arabische cijfers blijven (voorlopig) wat ze zijn. Bij telwoorden kan de voorcodering met \% en \# overbodig worden, als een aparte ontleder van telwoorden wordt ontwikkeld.

\subsubsection{Aanvullingen op de transcripties: eigennamen en fictieve woorden}

Eigennamen kunnen vaak niet automatisch als zodanig worden herkend. Is lan de Bakker bakker of heet hij alleen maar zo? Ze worden daarom voorgekodeerd. Dat gaat heel snel, we zetten er een 3 (= eigennaam in onze invoercode) achter, zie aemstelre+damme 3 in figuur 3 dat daarmee één eigennaam wordt, niet twee. Oorkonden bevatten meestal heel wat eigennamen.

Een speciaal geval vormen de fictieve woorden. Woorden in middeleeuwse tekst kunnen volledig geassimileerd zijn aan een buurwoord. Dan zijn ze dus compleet verdwenen. Wij voeren ze weer in als fictieve woorden. Dat is nodig voor de syntactische analyse en kan ook bij onderzoek naar assimilatie van pas komen. De fictieve woorden worden gevolgd door $f$ (van fictief). In nemet $t f(=$ "neemt het") bijvoorbeeld is de tweede $t$ fictief. Het vormt een eenheid met het voorafgaande woord.

\subsubsection{Discontinue morfemen}

Voornaamwoordelijke bijwoorden en werkwoorden komen nogal eens gesplitst in twee, soms zelfs meer, elementen voor (zie figuur 2: daer ... van en droech ... op). Het inputformaat van deze woorden is vastgelegd in figuur 4 .

Het zal duidelijk zijn dat >morfeem moet worden verbonden met <morfeem en morfeem $>$ met $<$ morfeem. Aangezien de posities van " $>$ " en " $<$ " het punt van koppeling aangeven, zal ook duidelijk zijn dat morfeem $>$ en <morfeem al in de volgorde staan waarin ze aan elkaar gekoppeld moeten worden, terwijl dat niet zo is bij >morfeem en morfeem<. Dus zowel begin als eind van een morfeem kunnen als koppelpunt dienen, zodat in het zeer zeldzame geval dat een derde morfeem voorkomt na de twee anderen, het derde morfeem kan worden genoteerd als <morfeem en het tweede morfeem als <morfeem >.

In de oorkonde van figur 4 is er nog een tweede complikatie, die weliswaar zelden optreedt, maar waarin toch moet worden voorzien. $1>1$ droech ... $o p<1$ en daer $>2$... $<2$ van behoren tot twee paren discontinue morfemen waar- 
van de domeinen verstrengeld zijn. In dat geval kan " $>1$ " en " $<1$ " worden gebruikt voor het eerste paar morfemen, " $>2$ " en " $<2$ " voor het tweede paar. De twee voorbeelden illustreren tevens beide volgordes. Het voomaamwoordelijk bijwoord daer> ... <van heeft zijn normale volgorde. Het werkwoord opdragen heeft dat niet. Werkwoorden kunnen in twee volgordes voorkomen en een keuze moet worden gemaakt wat als de basisvolgorde word beschouwd. De derde persoon enkelvoud <droech ... op > in de oorkonde van figuur 3 wijkt dus af van de basisvolgorde.

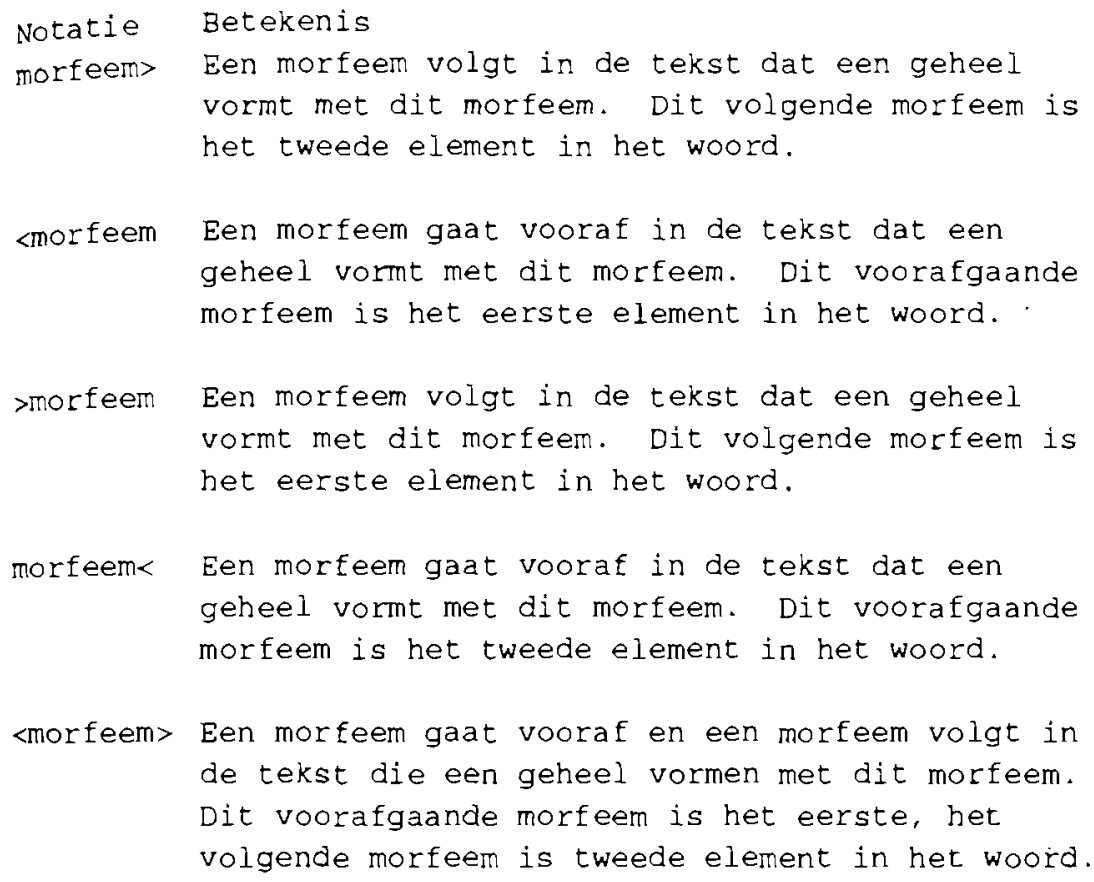

Figuur 4: Het invoerformaat van woorden bestaande uit discontinue elementen.

\subsubsection{Aanvullingen op de transcripties: noten}

De moderne uitgever heeft soms behoefte tekst en noten toe te voegen aan het middeleeuwse origineel. Noten kunnen bijvoorbeeld betrekking hebben op onzekerheid bij de transcriptie. Noten in de tekst worden voorafgegaan door $n$. Daarachter staat ofwel korte aanvullende informatie ofwel een verwijzing naar elders. Een voorbeeld van korte aanvullende informatie is $\_n, u=n$ ? achter Ricout. Heel handig is gebruik te maken van $\_n$, sic voor afwijkende vormen. Het voorkomt telkens opnieuw verifiëren of de transcriptie van het origineel 
wel correct was. Informatie over de oorkonden en hun herkomst uit de archieven of over scribenten kan meteen achter het oorkondenummer $\_0$ als noot $n$ worden vermeld, zolang hier geen speciale categorie voor is voorzien.

\subsection{Van invoerformaat naar computerformaat}

Uit het invoerformaat wordt volautomatisch het computerformaat afgeleid. $\mathrm{Bij}$ het tot stand brengen van het invoerformaat moest alle informatie met zo min mogelijk handwerk voor de taalkundige of leksikograaf worden aangebracht. Voor het tot stand brengen van het computerformaat geldt een andere doelstelling: de verwerking - bevraging en verder verrijking van het materiaal, een interactief proces - zo eenvoudig mogelijk te laten geschieden. Dat kan door het formaat, zodra het op computer is, af te stemmen op de systematiek van de programmatuur. Dat betekent dat we rekening houden met noties als sorteren: een preciese vorm van alfabetiseren die letters, cijfers en leestekens betreft. Aangezien we bij het sorteren geen rekening willen houden met haakjes, hoofdletters, voorcoderingen e.d., voeren we twee grote operaties uit. We zorgen dat (a) de middeleeuwse tekst alleen met kleine letters wordt geschreven; (b) de middeleeuwse woorden intern geen toegevoegde informatie bevatten. Omdat nog steeds de eis geldt dat geen informatie mag verloren gaan, wordt de toegevoegde informatie vanaf dit stadium niet meer in, maar achter het woord opgeslagen. Middeleeuwse tekst is te onderscheiden van toegevoegde tekst door middel van het "_", zie figuur 3 en vooral figuur 5. Het streepje wordt gevolgd door een aanduiding die het type code aangeeft, bijvoorbeeld $-8=$ getal, _l=leesteken, $c=$ capitaal (hoofdletter), $\_0=0$ orkonde. De voorcodering 3 wordt hier vervangen door_e (= eigennaam): Jan $3 \rightarrow$ Jan_e. Een woord dat de onderzoeker zelf (gedeeltelijk) heeft aangevuld behoort nu in zijn geheel tot de middeleeuwse tekst. Via de code achter het woord kan worden achterhaald dat dit niet werkelijk zo is.

De metatekst, of het kommentaar, achter de diverse "_"'s is vaak karaktergeoriënteerd. Dat houdt in dat het betrekking heeft op de positie van de letters in de middeleeuwse tekststring. De positie van die letters wordt aangegeven door middel van twee soorten tellers.

Het eerste type teller geeft binnen het woord de positie aan van de letter waarop het commentaar betrekking heeft. 'Dit is bij haakjes het geval en bij hoofdletters.

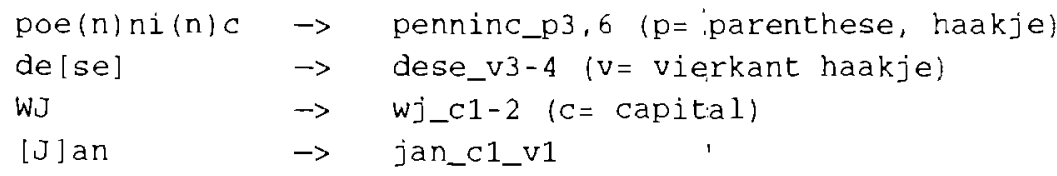


In pe(n)ni(n)c $\rightarrow$ penninc_p3,6 staan haakjes romdom letter 3 en romdom letter 6 van het woord, in de[se] staan vierkante haken om letter 3 en 4 . In WJ $\rightarrow w j_{-} c 1$ 2 zijn de letters 1 en 2 hoofdletters.

Het tweede type teller geeft binnen het woord de positie van de letter aan die aan het te signaleren verschijnsel voorafgaat. Dit is bij discontinue elementen het geval, evenals bij koppeling en scheiding van woorden, en sommige speciale tekens.

$\begin{array}{lll}\text { doer\$gesteken } & \rightarrow & \text { doer_a4 gesteken_a0 (a=punt van aanhechting) } \\ \text { aemstelre+damme } & \rightarrow & \text { aemstelredamme_k9 (k=koppelteken) } \\ \text { bru"ns_u3 } & \rightarrow & \text { bruns_u3 (u=umlaut) } \\ \text { daer> } & \rightarrow & \text { daer_ba4 (b=begin) } \\ \text { <doer } & \rightarrow & \text { doer_ea0 (e=eind) } \\ >1 \text { droech } & \rightarrow & \text { droech_bbo } \\ \text { op<1 } & \rightarrow & \text { op_eb2 } \\ \text { daer }>2 & \rightarrow & \text { daer_bc4 } \\ <2 \text { van } & \rightarrow & \text { van_ec0 }\end{array}$

In doer\$gesteken $\rightarrow$ doer_a4 gesteken_a0 geeft "a" gevolgd door het cijfer het punt van koppeling aan. Bij droech op en daer van is er een probleem, omdat daer in de tekst tussen droech en op in staat. Om de juiste woorddelen bij elkaar te krijgen wordt droech en op daarom gevolgd door $b 0$ en $b 2$, daer en van door $c 4$ en $c 0$. In aemstelre+damme wordt "+" vervangen door "_k": aemstelredamme_k9. Bij ">" en " $<$ " worden $\_b$ (=begin) of $\_e$ (=eind) ingevoerd. Bij leestekens en arabische getallen doen we of er geen middeleeuwse tekst aanwezig is: ze komen als geheel achter het "_" te staan. Bij omzettingen komen ze er als volgt uit te zien:

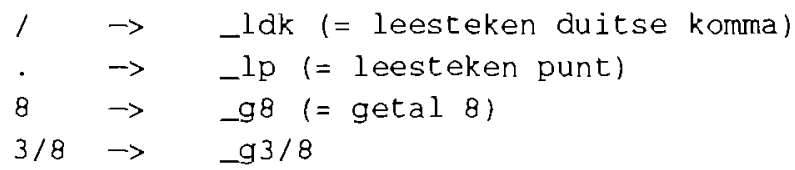

\subsection{Van computerformaat naar onderzoeksformaat: homografen}

De tekst in computerformaat wordt op zijn beurt - semi-automatisch, dat wil zeggen interactief - van morfologische kodering voorzien. Het resultaat is het onderzoeksformaat: een verzameling teksten, niet alleen gekodeerd in termen van plaats en jaar, maar bovendien voorzien van een taalkundige kode per woordvorm.

De kodes in het computerformaat beginnen allemaal met een " -" gevolgd door een specifieke letter. In het onderzoeksformaat wordt alleen nog de morfologische kode toegevoegd. Die hoeft dan niet te worden voorafgegaan door een letter om van alle andere koderingen onderscheiden te zijn. 
Bij het semi-automatisch koderen van de tekst worden de te koderen vormen telkens vergeleken met een lijst van items die al eerder gelemmatiseerd zijn: werkwoorden, zelfstandige en bijvoeglijke naamwoorden, voornaamwoorden, voegwoorden, telwoorden enz. Elk lemma bestaat uit een lijst van alle verschillende morfologische vormen die er in geschreven vorm zijn, voorzover ze al in het corpus zijn voorgekomen. Naast gekodeerde tekst wordt dus een tweede output gekreëerd: een lijst van gelemmatiseerde items. Bij elkaar vormen deze twee resultaten een zeer krachtig hulpmiddel bij het systematisch onderzoek van Middelnederlands. Ongeveer de helft van ons corpus is inmiddels van een morfologische kode voorzien. Gedurende deze fase wordt de lijst van gelemmatiseerde items telkens aangevuld. Uiteindelijk ziet onze oorkonde eruit als in figuur 5, waarin zogewenst de aard van de verschillende coderingen nader kan worden gespecificeerd.

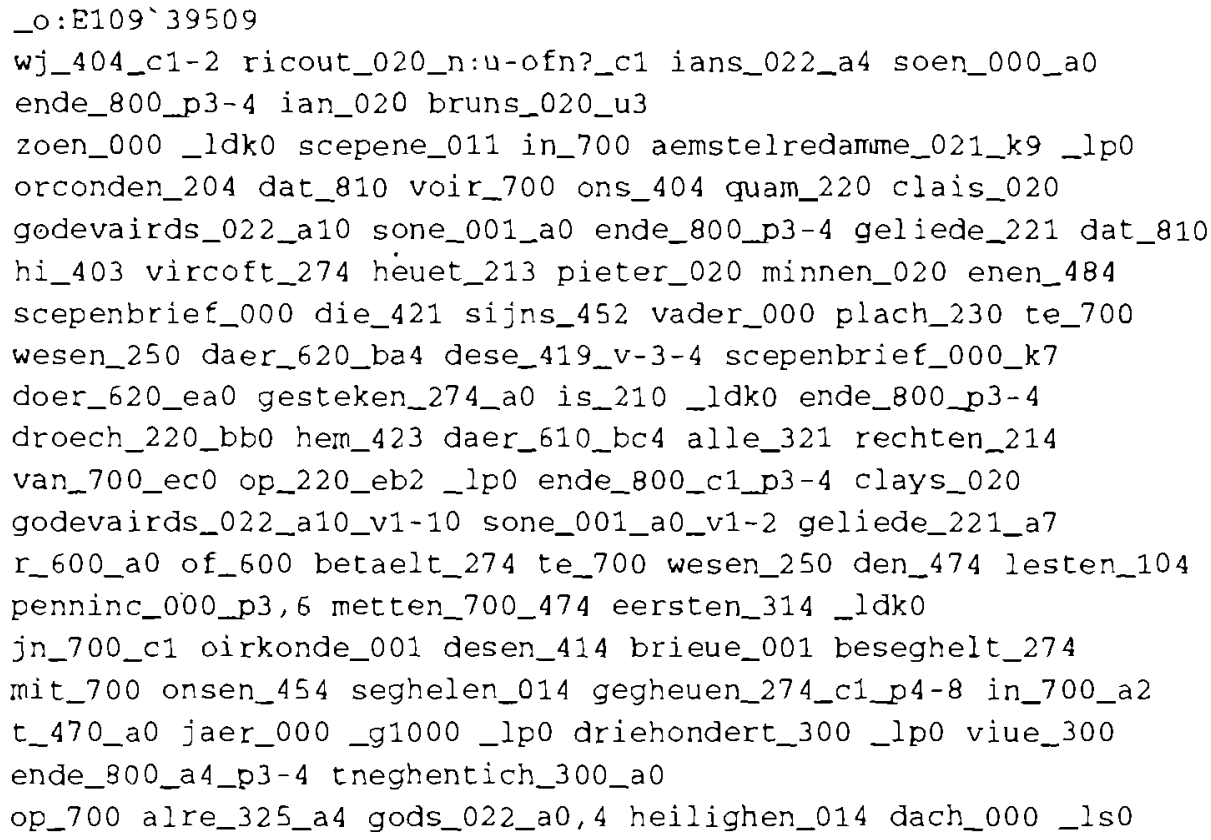

Figuur 5: De oorkonde uit figuur 3 omgezet naar onderzoeks formaat.

Een van de lastigste problemen bij het koderen is het disambigueren van homografen. Het is meestal handwerk. Soms is het handig de code al aan te brengen in het invoerformaat, zoals bij eigennamen: bakker $3=b a k k e r \_e$ versus bakker als beroep. De voorkodering moet zo kort mogelijk zijn, ter voorkoming van extra werk. Disambiguering van homografen kan ook tot stand worden gebracht tijdens het koderen. In de toekomst moet een deel van de homo- 
grafen door contekstgevoelige regels automatisch kunnen worden onderscheiden.

Zolang ze tot verschillende woordsoorten behoren, kunnen homografen worden onderscheiden door middel van de taalkundige kode. Zijn het echter allebei zelfstandige naamwoorden, of werkwoorden, dan kan dat niet. Bijvoorbeeld, er zijn twee woorden grave nl. "comes" en "gracht". Beide worden als grave_000 gecodeerd. Maar ze behoren tot verschillende lemma's. Wij lossen dit probleem als volgt op: grave_000_hl,comes en grave_000_hn, gracht, waar de " $\mathrm{h}$ " = homograaf, en de "l" voor Latijn als disambiguerende taal staat, de " $\mathrm{n}$ " voor Nederlands. De disambiguering moet zo kort mogelijk zijn, en niet in termen van etymologie.

Vergelijken we nu de figuren 1, 2, 3 en 5, dan zien we hoe de metamorfose van archiefstuk tot dokument in onderzoeksformat in diverse stappen tot stand gekomen is. Verdere verrijkingen van het onderzoeksformaat blijven in de toekomst mogelijk.

\section{De klinkers van het werkwoord ZULLEN: geografische contrasten}

Als het corpus oorkonden eenmaal in onderzoeksformaat (tot op zekere hoogte ook al in computerformaat) beschikbaar is, kan het leksikografisch of taalkundig onderzoek pas goed een aanvang nemen. Veel van dat onderzoek is woordvorm- of spellingsonderzoek. Soms kan dat direct worden vertaald in klankverschillen, zonder dat er veel interpretatie aan te pas komt. Dat zullen wij in deze sectie laten zien aan de hand van de klinkers van het werkwoord zullen (dat wij hier altijd met een $z$ zullen schrijven: in Van Reenen en Wattel (1992) hebben wij de spelling met $s$ of $z$ bijo.a. dit werkwoord nader onderzocht). Wij beperken ons tot de infinitief en tot de eerste en derde persoon enkelvoud en meervoud van de tegenwoordige tijd. We vinden hier in het meervoud korte of lange klinker, $0, u, e$, en in het enkelvoud zal of zel.

Op basis van een serie kleine programma's hebben wij a utomatisch tabellen tot stand gebracht waarin het voorkomen van zal en zel, van zullen, zellen, zelen, zolen, zoelen is vastgelegd in termen van plaats en tijd, in totaal meer dan 2.000 vormen.4

De resultaten kunnen op kaarten worden weergegeven dankzij programmatuur ontwikkeld door E. Wattel, zie Wattel (1990). Voor de weergave op de kaarten heeft elke oorkonde geteld als een getuige. Een oorkonde met meer

Een kleine toelichting op de programma's voor de kenners: Het gaàt om korte programmaatjes geschreven onder UNIX in de shell: egreps en AWK-programmaatjes selecteren relevante vormen en printen ze op de juiste plaats. Verder wordt gebruik gemaakt van commando's als tr en sort gecombineerd met uniq- $c$ en join, en substitutie-commando's in de ex. Al deze features zijn standaard onder UNIX beschikbaar. Ze zijn ook op PC beschikbaar: o.a. onder MINIX of onder MS-DOS via de MKS-toolkit. 
dan een relevante vorm telt echter zwaarder dan een oorkonde met slecht één relevante vorm: 1 vorm telt voor 1, 4 vormen voor 2 , en 9 vormen voor 3 (de vierkantswortel uit het aantal voorkomens per oorkonde). In de tabel in de Appendix telt een oorkonde als een getuige, ongeacht het aantal relevante vormen.

\subsection{Zel en zal}

Een eerste resultaat betreft zel en zal. Het is te zien in tabel 1. Voor de corresponderende dialectkaart, zie Van Reenen (te verschijnen). Zel - ongetwijfeld met een [ $\varepsilon$ ]-achtige klank uitgesproken - is westelijk, maar komt ook sporadisch in Groningen voor. Van Loey (1966: $§ 68$ ) komt aardig in de richting als hij zel in Holland plaatst. Toch kent Holland ook zal, Dordrecht zelfs overwegend. En verder doet ook Utrecht flink met zel mee. In de loop van de eeuw spreidt het gebruik van zel licht naar het oosten: Amersfoort, en komt de vorm in het noorden in Groningen op. Volgens de gegevens van De VriendtDe Man (1958) komt zel in de 16de eeuw nog voor in Haarlem, maar vooral in Leiden. ${ }^{5}$

Ook in het Afrikaans is de vorm wel eens gesignaleerd, zie Ponelis (1990: $\S 4.2$ ). In het Kaapse Afrikaans is [sol] normaal. Tenslotte treffen we ook in de moderne Nederlandse dialecten nog resten van het middeleeuwse kaartbeeld aan, zie kaart 1. Weijnen signaleert de vormen ook in Gouda en Katwijk aan Zee (1958: 373, 374 en 370).

\subsection{Zellen, Zelen, Zo(e)len, lange klinker en korte klinkers}

De frekwenties van de klinkers van zullen (infinitief of meervoud) staan in tabel 2 per (deel van een) provincie geordend. Zellen hoort bij zel te horen, maar vergelijking van tabel 1 en 2 laat zien dat dat geografisch niet helemaal klopt. De vorm is namelijk vooral in Utrecht te vinden, veel minder in Holland, en een

De Vriendt-De Man (1958) heeft 540 vormen verzameld waarvan $18 z e l$. Het is opmerkelijk hoe sceptisch ze staat tegenover de betrouwbaarheid van haar gegevens: "De taal der ambtelijke documenten ... wemelt van traditionele formules en archaïstische zinswendingen die dikwijls klakkeloos werden overgeschreven uit een ouder, gelijkaardig stuk". Zou zij gelijk hebben, dan heeft haar onderzoek geen zin gehad. Men vraagt zich af waarom zij het heeft uitgevoerd. Nu is vaststellen of een tekst van een 16de-eeuwse oorkonde al dan niet klakkeloos is overgeschreven geen eenvoudige opgave. $\mathrm{Zij}$ heeft voor haar scepticisme dan ook geen overtuigend bewijs gevonden. Tot het tegendeel is aangetoond beschouwen wij daarom de informatie die zij aan deze ambtelijke dokumenten ontleent als betrouwbaar. Wel delen wij haar scepsis ten aanzien van de literaire teksten waar zij zich op baseert, zolang die niet nader in tijd en ruimte zijn geplaatst. 
enkele vorm in Noord-Brabant. In Noord-Holland lijkt zellen in de loop van de eeuw wat af te nemen, in Zuid-Holland en Utrecht wat toe. De vorm komt op in Groningen. Raadplegen we Van Loey (1966: $\S 68$ ), dan vinden we vooral in Holland en Utrecht andere accenten. Zellen zou Noordhollands zijn (p.88) en de vorm zou ook wel eens in Brabant voorkomen (p.90). Het beeld gesuggereerd in Van den Berg en Vermeulen (1973) - in belangrijke mate gebaseerd op een kleine deelverzameling van de gegevens die wij ook hebben gebruikt klopt beter. In haar 16de-eeuwse gegevens heeft De Vriendt-De Man (1958) de vormen niet meer aangetroffen.

Naast zellen is er nog een andere vorm met een e-achtige klinker. Kaart 2 laat zien dat zelen een typisch Belgisch Brabantse vorm is met als centrum Brussel. Dat vinden we ook bij Van Loey en Van den Berg en Vermeulen en Goossens (1980: 62) terug. Blijkens De Vriendt-De Man (1958: 213-232) komen ze ook in de 16de eeuw nog veelvuldig in Brussel en omgeving voor: 50 op de 109 vormen.

Uit tabel 2 blijkt verder dat zoelen en zolen oostelijke vormen zijn, zie ook kaart 3, waar zoelen en zolen samen tegenover de andere vormen zijn gekarteerd. Van Loey $(1966: 88,91)$ beschouwt solen als Limburgs en Hollands. In het licht van onze 14de-eeuwse kaart moet in Holland die vorm dan wel de laatste der Mohikanen zijn geweest, wellicht ook de eerste. De informatie van Van Loey is op dit punt zeker niet representatief. Voor 13de-eeuwse gegevens, zie ook Van Loey (1952).

Tenslotte valt uit tabel 2 de tegenstelling tussen zullen met een enkele $-l$ en zullen met een dubbele - $l l-$, af te lezen, een verschil dat algemeen wordt opgevat als tussen lange klinker en korte klinker. De vorm met dubbel -ll- (korte klinker) is duidelijk aan de winnende hand, vooral in Noord-Brabant en in het Noorden, zo leert een nadere analyse van de gegevens.

\subsection{Discussie}

Uit de kaarten en tabellen die wij hierboven hebben gegeven komt een algemeen verschil naar voren met bestaande kennis. Daar worden vanouds de dialectverhoudingen in algemene termen aangegeven, vaak vaag, een enkele keer ook te precies. Betekent een uitspraak: "Zellen komt in Holland voor", dat zullen daar niet voorkomt? Of dat zellen alleen in een deel van Holland voorkomt? En is dat dan weleens of altijd? Zelfs wanneer Van Loey een vorm met een datering geeft, kunnen we niet weten of die vorm representatief is. Verder worden veel Nederlandse dialectgebieden niet of nauwelijks vermeld: Utrecht, Gelderland en Zeeland schitteren vaak door afwezigheid. De wel vermelde streken zijn soms wel erg groot en niet altijd precies afgebakend: Holland, Brabant, Limburg en Vlaanderen.

Overigens worden Gelderland, Overijssel, Drente en Groningen niet altijd tot het Middelnederlandse taalgebied gerekend, al hebben wij ze wel onder- 
zocht. Ook Friesland valt erbuiten. Onze kaarten suggereren dat in Friesland $z e l$ - en zellen-achtige vormen moeten hebben voorgekomen. Raadpleging van Vries (1977) leert dat dit klopt. Het middeleeuwse Fries kent skel en sel, skellen en sellen.

\section{Conclusie}

Deze studie valt uiteen in twee delen. Het eerst deel had tot doel te laten zien hoe grote bestanden middeleeuwse teksten op computer kunnen worden opgeslagen en zinvol worden ingericht. De inrichting van de bestanden maakt duidelijk hoe de taalgegevens betrekkelijk eenvoudig kunnen worden gebruikt met het oog op o.a. leksikografisch onderzoek. In het tweede deel werd daarom kort een ander aspect van het taalmateriaal belicht dat onvermijdelijk, bij gebrek aan een standaardtaal, door alle taal- en leksikografisch onderzoek uit die periode heen speelt: de spreiding der gegevens in de ruimte (en de tijd). Getoond werd - aan de hand van de klinkers van het werkwoord zullen wat dit type onderzoek aan resultaten kan opleveren. Door grote aantallen gegevens te destilleren uit gedateerde en plaatsgebonden taalgetuigen en die te systematiseren op dialectkaarten en in tabelvorm, kan onze kennis van het Middelnederlands niet alleen taalkundig maar ook leksikografisch met sprongen toenemen.

\section{Verwijzingen}

De Vriendt-De Man, M.J. 1958. Bijdrage tot de kennis wan het gebruik en de flexie van het werkwoord ZULLEN in de 16de eeuw. Koninklijke Vlaamse Academie voor Taal- en Letterkunde, Reeks VI, Nr. 81. Gent.

Erens, M.A. 1950, 1952. De oorkonden der Abdij van Tongerloo II, III. Tongerloo: St. Norbertsdrukkerij.

Goossens, J. 1980. Middelnederlandse vocaalsystemen. VMA, afl. 2.

Gysseling, M. 1977. Corpus van Middelnederlandse Teksten (tot en met het jaar 1300). Reeks I: Ambtelijke Bescheiden. 's-Gravenhage: Martinus Nijhoff.

Huber, O.C. 1989. The Construction of Lexically Analyzed Text Corpora on the Computer. -Corpus Based Word Analysis, Report \#1, Vakgroep Taalkunde, Vrije Universiteit, Amsterdam.

Moors, Joseph. 1952. Bouwstoffen tot de historische toalgeografie van het Nederlands, $I$, De oorkondentaal in Belgisch-Limburg. Belgisch Interuniversitair centrum voor Neerlandistiek.

Ponelis, F.A. 1990. Historiese klankleer van Afrikaans. Universiteit van Stellenbosch, Annale 1.

Van den Berg B. en A.G.M. Vermeulen. 1973. 'Zullen' als proefgeval. De Nieuwe Taalgids 66: 445452.

Vangassen, H. 1964. Bouwstoffen tot de historische taalgeografie van het Nederlands, VIII, Noordhollandse charters. BeIgisch Interuniversitair centrum voor Neerlandistiek.

Van Loey, A. 1952. Een en ander over Mnl. Sullen. VMA: 919-922. 
Van Loey, A. 1966. Middelnederlandse spraakkunst 1. Vormleer, 5de druk. Groningen: Wolters.

Van Reenen, P. Te verschijnen. The Study of Medieval Language in the Low Countries: the Good, the Bad and the Future. Medieval Dialectology, Workshop Taxonomy and Typology in Medieval Dialect Studies. Edinburgh, April 1992.

Van Reenen, P. en E. Wattel. 1992. De uitspraak van /s/ en /z/ voor klinker in het Nederlands: zes eeuwen variatie. Bennis, H.J. en J. de Vries. (Red.). 1992. De binnenbouw oan het Nederlands: 291-309. Dordrecht: ICG Publications.

Vries, O. 1977. Oudfriese oorkonden. Vierde deel. (Oudfriese taal- en rechtsbronnen uitgeven door dr. P. Sipma. Veertiende deel.) 's-Gravenhage: Martinus Nijhoff.

Wattel, E. 1990. A Mathematical Model to Describe the Boundary of a Vowel Shift in the Past on the Basis of Data from Contemporary Dutch Dialects. Rapportnr. WS -359, Mei 1990, Vrije Universiteit Amsterdam.

Weijnen, A. 1958. Nederlandse dialectkunde. Assen: Van Gorcum. 


\section{Appendix}

\begin{tabular}{rrrl}
\hline 1 & 2 & 3 & 4 \\
\hline & zal & zel & provincie \\
& & & \\
01 & 6.5 & 1.5 & 01 = Groningen $/$ Drente \\
02 & 10 & 0 & 02 = Overijssel \\
03 & 11 & 0 & 03 = Gelderland \\
04 & 11 & 17 & 04 = Utrecht \\
05 & 8.5 & 11.5 & $05=$ Noord-Holland \\
06 & 4 & 6 & 06 = Zuid-Holland West \\
07 & 3 & 2 & 07 = Zuid-Holland Oost \\
08 & 1 & 0 & 08 = Zeeland \\
09 & 6 & 1 & 09 = Noord-Brabant West \\
10 & 18 & 0 & 10 = Noord-Brabant Oost \\
11 & 7 & 0 & $11=$ Limburg \\
12 & 1 & 0 & 12 = West-Vlaanderen \\
13 & 2 & 0 & 13 = Oost-Vlaanderen \\
14 & 3 & 0 & 14 = Antwerpen \\
15 & 4 & 0 & 15 = Brabant \\
16 & 23 & 0 & 16 = Belgisch Limburg
\end{tabular}

Tabel 1: Frekwentie van zal en zel in het 14de-eeuws Middelnederlands.

\begin{tabular}{llllllllll}
\hline 1 & 2 & 3 & 4 & 5 & 6 & 7 & 8 & 9 & 10 \\
\hline
\end{tabular}

prov zullen zellen zelen zoelen zolen zuelen zulen zollen zoellen

$\begin{array}{lrrrrrrrrr}01 & 26.6 & 6.2 & 0.5 & 6 & 33.5 & 0 & 0 & 1.2 & 0 \\ 02 & 18.07 & 0 & 0 & 33.87 & 29.56 & 0 & 5.5 & 0 & 1 \\ 03 & 2.83 & 1 & 0 & 15.25 & 38.31 & 19.48 & 6.13 & 1 & 0 \\ 04 & 11.33 & 110.17 & 0 & 18 & 1 & 0.5 & 0 & 0 & 0 \\ 05 & 49.83 & 15.17 & 0 & 0 & 0 & 0 & 0 & 0 & 0 \\ 06 & 20.64 & 8.36 & 0 & 0 & 0 & 0 & 0 & 0 & 0 \\ 07 & 40.47 & 2.53 & 0 & 0 & 1 & 0 & 0 & 0 & 0 \\ 08 & 50 & 0 & 0 & 0 & 0 & 0 & 0 & 0 & 0 \\ 09 & 12.89 & 4.11 & 7 & 4 & 1 & 0 & 0 & 0 & 0 \\ 10 & 29.39 & 0 & 2 & 24.22 & 15.39 & 0 & 1 & 1 & 0 \\ 11 & 10.5 & 0 & 0 & 2.62 & 18.88 & 20 & 2 & 0 & 0 \\ 12 & 71 & 0 & 0 & 0 & 0 & 0 & 0 & 0 & 0 \\ 13 & 32.25 & 1 & 0.75 & 0 & 0 & 0 & 0 & 0 & 0 \\ 14 & 0 & 0 & 7.5 & 2.83 & 2.67 & 1 & 0 & 0 & 0 \\ 15 & 1 & 0 & 40 & 0 & 2 & 0 & 0 & 0 & 0 \\ 16 & 19 & 0 & 3.5 & 46.32 & 44.76 & 9.42 & 1 & 0 & 1\end{array}$

Tabel 2: De klinkers van het werkwoord zullen in 14de-eeuws Middelnederlands 
Kaart 1: Verdeling zel (donker gebied) versus zal in 14de-eeuws Middelnederlands.

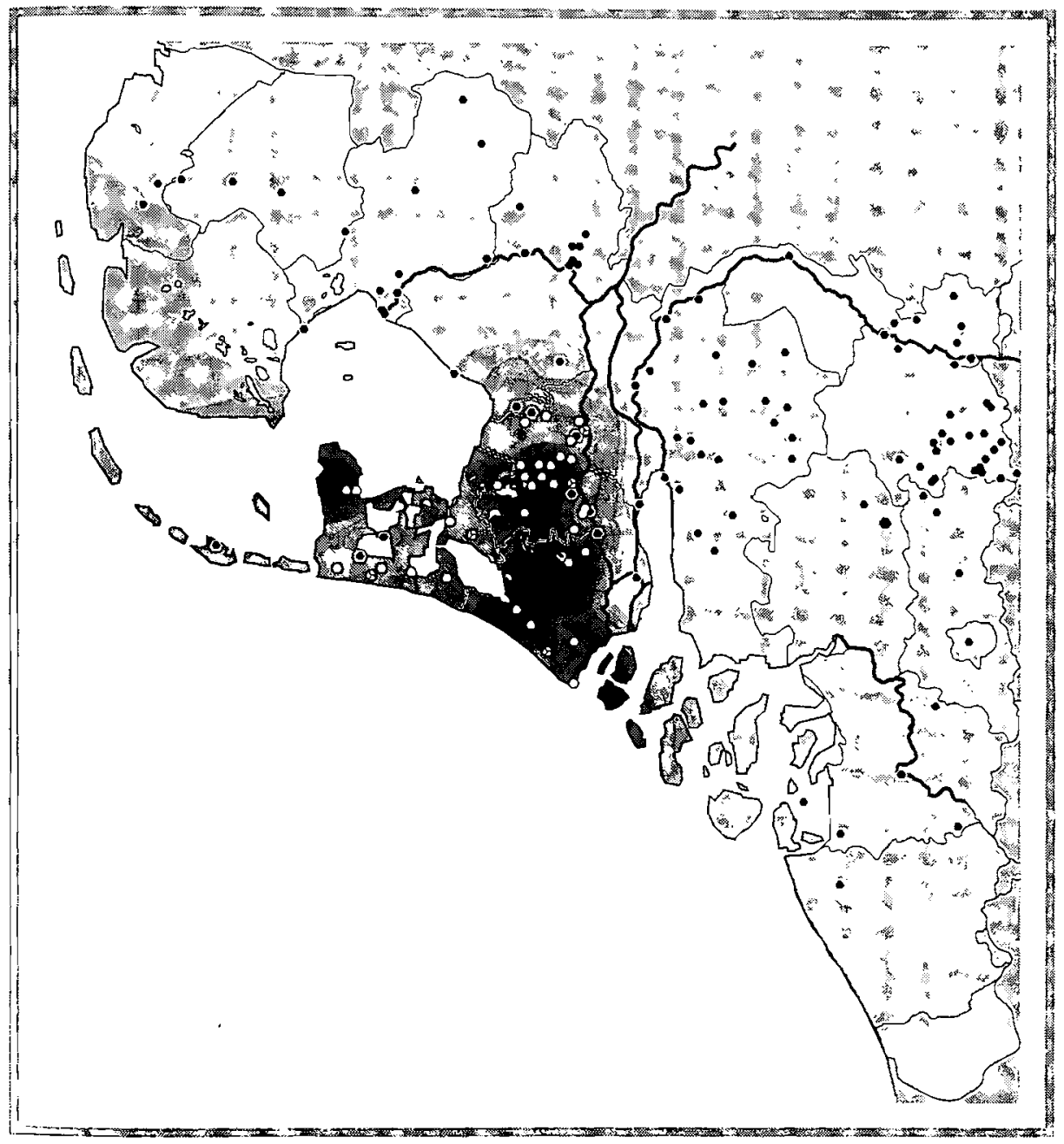


Kaart 2: Spelling zelen (donker) versus andere vormen van zullen.

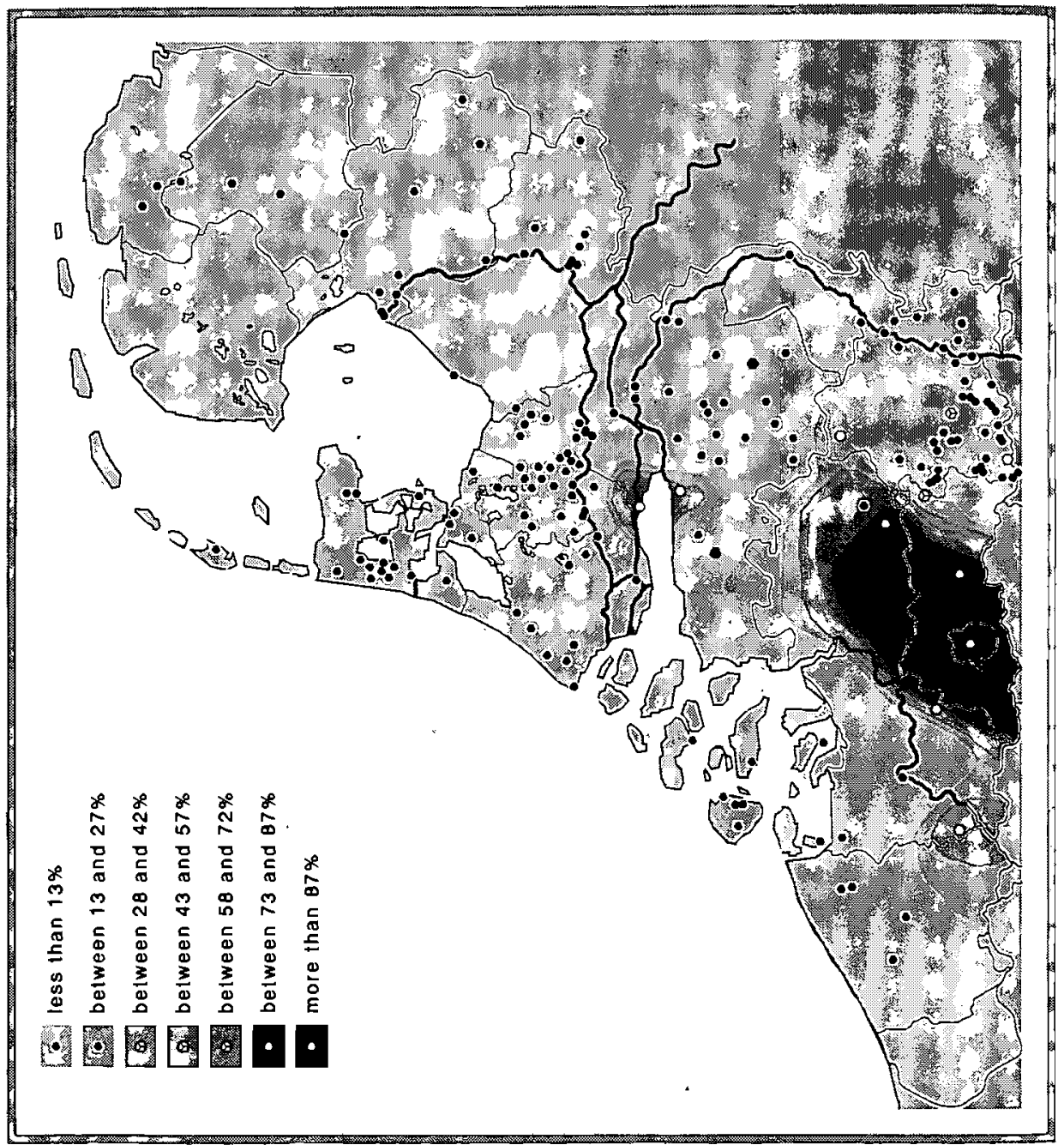




\section{Kaart 3: Spelling zolen of zoelen (donker) versus andere vormen van zullen.}

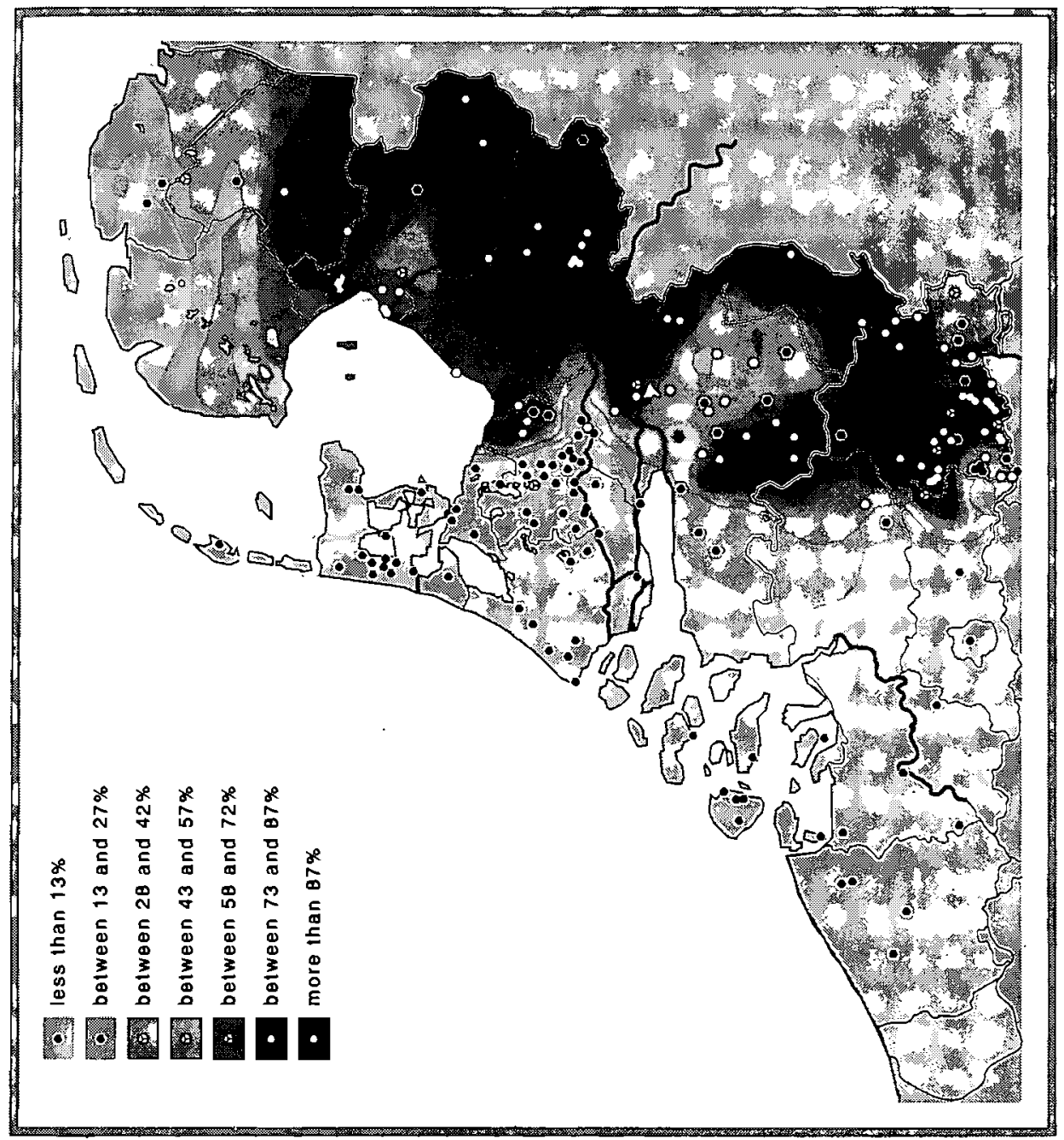




\title{
Komponentontleding as leksikografiese instrument
}

\author{
I.L. Vos, Departement Afrikaans, Randse Afrikaanse Universiteit, Suid-Afrika
}

\begin{abstract}
Componential Analysis as Lexicographical Instrument. One of the most important functions of descriptive dictionaries is to convey semantic information. The lexical meaning of a collection of lexical items must be defined according to certain semantic norms.

One of the lexicographer's major problems is that inadequate semantic norms have been identified and defined for the introduction of encyclopedic information into standard dictionaries. It is for example generally accepted that encyclopedic information has no place in descriptive dictionaries because it describes extralinguistic reality, while descriptive dictionaries should be confined to language. Nevertheless, a complete, clear and unambiguous conveyance of meaning sometimes requires that a certain amount of encyclopedic information should be incorporated in the elucidation of meanings. The lexicographer needs practical guidelines in order to accomplish a proper conveyance of meaning.

Componential analysis can be regarded as an instrument through which the lexicographer can differentiate between components that convey lexical meaning and components that are supplementary and therefore redundant.

Although valid objections can be raised to certain aspects of componential analysis, it should not be completely discarded as a lexicographical instrument. The shortcomings and possible insufficiencies of componential analysis should rather be regarded as a stimulus to enhance the co-operation between the linguist and the lexicographer.
\end{abstract}

Keywords: COMPONENTIAL ANALYSIS, DEFINITION, DESCRIPTIVE DICTIONARY, ENCYCLOPEDIC INFORMATION, LEXICAL MEANING, LEXICOGRAPHY, SEMANTIC FIELDS, SEMANTIC COMPONENTS, SUBJECT DESCRIPTION

Opsomming: Komponentontleding as leksikografiese instrument. Een van die belangrikste funksies van verklarende woordeboeke is om betekenisinligting te verskaf. Die verklaring van leksikale betekenis moet in ooreenstemming wees met semantiese norme wat vanuit die leksikale semantiek geformuleer moet word.

Semantiese norme vir die hantering van ensiklopediese inligting in handwoordeboeke het tot dusver nie baie aandag van Afrikaanse taalkundiges gekry nie. Daar word byvoorbeeld algemeen aanvaar dat ensiklopediese inligting nie in verklarende woordeboeke tuishoort nie omdat dit die buitetalige werklikheid beskryf, terwyl verklarende woordeboeke op taal en taalgebruik gerig is. Tog is dit soms nodig om ' $n$ hoeveelheid ensiklopediese inligting in ' $n$ betekenisverklaring in te

Hierdie artikel is 'n gedeelte van 'n hoofstuk, met geringe wysigings, uit 't M.A.-tesis Semantiese norme in Afrikaanse verklarende woordeboeke wat in Februarie 1992 deur die Universiteit van Stellenbosch anvaar is. 
sluit om 'n volledige, duidelike en eenduidige betekenisoordrag te bewerkstellig. Ook hiervoor het die leksikograaf praktiese riglyne nodig.

Komponentontleding kan as instrument dien aan die hand waarvan die leksikograaf kan onderskei tussen komponente wat bydra tot die verklaring van leksikale betekenis en komponente wat bloot aanvullend en dus oorbodig ten opsigte van die betekenisverklaring is. Komponentontleding is gebaseer op die aanname dat betekenis 'n deelbare geheel is. Betekenis word beskryf in terme van betekeniskomponente. Daar word drie soorte komponente onderskei, naamlik gemeenskaplike, diagnostiese en supplemientêre komponente. Dit is veral die diagnostiese komponente wat leksikale betekenis oordra en in die definisie gebruik behoort te word.

Alhoewel daar geldige besware teen sekere aspekte van komponentontleding geopper kan word, mag komponentontleding as leksikografiese instrument nie summier verwerp word nie. Die gebreke of tekortkominge kan liewer beskou word as 'n stimulus tot groter samewerking tussen die leksikograaf en die teoretiese taalkundige.

Sleutelwoorde: BETEKENIFKOMPONENTE, DEFINISIE, ENSIKLOPEDIESE INLIGTING, KOMPONENTONTLEDING, LEKSIKALE BETEKENIS, LEKSIKOGRAFIE, SAAKBESKRYWING, SEMANTIESE VELDE, VERKLARENDE WOORDEBOEK

\section{Inleiding}

Die belangrikste funksie van verklarende handwoordeboeke is om leksikale betekenis te verskaf. Leksikale betekenis moet verklaar word in ooreenstemming met semantiese norme wat vanuit die leksikale semantiek geformuleer moet word. Die leksikograaf se probleem is egter dat daar nog maar min semantiese norme geïdentifiseer is en die norme wat wel geformuleer is, word nie altyd na behore uitgespel nie.

In die Afrikaanse leksikografie het semantiese norme vir die hantering van ensiklopediese inligting in verklarende woordeboeke tot dusver nie baie aandag gekry nie. Daar word beweer dat ensiklopediese inligting uit verklarende woordeboeke geweer moet word omdat dit op die buitetalige werklikheid dui, terwyl verklarende woordeboeke op taal en taalgebruik gerig is. Alhoewel daar reeds telkemale kritiek teen 'n oormaat ensiklopediese inligting in die Woordeboek van die Afrikaanse Taal (voortaan afgekort tot WAT) uitgespreek is (Combrink 1979; Odendal 1979; Gouws 1985), word min praktiese riglyne verskaf vir die korrekte leksikografiese hantering van ensiklopediese inligting in handwoordeboeke.

Die heftige kritiek teen die ensiklopediese werkswyse in die WAT het waarskynlik daartoe bygedra dat leksikograwe so sku vir ensiklopediese inligting geword het dat kriptiese en daarom soms ook onvolledige betekenisverklarings in Afrikaanse verklarende handwoordeboeke verskyn het. 'n Voorbeeld van so ' $n$ onbevredigende definisie kom uit die sesde uitgawe van die Nasionale Woordeboek (voortaan afgekort tot NW):

geelbek: "soort vis". 
In die sewende, hersiene uitgawe van die NW is daar heelwat minder sulke definisies, maar onvolledige betekenisverklarings kom tog nog voor:

kataplasma: "pleister van warm pap."

In die Verklarende Handwoordeboek van die Afrikaanse Taal (voortaan afgekort tot HAT) se definisie van dieselfde lemma is daar meer ensiklopediese inligting, maar dit is duideliker:

kataplasma: "sagte pap, bv. van brood, semels, of klei, met warm water aangemaak, wat op 'n ontsteekte plek geplak word."

Vergelyk ook die definisies van sikofant in die HAT en die NW:

sikofant:

"beroepsverklikker." (HAT)

sikofant:

"verklikker (wat deur die polisie betaal word)." (NW)

Uit die bostaande voorbeelde is dit duidelik dat ensiklopediese inligting soms ook in 'n handwoordeboek funksioneel kan wees omdat dit kan bydra tot 'n volledige en duidelike betekenisverklaring. Die leksikograaf kan dus nie summier alle ensiklopediese inligting uit woordeboekartikels weglaat nie.

Die semantiese norm wat ' $n$ verbod wil plaas op ensiklopediese inligting in verklarende handwoordeboeke moet aangepas word en kan soos volg lui:

Ensiklopediese inligting in woordeboekartikels moet tot die minimum beperk word. Waar dit wel toegelaat word, moet dit die betekenisbeskrywing ondersteun sodat die lemma eenduidig onderskei word.

As dit by die praktiese toepassing van hierdie norm kom, ondervind die leksikograaf dikwels probleme. Dit is moeilik om te besluit hoeveel ensiklopediese inligting aanvaarbaar is. Vergelyk byvoorbeeld die volgende definiense wat in drie verskillende handwoordeboeke by die lemma wolf verskyn:

"Erect-eared, straight-tailed, harsh-furred, tawny-grey, wild, gregarious, carnivorous quadruped allied to dog preying on sheep, etc. or combining in packs to hunt larger animals." (Concise Oxford Dictionary)

Die HAT laat ' $n$ bietjie minder ensiklopediese inligting toe:

"Enigeen van 'n aantal vraatsugtige roofdiere van die Hondegeslag (Canis), wat groot skade onder veee (sic), wild, beeste aanrig, en, in 'n groep, die mens aanval, veral die soort $C$. lupus."

In die NW word net 'n kort, kernagtige definiens gegee:

"groot, hondagtige roofdier." 
Uitsprake in die geraadpleegde literatuur oor die insluiting van ensiklopediese inligting is baie vaag. Vergelyk byvoorbeeld:

"The definition should be sufficiently specific, but not overspecific" (Zgusta 1971: 254).

Volgens Crystal (1986: 75) is een van die vereistes waaraan die "ideale woordeboek" moet voldoen "thoroughness of treatment".

Leech (1974: 204) beweer: "Encyclopedic information about the referents of the item is often added for good measure".

"If the definer uses ambiguous wording, he may write definitions which are too broad. (...) The definer must also be wary of making either the genus or differentiae too broad or inaccurate" (Kipfer 1984: 68).

Daar bestaan ' $n$ behoefte aan praktiese riglyne ten opsigte van die insluiting van ensiklopediese inligting in 'n woordeboekartikel.

\section{Ensiklopediese inligting}

Ensiklopediese inligting kan verdeel word in drie soorte. Gouws (1989: 186) onderskei tussen saakbeskrywing en gebruiksbeskrywing. 'n Derde soort ensiklopediese inligting is tegniese of wetenskaplike beskrywings. Die verdeling van ensiklopediese inligting in saak-, gebruiks- en tegniese beskrywings vergemaklik die identifisering van probleme in verband met hierdie soort inligting in handwoordeboeke. Semantiese norme waarvolgens die leksikograaf ensiklopediese inligting kan hanteer, kan sodoende meer spesifiek en praktykgerig geformuleer word.

In hierdie artikel word daar hoofsaaklik na saakbeskrywing verwys omdat komponentontleding veral by soortname gebruik word. Die term saakbeskrywing dui op 'n beskrywing van die saak waarna 'n bepaalde leksikale item verwys. Saakbeskrywing kan as 'n soort ensiklopediese inligting beskou word omdat dit met die buitetalige werklikheid te make het. Die ooreenkoms tussen saakbeskrywing en verwysing kan daartoe aanleiding gee dat alle elemente van saakbeskrywing summier uit die woordeboekartikel gehaal word. Dit kan egter veroorsaak dat sommige betekenisverklarings onvolledig en dubbelsinnig sal wees. Die leksikograaf moet soms 'n bietjie ensiklopediese inligting in die vorm van saakbeskrywing in 'n betekenisverklaring insluit omdat saakbeskrywing in sekere gevalle funksioneel ten opsigte van 'n eenduidige betekenisoordrag kan wees. 


\section{Komponentontleding}

Volgens Gouws "bied (komponentontleding) aan die leksikograaf 'n betroubare hulpmiddel om betekenis op ' $n$ sistematiese en doeltreffende manier van buitetaalkundige inligting te onderskei" (1989: 191). Komponentontleding is ' $n$ uitvloeisel van die teorie oor semantiese velde. Die teorie het binne die strukturele semantiek ontstaan en behels dat leksikale items gekategoriseer of gegroepeer word op grond van 'n gemeenskaplike betekeniskenmerk. 'n Leksikale item in ' $n$ semantiese veld staan in 'n bepaalde verhouding tot die ander items binne dieselfde kategorie of veld. Die behoefte aan 'n metode om ooreenkomste en verskille tussen die lede van 'n semantiese veld te beskryf, het gelei tot die ontwikkeling van komponentontleding.

Komponentontleding is gebaseer op die aanname dat betekenis ' $n$ deelbare geheel is. Betekenis word dus beskryf in terme van betekeniskomponente. Die leksikale item man se betekenis word byvoorbeeld voorgestel deur die semantiese kenmerke [+ menslik], [+ volwasse] en [+ manlik], terwyl vrou se betekeniskomponente [+ menslik], [+ volwasse] en [+ vroulik] is.

Louw (1985: 59 e.v. en 1985a: 159) onderskei drie soorte komponente wat vir die leksikograaf belangrik is, naamlik gemeenskaplike, diagnostiese en supplementêre komponente. Leksikale items word op grond van hul gemeenskaplike betekeniskomponente in 'n semantiese veld gegroepeer. Die leksikale items stoel en bank deel die betekeniskomponente [meubel] en [sitplek] en word dus in dieselfde semantiese veld geplaas. Binne die semantiese veld word die leksikale items van mekaar onderskei met behulp van diagnostiese komponente:

$\begin{array}{ll}\text { stoel: } & {[+ \text { vir een persoon }]} \\ \text { bank: } & {[+ \text { vir meer as een persoon }]}\end{array}$

Volgens Louw (1991: 117) is die betekenis van 'n leksikale item 'n stel semantiese komponente. Hy verduidelik dat betekenis "beswaarlik anders aangedui (kan) word as met 'n omvattende definisie". Hierdie "omvattende definisie" is 'n parafrase van die leksikale item se semantiese komponente. Die semantiese komponente word op ' $n$ informele manier omskryf sodat elke deel van die definisie 'n betekeniskomponent is. (Vergelyk Lehrer 1974: 46.) Dit is veral die diagnostiese komponente wat in die definisie voorkom. "The process of defining would seem to be simply another form of paraphrase. In a sense this is true, but defining is a highly specialized form of paraphrase and is rarely used in actual language situations. It consists essentially in combining all the various specific paraphrases into a single statement based on the diagnostic components of the particular meaning in question" (Nida 1979: 65).

In die NW word vrou onder andere gedefinieer as "'n vroulike persoon van volwasse leeftyd". Die leksikale items eggenote, weduwee, oujongnooi, meisie en dame besit almal die semantiese kenmerk [+ vroulik]. Hulle word 
dus in die semantiese veld "vrou" gegroepeer en daarna van mekaar onderskei op grond van hul diagnostiese kenmerke:

$\begin{array}{ll}\text { eggenote: } & {[+ \text { getroud }]} \\ \text { weduwee: } & {[+ \text { was getroud]; [+ man oorlede] }} \\ \text { oujongnooi: } & {[- \text { getroud]; [-jonk] }} \\ \text { meisie: } & {[- \text { getroud]; [+ jonk] }} \\ \text { dame: } & {[+ \text { hoë opvoedingspeil]; [+ beskaafd] }}\end{array}$

In die woordeboekdefinisies word die diagnostiese komponente informeel omskryf:

$\begin{array}{ll}\text { eggenote: } & \text { "vrou met wie 'n man getroud is." (NW) } \\ \text { weduwee: } & \text { "vrou wie se man oorlede is." (NW) } \\ \text { oujongnooi: } & \text { "ouerige, ongetroude vrou." (NW) } \\ \text { meisie: } & \text { "jong, ongetroude vrou." (NW) } \\ \text { dame: } & \text { "beskaafde of fyn opgevoede vrou." (NW) }\end{array}$

Siektes soos masels, pampoentjies en waterpokkies deel die betekeniskomponente [+ kindersiekte] en [+ aansteeklik] en word van mekaar onderskei op grond van diagnostiese kenmerke wat verband hou met die sigbare simptome van die siektes, soos byvoorbeeld uitslag, klierswelling en blasies. Die definisies van hierdie lemmas is informele omskrywings van die betekeniskomponente:
masels: "aansteeklike koors(siekte) veral by kinders, met 'n uit- slag van klein rooi vlekkies oor die liggaam." (NW)
pampoentjies: "aansteeklike siekte met swelling van die kliere." (NW) waterpokkies: "aansteeklike kindersiekte met blasies op die lyf." (NW)

As die leksikograaf nie van komponentontleding (en die veldteorie) gebruik maak nie, kan dit gebeur dat die betekenisverklaring onvolledig is of dat die verband tussen lede van 'n semantiese veld vir die gewone woordeboekgebruiker verlore gaan.

Volgens die HAT se definisies word die drie lemmas nie in dieselfde semantiese veld gegroepeer nie:

masels: pampoentiies: waterpokkies:
"Aansteeklike kindersiekte met rooi uitslag as kenmerk." "Aansteeklike siekte; gekenmerk o.a. deur die opswel van speekselkliere."

"Onskuldige velsiekte wat soos pokkies lyk."

'n Voordeel van komponentontleding is dat dit tot 'n sterker patroonmatigheid in die betekenisbeskrywing aanleiding gee. Die leksikograaf wat van kompo- 
nentontleding gebruik maak, word gedwing om paradigmaties te dink en te werk. Dit kan dan daartoe bydra dat betekenisinligting korrek en volledig aangebied word en dat lede van dieselfde veld op 'n soortgelyke manier behandel word.

\section{Probleme in verband met komponentontleding}

Die leksikograaf ondervind dikwels probleme met die identifisering van betekeniskomponente. Dit is maklik om die leksikale items lemoen, suurlemoen, nartjie en pomelo in die semantiese veld "sitrus(vrug)" te groepeer, maar as dit by die identifisering van diagnostiese komponente kom, word die saak ingewikkelder. Vergelyk byvoorbeeld die definisies van hierdie lemmas in die NW:

lemoen:

suurlemoen:

nartjie:

pomelo: "sitrusvrug met baie huisies, soet sap en oranje skil, wat in warm streke voorkom, Citrus sinensis."

"soort sitrusvrug met 'n hoë suurgehalte."

"geurige sitrusvrug met 'n los, dun skil."

"bitterige sitrusvrug, veral as voorgereg geëet, Citrus grandis."

Al vier die lemmas word in die semantiese veld "sitrusvrug" geplaas, maar die aard van die diagnostiese komponente verskil aansienlik. Ter wille van suiwer en effektiewe betekenisoordrag moet soortgelyke lemmas soortgelyke definiense kry. Die hiërargie van komponente in die verklarings van lemmas wat tot dieselfde semantiese veld behoort, moet so ver moontlik ooreenstem.

Die HAT se hantering van die lemmas onder bespreking is ook nie konsekwent nie. Die lemma suurlemoen is nie direk in die semantiese veld "sitrus(vrug)" geplaas nie en die lemma nartjie word nie met behulp van diagnostiese komponente van ander sitrusvrugte onderskei nie. (Die in- of uitsluiting van Latynse terme word nie hier behandel nie.)

lemoen: $\quad$ "Sappige sitrusvrug met soet sap en oranje skil; Citrus sinensis." (HAT)

suurlemoen: $\quad$ Liggeel lemoen ryk aan vitamine $C$, met 'n baie suur sap, gebruik om voedsel smaaklik te maak en vir dranke." (HAT)

nartilie:

"Sitrusvrug; Citrus recticulata (sic)." (HAT)

pomelo:

"Groot, geel sitrusvrug met suur-bitter smaak, wat veral by die ontbyt geëet word. Citrus paradisi." (HAT) 
Die betekenisverklarings van lemoen, suurlemoen, nartjie en pomelo sou soos volg kon lyk:

$\begin{array}{ll}\text { lemoen: } & \text { "sitrusvrug met oranje skil en soet sap." } \\ \text { suurlemoen: } & \text { "sitrusvrug met geel skil en suur sap." } \\ \text { nartjie: } & \text { "sitrusvrug met los, oranje skil en geurige sap." } \\ \text { pomelo: } & \text { "groot sitrusvrug met gelerige skil en bitter sap." }\end{array}$

Sitrusvrug dien as genus in die definisies van die verskillende soorte sitrusvrugte. Sitrus(vrug) moet ook as lemma in die woordeboek opgeneem en verklaar word. Die betekenisverklaring van sitrus kan soos volg lyk:

sitrus:
"algemene benaming vir lemoene, suurlemoene, pome- lo's en ander vrugte van die geslag Citrus. Dit is sappige vrugte met sagte huișies in 'n dik skil, aangetref aan immergroen bome."

Die leksikograaf moet dikwels met komponente werk wat nog nie elders gebruik is nie. Hy kan nie net op gestandaardiseerde universele komponente soos byvoorbeeld [menslik], [manlik], [volwasse] staatmaak nie. Leksikografie vra om ' $n$ produktiewe identifisering van komponente. Dit vereis oorspronklike navorsing en denke.

Nog 'n probleem vir die leksikograaf is die onderskeid tussen diagnostiese en supplementêre komponente. Supplementêre komponente verskaf bykomende inligting wat gewoonlik as ensiklopediese inligting beskou word omdat dit aanvullend is en nie altyd bydra tot die eenduidige betekenisverklaring van die leksikale item nie.

Die leksikale item bank het die volgende betekeniskomponente:

$$
\begin{aligned}
& \text { [+ meubel] } \\
& \text { [+ sitplek] } \\
& \text { [+ vir meer as een persoon }] \\
& \text { [+ of - rugleuning] }
\end{aligned}
$$

Die betekeniskomponent [+ vir meer as een persoon] het 'n diagnostiese funksie, want dit dui die verskil tussen stoel ([+ vir een persoon]) en bank aan. Die betekeniskomponent [+ of - rugleuning] is nie nodig om die betekenis van bank eenduidig te verklaar nie. Dit is 'n aanvullende of supplementêre komponent wat die saak beskryf en daarom uit die definisie weggelaat moet word.

In die HAT word die supplementêre komponent wel in die definisie van bank opgeneem:

bank:

"Meubel met of sonder leuning vir meer as een persoon om op te sit." 
Die NW vermy hier onnodige saakbeskrywing:

bank:

"langwerpige sitmeubelstuk vir 2 of meer persone."

Ander voorbeelde van definisies wat onnodige supplementêre komponente bevat, is die volgende:

skottel:

skottel:

pot:

transistor:

torium:

bilharziase:
"Houer van wisselende vorm, met of sonder ore, om kos in op te dien of om iets in te bewaar, te was, ens." (HAT) "diep of vlak bak van erdewerk of metaal vir die bediening en voorbereiding van kos en vir wasdoeleindes." (NW)

"Houer van erdewerk, metaal e.d., gewoonlik rond en wyd, met of sonder deksel en pote, waarin allerlei stowwe bewaar word." (HAT)

"Betreklik klein, ligte, duursame apparaat om elektriese stroom te versterk en (of) in een rigting te laat vloei, bestaande uit ' $n$ sg. halfgeleier, soos 'n spesiaal bewerkte kristal van germanium of silikon, wat voorsien is van twee geleidende draadjies (elektrodes), op so 'n manier aangebring dat as stroom, bv. van 'n lugdraad, langs een van die draadjies in die halfgeleier ingevoer word onderwyl die kristal deur 'n stroombron (battery) van elders gevoed word, ' $n$ versterkte stroom die halfgeleier by die ander elektrode verlaat - gebruik bv. in radiostelle i.p.v. die gewone radiogloeilampies (elektronbuise)." (HAT)

(chemie, fis.) Grys, radioaktiewe, metallieke element, simbool Th, wat by $1845{ }^{\circ} \mathrm{C}$ smelt, die 90ste posisie inneem $\mathrm{i} / \mathrm{d}$ sisteem van elemente, baie langsaam onder die uitsending van strale omgevorm word $i / d$ eerste van 'n reeks radioaktiewe elemente, wat agtereenvolgens in mekaar oorgaan totdat uiteindelik lood bereik word, en wat dien as grondstof vir die bereiding van 'n vorm van uraan wat bruikbaar is as brandstof in kernreaktors; so genoem na Thor, god van die donder." (HAT)

"Siekte veroorsaak deur slakwurms (Schistosoma) wat in vars water in tropiese streke voorkom; hulle boor deur die vel, trek deur die weefsels tot in die blaas en ingewande waar hul doringagtige eiertiles bloeding veroorsaak en na uitwerping weer 'n nuwe kringloop van besmetting in slakke aan die gang sit; rooiwater." (HAT) 
Alhoewel supplementêre komponente beskou word as aanvullende inligting wat nie noodwendig bydra tot eenduidige betekenisverklarings nie, is daar tog lemmas waarvan die definisies 'n hoeveelheid supplementêre komponente moet bevat - juis ter wille van eenduidige betekenisonderskeidings. Dit is veral by hiponieme dat supplementêre komponente suksesvol gebruik kan word. Om bloot net te sê dat 'n galjoen of 'n baber 'n soort vis (superordinaat) is, is nie voldoende nie. Supplementêre komponente kan aangewend word om tussen die verskillende hiponieme te onderskei.

baber:

baber:

blaasop:

blaasop:

galjoen:

galjoen:

salm:

salm:

snoek: snoek:

"enigeen van verskeie soorte varswatervisse met slymerige vel sonder skubbe en met baard aan die bek." (NW) "Varswatervis sonder skubbe met baard om die bek." (HAT)

"enigeen van verskeie vissoorte wat sy liggaam kan opblaas." (NW)

"Kleinerige, giftige vissie wat sy lyf kan opblaas, veral Tetrodon honckeni, 'n groen vis met geel kolle; bontstefanie. (HAT)

"stompvormige vis, gewild by hengelaars; Coracinus capensis." (NW)

"Eetbare seevis, Coracinus capensis, wat aan die Suid-Afrikaanse kus voorkom en van 1 tot sowat $5 \mathrm{~kg}$ weeg." (HAT)

"vis met lekker rooi of ligroos vleis wat uit die see in riviere opswem om kuit te skiet, Salmo salar." (NW)

"Groot soort seevis, bruinerig van kleur met silwer sye, wat in varswater van riviere aanteel." (HAT)

"groot, roofsugtige, trekkende en eetbare seevis." (NW)

"Byna gladde, getande seevis, Thyrsites atun, blouswart met klein skubbetiies, tot $102 \mathrm{~cm}$ lank, wat aan ons kuste op gesette tye in skole voorkom en as eetvis veral gesout verkoop word." (HAT)

Uit die definisies van vissoorte blyk dit dat daar geen vaste of absolute reël is vir die in- of uitsluiting van sekere betekeniskomponente nie. Die norm wat gestel word, is bloot ' $n$ riglyn, naamlik dat betekeniskomponente wat 'n diagnostiese funksie het in die definisie opgeneem kan word, selfs al is dit saakbeskrywing. Selfs supplementêre komponente is aanvaarbaar, met die voorwaarde dat dit moet bydra tot eenduidige betekenisonderskeidings. Die leksikograaf, as taalkundige wat vertroud is met die leksikale semantiek, moet self oordeel wanneer supplementêre komponente gebruik kan word en hoeveel daarvan nodig is.

Die status van semantiese komponente is in die semantiekteorie nog problematies, juis omdat daar nie vaste reëls of formules neergelê kan word om te 
bepaal watter kenmerke belangriker as ander is nie. Die leksikograaf moet dus in 'n groot mate op sy eie taalgevoel of intuïsie en sy eie toepassing van teoretiese taalkundige beginsels staatmaak.

\section{Definiëring van abstrakte begrippe}

Een van die groot punte van kritiek teen komponentanalise is dat dit slegs met eenvoudige en konkrete begrippe werk. Die voorbeelde wat in die semantiekteorie gebruik word, is eenvoudige begrippe wat relatief maklik in betekeniskomponente verdeel kan word en dit wil voorkom asof daar van moeilike en abstrakte begrippe weggeskram word. Die leksikograaf het die probleem dat hy nie linguistiese kriteria vir die hantering van sodanige begrippe uit die leksikale semantiek kry nie. Samewerking tussen die teoretiese semantikus en die leksikograaf ly soms skipbreuk omdat die teoretikus sy teorie rondom studeerkamervoorbeelde kan bou, terwyl die leksikograaf werklike voorbeelde met behulp van die teorie moet verklaar.

Die feit dat komponentanalise nie die hele leksikon dek nie, beteken nie dat dit heeltemal verwerp moet word nie. Komponentontleding kan gebruik word as hulpmiddel vir suiwer betekenisverklaring by die leksikale items waarop dit wel toegepas kan word. Vir abstrakte begrippe sal dit dalk beter wees om ook ' $n$ ander metode van betekenisontleding en -verklaring te ontwikkel. Die inkonsekwentheid en/of onvolledigheid van definisies van abstrakte selfstandige naamwoorde in die HAT en die NW toon dat hier nog baie ruimte vir navorsing in die semantiek en die leksikografie is. Vergelyk in die verband die definisies van jaloesie, afguns, naywer, nyd in die NW; smart, hartseer in die HAT en blydskap, haat, ekstase in die NW en die HAT.

\section{Binêre opposisies}

Dit lyk asof komponentanalise net met binêre opposisies werk. Leksikale items wat nie noodwendig positief of negatief is nie, maar neutraal staan met betrekking tot ' $n$ bepaalde kenmerk, lewer probleme. Die leksikale item bul het onder andere die kenmerk [+ manlik] en koei is [+ vroulik], maar bees is ongemerk ten opsigte van die kenmerk [manlik]. Binne die geformaliseerde teorie van komponentontleding kan die kenmerk nie net weggelaat word nie, maar dit word byvoorbeeld as [ \pm manlik] gemerk. Die konteks bepaal of die kenmerk [+ manlik] of [- manlik] (laasgenoemde soms geïmpliseer deur [+ vroulik]) aan die leksikale item toegeken kan word.

In die woordeboek werk dit anders. As 'n leksikale item neutraal staan teenoor ' $n$ bepaalde kenmerk, word die kenmerk uit die definisie weggelaat sodat die lemma semanties ongemerk is wat dié kenmerk betref. 
bees:

"herkouende soogdier met gesplete hoewe, gew. met horings, aangehou vir melk- en vleisproduksie en as trekdier." (NW)

bul: "manlike bees; stier." (NW)

koei:

"vroulike bees wat al gekalf het." (NW)

Die feit dat komponentontleding skynbaar met binêre opposisies werk, bring probleme mee as dit kom by gradeerbare teenoorgesteldes, soos byvoorbeeld warm en koud wat tussen hulle ook nog lou en koel het. In 'n poging om die gradeerbare verskille te formaliseer, word daar van syfers gebruik gemaak om die skaalwaardes aan te dui. Die syfers $1,2,3$, ens. in [1 temperatuur], [2 temperatuur], [3 temperatuur], ens,, verwys na verskillende skaalwaardes van die onderskeidende kenmerk [temperatuur] (De Stadler 1989: 111).

Ook die relatiwiteit van sekere betekeniskomponente is 'n probleem vir semantici. Groot en klein, oud en jonk, soet en suur het nie noodwendig vaste betekeniswaardes nie. 'n Soet suurlemoen kan byvoorbeeld suurder wees as 'n suur lemoen en 'n groot mier kan steeds as klein beskryf word. Volgens De Villiers (1975: 65) het dit "min waarde om iets soos grootte as onderskeidende kenmerk te kies want dit lewer nie so maklik 'n plus of minus nie, grootte is immers 'n betreklike begrip ... Ons moet dus vermy om gradeerbare verskille as kenmerke te kies."

Die leksikograaf kan formaliseringsprobleme ten opsigte van die gradeerbaarheid en relatiwiteit van betekeniswaardes in 'n mate omseil omdat 'n woordeboekdefinisie ' $n$ informele weergawe van betekeniskomponente is. In sy omskrywing van betekeniskomponente kan die leksikograaf gebruik maak van beskrywende woorde soos bywoorde en byvoeglike naamwoorde om die relatiwiteit van 'n begrip aan te dui. Daarby kan voorbeeldmateriaal (sitate en poëme) aangewend word om die betekenisverklaring toe te lig. Vergelyk die volgende voorbeelde:

klein: "Betreklik gering van a fmeting; nie groot nie." (HAT)

groot: $\quad$ "Van meer as normale afmeting." (HAT)

kort: "1a. Van geringe lengte vergeleke met die normale, gemiddelde: in Kort rok, mannetile. (...) Kort bene, vingers, naels, horings." $1 \mathrm{~b}$. Wat nie die nodige maat bereik nie, maar nie noodwendig van geringe lengte nie: Die kortste pad kies. Jy het die draad te kort geknip." (HAT)

lank: "Wat 'n sekere lengte het; wat in die lengte groot is: 'n Lang man. Die pad is lank en eentonig." (HAT)

koud: $\quad$ "met 'n lae warmtegraad; nie warm nie." (NW)

koel: $\quad$ "aangenaam, fris, of nie warm genoeg nie." (NW)

lou: $\quad$ "tussen warm en koud, effens warm." (NW)

warm: "met 'n taamlike hoë temperatuur, minder as heet." (NW)

heet: "gekenmerk deur 'n hoë temperatuur; baie warm." (NW) 


\section{Slot}

$\mathrm{Al}$ is daar heelwat probleme rondom komponentontleding, mag die waarde van hierdie leksikografiese instrument nie onderskat word nie. Komponentontleding is ' $n$ nuttige hulpmiddel vir die leksikograaf om ' $n$ onderskeid te tref tussen komponente wat leksikale betekenis help vorm en komponente wat as oorbodige ensiklopediese inligting beskou kan word. Deur middel van komponentontleding kan onnodige ensiklopediese inligting (saakbeskrywing) in woordeboekartikels vermy word. Met komponentontleding word daar gepoog om sistematies te werk (Lehrer 1974: 46). Dit dra by tot volledige, duidelike en eenduidige betekenisverklarings wat die verklarende handwoordeboek vir die gewone woordeboekgebruiker meer toeganklik maak.

\section{Verwysings}

\section{Woordeboeke}

De Villiers, M. e.a. 1987. Nasionale Woordeboek. Kaapstad: Nasou.

Fowler, H.W. en F.G. Fowler (Reds.). 19645. The Concise Oxford Dictionary of Current English. Oxford: Oxford University Press.

Odendal, F.F. e.a. 19792. Verklarende Handwoordeboek oan die Afrikaanse Taal. Doomfontein: Perskor.

\section{Ander bronne}

Combrink, J.G.H. 1979. Die sesde deel van die W.A.T. Standpunte 140, 32(2): 49-64.

Crystal, D. 1986. The Ideal Dictionary, Lexicographer and User. Ilson, R. (Red.). 1986: 72-81.

De Stadler, L.G. 1989. Afrikanse semantiek. Johannesburg: Southern Boekuitgewers.

De Villiers, M. 1975. Die semantiek van Afrikens. Kaapstad: HAUM.

Gouws, R.H. 1985. Die sewende deel van die Woordeboek van die Afrikanse Taal. Standpunte 178, 38(4): $13-25$.

Gouws, R.H. 1989. Leksikografie. Pretoria: Academica.

Ilson, R. (Red.). 1986. Lexicography: An Emerging International Profession. Manchester: Manchester University Press.

Kipfer, B.A. 1984. Workbook on Lexicography. Exeter: A. Wheaton and Co. Ltd.

Leech, G. 1974. Semantics. Harmondsworth: Penguin.

Lehrer, A. 1974. Semantic Fields and Lexical St nucture. Amsterdam: North-Holland.

Louw, J.P. (Red.). 1985. Lexicography and Translation. Kaapstad: Bybelgenootskap van S.A.

Louw, J.P. 1985a. A Semantic Domain Approach to Lexicography. Louw, J.P. (Red.). 1985: 157 197.

Louw, J.P. 1991. Semantiese norme in die leksikografie. S.A. Tydskrif vir Taalkunde 9(4): 115-118.

Nida, E.A. 1979. Componential Analysis of Meaning. Den Haag: Mouton.

OdendaI, F.F. 1979. Plus positief en plus negatief. Tydsknif vir Geesteswetenskappe 19(1): 24-41.

Zgusta, L. 1971. Manual of Lexicography. Den Haag: Mouton. 


\section{Resensies / Reviews}

\section{Woordeboeke en Woordelyste / Dictionaries and Word-lists}

Chambers Schoolbag Dictionary including Southern African usage and pronunciation, 1st edition 1986, 2nd impression 1990, $134 \mathrm{pp}$. ISBN 0 86486-046 3. Cape Town, Johannesburg: David Philip Publishers. Price R14,85.

Most dictionaries are small, bulky books. This one is not. It has large pages and is light and slim enough to fit into a schoolbag, so that it can be ready to hand both at school and at home. There is a strong likelihood that it will be used often.

It is practical for other reasons. First, there is an obvious economic advantage to producing a dictionary on cheaper paper. Better paper would have made the dictionary more attractive, but this way the costs are kept low. The paper and the binding are good enough to withstand average use during the middle and secondary school years of a particular user. The second clear advantage is that a low budget dictionary of this kind can be updated, adapted or expanded on a regular basis.

The claim in the preface that this dictionary will serve the needs of "all middle and secondary schools in Southern Africa", appears to indicate that the compilers had second-language users in mind. Bill Holderness and others associated with the University of Bophuthatswana are well-placed to provide informed opinions on the needs, motives, expectations and performance limitations of such users. It should also be said that, although it is a school dictionary, it is not narrowly classroom-orientated. There are more than 39000 entries, 1500 of which may be described as "South African".

A number of strategies are used for economy. There are the obvious ones of providing only irregular past tense and past participle forms of the verb, a pronunciation guide only where the spelling of the word does not give a clear indication of pronunciation, and plurals only when these are not formed by adding -s. These are sound decisions. The introductory section is also kept as short as possible. As Lemmens and Wekker (1986) have shown, users of a dictionary are unlikely to consult detailed discussion in an introduction. In this case, "How to use this dictionary" is clear and crisply presented, and users should find it most accessible.

Other strategies seem less wise. One such is the unduly prescriptive decision to use the -ize form only of words that can be spelt either -ize or -ise. The other form has strong support, and is officially preferred by the English Acade- 
my of Southern Africa. As a result, the desire to simplify and give a firm lead may well issue in confusion and the creation of a new shibboleth.

Another less happy strategy relates to vocabulary. Since the 1920 s vocabulary building has generally been viewed as one of the most important elements in foreign and second language learning (Richards and Rogers 1986). In line with the view that foreign and second language learners need simple, accessible definitions, this dictionary clearly and economically defines a great number of words. I checked cousin, technology, definition, memory, drive, assault, negotiate, economic, consequence and imperialism, and found the definitions clear and helpful.

However, the potential users of the book will not always easily find the explanations they most need. Generally, one headword is used for words which have more than one meaning or grammatical function, and semicolons, italics and parentheses are used to distinguish these meanings. This can be confusing. For example:

sound $n$ anything that can be heard, a noise; a distance from which something may be heard: within the sound of the sea; a narrow passage of water, esp one connecting two seas. $-v$ to strike one as being. That sounds awful; (with like) to resemble in sound. That sounds like Henry's voice; to cause to make a noise. He sounded his hooter; to examine by listening carefully to: to sound the patient's chest; ....

The difficulties are compounded by having a full stop before an example, which in turn is separated from the next definition by a semicolon.

Another difficulty concerns the use of quotations. The compilers of the Chambers Schoolbag Dictionary (CSD) are aware of the value of illustrations. They make some use of short invented phrases to support definitions in providing basic meaning. But they stop there. Burchfield (1986: 19) suggests the larger possibilities when he says that while "quotations support and confirm the definitions", they also add "contextual dimensions of their own". Some of these are specified by Landau (1984: 166):

Illustrative quotations can convey a great deal of information about collocation, variety of usage (degree of formality, humorous text or sedate context), connotation (affective implications), grammatical context (if verb, does it take an indirect object?) and, of course, designative meaning.

It is worth examining the usefulness of the CSD in these terms.

Since it does not illustrate the collocation of words, the CSD is not able to clarify the differences between words like react and respond:

react $v$. to act or behave in response to something which is done or said; to undergo a chemical change 
respond $v$. to answer; to act or react in response to (something or an action). The baby responded to her new toy with a smile. I smiled but she did not respond; to show a reaction to esp as a sign of improvement. He responded to treatment.

Here the problem is exacerbated by the fact that each of the words is defined as if it were synonymous with the other. The same tendency to define one word in terms of another can be seen in the definitions of pile and heap.

Variety of usage is not addressed either. For instance, there is no reference to the degree of formality of a word. Affective implications are largely ignored. And the compilers have not included any slang or colloquial terms. These omissions obviously limit the usefulness of a dictionary that claims to offer "comprehensive coverage of words pupils are likely to encounter in readings for school and in wider reading". A few examples will suggest the nature of these weaknesses. The entry for miscegenation makes no reference to offensive or judgemental flavour. The one for fellow does not indicate that the word may be dismissive ("that fellow") or reveal a close relationship ("my fellow" = boyfriend). And the one for student makes no reference to its being the preferred term to pupil in the South African black community. Finally, there is no indication in the entry for adorable that it may have a trivial flavour when it is used informally in sentences like " $\mathrm{O}$, what adorable curtains."

There are also troubling deficiencies in the treatment of grammatical and idiomatic aspects. For example, learners are given no way of checking such basics as which preposition would normally follow a particular verb.

In many cases, illustrative examples are not used at all. This arises from the obvious and laudable desire to keep this dictionary as slim as possible. However, while it can be argued that most of the entries of this kind provide clear, economical definitions, there are instances where this is not the case, as in the entry for fellow below.

fellow $n$ an equal; one of a pair; a member of a learned society, a college etc.; a man, boy. $-n$ fellowship state of being on equal terms; friendship; an award to a university graduate.

Here, apart from the obvious comment that it would have been better to place the most common of the meanings (the fourth one given) first, the various meanings of fellow are not clearly delineated. The first two meanings apply only in certain idiomatic phrases which are not even hinted at here. The third definition is simply wrong: most members of colleges are not Fellows, and learned societies usually distinguish between Members and Fellows (e.g. MRCS and FRCS). Finally, it seems a serious limitation that the definition of fellowship makes no reference to shared interest or activity, nor to the common religious meaning. 
These criticisms are substantial. Nevertheless, CSD represents a sensible and useful reference tool. Its claim to be the "perfect reference companion" cannot be sustained, but it does offer easy access to simple definitions of a large number of words. While other dictionaries such as the Collins COBUILD Dictionary and the Longman Dictionary of Contemporary English may more justifiably be described as "comprehensive reference works", this dictionary is more likely to be widely used. Its slim.format and inexpensive pricing make it a realistic choice for the majority of pupils.

\section{References}

Burchfield, R. 1986. The Oxford English Dictionary. Ilson, Robert (Ed.). 1986: 17-27.

Ilson, Robert (Ed.). 1986. Lexicography: An Emerging International Profession. London: Manchester University Press and the Fulbright Commission.

Landau, Sydney I. 1984. Dictionaries: The Art and Craft of Lexicography. New York: Scribner Press.

Lemmens, M. and H. Wekker. 1986. Grammar in English Learners' Dictionaries. Tübingen: Niemeyer.

Richards, J.C. and T.S. Rogers. 1986. Approaches and Methods in Language Teaching: A Description and Analysis. New York: Cambridge University Press.

Elaine Ridge University of Stellenbosch South Africa

G.R. Dent (Compiler) and C.L.S. Nyembezi (Editor). Compact Zulu Dictionary. Eng.-Zulu; Zulu-Eng., 5th edition 1990, 2nd impression 1992, 152 pp. ISBN 0796002657 . Pietermaritzburg: Shuter and Shooter. Price R13,65.

\section{Introduction}

The dictionary is small, condensed and portable. One can keep it in one's back pocket. This makes it a very handy publication for quick reference by a learner of Zulu or English as the case may be.

The dictionary appears to have been compiled for the purpose of assisting nonZulu speakers to learn Zulu.

The main title Compact Zulu Dictionary is somewhat misleading. This is a bilingual dictionary as the sub-title English-Zulu/Zulu-English shows. 


\section{Organisation of the Dictionary}

\section{$2.1 \quad$ Identification of Words}

The compiler of the dictionary has attempted to present Zulu nouns in their complete form (prefix + nounstem). It appears that his aim in doing so is to assist the user of the dictionary to identify nouns easily. This is good as far as it goes but Zulu nouns occur in varying contexts in the sentence and are likely to baffle the uninitiated when they occur in the locative, agentive, vocative, possessive, instrumental and other forms.

This is exemplified by the needless entry of locative, instrumental and other forms of Zulu nouns in the dictionary. These entries clutter the dictionary with grammatical forms of nouns and confuse rather than facilitate the user's task of learning the Zulu language.

The verbs have been entered in the imperative. This arrangement is flawed on two counts, firstly, it disregards the fundamental syntactic structure of sentence concordance.

An impression could be created to the user of the dictionary that verbs always occur in the form in which they have been entered in this dictionary. To suggest, as the compiler does, that "concords are prefixed to the different parts of speech" is misleading. A part of speech comprises the complete word (i.e. prefix + stem). The word stem alone is not the distinguishing factor of a part of speech. Secondly, only activity and achievement verbs are amenable to use in the imperative. The entering of verbs in the imperative does not accommodate stative and process verbs.

The compiler of the dictionary assumes that the adjectives in English can be classified in a corresponding part of speech in Zulu. Compilers of translation dictionaries would be well advised to give the part of speech of the corresponding English adjectives in Zulu or use some method of showing the difference of classification of the adjectives in English and Zulu.

The classification of numerals as an independent part of speech is a misconstruction. These are nouns in Zulu. They may be classified as nouns and adjectives in English much depending upon their use in the sentence.

The entry of the possessive forms of the absolute pronoun for all classes in the dictionary testifies of the lack of economy in this dictionary (for example, practically the whole of page 129 is devoted to this form of the nominal). This is certainly not the function of a dictionary.

\subsection{Definition of Words}

The foregoing paragraph touches upon the primary purpose of a dictionary. Is the main purpose of a dictionary to define meanings of words or simply to give equivalents or translation of words? 

lems:

A translation dictionary is confronted by, inter alia, the following prob-

(1) The paucity of technical terms in one of the languages, Zulu in this case. This results in inelegant descriptions of actions, phenomena and matter rather than providing a direct equivalent word.

(2) The difference in the word and sentence structure in the two languages. Many English words, particularly adverbs, adjectives and interrogatives, can only be defined in terms of corresponding Zulu stems. This could impede a rapid mastery of the Zulu language by a foreigner. Sentence concordance only occurs in Zulu and varies according to the noun prefix used. This also complicates the use of the dictionary as the word sought by the user of the dictionary may not be entered in the form in which it is encountered in use.

(3) Difference in suprasegmental structure. English words have stress and Zulu words have tones. Failure to indicate these in the entries of a dictionary does not facilitate pronunciation. The method suggested by the compiler, i.e. asking native speakers of English or Zulu, as the case may be, to pronounce "exceptional or unusual words" is impractical.

(4) The selection of entries. This is very important for the compilation of a compact dictionary. 'Ideally, it would be helpful to select a vocabulary that includes commonly used words, expressions and other items for a compact dictionary.

\title{
3. Definitions
}

The definitions used in the Compact Zulu Dictionary are satisfactory.

A more complete definition of many English adjectives could have enhanced the quality of this work.

\author{
A.C. Nkabinde \\ University of Zululand \\ South Africa
}


G.R. Dent and C.L.S. Nyembezi (Compilers). Scholar's Zulu Dictionary. Eng.-Zulu; Zulu-Eng., 2nd edition 1988, 3rd impression 1991, 519 pp. ISBN 079600111 1. Pjetermaritzburg: Shuter and Shooter. Price R29,05.

\section{Introduction}

The introduction to the Scholar's Zulu Dictionary is practically identical with that of the Compact Zulu Dictionary. The only additional information is that synonyms with phonological variants are defined under a single entry and some attention is also given to avoiding unnecessary listing of verbal extensions. Further, a list of abbreviations used in the identification of the various entries in the dictionary is also given.

The Scholar's Zulu Dictionary is a translation dictionary explaining Zulu words in English and English words in Zulu.

\section{Entries}

The dictionary contains a very good selection of English vocabulary comprising a large number of commonly used words. The acquisition and mastery of an equivalent number of Zulu words would give the user a very good vocabulary in the latter language.

There is an imbalance in the quantity and quality of entries in the two languages. There are more English vocabulary items than Zulu ones. A balance in the number of entries from the two languages would have enhanced the quality of the dictionary.

The dictionary has a very large collection of Zulu idiomatic expressions. It is one of the largest I have seen in a Zulu dictionary.

There is some inconsistency in the entry of idioms. The key verb stem is not always given in the infinitive form in the Scholar's Zulu Dictionary.

\section{3. "Parts of Speech"}

The entry of Zulu parts of speech presents problems in this dictionary. The inclusion of derivative nouns and verbs in a Zulu dictionary is unwieldy and cumbersome.1 Ideally, only those derivatives that have attained an independent meaning from the primary word should be entered.

The inclusion of demonstratives and locative demonstratives in the dictionary is inappropriate. These can be described in the preface of the dictionary.

The dictionary fails to distinguish nouns with full prefixes from those shorn of the first syllable in noun classes $m a-, l u-$, and $b u-$. The latter are identi- 
fied either as adverbs or relatives, apparently without any connection with their counterparts viz. primary nouns. ${ }^{2}$

\section{Homonyms}

The homonyms ${ }^{3}$ such as -funda, -futha, gquma, -qweba, -thunga, -hlahla are classified as synonyms. This classification causes two types of problems:

(1) the conflation of variant forms of verbs, e.g. the mergence of a derivative form with a primary one. The following stems illustrate this:

fela: 1. die for/on behalf of (derived)

2. spit (primary)

fisa: 1. fake death (derived)

2. desire/covet (primary)

(2) the fusion of variant types of verbs, e.g.

-futha: 1. blow / inflate (activity verb)

2. throb (pain) (stative)

-hlahla: 1. cut down (activity verb)

2. clarify (stative)

\section{Conclusion}

Notwithstanding some negative features noted above, the Scholar's Zulu Dictionary is a worthy contribution to the technique of compiling translation dictionaries.

\section{Notes}

1 The entry of so-called adverbs, locatives, conjunctives, pronouns, the relative, adjective etc. in the dictionary is unnecessary.

2 amankonovana, amanzi, ulucezu, ulukhuni, ubushelelezi, and ubuthaka show a clear relationship with the derivations.

3 Each of these stems comprises a pair.

A.C. Nkabinde

University of Zululand South Africa 
P.A. Joubert. Bilingual phrase dictionary / Tweetalige frasewoordeboek $(E-A)^{1}$, 1st edition 1992, xiii + 331 pp. ISBN 0624031497 hard-cover; ISBN 0624030806 soft-cover. Cape Town: Tafelberg. Prices: R39,95 hard-cover; R24,95 soft-cover.

Rarely can a first-rate dictionary be written for anyone and everyone who might be interested in the language or languages with which it deals. Generally, good dictionaries are tailored to specific audiences: an all-Xhosa dictionary for primary-school pupils who are native speakers of Xhosa, an EnglishAfrikaans dictionary for adult native speakers of English, an Afrikaans-English medical dictionary for medical personnel who are native speakers of Afrikaans, etc. If a dictionary is adequate for anyone and everyone, its potential usership is inevitably small and well defined. A Sumerian-English dictionary, for example, would be of interest to only a small number of people: no one now speaks Sumerian, hence no Sumerian-using audience, who might want to learn English, need be served; only a small group of highly specialized researchers are interested in Sumerian, hence the potential audience for such a dictionary is a well defined group; and all of those needing a Sumerian dictionary can, presumably, read English. In contrast, a general Spanish-English dictionary suitable for everyone and anyone interested in those two languages cannot be written because diverse groups of people need such a work.

Thus, at one extreme, we have Sumerian - a language which no one uses today, a language in which few people are interested, and a language which attracts only a small, homogeneous group - and, at the other extreme, English and Spanish - two widely used languages with diverse groups of people interested in them. Afrikaans lies somewhere between those two extremes: much more used than Sumerian, but much less used than English or Spanish.

The different status of English and Afrikaans in the world today must therefore be considered when a dictionary involving both of those languages is being planned, though that is not necessarily a final consideration. If the compiler of such a work decides to write it for all English-speakers and all Afrikaans-speakers, the two languages indeed continue to be on an unequal footing (a fact which will entail certain further decisions), but if the dictionary is planned only for South Africans, then the two languages will be on an equal footing, for in South Africa the two are used more or less to the same extent.

An example will illustrate the different approaches. At cater, the dictionary under review here contains three subentries: cater for, cater for all tastes, and cater to s.b. Those are South African usages (of British English origin). In American English, cater always takes the preposition to, hence only the third subentry will be familiar to speakers of American English. If this dictionary is intended for speakers of South African English, British English, or both varieties, all is well so far, but if it is intended for speakers of American English (or, for speakers of that variety too), an adjustment would be needed to cater to the needs of speakers of American English. 
Given the fact that Afrikaans-speakers learning English learn the South African variety (and only specialists go on to study non-South-African varieties of English), it is natural that South African English would be the variety of English used in this dictionary. And in view of the fact that contemporary written Afrikaans is quite uniform, the question of what kind of Afrikaans to use in this dictionary should probably hardly ever come up. The only serious question facing the compilers of a dictionary involving English and Afrikaans is, therefore, what kind of English to use. Since most anglophones interested in Afrikaans are speakers of South African English, it seems reasonable to pick that variety. Both of those expectations are met here: the Afrikaans is Contemporary Afrikaans and the English is Contemporary South African English (in both cases, including slangisms and other informalisms). In effect, then, this is a dictionary of two languages used in South Africa written for South Africans. ${ }^{2}$

Another consideration for the compiler of such a dictionary is the function which Afrikaans and English may each have as a path to learning the other language. Say a speaker of Greek wants to learn Afrikaans. Afrikaans teaching materials for Greek-speakers are presumably non-existent, hence a third language must serve as a path to Afrikaans. Most Afrikaans teaching materials are written either in English or in Dutch. Since Greek-speakers would be much likelier to know English than Dutch, English is for most Greek-speakers the only path to Afrikaans (unless the direct method, without any path language, is used). In contrast, Greek-speakers wanting to learn English have a wide range of materials at their disposal, with many different path languages, including Greek, available to them (as well as material following the direct method). Hence it is improbable that any Greek-speaker would choose Afrikaans as a path to English. The compiler of a bilingual dictionary should therefore give thought not only to the considerations discussed in the first five paragraphs of this review, but also to the possibility that such a work might help speakers of third languages. ${ }^{3}$

A dictionary should not only be tailored to a specific audience or audiences. The compiler ought to consider what the dictionary can do for that audience or audiences. Will a dictionary involving English and Afrikaans allow English-speakers to use Afrikaans passively; allow English-speakers to use Afrikaans actively; allow Afrikaans-speakers to use English passively; allow Afrikaans-speakers to use English actively? Will it try to achieve just one of those goals or two, three, or all four? Naturally, the more goals, the larger the dictionary must be and the harder it will be to put together.

Responsible dictionary-compilers are expected not only to give careful thought to those questions, take explicit decisions, and give effect to their decisions, but also to tell potential users of their works precisely what they can expect from them. Accuracy in advertizing is no less important than accuracy in the dictionary itself. Unfortunately, however, exaggeration, half-truths, and worse are the hallmarks of Madison Avenue and few are the dictionaries which actually deliver everything they promise. Furthermore, users of dictionaries 
rarely speak up if they find they have been shortchanged. Whereas consumers in advanced countries are by now accustomed to complain if the toaster or refrigerator they have bought does not do what the manufacturer claims it can do, few people who buy dictionaries ever think of complaining to publishers (except to protest the inclusion of "dirty words" and other "illiteracies," which is a different issue).

The cover of the book under review is fully bilingual (and both languages are given equal prominence) except for the fact that it contains the words English-Afrikaans but not Engels-Afrikaans. That suggests that the dictionary is aimed more at the English-speaker than at the Afrikaans-speaker, but let us not come to that conclusion on the basis of a single minor inequality in the wording.

The spine of the book is fully bilingual (here, we find only $E-A$, which can be interpreted as both English and Afrikaans). The back cover is fully bilingual.

The title page (given in the heading of this review) is fully bilingual, but it should have been fleshed out, with (English-Afrikaans) added in the English part and (E-A) fleshed out to. (Engels-Afrikaans) in the Afrikaans part.

Turning to the preliminaries, we find that the preface (Preface and Voorwoord) and list of abbreviations (Abbreviations/Afkortings) are in both languages, but the Guide to the use of the dictionary is in English only, as is the half title (Bilingual phrase dictionary) appearing on the page before the first page of the dictionary. That slights Afrikaans.

At the end of the dictionary, we find a Toeligting by die gebruik van die woordeboek (= the Afrikaans equivalent of the Guide to the use of the dictionary) and seven blank pages headed Notes/Aantekenings. The location of the Afrikaans guide appears to strengthen our feeling that this dictionary was planned more for English- than for Afrikaans-speakers, but, again, let us reserve final judgment, for it is also possible that the Toeligting was put there in order to be more easily accessible (the user wanting the Guide will know that it is at the beginning of the book and the user wanting the Toeligting will know that it is at the end). If so, ALL PARTS of the Afrikaans preliminaries should have been EITHER at the beginning OR at the end of the dictionary and ALL PARTS of the English preliminaries at the other end. Another possibility would have been to place all of the Afrikaans and all of the English preliminaries at the beginning, either first in one language and then in the other (with, preferably, differently colored pages for each language so that the user could quickly flip to the desired language) or with English on one page and Afrikaans on the facing page.

All in all, then, we seem to be getting three subtle hints that this dictionary is geared a bit more to the English-speaker than to the Afrikaans-speaker.

This is an English-Afrikaans dictionary, hence a one-way bilingual dictionary. Such a work can be useful to speakers of both languages, but in different ways: English-speakers can use it to speak and write Afrikaans; and Afrikaans-speakers can use it to understand spoken and written English. The 
English-speaker CANNOT use such a dictionary to understand Afrikaans (for that purpose, an Afrikaans-English dictionary is needed) nor can the Afrikaans-speaker, except in a limited way, use it to speak or write English (for that purpose, an Afrikaans-English dictionary is needed). ${ }^{6}$

We therefore question the claim made on the back cover that this dictionary is designed for those who want to "speak and write idiomatically correct English and Afrikaans." Afrikaans, yes, but English, only in minor ways. Furthermore, the dictionary will help English-speakers, not Afrikaans-speakers, who want to speak and write Afrikaans. Afrikaans-speakers wanting to speak and write their language will consult MONOLINGUAL Afrikaans works. Speakers of language $x$ wanting to use that language have no need to use $y$ as a path language, unless monolingual dictionaries of language $x$ are not available (which is not the case for Afrikaans). Thus, the claim (again from the back cover) that this dictionary will help people to "Praat en skryf idiomaties korrekte Afrikaans en Engels" (which is patently aimed at the Afrikaans-speaker because it is stated in Afrikaans) is ALMOST COMPLETELY FALSE: Afrikaansspeakers cannot use this dictionary for speaking and writing Afrikaans and it will serve them only in a marginal way (see note 5) for speaking and writing English.7 The wording on the back cover should be: Speak and write idiomatically correct Afrikaans and Verbeter $u$ begrip van gesproke en geskrewe Engels.

The publisher announces that "an Afrikaans-English version is being planned as well" (p. [vii]). Only when that volume appears will the dictionary help both English- and Afrikaans-speakers to use both languages both passively and actively. ${ }^{8}$

The publisher's leaflet accompanying review copies says that "it has been established that people frequently do not use a dictionary to look up a word they need (or only the word) but to see how it can be used in a sentence - for instance which verb or preposition or adjective, etc. goes with it. Bilingual desk dictionaries do cater for this need to some extent, within the limits of their available space. Since such dictionaries have to give so much other information at the same time, however, there is room for an 'idiomatic dictionary' that concentrates on this one task and can therefore offer more. [...] It does not wish to compete with existing English-Afrikaans dictionaries, but to be a useful supplement to them. Even the outward appearance of the Bilingual phrase dictionary shows that Tafelberg wants it to be recognised as belonging to the same family as the Tweetalige woordeboek/Bilingual dictionary."

Yes, lexicography is constantly obliging dictionary-makers to supply ever more information (looking at older dictionaries in the light of today's requirements, we see that most of them were nothing more than skeletal word lists). Hence good dictionaries have become ever bigger and ever more specialized. Thus, for example, when lexicographers realized that a dictionary should deal with lexemes larger than the orthographic word and that they should indicate government (what preposition, for example, does this or that noun, verb, or adjective take?), the first impulse was to compile supplemental dictionaries. 
Later, it became evident that supplemental dictionaries should be merged with those concentrating on orthographic words (because the user should not have to look in more than one place for information about the same lexeme). Yet here two problems arise, one practical and the other commercial.

The practical problem is that if more information has to be supplied, the entries will be longer. As any habitual user of dictionaries knows, nothing is more forbidding than having to search through a long entry in pursuit of a certain subentry, subsubentry, subsubsubentry, etc. The problem was thus one of organization. Some compilers, especially in the United States, choose to solve that problem by breaking up a long main entry into main entries, that is, by converting subentries, subsubentries, etc. into main entries. For example, instead of listing two-part verbs with make (like make into, make out, and make over) as subentries of make, they list each of them as a main entry. That helps the user, but the dictionary becomes larger because main entries take up more space than the corresponding number of subentries. Another solution is the menu (Tono 1992). A third solution is more efficient use of typefaces and other visual aids to take users as quickly and efficiently as possible right to the desired (sub...)subentry. A fourth solution is to computerize dictionaries and in that way to pass the task on to the search command.

And the commercial consideration: the larger the dictionary, the more expensive it is, hence fewer people will buy it. Realizing that the average person would rather spend $x$ amount of money on dictionary $a$ and $y$ amount on dictionary $b$ rather than $x+y$ on a dictionary which contained everything in dictionaries $a$ and $b$, publishers usually prefer to put two dictionaries on the market, one being the larger dictionary, which concentrates on orthographic words, and the other being the smaller dictionary, which concentrates on multiword lexemes and government. Yet having to look in two dictionaries takes more time than looking through a long entry in one dictionary, hence the best solution is to merge both the general and supplemental dictionaries - something which Tafelberg, at least now, prefers not to do.

$* * * * *$

Coming to the heart of the work, the 325 pages of alphabetically arranged entries, we find it superbly arranged: there are no blind references; there are no hidden entries; there are no cross-references which cite an entry head in a spelling different from the one actually used in the entry head. Several ingenuous typographical devices have been devised to provide a maximum of information in a minimum of space (see pp. $x$-xiii or 328-331). 9

This dictionary offers rich material. The choice of English usages is almost always excellent. We may question whether the fair/gentle sex, the softer/weaker sex, HE made an honest woman of her, and the little woman should appear in a dictionary like this one, i.e., in a less than complete record of English. Is any- 
one still using those sexist terms? Should their use not be discouraged? If listed, they should at least be labeled as condescending or sexist.

For the student of South African English who, like the undersigned, may not always have easy access to the latest usages, this dictionary is useful in that it documents the growing influence of American English. It lists, for example, the bottom line is (South African English the bottom line < general American English < Eastern Ashkenazic American English = translation of Eastern Yiddish di untershte shure [Steinmetz 1976 and Gold 1981] ${ }^{10}$ ) and come to the nittygritty / get down to the nitty-gritty (South African English nitty-gritty < general American English < Black American English < ?). The dictionary can also be used to document the confluence of British and American English in South Africa: it lists, for instance, both be affiliated to (= the older South African usage, of British origin) and be affiliated with (= the newer usage, of American origin). Certain verbs, like agonise / agonize and organise / organized, are listed in both spellings, a possible example of British and American influence (since -ize is not unknown for older British English, it remains to be seen how this spelling came to South Africa; the same may be said of Australian English, where both variants are likewise found).

Since one of the aims of this dictionary is to teach correct Afrikaans, an entry could be added for more or less: the Standard Afrikaans equivalent is $\mathrm{min}$ of meer, but, under English influence, the substandard form meer of min is also used." That would encourage English-speakers to use the Standard Afrikaans form. To encourage Afrikaans-speakers to do so, a monolingual Afrikaans work would be the most efficient means.

The translations in this dictionary are in almost every case just as superb as its arrangement. One might entertain a doubt only here and there, for example with respect to have political/etc. muscle 'politieke/ens. invloed hê'. Is not muscle much more than mere influence (= Afrikaans invloed)? Perhaps 'baie politieke/ens. invloed hê' would be better, unless something more graphic could be found.

The only chief fault which this reviewer finds in the Bilingual phrase dictionary / Tweetalige frasewoordeboek $(E-A)$ is the language of the sense discriminations. Say an English-Afrikaans dictionary has entries for drive and set. These two English words have so many meanings and so many Afrikaans equivalents that English-speakers need guidance in choosing the appropriate one. In contrast to English-speakers, Afrikaans-speakers require no such guidance because, as speakers of Afrikaans, they will know which equivalent to choose. Thus, an English-speaker wanting to translate into Afrikaans a sentence referring to tennis like "Smith won the first set" will need a sense discrimination (tennis) next to the appropriate Afrikaans equivalent. In contrast, Afrikaans-speakers need no help: if they have come across an English sentence like "Smith won the first set," they have most likely not come across it in isolation but in a context where it is clear that set is a tennis term. That is, whereas the English-speaker knows the meaning of English set in a tennis context and 
wants to know its Afrikaans equivalent, the Afrikaans-speaker does not know the meaning of set in a tennis context but will presumably recognize its Afrikaans equivalent upon finding it under set.

Consequently, sense discriminations are intended for the speaker of the source, not the target, language. If so, they should be in the source, not the target, language. Yet this dictionary does just the opposite: all of the sense discriminations are in Afrikaans. ${ }^{12}$

And often there are fewer than the optimal number of sense discriminations. We see that in the Afrikaans equivalents given for set up s.t. (quoted in note 11), where eight meanings of this verb are translated, but only five of them are discriminated. Another example of the lack of meaning discriminations is seen at take in s.t., for which these translations are offered:

'iets inneem; iets verstaan/begryp/volg; iets raak sien; iets insluit/ om$\mathrm{vat} /$ inbegryp; iets ontvang; iets laai/inlaai/inneem/opneem; iets glo/ sluk; iets verklein (klere); iets aanneem (wasgoed); iets (ver)minder (seil)'

Thus, eight meanings are translated, but only the last three are discriminated. The Afrikaans-speaker will know whether to pick, for instance, 'raak sien' or 'ontvang' even if no sense discriminations appear, but the English-speaker needs guidance.

Therefore, whereas three peripheral aspects of the dictionary appear to suggest that the compiler planned it more for the English-speaker than for the Afrikaans-speaker, the dictionary itself favors the latter. It would seem, then, that the three subtle hints mentioned above are merely fortuitous and that the compiler's actual intent was to serve the Afrikaans-speaker more than the English-speaker.

All in all, then, we gain the impression that this dictionary could have been better planned, it tries to do too much, it serves the English-speaker more than the Afrikaans-speaker in three extremely minor respects, and it serves the Afrikaans-speaker more than the English-speaker in a major respect.

To conclude, reviewing a dictionary means not only scrutinizing the lexical material which it provides, but also examining its front matter, back matter, covers, spine, jacket, and title, as well as the publisher's advertizing for it.13 Most of the present review dealt with those peripheral, yet important, parts of the Bilingual phrase dictionary / Tweetalige frasewoordeboek $(E-A)$, which is to say that most of the criticism expressed here concerns minor details that would be easily correctable in a second edition.14

This dictionary has been written essentially for a South African usership. Although it at first seemed to slightly favor the English-speaker over the Afri- 
kaans-speaker, an examination of the sense discriminations showed that the Afrikaans-speaker is actually better served than the English-speaker.

The dictionary will be useful to Afrikaans-speakers who want to improve their understanding of spoken and written English (that is, in decoding English) and to English-speakers who want to speak and write better Afrikaans (that is, in encoding Afrikaans). Because, however, meaning discriminations are often lacking and, when they are given, they are always in Afrikaans, this book is more useful to Afrikaans-speakers than to English-speakers. Afrikaans-speakers who want to improve their Afrikaans and English-speakers who want to improve their English will turn to monolingual works in those languages. If they are able to read English, speakers of other languages can use this volume to improve their knowledge of Afrikaans.

Afrikaans-speakers who want to increase their active knowledge of English and English-speakers who want to improve their passive knowledge of Afrikaans will have to await the Afrikaans-English companion volume (where the sense discriminations should be in Afrikaans)..$^{15}$

\section{Notes}

1 The full title on the title page reads: Bilingual phrase dictionary / Tweetalige frasewoordeboek (in both languages with only the first word being capitalized), whereas the full title on the cover of the book reads: Bilingual Phrase Dictionary / Tweetalige Frasewoordeboek (with all the words being capitalized). Where such discrepancies occur the form on the title page is usually considered to be the official citation form. This practice has been followed in the present review. (Editor, Lexikos)

2 The English title of the dictionary contains a specifically South African English usage which non-South-Africans will not readily understand: bilingual in the sense of 'English and Afrikaans'. The definition of this word in Branford and Branford 1992 ('in SA, proficient in both English and Afrikaans') should be expanded to read 'pertaining to Afrikaans and English; in Afrika ans and English; bilingual in Afrikaans and English:. See also Gold 1992: 94.

3 About twenty years ago a publisher asked me to evaluate a proposal for "the first" OccitanEnglish dictionary. Occitan being a much more esoteric language than French in the Englishspeaking world, any English-reader who wanted to learn to read Occitan would most likely already be able to read French, which has traditionally been the path to Occitan. Existing Occitan-French dictionaries can therefore serve most if not all English-readers. If so, the market for an Occitan-English dictionary would be tiny. Also, French being the traditional path to Occitan, Occitan-French dictionaries are probably the best of any Occitan bilingual dictionaries available. Rather than start from scratch, the compilers of an Occitan-English dictionary would therefore probably take a published Oxcitan-French dictionary and merely translate the French into English. That is not scholarship. Plans for an Occitan-English dictionary were fortunately dropped.

4 The list of abbreviations should include $P$ 'proverb', s.o.'someone', s.t. 'something', and any others used in the dictionary, even if they are explained in the guide. 
We may nole here the distinction between an Afrikans-English dictionary and an Afrikans and English dictionary. The first designates a one-way bilingual dictionary in which Afrikaans material is rendered into English. The second is shorthand for an Afrikans-English English-Afrikans dictionary, that is, a two-way bilingual dictionary (by convention, the name of the language into which the material is rendered always appears second in hyphenated compounds). This shorthand form is best avoided in the plural because "Afrikaans and English dictionaries," for example would be ambiguous ('Afrikaans dictionaries + English dictionaries' or 'Afrikaans-English English-Afrikaans dictionaries'?).

That limited way has to do with government. For example, if Afrikaans-speakers know the English word aversion but are not certain which preposition this noun takes, they will find an entry here which shows that it takes to and for. English-speakers might use this dictionary in that way too, but they would most likely go to an English-English dictionary for such information.

7 Stretching a point, one could argue that it Is possible for Afrikaans-speakers to use this dictionary to improve their knowledge of Afrikaans (if they simply read it entry by entry to see whether they knew all of the Afrikaans translations) and it is possible for English-speakers to use it to improve their knowledge of English (if they read the entry heads to see whether they knew all of them).

The wording on the back cover was presumably drafted in anticipation of that second volume. If so, it is not fair to make that claim until the second volume appears (or, at the very least, the publisher should say that it is the companion volume which will serve those additional purposes).

I have not checked the dictionary systematically, but it seems that it not infrequently (and perhaps always) lists collocations consisting of a verb and an object under the object, even if the only unusual part of the collocation is the verb. For instance, do a museum "n museum besigtig' and take (in) a newspaper 'op 'n koerant inteken' are noteworthy because of the special sense of the verbs and not because of their objects (which are nothing more than dummy objects, standing in the first instance for the name of any place that can be visited and in the second instance for that of any kind of periodical). It would thus occur to no one to look for do and take / lake in in these senses under those (or any other) nouns. Such collocations should appear under the verbs. That would have not only the advantage of practicality, but also that of coming closer to the ideal of listing all multiword (sub)entry heads in strictly alphabetical order (Gold 1992: 114-116).

Thus, South African use of the bot tom line is due to American English, not Yiddish, influence. See remarks on South African Fnglish robot in Gold 1992: 108-109.

11 lowe this information to D.C. Hauptfleisch.

12 The example of set as a tennis term is given merely for its theorebcal value (this word, like drite, happens to be one of the most polysemous words in English). Practically, there is no problem in this instance because the English and Afrikaans words for 'tennis' are spelled identically. An example truly applicable to English and Afrikaans would be set up s.t., for which several Afrikaans equivalents are offered in this dictionary. They are, with their sense discriminations: 'iets begin/oprig/stig; iets opstel (bv. ' $n$ kemera, ' $n$ rekord); iets instel; iets monteer; iets stel ('n masjien); iets aanhef (bv. 'n geskree/geskreeu); iets opwerp (bv. 'n verdediging); iets uitlok/veroorsaak ('n reaksie)'. 
All of the material in parentheses should be in English, not Afrikaans. Actually, no harm is done in giving it in Afrikaans, as long as it is also given in English.

Probably the first to formulate principles for sense discriminations was Edwin B. Williams. James E. Iannucci, his student and, later, colleague, refined the principles.

13 In recent years, as the study of dictionaries has progressed, all aspects of lexicography have been coming under closer and closer scrutiny, it thus being inevitable that dictionary titles would be examined too. Marello 1992 may be the first article on the subject (a footnote to that article: use of selva 'forest' in the titles of Italian dictionaries [p. 125] shows the influence of Classical Latin silva 'forest', which acquired the transferred meaning of 'plenty, abundance' [e.g., "silva virtutum et vitiorum"], especially with regard to materials for speaking and writing [e.g., "silva rerum" and "omnis ubertas et quasi silva dicendi silva"], hence was suitable for use in dictionary titles. Foresta 'forest' in the titles of ltalian dictionaries (ibid.) is modeled on selva).

Because many languages have been used in South Africa, it has a long lexicographical tradition. An article on "The Names of South African Dictionaries" would probably turn up interesting facts. For example, although the titles of A Dictionary of South African English (Branford and Branford 1991) and the Woordeboek van die Afrikaanse Taal are almost identical in form, the two have different goals: the first is a differential dictionary (concentrating on material not found in British English) and the second is a comprehensive dictionary (dealing with Afrikaans in its entirety, not just material absent in Dutch).

14 A few more minor comments concern the English of the Guide to the use of the dictionary. Since these comments are written from the viewpoint of American English, perhaps what appear to an American to be errors are in fact acceptable usages in South African English. If so, the following comments may serve, not as suggestions for change, but as a comparison of the two varieties of English:

[a] The male singular forms $H E, H I S, H I M(S E L F)$.... (p. vii) seems to contain the wrong translation of Afrikaans manlik (cf. die manlike enkelvoudsvorme HY, sY, HOM.... on the next page). Is not masculine the usual word in a grammatical context?

[b] AIthough English certainly has the word juridical, its use as a label (p. ix) seems to be induced by Afrikaans juridies. Legal appears to be the most frequently used word as a label in dictionaries.

[c] In Guide to the use of the dictionary (p. xi), the first occurrence of the (induced by Afrikaans? cf. Toeligting by die gebruik van die woordeboek) should be deleted.

[d] In words repeated frequently in the Afrikaans text are sometimes abbreviated to the first letter, as done with the words "skool" and... (p. xi), as done sounds odd to an American ear, which is accustomed to as is done.

15 This brief review was written by a student of dictionaries who is not a specialist in Afrikaans. A review by an Afrikaansist might be worthwhile.

\section{References}

Branford, Jean, with William Branford. 1991. A Dictionary of South African English. Fourth edition. Cape Town: Oxford University Press [rev. Gold 1992]. 
Gold, David L. 1981. Review of Steinmetz 1976. Jewish Language Review 1: 158 [additions in 2: 318-319, 3: 417, 4: 420, 6: 393-394, 7: 614, and Jewish Linguistic Studies 2: 507].

Gold, David L. 1992. Review of Branford and Branford 1991. Lexikos 2: 85-136.

Marello, Carla. 1992. "I titoli dei dizionari." Cortelazzo, Michele A. (Ed.). 1992. Il titolo e il testo: Atti del XV Convegno Intenuniversitario (Bressanone 1987): 121-39. Padua: Editoriale Programma.

Steinmetz, Sol. 1976. "The Bottom Line on the Bottom Line." American Speech 51: 56 [rev. Gold $1981]$.

Tono, Y. 1992. "The Effect of Menus on EFL Leamers' Look-Up Processes." Lexikos 2: 230-253.

\author{
David L. Gold \\ Jewish English Archive \\ New York NY, USA
}

M.L.A. Kgasa. Thanodi ya Setswana ya Dikole, 4th impression 1991, 134 pp. ISBN 9991266003. Gabarone: Longman Botswana. Prys R22,95.

\title{
1. Inleiding
}

Die woordeboek Thanodi ya Setswana ya Dikole wat reeds in 1976 verskyn het, was 'n ware wegbereider (mabulatsela). Hierdie hersiene vierde oplaag is dan ook ' $n$ aansienlike verbetering op hierdie intrede in 1976. In hierdie opsig is dle voorwoord wat geskryf is deur pres. Seretse Sekgoma-a-Khama 'n ware weergawe van sy gevoel as 'n leier namens alle Tswana-sprekendes: "Ga ke lebale ka lobaka lope, tiro e Setswana, puo ya rona ya setshaba e e dirang mo matshelong a batho ba rona" (Ek vergeet vir geen oomblik die rol wat Setswana, ons volk se taal, speel in die lewe van sy mense nie). "Ke puo e e tshelang" (Dit is 'n lewende taal).

\section{Tipe woordeboek}

Die woordeboek kan getipeer word as 'n eentalige verklarende pedagogiese woordeboek. Die teikengroep is skoolkinders. Hierdie afbakening bring mee dat die bestek daarvan nie omvangryk is nie en dat die aanbieding daarvan redelik eenvoudig is. Dit bied ongeveer 4000 lemmas . 


\section{Inleidende gedeelte van die woordeboek}

Die voorwoord is, soos reeds vermeld, deur die land Botswana se president geskryf. Hy lê veral klem op Setswana as lewende taal en as medium vir die bewaring van kultuur en tradisie.

In die voorwoord deur die samesteller self is klem gelê op veral die hantering van grammatika en wel slegs die teenwoordigetyds- en perfektumvorme van werkwoorde. Uit hierdie uitsprake is dit duidellk dat iets van die uitgebreide morfologiese aard van die taal reeds probleme verskaf'en op ' $n$ bepaalde wyse hanteer word.

In die gedeelte oor die gebruik van die woordeboek spreek die samesteller hom oor ' $n$ aantal dinge uit. Eerstens word die meervoudsvorme van die naamwoorde nie in uitgeskryfde vorme aangebied nie maar slegs in hakies aangetoon. As dit in die meervoud verander, word die volle woord in hakies geskryf, bv.

lekgolo(ma) masomê a le somê = een honderd

mmele (mebele) nama, marapô a motho =vleis; bene van 'n mens

Tweedens wys hy daarop dat 'n sh-klank in hierdie oplaag as s geskryf word, bv.

sêba buêla kwa tlase $=$ skinder .

Derdens wys hy ook daarop dat leenwoorde ook opgeneem is. Vierdens word aangetoon watter terme hy vir dae van die week voorstel. Laastens word 'n hele aantal terme vir grammatiese én literêre studie voorgestel. Hierdie lys kom nie altyd ooreen met dié wat deur die Tswana Taalraad in die RSA gebruik word nie, bv.

leitsisi ideofoon (Botswana)

leetsi ideofoon (RSA)

têô betekenis (Botswana)

bokao betekenis (RSA)

Die woordeboek is dus primêr geskryf met as uitgangspunt die terminologie en spelreëls wat in Botswana geld. Dit bring mee dat daar talle probleme ontstaan wanneer dit in die RSA gebruik word.

\section{Lemmas}

Rondom die leksikale elemente wat in die woordeboek opgeneem is, kan die volgende kritiek uitgespreek word. 


\subsection{Kleur}

Die adjektiewe wat kleur aandui is op 'n lukrake wyse in die woordeboek opgeneem. Voorbeelde is die volgende:

- Kleure wat opgeneem is sonder enige verklaring of verduideliking daarvan

thaba mmala (kleur) sêtlha mmala (kleur)

- Kleure wat nie opgeneem is nie so swart hibidu rooi

- Kleure wat volledig opgeneem is nala bosweu le bofibidu (wit en rooi)

Uit hierdie gegewens blyk dit dat daar geen vaste strategie was in die hantering van kleuronderskeidings nie.

\subsection{Leenwoorde}

Leenwoorde uit 'n sestal tale is in die woordeboek opgeneem nl. Engels, Afrikaans, Hebreeus, Grieks, SuidSotho en Frans. Die afkoms word volledig by elke lemma aangetoon met 'n afkorting. Hierdie afleidings verryk die taal. Die meerderheid is uit Engels en Afrikaans afkomstig. Al die voorbeelde is volledig getransfonologiseer.

Voorbeelde is:

tomokeraga (domkrag)

founa (phone)

\subsection{Idiome}

Daar is nie 'n groot aantal idiome opgeneem nie maar dié wat wel ingesluit is, is funksioneel.

loga maanô = planne te beraam

Hierdie is 'n opvallende gebrek omdat daar in Tswana baie van idiome gebruik gemaak word. 


\subsection{Woordverdeling}

Dit is gou duidelik dat die woordverdelingsbasis wat in Botswana as riglyn geld in die woordeboek toegepas is.

- ga gona nyenyefatso (daar is nie minagting nie) wat geskryf moes word as: ga go na nyenyefatso

- nare ea fula (die buffel wei) wat geskryf moes word as: nare e a fula

Hierdie enkele voorbeelde kan uitgebrei word maar is nie hinderlik nie. As gevolg van twee strategieë wat gevolg word nl. dié in Botswana en dié in die RSA kan dit die gebruiker verwar. Dit is ' $n$ probleem wat met begeleiding maklik opgeklaar kan word (vir die gebruiker).

\subsection{Spelfoute en ortografie}

Enkele tikfoute is in die voorwoord opgemerk maar is nie hinderlik nie, bv. dithlôgô. In die teks is geen foute opgemerk nie.

Die ortografie is aanvaarbaar en deurgaans goed. Tog is daar enkele probleme, bv. sekole $/$ sekolo = skool $($ Botswana $/ R S A)$.

\subsection{Verklaring van betekenisse}

Die betekenisse is goed verklaar vir die teikengroep vir wie dit bedoel is. Daar is tog gevalle waar dit nie voldoende is nie, bv. die verklaring van kleure. 'n Ander voorbeeld is die beskrywing van 'n sekere soort boom:

mopipi setlhare se setala ('n groen boom)

Die meeste bome is tog immers groen.

Sinonieme word doeltreffend hanteer waar dit voorkom, bv.

- tala mmala wa bojang kgotsa wa loopi (kleur van gras of hemelruim)

- tala (blou; groen)

- $\quad$ setlhare = se se nang le medi; thitô, dikala le matlhare gongwe mitlwa; molemô (dit wat wortels het, 'n stam, takke en blare of dorings; medisyne)

- $\quad$ setlhare = boom; medisyne 


\subsection{Morfologie}

Tswana het net soos alle ander Afrikatale 'n groot aantal affigale morfeme by werkwoorde en naamwoorde. Dit kan op twee wyses hanteer word:

- by die lemma self

- alfabeties as aparte lemmas.

In hierdie woordeboek is dit alfabeties as aparte lemmas hanteer. Dit is konsekwent gedoen en doen nie afbreek aan die woordeboek nie. Die werkwoord rêka (koop) waaraan verskillende affikse geaffigeer is, is opgeneem as: rêka, rêkêgêla, rekisa, rekolola.

\section{Slot}

Hierdie verklarende woordeboek het ten spyte van sy tekortkominge tog talle pluspunte. Dit is tans die enigste verklarende woordeboek van Setswana en fokus op die gebruik in skole. Met die nodige leiding kan dit met vrug gebruik word. Dit is jammer dat uitgangspunte deur taalrade uit twee lande nl. Botswana en die RSA hierdie werk nie tot sy volle reg laat kom nie.

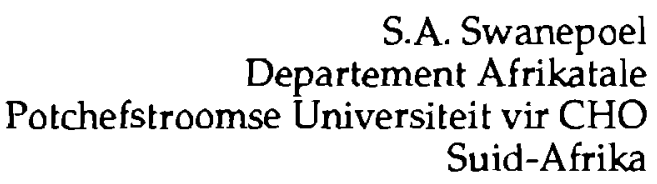

Ernst Kotzé en Patrick Wela (Opstellers), Afrikaans/Zoeloe-Woordeboek met Engelse vertalings, 1ste uitgawe 1991, 305 pp. ISBN 0624030938 hardeband; ISBN 0624029239 sagteband. Kaapstad: Tafelberg. Prices: R34,95 hard-cover; R19,95 soft-cover.

\section{Introduction}

The Afrikaans/Zoeloe-Woordeboek met Engelse vertalings is a translation dictionary. Its unique features are that:

1.1 all entries are in Afrikaans with Zulu equivalents given in each case

1.2 an English translation is provided for all entries

1.3 it is primarily a pedagogical dictionary aimed at assisting Zulu speakers who are students of Afrikaans. 
1.4 Bilingual dictionaries usually have entries given in two languages. The Afrikaans/Zoeloe-Woordeboek provides an Afrikaans vocabulary to Zulu speakers more directly and English-speaking persons indirectly. The compilers have used English translations to assist Zulu-speaking users of the work who have acquired English as a second language to master Afrikaans.

\section{Pedagogical Value of Dictionary}

The following are some of the important features of the dictionary that are of pedagogical value:

2.1 The entry of a noun followed by a formative in brackets indicating the plural form of the noun in question. This is particularly helpful in certain nouns which do not appear to follow the general rule of plural formation. For example, the voicing of the final fricative consonant in gif, drif; the distinction between plural forms of nouns containing long or short vowels in the final vowels of nouns: sprinkaan, doos; the substitution of a diphthong in the last syllable of a noun with a long vowel: skoonheid, swakheid. A similar trend is found in adjectives; cf. skurwe, growwe; wrede, dowe; the use of radical and voiced alveolar stop consonants in suffixal formatives following: uitgeputte, uitgedoste; gebraaide, hervormde.

2.2 The indication of the past tense forms of verbs in brackets after the verb entry. The distinction between verbs that use the formative ge- in the derivation of the past tense and those that do not do so is very clearly indicated.

2.3 The entry of homonyms as separate words to facilitate their identification as nouns, adjectives, verbs, etc.: glo (adverb), glo (verb); lui (adjective), lui (verb); kies (noun), kies (verb).

2.4 The use of copious examples to illustrate the use of each entry.

2.5 A description of the pronunciation of Afrikaans sounds to enable Zulu learners of Afrikaans to master these is given at the beginning of the dictionary.

\section{Evaluation}

3.1 One of the major weaknesses of the dictionary is that it contains Afrikaans entries only. An entry of Zulu words explained in Afrikaans would enhance the value of the dictionary. 
3.2 Zulu is a tone language. The tones are constituent parts of words. The omission of tone from a dictionary intended to assist learners of Zulu deprives them of an important element of meaning and the context of words in the intonation pattern of sentences. These make up the semantic import of words and the music or harmony of words in a sentence.

The statement that the penultimate syllable of every sentence (or word used in isolation) has full length must be viewed with caution. Ideophones occurring at the end of a sentence, interrogative sentences and exclamations refute this assertion.

3.3 The description of vowels in Zulu leaves much to be desired. These are imprecise and not very helpful to a Zulu speaker trying to learn Afrikaans. It is also misleading to suggest that Afrikaans diphthongs and triphthongs can be equated with Zulu counterparts of these vowels. Zulu has no diphthongs or triphthongs.

There is room for improvement in the Zulu description of Afrikaans consonants. Not only is the list of these consonants incomplete, but the description of several of the listed ones is, on the whole, unsatisfactory.

3.4 The past tense forms of verbs is not always indicated or used in the examples.

3.5 The passive form of the verb is not time bound as the compilers of the dictionary suggest. The list of sounds that undergo palatalisation is incomplete.

3.6 It is confusing to use the concept of long distant past tense with the long form of the present tense. It is erroneous to view khathele, phapheme, etc. as long past tense forms of khathala, phaphama.

3.7 Verbal extensions are not clearly distinguished from suffixes in the discussion of the grammar. The compilers of the dictionary do not explain why they regard the infinitive as a basic form of the verb. It is also misleading to say that a complementary verb in a compound verb in the infinitive form is the main verb in a sentence.

\section{Challenge}

A translation dictionary with a pedagogical focus demands the following from a compiler, in addition to a precise definition of entries:

4.1 A fairly exhaustive discussion and comparison of the sound systems of the languages involved. 
4.2 A translation dictionary involving Afrikaans (or any Germanic language) and Zulu puts exceptional demands on the compiler to define or describe the concept of a word, its structure [syllables, morphemes (both segmental and suprasegmental), variations of number, tense, compounding, etc.] and its classification into the relevant word category. The gap to be bridged is not simply that between one language and another within a language type but that of languages belonging to completely different language families.

4.3 A broad comparison of the syntax of the languages concerned. Words occur in sentences after all.

4.4 Finally, the following aspects of Afrikaans and Zulu deserve more than passing attention:

4.4.1 the absence of prepositions, primary adverbs, stress, definite and indefinite articles in Zulu on the one hand, and noun prefixes, the concordial system, tone and intonation in Afrikaans on the other requires some discussion of how either language accommodates these features.

4.4.2 the indication of stressed syllables in the Afrikaans entries would facilitate the mastery of the pronunciation of words in this language. Further, Zulu speakers often find the distinction between certain Afrikaans formatives such as on-/ond-, op-/opper-, on- and ont-in words in which they occur difficult to master.

4.4.3 We suggest that the entry of Afrikaans separable verbs (deeltjiewerkwoorde) under a common initial element would avoid confusion caused by a purely alphabetical listing of entries. The entries could be classified into two sections, viz. those that use the general past tense formative and those which do not.

\author{
A.C. Nkabinde \\ University of Zululand \\ South Africa
}


Sibusiso Nyembezi. Isichazimazwi Sanamuhla Nangomuso. (Dictionary for today and the future). Zulu dictionary, 1st edition 1992, $561 \mathrm{pp}$. ISBN 094745740 2. Pietermaritzburg: Reach Out Publishers. Price $\mathrm{R} 48,40$.

\section{Introduction}

Isichazimazwi Sanamuhla Nangomuso is an important addition to the development of explanatory dictionaries in Zulu and other Bantu languages of South Africa. The publication is a clear recognition of the importance of the preservation and development of Zulu as a language. It also establishes the need to reinforce and develop this language's capacity to explain itself.

\section{Word Classes}

The classification of words into various grammatical categories constitutes the key to the compilation of dictionaries.

Historically, the Dokean approach has dominated the classification of Zulu words into various categories. Later attempts to improve on the Dokean model have not been generally accepted. This has created a problem for the lexicographers.

The Dokean model classifies Zulu words into twelve parts of speech. The model mainly uses a functional approach. Consequently, nouns for example, are classified as different parts of speech if used as qualificatives (cf. Adjective, Relative, Enumerative, and Possessive) or when used as adverbs. Similarly, the pronoun is also recognised even where it is strictly speaking a qualificative, cf. the demonstrative. Other parts of speech identified in the Dokean classification include the Copulative and the socalled Conjunctive. Several of Doke's parts of speech do not constitute independent words with a particular meaning. Some of the "parts of speech" are not semantic units at all but mere grammatical entities.

Nyembezi has deviated somewhat from Doke's approach. He classifies the language into ten parts of speech, viz. the Noun, Verb, Ideophone, Pseudoverbs, Interjective, Adverb, Pronoun, Relative, Adjective and Conjunctive. He has left out Doke's Copulative and Possessive.

The identification of the following parts of speech by Nyembezi do not seem to facilitate the lexicographer's task:

(1) Pronoun: Although this part of speech is listed in the list of abbreviations, only a few pronouns could be traced in the text of the publication. The definitions given for the two words show clearly that the 'pronouns' are qualificative in use and import. 
(2) The Adverb: Many adverbs identified in the dictionary are simple nouns used as adverbs. Therefore, it appears that they should be labelled as nouns and defined as such, cf. certain nouns of classes $6,11,12$ and 14; nouns such as impela, imbala, obala (see ubala), ebusuku (ubusuku), ebusika, (ubusika), ekuphaleni (ukuphela), emini (imini), etc. It appears more feasible to define the primary forms of these nouns only. The meanings of secondary forms can be derived from the primary meanings. The identification of secondary forms of nouns for lexicographical purposes is inappropriate. No dictionary can contain an exhaustive description of all uses of nouns. This should be left to semantics which gives special attention to the connotations of words.

(3) Pseudo-verbs and the Conjunctive: It is a moot point if these parts of speech exist. The meaning contained by them is limited to the grammatical function they perform. The true realisation of the meanings conveyed by these words only occurs within the context of a following verb in the clause in which they are used. They belong more appropriately to the domain of grammar rather than the field of lexicography.

(4) The Adjective and the Relative: There are no natural adjectives and relatives in Zulu. These are derived from nouns or verbs. Therefore, the definition of the meanings of the nouns and the verbs covers the definitions of the adjective and the relative adequately.

An interesting phenomenon about the qualificative is that whereas some nouns undergo a structural change to perform a qualificative function, many Zulu nouns are inherently qualificative in nature. They do not co-occur with other nouns used qualificatively in the sentence. An intriguing question is whether or not these "nouns" should be classified under the relative.

(5) The Use of the Imperative form of the Verb: Nyembezi recognises the most important aspect of the Zulu verb, viz. that it can only be identified in its use. The use of the imperative as the key word for the verb is from a functional point of view an improvement over the use of the infinitive. The only shortcoming with its use as the keyword in a dictionary is that not all Zulu verbs are capable of being used in this form of the verb. Only the activity and achievement verbs are amenable to such usage. Process and stative verbs resist this use. For example, khula, futha, chachamba, khuluphala, buna, ncipha and a host of other verbs cannot be used in the imperative in normal speech. Therefore, the use of the imperative in the definition of the Zulu verb is inappropriate. 


\section{Technical Points}

The use of diacritic marks to indicate tones of words is very helpful.

The bold lettering used for the items defined gives the dictionary a very neat and pleasing appearance.

The use of the singular and plural noun prefixes behind the noun stems and one prefix (singular or plural) to show that the noun only occurs in one of the forms will assist users of the dictionary.

The conjunctive indicated as $h l$ is not given in the list of abbreviations. Similarly, the asterisk used to indicate hlonipha words is not explained.

The definitions of the diminutive, locative, and possessive forms of nouns, and derivative forms of verbs are unnecessary. These are functional forms of these parts of speech. They should be explained by the grammar of the language rather than the dictionary. Only exceptional cases of established derivations which have virtually become independent lexical items should be defined in a dictionary.

The entry of words with phonetic variants as independent items though defined identically is inelegant.

The preceding two observations mar the presentation of the definitions in the dictionary. They contribute to unnecessary repetition. This has resulted in lack of economy and unwarranted increase in bulk. This is unfortunate because it has adverse implications for the affordability of the dictionary.

\section{Definitions}

The definitions of words are very good.

The compiler has succeeded in maintaining a remarkable consistency in the format of definitions of nouns, verbs, the interjectives and the ideophones. For example, most definitions of nouns and verbs have the word bearing the key meaning occurring first in the definition. Similarly, the definition of the ideophone mostly commences with the words "ukuchaza isimo/isenzo/isenzeko" etc., and the interjective: "isibabazo soku ..." These features may be responsible for the concise and economical definitions found in the dictionary.

A.C. Nkabinde University of Zululand South Africa 
J. Smuts en I.J. Smuts. Woordeboek van Regs- en Handelsterme. Verklarend en vertalend, 1ste uitgawe, 1ste druk 1992, 191 pp. ISBN 0-625-02401-X. Kaapstad: Nasou Beperk. Prys R62,15.

Hierdie woordeboek word - aldus die Voorwoord daartoe - aangedien as "'n praktiese naslaanwerk waarin die betekenis van Afrikaanse regs- en handelsterme nageslaan kan word". Dit is hoofsaaklik op die behoeftes van regspraktisyns en sakemanne afgestem en bevat woorde en uitdrukkings waarmee hulle te doen sal kry "in die loop van hulle werksaamhede". Daar is ook woorde opgeneem "wat nie vakterme is nie maar noodgedwonge in regsdokumente en handelstukke voorkom sodat dit nie nodig sal wees om ander woordeboeke te raadpleeg nie". Verder vertaal die woordeboek Latynse terme wat deel is van die Afrikaanse regstaal in Afrikaans (maar nie in Engels nie). Handelsterme sluit in boekhouterme, bankterme, beursterme, belasting terme, versekeringsterme en rekeningkundige terme.

Die volledigste vorm waarin Afrikaanse inskrywings voorkom, is die hoofwoord in vet druk, gevolg deur agtereenvolgens die Engelse ekwivalent daarvan (in hakies), die Afrikaanse verklaring van die hoofwoord, 'n Afrikaanse uitdrukking of uitdrukkings waarin die hoofwoord gebruik word en 'n Engelse ekwivalent of ekwivalente van die Afrikaanse uitdrukking(s).

Ek kan hierdie werk slegs vanuit 'n regsoogpunt evalueer. Voorts is dit moeilik om ' $n$ waardebepaling van ' $n$ woordeboek te maak indien dit nie eers vir ' $n$ jaar of wat 'n gereelde gebruiksartikel op ' $n$ mens se lessenaar was nie. Met hierdie beperkinge in gedagte sou ek egter tog die werk oorwegend positief waardeer. Dit maak bepaald 'n belangrike bydrae tot die Afrikaanse regsen handelsliteratuur en die bevordering van 'n eiesoortige - en, sou 'n mens kon byvoeg, keurige - vaktaal op hierdie twee terreine. Die waarde van die werk sou egter groter gewees het indien dit ook 'n Engels-Afrikaanse woordeboek was, dit wil sê indien ten minste die Afrikaanse ekwivalente van Engelse woorde en uitdrukkings gegee sou gewees het. Dit is belangrik juis omdat Engels dié mees gebruikte taal in die sakewêreld is en in 'n al hoe groter mate ook die gebruikstaal in die regswese gaan word.

Die woordeboek kan by persone uit die teikenmark en selfs regstudente aanbeveel word. Regspraktisyns wat baie met formulerings werk, sou waarskynlik egter beter doen deur (selfs teen ongeveer drie maal die prys) 'n omvattender twee- of drietalige regswoordeboek aan te skaf - hoofsaaklik omdat in die meeste standaardregswoordeboeke die verklarings vollediger is en spesifiek die regstegniese betekenis van woorde en uitdrukkings gegee word.

Vir ' $n$ werk van beperkte omvang is die Woordeboek van Regs- en Handelsterme merkwaardig volledig - miskien selfs té volledig. Latynse uitdrukkings soos a mensa et toro ("van tafel en bed"), ex defectu sanguinis ("uit gebrek aan nakomelinge") en pro re nata ("vir 'n moontlike geval") wat haas nie meer in die Afrikaanse regstaal gebruik word nie, word byvoorbeeld vertaal en verklaar. Daarteenoor sal 'n leser nie vertalings en verklarings van meer gebruikte uit- 
drukkings soos nullum crimen sine lege of nullum crimen/nulla poena sine culpa in die woordeboek vind nie. Nêrens ook word 'n sleuteluitdrukking in die Afrikaanse regstaal soos "natuurlike geregtigheid"/"reëls van natuurlike geregtigheid" vertaal en verklaar nie hoewel van die twee reëls wat aan natuurlike geregtigheid uitdrukking qee - audi alteram partem en nenmo potest esse simul actor et iudex (die meer gebruiklike vorm is nemo iudex in re sua/sua causa) - wel vertaal en verklaar word. Voorts lig die woordeboek die gebruiker in dat 'n nasciturus 'n "verwekte maar nog ongebore kind" is maar swyg oor die bestaan van die nasciturus-reël (sommiges noem dit 'n fiksie): nasciturus pro iam natu habetur de comodo quotiens eius agitur. Die vraag is natuurlik of 'n woordeboek van hierdie beperkte omvang so "tegnies" moet raak. Wel word verwys na sekere ander meer tegniese reëls op die gebied van byvoorbeeld wetsuitleg, naamlik die eiusdem generis-reël (die tweelingbroer van hierdie reël, cessante ratione legis cessat et ipsa lex ontbreek egter) en die reëls inclusio unius est exclusio alterius (laasgenoemde egter sonder vermelding van die feit dat dit ' $n$ uitlegreël is).

Die voorgaande illustrasie van weglatings is nie bedoel as ernstige kritiek nie. Dit illustreer in 'n sekere sin die keusedilemmas waarmee die opstellers van vakwoordeboeke van 'n beperkte omvang gekonfronteer staan.

As beknopte naslaanwerk vir persone in die regs- en sakepraktyk en vir junior studente kan die Woordeboek van Regs- en Handelsterme beslis aanbeveel word. Akademici en nagraadse studente sal dit waarskynlik egter ontoereikend vind en liefs in 'n vollediger, meertalige regswoordeboek wou belê.

Lourens M. du Plessis Fakulteit Regsgeleerdheid Universiteit van Stellenbosch Suid-Afrika

\author{
J.W. Snyman (Editor, Redakteur), J.S. Shole and/en J.C. le Roux (Sub- \\ editors, Subredakteurs). Setswana English Afrikaans Dictionary Woorde- \\ boek, 1st edition, 1st impression 1990, 527 pp. ISBN 079941218 X. \\ Pretoria: Via Afrika Limited. Prys R79,50.
}

\title{
1. Inleiding
}

Hierdie woordeboek wat in drie tale saamgestel is, is op leksikografiese gebied ook ' $n$ ware "mabulaatsela (wegbereider). Dit is ' $n$ woordeboek wat gedeeltelik die realiteit van die taalsituasie in die RSA weergee. Die twee amptelike tale nl. Afrikaans en Engels word by Setswana betrek. Alhoewel dit so is kon 'n wyer horison nl. deur 'n Ngunitaal te betrek die taalsituasie op 'n meer realistiese wyse hanteer het. Nietemin is dit 'n baie waardevolle bydrae. Hierdie 
Hierdie woordeboek word verkeerdelik as die tweede woordeboek in die geskiedenis van Setswana uitgewys. Dit is ' $n$ eer wat gaan aan Thanadi ya Setswana ya dikole van M.L.A. Kgasa wat in 1976 verskyn het. In die voorwoord vermeld die redakteur dat hy in 1969 alreeds 'n behoefte vir so 'n woordeboek raak gesien het, $\mathrm{nl}$. 'n woordeboek wat in drie tale diensbaar moes wees aan skole, kolleges en universiteite. Hierdie woordeboek gaan wyer aandag trek en ook die algemene gebruiker baie hulp verskaf indien hy 'n bietjie aan sy taalinsig aandag gee.

\section{Tipe woordeboek}

Die woordeboek kan getipeer word as 'n vertalende drietalige woordeboek. Dit het as teikengroep skole, kolleges en universiteite. Dit is dus 'n pedagogiese woordeboek wat ingestel is op die taalaanleersituasie. Die bestek daarvan is redelik in omvang en 13000 plus lemmas word hanteer. Dit gee aan die woordeboek 'n te sterk akademiese kleur en doen afbreuk aan sy praktiese waarde as hulpmiddel by die aanleer van 'n vreemde taal.

Die woordeboek stel hom op die grondslag wat deur die Tswana Taalraad in die RSA en Bophuthatswana gevolg word.

In die gedeelte oor die uitspraak word waardevolle inligting oor die uitspraak van vokale en konsonante gegee. Die besluit om deurgaans kappies op die vokale $(\varepsilon)$ en (o) te plaas dra baie by tot korrekte uitspraak. Die gedeelte oor die fonologie bied aan die gebruiker vir die eerste keer in Setswana 'n geleentheid om so na as moontlik aan die korrekte uitspraak van die verskillende lemmas te kom. Hierdie afdeling is van onskatbare waarde.

In die afdeling oor die naslaan van woorde word riglyne daarvoor gegee. Dit is ook ' $n$ woordeboek met ' $n$ sinchroniese en diachroniese inslag. In die voorwoord onder die opskrif wOORDESKAT sê die samestellers self dat daar gefokus is op alledaagse woordeskat maar dat daar ook gepoog is om tradisionele woordeskat in te sluit. Die insluiting van hierdie woordeskat doen afbreek aan die primêre aard van die woordeboek, $\mathrm{nl}$. dat dit primêr ' $n$ woordeboek is vir die aanleer van taal en liefs moes konsentreer op sinchroniese woordeskat. Deur hierdie dubbelslagtigheid te handhaaf en daarop te fokus het baie alledaagse woordeskat in die slag gebly. Voorbeelde is o.a. lughawe, grondvloer, busstop, ens.

\section{Inleidende gedeelte}

In die voorwoord van die woordeboek word 'n hele aantal riglyne gegee vir die hantering daarvan. Hierdie inligting word ook drietalig aangebied. Die inligting wat verskaf is, is belangrik maar dit moet egter 'n ingeligte persoon wees om dit te kan volg. Dit gaan vir die leek talle probleme verskaf. Die vraag wat 
hier gaan ontstaan is: Waarom is woorde onder die eerste en derde letter opgeteken?

Verwantskapsterme gaan ook probleme lewer. Hoekom gebruik die een groep slegs die derde letter en die ander groep die eerste en derde letter? Die inligting oor die refleksief en by voorwerpskakels is vir ingeligte gebruikers waardevol maar sal vir die leek probleme verskaf want hy het nie die grammatikale inligting tot sy beskikking nie.

Die lys afkortings vir Afrikaans en Engels is baie waardevol. Waar is die lys vir Setswana? Hier kan ' $n$ waardevolle bydrae gelewer word vir Setswana self.

Die dilemma waarin die samestellers hulle bevind, word duidelik in hierdie voorwoord weerspieël. Hoever is die woordeboek prakties en slaag dit in sy doel? Is dit nie slegs ingestel op ingeligte gebruikers nie?

\section{Die hantering van die lemmas}

Die lemmas is baie goed hanteer. As voorbeeld kan die lemma reën/rain geneem word. Bykans alle tersaaklike inligting is hier verskaf. Alle tipes reën is aangedui asook talle idiomatiese uitdrukkings wat daarby pas.

Die inligting rondom werkwoordlemmas het die weg gevolg deur morfologiese afleidings as aparte lemmas te hanteer. Dit dra weer by tot die praktiese waarde van die woordeboek. Die werkwoord rêka (koop) het bv. die volgende afgeleide lemmas, $\mathrm{nl}$. rekisa (verkoop), rekisega (goed verkoop), rekisetsa (verkoop aan), rekisitse (het verkoop), rekolola (terugkoop), ens.

Daar is ook 'n groot aantal lemmas ingesluit wat tradisionele terme, begrippe, voorwerpe en gebruike aanraak. In die teks word daar ook baie aandag gegee aan oormerke en word sketse aangebied om dit te illustreer. Die nastreef hiervan deur die samestellers is baie verdienstelik maar dit geskied soms ten koste van lemmas wat sinchronies van meer praktiese waarde kan wees. Soms is sekere lemmas se praktiese waarde baie laag, bv. die lemma, rooibokagtig/sefala. In Afrikaans is die lemma buffelagtig meer in gebruik as rooibokagtig.

Alhoewel hierdie as ' $n$ punt van kritiek geopper word, moet dit nie as negatief of afwysend ervaar word nie. Dit toon slegs aan dat daar uit 'n groot aantal lemmas sekere keuses gemaak moet word en dat keuses nie in almal se smaak sal val nie.

\section{Slot}

Hierdie woordeboek gaan groot byval vind in gevorderde onderrigsituasies. Dit sal in gebruikswaarde toeneem indien begeleiding deur 'n kenner aan die gebruiker verskaf kan word. $\mathrm{Al}$ is dit so dat die insluiting van tradisionele. 
terme en begrippe uit praktiese oogpunt oorbodig is, word 'n sinvolle bydrae in kultuuropsig gelewer. Dit is terme wat indien hulle nie tydig opgeteken was nie, maklik kan verdwyn. Getrou aan 'n uitdrukking in Setswana: Batho ba lemogana leetong (Mense leer mekaar as hulle saam op reis is), kan ons sê: Mosola wa dikisinare re tla o lemoga re ntse re le mo leetong ka yone (Die waarde van hierdie woordeboek sal ons besef soos wat ons daarmee op reis is).

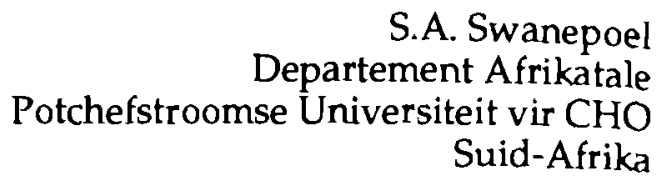




\section{Publikasie-aankondigings / Publication Announcements}

Chambers Schoolbag Dictionary including Southern African usage and pronunciation, 1st edition 1986, 2nd impression 1990, 134 pp. ISBN 0864860463 . Cape Town, Johannesburg: David Philip Publishers. Price R14,85. (Review in this number)

T.T. Cloete (Redakteur), Leon Strydom, Heilna du Plooy en Anna-Marie Bisschoff (Medewerkers). Literêre terme en teorië̈, 1ste uitgawe, 1ste druk 1992, xV + 598 pp. ISBN 079862707 7. Pretoria: HAUM-Literêr. Prys R114,99.

A.S. Coetser. Die Oxford Kortspelgids, 1ste uitgawe 1993, ix +379 pp. ISBN 019-570802-4. Kaapstad: Oxford University Press. Prys R25,99.

G.R. Dent (Compiler) and C.L.S. Nyembezi (Editor). Compact Zulu Dictionary. Eng.-Zulu; Zulu-Eng., 5th edition 1990, 2nd impression 1992, 152 pp. ISBN 079600265 7. Pietermaritzburg: Shuter and Shooter. Price R13,65. (Review in this number)

G.R. Dent and C.L.S. Nyembezi (Compilers). Scholar's Zulu Dictionary. Eng.Zulu; Zulu-Eng., 2nd edition 1988, 3rd impression 1991, 519 pp. ISBN 079600111 1. Pietermaritzburg: Shuter and Shooter. Price R29,05. (Review in this number)

Dictionary English-Xhosa, Xhosa-English, 1st edition, 7th impression n.d., 81 pp. ISBN 079940297 4. Goodwood: Via Afrika Limited. Price R12,87.

J.A. du Plessis, J.G. Gildenhuys en J.J. Moiloa. Bukantswe Ya Maleme-Pedi Sesotho-Seafrikanse. Tweetalige Woordeboek Afrikaans-Suid-Sotho, 1 st edition, 2nd impression n.d., 270 pp. ISBN 079940352 0. Goodwood: Via Afrika Limited. Price R25,70.

Madaleine du Plessis. Tweetalige aanleerderswoordeboek. Bilingual learner's dictionary, 1ste uitgawe 1993, 552 pp. ISBN 0624031802 hardeband; ISBN 0624031810 sagteband. Kaapstad: Tafelberg. Pryse R49,95 hardeband; R29,95 sagteband. 
Gertruida M. du Plooy. 500 Communications Concepts. English/Afrikaans, 1st edition 1991, vi + 177 pp. ISBN 0702126500 . Kenwyn: Juta \& Co., Ltd. Price R49,00.

P. Harteveld (Redakteur), L.G. de Stadler en D.C. Hauptfleisch (Medewerkers). Woordkeusegids. 'n Kerntesourus van Afrikaans, 1ste uitgawe, 2de en verbeterde druk 1993, 367 pp. ISBN 1868124401 . Halfweghuis: Southern Boekuitgewers. Prys R41,44.

P.A. Joubert. Bilingual phrase dictionary. Tweetalige frasewoordeboek $(E-A)$, 1st edition 1992, xiii + 331 pp. ISBN 0624031497 hard-cover; ISBN 0624030806 soft-cover. Cape Town: Tafelberg. Prices: R39,95 hardcover; R24,95 soft-cover. (Review in this number)

M.L.A. Kgasa. Thanodi ya Setswana ya Dikole, 4th impression 1991, 134 pp. ISBN 9991266003 . Gabarone: Longman Botswana. Price R22,95. (Review in this number)

Ernst Kotzé en Patrick Wela (Opstellers). Afrikaans/Zoeloe-Woordeboek met Engelse vertalings, 1ste uitgawe 1991, $305 \mathrm{pp}$. ISBN 0624030938 hardeband; ISBN 0624029239 sagteband. Kaapstad: Tafelberg. Pryse: R34,95 hardeband; R19,95 sagteband. (Resensie in hierdie uitgawe)

F.J. Labuschagne en L.C. Eksteen. Verklarende Afrikaanse Woordeboek, 8ste uitgawe 1993, 1117 pp. ISBN 062701740 1. Pretoria: J.L. van Schaik. Prys R99,00.

D.P. Lombard, R. Barnard en G.M.M. Grobler. SEDIBA. Practical List of Words and Expressions in Northern Sotho. Praktiese lys van woorde en uitdrukkings in Noord-Sotho, 1st edition, 1st impression 1992, 167 pp. ISBN 079941305 4. Pretoria: Via Afrika Limited. Price R29,99.

Roxana Ma Newman. An English-Hausa Dictionary; 1990, xxi + 327 pp. ISBN 0300-04702-9. New Haven and London: Yale University Press.

Sibusiso Nyembezi. Isichazimazwi Sanamuhla Nangomuso. (Dictionary for today and the future). Zulu dictionary, 1st edition 1992, 561 pp. ISBN 094745740 2. Pietermaritzburg: Reach Out Publishers. Price R48,40. (Review in this number)

J. Smuts en I.J. Smuts. Woordeboek van Regs- en Handelsterme. Verklarend en vertalend, 1ste uitgawe, 1ste druk 1992, $191 \mathrm{pp}$. ISBN 0-625-02401-X. Kaapstad: Nasou Beperk. Prys R62,15. (Resensie in hierdie uitgawe) 
J.W. Snyman (Editor, Redakteur), J.S. Shole and/en J.C. le Roux (Sub-editors, Subredakteurs). Setswana English Afrikaans Dictionary Woordeboek, 1st edition, 1st impression 1990, 527 pp. ISBN 079941218 X. Pretoria: Via Afrika Limited. Price R79,50. (Review in this number)

Taalkommissie van die Suid-Afrikaanse Akademie vir Wetenskap en Kuns. Afrikaanse woordelys en spelreëls, 8ste uitgawe, tweede druk 1991, 393 pp. ISBN 0-624-03012-1. Kaapstad: Tafelberg. Prys R59,95. (Resensieartikel in hierdie uitgawe)

J.J. Viljoen, P. Amakali and M. Namuandi. Oshindonga/English English/Oshindonga Embwiitya Dictionary, 1st edition 1984, 109 pp. ISBN 086848182 3. Windhoek: Gamsberg Macmillan. Price R22,40 + VAT.

J.J. Viljoen en T.K. Kamupingene. Otjiherero woordeboek dictionary embo romambo, 1983, xix + 197 pp. 1SBN 0868481955 . Windhoek: Gamsberg Publishers. Prys R18,00+BTW.

Woordeboek Afrikaans-Xhosn, Xhosa-Afrikaans, 1ste uitgawe, 4 de druk s.j., 90 pp. ISBN 079940296 6. Goodwood: Via Afrika Beperk. Prys R12,87.

Woordeboek van die Afrikaanse Taal. Agtste deel, KOS-KYW-, 1ste oplaag 1991, xxiii + 584 pp. Stellenbosch: Buro van die WAT. Pryse: R142,50 leerband; R71,00 plastiekband. (Resensie-artikel in hierdie uitgawe) 
